Wagner Francisco Araujo Cintra

\title{
NO LIMIAR DO DESCONHECIDO \\ - Reflexões sobre o objeto no teatro de Tadeusz Kantor -
}

\section{Volume I}

Tese apresentada à Escola de Comunicações e Artes da Universidade de São Paulo, como exigência parcial do Curso de Pós-Graduação, para obtenção do título de Doutor em Artes.

Orientador: Profa. Dra. Ana Maria de Abreu Amaral

Departamento de Artes Cênicas

Escola de Comunicações e Artes

Universidade de São Paulo 


\section{RESUMO}

Tadeusz Kantor (Polônia - 1915/1990) foi um dos mais importantes homens de teatro do século XX. O seu teatro possui uma intensa ligação com as artes plásticas e foi fortemente influenciado pelas vanguardas do início do século passado: Construtivismo, Bauhaus, Dadaísmo, Surrealismo, Expressionismo. Seu teatro é marcado pela ocorrência de imagens fortes e perturbadoras, principalmente a partir da encenação de $A$ classe morta (1975), espetáculo que se tornou uma lenda mundial. No teatro de Kantor existem vários elementos de sustentação, entretanto, o objeto, seja real, cotidiano ou construído exclusivamente para finalidade cênica, transpassa toda a sua obra. No entanto, Kantor nunca explicou satisfatoriamente essa ocorrência em seu teatro e em sua arte de uma maneira geral. Assim, esse trabalho trata de uma reflexão acerca do objeto no teatro de Tadeusz Kantor, tendo como tema central a demonstração do objeto como o elemento responsável pela criação de outra realidade, um outro espaço, onde os espetáculos acontecem. 
$\underline{\text { ABSTRACT }}$

Tadeusz Kantor (Poland - 1915/1990) was one of the most important men of theater of the 20th century. His theater has an intense connection with plastic arts and it was strongly influenced by the vanguards from the beginning of the last century: Constructivism, Bauhaus, Dadaism, Surrealism, and Expressionism. His theater is identified by the occurrence of strong and disturbing images, specialy after the "première" of The Dead Class. (1975), a play that became a world legend. In the theater of Kantor many support elements can be found, although, the object, being it real, dayto-day, or exclusively built for the scenic purpose, trespasses all his work. However, Kantor never explained satisfactorily that occurrence in his theater and in his art in a general way. Thus, this work is about a reflection concerning the object in Tadeusz Kantor's theater, having as a central theme the demonstration of the object as the responsible element for the creation of another reality, another space, where the play takes place.

PALAVRAS-CHAVES: teatro contemporâneo, encenação, vanguardas, imagens, objetos. 


\section{ÍNDICE}

ESCLARECIMENTOS INICIAIS - A PEQUENA HISTÓRIA DE TADEUSZ KANTOR NO BRASIL 01

$\underline{\text { INTRODUCÃO }}$ 06

PRIMEIRA PARTE - UM POUCO DE HISTÓRIA 06

SEGUNDA PARTE - UMA INTRODUÇÃO AO TEMA DA PESQUISA 11

CAPÍTULO I - CONSIDERAÇÕES SOBRE A IMAGEM E A FORMA NO TEATRO DE TADEUSZ KANTOR 18

Construtivismo - $\mathrm{O}$ amanhecer do teatro contemporâneo 20

O quarto da imaginação - onde as imagens se criam 44

Surrealismo - o reinado do desconhecido 58

CAPÍTULO II - OS OBJETOS E A POESIA DA MORTE DO TEATRO DE TADEUSZ KANTOR 72

OS MECANISMOS DA MORTE-VIDA 73

OS OBJETOS REAIS 73

A cruz 73

Os bancos de escola 80

A cama 86 As portas 90 
A ratoeira 108

$\mathrm{O}$ arco de Ulisses 115

A cama mecânica 119

A máquina fotográfica-metralhadora 125

O violino-realejo

OS OBJETOS CÓPIAS 137

A banheira com rodas 138

As metralhadoras 145

O tanque de guerra 150

O casaco de Ulisses 155

O pequeno carro 162

AS MÁQUINAS CÊNICAS 166

O velocípede 170

A máquina familiar 175

O berço mecânico 179

As máquinas de tortura 184

A trombeta de Jericó 190

CAPÍTULO III - A ESPECIFICIDADE DO TEMPO, DA MORTE E DO OBJETO-IMAGEM NA POÉTICA KANTORIANA 202

O EU DIVIDIDO E O TEMPO INVARIÁVEL 202

A MORTE COMO POÉTICA 209 
CAPÍtUlo IV - A REALIDAdE RELATIVA - O JOgo ENTRE REALIDADE E ILUSÃO, ESPAÇO E MEMÓRIA 226

A NEGAÇÃO DA ILUSÃO - O ESPAÇO REAL E O OBJETO REAL 216 O RETORNO DA ILUSÃO - MEMÓRIA: OUTRO ESPAÇO, OUTRO OBJETO_ 235 A RELATIVIDADE DO ESPAÇO E DA MEMÓRIA 243 OS NÍVEIS RELATIVOS DA ILUSÃO E DA REALIDADE 252

CAPÍTULO V - ILAÇÕES ACERCA DA VARIABILIDADE DO REAL DENTRO DA REALIDADE VARIÁVEL 265

OS ESPAÇOS MULTIDIMENSIONAIS 265

O DESLOCAMENTO DO REAL NO INTERIOR DA REALIDADE 271

CONCLUSÃO - UM TEATRO DE FRONTEIRAS 288

BIBLIOGRAFIA 297

\section{ANEXOS}

CONSIDERAÇÕES AOS ANEXOS 305

AS PEQUENAS ENCENAÇÕES - COMENTÁRIOS ACERCA DE ALGUMAS CRICOTAGES 308

UM CASAMENTO ENCENADO À MANEIRA CONSTRUTIVISTA E SURREALISTA 308

A MÁQUINA DO AMOR E DA MORTE 315

UMA LIÇÃO MUITO CURTA 319 
Ô DOCE NOITE 322

LIÇÕES DE MILÃO 327

NÃO VOLTAREI JAMAIS 410

APRESENTAÇÃO 411

TRADUÇÃO 414

HOJE É MEU ANIVERSÁRIO 483

APRESENTAÇÃO 484

TRADUÇÃO 487 563

CRONOLOGIA 576 


\section{ESCLARECIMENTOS INICIAIS \\ A PEQUENA HISTÓRIA DE TADEUSZ KANTOR NO BRASIL}

Tadeusz Kantor é relativamente jovem para o teatro brasileiro, apesar de toda a repercussão do seu trabalho pelo mundo. Mas, afinal, o que Tadeusz Kantor, um artista genuinamente polonês, significa para o teatro brasileiro? Nada, eu diria, pelo menos não em uma relação direta de causa e efeito. Entretanto, a importância do pensamento e das realizações cênicas de Kantor para o teatro mundial faz parte de muitas das nossas discussões diárias.

Nos últimos anos, a presença de Kantor no Brasil passou a se tornar mais efetiva, embora modesta. A nossa relação com esse polonês, até pouco tempo atrás se limitava a comentários de algumas pessoas que viram seus espetáculos na Europa ou em festivais em algum lugar do mundo. Uma situação muito pitoresca sobre isso, trata-se de um comentário feito nos anos setenta por Paulo Francis quando, na França, junto de Sábato Magaldi, disse que considerava um absurdo a atenção atribuída a Kantor pela intelectualidade francesa pois, para ele, Kantor era muito ruim, um sub-Beckett, apenas um cultor do grand-guignol ${ }^{1}$. Paulo Francis também atribuiu um comentário feito por Sábato Magaldi que, em se tratando das vanguardas, havia coisas melhores do que Kantor $^{2}$.

Apesar de não encontrarmos uma influência direta de Tadeusz Kantor no Brasil, muitos diretores que tiveram contato com a sua obra, foram indiscutivelmente influenciados por ele de alguma maneira. Gerald Thomas talvez seja o exemplo mais contundente disso. Recentemente, em uma entrevista concedida ao jornalista Marcelo Tas, no bate papo da UOL, realizada em 10 de agosto de 2007, Gerald Thomas atribui a

\footnotetext{
${ }^{1}$ Grand-guignol é um teatro de sentimentos e situações extremas que utiliza do pavor como propulsor do drama. Esse gênero teatral está circunscrito no tempo: de 1896 a 1962. Foi fundado por Oscar Metenier, em Paris, na região de Pigalle, que transformou uma antiga capela em teatro, adequando o espaço para encenações de espetáculos de horror naturalistas. O nome é freqüentemente usado como um termo geral para um tipo de teatro de entretenimento de horror amoral. Com 293 assentos, o teatro do Grand-guignol era o menor em Paris, e deve seu nome a Guignol, o boneco tradicional francês. O seu apogeu ocorreu entre a Primeira e Segunda Guerra Mundial quando foi frequientado pela realeza e diversas celebridades.

${ }^{2}$ Esse comentário sobre Tadeusz Kantor feito por Paulo Francis pode ser encontrado em $O$ dicionário da corte de Paulo Francis, organizado por Daniel Piza, para Companhia das Letras, Edição de 1996.
} 
Kantor a grande referência do seu teatro. Antunes Filho, no programa de Antígona, espetáculo encenado em 2005, também comenta sobre a possibilidade de Tadeusz Kantor ter influenciado, de alguma maneira, o seu pensamento e a sua forma de fazer teatro.

Além desses que tiveram contato direto com o teatro de Kantor, é possível observar questões relativas ao seu pensamento e sua poética em diversos outros artistas, mesmo que estes não o saibam. Evidentemente, os grupos que trabalham na congruência entre o teatro de ator com o teatro de animação, ou entre o teatro e as artes plásticas, lidam de alguma maneira com algum elemento que foi trabalhado e refletido por Tadeusz Kantor. Mesmo que Kantor não tenha, até então, uma ação direta de influência sobre o teatro brasileiro, as suas reflexões, pesquisas e realizações nos permitem pensar uma parte da nossa produção, aquela que tem a necessidade de ir além do simples fazer teatral. Tadeusz Kantor está sendo descoberto agora por nós, brasileiros, e a sua influência de forma mais ativa no teatro do Brasil talvez seja, acredito, um projeto daqui para o futuro.

Dentro das minhas observações pude mapear, simploriamente, o roteiro de Kantor no Brasil que começou com a sua participação, como pintor, na Bienal de Artes de São Paulo realizada em 1967. Após isso, oficialmente, teremos somente nos anos setenta, oitenta e noventa, a tradução de algumas entrevistas realizadas com Kantor e que foram publicadas nos "Cadernos de Teatro", publicação feita no Rio de Janeiro pelo "Tablado",

A partir dos anos noventa, teremos um interesse um pouco mais pontual por ele e por sua obra. Em 1993, em $O$ teatro de formas animadas ${ }^{4}$, Ana Maria Amaral faz um comentário sobre o objeto no teatro de Kantor. Em 1994, durante o quarto festival de teatro Ruth Escobar, tivemos a apresentação de um espetáculo realizado por alguns membros do antigo Cricot $2^{5}$. O espetáculo, segundo o autor do texto Andrzei Welminski, Maníacos (título em português) ${ }^{6}$, tratava-se de uma produção erigida sobre

\footnotetext{
${ }^{3}$ 1976, v. 68 - Conversa com Tadeusz Kantor - o objeto se torna ator; 1980, v. 87 - O teatro de Tadeusz Kantor; 1992, v. 128 - A arte é um tipo de exibicionismo.

${ }^{4}$ Amaral, Ana Maria, O teatro de formas animadas. São Paulo: EDUSP - 1993.

${ }^{5}$ Grupo de Kantor, assunto que será tratado em um momento específico desse trabalho.

${ }^{6}$ Their master's voice - título original.
} 
os postulados de Kantor. Basicamente, a memória era o foco principal. Em concomitância ao espetáculo, foi organizado um debate com Georges Banu, um dos principais teóricos do teatro de Kantor. Alguns dos jornais, de grande circulação, dedicaram alguns comentários sobre o espetáculo, localizando-o inevitavelmente à sombra de Kantor.

Em 1997, Sílvia Fernandes ao escrever sobre Gerald Thomas ${ }^{7}$, faz, em um momento do texto, relações entre o trabalho do diretor brasileiro e o do artista polonês. Ao que me parece, somente em 2001, Kantor voltou a fazer parte das discussões no país, propriamente em São Paulo. Através do SESC Belenzinho, a vinda do Ariel Theatre, grupo polonês, organizado por duas atrizes ${ }^{8}$ antigas participantes do grupo de Kantor, apresentou um espetáculo que se tratava de uma homenagem a ele: Pequeno réquiem para Kantor. Esse espetáculo também foi apresentado no festival de Curitiba. Durante as apresentações em São Paulo, mais que o espetáculo em si, o nome de Kantor, inevitavelmente, tomou conta da cena. Os espetáculos apresentados no Brasil, tanto Maníacos como o Pequeno réquiem para Kantor, se mostravam, conforme minha percepção, como um processo de "necrofilia teatral”, pois de Kantor havia muito pouco, embora Kantor estivesse sempre presente como sustentação da argumentação em relação aos objetivos das produções.

Durante as apresentações do Ariel Theatre em São Paulo, O SESC Belenzinho organizou uma mesa de discussão intitulada "As faces de Kantor". Alguns pesquisadores universitários se reuniram com a diretora polonesa para uma conversa sobre Kantor e o seu teatro. Durante a temporada, vídeos das produções de Kantor foram exibidos e uma exposição com fotos e publicações foi montada. Houve uma considerável participação de interessados em saber mais sobre tal teatro. Com reportagens feitas pelos principais jornais de São Paulo, e alguns de outros estados, Tadeusz Kantor deixou de ser objeto de estudo relegado à universidade e ganhou algum espaço fora dela. No mesmo ano de 2001, a Secretaria de Cultura do Estado de São Paulo, através da Oficina Cultural Carlos Gomes de Limeira, realizou uma exposição de imagens, fotografias e filmes dos espetáculos de Kantor durante a $4^{\mathrm{a}}$. Mostra de diálogos dramáticos.

\footnotetext{
${ }^{7}$ Fernandes, Sílvia. Gerald Thomas em cena-Memória e invenção. São Paulo: Perspectiva, 1996.

${ }^{8}$ Mira Richilika e Zófia Kalinska que também dirigiu o espetáculo.
} 
$\mathrm{O}$ interesse pessoal destinado ao tema que orbitava os desejos de alguns professores de algumas universidades, sobretudo a ECA (Escola de Comunicações e Artes da Universidade de São Paulo), estimulou alguns alunos, dois ao que me parece, eu, dentre esses, a iniciar uma pesquisa sobre o assunto. Em 2003, a minha dissertação de mestrado ( $O$ circo da morte - a especificidade do jogo entre o humano e o inanimado no teatro de Tadeusz Kantor) se tornou o primeiro trabalho acadêmico sobre Tadeusz Kantor realizado no Brasil. Alguns meses depois, na Universidade Federal de Santa Catarina, Maria Cecília Moretti defende a sua dissertação: Encanta o objeto em Kantor. No ano seguinte, em 2004, Márcia de Barros, também na ECA, apresenta a sua dissertação que estabelece uma relação de Kantor com as artes plásticas - Kantor, $o$ encenador e artista plástico. No mesmo ano, Antônio Abujamra, na encenação de $O$ que leva bofetadas ${ }^{9}$, usa em cena um personagem citação chamado Tadeusz Kantor. Um evento o qual acredito ter sido de fundamental importância, foi a presença de Michal Kobialka ${ }^{10}$, um dos notórios pesquisadores de Kantor, no Teatro Fábrica São Paulo, no ano de 2005 , onde realizou um ciclo de palestras.

Hoje, o interesse por Kantor tem avançado muito no Brasil. Existem alguns grupos de discussão na internet que tratam exclusivamente da sua obra. Mesmo nas universidades brasileiras, de uma maneira geral, o teatro de Kantor está deixando de ser um tema obscuro. Artigos estão sendo escritos, como nos dois primeiros volumes da "Moin Moin - revista de estudos sobre teatro de formas animadas", editada pela Sociedade Cultura Artística de Jaraguá do Sul em parceria com a UDESC (Universidade do Estado de Santa Catarina), na qual existem artigos sobre ele. A revista "Camarim"11, da Cooperativa Paulista de Teatro, assim como "Sala Preta - Revista de Artes Cênicas"12, da ECA-USP, publicaram artigos sobre Kantor durante a vinda de Michal Kobialka em $2005^{13}$. Anteriormente, A "Sala Preta” já havia publicado uma tradução do Manifesto do teatro da morte ${ }^{14}$, feita pela professora Sílvia Fernandes. Em 2007, em Leituras da morte, uma publicação organizada por Christine Greiner e Claudia Amorim, conta com uma tradução de um artigo de Kobialka chamado: Delírios da carne: arte e

\footnotetext{
${ }^{9}$ Texto de Leonid Andreiev traduzido e adaptado por Antônio Abujamra e Tatiana Belinky.

${ }^{10}$ Polonês, atualmente professor de teatro na Universidade de Minnesota, EUA.

${ }^{11}$ Ano 8, n. 35, 2005.

${ }^{12}$ V. 5, 2005.

${ }^{13}$ Michal Kobialka esteve por outras três vezes no Brasil, 2001, 2006, 2007, e, apesar de estar constantemente inserido na sua argumentação, Kantor não foi o foco desses encontros. $O$ evento organizado pelo Teatro Fábrica São Paulo sim esteve totalmente voltado para o seu teatro.

${ }^{14}$ V. 2, 2002.
} 
política no espaço do agora. Nesse texto, o autor, em um determinado momento, utiliza do teatro de Kantor e sua relação com a morte para exemplificar e sustentar a sua argumentação.

Em resumo, o interesse por Kantor como objeto de pesquisa está se intensificando a cada dia e espero que esse trabalho possa contribuir, de alguma maneira, com o processo de descoberta desse artista polonês, cujas produções teatrais aliadas a um pensamento muito específico acerca do teatro e a arte de uma maneira geral, transcendeu as fronteiras da Polônia para se tornar, ainda hoje, um dos mais importantes nomes da história do teatro mundial. Assim, a partir da ampliação das pesquisas e da constante presença de Kantor nos ciclos de discussão sobre teatro, é que poderemos vislumbrar o que Tadeusz Kantor, um artista que é produto de uma realidade aparentemente distante da nossa e que foi capaz de influenciar toda uma geração de homens de teatro pelo mundo, pode efetivamente fazer por nós, brasileiros. Eu pessoalmente acredito, obviamente movido pela paixão pelo tema que se apoderou de mim nesses dez anos, que as possibilidades para a pesquisa acerca da criação teatral são muito estimulantes. 


\section{INTRODUCÃ̃O}

\section{ASPECTOS GERAIS ACERCA DA PESQUISA E DA OBRA DE TADEUSZ KANTOR}

\section{PRIMEIRA PARTE - UM POUCO DE HISTÓRIA}

Tadeusz Kantor nasceu em 1915 em Wielopole, uma pequena vila polonesa situada próxima da fronteira com a Áustria. Diretor de teatro, realizador de happenings, pintor, cenógrafo, escritor, teórico da arte, ator dos seus próprios espetáculos, professor na Academia de Belas Artes da Cracóvia: Tadeusz Kantor merece o nome de artista total. Sua atitude artística se inspira no Construtivismo, no Dadaísmo, na Bauhaus e no Surrealismo. Kantor fez seus estudos na mesma academia na qual, posteriormente, se tornou professor, fez estudos de cenografia com Karol Frycz, eminente cenógrafo do período entre guerras, e que foi aluno de Edward Gordon Craig. Entre os espetáculos realizados por Kantor no período da juventude estão: Orfeu, de Jean Cocteau; Balladyna, de Juliuz Slowacki; O retorno de Ulisses, de Stanislaw Wyspianski. Essas são encenações realizadas pelo Teatro Independente Clandestino, fundado por ele, e que foram feitas em apartamentos privados durante a ocupação da Cracóvia pelos nazistas.

Após a guerra, Kantor trabalha como cenógrafo, principalmente para o teatro Stary da Cracóvia. Ele continuará a se ocupar da cenografia, principalmente a abstrata, até o fim dos anos 60. Em 1947, em uma viagem feita a Paris, ele receberá um novo impulso que o levará a reformular a sua concepção pessoal sobre a pintura. No ano seguinte, Kantor funda o "Grupo da Cracóvia” e participa da "Grande exposição de Arte 
moderna" na Cracóvia ${ }^{1}$. Esse foi o momento em que as autoridades comunistas impuseram o realismo socialista na arte levando Kantor a se retirar da vida pública. As telas que ele realiza após 1949 não serão expostas até 1955, um ano chave na sua vida que foi marcado pela fundação do Teatro Cricot 2.

A fundação do Teatro Cricot 2 foi uma iniciativa de Kantor com um grupo de artistas plásticos, críticos e teóricos da $\operatorname{arte}^{2}$. O Cricot 2 se tornou um campo livre, aberto para o exercício prático das suas idéias artísticas. A primeira criação do Cricot 2 foi $O$ polvo, texto de Witkiewicz ${ }^{3}$, em 1956. Em cena, Kantor faz a colisão de um texto sublime com um ambiente vulgar e banal, um café, uma espécie de bar. $O$ polvo expõe os elementos característicos do estilo teatral de Kantor: os atores se movem como marionetes, de forma que as técnicas de construção das cenas remontam aos filmes mudos.

No espetáculo seguinte, $O$ circo, trata-se da encenação de um drama de um membro fundador do grupo, o pintor Kazimierz Mikulski; neste, apresenta-se um outro componente da arte de Kantor: a Embalagem. Kantor utiliza-se de sacos plásticos negros, que envolvem os atores. A embalagem deveria esconder as verdadeiras formas dos personagens e dos objetos e os transformar em uma substância homogeneizada.

\footnotetext{
${ }^{1}$ Cracóvia foi a antiga capital da Polônia e o principal entreposto cultural do leste europeu até os primeiros anos do século XX.

2 Em 1955, junto com Maria Jarema, Tadeusz Kantor funda, na Cracóvia, o Teatro Cricot 2, nome que se trata de um anagrama de to cirk, o circo, que é uma homenagem ao primeiro Cricot, um café literário no qual se reuniam artistas das vanguardas dos anos 30 . No início, as atividades do grupo funcionavam em uma sala da Associação dos Artistas Plásticos da Cracóvia, e a partir de 1961, a sede é transferida para os porões medievais do antigo palácio Krzysztofory, atualmente, uma galeria que leva o mesmo nome. Em 1980, o Teatro Cricot 2 deixa as dependências da Galeria para se instalar na atual sede, situada na rua Kanonicza, 5, onde funciona o serviço de documentação da obra de Tadeusz Kantor e do Cricot 2 que foi chamada de Cricoteka.

${ }^{3}$ Witkiewicz (1885 - 1939), Dramaturgo, ensaísta, romancista e pintor polonês. Intelectual e artista, também chamado de Witkacy, marcou o teatro do século XX por seus trabalhos sobre "A forma pura" no teatro que antecipa alguns dos pontos e reflexões de Artaud expressas no "teatro da crueldade", e pelas concepções dramatúrgicas em parte realizadas pelo "teatro do absurdo" dos anos cinqüenta. Adversário do Naturalismo e do Realismo psicológico, ele se interessa pelo espetáculo, não como obra literária, mas preconiza a cena teatral como igualdade de elementos visuais, sonoros, gestuais, e conceituais. Ao propor a reabilitação da metafísica, ele anuncia as posições de Artaud. Redescoberto na Polônia a partir de 1955, sobretudo pelo trabalho de Tadeusz Kantor, Witkiewicz é considerado hoje um precursor do teatro moderno devido à importância que ele deu à forma na dramaturgia.
} 
A próxima etapa faz a passagem da embalagem para o Teatro Informal (196062), teatro automático, regido pelo acaso, pelo movimento da matéria. O espetáculo do Teatro Informal, A pequena mansão, de Witkiewicz, encenada em 1961, tira dos atores toda a individualidade, colocando-os no mesmo nível dos objetos.

O Teatro Informal se tornou insatisfatório para Kantor que o achou muito complexo, com um excesso de elementos supérfluos. Dessa forma, o Teatro Informal foi substituído pelo Teatro Zero que é desprovido de toda ação ou intriga (1962 - 64). O exemplo mais ilustrativo dos princípios do Teatro Zero foi a encenação de $O$ louco e a freira, também de Witkiewicz, representado em 1963.

Suas pesquisas no domínio da prática e da estética das ações cênicas conduzem Kantor além do teatro na sua acepção tradicional ${ }^{4}$. Em 1965, ele realiza os primeiros happenings na Polônia: Cricotage, e Linha de partida. Dois anos depois, ele realiza seus happenings mais notórios: A carta, e Happening panorâmico do mar Báltico. Tadeusz Kantor irá afirmar que o happening é uma continuação lógica das suas pesquisas e das suas ações nos domínios do teatro e da pintura.

"Até o presente, eu pretendia subjugar a cena, doravante eu renuncio a toda a cena, quer dizer, ao espaço que permanece em uma relação definida com os espectadores. Em minha busca por um espaço novo, eu tive à minha disposição, no princípio, toda a realidade da vida.",

Após a experiência do happening, Kantor volta finalmente a fazer teatro. Em 1972, ele encena As belas e os feios, de Witkiewicz, espetáculo que assimila alguns elementos do happening. O espetáculo A classe morta, encenação feita três anos mais tarde, marca o início de uma outra corrente na criação teatral de Kantor designada, por ele mesmo, como Teatro da Morte. Dessa corrente se desenvolverão as suas obras mais importantes: Wielopole Wielopole (1980); Que morram os artistas! (1985); Não voltarei jamais (1988); Hoje é meu aniversário (1990). Esse último espetáculo foi encenado no

\footnotetext{
${ }^{4}$ Tradicional para Kantor trata-se de um teatro de imitação baseado na exposição e resolução de conflitos.

${ }^{5}$ Kantor citado por Klossowicz, (crítico polonês). A citação faz parte do acervo da Cricoteka.
} 
ano seguinte à sua morte. Os últimos espetáculos possuem uma temática que se concentra sobre os motivos da morte, do fluxo do tempo e do espaço, da memória e da história que é perenizada. Os espetáculos do Teatro da Morte estão diretamente ligados ao principio da "realidade de classe mais baixa", presente em toda a obra de Kantor e está diretamente ligado à idéia de realidade degradada de Bruno Schulz ${ }^{6}$. Isso será esclarecido no decorrer desse trabalho.

Com a encenação de $A$ classe morta, produção que se tornou uma lenda mundial, cujas idéias teóricas e conceitos do espetáculo estão expressos no Manifesto do teatro da morte, foi o início daquilo que viria a ser chamado posteriormente de "Teatro da Memória”. Kantor considerava seu teatro, assim como a sua obra de uma maneira geral, como uma longa e perigosa viagem em direção do desconhecido. Com a estréia de Wielopole Wielopole, através de um investimento mais pontual da memória na cena, ele revive no palco o seu passado e a sua infância. Nesse espetáculo encontramos personagens da sua própria história pessoal, passagens bíblicas e acontecimentos que se cruzam e se completam evidenciando, alhures, momentos importantes da história da Polônia e da própria humanidade.

Com Que morram os artistas!, Kantor começa a falar da morte, da sua própria morte. Ele fala ainda do funcionamento da memória, da atitude criadora, do destino do artista e da obra de arte. Já em 1988, com Não voltarei jamais, ele revisita o espetáculo que havia encenado em 1944, durante a ocupação da Polônia pela Alemanha nazista - $O$ retorno de Ulisses - que se transforma em uma espécie de máquina da memória. Por se tratar de um espetáculo recapitulativo, Kantor coloca em cena os personagens das suas produções anteriores como convidados para a festa do seu casamento. Nessa ocasião, ele apresenta um comovente manifesto acerca da criação e da dor que acompanham o desenvolvimento e o fluxo da vida.

\footnotetext{
${ }^{6}$ Pouco conhecido fora da Polônia até alguns anos atrás, Bruno Schulz (1892 - 1942) é admirado, hoje, pelo mundo afora, como um dos mais extraordinários escritores da primeira metade do século XX. Kantor vê em Schulz um dos criadores da "Realidade degradada", que se tornaria o centro da sua própria obra. Bruno Schulz foi assassinado em 1942 por um soldado da SS.
} 
Hoje é meu aniversário virá se constituir no seu derradeiro trabalho. Este, no qual o artista encenaria a sua própria morte, não chegou a ser realizado plenamente pois em um dos últimos ensaios antes da estréia, Kantor, após um repentino mal súbito, foi levado para o hospital onde faleceu na madrugada do dia 08 de dezembro de 1990 . O espetáculo estreou no ano seguinte sem a presença de Kantor em cena. O interessante é que, desde o início dos trabalhos, em uma atitude quase que testamentária, ele cogitava a possibilidade de um espetáculo que funcionasse sem a sua presença no palco ${ }^{7}$. Hoje é meu aniversário, motivado pelo acaso, algo que sempre foi muito bem recebido por Kantor, deixou de ser possibilidade. No entanto, apesar da ausência material de Kantor em cena, pelas circunstâncias, a sua presença como abstração se tornou emblemática no decorrer do espetáculo.

Dizer que Tadeusz Kantor é um dos mais iminentes artistas poloneses da segunda metade do século XX, é dizer pouca coisa. Para a arte polonesa, Kantor significa aquilo que Andy Warhol é para a arte americana, ou Hélio Oiticica para nós brasileiros. Kantor é detentor de uma visão nova, construída independentemente do teatro. Tadeusz Kantor participante ativo das revoluções da neo-vanguarda; teórico da arte; inovador solidamente enraizado na tradição; pintor anti-pictural, happenerherético; dentre outras - essas são algumas das suas múltiplas aparências desse artista total. Kantor foi, dentre muitas coisas, um estimulador da vida artística na Polônia do pós-guerra. Ele foi uma das principais forças motoras. Não são exclusivamente as suas obras que determinaram a sua grandeza, mas ele mesmo, considerado na sua totalidade, como uma gesamtkunstwerk específica, englobando a sua arte, suas teorias e sua vida.

\footnotetext{
${ }^{7}$ É importante lembrar, que desde a encenação de A galinha d'água, uma das principais características das produções de Kantor com o Teatro Cricot 2 tratava-se da presença do diretor em cena junto com os atores. Kantor, conforme seu interesse, podia alterar o andamento ou reposicionar os atores na cena. Essa atitude de estar não somente no palco, mas na própria cena, era uma reação a um teatro de ilusão. A presença de Kantor se traduz como uma estratégia para inibir a ação da ilusão na cena, considerada por ele como o principal sustentáculo do teatro tradicional.
} 


\section{SEGUNDA PARTE - UMA INTRODUÇÃO AO TEMA DA PESQUISA}

Para o teatro atual, torna-se cada vez mais difícil encontrar um assunto que tenha relevância por sua originalidade. No entanto, o universo artístico de Tadeusz Kantor, ainda hoje, é um vasto campo de investigação e, mesmo que muito já se tenha dito ao seu respeito e sobre seu trabalho, ainda é muito pouco diante da potencia criadora do seu teatro. As possibilidades de jogo entre os homens, objetos e bonecos são elementos de singular importância pois abrem as portas para um outro universo situado em um nível de espaço/tempo distinto da lógica cotidiana. Um mundo desconhecido no qual as leis da lógica formal não podem ser aplicadas.

O teatro de Tadeusz Kantor é uma forma de gesamtkunstwerk, uma obra de arte total, e nem sempre é fácil alcançar os verdadeiros desígnios que inspiraram o seu trabalho. Nele, encontram-se variadas formas de expressão artística, dentre as quais o confronto entre o humano e o inanimado. Em uma leitura superficial, sobressai a impressão de um interesse obsessivo pela morte, pelos manequins e objetos. Impressão de que o humano pouco importa. Isso não é verdadeiro. Kantor não é obcecado pela morte, ele apenas manipula os seus signos em função da criação artística. Entretanto, o ser humano deve ter a consciência da sua condição de efemeridade, degradação e finitude pois, no final, o inanimado persevera e ao homem restará apenas a arte como realização de eternidade, porque, para ele, arte é sinônimo de eternidade. A arte e o homem são as suas maiores motivações.

A arte de Tadeusz Kantor é um universo em eterna expansão, rico em conteúdo e em realizações de imprescindíveis importâncias para o teatro no século XX e para a própria história do teatro universal. Um dos aspectos mais significativos desse universo polissêmico, que se distende a todo instante, refere-se à importância atribuída ao objeto. 
Em se tratando do objeto, na linguagem, coexistem freqüentemente dois termos que se sobrepõem a uma mesma realidade: de um lado aquela de "acessório"; do outro, de "objeto teatral". Sobre o plano lexical, o termo "acessório" (empregado como adjetivo) é antônimo de essencial, ou seja: é dado a ele um aspecto secundário. É sem dúvida a razão pela qual, em um momento dado, à ordem de uma mudança de perspectiva na arte do espetáculo, como comentam Gourgaud e Verdeil ${ }^{8}$, se efetuou a passagem de uma palavra à outra. Não é de maneira fortuita que especialistas como Anne Ubersfeld e Georges Banu falam de objeto teatral:

“...hoje o objeto faz parte do projeto global da representação."

Até o início do século $\mathrm{XX}$, o objeto no teatro sempre ocupou o lugar de acessório, um elemento a mais da decoração. Sempre foi usado como um complemento, um instrumento para ajudar o ator a compor a personagem. No entanto, em Kantor, como parte de uma tendência que reinterpretava o objeto na arte, entre as quais o Construtivismo, o Surrealismo e o Dadaísmo, o objeto passou a ocupar um lugar de destaque. Em seu teatro, o objeto é valorizado no sentido de se criar a tensão. Tensão que está presente entre os diversos elementos da cena. $\mathrm{O}$ ator não possui mais o privilégio de concentrar a atenção e de catalisar a emoção. O elemento humano é um dos componentes do jogo teatral e a emoção surge das infinitas possibilidades de arranjo dos elementos que compõem o espetáculo.

Tudo aquilo que está materialmente presente na cena, mesmo que colocado ao acaso, torna-se significante somente por sua presença no universo cênico e, conseqüentemente, possibilita a leitura de algum significado. Significado que está contido em um universo recomposto pelo trabalho artístico da cena. Tudo o que é figurável em cena e manipulável pelos atores, constata Ubersfeld, é objeto ${ }^{10}$. A priori, a presença do objeto em cena escapa a toda isenção e se supõe a plena consciência de uso.

\footnotetext{
${ }^{8}$ Gourgaud, N et Verdeil, J. Est-il acessoire de parler de l'objet thèâtral? In. L'objet, no. 41.

${ }^{9}$ Ubersfeld, A. Lóbjet thèâtral. Actualité des arts plastiques, n. 40. Paris: CNDP, 1978. p.107 a 136.

${ }^{10}$ Ibid. p. 109.
} 
Imediatamente pode-se ver a sua função mais evidente que é uma função utilitária. Com Tadeusz Kantor, devido à importância dada ao objeto teatral, verifica-se a ocorrência de uma mutação, relativa não mais a sua presença, mas ao seu emprego como "essencial" no desenvolvimento do espetáculo.

O objeto torna-se um elemento ativo da narrativa kantoriana e através dele é possível adentrar um universo enigmático e distinto da realidade prosaica da vida cotidiana. O objeto no teatro de Kantor possibilita a entrada naquilo que nesse momento nomearei de uma "outra dimensão espaço/temporal" constituindo, assim, as relações poéticas de uma arte que é resultante de um conjunto de procedimentos os quais resultam de uma análise introspectiva que o artista exercia sobre o seu próprio trabalho. Kantor é consciente de que o processo ou o comportamento do artista é um modo autônomo e completo de estar na realidade e apreendê-la; assim, a sua arte configura-se como um investimento em todas as dimensões do ser, assumindo como campo próprio o universo na sua totalidade.

Kantor dá significativa importância ao objeto. Ele não o utiliza somente como um instrumento de jogo. Ele o agarra, o anexa, despoja-o de seus atributos estéticos ou formais, imediatamente utilitários. Ele o priva de suas funções habitualmente reconhecidas para lhe atribuir um novo peso e uma nova existência. Embora o objeto continue a existir e a exibir a sua natureza mesma, as relações imediatas entre os significantes e os significados são destruídas em função da reconstrução de um novo conteúdo, ou seja: o objeto não ilustra mais o conteúdo. Ele é o próprio conteúdo.

De acordo com a sua convicção, os objetos mais pobres, desprovidos de quaisquer prestígios, são capazes de revelar suas qualidades de objetos em uma obra de arte. A existência desses objetos, utilizados à imagem do homem, mas sem nenhuma humanidade, é uma manifestação desse lado tenebroso, noturno, revoltado e cruel do ser humano. Nesta atitude sacrílega e nos sortilégios do pecado, observam-se os traços da morte transformados em princípio de conhecimento. O teatro de Tadeusz Kantor é algo como um mundo de mortos que revivem as suas lembranças. De uma maneira geral, essas lembranças estão associadas ao objeto que é o elo que permite a criação de uma 
relação entre o passado, presente, e o futuro. Fazer o objeto intervir no jogo é dar-lhe uma importância idêntica àquela atribuída ao humano, esse condenado ao desaparecimento rápido. Essa importância dada ao objeto, quase que em detrimento do homem, não é sem razão. Dentro da lógica e do universo de Tadeusz Kantor, assinala alhures Mira Rychlika ${ }^{11}$ :

“.... nós mesmos não somos dominados pelos objetos que nos rodeiam?"12

A relação entre o ator e o objeto é o elemento mais importante no Teatro Cricot 2. Nesta relação não existe o elemento principal. Kantor continuamente fala sobre o respeito pelo objeto. Não se podia considerar o objeto como um acessório de teatro, mas sim como um objeto preso à vida corrente. Uma cadeira era sempre uma cadeira, uma cruz sempre uma cruz. Kantor constantemente criticava a maneira dos atores tratarem os objetos, ele freqüentemente repetia, como provocação, que os objetos eram mais importantes do que eles. Assim comenta Luigi Arpine, ator, que trabalhou com Kantor nos anos 80:

“.... ele pegava certos materiais e os transformava nos bio-objetos. A primeira vez que eu representei com os bio-objetos, em Wielopole Wielopole, ele nos fez prestar atenção nos manequins ${ }^{13}$, porque eles eram mais fortes, mais dotados, que eles possuíam mais talentos que nós..." 14

Com tal procedimento, ele reforçava no elenco a modéstia, graça da qual o ator é melhor percebido pelo público.

\footnotetext{
${ }^{11}$ Atriz que trabalhou com Kantor por mais de 20 anos.

12 Skiba-lickel, A. L'acteur dans le thèâtre de tadeusz kantor. France: Bouffoneries, n. 26-27. 1991. p. 75 .

${ }^{13} \mathrm{O}$ manequim como manifestação da realidade mais trivial. Como um processo de transcendência, um objeto vazio, um artifício, uma mensagem de morte, um modelo para o ator. (Kantor, Le Theatre de La Mort, 1977, p. 220).

${ }^{14}$ Skiba-lickel, A. L'acteur dans le thèâtre de tadeusz kantor. France: Bouffoneries, n. 26-27. 1991, p.112.
} 
Kantor exigia que o ator tivesse com o objeto um contato real e não mecânico. Este processo já acontecia durante o período dos happenings realizados nos anos sessenta. Para ele, os movimentos do happening são os movimentos característicos da vida. Quando repetidos, os movimentos ocorrem em um outro sentido, eles deixam a realidade da vida e passam para realidade da arte, pois são privados da prática da vida: Kantor era excepcional em seu culto do objeto. Ele conseguia provocar situações que levavam o ator a se estender verdadeiramente através dele, e que articulados no jogo cênico, constituíam-se nos elementos fundamentais da construção do espetáculo. Seus espetáculos organizavam-se na fusão de elementos diferentes que possuíam o mesmo valor, ele trabalhava no mesmo sentido que o artista plástico objetiva destinar a sua obra para a eternidade. No entanto, o drama do teatro é que ele não se conserva, é uma arte efêmera condenada a desaparecer, daí a necessidade de Kantor em fazer do seu teatro uma experiência em que desapareçam as fronteiras entre a arte e a vida.

Explicar o problema do objeto no teatro de Tadeusz Kantor, suas diferenças em relação ao teatro tradicional e sua importância para o teatro contemporâneo não é uma missão fácil. Entretanto, o desejo de compreensão de certas questões levantadas pelo artista polonês, e que muito repercutiram e ainda repercutem no pensamento teatral, tornaram-se temas polêmicos e que, por muito tempo, ainda serão responsáveis por acirrados debates no mundo do teatro - dos quais: o confronto do ator com o objeto.

Desde a fundação do Cricot 2, gradualmente os objetos se multiplicaram a tal ponto que Kantor foi obrigado, em seu último espetáculo, Hoje é meu Aniversário, a abandonar projetos de construir outros. Ele sempre foi obcecado pelo objeto: cada vez mais numerosos e inusitados eles dominaram o espaço cênico tornando-se indissociáveis dos atores que os manipulavam como a uma prótese.

No desenvolvimento do teatro de Kantor, existe um processo de transformação do papel ou da função do objeto que é de significativa importância na evolução do seu trabalho e até mesmo para o teatro, de uma maneira geral. No entanto, pouco ainda se sabe sobre o sentido da natureza e do surgimento dessa ocorrência em seu teatro. Dessa 
forma, esse trabalho se constitui como um meio para uma revisitação aos objetos dos espetáculos a partir de $O$ retorno de Ulisses, procurando vislumbrar um caminho para um melhor entendimento desde as primeiras manifestações, abordando o tema no intento de verificar como os objetos, reais ou inventados, se postulam cenicamente, desde a abstração intelectual até a sua concretização cênica como objeto de arte, em função das transformações no curso de sua evolução na história do teatro de Kantor.

O objeto no teatro de Tadeusz Kantor sempre foi tratado pelos principais pensadores do seu teatro, dentre eles - Denis Bablet, Brunella Erulli, Guy Scarpetta como mais um elemento articulado dentro de um teatro total. A situação do objeto na arte, sobretudo no teatro de Tadeusz Kantor, suas significações e suas funções merecem, acredito, um estudo mais aprofundado.

Para Kantor, a criação artística necessita de enfrentamentos e riscos para que seja possível se engajar em um processo de descobertas constantes. Por esse caminho, o problema do objeto torna-se um desafio no conhecimento da sua gênese e, mais ainda, na direção do entendimento do teatro em um processo de criação no qual o objeto se torna ator. E no mesmo processo, o ator torna-se objeto. Assim, um dos fatos assumidos por Tadeusz Kantor trata-se de permanecerem seus atores eles mesmos, são os chamados ready-men, sobre isso muito já se falou em diversas publicações. Entretanto, Kantor nunca explicou, de fato, o sentido do objeto em seu teatro. Ao meu ver, toda a problemática da sua obra está ai: se os atores e os objetos permanecem na cena como eles mesmos, ou seja, como "objetos prontos", não metamorfoseiam a especificidade da sua natureza, como são capazes de produzir essa "realidade outra" e distinta da lógica da realidade cotidiana?

Para responder a essa questão, inicialmente será preciso falar um pouco das transformações da forma no teatro de Kantor e, como o objeto é o maior responsável pela construção das imagens dos espetáculos e da relação do seu teatro com a pintura, assim como alguns dos principais elementos que influenciaram a sua arte, como o Construtivismo, a Bauhaus, o Dadaísmo, e o Surrealismo, além das influências mais conhecidas, Marcel Duchamps, Meyerhold, Bruno Schuls, Witkiewicz, que foram de 
fundamental importância para a construção da sua poética. Na seqüência, o objeto no teatro de Tadeusz Kantor será apresentado em seu aspecto histórico no curso do desenvolvimento da idéia do objeto nas diferentes etapas de criação do Cricot 2.

Para tanto, selecionei vinte objetos ${ }^{15}$, os quais acredito serem, dentre tantos, aqueles que poderão nos dar uma visão geral e objetiva sobre os objetos nas diferentes fases de criação de Tadeusz Kantor e do Cricot 2, e como esses objetos estão necessariamente ligados à existência de um outro estado de realidade na qual os espetáculos de Tadeusz Kantor se realizam, constituindo-se assim como os responsáveis pela entrada e criação desse universo paralelo. O teatro de Kantor se constituirá, como veremos, como um processo de deslocamento do real no interior da própria realidade e, esse é o ponto central desse trabalho, ou seja: uma realidade que se configura a partir da própria realidade evidenciando a relatividade dessa mesma realidade.

\footnotetext{
${ }^{15}$ Eventualmente, no desenvolvimento, outros objetos serão citados a título de ilustração ou complemento da argumentação.
} 


\section{CAPÍTULO I}

\section{CONSIDERAÇÕES SOBRE A IMAGEM E A FORMA NO TEATRO DE TADEUSZ KANTOR}

Todo o trabalho de Tadeusz Kantor foi sempre uma reflexão cruzada entre a arte e a realidade que se fundamenta, desde o início, no desejo de destruir e de reconstruir a forma a partir da matéria bruta, liberar o objeto de sua função prática e fazer obra de arte com os dejetos da realidade, com a realidade abandonada e esquecida nas lixeiras. Sua arte se situa, então, entre a eternidade e as latas de lixo, no sentido de a arte tender à eternidade - e somente a arte pode ser eterna - e através dela o ser humano realiza o desejo da eternidade. Assim, Kantor busca fazer arte com aquilo que não tem mais utilidade para a vida prática e a lixeira torna-se o signo maior da degradação da matéria, fazendo eco ao conceito de "realidade degradada", expresso na obra de Bruno Schulz. Aos poucos, alguns elementos irão constituir um grande vocabulário cênico que se tornarão recorrentes em toda a sua obra.

Com o início das atividades do Teatro Cricot 2, ele desenvolve um processo criativo único, próprio, extremamente subjetivo, mas totalmente amparado em uma realidade vivida e experimentada. Não se trata de um trabalho apenas autobiográfico, não, é algo que, a partir das suas lembranças, ele traça suas contas com o martírio histórico do povo polonês, com a religião católica e o anti-semitismo, com a família, com o exército, dentre outros. A partir destas lembranças, em geral representadas com

\footnotetext{
${ }^{1}$ Para Bruno Schulz não existe a matéria morta. O estado de morte é apenas uma aparência. Desse pensamento, Schulz cria uma nova noção para a criação artística: a esfera da realidade degradada. E seguindo o mesmo princípio, Kantor desenvolve a idéia da "realidade de classe mais baixa". Em Schulz encontramos a personificação da matéria morta através dos manequins que devem ser utilizados na arte como um processo de uma segunda gênese. Em Kantor isso se transforma em um objeto que prende o papel principal, ainda que se torne igual ao da personagem humana, torna-se o elemento do seu corpo para se transformar em seu parceiro. A vida secreta da matéria morta que preocupa Schulz, Kantor a direciona para os objetos que tornam-se parceiros do ator, para as máquinas que tomam posse desse. Por outro lado, o manequim tornar-se-á o modelo do ator no teatro de Tadeusz Kantor. O manequim carrega em si o duplo sentido: a imagem de um homem e de um objeto, e dessa maneira Kantor realiza, não somente o sonho de Schulz, mas, em parte, os ideais de Kleist, Maeterlinck e Craig: criar o homem pela segunda vez conforme a imagem de um manequim semelhante a ele. Schulz personifica a matéria morta, ao passo que Kantor dá aos vivos os traços dessa matéria. Os atores se fundem com a imagem dos manequins e a vida se constrói conforme a imagem da morte.
} 
pouco ou nenhum afeto, seus espetáculos são espécies de "via crucis", um caminho tanto doloroso quanto blasfematório. De uma certa maneira:

"Kantor criou o arquétipo da sua própria commedia dell'art de uma peça a outra."”

Os personagens de Kantor se superpõem, revivem situações em um universo marcado pelo desespero, pela incapacidade de ação da consciência individual frente ao esmagador e brutal movimento coletivo dos governos e das próprias instituições artísticas (que não são menos agressivas e totalitárias) associadas ao desespero da guerra e à bestialidade humana da ação dos nazistas nos campos de concentração. Neste cenário de horror, degradação, impotência e morte, surge uma veia cômica, quase burlesca que transpassa o terror e a humilhação humana, criando um clima de ironia marcado pelos diálogos e pelo gestual freqüentemente cômico e grotesco dos atores. Diante deste espetáculo orquestrado na fronteira entre a vida e a morte, a matéria viva e a inanimada, a qual nos remete novamente a Bruno Schulz, e que "nunca havia aparecido na arte antes dele com tanta força de humor e ironia", , se inscreve uma reflexão sobre o teatro na qual, em uma civilização de consumo, Kantor propõe uma obra de arte desprovida de todo valor e de toda significação, portanto impossível de ser consumida.

Apesar da dimensão coletiva da produção teatral, para Kantor o teatro é algo de solitário da mesma maneira que solitária é toda arte pictórica. É evidente que em seu trabalho existem os atores, entretanto, por sua formação como artista plástico, ele cria uma obra com o mesmo grau de autonomia que um trabalho pictórico possui. Ele falava muito sobre a arte em geral, sobre os caminhos abertos pelas vanguardas do início do século e daquilo que ficou para os movimentos posteriores. A evolução das artes plásticas muito o preocupava,

“...ele tinha a necessidade de não se deixar adoecer em um só território do teatro"4.

\footnotetext{
${ }^{2}$ Eruli, Brunella. In, Corvin, Michel. Dictionnaire encyclopédique du trèâtre. Larousse, Bordas: 1988. p. 914.

${ }^{3}$ Id.Ibid. p. 913.

${ }^{4}$ Scarpetta, Guy. Kantor au present. Arles: Actes Sud, 2000. p.67.
} 
A arte do século XX configura-se e desenvolve-se através do choque de diferentes domínios artísticos, no qual suas funções e suas formas constantemente se entrecruzam e se distanciam, se provocam e se contaminam. O teatro de Tadeusz Kantor está situado, conforme comenta Guy Scarpetta, em uma “zona de desafio", um lugar de concorrência e interação entre duas artes: o teatro e a pintura, um processo criativo no qual ele "teatraliza a sua pintura e picturaliza o seu teatro", daí a sua força de invenção.

Após o final da guerra, e a consequiente ocupação da Polônia pelo Exército Vermelho, iniciando o período stalinista, ele se dedica ao trabalho de cenógrafo e concebe um novo espaço - o espaço nu ou espaço mental ${ }^{6}$ - e realiza cenografias de inspiração construtivista, o que o inspirará, em algumas das suas encenações, a partir de 1955 com a formação do Teatro Cricot $2^{7}$.

Para Kantor, o teatro é uma criação demiúgica e o espetáculo é uma obra de arte. Assim, não é possível pensar o seu teatro somente no domínio da encenação, desta forma, faz-se necessária a reflexão sobre alguns contextos da arte do século XX, dentre outras: o Construtivismo, o Abstracionismo, o Dadaísmo e o Surrealismo, e como estas dialogaram com o teatro de Kantor.

\section{CONSTRUTIVISMO - O AMANHECER DO TEATRO CONTEMPORÂNEO}

O nascimento do Construtivismo é tradicionalmente situado em 1915 com os primeiros contra-relevos de Tatlin, colagens não figurativas de materiais diversos

\footnotetext{
${ }^{5}$ Ibid. p. 138.

6 Basicamente trata-se de um espaço que não é psiquicamente construído. De uma maneira geral, o cenário arquitetônico era substituído por elementos soltos pelo espaço, como grandes manequins, como objetos diversos. Não existindo o espaço arquitetural, subsistindo apenas o espaço vazio, os objetos que se encontravam no espaço eram tratados como "buracos" na vida arquitetural. Essa concepção do espaço, segundo ele, permitia aos atores a agirem e se deslocarem pela cena sem se depararem com os obstáculos da arquitetura. Por outro lado, as correspondências que se estabeleciam entre os atores e os objetos, faziam com que o atores se movessem conforme as idéias e não em relação à arquitetura.

${ }^{7}$ Aquilo que é normalmente chamada de a "grande obra de Tadeusz Kantor" tem seu início em 1955, com a fundação do Teatro Cricot 2.
} 
(madeira, metal, vidro, etc.). Desde o principio, percebe-se o desenvolvimento de duas tendências diferentes: uma orientada na direção de novas pesquisas formais sobre a construção oposta à composição, ou seja: só o trabalho do material e as forças cinéticas; a outra, resolutamente anti-artística definida como "produtivista". A oposição entre estas duas tendências se concretiza pela publicação, em 1920, do manifesto dos irmãos Pvsner que se apresentam ao ocidente como os inventores do Construtivismo artístico. Existe, nesse período, coincidente com a revolução socialista, a adoção de contornos de uma utopia que desejava modificar os comportamentos do "novo homem" que nascia com a revolução. Esta modificação se daria em diversas frentes, tais como o habitat, as vestimentas, dentre outras, e também pela organização das possibilidades contidas nos novos organizadores sociais. Na maioria dos casos, o Construtivismo está ligado ao pensamento de esquerda, embora os objetivos políticos do movimento não fossem claramente afirmados. Em seu âmago, como comenta Aaron Scharf:

“...o construtivismo era acima de tudo a expressão de uma convicção profundamente motivada de que o artista podia contribuir para suprir as necessidades físicas e intelectuais da sociedade como um todo, relacionando-se diretamente com a produção de máquinas, com a engenharia arquitetônica e com os meios gráficos e fotográficos de comunicação. Satisfazer as necessidades materiais, expressar as aspirações, organizar e sistematizar os sentimentos do proletariado revolucionário - eis o objetivo: não a arte política, mas a socialização da arte."

De certa maneira, nenhuma outra arte esteve tão ligada à ideologia marxista e aos movimentos revolucionários como o Construtivismo. Antes dele, os artistas, pelo menos aqueles que tinham aproximações com o pensamento de esquerda, eram por muitas vezes motivados não somente por aspirações sociais e políticas, mas também por aquelas que eram estritamente formais. Apesar dos desmentidos:

“...o Construtivismo era de fato vermelho." 9

Com relação ao teatro, o Construtivismo surge do desejo de um grupo de artistas plásticos de fazer da cena um lugar de experimentação, desejo que remonta a alguns encenadores como Meyerhold que queria abrir o teatro para as novas formas plásticas

\footnotetext{
${ }^{8}$ Scharf, Aaron. Construtivismo. In. Conceitos da arte moderna. Org. Nikos Stangos. Rio de Janeiro: Zaar, 2000, p. 148.

${ }^{9}$ Id. ibid.
} 
redefinindo o status social da representação. Durante alguns anos, essa vontade comum resultou em verdadeiros projetos utópicos, espetáculos nos quais artistas plásticos, homens de teatro e teóricos diversos, buscavam criar sobre a cena um "laboratório da vida futura". Neste dispositivo a biomecânica ${ }^{10}$ tem um lugar central, sendo esta, como comenta Camila Gray ${ }^{11}$, a aplicação das idéias construtivistas no teatro. Este método acelerado de formação focalizado por Meyerhold submete os atores a um princípio de organização racional do trabalho, procurando obter, com o mínimo de tempo e de atividade, o máximo rendimento. Para tanto é preciso suprimir todos os movimentos inúteis. Esta percepção, tipicamente taylorista, buscava ainda a formação de um homem hábil e esportivo, cujos movimentos precisos e sem hesitações serviriam de modelo de trabalho-prazer ao público.

A primeira vez que se falou em construtivismo teatral foi em 1922 com a montagem de $O$ cornudo magnífico, dirigido por Meyerhold. Para esta encenação, Livbov Popova consagra uma fórmula que rejeita a idéia de decoração cenográfica: "a máquina para representar", tratava-se de uma estrutura de madeira leve, em vários níveis, recoberto de negro e vermelho e integrava um tobogã das portas e dos elementos cinéticos sob a forma de rodas que evocavam um moinho ${ }^{12}$. Todas as situações da peça se traduzem em saltos, quedas, perseguições nas quais a referência ao circo está sempre presente. Em outros espetáculos foram introduzidos objetos técnicos autênticos como um caminhão e motocicletas em movimento se avizinhavam com telefones e máquinas de escrever, além do uso de telas nas quais imagens eram projetadas. Popova construtora desses espaços cênicos buscava constante e insistentemente uma relação mais radical com o real. Por esse caminho, a encenação de Máscara de gás ${ }^{13}$, dirigida por Eisenstein em 1924, é representada em uma verdadeira usina a gás em Moscou. No entanto, "a utopia construtivista é irremediavelmente negada pela ficção teatral"14, tornando-se o Construtivismo, antes de tudo, a ocupação dos artistas plásticos:

\footnotetext{
${ }^{10}$ Método de treinamento do ator baseado na execução instantânea de tarefas "que lhe são ditadas de fora pelo autor, pelo encenador (...) Na medida em que a tarefa do ator consiste na realização de um objetivo específico, seus meios de expressão devem ser econômicos para garantir a precisão do movimento que facilitará a realização mais rápida possível do objetivo". In, Pavis, Patrice. Dicionário de teatro. São Paulo: Perspectiva, 1996, p. 33.

${ }^{11}$ Gray, Camila. O grande experimento da arte russa 1863 - 1917. São Paulo: Worldwhitewall Editora Ltda, 2004, p. 138.

12 Outros cenógrafos construíram estruturas semelhantes. Vesnine em 1923 construiu uma máquina de representar abstrata na qual integrava dois elevadores.

13 Texto de Tetriakov

${ }^{14}$ CH. Hamon-Sirejuls. Le construtivisme au théâtre. Paris: CNRS, 1992.
} 
“A teoria do Construtivismo não era só uma estética, mas uma filosofia de vida. Afetou não só o ambiente do homem, mas o próprio homem. O homem, este seria o rei deste mundo novo, mas um rei robô, uma entidade mecânica. Essa utopia vislumbrava um mundo no qual a arte não era mais um mundo de sonhos para o qual o trabalhador se retirava a fim de relaxar e recuperar seu equilíbrio, mas tornou-se a própria substância da sua vida."15

Entretanto, é fora da Rússia que o Construtivismo se une ao teatro. É na Bauhaus, no período entre guerras, que se opera a junção efetiva do Construtivismo com as pesquisas teatrais através de procedimentos originais que revelam um espírito construtivo em sentido amplo.

No início de Lições de Milão ${ }^{16}$, Kantor se dedica a alguns comentários sobre a Bauhaus:

"A abstração, no sentido mais radical, foi um fenômeno raro no teatro. Ela foi plenamente realizada na Bauhaus, no teatro de Oscar Schlemmer."17

Segundo ele, são os elementos da abstração e suas potencialidades:

“...o quadrado, o triângulo, o círculo, o cubo, o cone, a esfera, a linha reta, o ponto, as concepções do espaço, as tensões, os movimentos, são os elementos do drama.

Elementos estes possíveis de serem traduzidos em categorias filosóficas, humanas, psicológicas.

Cada um deles tem a sua essência, a sua irrevogabilidade e sua finalidade.

A linha infinita, o círculo contínuo, o ponto solitário, se pode com esses, assim como com todas as peripécias da vida, conflitos e catástrofes, criar um drama também interessante, tal qual uma tragédia grega.

A criação abstrata nasce, desenvolve-se, conquista o mundo, reina." 18

Em seus experimentos, Oscar Schlemmer, com o uso dos figurinos, dá ao corpo dos atores a aparência de uma estrutura forte através do arranjo de formas simples, as formas básicas da geometria. Nascia assim, no teatro pelo menos, o conceito da figura de arte por oposição à simples figura humana. Assim como as vanguardas do seu tempo, ele desejava livrar os homens do caos da vida e da tragédia cotidiana. Schlemmer,

${ }^{15}$ Gray, Camila. O grande experimento da arte russa 1863 - 1917. São Paulo: Worldwhitewall Editora Ltda, 2004, p. 138.

${ }^{16}$ Kantor, Tadeusz. Leçons de Milan. Paris: ACTES SUD - PAPIERS, 1990.

${ }^{17}$ Ibid. p. 16.

${ }^{18}$ Ibid. p. $16 / 17$. 
confrontando o corpo com o espaço, através da elementariedade do ponto, da linha e da superfície, do espaço e de suas leis, das posições do corpo lançado nesse espaço, faz com que um simples mover de dedos torne-se uma admirável aventura teatral. $\mathrm{O}$ ator, transfigurado pela abstração, se confronta com as leis determinadas pelo novo espaço no percurso da geometria abstrata configurada em seus gestos que se misturam aos volumes do cenário. Nesse processo simbiótico, o homem não é mais o artista. Ele torna-se a própria obra de arte.

Oscar Schlemmer fez diversas experimentações no teatro. Criou estudos e códigos de movimentos e buscou realizar novas linguagens. Ele se preocupou com os gestos dos atores e os significados de cada movimento. Cada elemento colocado em cena é metodicamente pensado e correspondia às necessidades visuais alicerçadas no desejo de compartilhar um sentimento espiritual com o espectador através de vivências poéticas abstratas. A emoção se dinamiza ao se aliar às leis da geometria e da matemática. Ele utiliza a simplicidade de figuras como o círculo, a linha, o cubo. Tratase de um momento original na história do teatro.

Tadeusz Kantor, a exemplo de Oscar Schlemmer, também realizou estudos sobre a abstração. Em 1985, por ocasião de um curso realizado em Milão, Itália, na Escola Municipal de Arte Dramática, Kantor faz uma exposição sobre abstração no teatro:

“(Em cena se encontram duas personagens, uma branca e outra negra).

A personagem branca marcha traçando um CÍRCULO.

O negro vai e vem traçando uma LINHA RETA.

No encontro da cena e na direção do fundo, ao lado do círculo.

Os personagens não executam nenhuma atividade prática da vida.

Eles não tratam de motivos psicológicos ou emocionais.

Eles pertencem, pois a uma composição abstrata.

Estas atividades se repetem e podem não ter fim.

Desta maneira, elas afirmam e se definem sempre mais fortes.

A repetição obriga à reflexão, à interpretação dramática.

Estudo: "o círculo e a linha reta".

Um personagem faz um círculo. O outro faz qualquer coisa de contrário em oposição ao CÍRCULO: A LINHA. 
Quando a linha reta se aproxima do círculo, o drama se intensifica.

Quando ela o ultrapassa e se afasta: o perigo desaparece pouco a pouco.

A repetição nos sugere o pensamento do infinito, o pensamento de nossa vida em relação ao infinito, da iminência de QUALQUER COISA de passagem e do desaparecimento..."19

É evidente o caráter anti-naturalista tanto em Kantor quanto em Schlemmer. Não há, evidentemente, nenhuma relação com o desenvolvimento de qualquer fator emocional ou psicológico. As forças que atuam no espetáculo, abstraídas da natureza e evocadas pela abstração, são capazes de revelar conteúdos muito mais profundos.

A propósito do Naturalismo, Kantor dizia que o Naturalismo é algo de artificial e ridículo, e mesmo as formas abstratas, quando aplicadas à construção de objetos são falsas e não passam de estilização. Para ele as formas abstratas puras existem por si mesmas, criam a sua própria existência, ou seja: uma existência concreta. A abstração e a cena possuem uma ligação intrínseca, ao passo que o Naturalismo, ao estimular a contemplação, constitui um obstáculo para a percepção da verdadeira obra de arte. Isso se dá pelo fato de as formas concretas atuarem de uma maneira muito mais imediata no mecanismo de compreensão humana e que, na sua superficialidade, a percepção humana responde mais rapidamente à objetividade das formas naturalistas. Entretanto, as formas abstratas não nos lembram nada e por isso agem diretamente no nosso subconsciente. Isso quer dizer que o expectador experimenta, ao invés de os distinguir e os analisar objetivamente. É por esta razão que, conforme as palavras de Tadeusz Kantor:

“...as formas abstratas são capazes de exprimir estados psíquicos."20

Tais formas se apresentam e se organizam das maneiras mais inesperadas e inusitadas e esperam o momento exato para ganhar exterioridade:

"Neste sistema, o objeto e o homem atraem sobre si toda a atenção."21

Para Kantor, a imagem abstrata (a cena) não é um ornamento. Trata-se de um mundo fechado, dinâmico, repleto de tensões e energias. Um universo próprio que

\footnotetext{
${ }^{19}$ Ibid. p. 21.

${ }^{20}$ Kantor, Tadeusz. Le Théâtre de la mort - Textes Réunis et Rassemblés par Denis Bablet. Lausanne: L'Age D'Home - 1977. p.38.

${ }^{21}$ Ibid.
} 
existe por si mesmo cuja esfera das formas abstratas penetra no subconsciente. Esta estrutura apresenta, sem dúvida, uma estrutura metafísica semelhante àquela de algumas tendências da Bauhaus. O próprio Oscar Schlemmer definia seu teatro como metafísico, ao passo que Kantor repudiava esta idéia, apesar de admitir a existência de misticismo na abstração:

“Alguém entre os ouvintes colocou esta questão.

Eu respondo: sim, existe misticismo na abstração.

$\mathrm{Na}$ abstração autêntica.

O "Quadrado negro sobre fundo branco" de Malevitch é um mundo.

O "fundo" branco é igualmente uma realidade.

Dois elementos formam a unidade.

Dois iguais a um!

O quadrado em Malevitch é uma realidade. Ele é o objeto.

Seus imitadores não eram mais que estetas.

Este quadrado real existe como conceito em geometria.

$\mathrm{Na}$ linguagem religiosa este quadrado é DEUS.

Através deste quadrado, nós podemos hoje, formular uma definição paradoxal: não existe diferença entre a abstração e o objeto.

E isto é uma UNIDADE MÍSTICA.

A ABSTRAÇÃO é talvez o conceito do OBJETO em um outro mundo, e cuja arte nos dá a intuição". ${ }^{22}$

Em Lições de Milão, Kantor fala sobre o espetáculo O Retorno de Ulisses, de 1944. Este trabalho marca o momento em que a abstração na Polônia cede lugar à realidade e só voltaria para lá nos anos cinqüienta e é através da arte informal, que acontece no período de 1955 a 1964, que Kantor faz sua incursão pelos caminhos das formas geométricas ou abstratas. É clara a existência de um fator que é determinante para esta ocorrência na obra de Tadeusz Kantor e da própria arte polonesa em geral. Trata-se de uma maneira da arte transcender a dolorosa experiência de duas guerras mundiais e da bestial época do genocídio nos campos de concentração. Permitindo-me aqui uma paráfrase a Theodor Adorno: qual o sentido da arte após Auschwitz? ${ }^{23}$

\section{“ANO DE 1944. CRACÓVIA. TEATRO CLANDESTINO. O RETORNO DE ULISSES DE}

\section{STALINGRADO.}

\footnotetext{
${ }^{22}$ Kantor, Tadeusz. Leçons de Milan. Paris: ACTES SUD - PAPIERS, 1990. p. 23.

${ }^{23}$ Nos primeiros anos após o término da Segunda Guerra Mundial, em um pronunciamento Adorno irá dizer que "fazer poesia após Auschwitz é imoral". Diante da reação que se desenvolveu, ele reformula a afirmativa transformando-a em pergunta: “como fazer poesia após Auschwitz?".
} 
A abstração existiu na Polônia até a explosão da guerra (isto não significa um fenômeno tardio).

$\mathrm{Na}$ época do genocídio bestial, ela desapareceu. Isto se produzia sempre em tais circunstâncias.

A crueldade que veiculava esta guerra era demais estranha à esta idéia purista.

A realidade era mais forte.

Toda idealização torna-se igualmente impotente,

a obra de arte, a estetizante reprodução tornaram-se impotentes.

O furor do homem encurralado pelo monstro humano excluiu A ARTE.

Nós tínhamos força somente para agarrar

AQUILO QUE ESTAVA SOB A MÃO, O “OBJETO REAL”,

e o proclamar como obra de arte!

No entanto era:

um objeto miserável, POBRE, incapaz de servir na vida, bom para ser jogados às sujeiras. Liberto de sua função vital, protetora,

nu, desinteressado, artístico!

Apelando à piedade e à EMOÇÃO!

Este era um objeto completamente diferente do outro.

Uma roda lamacenta de carroça.

Um pedaço de madeira podre.

Um andaime de pedreiro borrado de cal.

Um horrível alto-falante urrando comunicados de guerra...

sem voz...

Uma cadeira de cozinha...,"24

Kantor define a abstração como a ausência do objeto e é nesta falta que reside, ao seu ver, todo drama de abstração, que é também a ausência da figura humana. No teatro, existem formações que são espontâneas e que mesmo não estando presentes, não significa que elas desapareceram. O ato de carregar um objeto não significa a derrocada da abstração. Não, ela continua existindo em germe, esperando as condições propícias para germinar. Em O Retorno de Ulisses, a abstração é substituída pelo objeto real. Isto porque, diante da miséria, do genocídio e da degradação humana, a realidade era muito mais forte do que qualquer forma criada pela imaginação. Em face desta realidade degradante e degradada pelos horrores da guerra, Kantor se apropria dos objetos da realidade iminente a fim de explorar o seu potencial como objeto artístico em um meio no qual fosse possível estabelecer outras funções com outros elementos colocados no espaço. Em se tratando de O Retorno de Ulisses, este objeto tratava-se de um objeto pobre, miserável, incapaz de ter qualquer utilidade para a vida prática. Tratava-se de um

\footnotetext{
${ }^{24}$ Kantor, Tadeusz. Leçons de Milan. Paris: ACTES SUD - PAPIERS, 1990. p.18.
} 
objeto destinado ao lugar reservado para a sujeira e onde a inutilidade da matéria se define como forma: as latas de lixo. O espetáculo, que aconteceu fora do lugar predestinado às produções oficiais, ou seja, o teatro, desenvolvia-se em meio aos escombros de edifícios bombardeados pelo exército alemão. Neste espaço marcado pela realidade do dejeto, da podridão e da morte, um outro objeto aparece e é por Kantor despido e liberto de sua função real, objetiva, para ganhar um novo status na representação:

"Surge um objeto ARRANCADO DA REALIDADE DA VIDA, SUBTRAÍDA A SUA FUNÇÃO

VITAL, QUE MASCARAVA A SUA ESSÊNCIA, SUA OBJETIVIDADE.

Isto acontecia em 1916.

Marcel Duchamps fez isto.

Ele o despiu de todo o sentido estético.

Ele o chamou de "OBJETO PRONTO".

O objeto puro.

Se poderia dizer: ABSTRATO!

A abstração agia assim "subterraneamente." 25

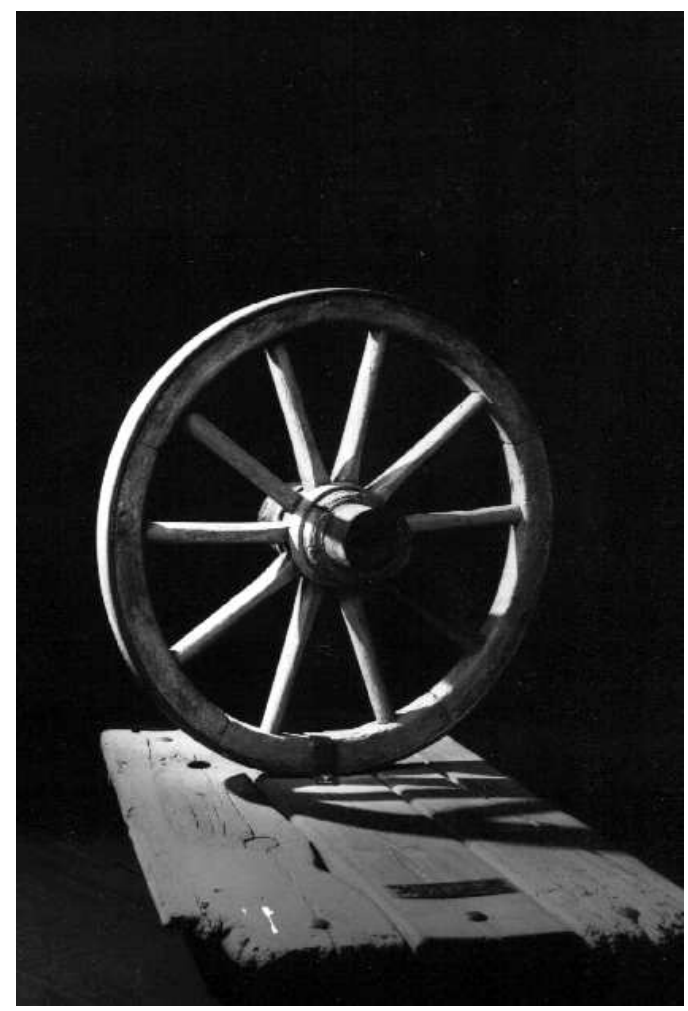

Tadeusz Kantor. Roda de canhão sobre prancha de madeira composição feita com objetos usados no espetáculo $O$ retorno de Ulisses - trata-se de uma citação a Marcel Duchamp. A obra está exposta no antigo atelier do artista. Foto: Janusz Podlecki.

25 Ibid. 
O cenário do espetáculo era composto por uma roda lamacenta, um andaime de pedreiro borrado de cal, uma cadeira de cozinha, dentre outros, cuja realidade era marcada pelos eventos mais marcantes da guerra e, segundo Wiesaw Boroski, citado por Michal Kobialka:

“... esta realidade não funciona como uma estratégia artística, mas sim como uma indução tática, que permitirá ao artista ser surpreendido, acidentalmente ou de forma inesperada, pela esfera desconhecida e ignorada da realidade que intervém na arte."26

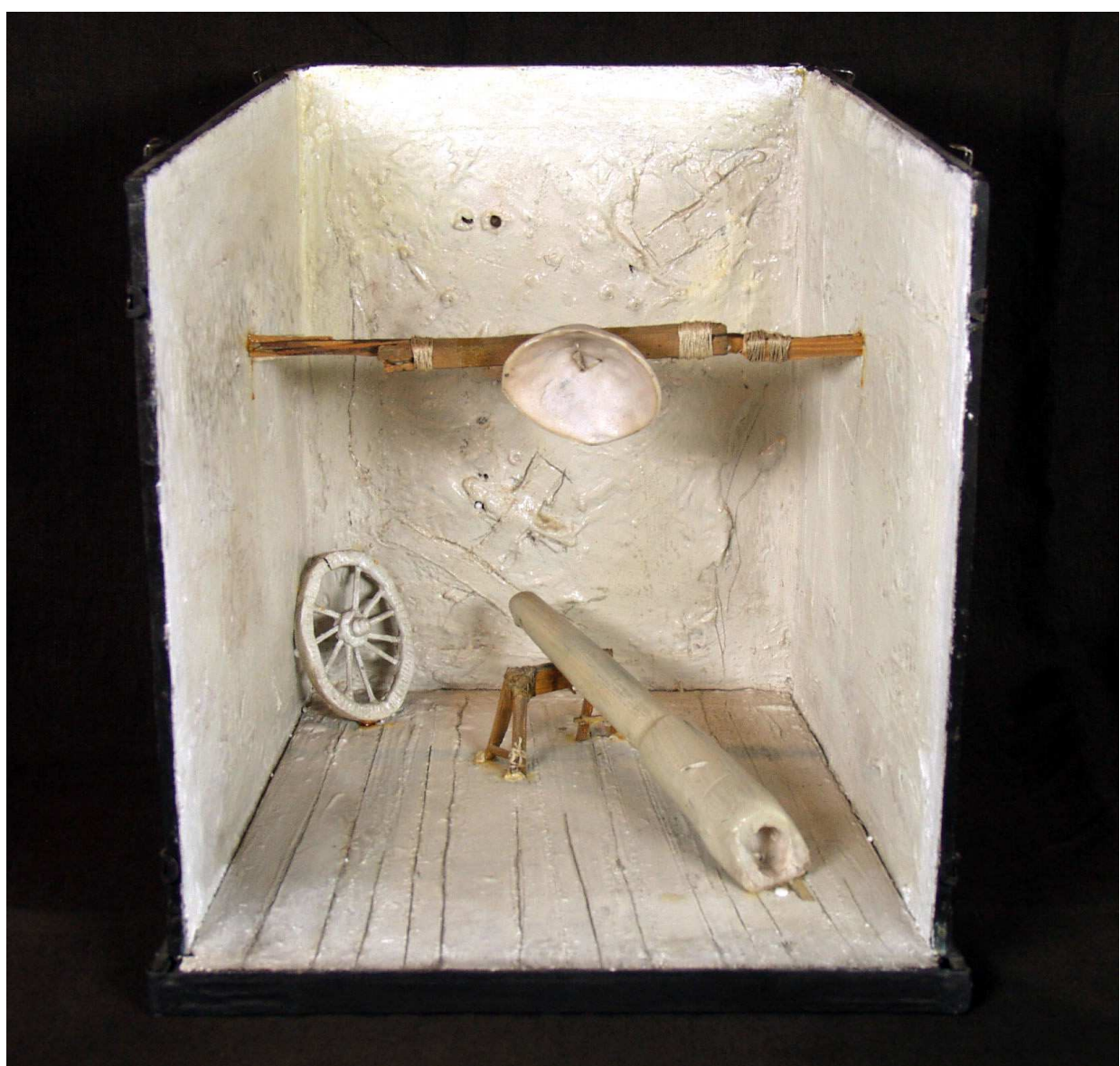

Maquete do cenário de $O$ retorno de Ulisses. Foto: arquivos da Cricoteka.

Apesar do retorno do objeto, a abstração ainda se encontrava no teatro de maneira subsumida ao objeto real; este, liberto de sua função vital, torna-se esvaziado de significação e revela a existência em si mesmo, não necessitando sua existência de

\footnotetext{
${ }^{26}$ Kobialka, Michal. O trabalho de Kantor. São Paulo: Camarim/Cooperativa Paulista de teatro. Ano 8, n.35. p.14.
} 
qualquer justificativa. Por este caminho, a imagem humana também é abstraída da sua significação. $\mathrm{O}$ ator, esvaziado da noção de imitação, integra-se plenamente aos demais elementos do espetáculo.

“A figura inclinada de um soldado com um capacete, usando um sobretudo surrado (de soldado alemão) em pé contra a parede, neste dia, seis de junho de 1944, ele se torna parte da sala."27

Neste espetáculo, a dimensão do drama de Stanislow Wyspianski é fundido por Kantor aos aspectos da vida contemporânea. Este retorno, conforme assinala Kantor, não se opera na dimensão da ilusão, mas na própria realidade. A ação se desenvolve no meio de objetos reais e em um espaço real. Ulisses é um homem real. Ulisses se recusa determinantemente a ser uma imagem, uma representação.

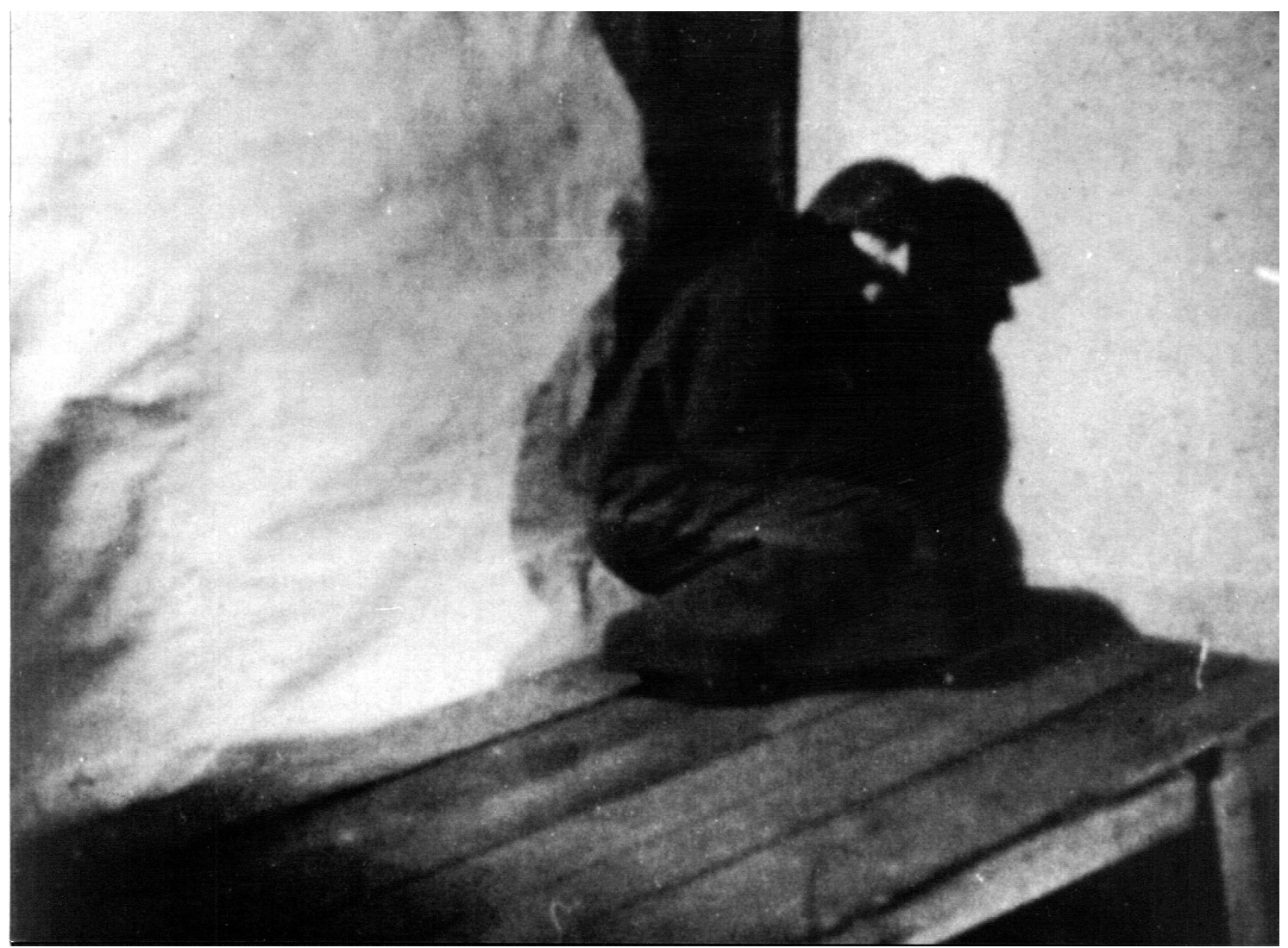

Cena de $O$ retorno de Ulisses. Um dos poucos documentos preservados do espetáculo. Foto: arquivos da Cricoteka.

27 Kobialka, M. A journey through other spaces. Essays and manifestos, 1944-1990 - Tadeusz Kantor. Los Angeles: University of California Press, Ltd. 1993, p. 272. 
Este homem real carrega sobre os ombros um manto, andrajos, com o qual se veste. Não se sabe ao certo quem é e o que é. Trata-se de uma massa disforme, literalmente irregular, não se sabe efetivamente o que é esta coisa. Movimenta-se, mistura-se e se liga aos demais objetos da cena. Em um dado momento, mostra seu rosto humano e, como já foi dito anteriormente, as formas abstratas que são capazes de exprimir estados psíquicos, evocam a abstração e seus sistemas que estão inevitavelmente soldados à cena, $\mathrm{e}$

“os sentidos do espectador, visão e audição, se concentrarão intensivamente e a esfera das formas abstratas penetrará no seu subconsciente" ${ }^{28}$.

Ao se revelar esta forma incompreensível, e porque não dizer abstrata, diz:

“...eu sou Ulisses, eu volto de Tróia.”

Neste momento a dimensão histórica do mito se funde à realidade da vida. No entanto, Ulisses não é a imagem ou reflexo do herói grego. Não, Ulisses é um homem atual ${ }^{29}$, comporta-se como um homem atual, sua Tróia todos sabem tratar-se de Stalingrado. Assim, o drama em cena não se passa diante dos olhos do espectador, mas torna-se um contínuo "devir" no qual o desenvolvimento dos acontecimentos é espontâneo e imprevisível.

A Segunda Guerra Mundial modificou o desenvolvimento de uma vanguarda na arte polonesa. Neste período de transformação, com a descoberta da realidade, Kantor faz uma série de reflexões sobre a arte e suas convenções que se estende até 1963. $O$ Retorno de Ulisses foi de fundamental importância para a elaboração de alguns dos seus principais conceitos, sobretudo o espaço, noção que será desenvolvida oportunamente. Mas voltando à questão da abstração, após esvaziar o objeto da sua natureza prática, livrando-o da ditadura da utilidade e a sua promoção a objeto de arte, esta atitude constitui-se como um ato demiúrgico e, como já foi dito, a criação artística para Kantor é demiúrgica e cada acontecimento em cena ocorre como se fosse feito pela primeira vez. Ao se utilizar de uma cadeira quebrada, destinada ao lixo por sua falta de utilidade,

\footnotetext{
${ }^{28}$ Kantor, Tadeusz. Le théâtre de la mort - Textes Réunis et Rassemblés par Denis Bablet. Lausanne: L'Age D'Home - 1977. p. 38.

${ }^{29}$ Lembrando que essa atualidade trata-se da Europa dos anos 40.
} 
este ato de sentar torna-se um ato único, primordial e em meio aos escombros, a arte, o teatro escreve um novo capítulo do gênesis. Uma nova fase da criação, criação puramente humana - original, genuína, sem intervenção divina. Uma criação associada à realidade da vida que se utiliza dos dejetos da vida.

"Pela primeira vez na história, o objeto aparece liberto de sua função vital.

Ele torna-se vazio.

Ele não se justificava mais pelas circunstâncias estranhas, mas por ele mesmo.

Ele revelou a sua existência.

E se uma ação, decorrente de sua função estava a ele ligada, isto era de tal forma que esta ação teve lugar pela primeira vez após a criação do mundo.

Em O Retorno de Ulisses, Penélope sentava sobre uma cadeira de cozinha, manifestando, mostrando ostensivamente - o estado de estar sentado - como um primeiro ato "humano".

O objeto adquire uma função histórica, filosófica, artística!"30

A primeira encenação que Kantor realizou foi uma peça romântica, Balladyna, de Juliusz Slowacki, espetáculo em que ele transpôs para o palco formas inspiradas pela Bauhaus em uma erupção da forma abstrata na realidade do drama e da cena. Já em $O$ retorno de Ulisses, a promoção do objeto real elevado à condição de objeto de arte, o uso da vida real, promove o aparecimento de formas cênicas ilusórias que agiam subliminarmente no processo de desenvolvimento da abstração. Por este caminho, por paradoxal que seja, ao se voltar para a realidade, e por mais que tenha se empenhado em abstrair toda forma real, Tadeusz Kantor inevitavelmente desperta a ilusão que estava escondida atrás do gesto criador, do pensamento construído, dos atores que são percebidos como signos. Assim, faz-se necessário encontrar meios para afastar a ilusão da cena e encontrar as condições para a edificação de uma obra que não tenha nenhuma causa anterior.

Na encenação de $O$ casamento, realizada em Milão em 1986, na primeira parte, que se tratava de um exercício sobre o Construtivismo no teatro, Kantor desenvolveu com os atores, que participaram do estágio, suas noções sobre a abstração. Dos elementos básicos da abstração, apontados por Kantor, ainda se incluem o espaço, a tensão e o movimento que, segundo ele, são noções indispensáveis para o teatro. Nos estudos teóricos que sustentaram o espetáculo, Kantor desenvolve um metódico estudo

\footnotetext{
${ }^{30}$ Kantor, Tadeusz. Leçons de Milan. Paris: ACTES SUD - PAPIERS, 1990. p.19.
} 
sobre a abstração para, em seguida, estabelecer e definir a sua concepção sobre o espaço e as forças que nele atuam; noções que merecerão um estudo aprofundado no desenvolvimento deste trabalho, mas que, para o espetáculo, se tornaram a base para a sua concepção sobre o Construtivismo no teatro.

Segundo Naum Gabo, o Construtivismo trata-se do primeiro movimento artístico a aceitar e assumir o espírito da era científica, fazendo dele a base para as suas percepções do mundo exterior e interior à vida da humanidade. O Construtivismo estabeleceu-se como a primeira ideologia do século XX a negar a crença de que apenas a personalidade do individuo deveria servir de valor para a criação artística. Esta atitude revolucionária instaura uma nova percepção e um processo de reflexão quanto à finalidade da arte e quais os desígnios do artista. Existe uma concepção de que o conhecimento que nos é dado pelo sentido não é o suficiente para que tenhamos uma ampla percepção da natureza e da vida. Existem forças muito maiores e profundas que se escondem do a-priori dos sentidos. Nestas profundezas habitam forças e valores nunca vistos mas que, por vezes, acabam, sem o controle, ganhando forma através de algum tipo de imagem ou sensações capturadas pela razão ou pelas percepções imediatas dos sentimentos da vida cotidiana e da natureza. A ideologia construtivista rejeita este tipo de percepção, exigindo do artista a mais alta exatidão de meios de expressão de todos os campos da criação humana. Kantor, sem dúvida, era sensível à esta necessidade, não só do desenvolvimento, mas também do conhecimento dos meios de expressão e sua produção.

"É necessário abraçar toda a arte para compreender a essência do teatro. A profissionalização teatral conduz o teatro a sua derrota. Isto é uma opinião particular.

O teatro não tem pontos de apoio específicos.

Ele se apóia sobre a literatura, o drama, a arte visual, a música, a dança, a arquitetura.

Mas tudo isso "caminha” para o teatro, mas não provém dele.

Tudo isso servirá igualmente ao teatro como matéria.

Assim, tentaremos descobrir a matéria original, "a UR-MATÉRIA",

a PROTOMATÉRIA do teatro, o "ELEMENTO ESPECÍFICO” do teatro.

Independente! Autônomo!

Se tivermos êxito, isso será paradoxalmente a conseqüência do conhecimento de TODA A ARTE contemporânea, de sua idéia, de sua problemática, de seus conflitos..., 31

\footnotetext{
${ }^{31}$ Kantor, Tadeusz. Leçons de Milan. Paris: ACTES SUD - PAPIERS, 1990. p.16.
} 
Após o esclarecimento dos pontos fundamentais e necessários para a elaboração da concepção do espetáculo, para a encenação de $O$ casamento, é instalada em cena uma "máquina de representar", idéia que remonta aos primeiros construtivistas. Este "aparelho cênico" foi construído com materiais encontrados no depósito do teatro. Elementos como: uma plataforma e tábuas de madeira, postes, uma roda de bicicleta, dentre outros. Os utensílios utilizados não representavam objetos e não eram cenários. Tratavam-se de dispositivos que ajudavam os atores a se moverem sobre diferentes níveis favorecendo a ampliação das possibilidades de movimentos, o que não seria possível realizar em uma cena plana. Esta construção está liberada de qualquer tema, de qualquer imagem utilitária, uma construção que se comporta como uma escultura, e em escultura, assim como nas atividades técnicas, qualquer material é bom, valioso e útil, pois cada material específico tem seu próprio valor estético:

“...em escultura, assim como nas atividades técnicas, o método de trabalho é determinado pelo material" 32 .

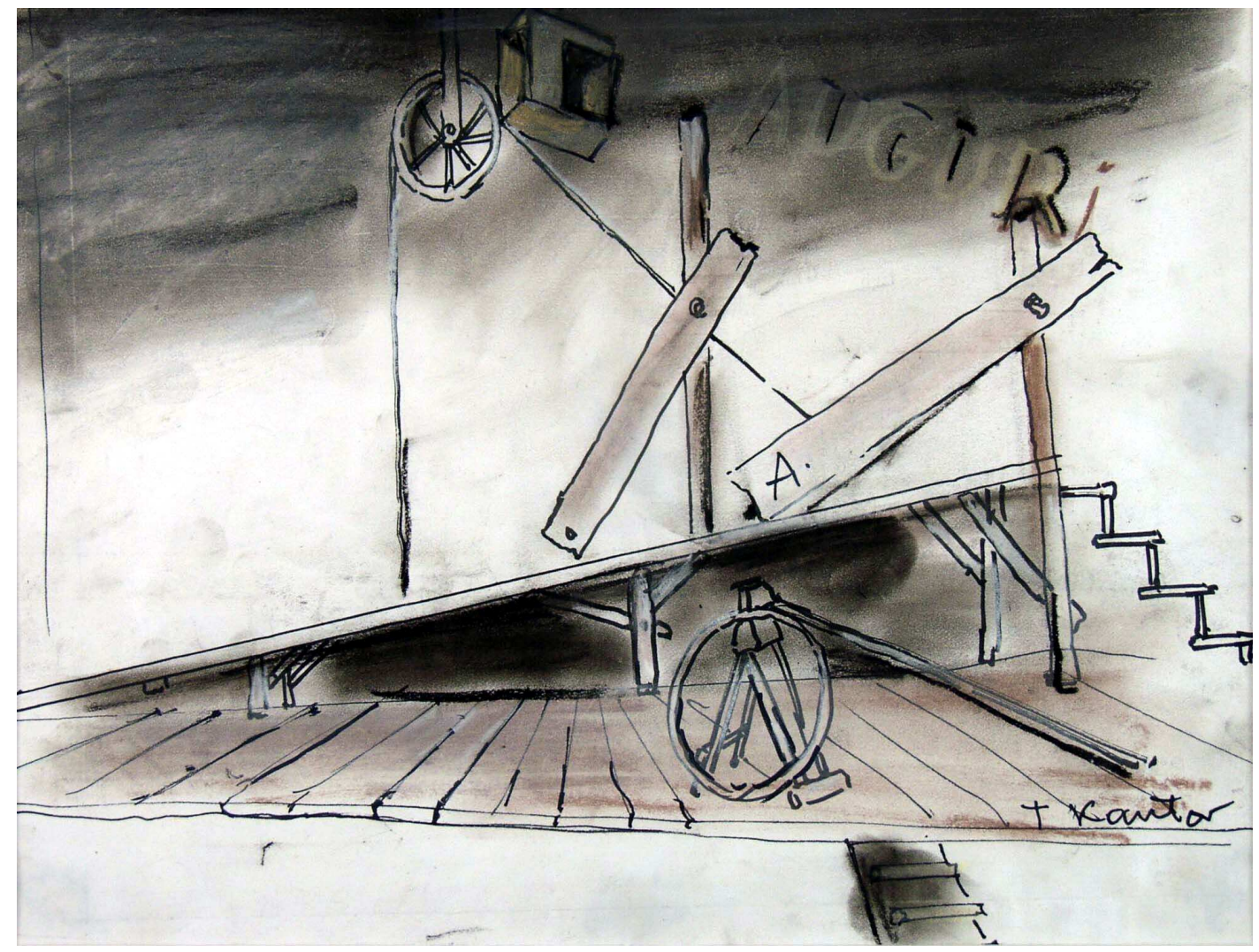

Desenho do cenário de $O$ casamento na versão construtivista. Foto: arquivos da Cricoteka. ${ }^{32}$ Gabo, Naum, In, Rickey, George. Construtivismo - Origens e evolução. São Paulo: COSAC \& NAIF,
2002. p. 48. 
Esta "máquina de representar" segue os mesmos princípios de construção das vanguardas construtivistas do início do século $\mathrm{XX}$ que tinham, como um dos objetivos, liberar a arte do mundo representacional. O Construtivismo englobou tanto a pintura quanto a escultura e absorveu muitas das idéias do Suprematismo e não se restringiu ao "construído" a partir de materiais industriais. Também não se limitou à geometria pura nem, tão pouco, canonizou o espaço vazio:

"O caráter essencial da arte construtivista não se concentrava no estilo, no material ou na técnica, mas sim na imagem. Esta requeria do artista uma alteração radical de idéias que se mantinham há milhares de anos. Agora, a imagem em si mesma era real. Gabo resumiu a questão da seguinte maneira: “...não fazemos imagem de...",33

Tadeusz Kantor, seguindo um princípio semelhante, ao se reportar ao texto teatral, dizia a propósito da encenação de uma peça de Stanislas Ignacy Witkiewicz:

“...nos não representamos Witkiewicz, nós jogamos com Witkiewicz.”34

Aqui, tanto em Gabo quanto em Kantor, existe um completo repúdio ao conceito de mimeses.

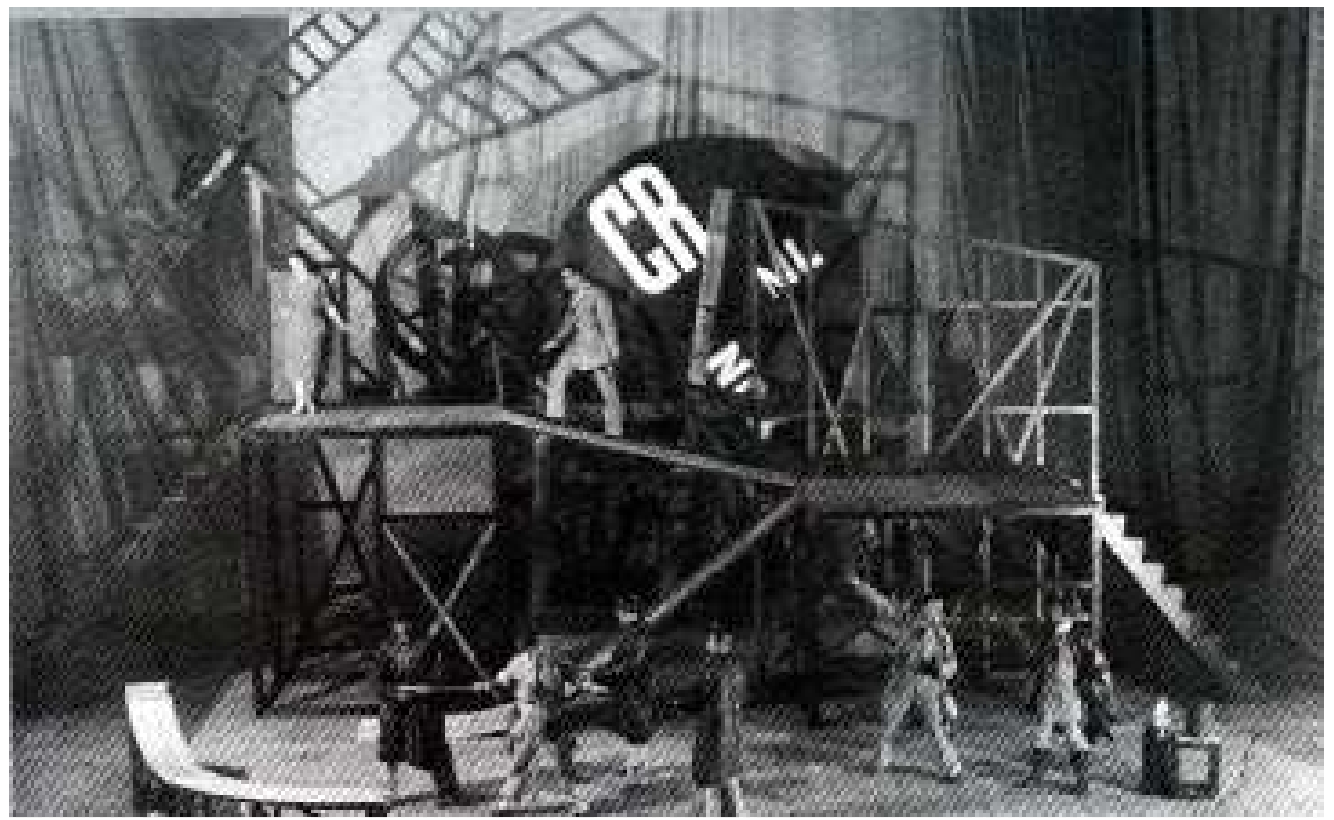

Cenografia para o espetáculo - O cornudo magnífico - dirigido por Meyerhold em 1922. Foto retirada de Gray, Camila. O grande experimento da arte russa 1863 - 1917. São Paulo: Worldwhitewall Editora Ltda.

\footnotetext{
${ }^{33}$ Rickey, George. Construtivismo - Origens e evolução. São Paulo: COSAC \& NAIF, 2002. p. 57.

${ }^{34}$ Kantor, T. Les voies de la création théâtrale, études de Denis Bablet et Brunella Eruli, réunis et présentés par D. Bablet, Paris, C.N.R.S. Vol. XI, 1983, p. 39.
} 
Originalmente, o Construtivismo não objetivava ser uma forma de arte qualificada como abstrata. Sobre isso comenta Aaron Scharf:

“...o Construtivismo não pretendia ser um estilo abstrato em arte, nem uma arte per se” ${ }^{\text {. }}$.

Posteriormente, devido ao insistente uso de figuras geométricas, alguns artistas perceberam na geometria e na uniformidade das cores puras, a existência de uma organização racional. Uma organização que eles queriam impor à sociedade.

O teatro construtivista, no modelo de Kantor, limitar-se-á aos aspectos mais essenciais da construção cênica, incorporará elementos dos jogos populares e o ator será um comediante, um saltimbanco, um homem do circo:

"O CIRCO se misturará aos ecos da realidade presente, e aos elementos compatíveis com a natureza dos andaimes.. ${ }^{36}$

A primeira parte do espetáculo, encenado em Milão tem como título $O$ casamento e será um exercício sobre o Construtivismo. Trata-se da realização de um tema composto por acontecimentos da vida cotidiana. Há, pois, nesse trabalho, a exemplo de $O$ Retorno de Ulisses, uma realidade que se conecta com outra. Aqui, existem a realidade do tema e a realidade das ações, além da atmosfera ritual comum a todo casamento. Estes elementos deverão ser quebrados, destruídos pelas ações em função do lugar e dos objetivos das ações:

"Em conseqüência, o curso naturalista da atividade vital encontra formas que nas categorias da vida podem parecer bizarras, absurdas, desprovidas de sentido lógico, provocantes, incompreensíveis, mas nas categorias da arte, elas tornam-se AUTÔNOMAS, não reproduzem nada, nada informam, e já falamos claramente sobre isto, que a partir de agora é dito, isto que é o original e reconhecido como tal.

FORMAS AUTÔNOMAS, OBRAS AUTONÔMAS

LIBERTAS, NÃO SUBMISSAS!"37

\footnotetext{
${ }^{35}$ Scharf, Aaron. Construtivismo. In. Conceitos da arte moderna. Org. Nikos Stangos. Rio de Janeiro: Zaar, 2000, p. 148.

${ }^{36}$ Kantor, Tadeusz. Leçons de Milan. Paris: ACTES SUD - PAPIERS, 1990. p.34.

${ }^{37}$ Ibid. p. 35.
} 


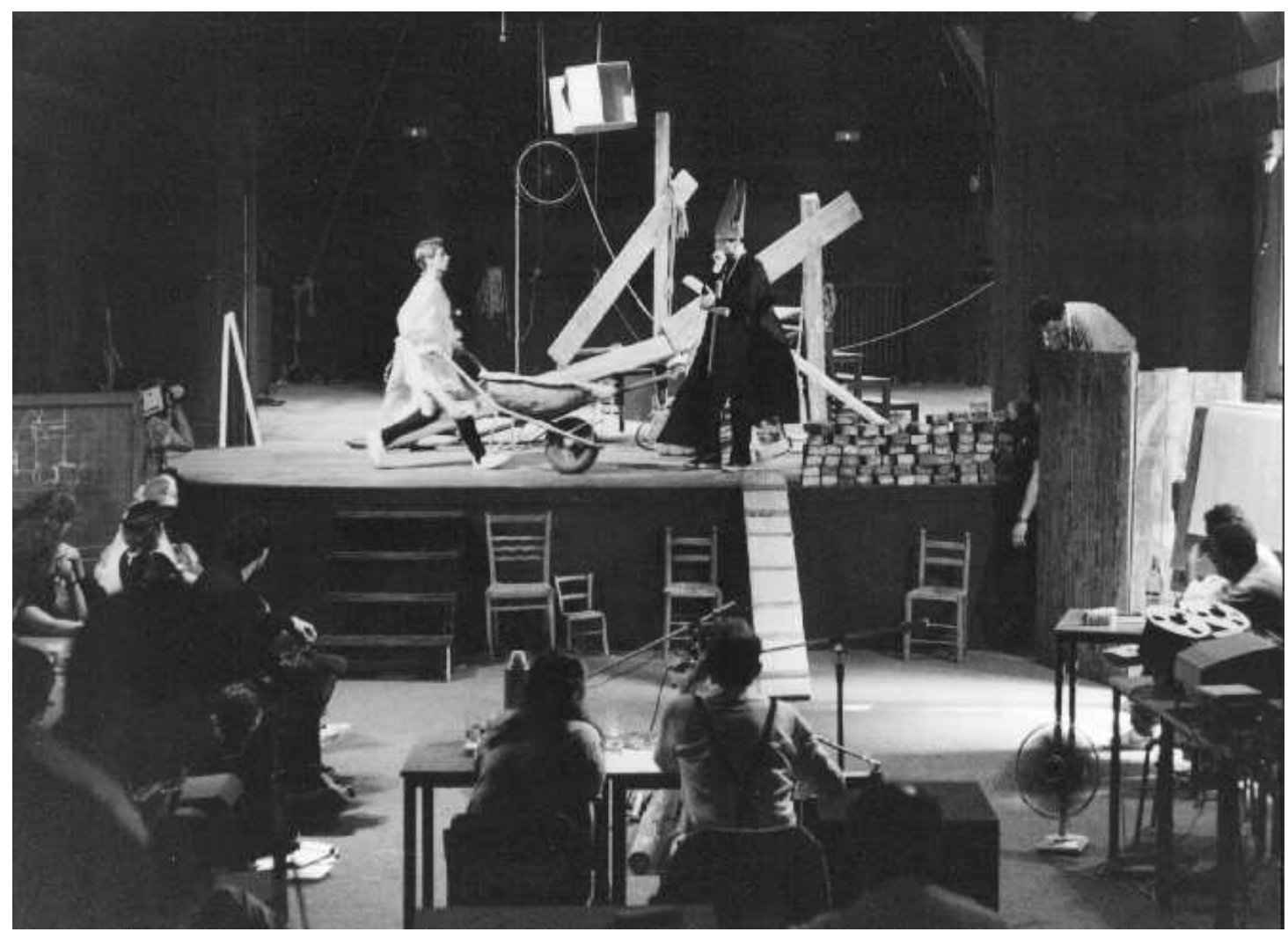

Ensaio da primeira parte de O casamento. Foto: Fábio d’Amico.

É muito difícil distinguir as experiências teatrais e picturais de Tadeusz Kantor. De uma certa maneira, sua pintura e seu teatro são partes de uma mesma experiência. Suas primeiras descobertas aconteceram através do desenho e da pintura, mas uma arte não vive em função da outra, mas com a outra:

“...trata-se de fazer o mesmo tipo de descoberta, com o mesmo risco, de se comportar com o mesmo tipo de liberdade...",38

Tadeusz Kantor:

“...contribuiu como nenhum outro para liberar a arte da encenação de sua função ilustrativa, para fazer dela um lugar de exploração de territórios desconhecidos, jamais vistos, e que não existem fora deste teatro..., 39 .

\footnotetext{
${ }^{38}$ Scarpetta, Guy. Kantor au present. Arles: Actes Sud, 2000. p.32.

${ }^{39}$ Ibid. p. 15.
} 
O seu trabalho trata-se então de uma arte liberta e liberada de toda e qualquer preocupação com a imitação. Uma linguagem que, antes de tudo, constitui-se como plástica na qual todos os elementos teatrais se constituem como independentes de toda e qualquer função ilustrativa, e nenhum elemento está subordinado a outro. De uma certa maneira ele realiza o desejo utópico de Antonin Artaud:

“...de uma arte que não seja o reflexo da vida, mas se situe do mesmo lado, no qual cada espetáculo seja percebido como uma ação real, e não a reprodução de uma ação..." ${ }^{40}$.

Para Kantor trata-se da realização de uma obra que não dependa da natureza e que seja totalmente auto-suficiente, que exista unicamente por existir. Uma arte que não represente e não seja a imitação de nada.

Kantor dizia não possuir cânones estéticos ${ }^{41}$, sendo Meyerhold, assumidamente a única influência admitida por ele. No entanto, esta influência configura-se muito mais como inspiração de um movimento artístico revolucionário do que uma influência poético-formal. É claro que as barracas de feira, o circo, a commedia dell'art são estruturas comuns aos dois encenadores e, sem dúvida, tratam-se de alguns dos fundamentos formais da linguagem kantoriana. Por outro lado, aquilo que se tornou em Meyerhold a base do seu trabalho com o ator no universo construtivista, distancia-se radicalmente do interesse do encenador polonês, o corpo do ator no teatro. O status do trabalho do ator no teatro de Kantor emana da sua presença real. Neste caso, a representação é levada a um ponto de desenvolvimento em que o jogo do ator contamina o real, ao contrário daquelas das vanguardas construtivistas que desejavam fazer surgir do real o lugar simbólico. São duas maneiras distintas de subverter a representação. Na encenação de $O$ casamento, na sua primeira parte, o corpo do ator está associado, necessariamente, a todo o processo da construção e seus objetos. O espaço do jogo é liberado de qualquer frescor ilusionista. Mesmo os bastidores, as passagens para os camarins, que poderiam dar guarida à ilusão, foram suprimidas. A ilusão neste espetáculo foi insistentemente bloqueada e o processo de bloqueio tornouse mais importante do que o próprio tema do casamento e os meios de combate assumiram o status da forma do espetáculo:

\footnotetext{
${ }^{40}$ Ibid. p 26.

${ }^{41}$ Kantor, Tadeusz. Le théâtre de la mort - Textes Réunis et Rassemblés par Denis Bablet. Lausanne: L'Age D'Home, 1977. p. 31.
} 
"Os atores estarão inicialmente sentados na sala e terminarão sua transformação em personagens do espetáculo.

A coisa se passa na igreja - será preciso preparar esta igreja diante dos olhos do público. Nada a esconder!

Na sala, se reúne a cruz, qualquer coisa que entre o jogo dos atores em uma ação prática.

Em seguida a cruz é montada em cena pelo bispo e o sacerdote. Eles procuram um lugar.

$\mathrm{O}$ cortejo do casamento se forma em cena. Sobre o plano inclinado a jovem noiva é empurrada em um carrinho de mão de metal borrado de cal. Isto é feito com crueldade. A situação está em contradição com a realidade da vida.

Interpretação lúdica de uma cerimônia convencional.

No espírito do construtivismo.

A jovem noiva fica atrás, esquecida.

A mãe da jovem chora o tempo todo.

Ela não se separa de sua cadeira, que é uma paródia de construção e prova que o construtivismo no teatro deve se colocar às margens do cômico.

A construção é complicada a cada vez que a Mãe, em pranto quer se sentar, ela se curva e desaba quase como um trejeito de circo CONSTRUTIVISTA.

É obvio, à cada vez, a mãe cai por terra e chora. Este choro, no momento da queda "compromete" o outro choro, aquele que todas as mães derramam no casamento de seus filhos.

A irmã da jovem noiva salta através de um arco cantando ulalala... ulalala...ulalala...

O sacristão puxa uma corda que está no lugar do sino do campanário. Esta corda está esticada sobre uma roda de bicicleta e faz o papel de uma correia de transmissão. Apesar disto, se entende o som de um sino de igreja.

O Bispo dirige esta cerimônia ambígua. "42

No jogo de ambigüidades sob o qual o espetáculo é conduzido, torna-se possível observar a relação entre dois mundos distintos, mas complementares: o do teatro, e o da vida. É evidente a existência de um discurso de oposição à cena tradicional. Um discurso que confronta a "construção" com a instituição, no sentido de romper com as fronteiras que separam a arte da realidade. Conforme as reflexões de Kantor, o Construtivismo é o responsável pela destruição daquilo que ele considera o estreito mundo da cena tradicional e abriu o caminho para o infinito horizonte da criação humana.

O Construtivismo nasce do espírito da revolução e da fé na transformação de um mundo antigo, sustentado por uma armadura escura, enferrujada e obsoleta, em um

\footnotetext{
${ }^{42}$ Kantor, Tadeusz. Leçons de Milan. Paris: ACTES SUD - PAPIERS, 1990. p.38.
} 
mundo novo do qual surgiria um novo homem e, conseqüentemente, no pleno desenvolvimento da humanidade e fundamentalmente, na convicção de que a arte representa um papel capital na construção deste mundo.

"O construtivismo exigia a liberação da arte da servidão naturalista da reprodução da vida.

Esta liberação era a condição indispensável para tornar possível a criação de uma obra autônoma, independente, criação situada sobre o mesmo plano hierárquico como a natureza ou Deus.

Obra humana, e não obra da natureza ou obra "divina".

Esta era uma ambição que justificava todos os sacrifícios, aí inclusos aqueles da sua própria vida. "«3

$\mathrm{Na}$ condução da montagem do espetáculo $O$ Casamento, o ideal dos construtivistas é conduzido e elevado por Kantor à estatura da vida. Isso quer dizer que tudo está de acordo com as normas do cotidiano mas a junção dos acontecimentos se apresenta de maneira autônoma que deverá causar perplexidade. O curso dos acontecimentos, que na vida acontece de maneira servil ao pragmatismo da realidade, sustentados pelo Construtivismo e seus ideais, transformam-se em exercício pleno da liberdade - os construtivistas travavam uma luta de morte pela vitória da arte sobre o mundo da vida prática. Há certamente uma necessidade, tanto em Kantor quanto nos construtivistas, em arrancar as máscaras e as amarras do materialismo que envolve o mundo dos homens e das artes. Os meios para tal, e que ascenderiam ao novo e às camadas mais originais da vida, encontravam-se na zombaria, na ironia e na provocação do circo.

Como em $O$ retorno de Ulisses, quando as pessoas em $O$ casamento ganham a cena e se misturam ao espaço e seus elementos, não é possível saber o que são essas pessoas e o que pretendem. A abstração nos causa a dúvida. Os movimentos cerimoniais causam a impressão de tratar-se de um funeral. Percepção que é logo destruída pela entrada da noiva com seu véu branco. Este é o momento em que os códigos nos saciam a curiosidade e a ansiedade. No entanto, conforme o próprio Kantor diz, estas duas alternativas se reaproximam fora da nossa consciência convencional, ou seja: o casamento em alinhamento ao funeral institui uma relação direta entre amor e morte. Existe, nesta situação, um fenômeno que vai além daquilo que é visualmente percebido. O que é visto é desprovido de sentido em si mesmo, o significativo é a sensação, como

\footnotetext{
${ }^{43}$ Ibid. p.39.
} 
tal, interligada à estrutura da "máquina de representar". Existe algo no espetáculo que não pode ser tocado, conquistado pela razão, mas apenas intuído, o que me faz pensar em Malevitch para quem o mundo dos sentidos é ilusório; e a realidade encontra-se além, e de acordo com o pensamento de Kantor, era preciso, conforme os construtivistas:

“...arrancar a epiderme e descobrir as camadas profundas da vida" $"$.

Não existe nessa encenação uma causa anterior, uma peça que determina o acontecimento das ações e que é o primeiro impulso do comportamento teatral convencional. O drama, caso se faça necessário, nasce durante a criação do espetáculo. Durante este processo toda a estrutura imitativa é eliminada. Com este procedimento se substitui a noção da peça que se deve apresentar por algo essencial: o drama não é mais a razão de ser do teatro, mas a forma. Então, concluindo, neste universo da imagem e da abstração, no sentido construtivista, o drama, não nasce meramente da forma. A peça é a própria forma. A forma cria uma realidade que parece ser um estado de suspensão da vida:

"Sem passado, sem causas e sem consequiências.

Tudo vem "DE LUGAR ALGUM" e vai "NA DIREÇÃO DE NENHUM LUGAR"

OBRA DE ARTE!

AUTÔNOMA!"45

Todo o espetáculo, nessa primeira parte, é estruturado de maneira a enfatizar a necessidade de esclarecimento dos meios formais utilizados pelo Construtivismo. Pouco a pouco, a cerimônia do casamento é transformada em pretexto para introduzir na cena todos os elementos que contribuíram para a criação do teatro contemporâneo. Para ele, foi o Construtivismo que deu origem ao teatro contemporâneo ${ }^{46}$.

Em relação ao ator, a sua grande preocupação nesse trabalho, já que não eram aqueles atores do Teatro Cricot 2, tratavam-se de estudantes e de jovens atores recém

\footnotetext{
${ }^{44}$ Kantor, Tadeusz. Leçons de Milan. Paris: ACTES SUD - PAPIERS, 1990. p.42.

${ }^{45}$ Ibid. p.47.

${ }^{46}$ Ostatnie cricotages Tadeuza Kantora (Últimas cricotages de Tadeusz Kantor), Anna Halczak, texto publicado em "Didaskália", dezembro de 2000.
} 
formados, e que não tinham, evidentemente, nenhum treinamento ou domínio da linguagem de Kantor, que se dedicava intensamente a esclarecer aos jovens a necessidade de dar vida, através de cada movimento, a todos os elementos presentes na cena, como por exemplo: a rampa, cujo movimento devia ser cadenciado, ritmado. $\mathrm{O}$ ator deveria incessantemente adaptar o seu jogo à forma do objeto, nesse caso, a construção que foi erguida na cena. $\mathrm{O}$ ator deveria se empenhar para dar, de qualquer maneira, vida a essa construção. Em relação à rampa inclinada, ele diz:

"No teatro, o melhor para o ator é manter o corpo em posição obliqua, porque nesse momento, todo o corpo pode representar." 47

Após cada seqüência, os atores deveriam se imobilizar por um instante como se eles não soubessem o que deveriam fazer em seguida. Evidentemente, esse se trata de mais um recurso para melhor destruir a ilusão que eventualmente viesse a se erguer na tentativa de estabelecer critérios de verossimilhança com um casamento real. Dessa forma, o espetáculo começa como um ensaio do casamento, e esse deveria atender a todos os princípios da construção. Como a cerimônia deveria acontecer em uma catedral, faz-se necessário que essa seja construída diante dos olhos dos espectadores. No meio dos espectadores, o Bispo e o Padre constroem uma cruz e a levam em seguida para a cena. Os momentos trágicos e cômicos se sucedem constantemente. As emoções nascem surpreendentemente de situações que são anunciadas por ações que a precedem. Assim, o simples ato de construir uma cruz, que é reduzido ao próprio ato de construir através de uma ação cotidiana e neutra, mas é graças a esta ação que uma cruz e uma catedral tornam-se visíveis para o espectador.

Durante a cerimônia, os noivos que são unidos por uma corda que os aproxima e os separa, durante esse processo, freqüentemente a ação é interrompida pelo som de um alto-falante que mecanicamente repete:

“Com a revolução surge o construtivismo que destruiu toda transposição duradoura da ilusão..."48

\footnotetext{
${ }^{47}$ Fragmento do artigo: Ostatnie cricotages Tadeuza Kantora (Últimas cricotages de Tadeusz Kantor), Anna Halczak, texto publicado em "Didaskália”, dezembro de 2000.

${ }^{48}$ Ibid.
} 
Seguindo esse princípio da construção, os noivos, durante a noite de núpcias, são emparedados, cercados por tijolos de forma que o leito nupcial se transforme em tumba que é erguida tijolo após tijolo. Entretanto, apesar desse fim catastrófico de um casamento marcado pela morte dos noivos, tudo isso se apoiava na convenção do circo.

Da mesma forma que os construtivistas, talvez essa seja a principal inferência do Construtivismo em Kantor, ele se servia do cômico para reforçar o efeito catastrófico ulterior; e apesar do Construtivismo ter suas bases alicerçadas na transformação social do homem através da construção de um novo homem que seria estruturado em outras bases sociais, políticas e ideológicas, Kantor não está preocupado com questões políticas, pelo menos não no sentido ideológico. Por outro lado, uma nova ordem social dá necessariamente vida a novas formas de expressão, assim pensavam os primeiros construtivistas, que também repudiavam a idéia da arte pela arte. A orientação materialista das suas obras desvendaria, acreditavam eles, estruturas formais, novas e lógicas em relação à qualidade e à expressividade que são inatas aos materiais que o artista utiliza. Por esse caminho, a meu ver, o Construtivismo em Kantor se direciona não no sentido da concepção ou da fabricação de coisas socialmente úteis, mas na objetividade do processo que transforma a matéria e a reinterpreta em novas formas e novos significados sem se desvencilhar da forma anterior. Nesse sentido, podemos até perceber, em função da multiplicação dos significados, principalmente através da constante incidência do humor e da ironia nas imagens que se formam na cena, questionamentos ideológicos, sociais ou políticos. Esses elementos, caso existam, tratam-se unicamente de leituras posteriores, não do objetivo de Kantor. Uma das principais preocupações de Tadeusz Kantor, se não for a principal, reside na sua preocupação, no seu desejo de valoração do artista em sua individualidade de criador. Inegavelmente, essa postura se constitui como uma reação ao mercado e conseqüentemente aos valores sociais e políticos que sustentam o mercado e seus valores. Assim, por esse caminho, outro elemento que virá a se constituir como uma estrutura que se constituirá como o principal elemento reativo às instituições artísticas e ao mesmo tempo, se tornará um dos componentes mais fortes da forma kantoriana, trata-se do Surrealismo.

Se a primeira parte de $O$ casamento faz uma investida no universo da forma construtivista, a segunda parte por sua vez, sem abandonar os princípios do 
Construtivismo, fará uma imersão no universo surrealista, estrutura que na sua obra se caracterizará como um elemento que nos conduzirá, uma vez mais, ao limiar do desconhecido do seu teatro. Entretanto, antes de entrar efetivamente nesse tema, faz-se necessário atentar para uma estrutura muito significativa e peculiar ao processo de criação de Tadeusz Kantor . Um lugar significativo no qual ele se recolhe e de onde as imagens são convocadas - o "quarto da imaginação". Assim, é de necessária importância o entendimento deste elemento antes da averiguação das relações de Kantor com o Surrealismo.

\section{O QUARTO DA IMAGINAÇÃO - ONDE AS IMAGENS SE CRIAM}

Em uma passagem de Lições de Milão, Kantor fala sobre esse lugar insólito e de alguns dos seus objetivos e funções:

“Eu pertenço à geração surgida na época dos genocídios e dos atentados mortíferos contra a arte e a cultura.

Eu não quero salvar o mundo com a minha arte.

Eu não acredito na "universalidade".

Após todas as experiências do nosso século, eu sei como isso termina, e a quem e a que serve essa célebre "universalidade", tanto mais perigosa que hoje ela atingiu a dimensão do globo terrestre.

Eu quero SALVAR A MIM MESMO,

não egoisticamente, mas somente com a fé

no VALOR INDIVIDUAL!

Eu me tranco no meu estreito quarto da imaginação.

E LÁ

E SOMENTE LÁ

EU ARRANJO O MUNDO.

COMO NA INFÂNCIA.

EU ACREDITO FIRMEMENTE QUE NESSE PEQUENO QUARTO DA INFÂNCIA

SE SITUA A VERDADE!

E HOJE, TALVEZ COMO NUNCA, ESSA É A VERDADE EM QUESTÃO!,"49

\footnotetext{
${ }^{49}$ Kantor, Tadeusz. Leçons de Milan. Paris: Actes Sud - Papiers, 1990, p. 66/67.
} 
Conforme o pensamento de Gaston Bachelar:

“...a imagem existe antes do pensamento..."

Assim, neste "pobre e estreito quarto" residem as lembranças e as imagens que se constituirão no núcleo cervical da sua criação, imagens existentes à espera de forma.

Mas o que é este quarto? Certamente não se trata de uma invenção criada unicamente para justificar ou para escamotear as definições de um processo de criação de um artista movido por excentricidades. Não. Trata-se, antes de tudo, de uma maneira pessoal de encarar o mundo e a sua realidade no mundo. Um lugar no qual o valor individual se recusa, determinantemente, a ser diluído na generalidade do coletivo e de ser absorvido pelas instituições artísticas:

"UM QUARTO

O meu.

Pessoal.

Privado.

(...)

Único lugar

onde, "minada" pela sociedade,

a individualidade humana,

o homem,

pode se proteger,

e nele ser mestre." 51

Este lugar também não se trata de um refúgio para o qual Kantor se recolhe a fim de se proteger da banalidade e das ameaças das instituições. Como ele mesmo comenta:

"Lugar POBRE,

constantemente ameaçado

pelos

“ORGANISMOS PÚBLICOS..." 52

\footnotetext{
${ }^{50}$ Bachelard, G. Poética do espaço.In. Os pensadores. São Paulo: Abril Cultural, 1978, p. 185.

${ }^{51}$ Kantor, Tadeusz. Les voies de la création théâtrale, Paris: C.N.R.S. Vol. 18, 1993, p. 158.

${ }^{52}$ Ibid.
} 
Kantor cria um lugar no qual ele pode exercer o direito de ser independente, de ser individual, um espaço que habitado pelas experiências e vivências do passado e que é capaz de transcender o próprio espaço e burlar as barreiras do tempo. Mas isso será tratado mais detalhadamente em um momento específico do trabalho. Neste momento devo me ater ao funcionamento deste espaço onde as imagens se criam.

Devido à importância da imagem no teatro de Tadeusz Kantor, eu, como outros o fizeram, até poderia qualificá-lo de um teatro de imagens, mas se assim o fizesse, eu também acometeria o mesmo deslize de uma análise por demais simplista. Kantor não cria a imagem pela imagem; não, ela é constituída de uma série de vivências históricas e de experiências poéticas que se avolumam e se sobrepõem neste lugar insólito onde a sua imaginação tem o poder pleno da liberdade. O "quarto da imaginação" não é um artifício mas um lugar concreto, reduto de sensações e paixões experimentadas e que lá são reestruturadas, sentidas novamente e, com outra intensidade, tornam-se mais apaixonadas.

$\mathrm{Na}$ astrofísica, "buraco negro" é uma região do espaço no qual o campo gravitacional é tão forte que a tudo atrai e dele nada escapa. A matéria atraída é que produz o campo gravitacional a sua volta e que impede até mesmo que a luz capturada saia. Pois bem, essa imagem do "buraco negro" bem se aplica a esse tal "quarto da imaginação". Ao que me parece, este local condensa de uma maneira extrema e extremada toda a experiência da arte do século XX, associada às experiências da sua contemporaneidade histórica que se avolumam mais e mais e, como que produzindo um campo gravitacional, torna-se cada vez mais denso, cuja única possibilidade de desenvolvimento é exatamente o inverso, um universo nascente em um estourar de imagens, como um "big-bang" de sensações, ou seja: um "buraco branco"53.

\footnotetext{
${ }^{53}$ Teoricamente trata-se de uma região do espaço na qual a matéria é criada e ejetada para o universo. Está em contraste com o "buraco negro", que suga a matéria em suas vizinhanças, retirando-a do universo. Especula-se que, de uma maneira ainda não totalmente compreendida, um "buraco negro" e um "buraco branco" estão ligados por meio de um túnel chamado "buraco de minhoca", que pode atuar como meio de transportar a matéria de um ponto de nosso universo para outro.
} 
Este "quarto da imaginação", uma espécie de nascedouro de imagens, faz com que cada imagem presa na memória se constitua como universo próprio e que, no processo da explosão, toda a energia acumulada seja liberada como forma, principiando o espetáculo. Assim, parafraseando o livro do Genesis: no início era a imagem, e Kantor viu que a imagem era boa, e uma nova realidade se fez.

Este movimento criativo é um universo rotatório em forma de "toro" no qual um fluxo ininterrupto de energia, cuja matéria é a imagem afixada na memória, traça um caminho que se fecha sobre si mesmo em um movimento contínuo. Mas o que isso significa? Trata-se da maneira como cada imagem construída exteriormente é novamente atraída para o interior do estreito "quarto da imaginação" e se refaz como imagem autônoma e independente, apesar de conter elementos da anterior. Esse é o caso da banheira utilizada em A galinha d'água, espetáculo de 1968, em que uma banheira, um objeto real encontrado em uma construção em estado de demolição é utilizado como elemento de jogo, mas utilizada na sua condição de objeto real, ou seja, uma banheira cheia de água com a Galinha d'água no seu interior.

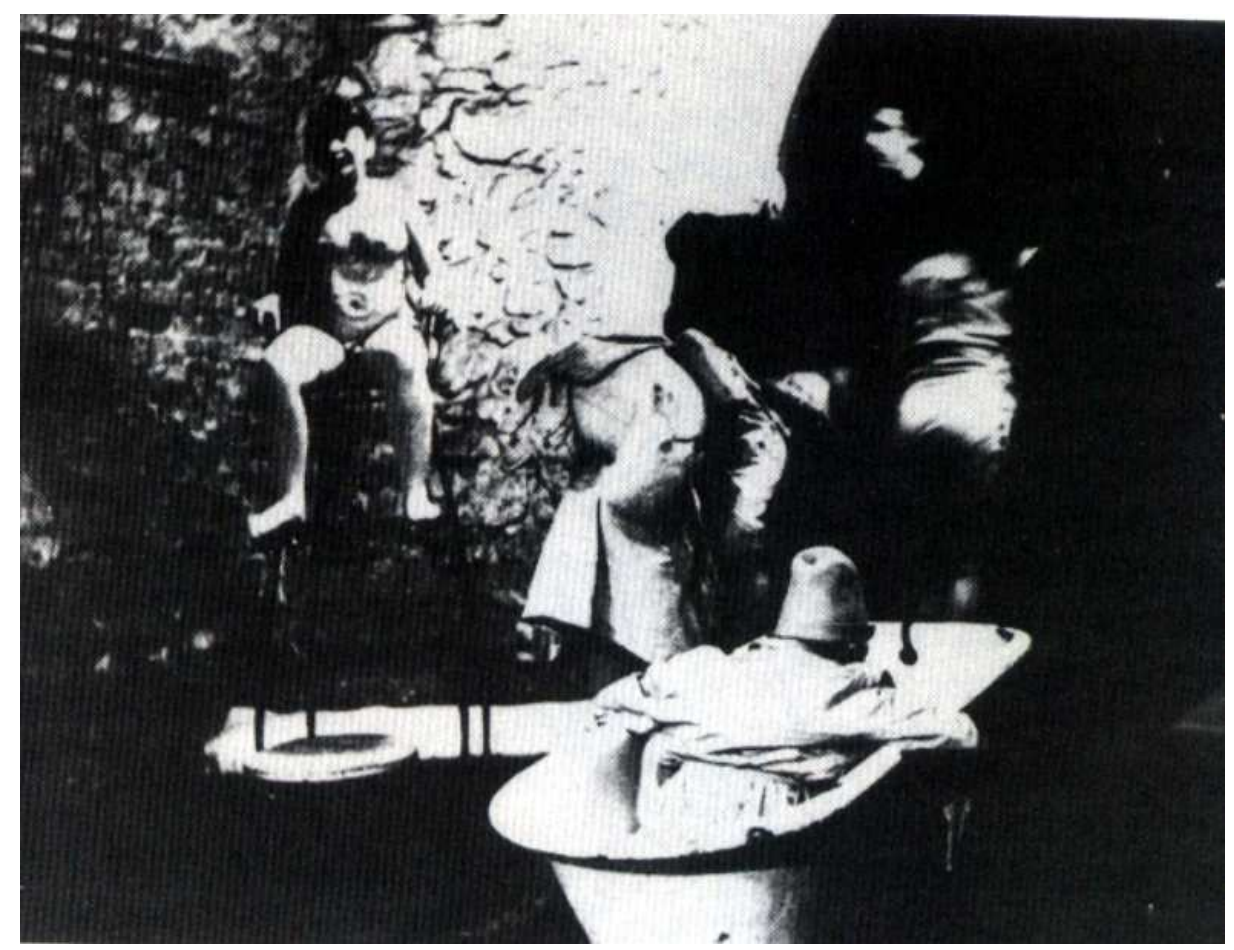

Cena de $A$ galinha d'água. Foto: arquivo da Cricoteka 
Já em 1988, em Não voltarei jamais, existe um retorno da banheira, não mais como objeto real, mas reinterpretada como barco. O barco de Caronte, o barqueiro que transporta as almas para o Hades. A imagem inicial, presa na memória, é transformada e uma nova imagem se constitui. Entretanto a relação antiga, banheira/água/ator permanece na nova relação: barco/água/ator, na qual a água é somente uma ilusão.

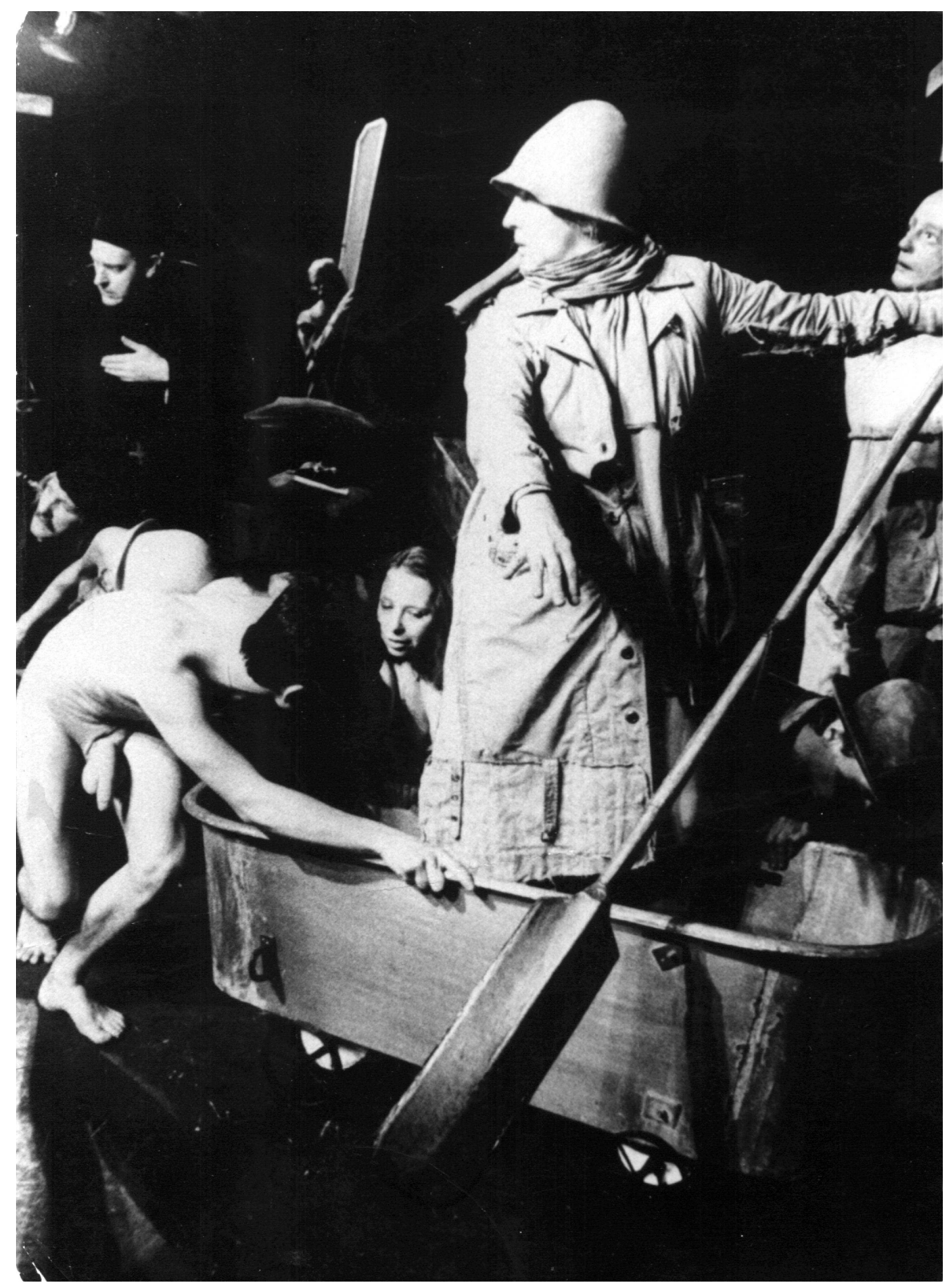

Não voltarei jamais. Na cena, a Galinha d'água no interior da banheira como o barqueiro Caronte. Foto:G.K. Kuhnel. 
Outra situação, através da qual posso ilustrar este processo, trata-se da utilização de imagens retiradas do seu universo pictórico e que invadem incessantemente a dimensão do teatro, e, da mesma forma, o inverso é verdadeiro. Kantor sempre foi um apaixonado pela arte espanhola, e essa paixão, sobretudo por Velázquez e Goya, fará constantemente a passagem de um universo a outro, contemplando mais uma vez este processo de utilização e reaproveitamento interpretativo da imagem. Na série As Infantas de Velásquez, na obra Certa noite pela segunda vez a Infanta de Velásquez entrou em meu quarto, Kantor se utiliza do quadro do pintor espanhol como motivo para a sua pintura, na qual o seu auto-retrato dialoga com a pintura de Velásquez. Em outro sentido, temos nessa tela uma relação temporal em que o passado se associa ao presente do artista em uma simbiose perfeita. $\mathrm{O}$ tempo relativo identifica o passado e o presente acontecendo em um único instante. A Infanta nos remete instantaneamente ao passado e a Velázquez ao passo que, o auto-retrato, à obra no presente. Um passado que se movimenta continuamente na direção do presente.

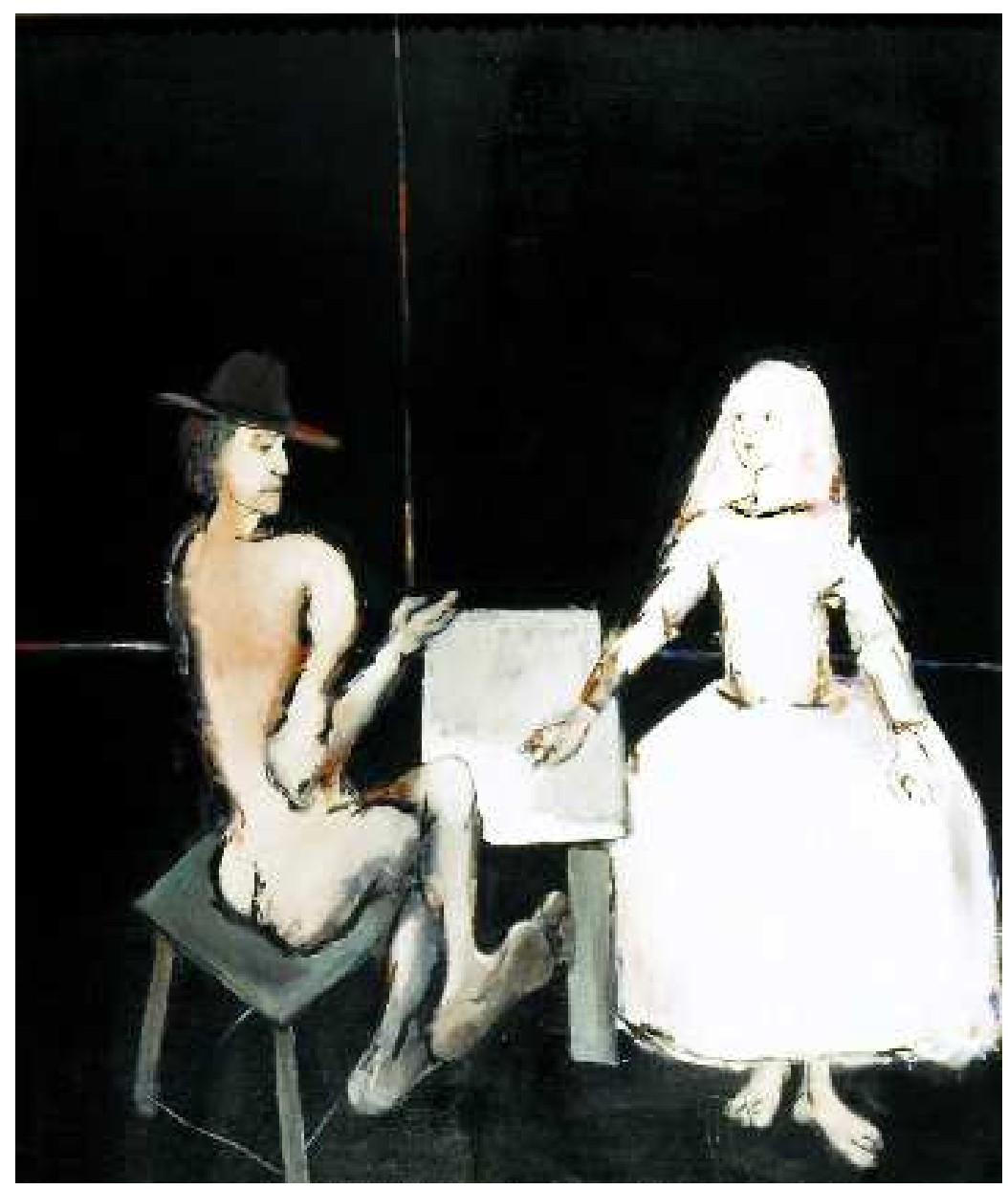

Tadeusz Kantor - Certa noite pela segunda vez a infanta de Velázquez entrou em meu quarto - acrílico sobre tela 1990. Foto: arquivos da Cricoteka. 
Já na peça Hoje é meu aniversário, a pintura é materializada na cena. O autoretrato do artista torna-se o próprio artista em cena. Mais uma vez a relação passado e presente se mantém, só que com maior intensidade. Isso devido ao acúmulo das dimensões temporais. Existe um presente que se justapõe a passados diferentes e que estão perfeitamente integrados na realidade do artista que os conjuga harmoniosamente.

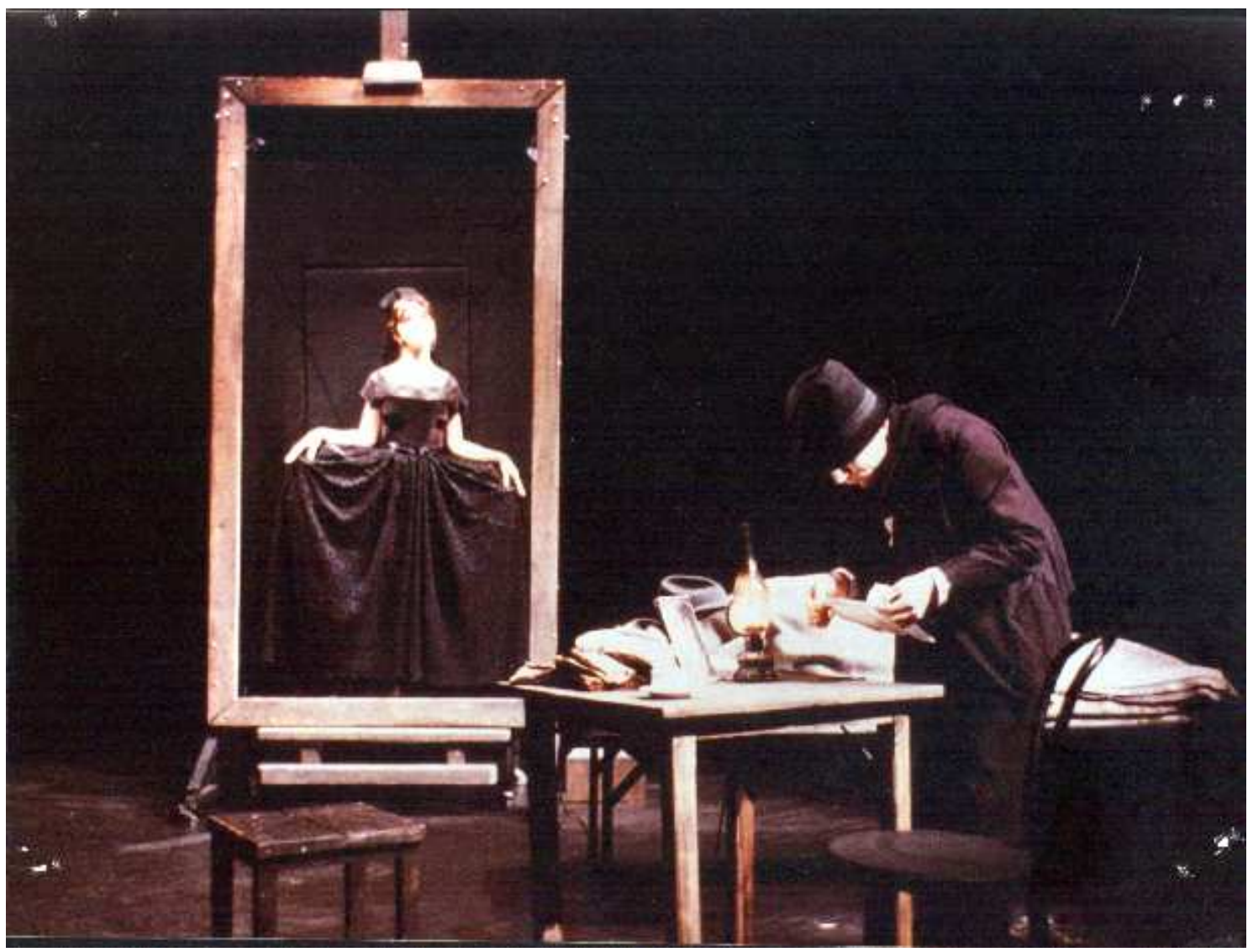

Hoje é meu aniversário. Na cena, a Infanta com o Auto-retrato. Foto: Caroline Rose.

Um terceiro exemplo dessa pluralidade de universos que nascem no interior do seu "estreito quarto da imaginação", diz respeito à maneira como o espaço é pensado. Um espaço que pode coexistir com outros espaços: o bidimensional interage ao mesmo tempo com a terceira dimensão, em um mesmo instante. 


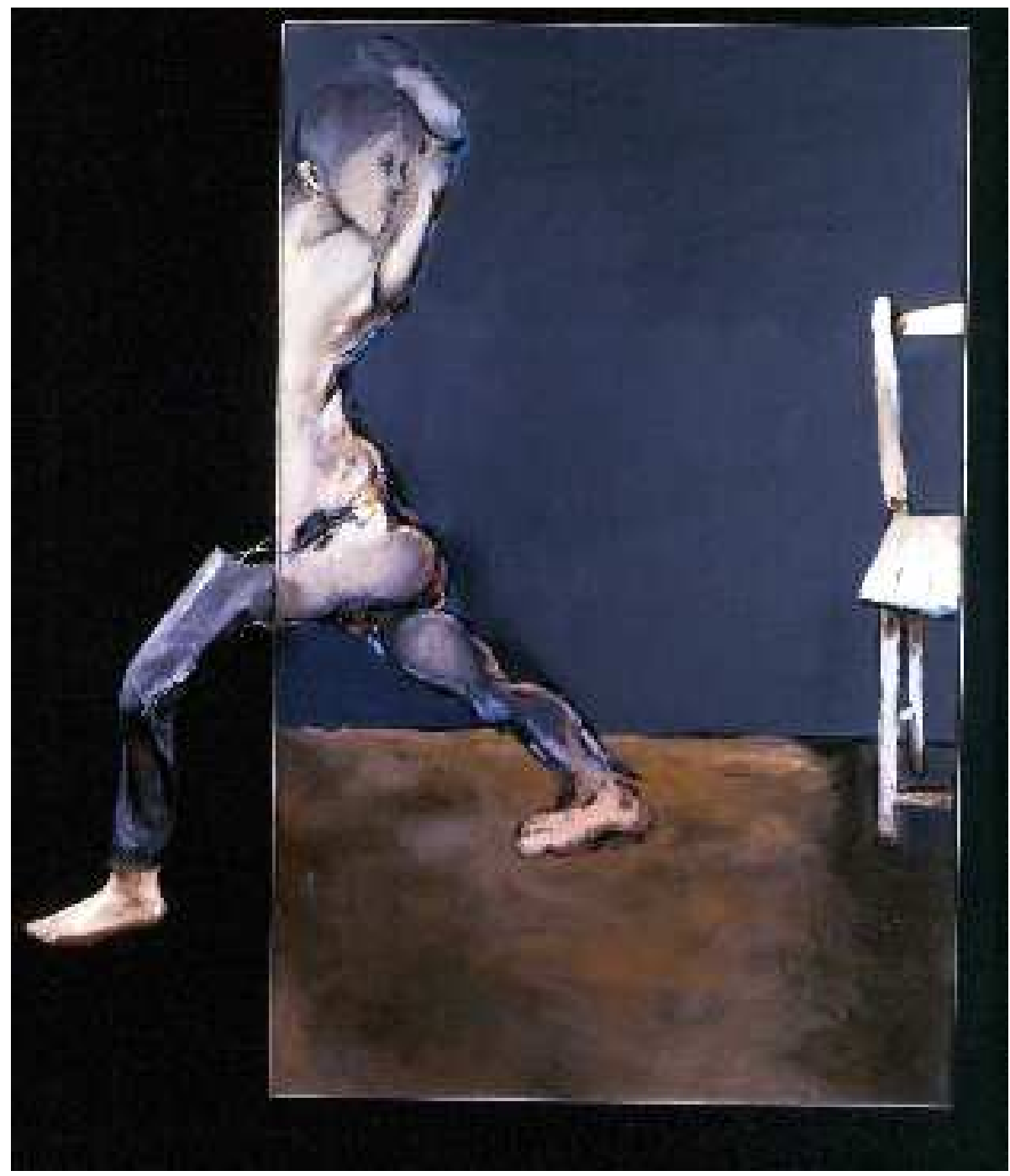

Tadeusz Kantor - Eu tive o bastante. Eu estou de partida desta pintura (1988). Galerie de France, Paris. Foto: arquivo da Cricoteka.

Na figura acima, uma composição mista faz um jogo entre duas realidades. O próprio Kantor está deixando o espaço da tela. Está saindo do domínio da ilusão interior do quadro e caminha em direção à realidade exterior a ele, ou seja: passa de uma realidade bidimensional para uma outra em três dimensões. De uma certa maneira, esse tipo de composição ilustra bem a natureza do seu trabalho, um jogo de tensões entre a pintura e o teatro, entre a realidade e a ilusão, na qual: 
“...apagada a linha de demarcação entre o espaço real e o espaço imaginário, se confundem os discursos tradicionais sobre a representação em arte." 54

Em uma exposição realizada em Nova York, este quadro teve muitos problemas para entrar nos Estados Unidos devido à sua ambigüidade enquanto obra de arte. As leis norte-americanas não conseguiram classificar a obra nem como pintura, nem como escultura, ficando o quadro retido, por um bom tempo, na alfândega daquele país.

Em seu último espetáculo, Hoje é meu aniversário, essa situação é evidente. A exemplo da obra anterior, os personagens tentam deixar a realidade da tela em direção à realidade do teatro. Mais uma vez a metáfora do "buraco de minhoca", ou seja: um universo criativo que se comprime e se expande em direção a outro em um processo de transformações de energias e tensões, em que uma imagem se alimenta de outra, ou de diversas imagens anteriores a ela.

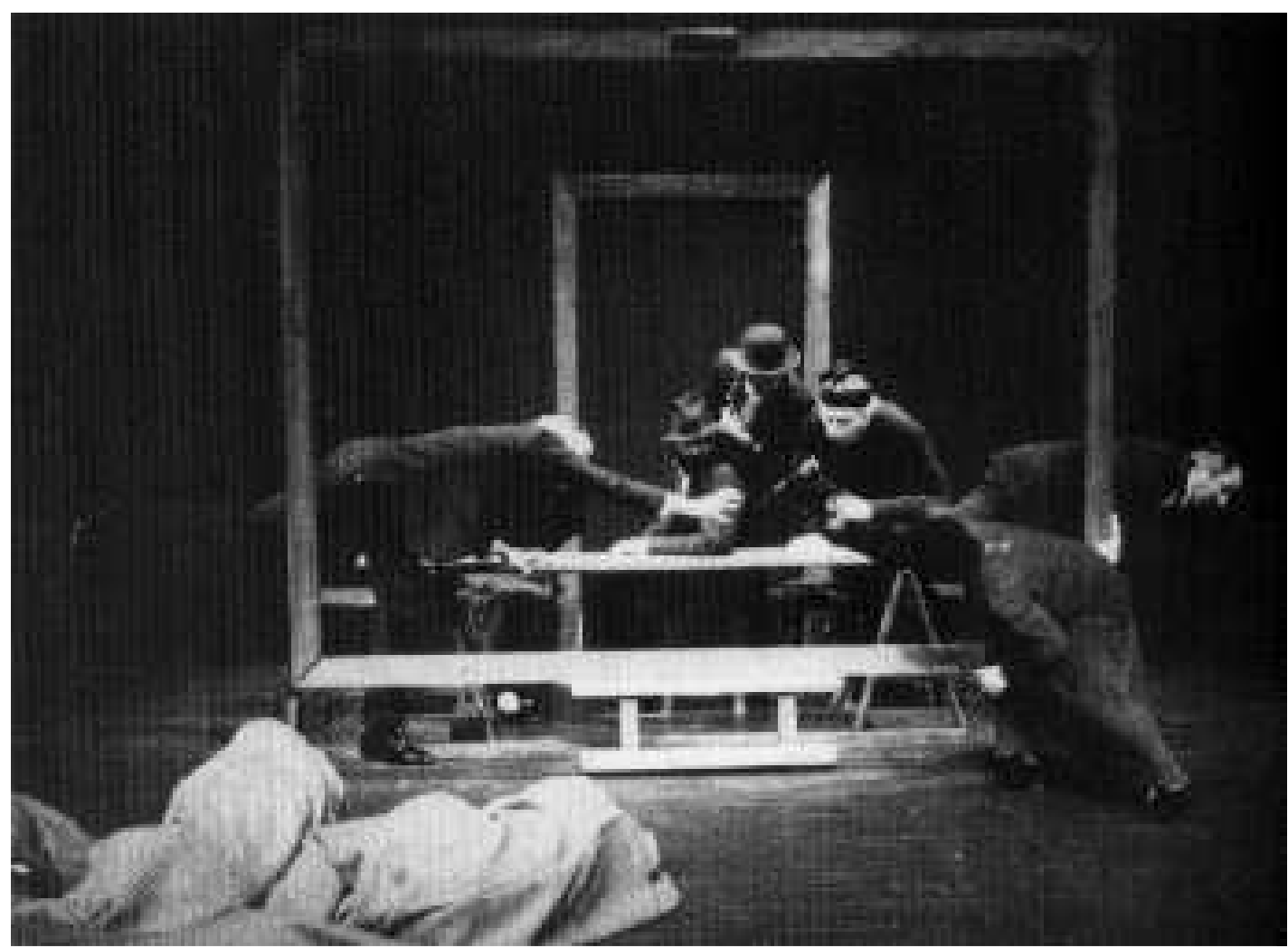

Hoje é meu aniversário. Na cena, as personagens tentam sair do espaço bidimensional da tela em direção ao tridimensional do teatro. Foto: Bruno Wagner.

\footnotetext{
${ }^{54}$ Kobialka, Michal. Tadeusz Kantor - A journey through other spaces. Essays and manifestos, 1944-
} 1990. Los Angeles: University of California Press, Ltd. , 1993. p. 380/383. 
Não há dúvida de que em cada situação, seja a da tela, seja a do palco, cada objeto exibe sua individualidade densa, onde cada imagem, possibilidade da mesma coisa, inaugura uma nova figura que contém em si os mesmos dispositivos que as contém.

O repertório de imagens utilizadas por Kantor faz parte do acervo de suas experiências e vivências adquiridas. As imagens do passado são incessantemente convocadas para se colocarem a serviço do criador. O passado está pronto e Kantor não olha para ele de maneira saudosista, mas sim de uma maneira cuja articulação das imagens, das formas e das coisas, desse passado que se apresenta como imagem, se constitua de tal modo que a conivência entre aspectos das coisas e os aspectos da própria imagem sejam apresentadas como uma enorme fonte de sentimentos íntimos, que em um jogo de linguagem não-verbal, nascido graças ao trabalho da memória e da imaginação que depositam na imagem atual seus modos já vistos no passado, e aqueles que serão vistos no futuro, de forma que cada sinal ao transbordar para a tela, no caso de sua pintura, ou para o palco, no teatro, se transforma em signo, o qual ao lado de outros objetos igualmente providos de suas possibilidades de vínculo, criam um mundo em si, um universo próprio. $\mathrm{O}$ do artista. O universo de Tadeusz Kantor.

A pintura e o teatro, em Kantor, uma arte sempre atua no limiar da outra, que nessa relação que as enviesa, conferem às imagens concebidas, nos dois campos de trabalho, dimensões altamente expressivas, nas quais seus elementos constituintes se configuram como objetos de um mesmo universo pictórico que se cruzam num quadro virtual, o "quarto da imaginação", invocando outros elementos cujo cruzamento se faz na medida em que promete algo além dele mesmo. E é no cruzamento desses elementos, a princípio relativamente simples, que nasce a obra de arte. Seja o teatro, seja a pintura, elementos pertencentes a um mundo criado por eles mesmos, cujos objetos conservam a sua singularidade impar pois, do cruzamento desses, um novo espaço se abre para além das regras que eles mesmos significam. Criar, para Tadeusz Kantor, significa tanto imprimir forma ao objeto quanto abstrair e mostrar as propriedades do objeto que são mais apropriadas ao uso. O objeto traz de fora o seu princípio de individuação ${ }^{55}$ que se associa ao conhecimento do artista que o separa e re-arranja suas partes para torná-lo

\footnotetext{
${ }^{55}$ No sentido de que cada coisa é por si, idêntica ou diferente de outra coisa.
} 
mais adequado a determinados usos e interesses e um novo código se sobrepõe ao código da linguagem cotidiana, histórica, do qual o objeto/imagem foi convocado. Nessa sobreposição de códigos, uma individualidade, ou seja: uma nova obra se configura ao mesmo tempo em que a distribuição de imagens determina os parâmetros lingüísticos que irão orientar a realização da obra. Assim, o conteúdo estético é tecido neste jogo entre a forma representativa e a forma "apresentativa" da imagem. Imagem que se mostra, pois, como o produto do trabalho do artista, constitui-se como bela, que segundo José Arthur Giannotti:

“...belo é um sistema de imagens que tanto captura variações de aspectos de uma coisa, de uma situação do mundo, como se apresenta para que seus próprios aspectos sejam explorados por um expectador."56

Assim, mais do que impor uma forma à imagem, faz-se necessário que Kantor estabeleça padrões estruturados e estruturantes, passíveis de se fazerem ver, e consequientemente, de serem lidos pelo expectador na medida em que são articulados em momentos presentes e ausentes, visíveis e invisíveis, tanto do objeto como do seu meio de apresentação. Em resumo, ao cruzar o "buraco de minhoca", a imagem expulsa do "quarto da imaginação", ao ganhar exterioridade no palco, ela já possui uma sintaxe própria, um complexo lingüístico definido, cujo processo de dar vida ao todo, na cena, também se torna o caminho para se decifrar a universalidade da obra e de seu autor em seus aspectos mais íntimos e mais específicos.

O "quarto da imaginação" de Tadeusz Kantor está prenhe de matéria visível. Matéria que se individualiza mediante as diferenças de tensões entre matérias diversas gestadas que sobressaltam para a cena. No seu último espetáculo, Hoje é meu aniversário, temos o apogeu desse mecanismo. A peça é o seu próprio "quarto da imaginação" em cena:

\footnotetext{
"Meu quarto

Algumas explicações e digressões suplementares

em um turbilhão

de reflexões, de sentimentos, de dúvidas,

de esperanças

que me atormentam,
}

${ }^{56}$ Giannotti, J.A. O jogo de belo e do feio. São Paulo: Companhia das Letras, 2005. p. 81. 
eu devo colocar em ordem

o meu passado,

concluir o exame

das minhas idéias

em função do dia

de hoje,

depositar os

"velhos" no cofre da

lembrança, e

simplesmente limpar o campo

de ação

para um novo espetáculo.

"Meu quarto em cena,

e qual será sua

fábula?",57

A partir de Wielopole Wielopole, essa estrutura, aliada à memória, tornar-se-á cada vez mais intensa e presente na cena, retornará de espetáculo em espetáculo se movimentando de um para o outro, de maneira ao mesmo tempo semelhante e diferente. Em algumas oportunidades, durante os ensaios de Hoje é meu aniversário, Kantor define o caráter e o simbólico dessa estrutura no espetáculo:

"Eu quero deixar claro que esse é somente o meu quarto; não é um asilo cheio de mendigos (...) Porque digo isso com tanta precisão? Trata-se de não criar uma narrativa além das minhas possibilidades de pintor: eu estou aqui como pintor, este é meu ateliê, e ele é natural..., 58

O espetáculo é notadamente um jogo com o seu "duplo". A exemplo dos seus outros trabalhos, Kantor está presente em cena. Sua presença é muito mais acentuada neste do que nas peças anteriores. Nesse trabalho, especificamente, ele está em cena não somente como demiurgo mas como pintor. Sua presença é ativa. Ao materializar na cena o seu "quarto da imaginação", Kantor se torna o próprio objeto da sua criação. Um homem privado em cena. Um ready-made em constante conflito com o seu auto-retrato, um ator vestido como ele e que copia seus gestos habituais. Kantor reúne nesse local, não somente a medida do ateliê do pintor, como convoca as imagens, personagens e

\footnotetext{
${ }^{57}$ Kantor, Tadeusz. Les voies de la création théâtrale, Paris: C.N.R.S. Vol. 18, 1993, p. 157.

${ }^{58}$ Ibid.
} 
situações abrigadas em sua memória, desenvolvendo também uma incessante retrospectiva dos signos e das personagens dos seus espetáculos anteriores.

"Então, meu - como eu o chamo -

Pobre quarto de imaginação -

em cena

Eu devo arrumá-lo."59

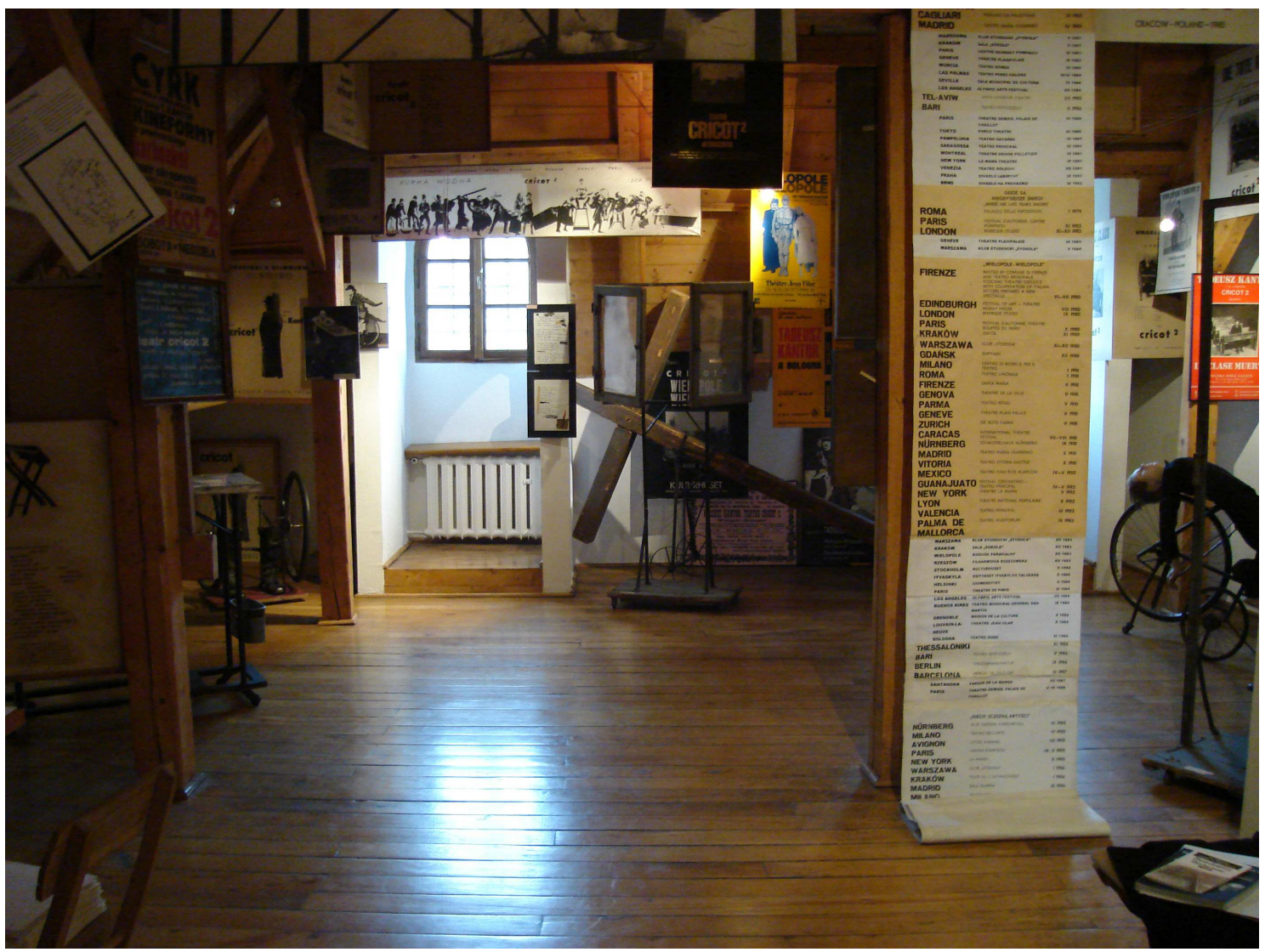

O quarto, atelier de Kantor, na rua Siena, na Cracóvia. Hoje um centro de documentação administrado pela Cricoteka. Foto: Wagner Cintra.

Esse quarto materializado é um instrumento de entrada para a alma de Kantor. Em se tratando da alma do artista, Gaston Bachelard definira:

“Nossa alma é uma morada. E quando nos lembramos das casas, dos aposentos, aprendemos a morar em nós mesmos. Vemos logo que as imagens da casa seguem nos dois sentidos: estão em nós assim como nós

${ }^{59}$ Ibid. 
estamos nelas. ${ }^{, 60}$

A cena é também uma casa. A tela, a obra de arte, sua obra, seu interior. Nessa situação, existe uma linha, uma fronteira que impede que o público penetre no privado. Nessa sala, uma realidade se cria e atende aos interesses do criador que manipula os signos da sua história privada em um processo de percepção e reflexão dos acontecimentos e transformações da história pública. Nesse sentido, a tela, a cena, pode estar presente na vida do público, apesar desse não poder ultrapassar a fronteira, os limites da sala ou da tela.

A vida de Kantor se identifica com a sua obra. Não existe uma divisão entre os campos da vida e da arte. Assim, o seu destino está atrelado à sua criação artística e se ele se realiza em sua obra, é na própria obra que deve encontrar sua solução. A casa é sempre a sua obra, tal como a tela, o teatro, a cena é a sua casa. Nesse espaço, Kantor pode exercer plenamente aquilo que constantemente ele reivindica: o direito à vida individual.

\footnotetext{
"Meu credo:

a solitária verdade na arte

é a de representar sua própria vida,

de os desvendar

sem vergonha

de desvendar

sua própria sorte

seu DESTINO.
}

Eu expliquei em várias oportunidades que a razão não é nem

o exibicionismo, nem narcisismo,

mas o desejo de "reforçar" as noções de:

"vida individual",

a fim de fugir diante da destruição

para a "massa"

inumana e horrível.

O reforço da noção de "vida individual” pela adição

dessa pequena palavra: a minha!

a fronteira entre

a cena e a sala

${ }^{60}$ Bachelard, G. Poética do espaço.In. Os pensadores. São Paulo: Abril Cultural, 1978, p. 197. 
é a linha da vitória.

Intransponível.

Impenetrável."61

Em Hoje é meu aniversário, Kantor não procura criar a ilusão da realidade. Não, ele manipula o concreto, o real. Mas recluso no seu "quarto da imaginação" onde ele é inteiramente livre, às escondidas, ele sonha. E sonhando, ele se utiliza desse coeficiente do sonho ou da ilusão, não como os surrealistas, mas mais próximos de Goya, que segundo Guy Scarpetta:

"Kantor, pela sua forma de se servir dos signos de uma realidade histórica, concreta, precisa, e de lhes dar uma força universal, ele transfigura os signos e os arrasta para o lado da fantasmagoria e do imaginário." 62

O interesse por essa ação de deformar começou com o seu contato, em 1947, em Paris, durante a exposição surrealista, e tal experiência tornou-se decisiva em sua criação. E apesar de todas as divergências dos surrealistas com o teatro, o Surrealismo na visão de Tadeusz Kantor trata-se de um momento de fundamental importância para as artes no século XX.

\section{SURREALISMO - O REINADO DO DESCONHECIDO}

Para Kantor, o Surrealismo surge na história da arte como o elemento que consolidaria e definiria os objetivos e fundamentos da arte no seu mais amplo sentido de maneira a não se limitar ao estético e ao emocional, mas que atuaria sobre o desejo de inspirar as ações humanas em busca daquilo que ele considera o maior dos valores, ou seja: a plena liberdade do homem.

A influência do Dadaísmo e do Surrealismo levou Kantor à descoberta de um dos elementos mais importantes do seu teatro: a escrita automática. Em seus últimos

\footnotetext{
${ }^{61}$ Kantor, Tadeusz. Les voies de la création théâtrale, Paris: C.N.R.S. Vol. 18, 1993, p. 159.

${ }^{62}$ Scarpetta, Guy. Kantor au présent. Arles: Actes Sud, 2000. p. 158/159.
} 
espetáculos ele rejeita prontamente o texto literário e, aquilo que se pode chamar de o texto da peça, era criado durante os ensaios. O texto era concebido simultaneamente com o ensaio, mas o valor das palavras não estava no seu significado habitual, mas sim pelo que assumem no contexto como geradoras de imagens. Como no teatro, cada coisa existente no palco pode assumir uma dimensão simbólica, não existem mais limites para a gramática teatral. Tudo passa a ser estruturado e criado como original, seja em substância, seja como possibilidade de criação. Assim, o ideal de liberdade, inspiração surrealista, permite a Tadeusz Kantor, a partir das transformações das imagens realizadas no seu "quarto da imaginação", realizar formas totalmente diferentes de toda morfologia utilizada pelo teatro tradicional. Essas formas não podem mais ser explicadas em termos simplistas de analogias com relação de causa e efeito, mas pelo valor de signos, próprio de uma existência profunda que transcende e escapa a apreensão dos sentidos, mas que pode e só pode ser revelada através da arte.

Segundo Giulio Carlo Argan ${ }^{63}$, o Simbolismo antecipa a concepção surrealista do sonho como revelação da realidade profunda do ser, da existência inconsciente. Como no inconsciente se pensa através de imagens, esse se tornou o meio mais adequado para se trazer à superfície os conteúdos mais profundos do inconsciente do teatro de Kantor. Não é por acaso que o Surrealismo tanto o inspirou. A imaginação manifestadamente livre está totalmente liberta de toda preocupação estética e moral que diante de um mundo cada vez mais complexo, e a possibilidade de interferir na realidade através da representação do irracional e do subconsciente, abre caminhos sem precedentes.

Os surrealistas deixam o mundo real para penetrar no irreal pois a emoção mais profunda do ser tem todas as possibilidades de se expressar com a aproximação do fantástico no ponto em que a razão humana perde o controle. Parece que a obra de Kantor é uma realização parcial dessa exigência. Parcial pois Kantor não abandona o real. O real é o ponto de partida para todas as transformações que se seguirão. $\mathrm{O}$ irreal, por sua vez, é o impulso, a força motriz do processo de criação das imagens. A arte de Kantor, tanto o teatro quanto a pintura, habita exatamente essa zona de intersecção entre o real e o irreal. Constantemente ele ultrapassa essa fronteira, a exemplo de Hoje é meu

\footnotetext{
${ }^{63}$ Argan, G.C. Arte Moderna. São Paulo: Companhia das Letras, 2004, p. 84.
} 
aniversário, no qual ele encena a sua própria vida ultrapassando a fronteira do sacrílego encenando a sua própria morte.

“...em Kantor, não é mais a convenção teatral, é o real, ou melhor: a nossa percepção imaginária do real que entra na esfera da dúvida." ${ }^{\circ 4}$.

A poiesis de Tadeusz Kantor tornou-se uma maneira muito particular de manipular os signos da morte. Nesse sentido, conforme o pensamento de Guy Scarpetta $^{65}$, a sua poética reata com a tradição barroca ou a escola simbolista que precede o Construtivismo e que foi ofuscada por ele. Os simbolistas percorreram os caminhos das imagens que buscavam a essência das coisas, que surgem na fantasia sem a presença e a lembrança das coisas, revelando os processos e os fenômenos da existência. A inconsciência, considerada inacessível após Freud, mostra-se como um mundo de conhecimento ilimitado que pode ser revelado através dos sonhos e que anteriormente era tido como um estado de irrealidade. De uma maneira geral, o Simbolismo continuou exercendo uma grande influência se associando a várias correntes das vanguardas do século XX.

Após a Primeira Guerra Mundial, o Simbolismo encontrará no Surrealismo um parceiro de crédito pois esse, ao colocar a experiência onírica como fundamento da arte, decorre, conforme a observação de Argan ${ }^{66}$, como um modo do pensamento pelo qual a experiência do mundo realizada através dos sentidos assume uma dimensão de conhecimento, através do qual o dado da percepção se apresenta instantaneamente como forma. Dessa maneira, a livre associação e a análise dos sonhos transformaram-se nos procedimentos básicos do Surrealismo, utilizados e aplicados ao seu modo. Por meio do automatismo, qualquer forma de expressão em que a mente não exercesse nenhum tipo de controle, os surrealistas tentavam modelar, fosse por meio de formas abstratas ou figurativas simbólicas, as imagens mais profundas do ser humano: o subconsciente.

O Manifesto do Surrealismo, assinado por André Breton em 1924, propunha a restauração dos sentimentos humanos e do instinto como partida para uma nova linguagem artística. Para que isso se tornasse possível seria necessário que o homem

\footnotetext{
${ }^{64}$ Scarpetta, Guy. Kantor au présent. Arles: Actes Sud, 2000. p. 42.

${ }^{65}$ Ibid.

${ }^{66}$ Argan, G.C. Arte Moderna. São Paulo: Companhia das Letras, 2004, p. 272.
} 
tivesse uma visão totalmente introspectiva de si mesmo e encontrasse esse ponto do espírito no qual a realidade interna e externa pudessem ser percebidas totalmente isentas de contradições. Em Kantor, esse estado de introspecção aliado à necessidade de recolhimento a si mesmo, levou-o a criar um lugar em que ele pudesse se recolher à sua mais íntima individualidade e no qual o seu espírito livre pudesse exercer plenamente a liberdade de criação. Um lugar virtual do qual nascessem as formas, as fantasmagorias, as suas visões interiores, e dentro desse lugar ser capaz de escolher a especificidade de cada código e a essência a ser trabalhada. A esse lugar, ele chamou de o "quarto da imaginação", que posteriormente também será compreendido como o "espaço da memória".

O Surrealismo apresenta ligações com o Futurismo e com o Dadaísmo, no entanto se os dadaístas propunham apenas a destruição, os surrealistas pregavam a destruição da sociedade em que viviam e a criação de uma nova em outras bases. Pretendiam os surrealistas, dessa forma, atingir uma outra realidade situada no plano do inconsciente e do subconsciente. A fantasia, a tristeza e a melancolia exerceram muita influência sobre os surrealistas e por esse caminho a atração exercida sobre o teatro de Kantor que se estrutura de uma maneira muito mais radical. Kantor introduz a dimensão obstinada da autonomia da arte do teatro como criação demiúrgica. Dimensão que muito se aproxima do ideal utópico de Antonin Artaud de uma linguagem psíquica e concreta, da criação de uma poesia para os sentidos, a qual Kantor conduz até o paroxismo de uma beleza convulsiva e dos múltiplos recursos dos quais ela se serve: os sonhos, os mitos, a fantasia, as visões, as alucinações, a fantasmagoria, a transgressão e o sentido do pecado, entre outros.

Se a arte de Kantor tem a ambição de ser demiúrgica, isso não é somente pelo interesse de criar um universo autônomo. Mas, sobretudo, porque esse universo é composto de uma experiência pessoal - a memória reativa de um passado destroçado. Destroços de uma vida marcada por duas guerras mundiais e a barbárie nazista simbolizada pelos campos de concentração. Imagens que alimentam a sua subjetividade e que são levadas para o seu "quarto da imaginação" onde procede a exumação de todo um passado que será conduzido para uma outra dimensão, a dimensão da arte - a dimensão do teatro, na tentativa de Kantor de colocar ordem na história. Isso não significa que o passado seja transformado na realidade da cena. Não. O passado é 
desmascarado, é enfrentado para que sua vida e o seu destino encontrem em sua obra os meios para a sua realização:

"Minha vida, meu destino,

se são identificado com minha obra, uma obra de arte,

se eles são realizados em minha obra, eles encontraram sua

solução."

Um exemplo que ilustra essa situação, trata-se da idéia de um espetáculo que Kantor nunca chegou a realizar plenamente, a não ser na forma de cricotage, uma espécie de "performance",68 muito utilizada pelo Teatro Cricot 2. O cenário do espetáculo seria constituído por uma única chaminé. Chaminés que ele usou como tema em muitas das suas telas. A imagem do espetáculo se debruçava sobre muitos corpos amontoados pela cena. Corpos dos judeus ${ }^{69}$. Em cena estão os corpos dos judeus mortos após a catástrofe, a barbárie do holocausto. Em seguida existe um processo de ressurreição, os corpos começam a se mover. Esses seres não sabem mais nada da vida. Eles perderam a memória. Entretanto, existem ao redor deles muitos fragmentos, restos do mundo desaparecido. Utilizando-se desses fragmentos eles procuram criar ou recriar o mundo, mas não conseguem pois não sabem para que as coisas servem. Por exemplo, existe uma cadeira quebrada que eles tentam reconstruir, mas eles não sabem como fazer. Eles constrõem qualquer coisa que não é a cadeira e no final não compreendem para que aquilo serve. Segundo Kantor, isso é uma situação fantástica para a ação teatral. Com um pouco de humor, de sarcasmo eles constrõem coisas absurdas, sem utilidade. No final eles constroem uma cruz sem saber o que fazer com ela. E como se existisse alguém contra, e que detestam, eles acabam por crucificá-lo como o Cristo, mas sem saber. Utilizando os restos do mundo anterior, eles encontram os restos de um

\footnotetext{
${ }^{67}$ Kantor, Tadeusz. Les voies de la création théâtrale, Paris: C.N.R.S. Vol. 18, 1993, p. 158.

${ }^{68}$ Não no sentido de experiências "estéticas" extremamente variadas, mas como teatralização de uma atitude ou de obras plásticas que rompem deliberadamente com a representação, pretendendo ser a apresentação de uma situação ou de uma ação que pode ou não ser real, mas certamente imediata. Uma atitude que ultrapassa as convenções dramáticas e teatraliza os elementos tradicionalmente descartados pela cena.

${ }^{69}$ Kantor destinava especial atenção para o povo judeu que segundo ele, trata-se de um povo singular entre os povos que foram perseguidos. É o povo elo porque eles esperam o Messias. E essa espera permite a eles continuar. Para os cristãos é o fim, pois esses já têm o seu. Para Kantor, os judeus são mais sábios nesse sentido.
} 
fuzil e o reconstituem e começam a servir como soldados. Por fim eles destrõem tudo novamente ${ }^{70}$.

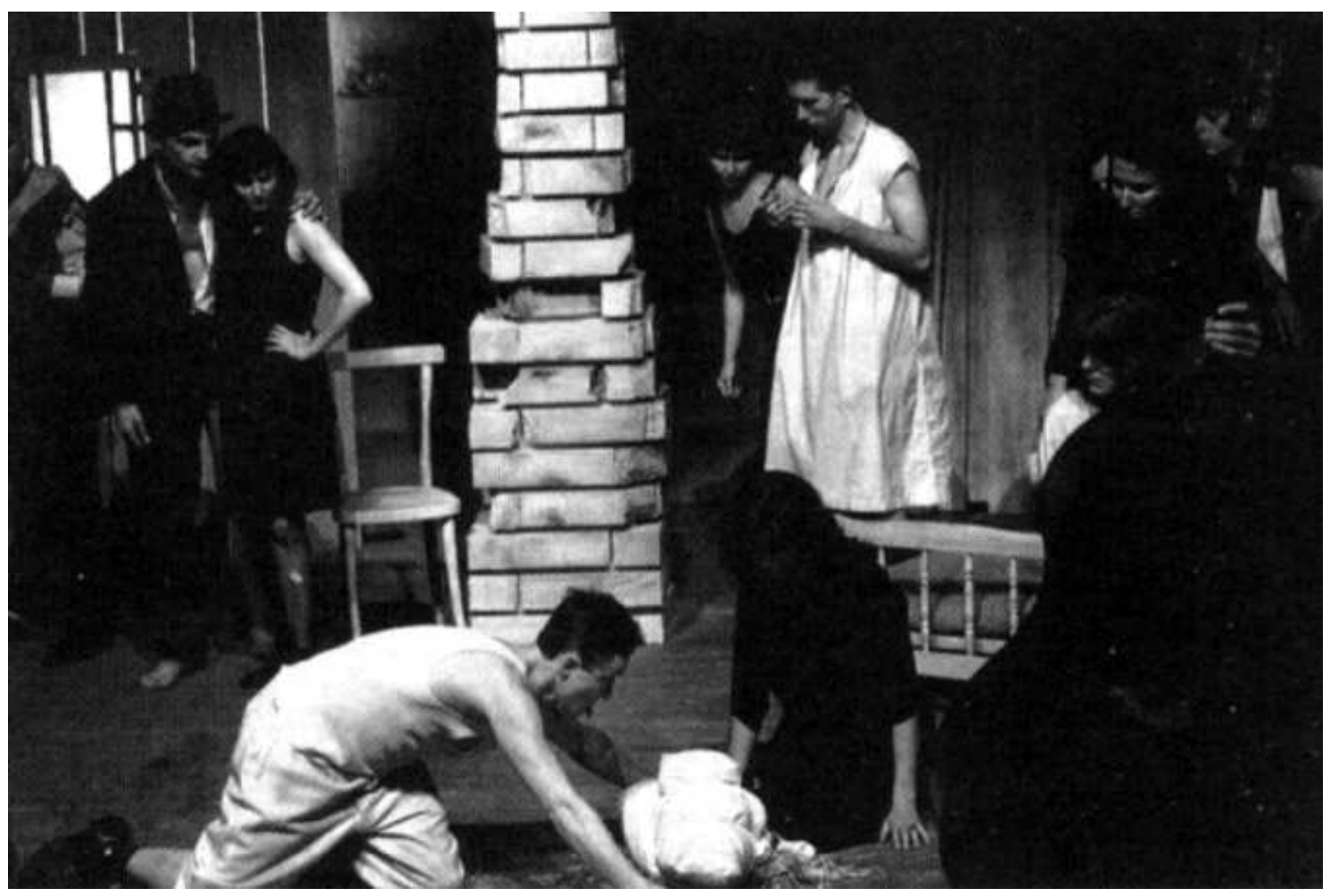

Cena da cricotage Ô docê noite. Foto retirada de: Kantor, Tadeusz. Ô douce nuit Les classes d'Avignon. Paris: Actes Sud Papiers,1991.

As imagens desse projeto são esclarecedoras pois são evidências do conturbado universo habitado por Tadeusz Kantor. A carga emocional do trabalho está latente em sua memória. São imagens que vão além dela, são estruturas que estão incrustadas em seu subconsciente como as chaminés dos campos de extermínio, a sua dupla origem, dividida entre mãe católica e o pai judeu, a sua ligação com o exército e com pai que não voltou da guerra, o apego aos objetos pobres e a noção de ressurreição que, além da idéia da morte, também traz a noção de retorno e, conseqüentemente, a idéia de uma outra realidade, realidade distinta da realidade cotidiana. Esses elementos, associados a muitos outros, determinam o surgimento de um movimento de intensa energia no estado

\footnotetext{
${ }^{70}$ Parte dessa idéia foi realizada com 20 estudantes durante o festival de Avignon, França, em 1990, sob o título $\hat{O}$ docê noite.
} 
psíquico de Kantor que o obriga a se recolher ao seu "quarto da imaginação" a fim de trabalhar sobre a carga emocional.

O que interessa a ele é o apocalipse, é o sentido catastrófico da vida. A vida após o fim do mundo, disso decorre a necessidade de se pensar postumamente:

"Kantor desejava reconstruir o mundo com os detritos de uma explosão"

Dessa forma, aquilo que se vê em cena trata-se de um alucinante cortejo saído de um mundo sepultado, em que uma memória individual e, às vezes, coletiva comporta-se como um retrato de um mundo perdido

“...uma Europa desaparecida, que no palco é reconstituída em uma dimensão concomitantemente patética e burlesca: como se a própria morte colaborasse com as imagens exumadas"72.

Enfim, o teatro de Tadeusz Kantor possui a capacidade de convocar os temas mais negros, os mais violentos e de tratá-los com o máximo de euforia, de excentricidade, exumando os temas mais traumáticos do século XX: a barbárie nazista e as perseguições stalinistas, e apesar das questões mais dolorosas, como diz Guy Scarpetta $^{73}$, a capacidade de evacuá-los de todo pathos e de lhes insuflar uma dimensão de humor e ironia. Em resumo, o passado que faz o seu retorno não é, em nenhuma hipótese, idealizado. Não se trata de um paraíso perdido, mas de um lugar no qual todos os seus elementos característicos estão ligados a uma veia de inspiração grotesca: destruidora, caótica e profanadora; contigüidades que constantemente retornam como um processo de renovação do lamento, da dor, do sofrimento e da morte.

Para Kantor, o teatro é uma atividade que só pode acontecer quando a vida é levada às últimas conseqüências e todos os seus conceitos perdem a sua significação. Nesse sentido, a ação do inconsciente no seu trabalho ocorre não somente como uma dimensão psíquica explorada com maior facilidade pela sua arte, devido a sua familiaridade com a imagem, mas é necessariamente uma questão de liberdade. A liberdade, conforme a visão dos surrealistas, habita a inconsciência, ao passo que para

\footnotetext{
${ }^{71}$ Scarpetta, Guy. Kantor au présent. Arles: Actes Sud, 2000. p.40.

${ }^{72}$ Ibid. p. 51.

${ }^{73}$ Ibid. p. 53.
} 
$\operatorname{Kantor}^{74}$, é na consciência que nasce o medo e o medo inibe a liberdade. Então, ser livre é superar o medo, é vencer a consciência e penetrar nas camadas profundas da vida. E como o Surrealismo fazia da liberdade do homem a sua palavra de ordem, eis o ideal surrealista subsumido à estética kantoriana:

\section{“A MAIOR META DA ARTE É}

\section{A LIBERDADE DO HOMEM!}

A liberdade não funciona unicamente nos limites de um remexer das convenções artísticas, a liberdade não funciona unicamente no quadro de um sistema social postulado pelo comunismo - sistema de igualdade e de justiça, mas

a LIBERDADE

reconhecendo a CONDIÇÃO HUMANA TOTAL

em suas mais profundas camadas, reconhecendo este lado da natureza humana que jamais havia sido considerado no movimento social:

\section{a ESFERA PSÍQUICA DO HOMEM,}

suas profundezas, a imensa força de ação, que até aquele momento era pressentida pelos poetas, e agora estudada pela inteligência (a ciência) e a imaginação (a arte).

Essa atitude é incontestavelmente a maior descoberta do século XX.

Nós não podemos contestar nem a substituir por uma outra.

Nós somos os herdeiros."75

Esse posicionamento diante da arte e da vida expresso nessa passagem das Lições de Milão faz eco à atitude de alguns surrealistas do passado e que denunciam o envolvimento ideológico de Kantor com o universo surrealista, dentre eles o jovem Antonin Artaud que fundou o revolucionário Teatro Alfred Jarry. Artaud, quando na direção do Centro de Pesquisas Surrealistas, publicou a sua famosa "Carta aos Reitores das Universidades Européias", na qual ele expõe o consistente furor por liberdade, a qual tanto ansiavam os surrealistas:

"Mais longe do que a ciência irá chegar, lá onde as flechas da razão se quebram contra as nuvens, existe esse labirinto, um ponto central para o qual convergem todas as forças do ser e todos os nervos essenciais do Espírito. Nesse dédalo de paredes móveis e sempre mutantes, fora de todas as formas conhecidas de pensamento, o nosso Espírito se agita, atento aos seus movimentos mais secretos e espontâneos - aqueles com o caráter de revelação, um ar de ter vindo de alhures, de ter caído do céu... A Europa se cristaliza, mumifica-se lentamente sob o envoltório de suas fronteiras, suas fábricas, seus tribunais de justiça, suas

\footnotetext{
${ }^{74}$ Kantor, Tadeusz. Leçons de Milan. Paris: Actes Sud - Papiers, 1990, p. 68.

75 Ibid. p. 63/64.
} 
universidades. A culpa está nos vossos sistemas bolorentos, na vossa lógica de dois mais dois igual a quatro; a culpa está em vocês reitores... O menor ato de criação espontânea é um mundo bem mais complexo e revelador do que qualquer metafísica." 76

Essa atitude rebelde observada em Artaud e em Kantor, cuja origem está no posicionamento do Dadaísmo em relação à arte e à sociedade, sob muito aspectos era muito semelhante ao Surrealismo que acabou herdando a burguesia como inimigo declarado e que ecoou em Kantor através dos seus ataques ao mercado e às formas tradicionais de arte. $\operatorname{Arp}^{77}$, um dos principais dadaístas, dizia que a sua aproximação com os surrealistas se deu em função da rebeldia do movimento em relação à arte e à vida que eram semelhantes as do Dadaísmo. Kantor, por sua vez, sabendo do poder do Surrealismo, principalmente em relação ao automatismo que foi assimilado por ele na forma do acaso como processo de criação, acreditava, assim como os surrealistas, que através do automatismo seria possível revelar a verdadeira natureza individual do artista, pois esse se trata de um processo de criação muito mais rico e abrangente do que qualquer técnica conscientemente estruturada. Para os surrealistas, a estratégia do automatismo como ação criadora era um meio para se alcançar o inconsciente e suas estruturas. Em Kantor, o acaso, era um meio de se alcançar os reinos desconhecidos da realidade.

O Surrealismo desloca decididamente a posição psicológica da arte, transferindo-a da esfera da consciência para a do inconsciente, introduzindo a teoria do irracional como fonte da criação artística. O Surrealismo se apropria da desinibição dadaísta referente à produção de objetos de fundamentos simbólicos e afastados dos seus significados habituais. O Dadaísmo, por sua vez, era um movimento livre, antiburguês, seguramente niilista que proclamava a ruptura com a lógica realista e a negação da realidade. Este é o início de uma nova realidade, própria ao artista que a cria. Marcel Duchamp traz para a arte os objetos prontos, os ready-mades que se tornarão, na obra de Kantor, um dos elementos principais. Os objetos são arrancados da vida e apresentados como objetos artísticos em uma galeria de arte. Assim, o Dadaísmo é antes de tudo um posicionamento, uma atitude diante da vida e da arte, através da qual

\footnotetext{
${ }^{76}$ Antonin Artaud. La révolution Surréaliste - n. 3, abril de 1925. In. Conceitos da arte moderna. Org. Nikos Stangos. Rio de Janeiro: Zaar, 2000, p. 148.

${ }^{77}$ Jean Arp (1887-1966), também chamado de Hans Arp - pintor, escultor e poeta francês - foi um dos líderes da vanguarda européia na arte durante a primeira metade do século XX.
} 
temos a negação das instituições e do mercado, assumindo uma dimensão de desafio e de provocação - A Fonte, um urinol é exposto como uma obra de arte.

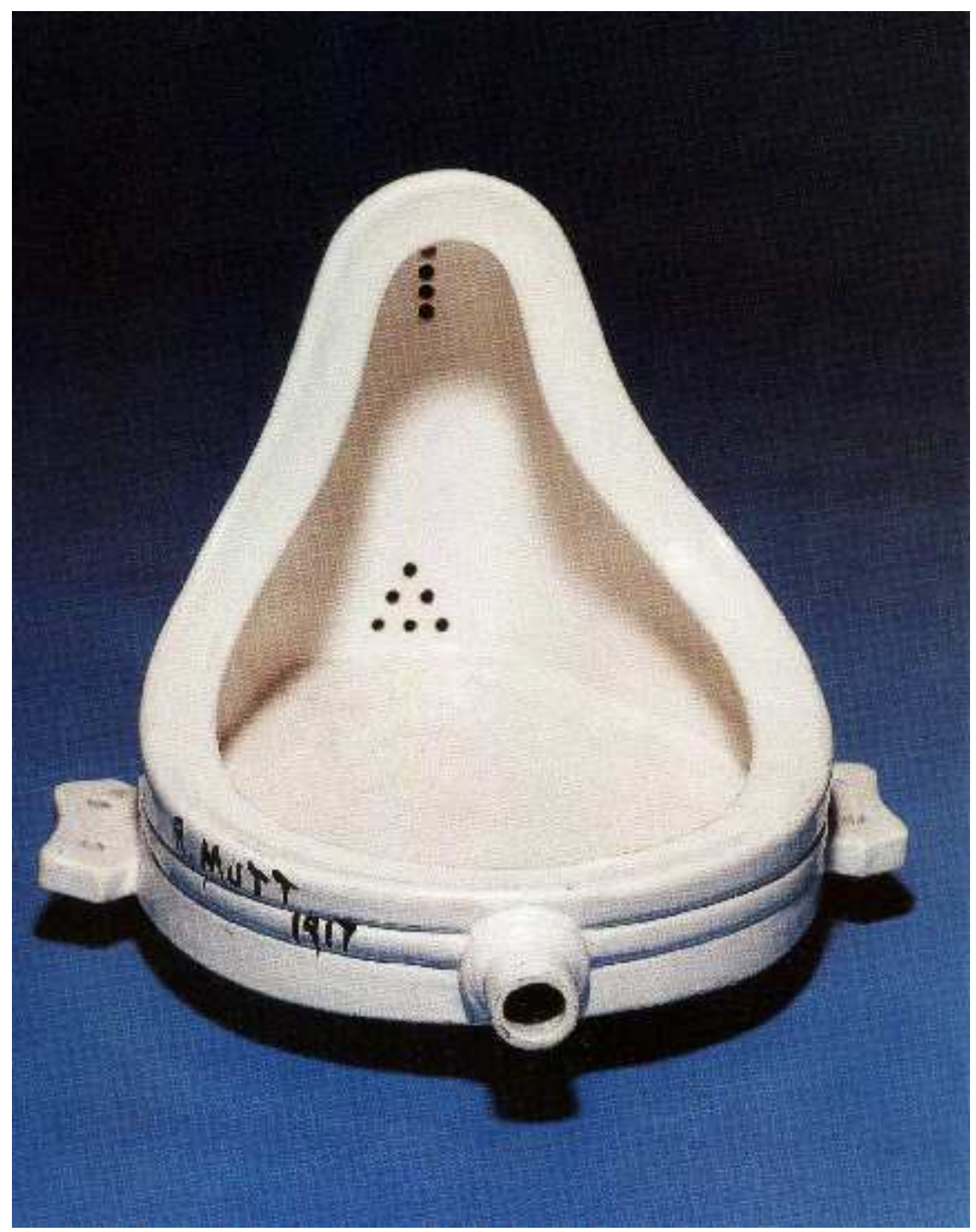

Marcel Duchamp - $A$ fonte. Foto retirada de: Mink, Janis. Marcel Duchamp - l'art contr l'art. Paris: Taschem, 2004.

As transformações sociais, políticas, científicas do início do século XX criaram a necessidade de se pensar o homem em outros parâmetros. Freud influenciou André Breton que rompe com o Dadaísmo pelo Surrealismo, que proclama o homem como unidade da razão e do subconsciente. Como estética, o Surrealismo busca ir além da mera reprodução da realidade e toda expressão estética deve referir-se não a um modelo externo, mas sim a outro, o interno, não condicionado por modelos culturais. Para 
alcançar esse modelo interior, os surrealistas propuseram uma série de técnicas: associações livres, hipnoses, colagens, a escrita automática: todas destinadas a liberar o potencial criativo do artista. Nesse contexto, dentre outros elementos que também costeiam a esfera do subconsciente, a escrita automática é transposta por Kantor em uma forma de criação de textos muito utilizada nos seus espetáculos posteriores a $A$ classe morta. Nesse processo de trabalho, Kantor e os atores inventam o texto durante os ensaios, e a partir de um texto inicial, Kantor o re-trabalha e o transforma no texto da peça. Kantor também usa do subconsciente dos atores que, materializado, também é posto em cena. O sonho é outro elemento da mesma natureza. Como nos surrealistas, os espetáculos estão baseados sobre a técnica do sonho na qual a ação é a repetição. Os espetáculos possuem a estrutura de um sonho em que as imagens estão justapostas criando, pois, outra possibilidade de interpretação do conjunto do qual ela é componente. Assim, como comenta Skiba-lickel,

“...os espetáculos criados por Kantor após A classe morta, pertencem ao folhetim do mesmo pesadelo.”78.

Certamente, o Surrealismo com o Construtivismo são os principais motivadores da forma no teatro de Tadeusz Kantor. Nesse contexto, os objetos ganharão uma indiscutível importância e se constituirão nos instrumentos de construção de um estado artístico que permite compreender o mundo que está do outro lado, ou seja, a realização da imagem de um objeto material em um universo diferente que só pode ser atingido através da arte. Na segunda parte da encenação de $O$ casamento, na versão surrealista, Kantor irá demonstrar alguns dos procedimentos e concepções sobre a criação desse universo.

Inicialmente, os atores mudam o cenário e a maquiagem. A aparência dos atores deveria ser a de pessoas velhas. Tudo isso deveria seguir os princípios e concepções do Construtivismo, com muito humor e ironia, tudo muito próximo aos efeitos das gags circenses. A ação deverá acontecer sob uma luz tênue, para acentuar o clima de mistério. Esse tratava-se de um mundo criado pela imaginação e os espectadores deveriam descobrir os personagens que estavam na cena. A realidade da cena era exatamente aquela após o casamento, o momento no qual as personagens envelheceram.

\footnotetext{
${ }^{78}$ Skiba-Lickel, A. L'acteurs dans lê thèâtre de Tadeusz Kantor. France: Bouffonneries, n. 26/27, 1991p.13.
} 
É esse o momento no qual a história será contada. Os membros da família são os velhos que um a um saem literalmente de uma tumba instalada no centro do palco.

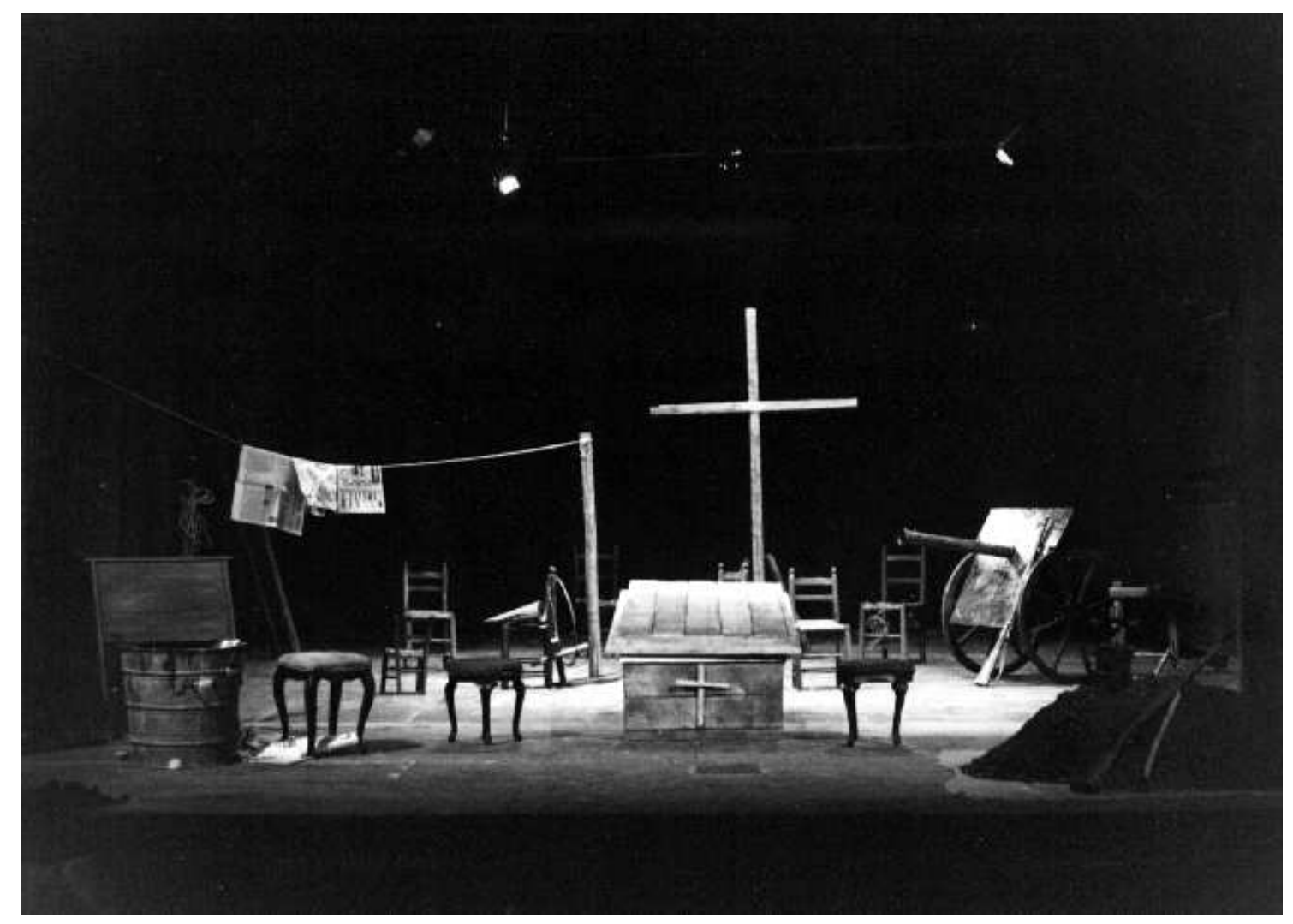

Cenário da segunda parte de $O$ casamento. Foto: Fabio d’Amico.

Do cenário anterior, o relógio desapareceu pois o tempo, nesse momento, é incomensurável. O que permanece do cenário anterior são pequenas lembranças do passado. O tempo é então entendido como devastação do passado. Através desses elementos os atores farão ressurgir todos os elementos do inconsciente, do sonho, do pesadelo e da alucinação.

$\mathrm{Na}$ estrutura surrealista da narrativa da segunda parte de $O$ casamento, é possível observar um universo aparentemente caótico, a exemplo do soldado que volta da guerra e se movimenta mecanicamente proferindo palavras de ataque como: pai, mãe, padre, etc. Está em constante luta com um inimigo invisível. Uma tumba que está no centro da cena e que na seqüência irá se tornar uma mesa na qual os parentes e convidados estarão sentados para o banquete. A refeição é servida em uma mala, que se abre e está cheia de 
espaguete e, em uma intensa bagunça, todos comem com as mãos, agridem-se com a comida. Existe na cena um insistente estado de loucura, de frenesi. A noiva e o soldado, que na primeira parte foram sepultados no leito nupcial, agora saem do túmulo/mesa em meio à cena. Olham a confusão, as lutas, o frenesi, e voltam novamente do lugar de onde vieram. Todos saem, o que permanece é apenas a cruz, iluminada com uma luz tênue. Mais uma vez, os ideais surrealistas subsumidos à poética de Tadeusz Kantor, pois após o surgimento do Surrealismo a arte se tornou uma linguagem e uma narração que nos fala de um outro mundo. Mas mesmo em Kantor, cuja arte, a partir da fase do Teatro da Morte, trata-se de um mundo de mortos, esse mundo outro não pode ser entendido como um mundo sobrenatural, mas como um mundo que está situado além das fronteiras da realidade imediata, um mundo que só pode ser revelado através de um estado artístico de extrema sensibilidade do criador.

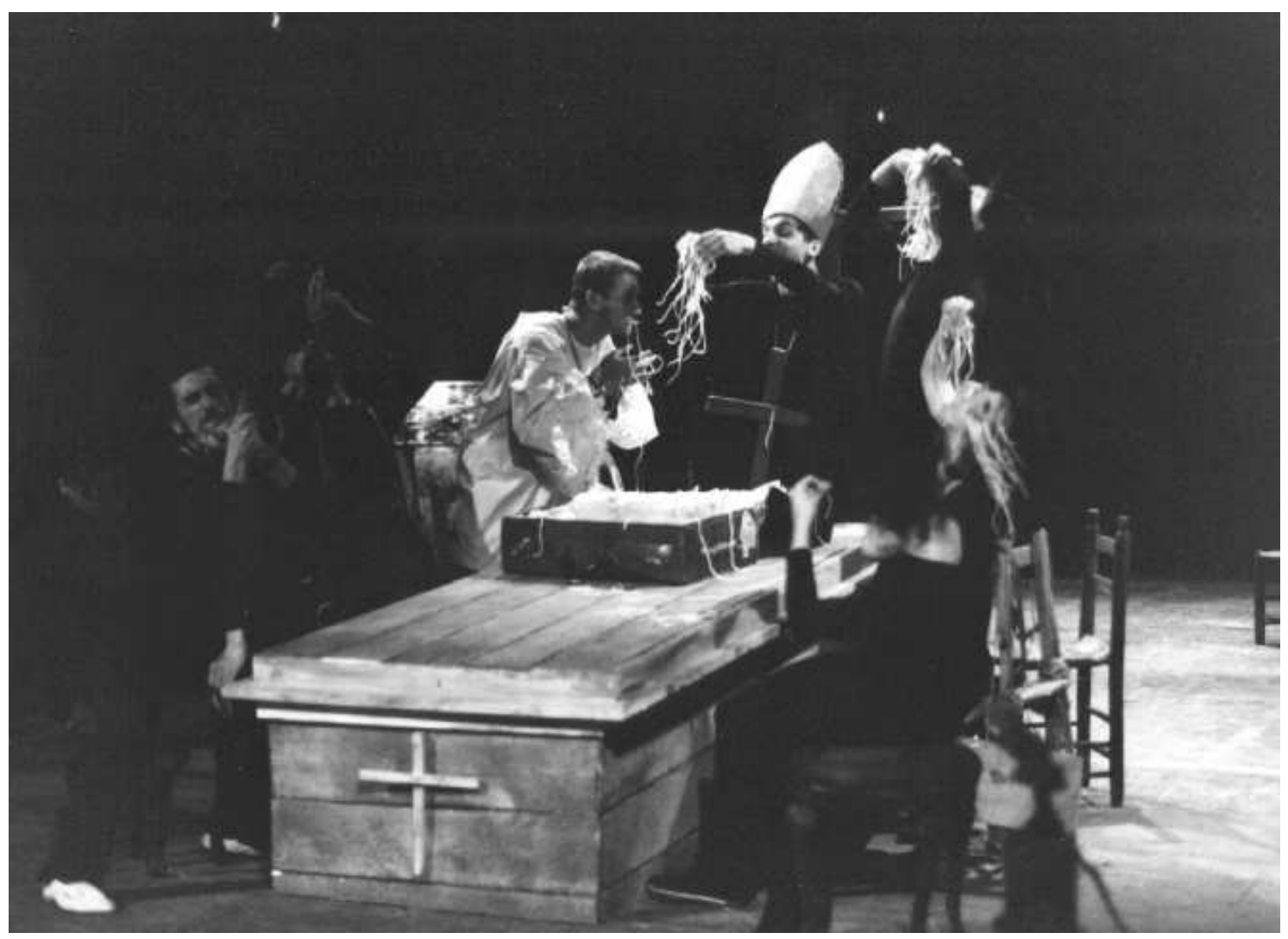

Cena final da segunda parte de O casamento. Foto: Fabio d'Amico. 
Em toda a história da sua arte, apesar, como veremos, das diferentes fases de sua expressão artística, a criação de imagens fortes, até mesmo violentas, transpassa toda a sua obra. Os objetos por sua vez, como muito tenho insistido, são indissociáveis do seu teatro e também transpassam toda a sua obra. Evidentemente o objeto é reinterpretado constantemente em relação à sua natureza como elemento de uma obra de arte. As diversas correntes artísticas que dialogaram com Kantor durante todos esses anos, se constituirão nos princípios de um procedimento criativo através do qual a natureza dessas correntes deixa de ser forma para se constituírem em um processo genuíno, único, original. Seja o Construtivismo, seja o Surrealismo ou o Dadaísmo, dentre outras, se transformarão em Kantor e se constituirão na sua maneira estritamente pessoal e subjetiva de perceber a arte e o mundo em que vive. Kantor não é construtivista, surrealista ou dadaísta ou outra que se queira atribuir. Kantor é Kantor, apaixonado pelas imagens e pelos objetos, através dos quais percebemos a síntese de todas as principais correntes das vanguardas do século XX.

Após a encenação de $O$ casamento, Tadeusz Kantor passou a pensar na rarefação das principais influências históricas no seu teatro. A diminuição das influências não significa absolutamente negação, mas um grande abrandamento, muito significativo, na utilização direta do Construtivismo, do Surrealismo e das diferentes tendências da arte que por muito tempo configuraram o seu teatro. Ao que me parece, o que permaneceu, principalmente após a encenação de Que morram os artistas!, foi apenas a atitude, o impulso criador, sobretudo pela conquista do desconhecido. Desconhecido esse que terá nos objetos, como veremos, o vórtice de condução para uma outra realidade, uma realidade sustentada pela imagem e que existe em concomitância com a realidade da vida. Mas antes de adentrarmos nesse universo outro faz-se necessário, pelo momento, o entendimento de questões relativas aos objetos, observados na sua individualidade, em suas funções objetivas, nos espetáculos de Kantor. 


\title{
CAPÍTULO II
}

\section{OS OBJETOS E A POESIA DA MORTE DO TEATRO DE TADEUSZ KANTOR}

\begin{abstract}
Chantal Meyer-Plantureaux ${ }^{1}$ comenta que a história do objeto em Kantor tem seu início com a tábua de madeira e com a roda de canhão em $O$ retorno de Ulisses, espetáculo de 1944. Esses objetos se constituirão nas idéias essenciais de Kantor sobre o objeto no seu teatro, ou seja: aquela do objeto pronto ou encontrado, "objet trouvé", na concepção de Kantor, idéia semelhante ao "ready-made" de Marcel Duchamp, e aquela da "matéria arrancada da vida", o objeto pobre que caracterizará a "realidade de classe mais baixa", idéia que está em conexão ao conceito de realidade degradada expresso na obra de Bruno Schulz. Mas, ao lado dessa idéia que percorre toda a sua obra, outros objetos mais sofisticados aparecerão, não mais arrancados da vida, mas construídos, fabricados, revelando um outro universo poético. Uma outra concepção do objeto em Kantor.
\end{abstract}

Entre O retorno de Ulisses (1944) e Hoje é meu aniversário (1990), os objetos se multiplicaram muito (de um espetáculo a outro). Essa multiplicação se deu não somente no sentido físico, mas também no nível do desenvolvimento conceitual da natureza e da função do objeto na cena. Para melhor compreender a especificidade de cada objeto, selecionei alguns, dentre tantos, e os separei em grupos conforme a proximidade de sua natureza física e conceitual em relação à expressão da sua existência em cena. Ao comentar sobre a especificidade desses objetos, aproveito do momento para tecer alguns comentários na tentativa de algum aprofundamento na análise de algumas de suas produções.

\footnotetext{
${ }^{1}$ Kantor, T. Les voies de la création théâtrale. Paris: CNRS, vol. 18, 1993, pg. 239.
} 
OS MECANISMOS DA MORTE-VIDA:

Os objetos reais.

Os objetos híbridos.

Os objetos cópias.

Os objetos máquinas.

OS OBJETOS REAIS - Nesse grupo estão os objetos retirados do cotidiano, ou que foram confeccionados como retratos da realidade cotidiana.

A cruz

Algumas imagens da morte nos confortam, ao passo que outras nos aterrorizam. No entanto, algumas imagens, eu diria, podem causar conforto e terror ao mesmo tempo. Nesse contexto, a cruz é um objeto de singular especificidade. 


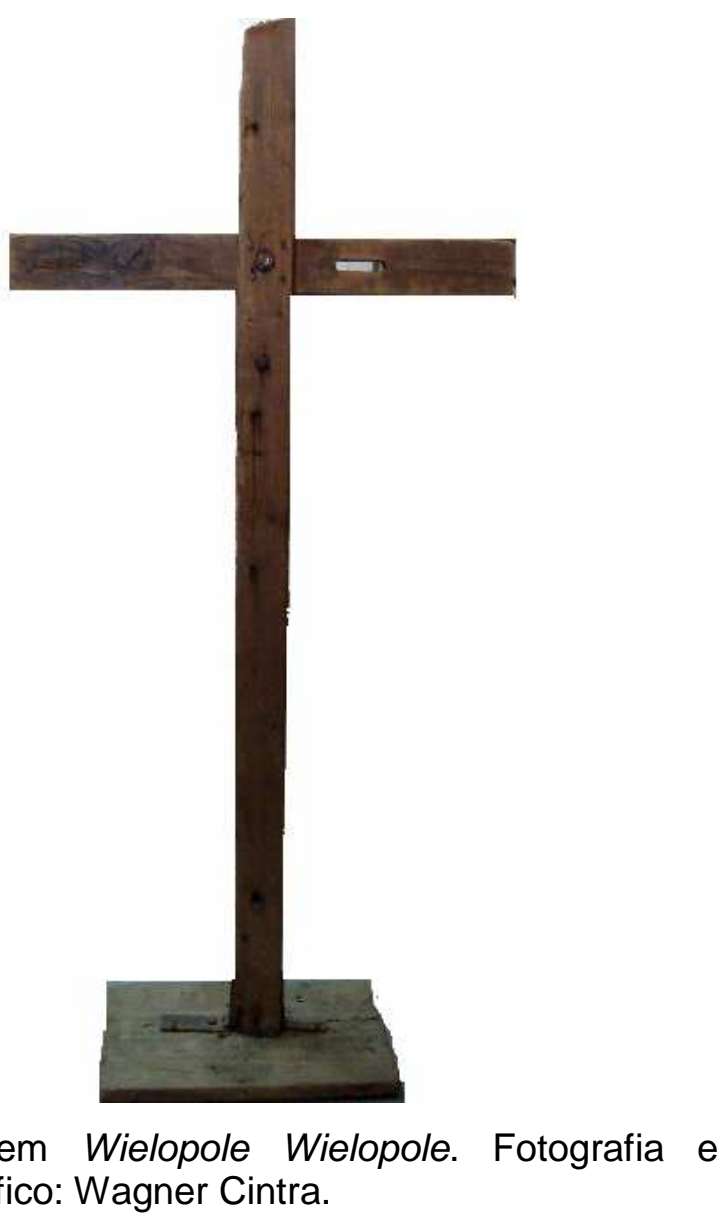

Cruz usada em Wielopole Wi
tratamento gráfico: Wagner Cintra.

O ser humano é a única espécie que sabe que a morte é inevitável e que não há como escapar disso. O conhecimento de toda e qualquer morte reforça em nós a consciência da nossa própria morte. Essa é uma idéia apavorante, mas a única certeza da vida é de que tudo o que é vivo, morre. Diante dessa verdade inexorável, fez-se necessário que o ser humano, na especificidade de cada cultura, encontrasse meios de aliviar o medo e de se conformar com a morte, a própria morte. Talvez isso explique o fato dos homens se cercarem insistentemente de imagens da morte. O ser humano, através da imaginação, não custou a criar um mundo no qual não estamos mais vivos e a maneira exclusivamente humana de realização dessa idéia é através da arte. Nesse sentido, com a arte, o artista encontra uma forma de ter algum controle sobre o mundo material e sobre a realidade que o cerca. Assim, aquilo que nos leva a nos cercar de imagens da morte, sobretudo dos ancestrais, é para se criar a impressão de que aqueles que povoam nossas lembranças ainda continuam ao nosso lado, mesmo que eles não se comportem como se comportavam anteriormente. Daí a aparência dos personagens de 
Kantor, como se estivessem saídos do túmulo. Em Que morram os artistas! esse é um aspecto essencial no desfile do Marechal Pilsuldski e de seus soldados.

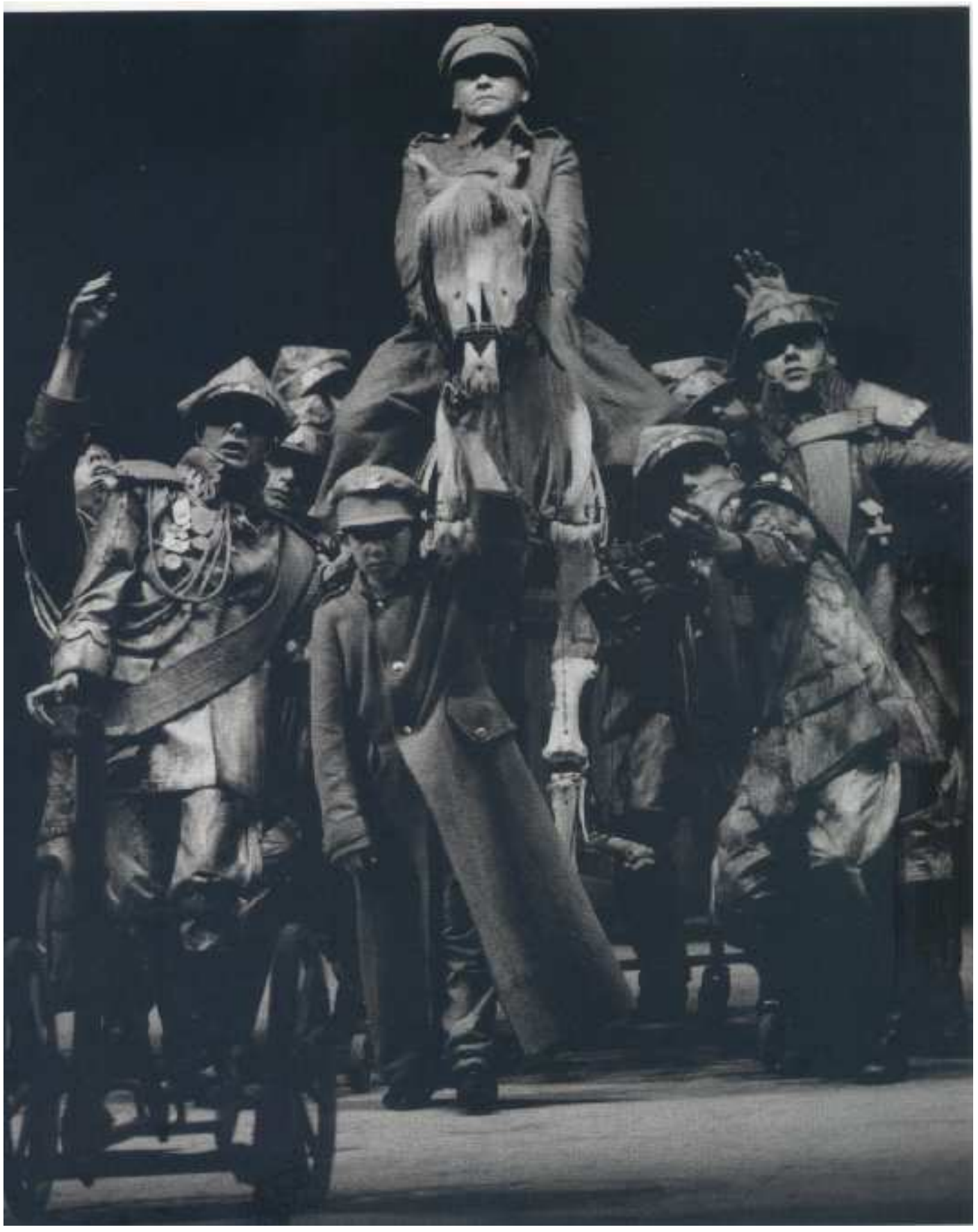

Que morram os artistas! - desfile do Marechal Pilsuldski. Foto: Maurizio Buscarino. 
Ao buscarmos conforto nas imagens que lembram a morte, criamos a impressão de que a morte não é tão ruim quanto parece. Ao pensarmos a nossa própria morte, adquirimos consolo ao contemplar as imagens daqueles que já morreram. Mas esse é só um lado da história. Se o temor pela nossa própria morte é tão intenso e isso faz com que nos cerquemos de lembranças e imagens da morte a fim de nos consolar, o outro lado da história trata-se do fato de que existem imagens que exploram o nosso medo da morte. Algumas imagens não são reconfortantes. São perturbadoras e até apavorantes. Essa é uma questão interessante e que está no centro da discussão do teatro de Kantor, ou seja: a criação de imagens que são profundamente inquietantes.

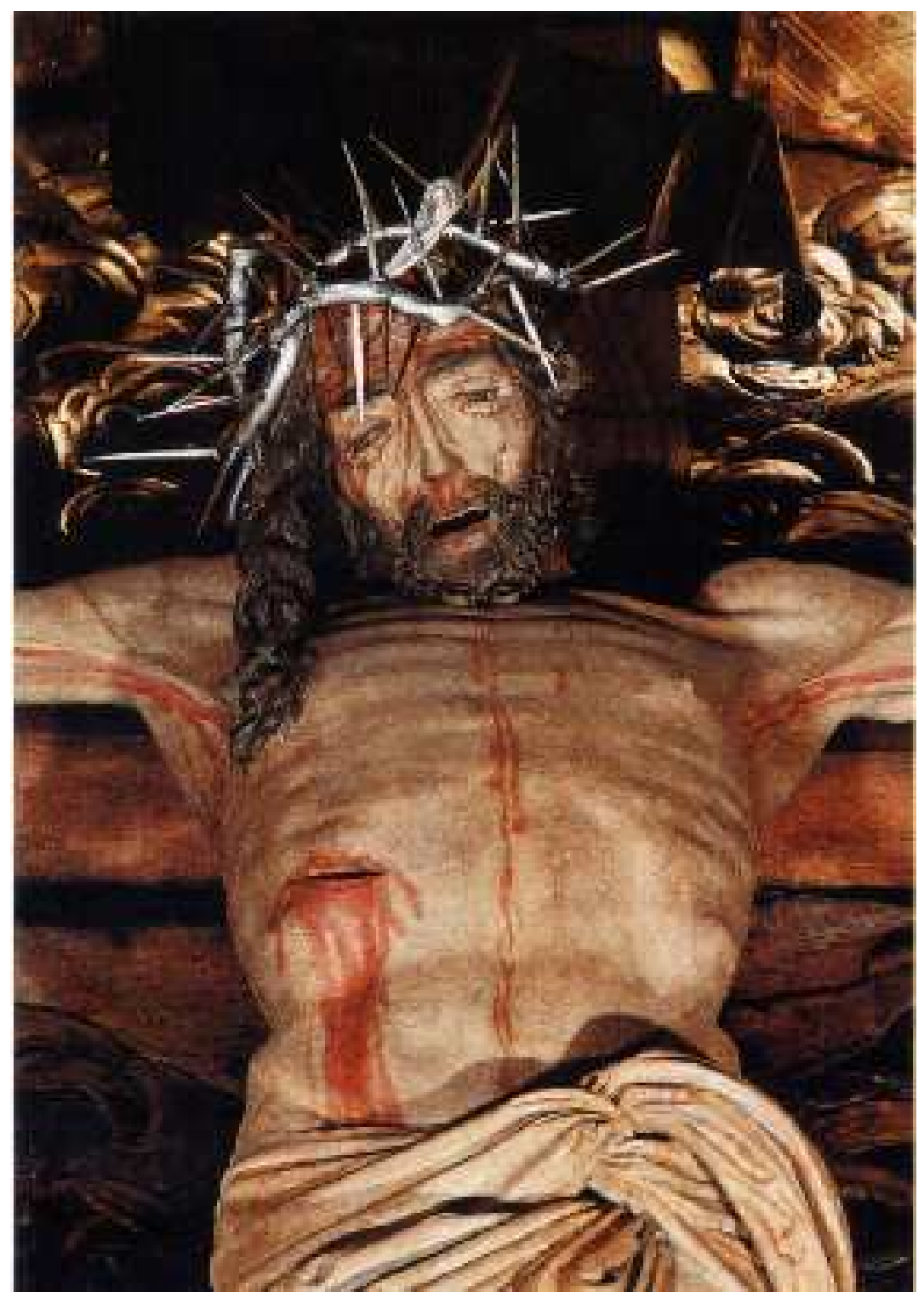

O crucifixo (detalhe da escultura feita por Veit Stoss, no final do século XV, para a Basílica de Santa Maria, na Cracóvia). Foto: Piotr Guzik. 
A cruz, no ocidente cristão, como símbolo religioso, é usada para confortar as pessoas. No entanto, a cruz, como imagem, é a figura de um homem que sangra e agoniza próximo da morte. Essa imagem deveria causar pavor, entretanto trata-se de uma imagem que apavora e conforta ao mesmo tempo, como pode ser observado na imagem do Cristo crucificado esculpida por Veit Stosz. Mas afinal, qual o sentido da criação de tais imagens? Talvez porque a combinação de imagens exerce um poder muito grande sobre a mente humana, e nesse caminho, a cruz é única, uma imagem que opera de duas formas opostas: é uma imagem aterrorizante que representa dor, perda e sofrimento, mas, ao mesmo tempo, é uma imagem que conforta e mantém a esperança. Kantor, certamente sabia que essa combinação fazia da cruz um símbolo extremamente poderoso, daí a sua utilização em todos os seus espetáculos. Ele se utilizava da cruz, não na forma habitualmente usual, aquela de dar sentido à incompreensível perda da vida, mas fundamentalmente para categorizar a vida diante da opressão totalitária.

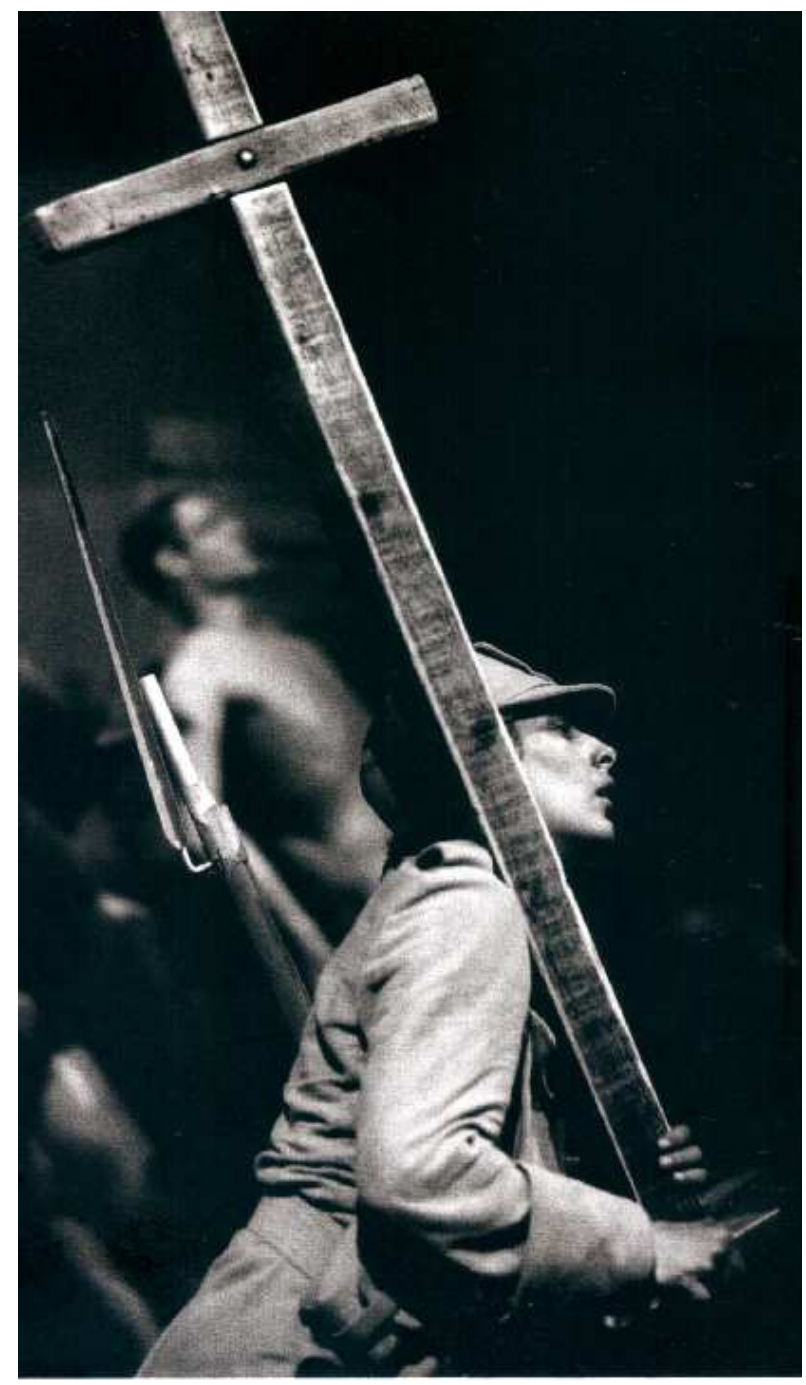

Wielopole Wielopole - o soldado e sua cruz. Foto: Maurizio Buscarino. 
Para Kantor, a morte se institui ainda em vida, a cruz não se apresenta de maneira reconfortante frente à inexorabilidade da morte, mas como agonia da vida diante da própria vida. Isso pode ser percebido em Wielopole Wielopole, na cena intitulada - Aqueles do front - na qual os soldados, supostamente vivos, misturados aos manequins, supostamente não-vivos, ao partirem para a guerra, desconhecem estar mortos. A transparência da situação é exposta por Kantor através do Padre Smietana, que consciente dos fatos, cobre com terra homens e manequins, movimento e ausência de movimento, ambos indubitavelmente inertes, mortos diante da impotência de sublevação da vontade individual.

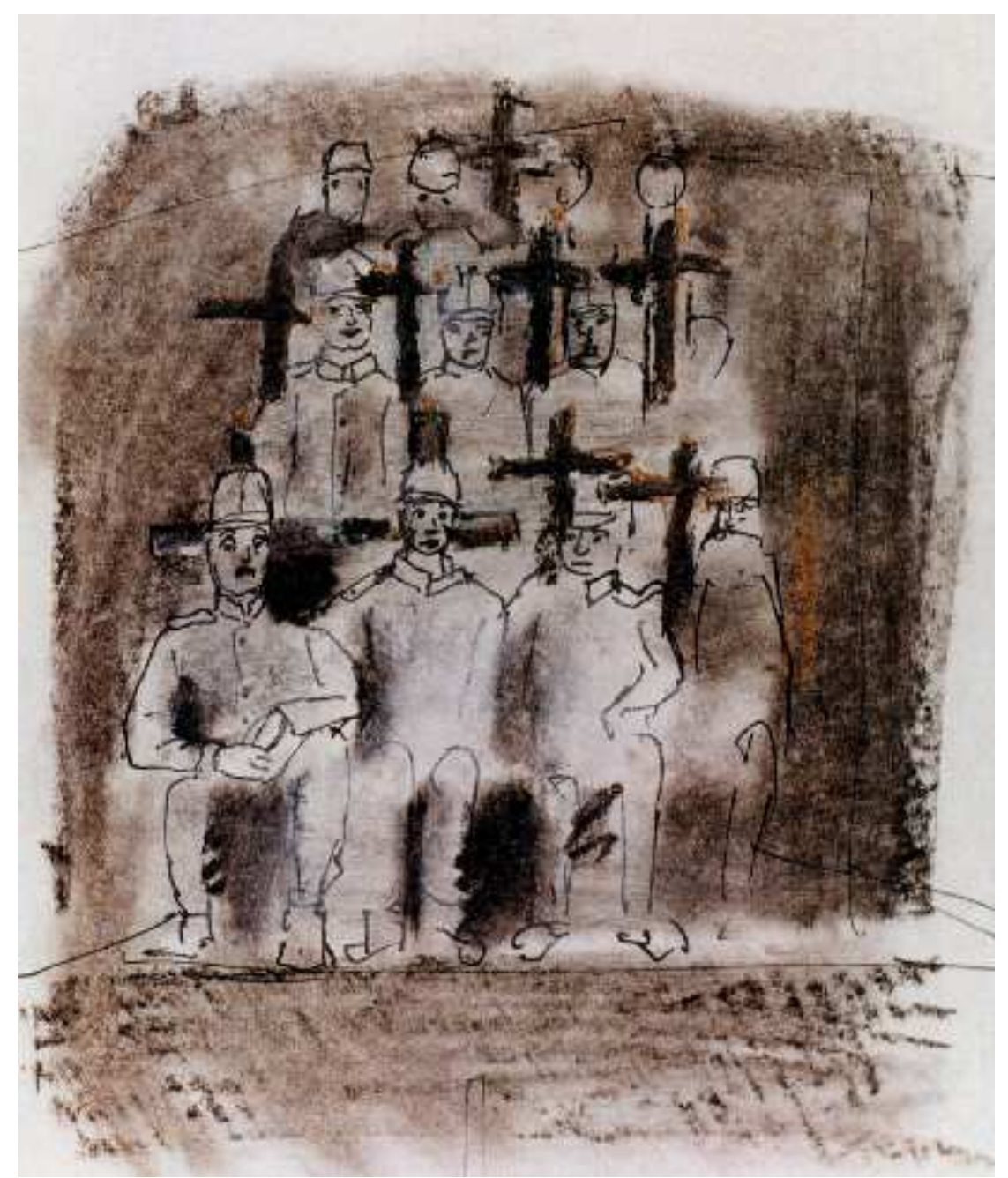

Aqueles do front - projeto de Kantor para a cena. Foto: arquivos da Cricoteka.

Pouco antes da cena descrita anteriormente, existe a entrada de uma cruz inclinada sobre rodas na qual um soldado está depositado, em uma posição que cultiva a 
idéia de crucifixão. Na seqüência da cena, o soldado morto, ou quase morto, é colocado pelo Padre Smietana junto aos soldados que partem para o front. A cruz sobre as rodas, nesse contexto, adquire a função de carro funerário, veículo que conduz ao calvário e à morte.

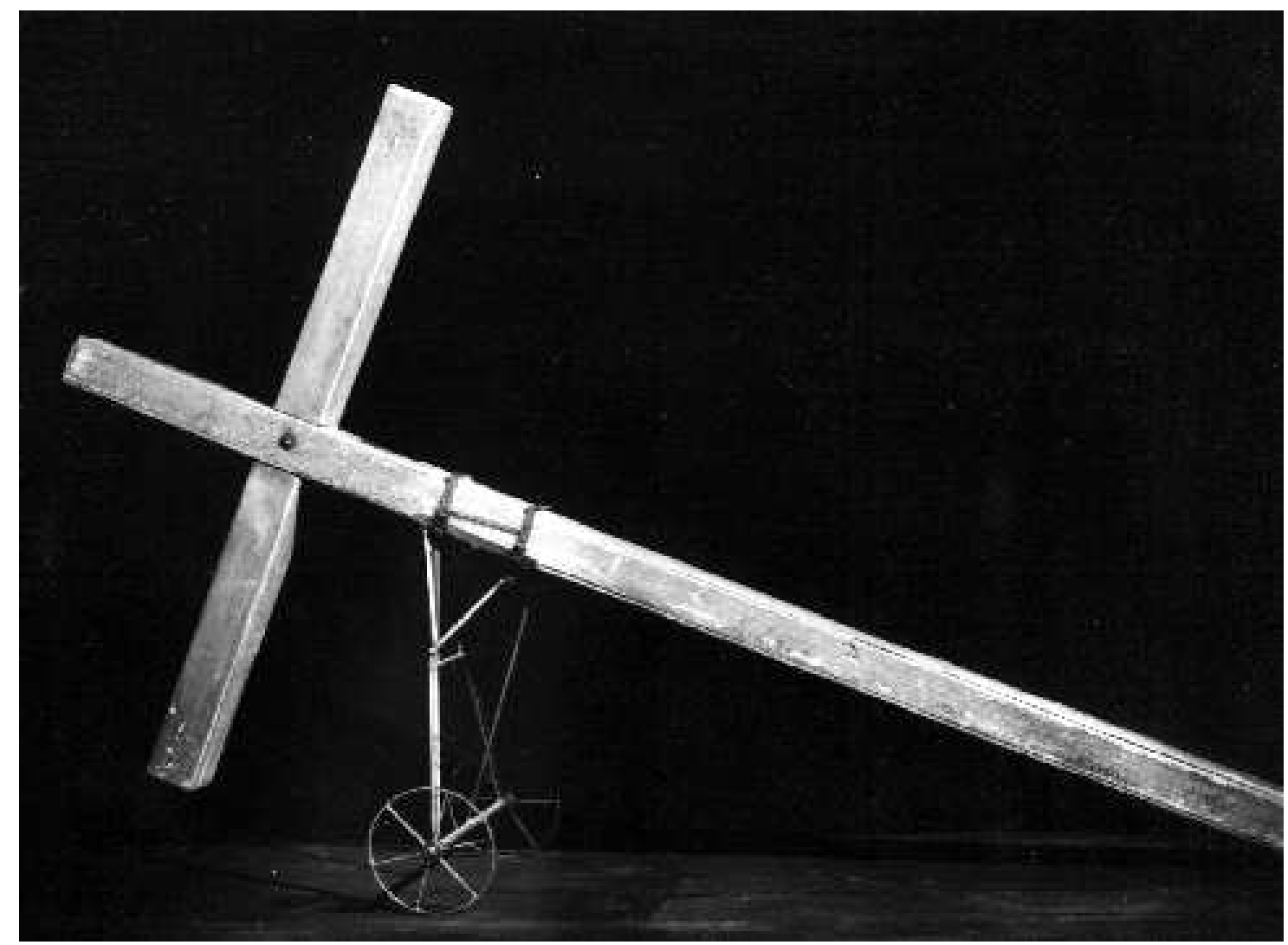

Wielopole Wielopole - cruz inclinada sobre rodas. Foto: Janusz Podlecki.

Em Kantor, a cruz assimila diversas funções e conceitos. Entre essas, o fim da vida em toda a sua singularidade religiosa. Conforme a práxis católica, existe algo na existência humana que não se pode crer suscetível de destruição, daí o inevitável recurso à fé religiosa para aplacar o temor diante do desconhecido. Nesse ponto, a morte realiza a principal vocação do ser, ou seja: deixar de ser o que é para ser colocado noutro mundo para mudar inteiramente de Ser. Ao assumir o signo da morte, a cruz se apresenta como fronteira que não significa apenas o fim da vida, mas o limiar de outra realidade. Se entre os crentes encontramos o paraíso ou o nirvana, em Kantor o teatro. 


\section{Os bancos de escola}

Os bancos de escola fazem parte de uma categoria que Chantal MeyerPlantureaux ${ }^{2}$ chama de objetos emprestados da vida cotidiana. Os bancos em A classe morta compõem um grupo de cinco unidades, sendo que os dois últimos são ligeiramente mais altos que os outros. Quando em conjunto com os atores e manequins possibilitam uma composição em forma de pirâmide, uma espécie de instalação, "um monumento funerário"3 que abriga os dejetos da infância morta, os velhos. Seu valor dramático se duplica em sua função metafórica, ou seja: por um lado, os bancos de escola associam a idéia de escola, de infância, do momento onde a vida se revela em sua plenitude. Por outro lado, como concepção da morte no sentido de registrar para o espectador o inevitável escoamento da vida na direção da cessação definitiva de toda matéria viva.

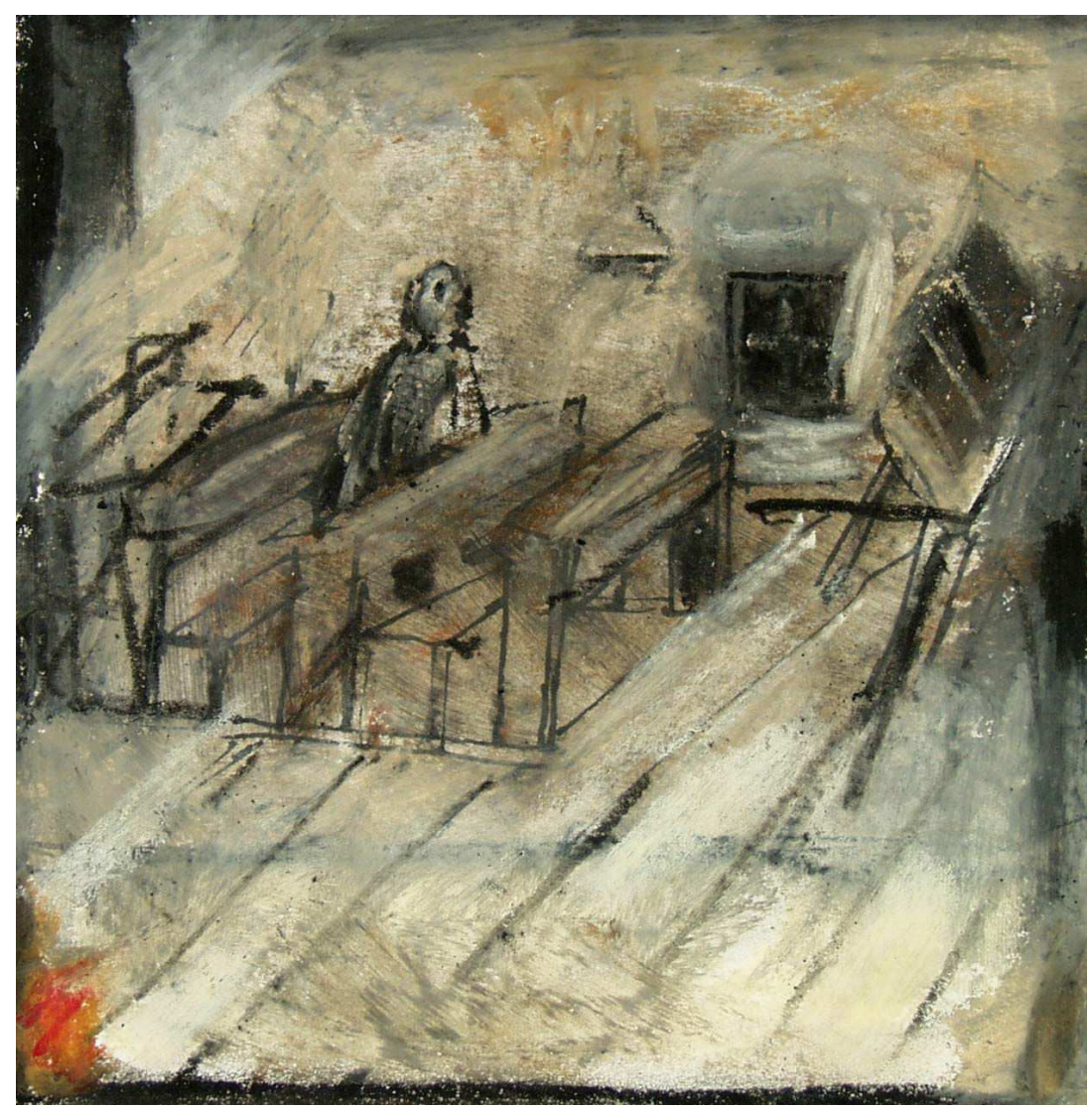

A classe morta - desenho dos bancos feito por Tadeusz Kantor. Foto: arquivos da Cricoteka.

\footnotetext{
${ }^{2}$ Ibid.

${ }^{3}$ Ibid. p. 240.
} 
Apesar de Chantal Meyer-Plantureaux comentar, no artigo sobre o objeto editado na publicação número dezoito de Les voies de la crèation thèâtrale, que em seu confronto com os velhos e os manequins, eles, os bancos, "não evocam a idéia de morte, mas a de cadafalso", , no entanto, na medida em que vida e morte são dois temas recorrentes ao espetáculo e que se sobrepõem um ao outro continuamente, os bancos como prisões nos quais os manequins de crianças, aquelas que os Velhos já foram um dia, a morte é evocada na cena pelos manequins de cera; nesse sentido, os bancos são instituídos como monumento funerário, como túmulo, como prisão de onde se é impossível escapar e da morte não existe escapatória.

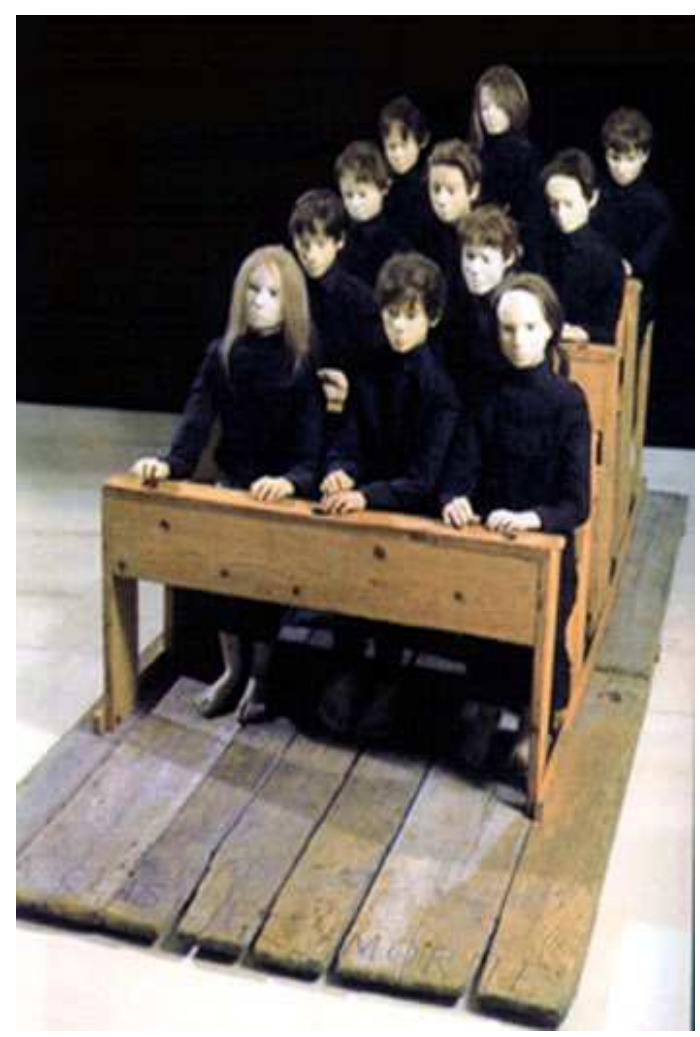

Manequins nos bancos de escola. A composição está em exposição na Cricoteka. Foto: arquivos da Cricoteka.

Os manequins nos bancos de escola acionam a memória criando a sugestão de vida, mas é uma vida retida na memória do espectador, uma vida que ficou no passado, e que, ao movimentar a memória do espectador, os bancos estabelecem uma relação

\footnotetext{
${ }^{4}$ Ibid.
} 
intrínseca entre o passado e o presente, pontuando a inexorabilidade do futuro. Assim, a morte se institui como uma imagem tanto do futuro quanto do passado. O presente, entretanto, é um estado em constante corrupção da vida, uma vida que se esvai incessantemente e impregna os bancos com a força das suas lembranças.

Como outros objetos construídos por Kantor, o material utilizado geralmente era encontrado ao acaso em canteiros de demolição, o que já dava aos objetos uma natural aparência de velho e usado. No caso dos bancos de A classe morta, essa característica é realçada por uma pintura que acentua a aparência da ação do tempo sobre a matéria bruta. Em A classe morta:

"por serem extraordinariamente reais e concretos, os bancos impõem imediatamente a sua presença, ocupam o espaço de maneira massiva e estável, ${ }^{5}$

que, imbuídos de uma rigidez escultural, sustentam os corpos frágeis dos Velhos decadentes ao mesmo tempo em que preserva a memória, e preservar a memória parece ser uma obsessão em Kantor, uma necessidade de não esquecer a experiência da Segunda Guerra Mundial. Os bancos como lembrança da morte: a morte nas prisões, nos cadafalsos da intolerância que vitimou todo um povo nos campos de concentração.

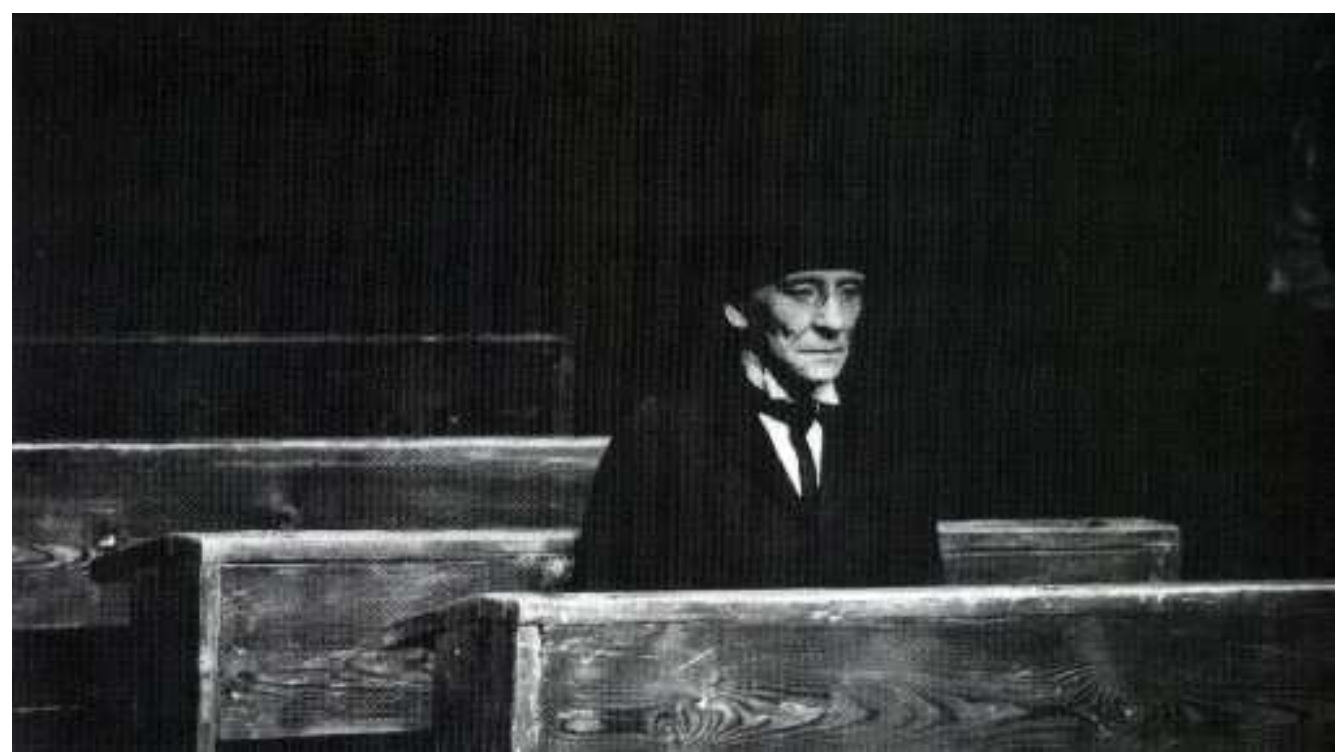

A classe morta - cena do espetáculo. Foto: arquivos da Cricoteka.

\footnotetext{
${ }^{5}$ Kantor, T. Les voies de la création théâtrale. Paris: CNRS, vol. 18, 1993, p. 240.
} 
Os bancos de escola, em A classe morta, tornam-se a escala da dimensão da memória de Kantor e também do espectador. Em Não voltarei jamais, os bancos se tornarão os elementos da memória do artista por não significarem mais a infância perdida, mas por assumirem a condição de personagem ao representarem um espetáculo antigo $^{6}$. Os bancos deixam de ser o depósito da memória para personificarem a própria memória, deixam de ser objetos estáticos para se tornarem sujeitos da ação. Os bancos como sujeitos da memória se apresentam na cena em número de quatro e da mesma altura. Estão pintados com uma tinta escura e têm o tamanho reduzido em relação aos de A classe morta. No espetáculo, não carregam mais a memória da infância mas estão carregados da história do seu uso, das representações do espetáculo realizado pelo Teatro Cricot 2. A memória de um espetáculo antigo que se presentifica em outro mantendo a relação anterior, passado e presente sendo que o presente de Não voltarei jamais torna-se "ilusoriamente" o futuro de A classe morta.

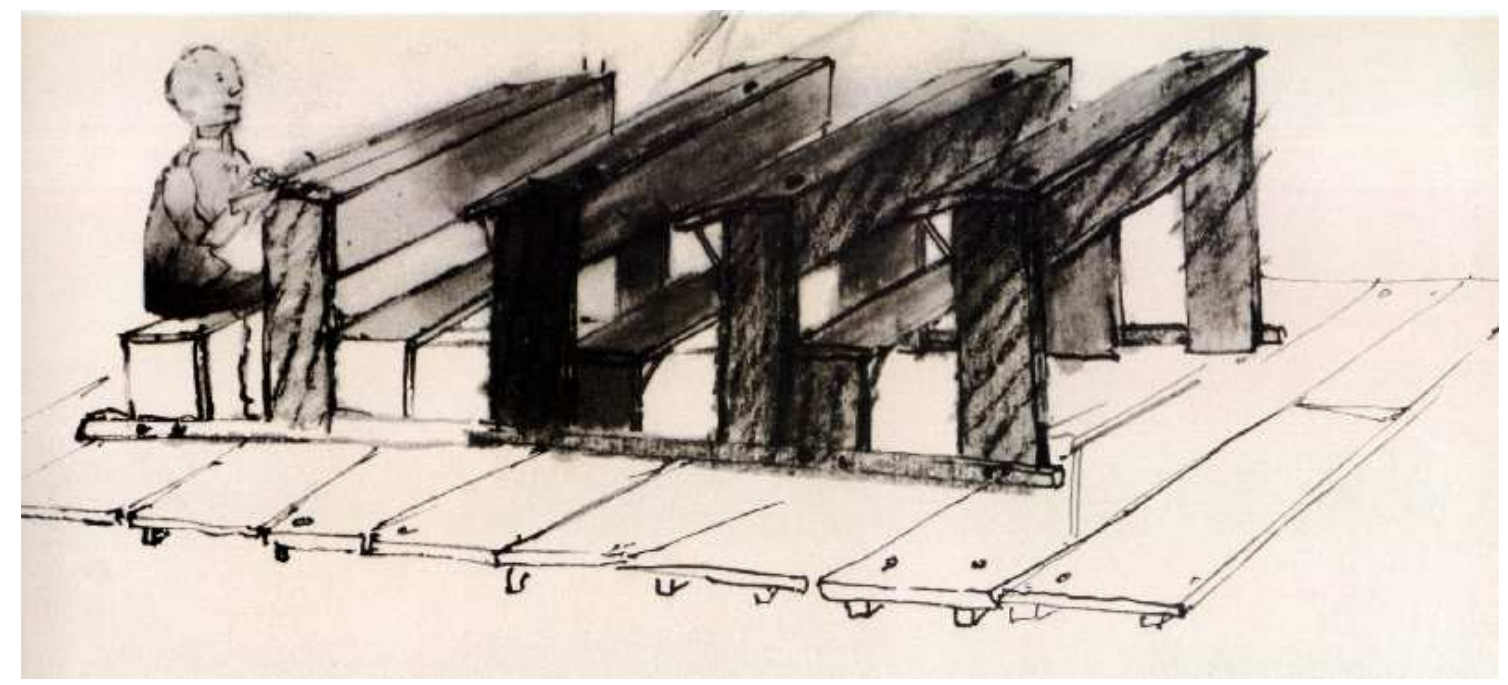

Tadeusz Kantor - projeto de cena. Imagem impressa gentilmente cedida pela administração da Cricoteka.

\footnotetext{
${ }^{6}$ É importante assinalar, que os bancos de escola em Não voltarei jamais, dentro da divisão que estabeleci para falar sobre os objetos no teatro de Kantor, seria classificado como um objeto cópia. No entanto, optei por falar sobre ele ao lado dos de A classe morta, para acentuar as semelhanças e diferenças conceituais na cena.
} 
Os bancos têm sua relação funcional alterada de um espetáculo para outro; em Não voltarei jamais, eles não representam mais o objeto essencial, massivo, que ocupa a maior parte do espaço. Eles estão todos em viés, tratam-se somente de um dos elementos em meio a uma proliferação de objetos. Isso justifica as suas dimensões reduzidas, ou seja: em A classe morta, a sua robusta solidez e infalível imobilidade permitiam que fossem ligados uns aos outros. No caso de Não voltarei jamais, os bancos são movimentados, manuseados e é acrescentado à cena como citação, a lembrança ativa do um espetáculo anterior. Eles não sustentam mais os corpos dos velhos decrépitos de A classe morta, eles esmagam os pobres fugitivos de Não voltarei jamais $^{7}$, signos residuais de uma narrativa que trata da resistência artística do Teatro Cricot 2. Recordações, "lembranças pesadas demais para carregar".

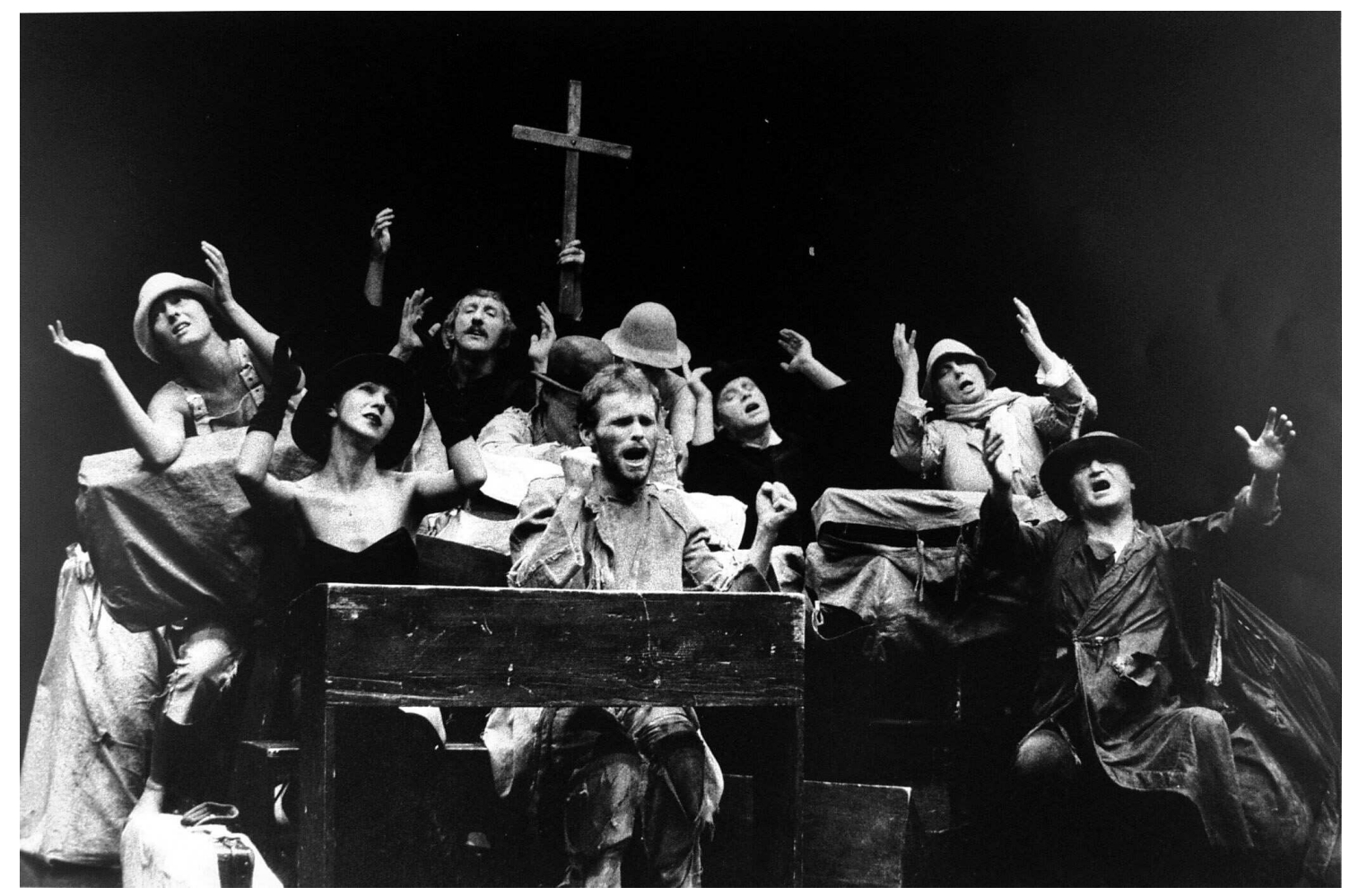

Não voltarei Jamais - nos bancos os personagens dos espetáculos anteriores. Foto: Romano Martinis.

\footnotetext{
${ }^{7}$ Ibid. Kantor, T. Les voies de la création théâtrale. Paris: CNRS, vol. 18, 1993, 241.

${ }^{8}$ Ibid.
} 
Os bancos escolares possuem para Kantor um significado assaz essencial e é significativo na evolução dos objetos no seu teatro. Aquilo que em A classe morta estabelece a noção de morte em relação ao passado e ao futuro, e que em Não voltarei jamais se constitui na referência citacional do passado que se presentifica no futuropresente, esse encontro entre duas realidades distintas no tempo e unidas pela memória, fazem dos bancos o símbolo essencial do não esquecimento, símbolo que Kantor eterniza ao esculpir para o túmulo de sua mãe um monumento, e que se tornou o seu próprio monumento funerário.

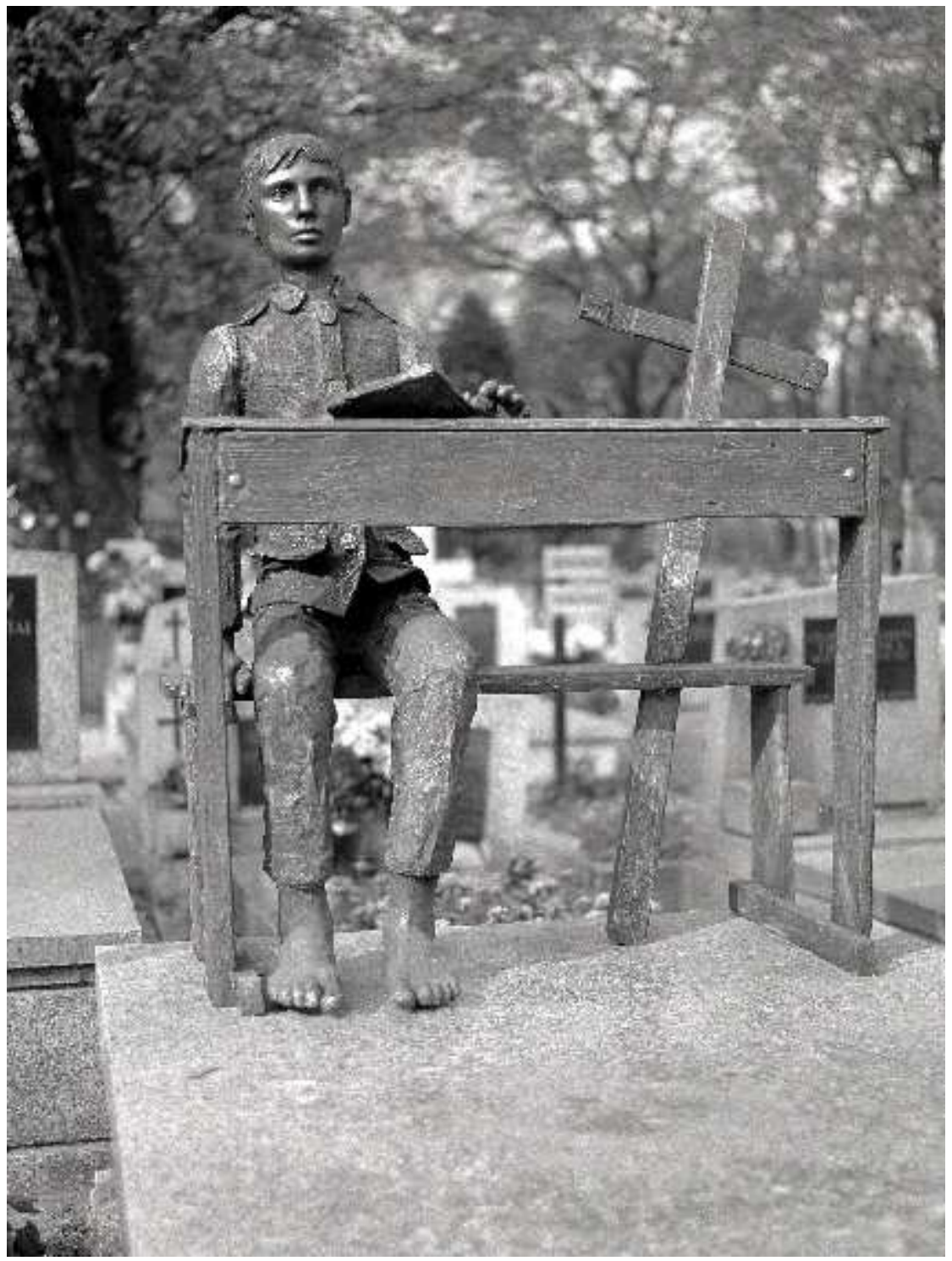

Tadeusz Kantor - monumento funerário. Foto: Konrad Pollesch 


\section{A cama}

Que morram os artistas! trata-se de um espetáculo que faz parte do chamado ciclo do "Teatro da Morte". Nesse trabalho, que ao meu ver é uma transição para o ciclo do "Teatro da Memória"9, Kantor começa a pensar aquilo que será a característica fundamental dessa última fase e que termina com a sua morte, em 1990. Essa característica lida com uma intensa reorganização de elementos cênicos até então por ele utilizados e cuja nova organização tem suporte nas lembranças de Kantor e dizem respeito a fatos históricos e à mítica da cultura polonesa. Na verdade esse processo já se iniciará em Wielopole Wielopole, no qual o espetáculo é basicamente uma autobiografia em que ele faz, através das suas memórias e a partir do seu quarto da imaginação, uma espécie de exumação da sua própria história pessoal em meio a fatos da história da Polônia. Que morram os artistas!, diferentemente de Wielopole Wielopole, é um apanhado de lembranças em que elementos da história real da Polônia convivem com o imaginário de Kantor e são interpretados segundo interesses muito específicos. A ele não interessa contar fatos da história, mas recordar personagens de outras épocas estabelecendo um jogo com o tempo através das lembranças da sua vida privada. Já no ciclo seguinte, as lembranças, muito mais pessoais, tratam de um retorno aos seus espetáculos anteriores. Kantor aproveita, em um processo de contínua exumação de seu trabalho, seus dois últimos espetáculos para refletir sobre a sua própria criação artística.

Após A classe morta, Tadeusz Kantor renuncia a todo texto pré-estabelecido. São as imagens o que mais importam ao espírito da peça. Não interessa a história das personagens mas as situações dramáticas e seus efeitos, os jogos e as tensões. Tensão alicerçada, sobretudo, no choque, na contradição entre a vida e a morte. Conforme o pensamento de Kantor:

\footnotetext{
${ }^{9}$ Kantor nunca chegou a nomear essa fase da sua criação. Teatro da memória foi um título atribuído pelos seus estudiosos e comentadores. O ciclo do teatro da morte é formado pelos espetáculos: A classe morta (1975); Wielopole Wielopole (1980); Que morram os artistas! (1985). O teatro da memória é composto por: Não voltarei jamais (1988); Hoje é meu aniversário (1990).
} 
“...o teatro é uma atividade que se situa nas fronteiras extremas da vida, no lugar onde os conceitos da vida perdem razão e significação, em que a loucura, febre, histeria, delírio, alucinação são as últimas trincheiras da vida frente ao surgimento da "trupe de feira da morte", seu Grande teatro."10

É exatamente nessa fronteira que o espetáculo acontece.

Walther e Metzger" dirão que "no limiar do século XX as vanguardas artísticas fizeram da morte um ato de revolta". No caso de Tadeusz Kantor essa revolta não se situa do mesmo lado da auto-aniquilação de um Van Gogh ou da demência de Antonin Artaud para quem somos todos suicidas, "já que temos criado miséria e horror para essa terra" ${ }^{\prime 2}$. A revolta em Kantor, não menos profana e repleta de pathos, permite a ele configurar a morte como elemento poético, ou seja: como linguagem criativa. Para ele, a obra de arte se constrói na esfera da morte e é na dimensão da morte que toda a sua linguagem se desenvolve e onde os objetos encontram a sua mais profunda existência.

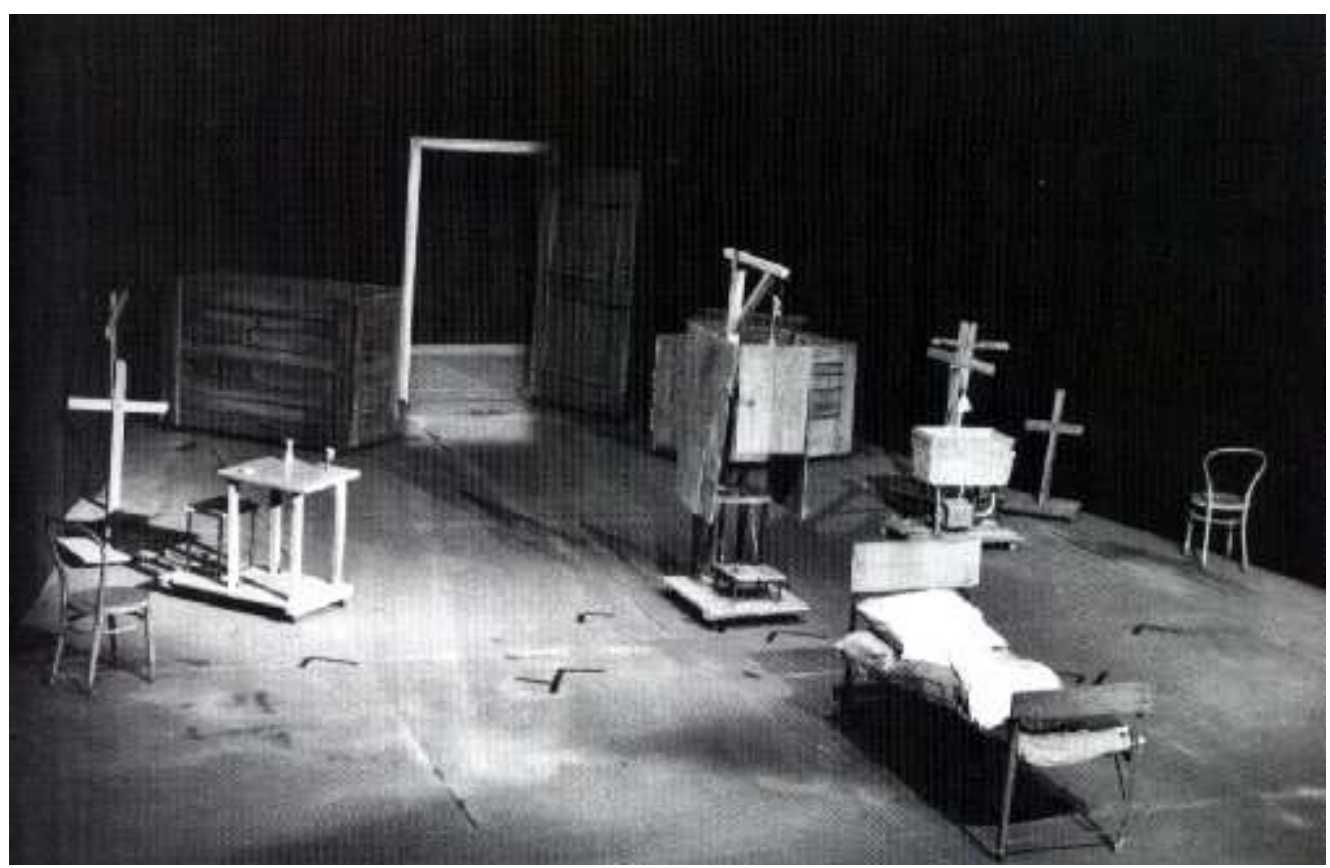

Que morram os artistas! - dispositivo cênico. Foto: arquivos da Cricoteka.

\footnotetext{
${ }^{10}$ Kantor, T. Les voies de la création théâtrale. Paris: CNRS, vol. 18, 1993,pg. 45.

${ }^{11}$ Walther, IF; Metzger, R. Van Gogh - L'oeuvre complet - pinture. Köln: Taschen, 2006, p. 678

${ }^{12}$ Ibid.
} 
Dotada de um princípio semelhante aos bancos de escola, a cama em Que morram os artistas! deixa de ser um local de repouso para se tornar uma espécie de lugar no qual se está prestes a morrer. O duplo sentido do objeto em Kantor se manifesta, de um lado, como uma realidade pronta: o objeto real, cotidiano, vulgar na sua simplicidade objetiva; e de outro, a reflexão metafísica sobre a esfera da morte, a sua própria morte. Reflexão que se estenderá até seu último espetáculo Hoje é meu aniversário.

Como outros objetos de Kantor, a cama, um objeto bruto, construído de ferro e madeira é dotada de uma estranha presença, como se estivesse carregada de tensão. Essa tensão, na verdade, diz respeito à ativação da memória retida no "quarto da imaginação" que produz imagens que constantemente entrecruzam passado, presente, futuro, imaginário e futuro-presente. Desse entrecruzamento sobressai uma nova maneira de "jogar com" os diversos elementos combinando-os em uma nova organização em que o sério e o cômico se aliam ao sarcasmo e à ironia que conduz seus espetáculos além do "pathos" da tragédia, mas para a própria história representada pelo terror dos campos de concentração. No entanto, Kantor dessacraliza o horror introduzindo a dimensão do humor nos domínios do trágico, sobretudo o da tragédia histórica do povo judeu. Essa intensa relação entre hilaridade e horror é determinante na arte de Kantor que se nutre dos signos da realidade histórica, além de diversos outros elementos e os combina em uma nova organização, conferindo a eles uma outra força universal. Não é por acaso que ele coloca sobre a cama, à espera da morte, o duplo do seu próprio personagem, representado pelos gêmeos que se designam: um como o autor com suas palhaçadas, suas mudanças de papéis, e o outro, morrendo. De certa maneira, esse fenômeno da duplicação tem em Kantor uma ligação direta com o pai esquizofrênico que via o seu duplo em todo lugar. Durante as refeições, ele falava consigo mesmo como se estivesse diante dele próprio. O pai de Kantor, que teria morrido em Auschwitz, deu origem a essa relação com o duplo, que para ele é a possibilidade de multiplicação ao infinito e, também, a crença na existência de realidades paralelas, assunto que será tratado oportunamente, o acompanhou até o final da vida. 


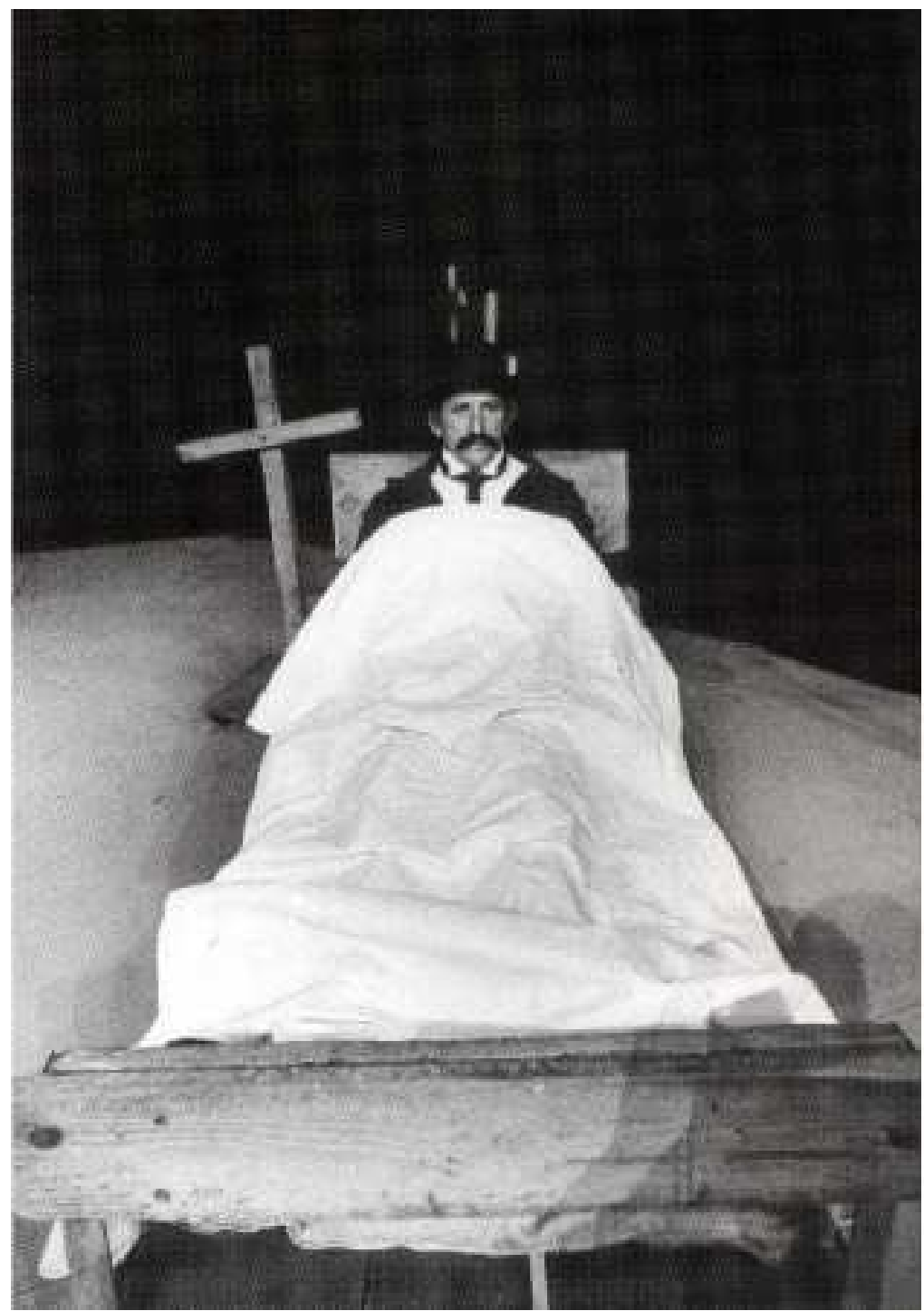

Que morram os artistas! - na cena, o personagem agonizando na cama - projeção de Kantor no futuro está à espera da morte. Foto: Romano Martinis.

Mas a morte em Tadeusz Kantor é mais do que a morte em si, ou seja: cessação da vida biológica. Talvez o maior significado da morte, no seu teatro, resida exatamente na "espera", naquele momento que antecede a morte, na agonia da vida que é incapaz de sublevação. A mesma agonia dos corpos amontoados nos depósitos humanos de Auschwitz em que os leitos, antes de ser repouso, tornam-se a materialidade da espera, a antecâmara da morte. À espera, os prisioneiros dormiam aos pares sobre estrados de madeira ou palha sobre o cimento. Em tais condições, a vida passou a ser espera. Apesar 
de toda humilhação e das mais perversas formas de degradação humana, da dor e do sofrimento, a vida se transformou no terror da espera pelo banho da morte.

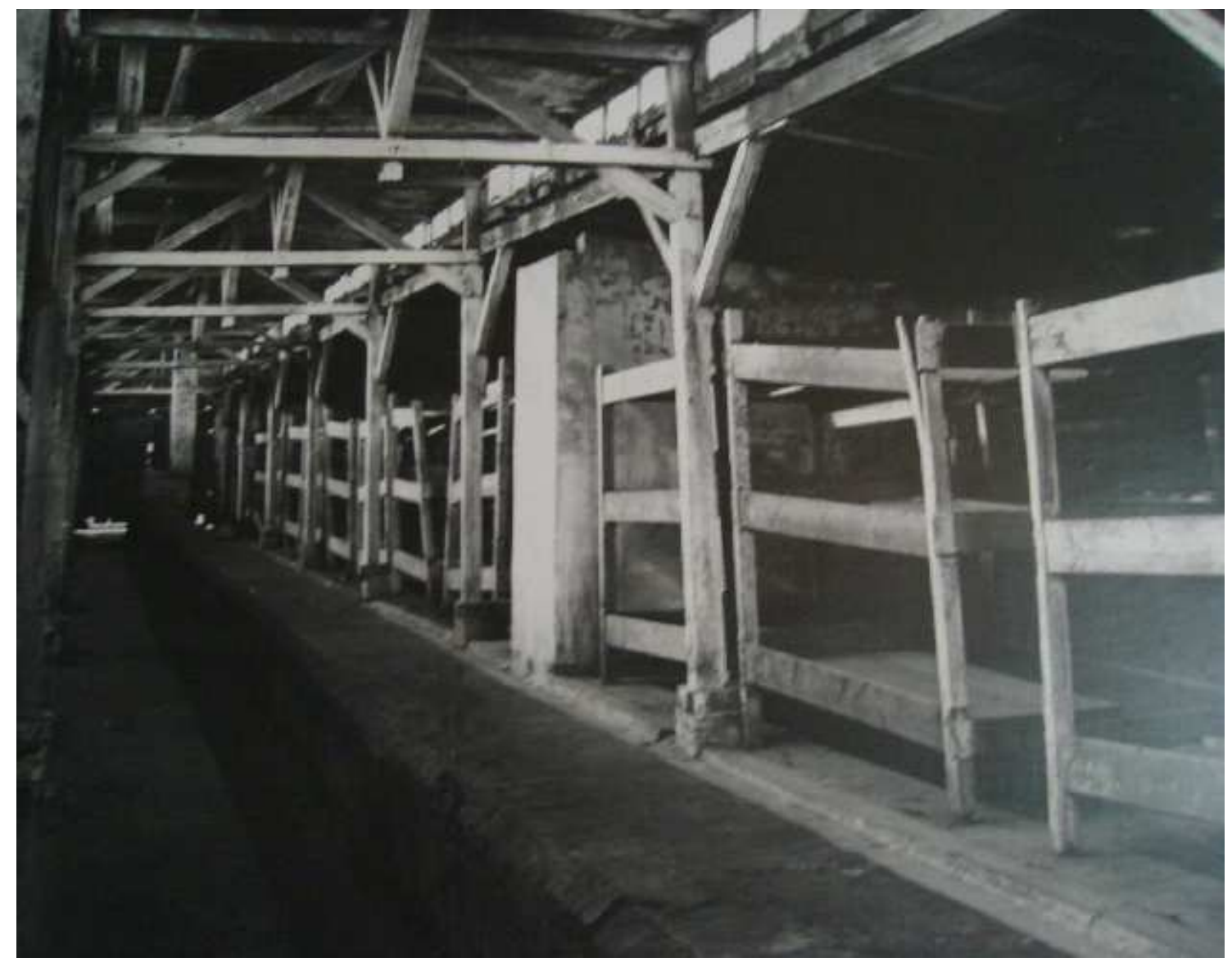

Camas nos alojamentos em Birkenau (Auschwitz II). Foto: Wagner Cintra

\section{As portas}

Como já foi dito insistentemente, acredito que a arte de Kantor se situa em uma zona de intersecção entre duas realidades, que nesse momento entendo como sendo a realidade da arte e a realidade da vida. Posteriormente, como veremos, essa intersecção será uma região na qual a morte e a vida se entrecruzam. Nessa região, a porta assume a 
sua condição de objeto real, que dentre os objetos, é o exemplo mais evidente de "objeto passagem" pois esse estabelece um acesso direto entre dois universos que, na linguagem de Kantor, identifica-se como "além de", ou seja: um mundo além da lógica cotidiana".

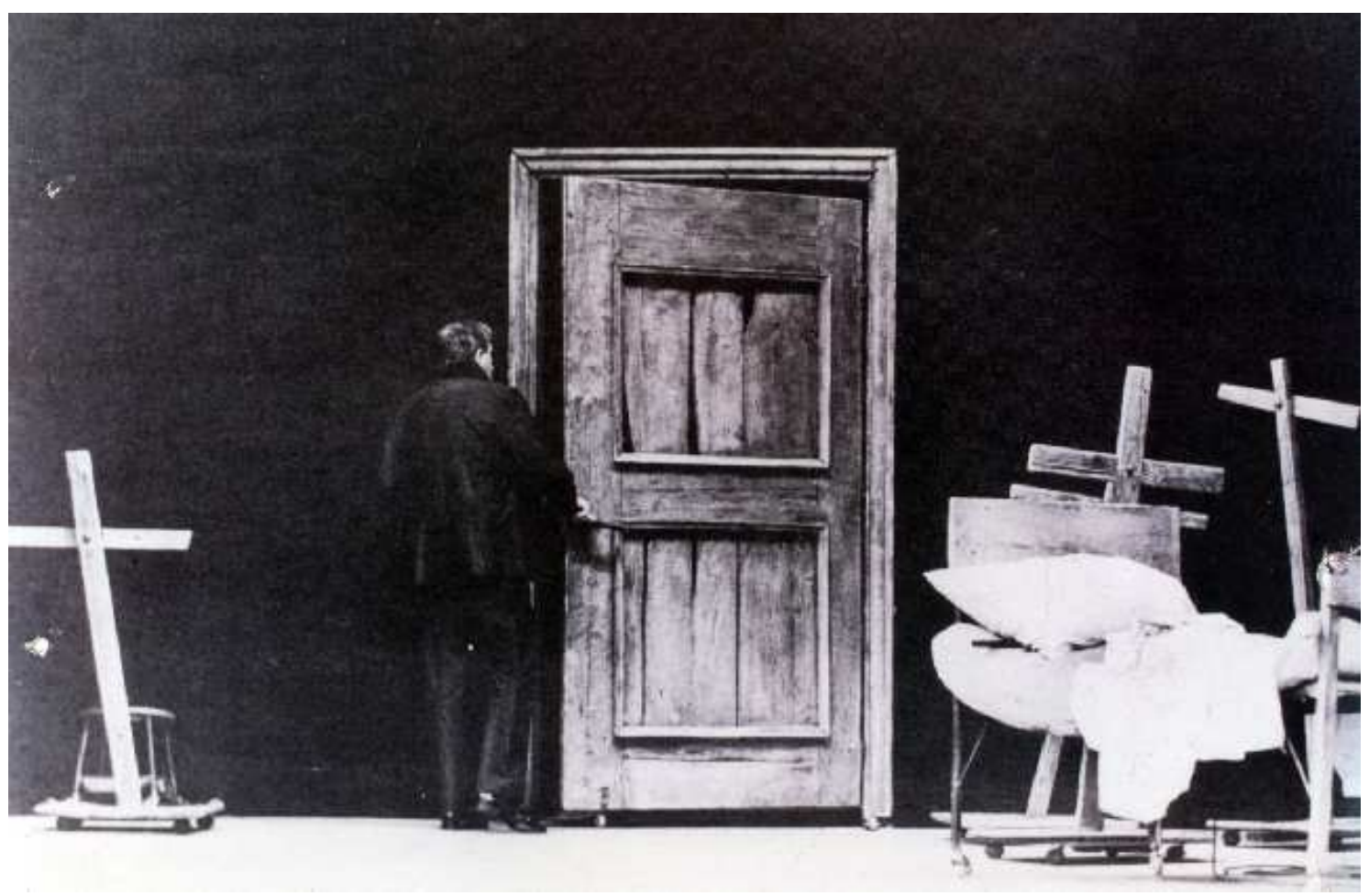

Que morram os artistas! - Foto: arquivo da Cricoteka.

Ao que me parece, essa noção da porta como objeto passagem tem sua origem com $O$ retorno de Ulisses, espetáculo de 1944, durante a fase do teatro clandestino ${ }^{14}$ e, como já foi dito anteriormente, o espetáculo fora realizado nos escombros de um apartamento bombardeado pelo exército alemão. Nesse espaço real, onde havia alguns objetos reais, objetos destruídos pela guerra, que não tinham mais nenhum valor para a civilização pois estavam quebrados, foram por Kantor anexados e chamados de objetos

\footnotetext{
${ }^{13}$ Esse conceito de outra realidade será examinado em um dos próximos capítulos.

${ }^{14}$ Em 1939, com a invasão da Polônia pela Alemanha, Kantor com o Teatro independente da Cracóvia desenvolve uma atividade totalmente destacada da realidade ambiente. Com um grupo de amigos, ele representava em casa de particulares ou em escombros, aquilo que chamou de espetáculos clandestinos. Esses espetáculos eram fundamentados sobre o efeito da fascinação pelo objeto que perde a sua significação prática, original, alterando a sua substância para uma nova realidade.
} 
de arte. Esses objetos criavam um conhecimento não conceitual $^{15}$ através do estabelecimento de novas relações entre eles e tudo o que existia naquele espaço.

$O$ retorno de Ulisses introduz algumas das noções sobre o objeto que serão recorrentes ao teatro de Tadeusz Kantor, sobretudo à idéia de objeto pobre ${ }^{16}$ que, conforme foi descrito nas Lições de Milão, a ele e seus contemporâneos não havia outra opção a não ser se apoderar do objeto que estivesse mais próximo. Esse objeto era retirado da realidade da guerra. De certa maneira, esse objeto era salvo do desaparecimento e da destruição. A realidade na qual Kantor explora esse objeto, que traz em si as lembranças da sua existência utilitária é chamado por ele de "realidade de classe mais baixa", uma realidade situada no nível mais inferior da civilização, ou seja, as latas de lixo. $\mathrm{Na}$ arte de Kantor, essa realidade se situa em um espaço que existe fora da realidade, ou seja: em uma realidade paralela à realidade cotidiana ${ }^{17}$, no caso, a realidade da Segunda Guerra Mundial.

Os objetos utilizados são objetos inúteis e aquilo que acontece no espaço é um processo de redefinição de novas relações que, necessariamente, se fundamentam na realidade da platéia. Ao entrar no espaço onde a ação acontece, ao cruzar a porta entre as duas dimensões, o espectador assume integramente a responsabilidade de entrar no espaço teatral e a partir da ultrapassagem dos limites estabelecidos não existe mais a possibilidade de volta. Ao cruzar tal fronteira é preciso fazer saber ao espectador que ele pode estar entrando em Auschwitz, na realidade da morte e talvez nunca mais consiga sair. Após a guerra, com uma realidade diferente, ocorre uma mudança na forma do teatro de Kantor. Mudança que o conduziu, em 1947, para o surgimento das primeiras experiências com a arte abstrata na Polônia.

\footnotetext{
15 Conhecimento não conceitual, pois não se tratava de objetos cuja imagem estava associada a especificidade do uso cotidiano. Uma cadeira quebrada, a priori, não tem nenhuma utilidade para a vida prática do dia-a-dia.

${ }^{16}$ Essa não é a idéia grotowskiana de objeto pobre. Grotowski, conforme a teoria do teatro pobre, impede a "utilização de quaisquer objetos-instrumentos de que o ator não tenha uma necessidade insuperável..." In. Roubini, J.J. A linguagem da encenação teatral. Rio de Janeiro: Zahar, 1980, p. 127.

${ }^{17}$ É preciso entender realidade cotidiana como o modo de ser das coisas existentes fora da mente humana ou independentemente dela.
} 


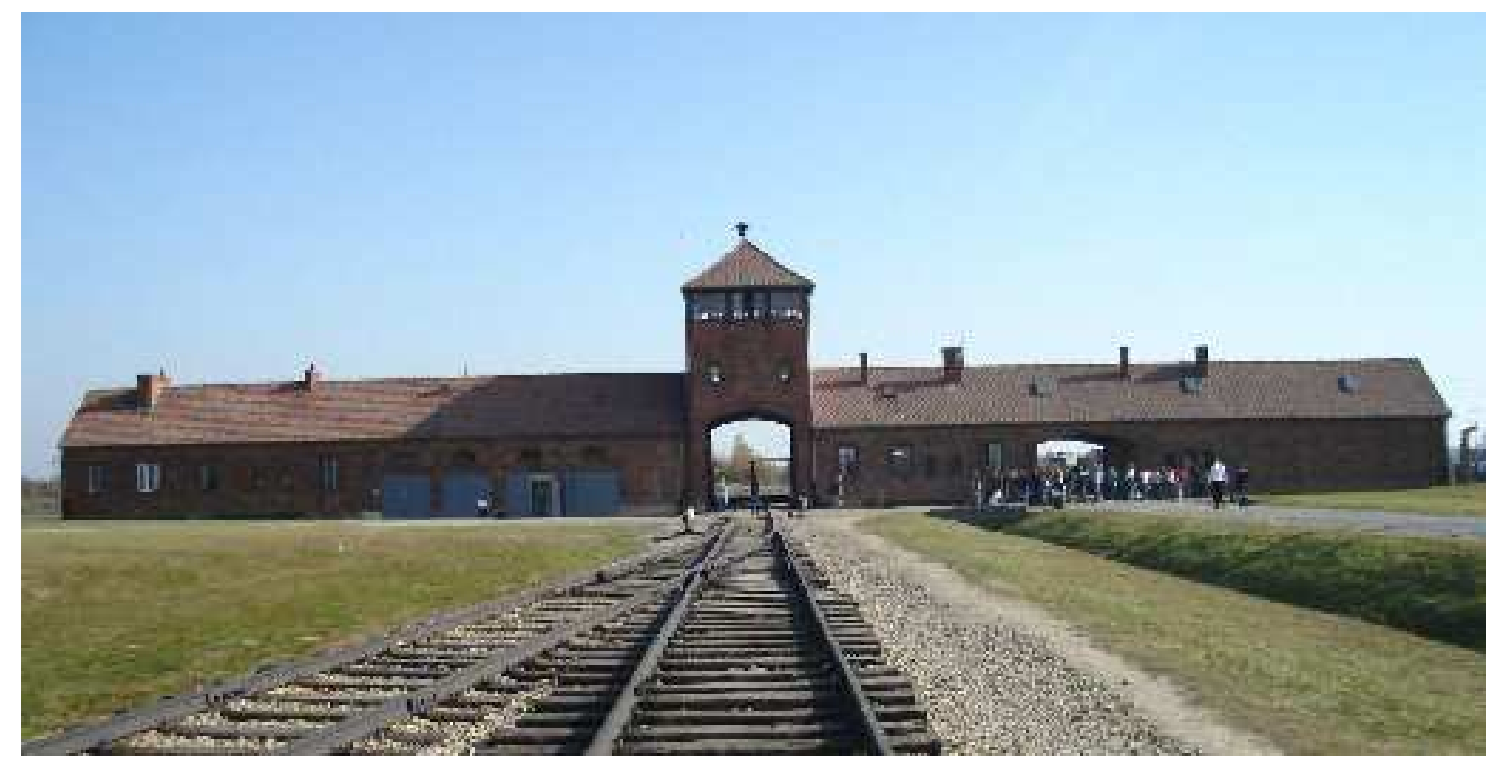

Entrada do campo de extermínio de Birkenau (Auschwitz II) - vista interna. Foto Wagner Cintra.

Por mais que as transformações tenham caminhado no sentido do abandono da arte representacional na direção de uma maior imersão no interior da matéria, ou seja: da exploração de aspectos desconhecidos da realidade, o teatro de Kantor irá aprofundar a discussão sobre a função do objeto no teatro. Dessa forma, alguns objetos retornarão de espetáculo em espetáculo. Nesse sentido, a porta trata-se de um objeto que aparece em todas as produções, não somente como elemento constituinte do espaço cênico mas como metáfora de passagem entre dois mundos. Em A classe morta, a exemplo de outros espetáculos, a porta é um elemento separador entre o real e a ilusão. Em As belas e os feios, espetáculo de 1973, ao entrar para assistir à peça, o público foi impedido de entrar na sala onde o espetáculo aconteceria sendo retido em uma espécie de chapelaria adaptada no porão da galeria Krzysztofory, que sugeria que na sala posterior estaria o teatro onde o espetáculo seria realizado. No entanto, o espetáculo estava em desenvolvimento no próprio espaço da chapelaria, o teatro era somente uma ilusão, uma abstração que existia apenas nas expectativas dos espectadores. Assim, a porta torna-se o elemento definitivo que, na volatilidade do abrir e fechar, acentua a duplicidade do teatro de Kantor naquilo que diz respeito ao choque entre realidade e ilusão. No caso de As belas e os feios, a constante negação da ilusão através da intensa apropriação do espaço real. 


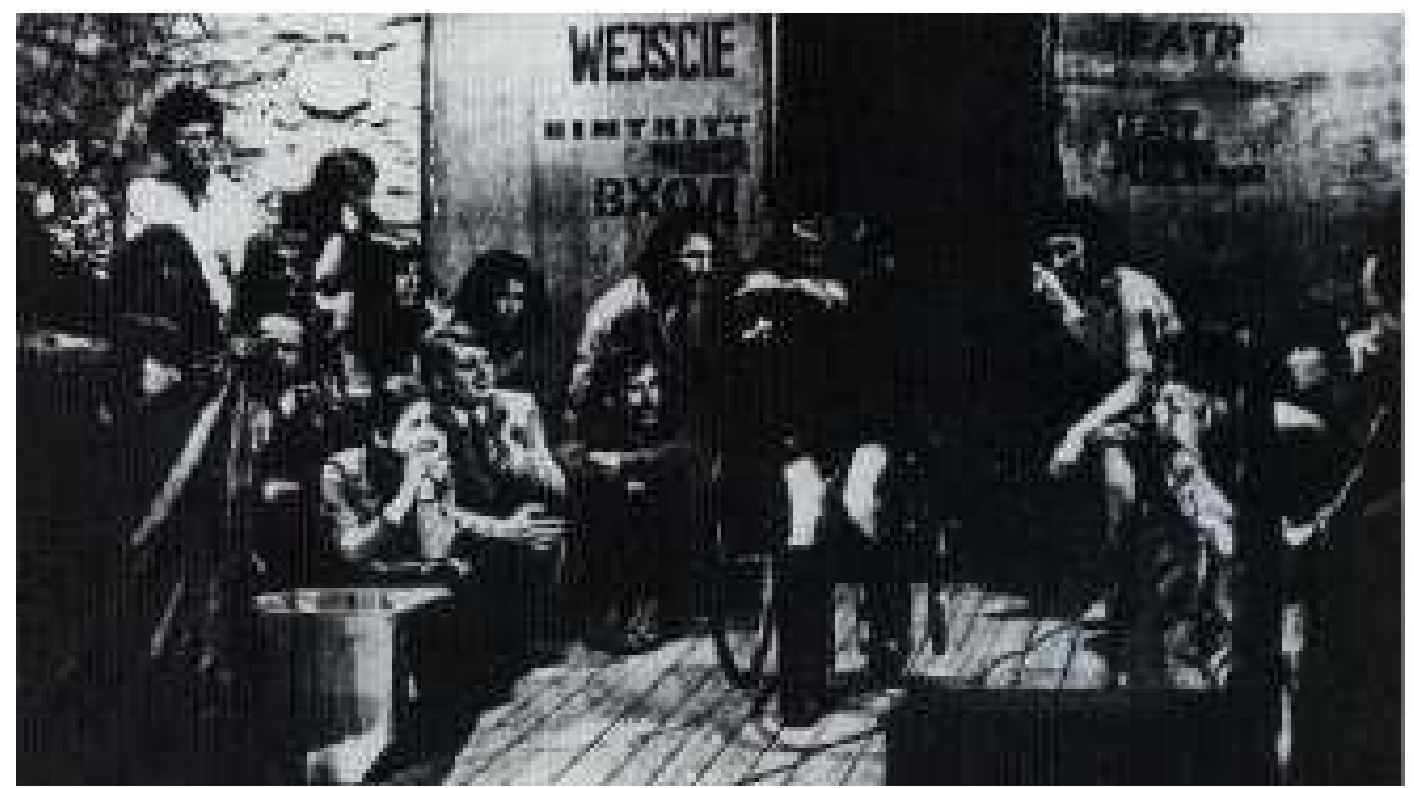

As belas e os feios. $\mathrm{Na}$ imagem, a porta de entrada para a cena. Foto: arquivos da Cricoteka.

Em A classe morta, por sua vez, também realizado na galeria Krzysztofory em 1975, como já foi dito, os bancos impunham a sua presença massiva e ocupavam a maior parte do espaço e funcionavam como receptáculo da memória da infância morta. Esse espetáculo, ao contrário de As belas e os feios, traz na aparência a forma do teatro tradicional apenas por uma distinção da cena e do público, ou seja: o espectador foi afastado da realidade da cena. $\mathrm{O}$ espetáculo funcionava para o público como uma tela exibida em uma galeria de arte na qual havia uma corda de separação que reforçava essa idéia. Entretanto, a porta constantemente aberta deixava à vista a passagem por onde os espectros, personagens históricos e todas as fantasmagorias de Kantor encontravam a passagem de um para outro mundo. $\mathrm{O}$ fato de a porta permanecer aberta no espetáculo produz uma ação às avessas, ou seja, na medida em que apenas a passagem dimensional é vista, o que proporciona ao espectador a percepção das personagens surgindo lentamente das sombras para a luz do teatro, a porta é apenas uma abstração, e como para Kantor a abstração nada mais é do que a existência do objeto em um outro mundo, a porta se mostra reveladora dessa concepção. Quando fechada em outros espetáculos, a sua realidade formal atua objetivamente na memória do espectador que vê o objeto como um instrumento conceitual, aquele que permite a comunicação entre dois aposentos ou, no caso de Kantor, a comunicação entre duas realidades. Por outro lado, 
quando aberta ou ausente, distante, escondida dos olhos do espectador, a porta induz à exploração interior da cena exterior e isso é algo que é próprio da arte abstrata. $\mathrm{O}$ movimento de uma realidade para a outra ${ }^{18}$, que se acentuará assustadoramente nos espetáculos posteriores, a A classe morta, o conduzirá a explorar aspectos desconhecidos da realidade aparente ${ }^{19}$.

Seguindo um princípio semelhante, em Wielopole Wielopole encontraremos duas portas. A primeira, aquela do armário, um tipo de guarda-roupas que já havia sido utilizado em espetáculos anteriores, a exemplo de A pequena mansão ${ }^{20}$, que também é usado como passagem, como local de jogo para algumas personagens da peça. Kantor vê o armário como um novo lugar teatral e o chama de "interior da imaginação".

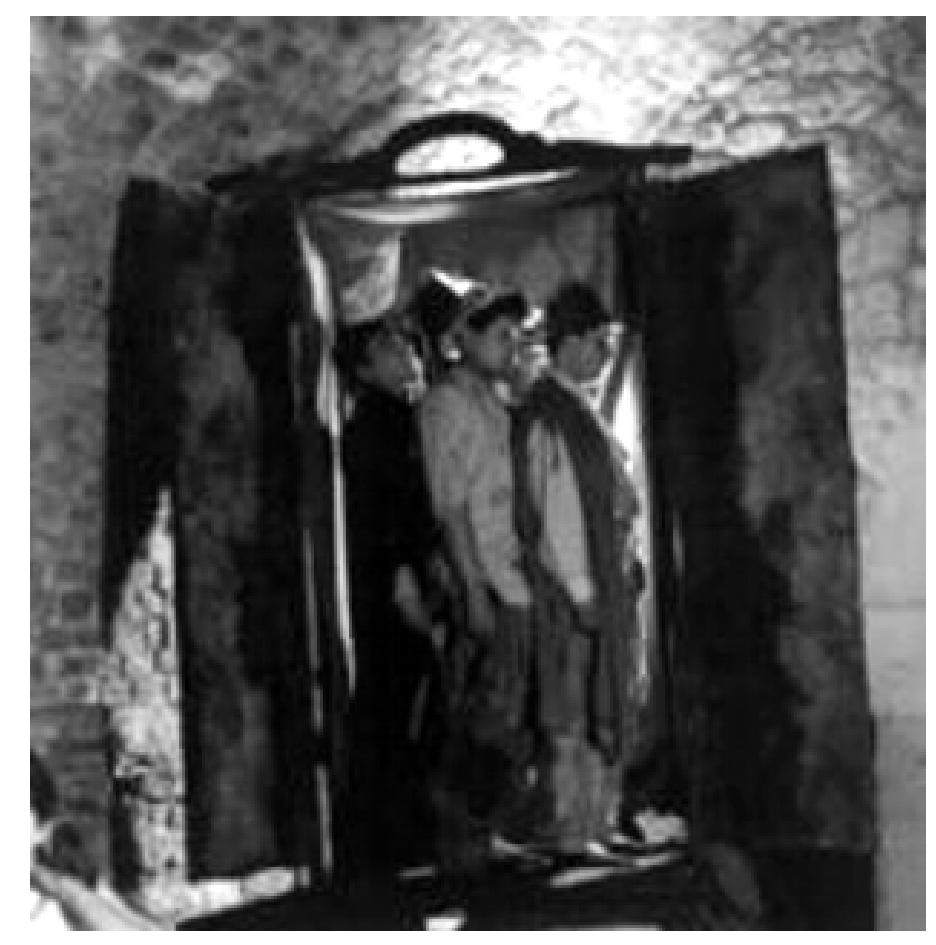

A pequena mansão. Foto: arquivos da Cricoteka.

\footnotetext{
18 A idéia de movimento entre duas realidades também pode ser observada em artistas como Jackson Pollock que é talvez o maior representante da Action Painting, ou expressionismo abstrato.

${ }^{19}$ A exploração de aspectos desconhecidos da realidade foi traduzida por Kantor no conceito de Teatro Autônomo.

${ }^{20}$ Kantor usa um armário velho que além de objeto, é também local de representação. Mais tarde, esse armário vai ser chamado de bio-objeto que é um objeto cujo organismo nas suas partes internas é um ator. Nessa produção, nesse armário, pendurados nos seus cabides arremessando-se uns contra os outros, batendo uns nos outros, os atores destrõem a possibilidade de interpretação do drama porque a verdadeira ação de representar está constantemente sendo destruída.
} 
Para Kantor, esse armário é exatamente o espaço que, quando é aberto, libera o ator para arremessar-se no espaço para criar um complexo de relações diferentes. Nesse sentido eles revelam a matéria que está fechada pela porta do armário. No momento em que a porta é aberta, a matéria é liberada das leis de construção que emolduram a abertura do próprio armário. Essa exploração é uma séria estratégia para tentar abrir o que está fechado pelas portas para aquilo que não é acessível ao olhar e ao entendimento. A porta pode ser vista, mas não se sabe o que se passa no seu interior. Somente quando as portas se abrem e os atores são jogados para fora, aí é possível perceber e liberar algum significado.

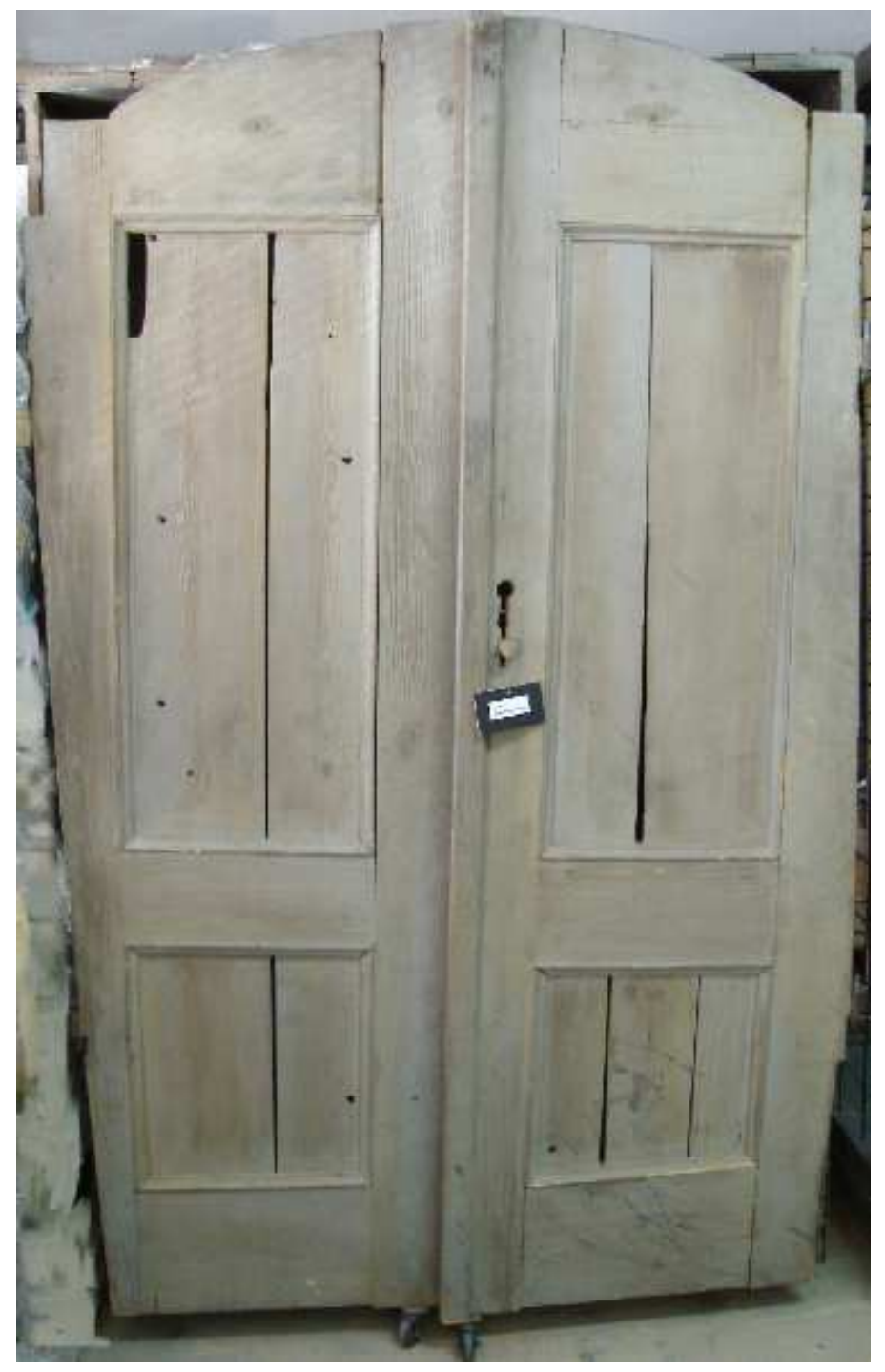

Armário de Wielopole Wielopole. Foto: Wagner Cintra. 
A outra porta de Wielopole Wielopole trata-se de duas folhas de madeira que correm sobre trilhos e que assumem variados aspectos e funções no espetáculo. Diferentemente dos espetáculos anteriores encenados pelo Cricot 2 no porão da galeria Krzysztofory, o espaço de Wielopole Wielopole tratava-se de uma espécie de instalação concebida em um espaço real, no caso da estréia em 1980, da Igreja de Santa Maria em Florença, Itália. A singularidade da porta, nesse espetáculo, reside no fato de que ela assume a condição de objeto memória, portal pelo qual as lembranças guardadas no quarto da imaginação de Kantor poderão ganhar materialidade na cena. Mas por outro lado, a porta também assume a condição de barco dos mortos. Um exemplo disso tratase do momento do espetáculo em que os soldados são enviados para a guerra. A porta com as duas folhas abertas abriga soldados e manequins; vida e não-vida estão associadas em uma espécie de frenesi alucinante. Nessa cena, a porta pela qual entram as personagens extraídas da memória de Kantor torna-se porta de vagão de trem que conduzirá os soldados para o front. Os personagens que representam parentes e amigos se despedem com lenços brancos esperançosos do retorno daqueles que partem. $\mathrm{O}$ Padre, entretanto, consciente da realidade da cena se despede dos mortos jogando terra sobre os cadáveres, mesmo sobre aqueles que estão aparentemente vivos, pois na percepção do padre Smietana aqueles que partem para o combate já estão mortos.

A ambigüidade da cena se constitui no fato da relação morte e vida estar associada ao mesmo espaço, o vagão. Nesse espaço, organizado pela porta corrediça, na medida em que os cadáveres são enterrados, também passa a ser cemitério, ou ainda, os vagões que conduzem a Auschwitz, para as portas dos alojamentos em Birkenau, a antisala da morte nas câmaras de gás. Nesse caso, Kantor se serve de uma realidade para falar de outra mais profunda, ou seja: os instrumentos da cena, personagens, figurinos, objetos etc, nos situam nos anos da Primeira Guerra Mundial, mas a ação realizada com os mesmos elementos remete o expectador para as dimensões da Segunda Grande Guerra. 


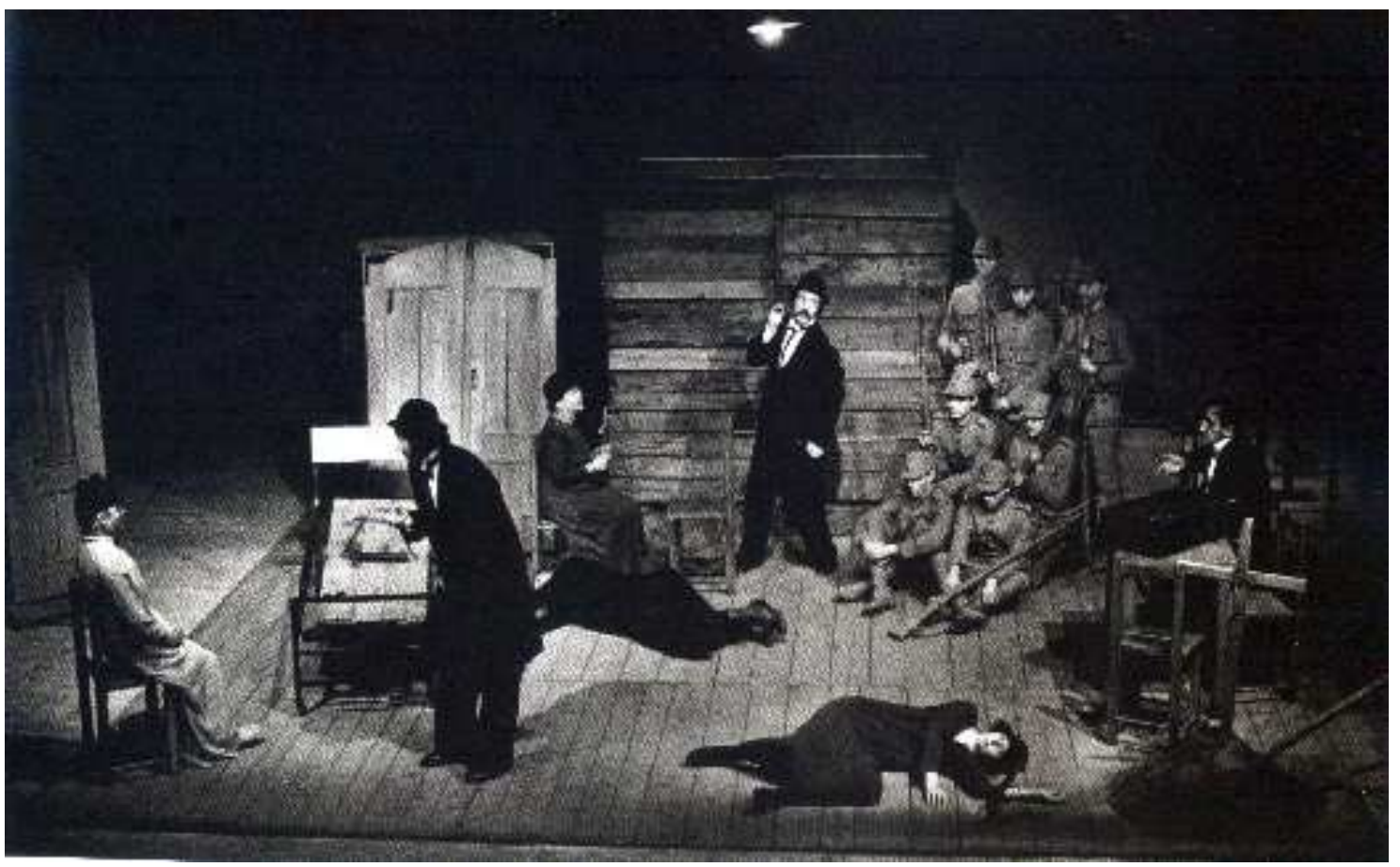

Wielopole Wielopole. Na cena, o armário e a porta corrediça ao fundo. Foto: Maurizio Buscarino.

Se em Wielopole Wielopole a porta do armário conduz para uma realidade não acessível, e a porta corrediça materializa o espaço da morte, em Que morram os artistas!, ao contrário, a porta de fundo age como acesso dos mortos para esse mundo, de forma que a cena é invadida por cadáveres retirados da memória e também das alucinações de Kantor. Nesse processo temos, conforme uma observação de Denis Bablet que:

“...após A classe morta o teatro tornou-se para Kantor como uma recordação da vida, ou ainda uma irrupção dos mortos que vêm se confrontar a nós..."21

E nas palavras do próprio Kantor:

“...o teatro, eu insisto afirmar, é o lugar que revela, um vau secreto em um rio, os traços de uma passagem de outra vida para a nossa vida..."22

\footnotetext{
${ }^{21}$ Kantor, T. Les voies de la création théâtrale. Paris: CNRS, vol. 18, 1993, pg. 44.

${ }^{22}$ Ibid.
} 
Isso pode ser exemplificado através da "personagem encontrada", ou "personagem/objeto encontrado", um fenômeno, que conforme a explicação de Kantor, a figura histórica de Veit Stoss, célebre escultor alemão do século XV, que em 1491 construiu, na Cracóvia, o belíssimo retábulo para o altar da Basílica de Santa Maria, é uma espécie de personagem viajante, alguém que pela sua obra é capaz de viajar pela história.

Para Kantor, a palavra "encontrada" não tem o mesmo significado que lhe atribuíam os dadaístas. A significação é muito mais profunda do que a sua simples aparência. Não se trata de recuperar alguma coisa, não é o resultado de uma ação cotidiana de procurar algo, como ele mesmo define:

“...o objeto encontrado tem ligação com o mundo do "outro lado", com o mundo supra-sensível, com as regiões da morte. Ele não pode ser explicado, ele é fútil, gratuito, ele é quase uma pura obra de arte! ",23

Veit Stoss, em suas viagens, veio só, ninguém o convocou, Kantor explica isso dizendo que a sua presença na cena não é devido a qualquer interesse por sua vida ou pela importância pela sua obra, não. Para ele, isso é para a história da arte não para o teatro. A criação teatral é um processo de trabalho do demiurgo cujas raízes mergulham no coração do "outro Mundo" 24 . Entretanto, Veit Stoss está na cena e duas realidades se justapõem, e qual será a sua obra nesse novo mundo? Mas isso será tratado no devido momento, por agora gostaria de retornar à questão da porta no teatro de Tadeusz Kantor.

Em Não voltarei jamais, existe uma porta que funciona como ekkyklema ${ }^{25}$, apesar da sua função não ser exatamente a mesma do teatro grego, baseia-se no mesmo princípio de revelar. E revelar, em Kantor, tem necessariamente uma ligação com o desconhecido. Desconhecido que se faz conhecer através das imagens que sobressaltam para a cena através das portas. Em Não voltarei jamais, vários eram os momentos em que isso acontecia. Talvez o momento mais surpreendente, e ao mesmo tempo aterrorizante, tratava-se daquele em que uma porta se abria e através de uma plataforma sobre rodas, um manequim, o manequim de Kantor vestido com trajes de casamento, o

\footnotetext{
${ }^{23}$ Ibid. p.43.

${ }^{24}$ Ibid. p. 45.

${ }^{25}$ No teatro grego, trata-se de uma plataforma sobre rodas, utilizada principalmente para revelar o resultado de ações violentas que não podiam ser realizadas à vista do público
} 
seu casamento, aparecia ao lado de uma urna funerária que substituía a figura da noiva. Essa imagem gerou muita polêmica entre artistas e pensadores pois se tratava de uma imagem que, para eles, era incompreensível, sem nenhuma função racional. As discussões sobre essa cena foram tão intensas que Kantor optou, nas repetições do espetáculo, em substituir a urna funerária por uma atriz, a menina pobre, vestida em farrapos, a aparência da morte inspirada nos manequins de cera. Por outro lado, a imagem inicial, do ponto de vista simbólico, vem corroborar exatamente com o pensamento de Kantor sobre o bio-objeto.

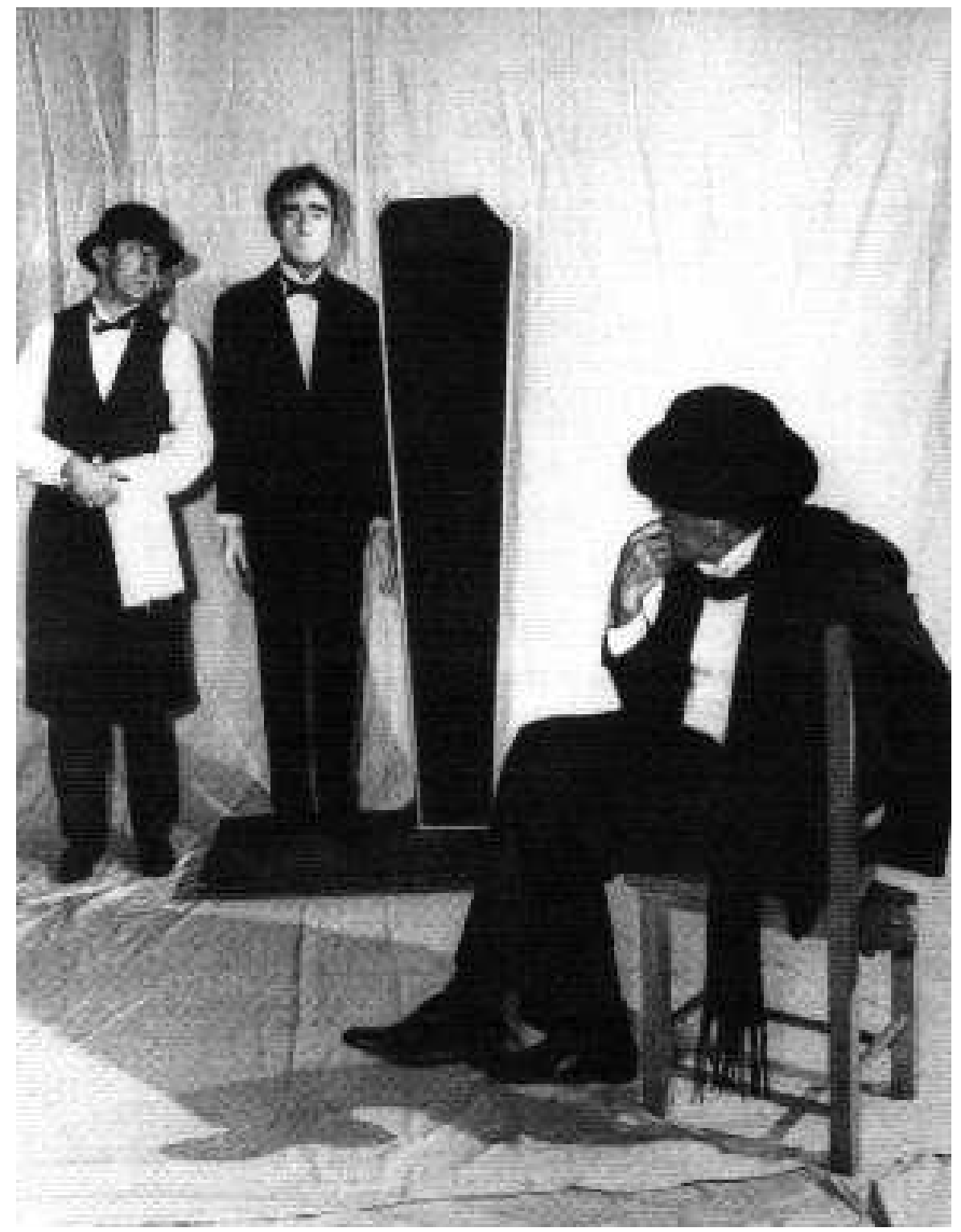

Não voltarei jamais. O manequim de Kantor ao lado da urna funerária. Foto: Jerzy Borowski. 
A história do teatro de Kantor é indiscutivelmente um diálogo amplo com as regiões da morte. Entretanto, é a partir de A classe morta que esse diálogo se intensifica e passa a dominar todas as suas reflexões. Kantor estabelece a sua arte e a sua própria vida como uma espécie de casamento com a morte. A urna funerária, personificação feminina da morte, a companheira inseparável, também se traduz como leito nupcial, o derradeiro bio-objeto que abrigará no seu interior o artista que, como a morte, converter-se-á em abstração.

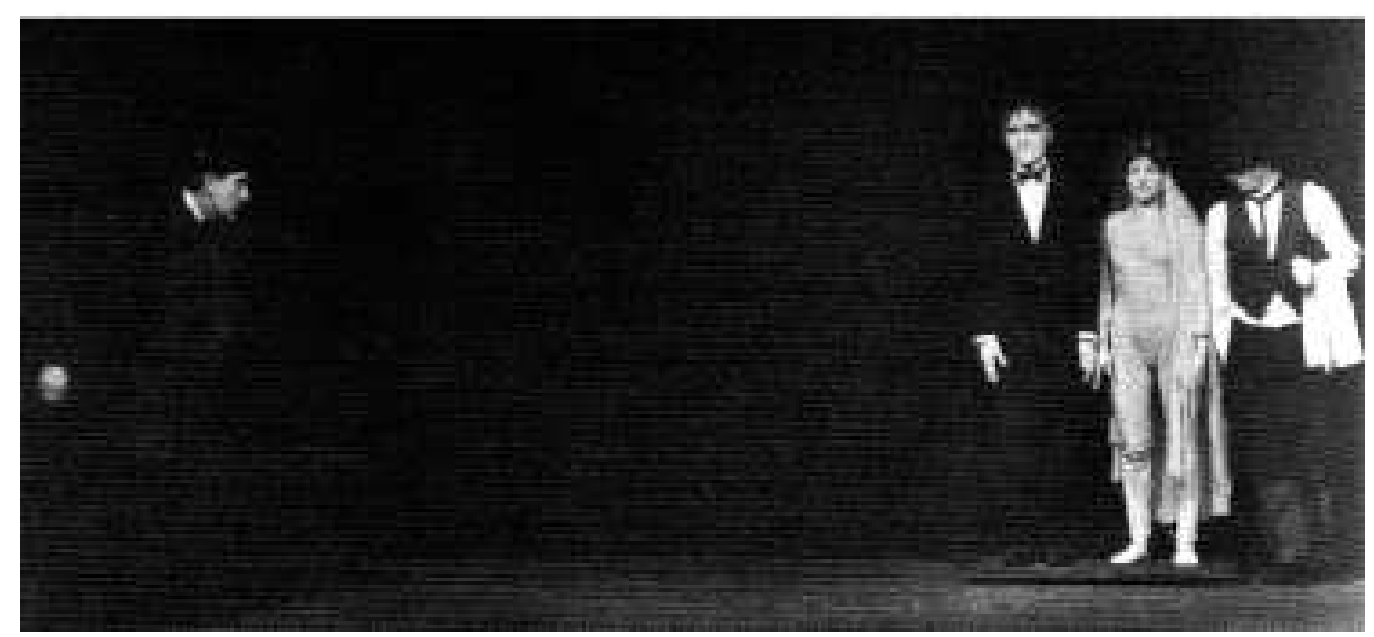

Não voltarei jamais. O manequim de Kantor ao lado da Pobre Menina. Foto: Jerzy Borowski.

Das várias utilizações da porta/ekkiklema, uma que também merece atenção trata-se da cena em que por ela o manequim de Mariam Kantor, o pai de Tadeusz Kantor, aparece amarrado ao pilar dos mortos. A cena toda é marcada pelo som característico que marca a entrada e passagem da orquestra de violinos e, na sequiência, as personagens de todos os espetáculos entoam um lamentoso canto judaico. Mais uma vez a referência aos mortos nos campos de concentração de Auschwitz. 


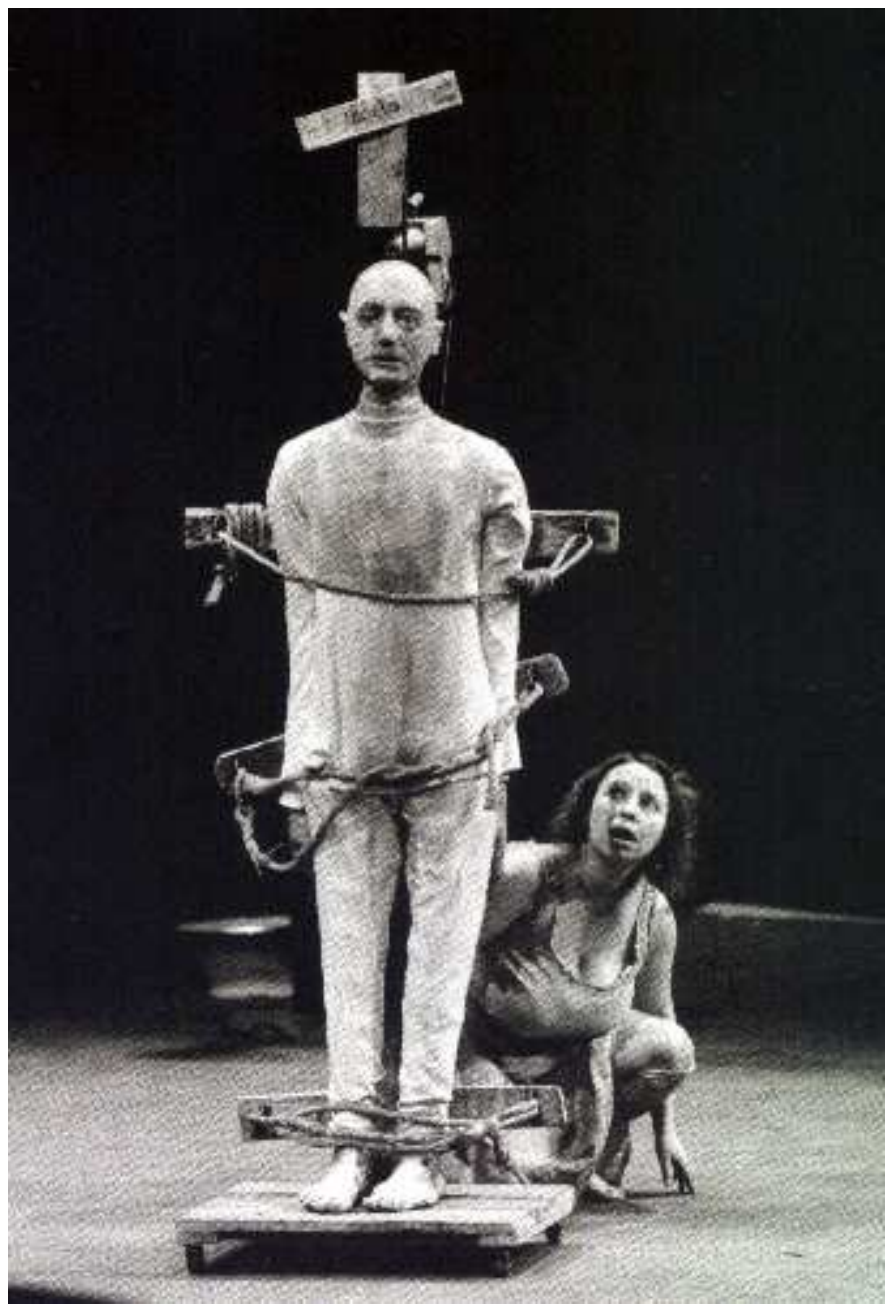

Não voltarei jamais. Mariam Kantor no pilar dos mortos. Foto: Maurizio Buscarino.

Mas o ekkyklema não é a única porta da peça. Existe outra porta pela qual personagens e situações dos espetáculos anteriores são convocados para a cena. Se em Que morram os artistas! - a exemplo de Veit Stoss, as personagens não surgem, eles aparecem espontaneamente da memória fragmentada ${ }^{26}$ de Kantor, em Não voltarei jamais, a cena é a própria memória, a porta como dimensão temporal através da qual as personagens são "convocadas". Aqui, personagens e cenas não acontecem ao acaso. Kantor traz para o palco cenas e personagens de suas produções passadas, um apanhado das obras da maturidade, um espetáculo quase recapitulativo - em que todas as espécies de signos de espetáculos anteriores e mesmo das realizações cênicas dos happenings dos

\footnotetext{
${ }^{26}$ Memória fragmentada no sentido da não existência de linearidade na exposição dos fatos e personagens extraídos da memória Kantor. Nesse espetáculo, personagens da sua história pessoal se misturam a personagens da história da Polônia. As cenas resumem-se em si mesmas. Autônomas.
} 
anos sessenta e setenta foram, como comenta Guy Scarpetta ${ }^{27}$, reintegrados, recombinados, re-conectados, relançados em um espaço "inter-temporal" no qual os espetáculos de antanho se sobrepõem uns aos outros.

Essa sobreposição de diversos elementos recolhidos nos espetáculos do passado, os quais são confrontados, refundidos em uma estética a qual Scarpetta chama de "neobarroca" 28 , que também é encontrado na pintura de Kantor e faz com que o quadro seja desnaturalizado pelas figuras que se evadem, ou pelos corpos trocados que se prolongam no "além de", em outra dimensão, em outra materialidade, trata-se de algo como aquilo que Scarpetta chamou de "pintura sobre pintura"29, o próprio Kantor acredita que a tela é algo como uma "cena em abismo", em uma espécie de representação redobrada, principio semelhante ao encontrado em Velázquez ${ }^{30}$, em As meninas $^{31}$, onde a pintura é vista através do seu reverso, o que significa que não é possível ver o conteúdo da tela no seu verso, o que visto é tão somente a parte posterior do cavalete. Disso decorre a dúvida se a pintura no verso já foi pintada ou não. O importante de tal dispositivo é exatamente o jogo entre realidade e ilusão, um jogo que acontece de um choque que opõe a representação à realidade em benefício da própria realidade. No espetáculo, o jogo de engaste das imagens decore disso, por contágio, ao despertar a suspeita sobre a própria realidade.

Guy Scarpetta, em uma passagem do seu livro Kantor au présent ${ }^{32}$, faz uma relação da obra de Tadeusz Kantor, no período do teatro da memória, com a viagem de Dante ao reino dos mortos. A relação é muito própria no sentido da ocorrência na obra de Kantor, assim como em Dante, de uma espécie de oscilação entre o passado da ficção e o presente da narração. Em Kantor, entretanto:

“...não se trata de fazer uma viagem ao mundo dos mortos, mas de fazê-los voltar ao real." ${ }^{, 33}$.

\footnotetext{
${ }^{27}$ Scarpetta, G. Kantor au présent. Arles: Actes Sud, 2000 p. 68.

${ }^{28}$ Ibid. p. 123/124.

${ }^{29}$ Ibid.

${ }^{30}$ Célebre pintor do Barroco espanhol

${ }^{31}$ Obra datada de 1656.

${ }^{32}$ Scarpetta, G. Kantor au présent. Arles: Actes Sud, 2000 p. 132.

${ }^{33}$ Ibid. p. 133.
} 
Esse retorno do mundo dos mortos necessariamente tem de estar associado a um símbolo muito específico. Assim, a porta assume a sua condição de passagem. Em seus espetáculos, nenhum personagem, objeto ou imagem surge do nada; existe, ao que me parece, depois ter assistido aos vídeos das suas produções, após As belas e os feios, uma regra que estabelece a entrada em cena, necessariamente por uma porta, um portal como elo de ligação entre dois universos. Em Hoje é meu aniversário, dando continuidade àquilo que foi feito em Não voltarei jamais, ou seja, à convocação de imagens e personagens de espetáculos antigos, Kantor convoca para a cena, não exatamente fragmentos de espetáculos anteriores, mas personagens da sua vida pessoal, amigos, ídolos, bem como a sua vida de artista plástico através da sua pintura.

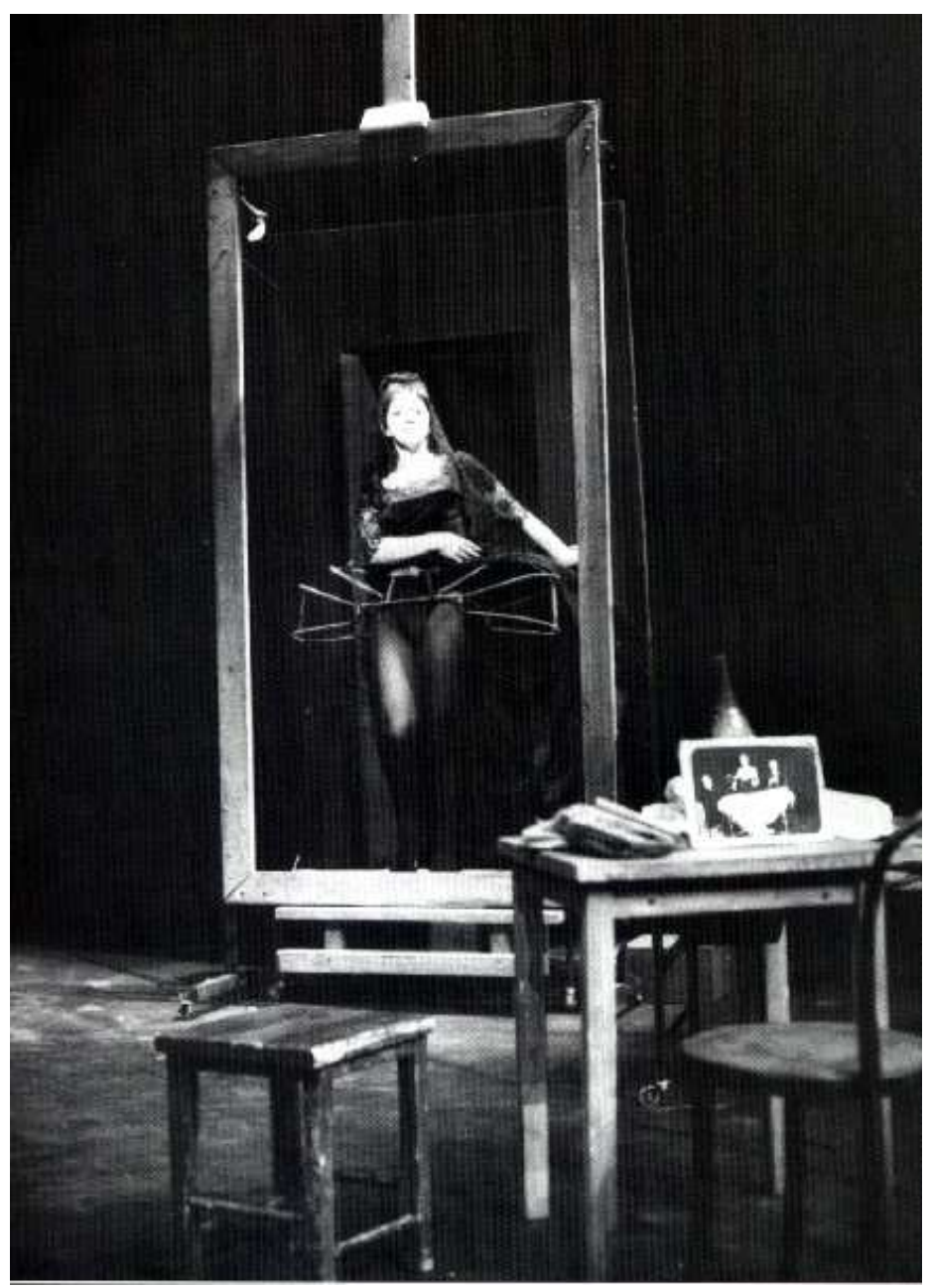

Hoje é meu aniversário. A infanta. Foto: arquivos da Cricoteka.

No cenário de Hoje é meu aniversário, que é basicamente composto por três molduras de telas, existem portas que dão acesso do fundo para o interior da tela. Essas 
portas, principalmente as das molduras laterais, em determinados momentos também assumem a função de ekkiklema, como aquele no qual o fascínio de Kantor por Velázquez, sobretudo pela pintura As meninas, materializa, aquela que anteriormente era apenas um tema de sua pintura, em uma personagem convocada para o seu teatro: a Infanta. Entretanto, a Infanta não é somente uma imagem, ela presume o estado amoroso atual de Kantor, um amor idealizado por uma mulher mais jovem.

A Infanta deixa a tela, na mesa de Kantor se insinua como se estivesse pousando para o pintor e, ao mesmo tempo, flerta com ele. Pela porta da tela central, sairão os personagens convocados, amigos e artistas. Dentre eles, Maria Jarema, artista de vanguarda que foi rejeitada pela arte polonesa dos anos 50, tornou-se para Kantor um emblema da arte abstrata que é definida por ele como a exploração do espaço, que não se trata de um receptáculo passivo no qual os objetos são lançados. Não, mas é o espaço que dá origem às formas, isso quer dizer que o espaço é um campo energético que pode se precipitar em relação ao objeto e modificar a sua forma. Um exemplo muito utilizado por Kantor trata-se do guarda-chuva que, na sua concepção, é muito mais do que um instrumento usado para proteger do sol ou da chuva, mas trata-se antes de tudo de um objeto autônomo que abre e fecha o espaço. Seguindo esse princípio, a porta, quando se abre, permite que um espaço invada outro espaço, ou seja: o espaço da representação. Temos assim a origem de novos objetos no espaço. Maria Jarema, através da porta é lançada para o interior da tela que está sendo metaforicamente pintada por Kantor ${ }^{34}$. Por outro lado, ao sair da tela em direção ao espaço do pintor, o espaço da tela, da pintura, ou até mesmo da fotografia, invade o espaço da representação em um processo de sobreposição. Esse recurso, que também foi usado com a Infanta, praticamente define todo o espetáculo.

\footnotetext{
${ }^{34}$ É importante lembrar, que originalmente, como nos espetáculos anteriores, desde a encenação de $A$ galinha D'água, Kantor sempre esteve em cena. Em Hoje é meu aniversário, devido a sua morte na véspera da estréia em dezembro de 1990, o espetáculo foi apresentado com uma cadeira vazia próxima a uma mesa onde ele estaria sentado.
} 


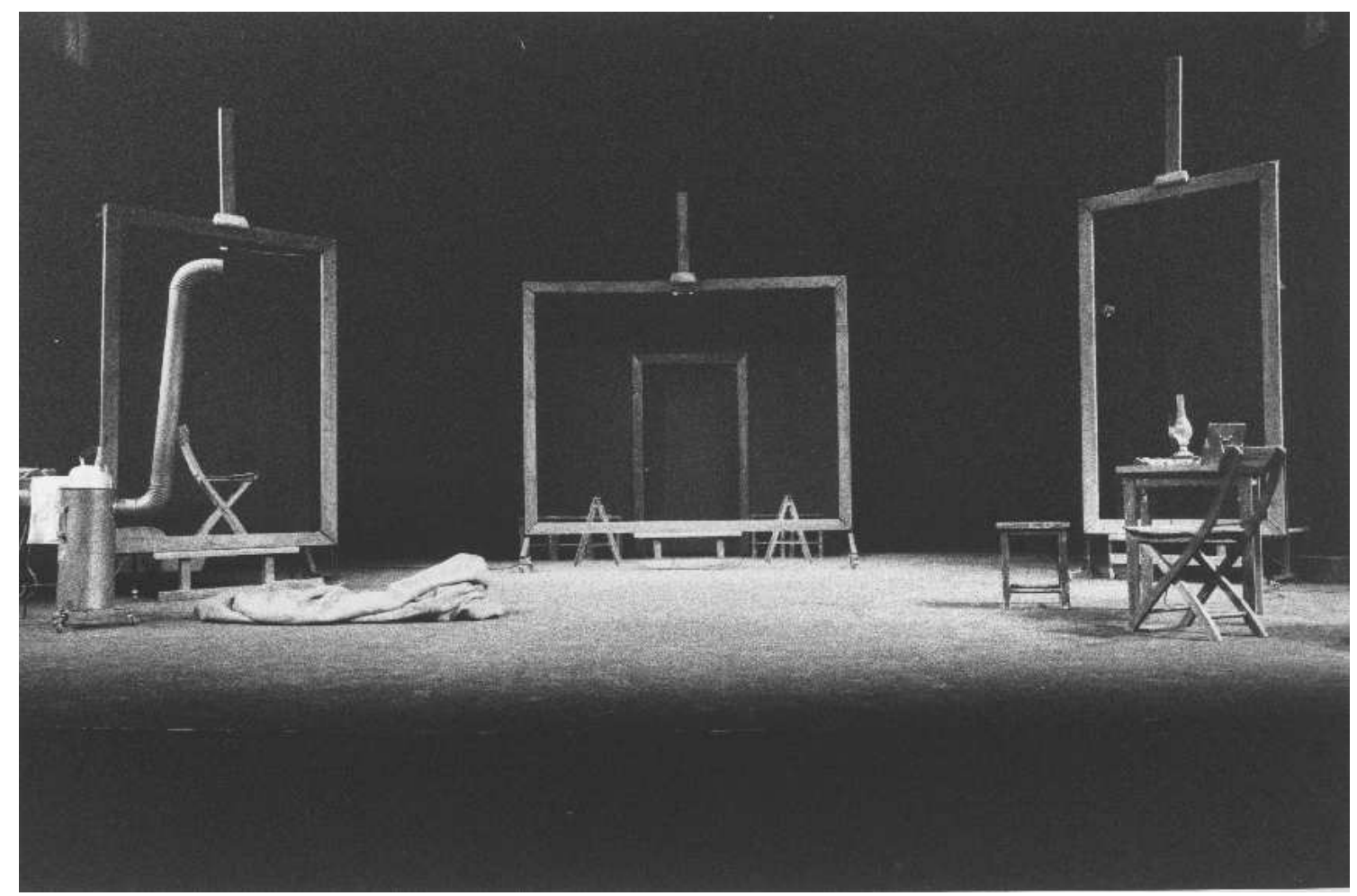

Hoje é meu aniversário - cenário. Foto: Romano Martinis.

Essa transformação dinâmica do espaço, criando estruturas autônomas ${ }^{35}$, não é exatamente um processo de busca de novos significados para essas estruturas, mas à necessidade de abandono das noções e conceitos a que estamos acostumados. Como aquilo que já foi dito, o teatro para Kantor é uma atividade que ocorre somente quando tudo aquilo que conhecemos perde o seu significado e sua razão de ser e todo sistema de referência deixa de existir. Assim, a única coisa que permanece na cena são as relações estabelecidas nesse espaço. Dessa forma, a autonomia em Kantor funciona como o estabelecimento de relações dentro do espaço, ou seja: entre objetos e atores. É essa construção do espaço, essa experiência metafísica com um espaço que não representa nada, não equivale a nada e nada traduz, o que possibilita um processo dinâmico na exploração das relações que levam o expectador a entrar no interior da cena ao invés de observá-la, como na frente de uma pintura.

\footnotetext{
${ }^{35}$ Entenda-se o conjunto de todos os elementos cênicos: espaço, objetos, imagens, personagens, etc.
} 


\section{OS OBJETOS HÍBRIDOS}

A história dos híbridos em Tadeusz Kantor é muito ampla, talvez a maior característica linguiística do seu teatro, já aparecia antes da fundação do Teatro Cricot 2 , em 1955. Esse conceito de dois em um pode ser observado em $O$ retorno de Ulisses com a fusão de duas realidades, com a utilização do espaço real e do objeto degradado como elemento da criação artística.

A partir do primeiro espetáculo do Cricot 2, O polvo, Tadeusz Kantor inicia um extenso diálogo com os textos de Stanislaw Ignacy Witkiewicz, que durará até A classe morta. Basicamente, Kantor utiliza as peças de Witkiewicz para a elaboração de uma segunda obra, independente da primeira, autônoma, apesar de se manterem nessa nova criação, os elementos da obra original. Esse processo criativo, híbrido, vai aos poucos adquirindo maior especificidade até $A$ classe morta, na qual Witkiewicz tornou-se apenas uma referência. Os elementos da peça Tumor cervical $^{36}$ estão subsumidos a essa outra realidade, totalmente independente da obra literária que não existe no espetáculo enquanto narrativa, mas como suporte para o desenvolvimento das imagens. Estamos então falando de uma realização artística híbrida, a realidade da obra literária e, conseqüentemente, a visão do autor em uma relação de simbiose com a criação de Tadeusz Kantor gerando uma realidade artística única, própria, original. É importante lembrar que Kantor não representa Witkiewicz, pelo menos não no sentido tradicional do termo. Conforme Kantor cansou de repetir, "ele representa com Witkiewicz". De certa maneira, trata-se de um processo através do qual a obra é continuamente esmagada, triturada na sua ínfima materialidade para revelar o seu significado mais profundo. Nesse sentido, A classe morta tornou-se o exemplo mais revelador desse procedimento no qual Witkiewicz se encontra fundido na peça. Não se observa mais a aparência da sua obra, mas se o seu pensamento condensado nas imagens criadas por Kantor.

\footnotetext{
${ }^{36}$ Em 1975 Kantor encena A classe morta, um espetáculo que foi concebido sobre o esboço do texto Tumor cervical de Witkiewicz.
} 
Sobre o objeto híbrido, um fator de fundamental importância trata do fato de que ele não tem mais a memória da utilidade. Ele torna-se um corpo alheio, possuidor de atributos estranhos e desconhecidos. O objeto híbrido priva o espectador da normalidade da sua condição de receptor. Ao ser confrontado com um objeto que se torna desconhecido devido à pluralidade da sua forma, ou seja, da união de estruturas diferentes, que sugerem diferentes usos, o espectador é forçado a entrar no desconhecido para interpretar alguma possibilidade simbólica. O primeiro exemplo de objeto híbrido, com o qual pretendo ilustrar essa outra concepção do objeto em Kantor, trata-se de um objeto utilizado no espetáculo As belas e os feios ${ }^{37}$, de 1972: a ratoeira.

\section{A ratoeira}

A ratoeira é um dos objetos extraídos do depósito da memória de Kantor e cuja característica é a de provocar dor e sofrimento. Mas antes de comentar sobre os princípios de construção e de jogo desse objeto, é preciso falar um pouco sobre o universo no qual ele está inserido, ou seja, a linguagem de Os belos e os feios.

Para Kantor, o teatro Cricot 2 é um espaço de exploração daquilo que o teatro é e ao mesmo tempo não é. As mudanças na história do Cricot 2 são marcadas por transformações muito específicas na exploração de linguagens que foram rotuladas de: Teatro Autônomo, Teatro Informal, Teatro Zero, Teatro Happening, Teatro Impossível, Teatro da Morte, e, Teatro da Memória. As belas e os feios é um espetáculo que faz parte do chamado Teatro Impossível, que é uma transição, a meu ver, entre o Teatro Happening e o Teatro da Morte.

Kantor, no Teatro Informal, explorou os aspectos desconhecidos da realidade em um processo de criação em que a matéria que é percebida por nós é uma imagem cujo significado é dado pela maneira convencional de ler a sua forma. Isso significa que a

\footnotetext{
${ }^{37}$ As belas e os feios ou a pílula verde, comédia com cadáveres em dois atos e três quadros. Texto de Witkiewicz.
} 
convenção interpreta a matéria de acordo com a experiência individual de cada expectador. Essa liberdade de interpretar libera a matéria das leis da realidade que, em dinâmica e em contínua mutação, torna impossível a apropriação simplória do olhar que dá forma a ela. Em resumo, Kantor deseja que o olhar se torne um processo de contínua desconstrução da forma da matéria. No Teatro Zero, por sua vez, que é antirepresentativo, no qual existe uma recusa da ação, mesmo a ação irracional, cujos movimentos que acontecem em cena são absurdos e praticamente são reduzidos ao nada, Kantor irá falar sobre os objetos marginalizados, a exemplo de um amontoado de cadeiras de madeiras que se transformam em máquina da morte na montagem de $O$ louco e a freira.

Com o Teatro Happening ${ }^{38}$, ele se voltará para a realidade do objeto pronto, para uma realidade existente, pronta. Com o Teatro Happening, em A galinha d'água, Kantor utiliza coisas da vida cotidiana, das atividades diárias, para abstrair de seus valores gerais em função da busca daquilo, que lhe é próprio, para revelar elementos imprevisíveis e desfamiliarizar esses objetos. O Teatro Impossível, assim como os anteriores, também deprecia o valor da realidade através da exploração daquilo que está escondido da nossa visão, por exemplo: os objetos que são marginalizados, os objetos que foram degradados, os objetos simples do cotidiano. Essa noção de impossibilidade, do não poder fazer ou do tentar fazer o impossível, é uma reflexão que acompanhou Kantor por muito tempo, desde os tempos da guerra. São reflexões que ultrapassam as dimensões do teatro como possibilidade de consumo e entretenimento. Isso porque um dos princípios elementares do Teatro Impossível reside exatamente na sua falta de atividade. A ação, que teria no ator a sua fonte motriz, desaparece. Esse não representa nada e nada transmite. O comportamento do ator deve paralisar a realidade do texto adotando na cena a sua própria maneira de ser na vida. Essa atitude, dupla, faz com que o jogo teatral, na hibridez da sua realidade, tenda ao infinito e ao se confrontar com a realidade do espectador, esse é levado a um estado de incerteza da realidade na qual ele se encontra. É nesse universo de dúvidas de As belas e os feios e do Teatro Impossível que a ratoeira está inserida.

\footnotetext{
${ }^{38}$ Utilizando o happening como receita, Kantor proclama "a representação da realidade pela realidade". Ele libera os objetos de suas prerrogativas vitais construindo algumas dependências entre eles. In. SkibaLickel, A. L'acteur dans le theatre de Tadeusz Kantor. France: Bouffannerrie, 1991, no. 26/27, p. 41.
} 
Ao classificar a ratoeira como um objeto híbrido, levei em consideração não somente a sua natureza física, mas também a natureza conceitual. A natureza imediata de uma ratoeira trata-se daquela destinada, obviamente, a capturar ratos. No entanto, a ratoeira também suscita a idéia de prisão e, para Kantor, como já foi dito insistentemente, a prisão se compara a uma tumba; evidentemente, a ratoeira trata-se de um discurso de morte. A ratoeira de As belas e os feitos destina-se ao aprisionamento e morte de homens.

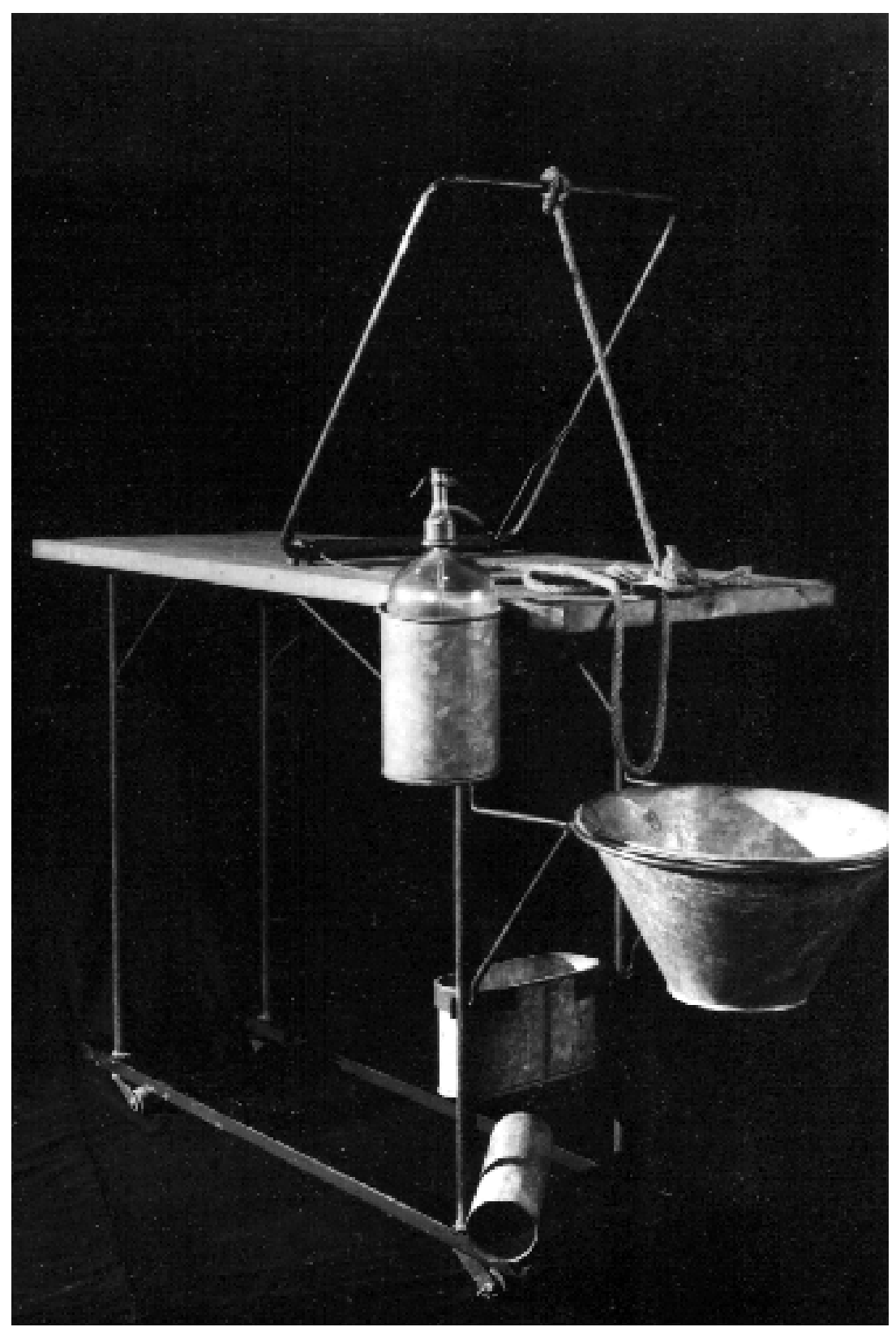

A ratoeira de As belas e os feios. Foto: Janusz Podlecki. 
Junto dos demais objetos dispostos no espaço, a ratoeira formava aquilo que a arte moderna chamou posteriormente de instalação ${ }^{39}$. A diferença da instalação com o teatro de Kantor está no principio de que a instalação é independente da atividade física do artista. O teatro de Kantor, por sua vez, não elimina a atividade física do ator: ele está imerso em uma constante negação da representação. Em um contexto geral, a instalação pressupõe um encontro com o todo espacial na qual ela está inserida propondo ao público alguma forma de participação, de penetração física na obra ${ }^{40}$.

Em As belas e os feios, as ações se desenvolviam sem qualquer ligação com as indicações de Witkiewicz. O público, ao ser abordado pelos atores, era introduzido no desenvolvimento do espetáculo sendo obrigado a assumir o papel de algumas personagens da peça. As ações dessas personagens assumidas pelo público eram guiadas pelos próprios atores sem qualquer preocupação com a construção de qualquer contexto verossímil em relação à peça de Witkiewicz. Os expectadores também eram obrigados a manipular diversos acessórios sem qualquer significação metafórica e sem nenhuma relação com a ação.

A exemplo de A galinha d'água, Kantor está em cena e a sua presença, que tem por objetivo a supressão da ilusão, faz com que o espetáculo não degenere em teatro "normal", de conflito de opiniões, eixo entre a expressão e a imitação da vida. O conflito, se é que existe, está relacionado ao confronto com o espaço e, principalmente, com os objetos. Um exemplo disso é um momento na peça em que a atriz Mira Richilicka, no chão, se desdobra em luta corporal tentando vencer uma caixa de papelão desfeita. Em geral, de alguma forma, o objeto sempre vence.

Outra situação ilustrativa que acontece com outro objeto híbrido que não foi inserido por mim na relação dos objetos que constituem a síntese do objeto em Kantor, mas que creio interessante comentar rapidamente sobre ele, é um objeto que chamei de

\footnotetext{
${ }^{39}$ A instalação é um fenômeno artístico multiforme que após os anos 80 tornou-se uma situação "cênica" que combina elementos plásticos os mais variados. Uma instalação pode ir da mais modesta composição de obras plásticas ou de objetos usuais dispostos no espaço, até a própria transformação do espaço.

${ }^{40} \mathrm{Na}$ peça de Kantor, assim como no contexto artístico da realização de uma instalação, também não existe mais a narrativa discursiva, a tensão dinâmica do teatro tradicional cujo movimento se dá através da ação dramática em um processo de exposição da exposição da fábula e do conflito.
} 
"bota com rodas"41 , que é composto por um calçado masculino, tipo coturno de soldado, preso a uma tábua de madeira. Através de canos de ferro, duas rodas de bicicleta, sem encostar no chão, são presas nas laterais dos coturnos. Trata-se de um objeto que não tem nenhuma função a não ser a de inibir a ação do ator que o utiliza. Ao colocar os pés no calçado, o único movimento de que o ator dispõe é o das mãos movimentando as rodas. Esse movimento caracteriza não um estado conflituoso entre o ator com objeto, mas reforça a tensão entre os dois elementos. O inerte movimento humano, entenda-se o não mover-se pelo espaço, contrasta com o movimento cinético das rodas. O homem está preso ao objeto, e dele não é possível escapar.

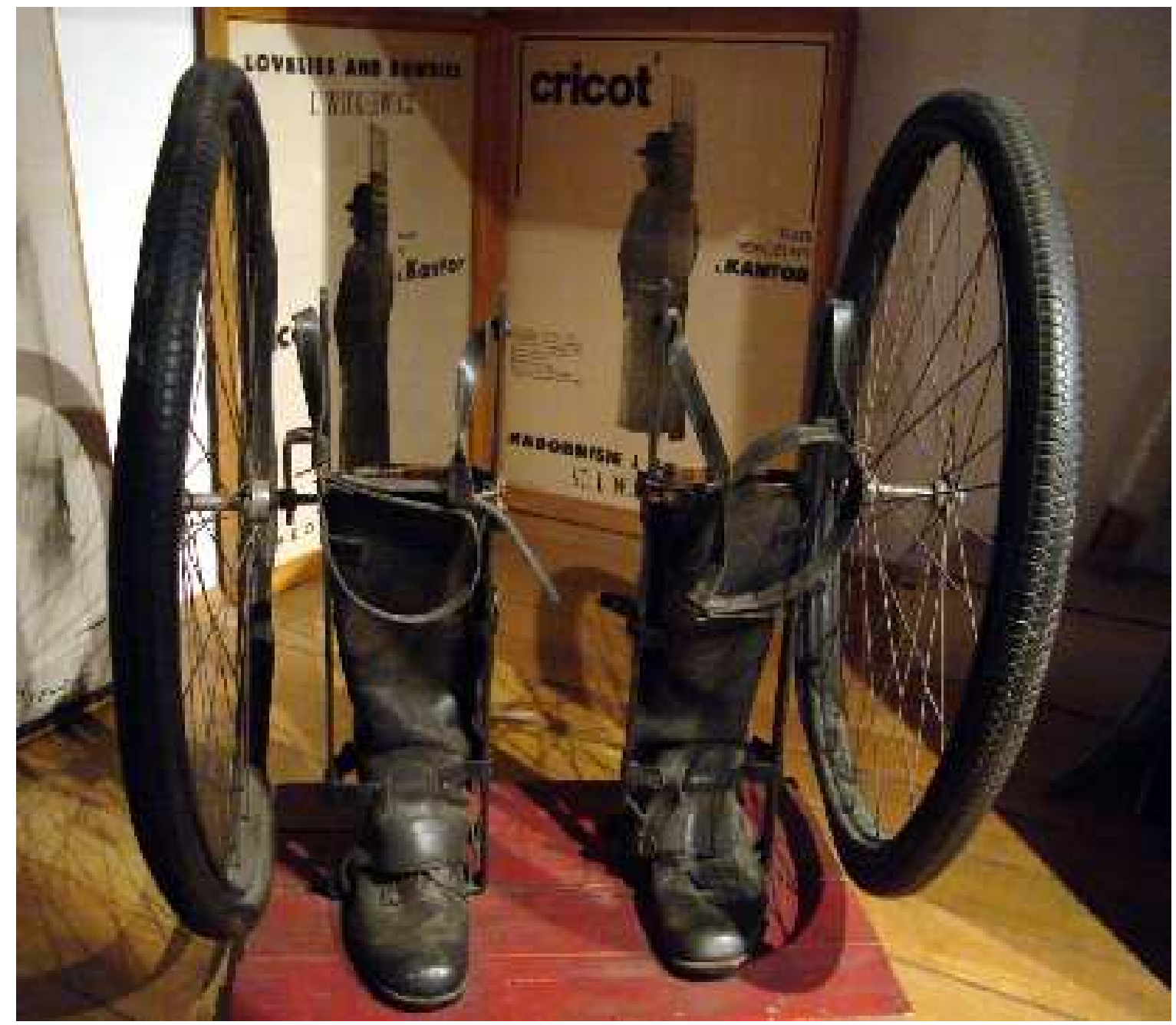

As belas e os feios - botas com rodas. Foto: Wagner Cintra.

\footnotetext{
${ }^{41}$ Essa é uma nomenclatura pessoal. Na Polônia, quando estive na Cricoteka, ninguém soube me explicar o nome correto desse objeto.
} 


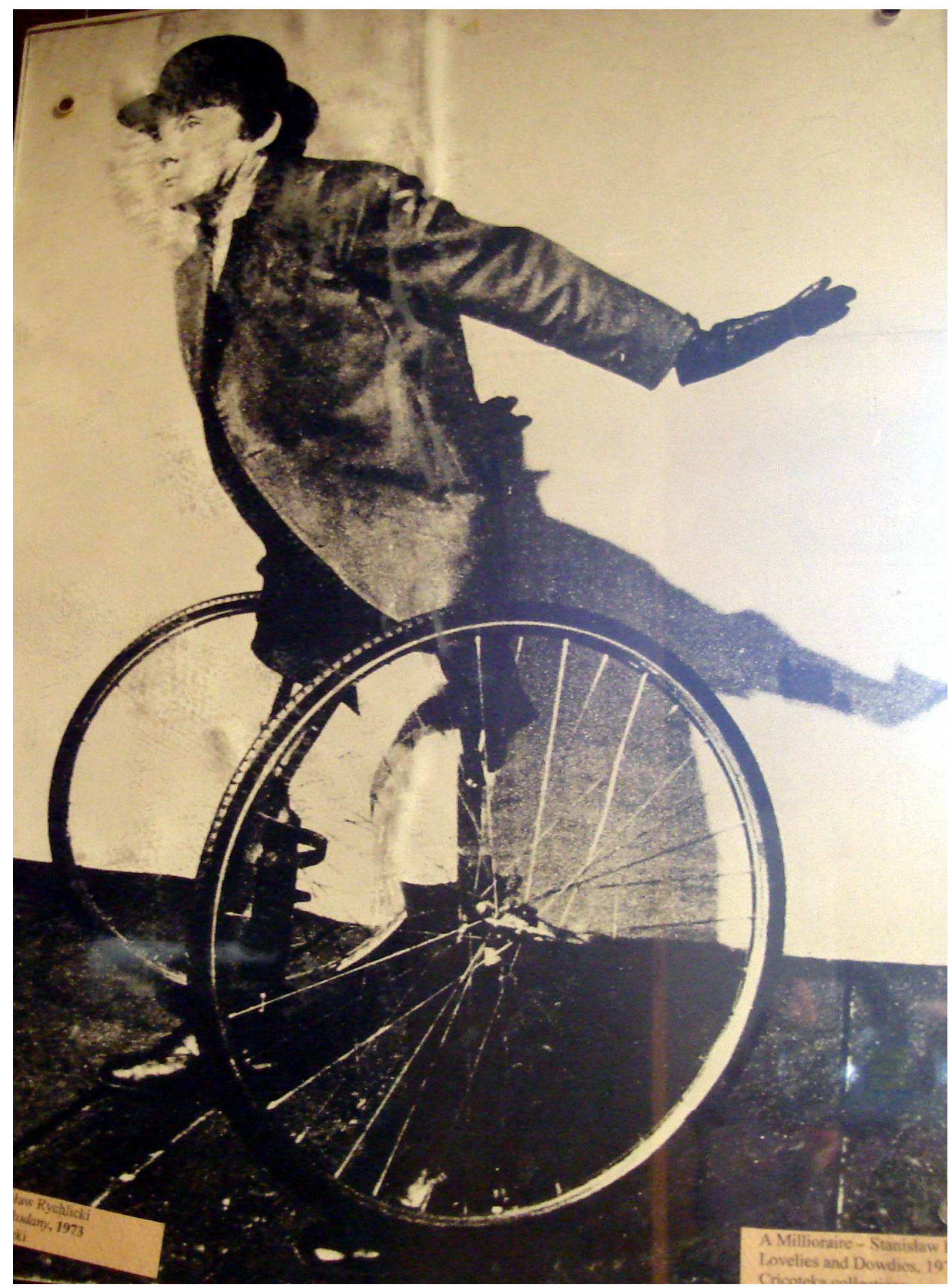

As belas e os feios - cena do espetáculo (pôster exposto no atelier de Kantor). Foto: Wagner Cintra.

A ratoeira, por sua vez, reforça essa idéia da impossibilidade de fuga. A principal cena de uso desse objeto se desenvolve de uma maneira na qual a ratoeira, um objeto que tem a aparência de uma mesa de ambulatório hospitalar ${ }^{42}$ sobre rodas, feita de madeira e canos finos, parece perseguir, como um animal, o ator que dela não

\footnotetext{
${ }^{42}$ Essa aparência é reforçada por alguns acessórios anexados a ela, tais como um funil, um garrafão de vidro, mangueiras de borracha, e também por uma atriz (Maria Kantor) vestida com um jaleco branco.
} 
consegue fugir e por ela é abocanhado. O engraçado desse jogo é que Kantor, que está em cena, orienta o ator na direção do inevitável, a submissão ao poder do objeto. É claro que outra relação de poder está implícita nesse jogo. No espetáculo, a representação simbólica do poder é relacionada à personagem que manuseia e domina o objeto de opressão. A ratoeira funciona em As belas e os feios de maneira semelhante ao arco utilizado por Ulisses para exterminar os pretendentes de Penélope.

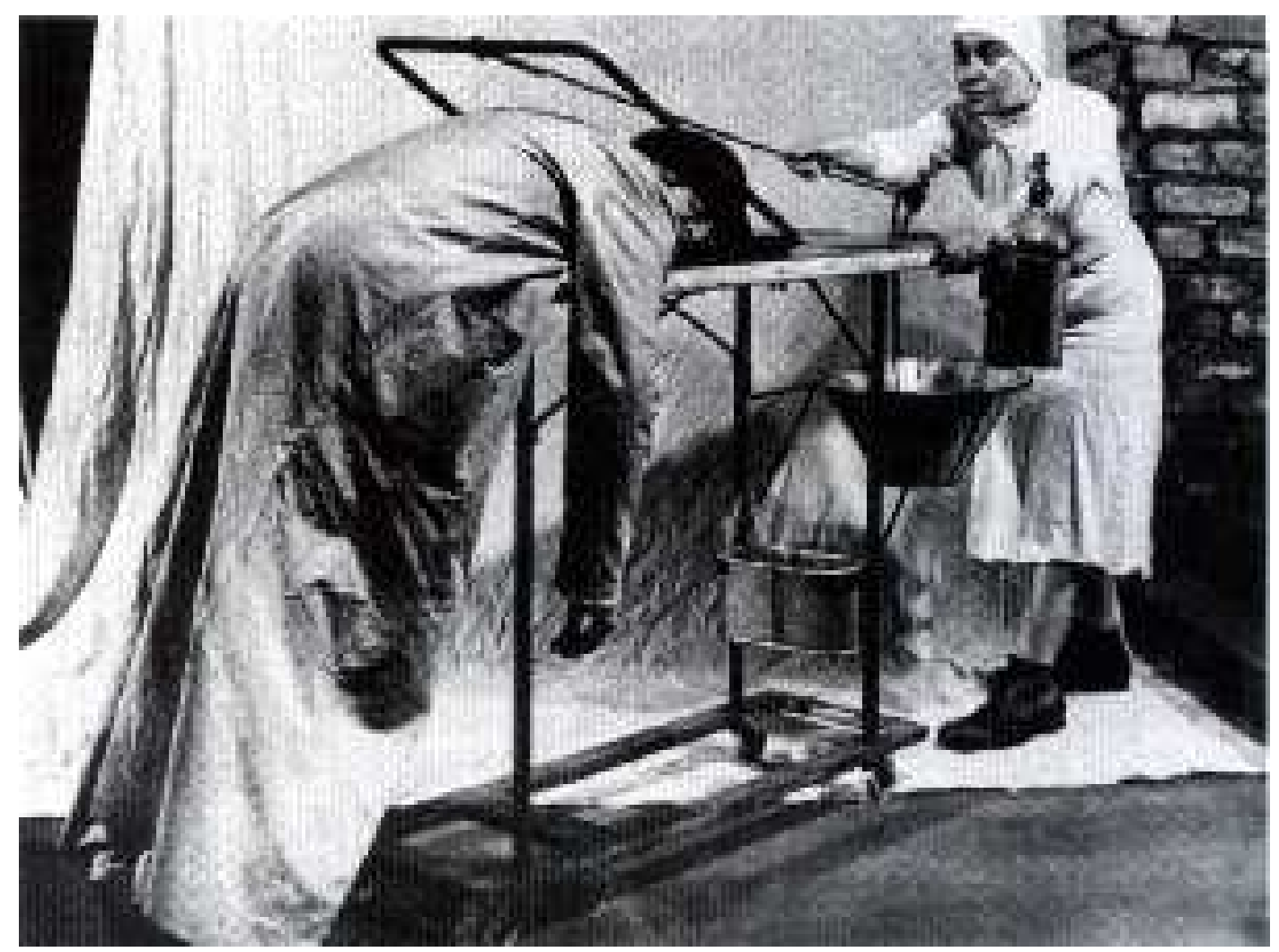

As belas e os feios. Foto:arquivos da Cricoteka.

Tadeusz Kantor está precisamente interessado na exploração da relação de poder entre os objetos e os homens fora das convenções impostas pela indústria cultural. É exatamente por isso que esses objetos, principalmente aqueles da "realidade de classe mais baixa", estão necessariamente associados a espetáculos que se realizam fora dos espaços tradicionais do teatro, fora da divisão tradicional entre palco e platéia, ou seja: entre ator e público. Nesse espaço "encontrado", o objeto pode ser liberado de toda e qualquer possibilidade de servidão utilitária. Liberar o objeto da escravidão da utilidade é a resposta de Kantor a esta realidade. 


\section{$O$ arco de Ulisses}

Não voltarei jamais é um espetáculo quase que recapitulativo no qual Kantor faz um apanhado das suas obras, sobretudo as do período da maturidade, ou seja: aquelas dos anos setenta e oitenta. Nesse trabalho se encontram diversas formas de signos dos espetáculos anteriores, mesmo os de algumas realizações feitas antes desse período, foram re-conectados, re-combinados, re-organizados em uma peça forte e divertida, quase que testamentária, na qual os personagens e objetos extraídos das suas encenações vêm se encaixar em uma nova dinâmica.

Talvez esse seja o mais comovente espetáculo de Kantor, não porque todos os modelos se cruzam, mas a utilização desse material retido na memória implicava para ele em um processo de renovação da sua fé na arte, através dos conteúdos mais significativos da sua vida pessoal. Conteúdo sustentado e marcado por uma história fortemente amparada na sua percepção individual do sofrimento, do desespero, da vergonha e da humilhação. Após ter assistido a essa produção, Guy Scarpetta comenta:

“... o espetáculo parece um teatro que foi construído com os restos dos destroços de um naufrágio, com os fragmentos caóticos de um universo devorado (o fim da história aconteceu), lançado nesse turbilhão de riso hilariante e de horror que evocava Mallarmé." ${ }^{33}$

Enfim, o universo de Não voltarei jamais trata de um mundo desaparecido que retorna através dos confrontos e dos rituais e o que é mais perturbador é que esse mundo ilusório permite a observação da realidade com outro olhar e, conseqüentemente, de torná-la mais transparente.

Um dos artifícios através do qual Kantor nos conduz para uma observação mais profunda da realidade é, sem dúvida, a utilização dos objetos. Em $O$ retorno de Ulisses, Kantor, inicialmente entra na realidade através dos objetos degradados, destinados ao lixo. Em um segundo momento, Ulisses mata com o arco os pretendentes de Penélope fazendo com que a dimensão histórica que é marcada pela entrada do herói grego e que

\footnotetext{
${ }^{43}$ Scarpetta, Guy. Kantor au présent. Arles: Actes Sud, 2000, p. 72.
} 
se apresenta vestido com um capacete e um "sobretudo militar", promova uma transição da realidade imaginada para a realidade da vida cotidiana. Ulisses é um soldado que volta da batalha de Stalingrado ${ }^{44}$. O instante em que Ulisses usa o arco para matar os rivais será reconstruído por Kantor em Não voltarei jamais, em uma cena que será recomposta de uma maneira surpreendente. Em O retorno de Ulisses, o arco era um pedaço de madeira curvado com uma corda presa nas extremidades sem nenhuma tensão.

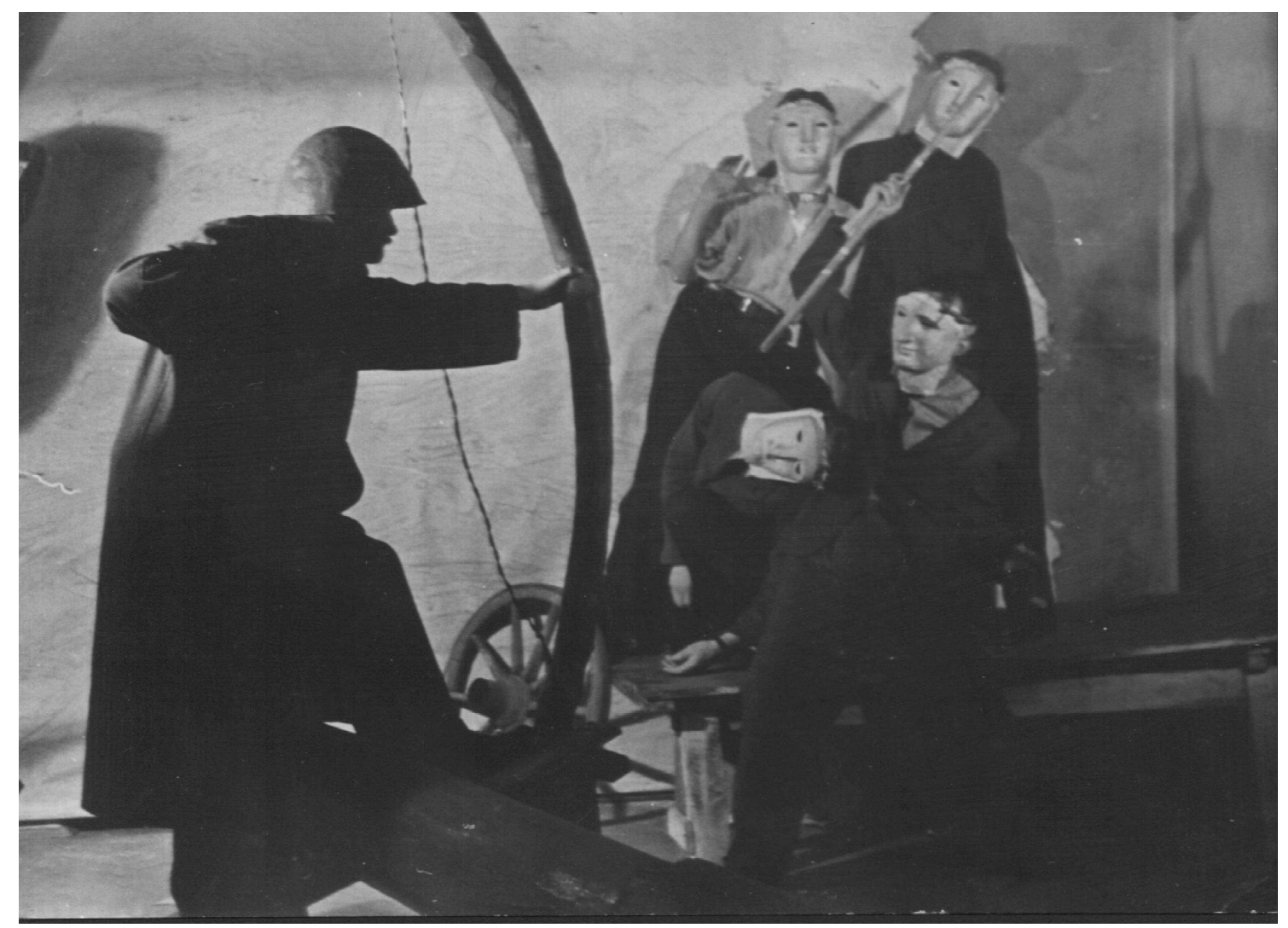

O retorno de Ulisses. Na cena, Ulisses com seu arco mata os pretendentes de Penélope. Foto: Zbigniew Brzozowski.

Em Não voltarei jamais, o arco é uma mistura de arco e metralhadora. Uma forma híbrida que une, mais uma vez, duas dimensões: aquela da representação do espetáculo em 1944 e a dimensão da realidade da produção de 1988. Assim, nesse jogo de associações, a própria cena reinterpretada apresenta um hibridismo na sua estrutura.

\footnotetext{
${ }^{44}$ A apresentação de $O$ retorno de Ulisses coincide com a data de aniversário da derrota dos alemães em Stalingrado em 25 de janeiro de 1943.
} 
Kantor está falando do espetáculo passado ao mesmo tempo em que cria uma nova obra no presente. Esse hibridismo da cena está diretamente conectado com o hibridismo do objeto e das personagens de Não voltarei jamais. Isso quer dizer que no processo de construção da nova cena, o passado existente na poderosa memória de Kantor e também dos espectadores, adiciona elementos extras nas lembranças originais, fortalecendo o conteúdo da cena. É importante entender que nesse espetáculo de 1988, as personagens e os objetos dos espetáculos antigos não reproduzem os trabalhos anteriores. As personagens de um espetáculo utilizam falas e objetos de personagens de outros espetáculos. Um exemplo disso é a prostituta de Que morram os artistas! que se apossa da gaiola de a Galinha d'água. Em A classe morta, um personagem da peça usa um objeto de Wielopole Wielopole e o mesmo acontece com os textos, com as músicas, em um tipo de colagem de momentos diferentes de criação. Nada é fixo, tudo está sempre mudando.

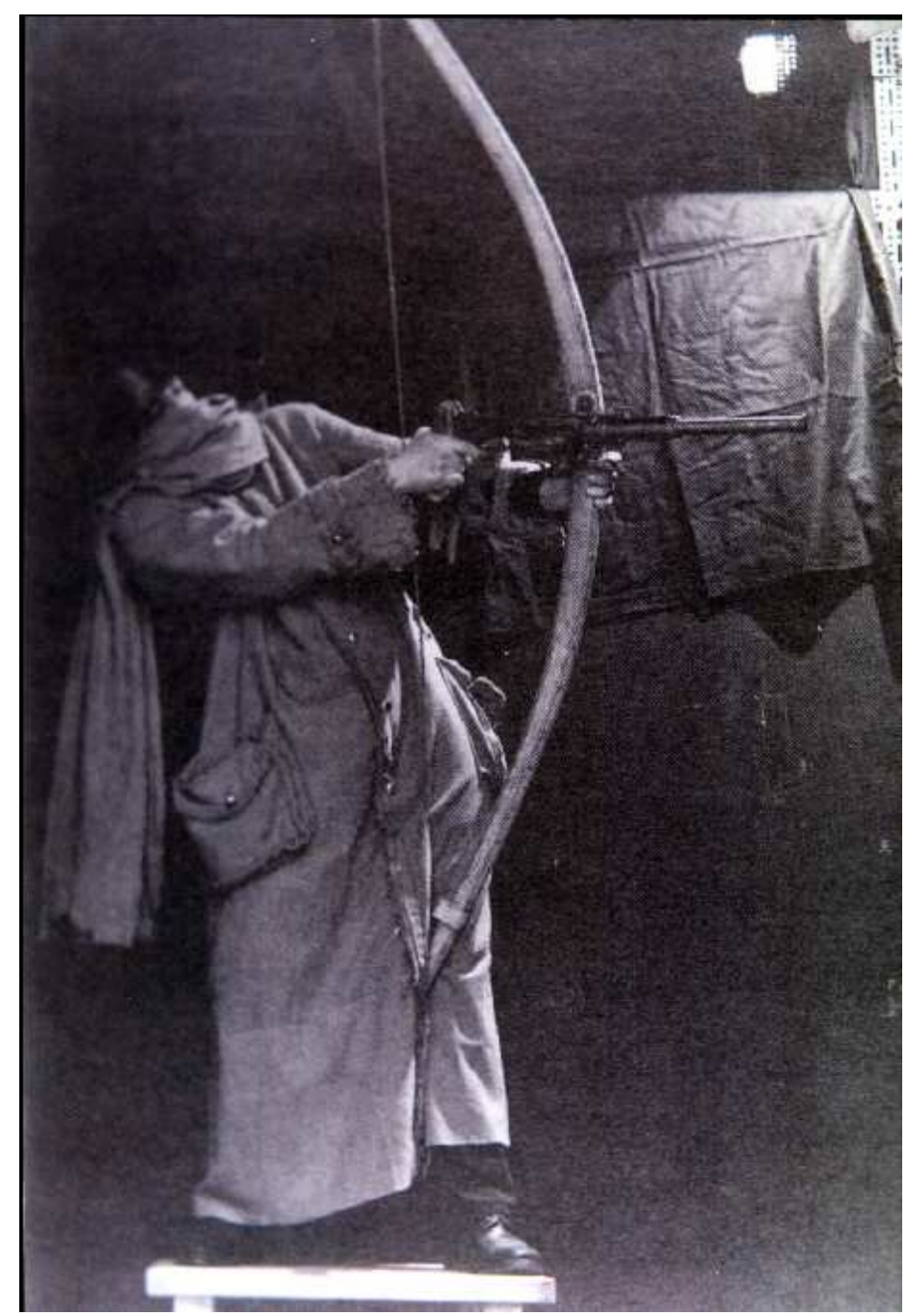

Não voltarei jamais. Ulisses com o arcometralhadora. Foto: arquivos da Cricoteka. 
A cena é um albergue para seres errantes, um espaço para os viajantes do teatro Cricot 2. Se anteriormente Kantor tinha domínio sobre a sua memória, nesse espetáculo ela está em confronto com o criador. Por vários momentos os personagens se dirigem a Kantor e o interrogam, evidentemente ele não se manifesta, a não ser através de uma gravação da sua voz que soa em off. Nesse ambiente destroçado, como comentou Guy Scarpetta, um espetáculo será representado: O retorno de Ulisses. No entanto, apesar de Kantor ter em suas mãos as anotações da produção de 1944, quem organiza a cena é o padre de Wielopole Wielopole. Ele distribui os papéis, as falas, movimenta as personagens, trata-os com uma certa indisposição. Os pretendentes de Penélope são os personagens de todos os espetáculos que estão amontoados nos bancos escolares. Ulisses desfere contra eles uma intensa rajada de tiros. Essa situação reflete mais uma vez a ambigüidade e a pluralidade de associações que o teatro de Kantor possibilita.

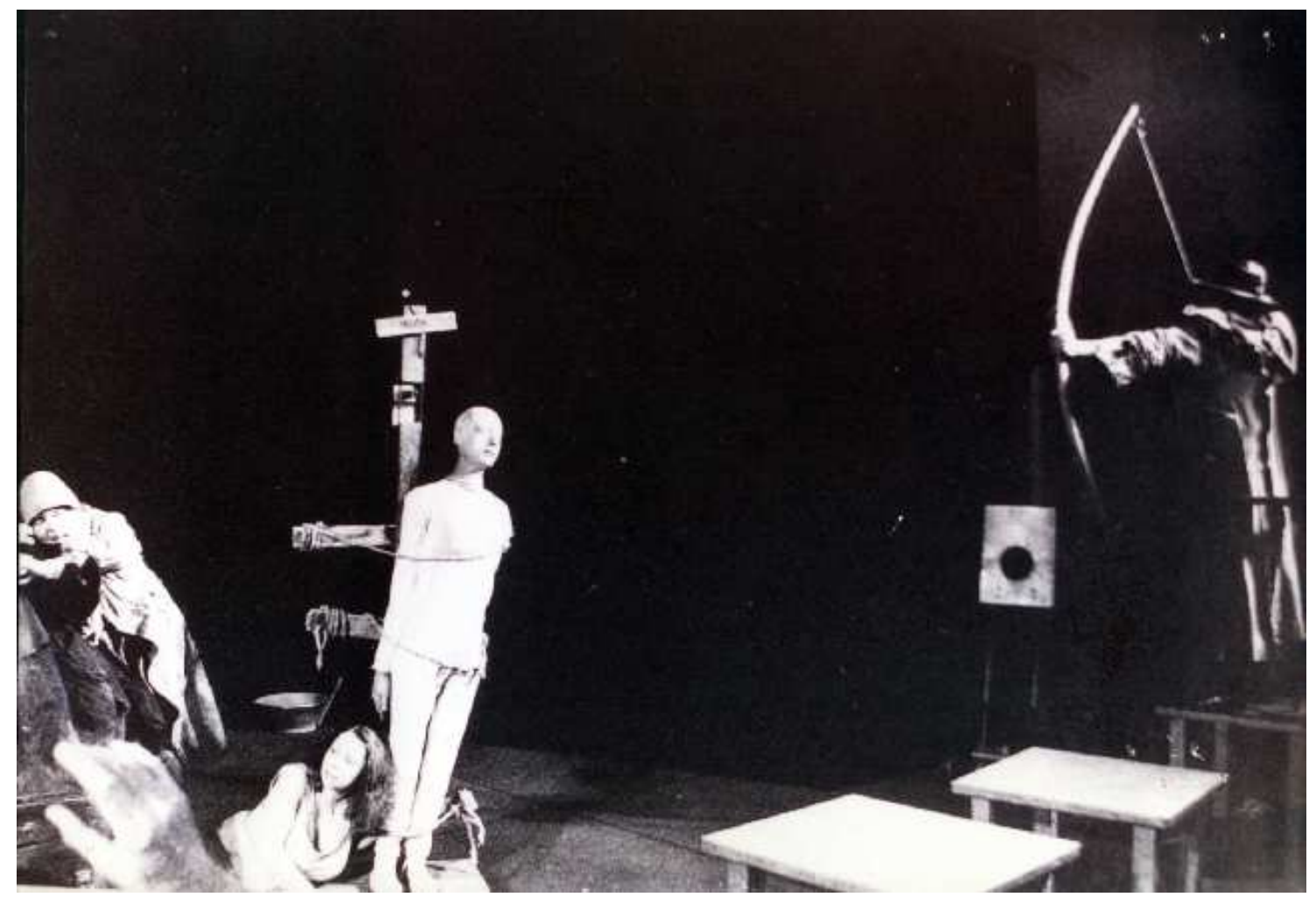

Não voltarei jamais. Na cena, Ulisses, com o arco- metralhadora, atira contra os pretendentes de Penélope (personagens dos espetáculos do passado), e também contra o manequim de Mariam Kantor, seu pai (supostamente morto em Auschwitz). Foto: arquivos da Cricoteka. 
Não é apenas uma estratégia de uso do espaço que faz com que aqueles que serão mortos por Ulisses estejam nos bancos escolares. Os bancos funcionam como máquina da memória para a nova história de $O$ retorno de Ulisses que será encenada como se tivesse sido originada dos bancos escolares. Assim, como um objeto encoberto pelo tempo, o espetáculo de 1944 deverá ser descoberto novamente. Dessa forma, a memória não pertence mais a Kantor e as personagens se tornaram autônomas ao invés de serem controladas por ele. No palco, Kantor entra no espaço de representação para encontrar os objetos de sua criação. Ao que me parece, a postura de Kantor nesse espetáculo diz respeito ao sentido do desdobramento do seu entendimento da realidade na qual ele está inserido. Anteriormente, fazia-se necessário um certo "mascaramento" da realidade para se atingir as profundezas dessa mesma realidade. Esse procedimento sempre esteve relacionado aos diferentes momentos históricos pelos quais a Polônia passou. No entanto, com o processo de redemocratização do país, ele parece nos dizer não ser mais preciso encobrir nada.

Assim, através de Ulisses com seu arco, ao metralhar a máquina da memória e seus ocupantes, Kantor está falando acerca dos atentados contra a arte e à cultura, contra a consciência individual, numa aberta crítica direcionada aos ideais dos comunistas que por muitos anos determinaram os caminhos do desenvolvimento artístico da Polônia. Por outro lado, e ao mesmo tempo, o arco- metralhadora também se refere ao genocídio, ao extermínio de toda uma geração de artistas, a exemplo de Bruno Schulz, que sucumbiram nos campos de concentração diante da intolerância e desumanidade dos comandados de Adolf Hitler. O arco de Ulisses, tanto no passado como no presente, assume o signo de instrumento da morte.

\section{A cama mecânica}

A cama mecânica trata-se de um objeto cuja função, antes de tudo, é a de estabelecer um jogo entre realidade e ilusão. Antes de A classe morta, Kantor acreditava que o único meio possível para se obter conhecimento e verdade de algo era lidar 
diretamente com a realidade e rejeitar a ilusão. Dessa forma, a realidade tornou-se para ele a única coisa que interessava ser explorada. Daí a concepção da "realidade de classe mais baixa" através da sua matéria prima: os objetos marginalizados. Outra situação também muito importante para ele é a opção pelos objetos "mortos". Essa opção também está muito relacionada com a emoção, com o sentimento de perda e de finitude que os objetos velhos trazem em si. O objeto destinado à lata de lixo que perde sua utilidade lembra o espectador, a todo instante, do seu próprio fim.

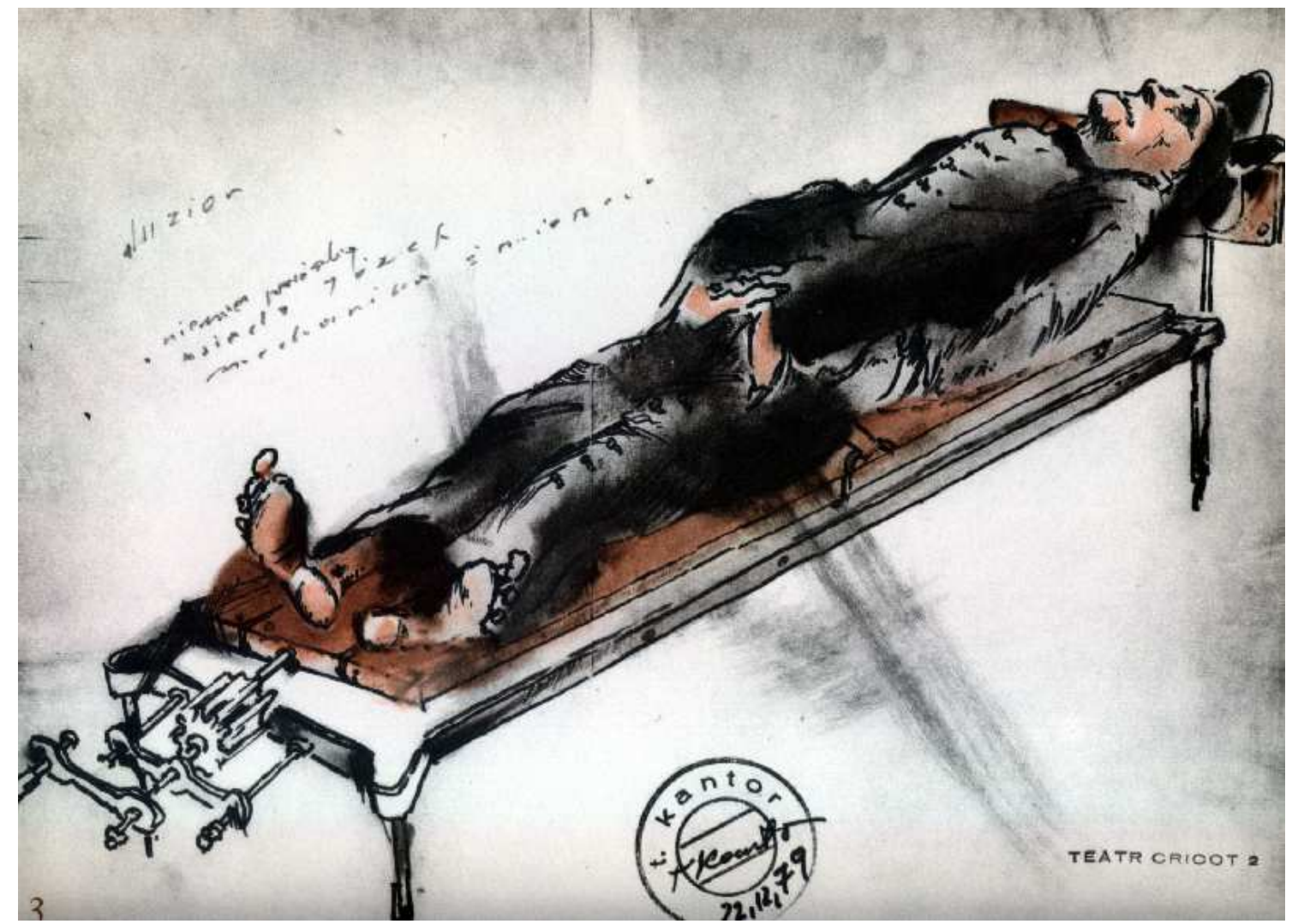

Tadeusz Kantor - projeto da cama mecânica. Imagem impressa gentilmente cedida pela administração da Cricoteka.

Para Kantor, a ilusão possui uma estrutura metafísica e essa estrutura baseia-se na repetição. A repetição é um gesto do ser humano que necessita confirmar a sua existência para fazer algo pela segunda vez para si mesmo. Isso significa que o ser humano, ao repetir a criação de um ato, mostra que esse ato já fora anteriormente realizado por um Deus. Assim, para Kantor, a repetição é um desafio a Deus. O ser 
humano agora, em uma atitude blasfematória, pode criar independentemente de Deus. Wielopole Wielopole traz no título esse sentimento metafísico. A repetição é um ato de criação, não criação divina, mas de Tadeusz Kantor.

No teatro aristotélico tudo o que acontece no palco é ilusão. É o deslocamento de um ato que acontece em um espaço real para um espaço de ilusão ou trata-se, como Kant a definiu na Crítica da razão pura ${ }^{45}$, como um jogo que persiste mesmo quando se sabe que o objeto pressuposto não é real. Assim, se para Aristóteles a arte é uma imitação da natureza, para Kantor a imitação também pode mostrar aquilo que a natureza pode não conseguir realizar. Kantor, que por muitos anos havia lutado contra a ilusão exatamente por sua capacidade de falsear a realidade, descobre no seu próprio teatro a possibilidade de manusear a realidade a partir da ilusão. Em Wielopole Wielopole, a repetição transpõe, rompe aquela barreira intransponível, preconizada no "manifesto do teatro da morte" ${ }^{46}$, criando outro status para a realidade. A ilusão encaminha a realidade para outra dimensão, para outro tempo e para outro espaço.

Esse jogo entre ilusão e realidade fica evidente no uso da cama mecânica. Um objeto, como a maioria, feito de madeira e ferro, possui um artifício, uma engrenagem acionada por uma manivela que faz com que o leito gire 360 graus ao redor de um eixo. Nesse dispositivo, o padre Smietana está preso por correias ao objeto, que quando iniciado o movimento giratório, se percebe o manequim do padre preso na parte inferior da cama. Os atores que participam da cena não sabem ao certo quem é quem. Qual é o verdadeiro e qual o falso. A cama gira diversas vezes para acentuar a dúvida. Essa cena em Wielopole Wielopole passou por várias modificações ${ }^{47}$. Em uma das concepções, a Fotógrafa/Viúva é quem movimentava o mecanismo chamando a atenção para o jogo com ator e manequim; vida e morte, uma brincadeira de pega-esconde com a morte materializada na fotógrafa. Na seqüência dessa cena, havia uma interação da Viúva/Fotógrafa com o seu objeto característico, a máquina fotográfica, que capturava

\footnotetext{
${ }^{45}$ Kant, Immanuel. Crítica da razão pura. São Paulo: Martin Claret, 2001.

46 "Nós devemos devolver à relação espectador/ator a sua significação essencial. Nós devemos fazer renascer aquele impacto original do instante em que um homem apareceu pela primeira vez diante de outros homens, exatamente semelhante a cada um de nós, e no entanto, infinitamente estranho, além dessa barreira que não pode ser transposta". In. Kantor, T. Les voies de la création thèâtrale - études de Denis Bablet et brunella Eruli, réunis et présentés par Denis Bablet. Paris: C.N.R.S. Vol. XI, 1983, p. 64.

${ }^{47}$ Desde a sua estréia em 1980 em Florença/Itália, o espetáculo passou por diversos arranjos das cenas feitas para representações na Cracóvia e outros lugares do mundo.
} 
aquele momento, uma prática de se fotografar os mortos que existia na Polônia até meados do século XX.

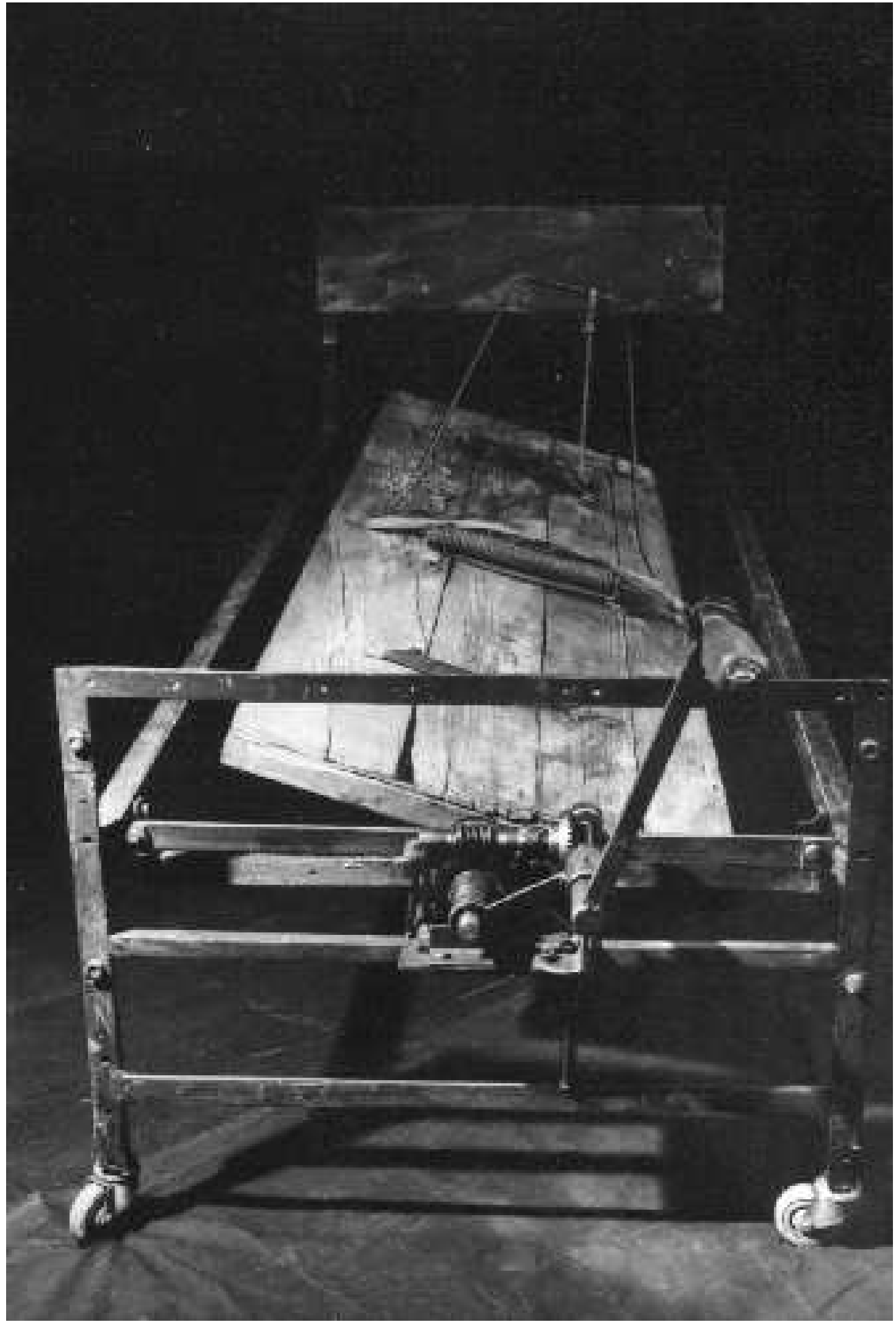

A cama mecânica de Wielopole Wielopole. Foto: Janusz Podlecki. 
Assim, além de jogar com a ilusão e com a realidade, a cama mecânica evocava a sua significação mortuária, o leito da morte, signo que mais uma vez joga com a duplicidade da cena, ou seja: a personagem está morta, mesmo que na organização espaço-temporal de Tadeusz Kantor a morte venha acontecer no desdobramento imediato da cena. Essa mesma situação ocorre na sequiência do casamento entre os pais de Kantor, ainda que o casamento aconteça antes da guerra, tanto o pai quanto a mãe já estão mortos. Ela está usando um vestido destruído pelas condições que a guerra impõe. O pai morto consegue expressar apenas uma única palavra, noite, cujo significado na tradição da cultura popular polonesa é morte.

Existe em Wielopole Wielopole um falseamento das aparências que constituem o espetáculo. Os objetos que Kantor coloca em cena não são elementos que pretendem ser a reprodução ilusionista ou hiper-realista de um modelo real. Não, eles são uma necessidade expressiva que têm garantida a sua existência no universo da arte ao lhes serem atribuídas alguma significação e por se situarem no plano artístico, ou seja:

"o objeto se torna uma verdade real"

Isso quer dizer que do mesmo modo que os atores, o objeto, seja ele fabricado, inventado, emprestado da realidade da vida, por mais ficcional que seja, não imita, ele é. Assim, a ilusão com a qual Kantor lida e aquela que ele permite que chegue ao espectador, não é, como diz Brunela Erulli ${ }^{49}$, hiper-realista, mas ela nasce das constantes trocas entre a realidade bruta do objeto, o modelo artístico de Kantor e sua organização simbólica. Não existe a reprodução da vida do objeto, mas sim uma espécie de condensação da vida. É exatamente isso que torna a cama mecânica um objeto tão inusitado. Esse objeto está muito além da força de um objeto da realidade cotidiana e é essa força a razão da sua existência na cena. Na realidade de Kantor, os objetos são capazes de existir somente como objetos artísticos.

\footnotetext{
${ }^{48}$ Kantor, T. Les voies de la création thèâtrale - études de Denis Bablet et brunella Eruli, réunis et présentés par Denis Bablet. Paris: C.N.R.S. Vol. XI, 1983, p. 235.

${ }^{49}$ Ibid. p. 239.
} 


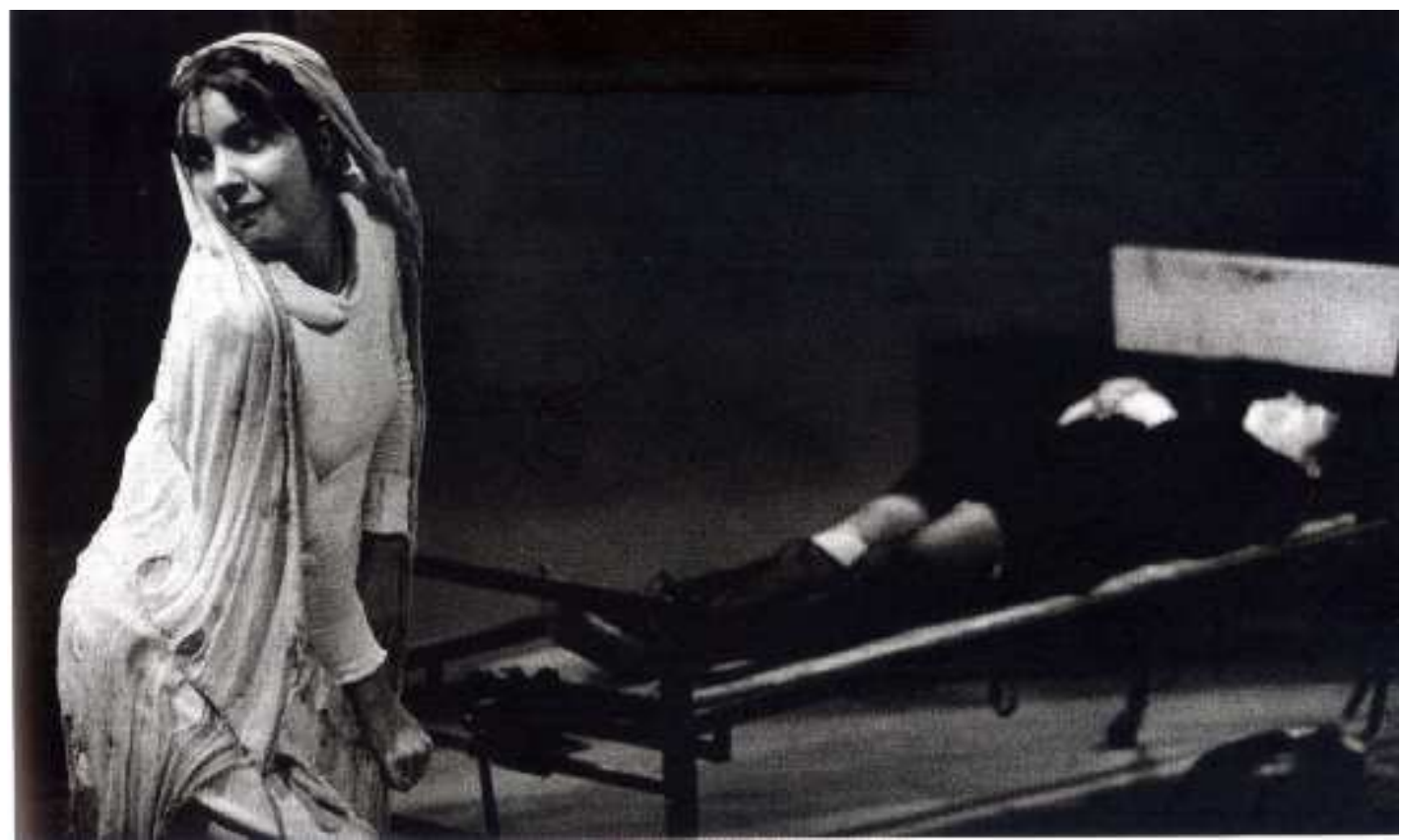

A cama mecânica em uma das versões de Wielopole Wielopole. Foto: Maurizio Buscarino.

É importante salientar que os objetos que rodeiam Kantor não são acessórios de teatro que ficam em um canto à espera do momento de serem manuseados. Não, eles partilham a mesma condição dos personagens humanos. Todos estão situados no mesmo nível de existência. Em determinados momentos em Wielopole Wielopole, alguns personagens que estão $\operatorname{associados}^{50}$ à família de Kantor, têm os corpos arrastados e abandonados no espaço. São movimentados como se fossem quaisquer objetos. Isso pode ser ilustrado com a cena na qual o manequim da noiva, após ter sido violentado, é deixado no solo, ou como o corpo do padre, martirizado pelos soldados, os mesmos violentadores da jovem noiva, é abandonado em uma posição que põe em dúvida a aparência humana. A violência extrema e a humilhação os reduzem a não serem mais do que coisas, objetos. Nessas cenas, mais uma vez sobressai o tema da Segunda Guerra e dos campos de concentração.

\footnotetext{
${ }^{50}$ Kantor não gostava de usar a palavra representação exatamente por lembrar a imitação aristotélica da natureza.
} 


\section{A máquina fotográfica-metralhadora}

Em Wielopole Wielopole, a máquina fotográfica-metralhadora é um instrumento que, a partir do seu manuseio, adquire outra função ou um significado duplo. A cena na qual esse objeto está inserido é uma das mais significantes do teatro de Kantor. Kantor sempre teve uma relação muito sentimental com a fotografia e muitas cenas dos seus espetáculos parecem imagens congeladas no tempo, como que capturadas por uma máquina fotográfica.

A cena significante a qual me refiro, no espetáculo, acontece no momento em que os soldados estão de partida para o front. Os soldados em pose esperam para ser fotografados. $\mathrm{O}$ aparelho fotográfico ${ }^{51}$ é posicionado pela fotógrafa que aciona seus mecanismos. Ao ser acionado o disparador, o "clic" que caracteriza o disparo da máquina, é substituído por uma rajada de metralhadora. A própria estrutura do aparelho muda. Existe, atrás dele, um dispositivo que quando ligado faz com que um cano de metralhadora saia da caixa que captura as imagens. Ao lado dessa caixa sobressalta um grande pente de balas. A metamorfose é evidente, um inofensivo aparelho de uso cotidiano revela o seu lado mais vil enquanto objeto: um instrumento da morte. Nesse contexto, a personagem, a profissional da imagem, também revela a sua hibridez. A fotógrafa ao manusear o seu instrumento, ao se fundir a ele, também revela a sua segunda natureza, terrível e aterradora - a materialidade da morte.

\footnotetext{
${ }^{51}$ Também chamado por Kantor de "a invenção do senhor Daguerre”.
} 


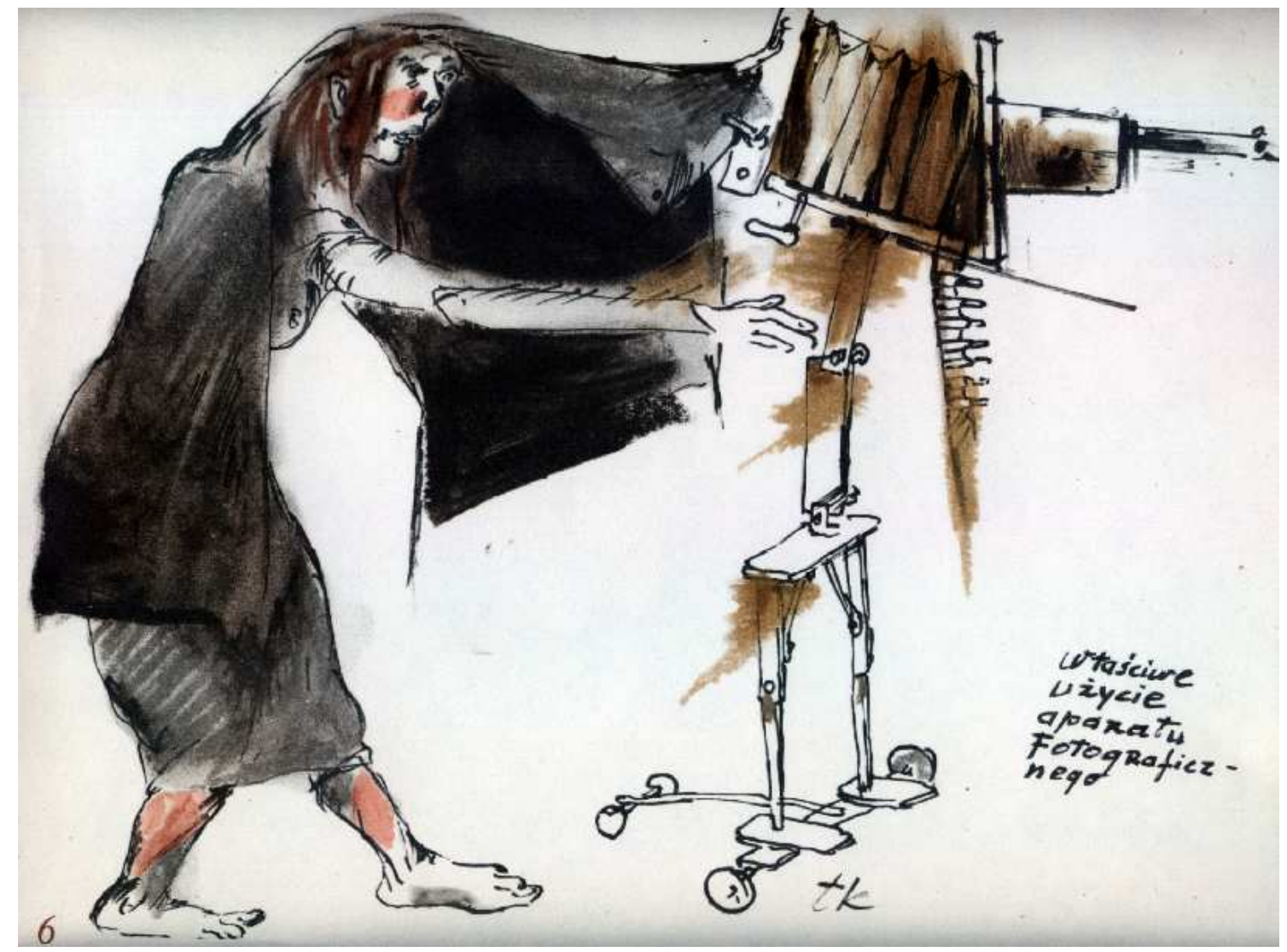

Tadeusz Kantor - projeto da máquina-fotográfica-metralhadora. Imagem impressa gentilmente cedida pela administração da Cricoteka.

Essa situação é muito peculiar no sentido em que, durante o desenvolvimento das cenas, a fotógrafa, conforme a memória de Kantor, é a viúva do verdadeiro fotógrafo de Wielopole e que, após a morte do marido, foi obrigada a assumir a função de fotógrafa por uma questão de necessidade. Mas esse não é o ponto. A questão principal está no fato de que aquela que tira a fotografia, que eterniza um momento vivo, prendendo por um ínfimo instante as pessoas na pose,

“imobilizando-os em um instante para a eternidade",52,

a fotógrafa em sua condição de viúva também assume a sua condição de personagem híbrida ao trazer em si o estigma da morte pois essa, a morte, estará insistentemente associada à sua condição de viúva. Nesse sentido, ao fotografar os soldados, objeto e

\footnotetext{
${ }^{52}$ Kantor, T. Les voies de la création thèâtrale - études de Denis Bablet et brunella Eruli, réunis et présentés par Denis Bablet. Paris: C.N.R.S. Vol. XI, 1983, p. 221.
} 
manipulador assumem a duplicidade das suas naturezas. Dessa forma, ao acionar o mecanismo que faz a foto nos soldados, a metralhadora é descarregada, acentuando a idéia de que aqueles que partem para o front partem para a morte. Isso, como já foi visto anteriormente, é reforçado e desenvolvido na seqüência da cena quando o padre Smietana joga terra sobre soldados e manequins. Essa cena cria uma metáfora muito mais significativa do que a simples aparência. Conforme comenta Brunella Eruli:

“...a fotografia, ao mesmo tempo em que eterniza, mata o momento..."53.

Mais uma vez, a dicotomia kantoriana - eternidade e morte.

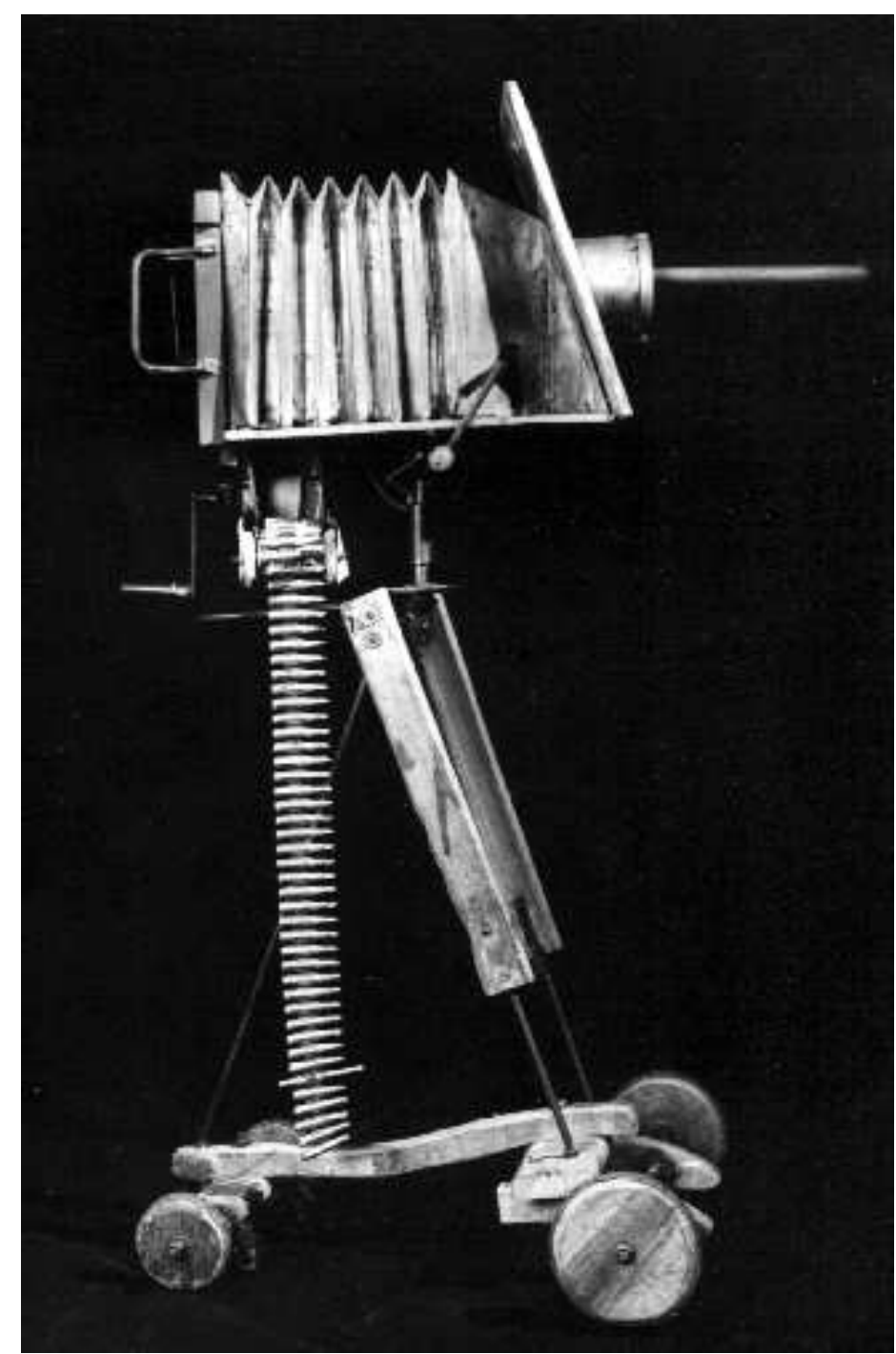

Máquina-fotográfica-metralhadora. Foto: Janusz Podlecki.

53 Ibid. 
A fotografia é uma presença constante em Wielopole Wielopole. Ela age de maneira a projetar a sua memória e, ao mesmo tempo, é uma porta de acesso para o real. A fotografia, como comenta Lorenzo Mango ${ }^{54}$, é a imagem de um mundo que já não existe, como um ícone do passado, como imagem que por um lado, carrega a vida que em um fluxo de tempo transcende o aqui e agora; e por outro lado, remove a imagem do tempo imobilizando-a em um momento que jamais poderá se repetir. Na fotografia, a realidade, a imagem afastada da vida, transforma-se em ícone e se torna um emblema, algo que é metáfora e alegoria em um insistente trocar de significados. É exatamente isso que interessa a Kantor. Ao mesmo tempo, ao fotografar e metralhar os soldados, um jogo entre significante e significado se institui e é destruído para ser novamente reinterpretado.

Em todo objeto em cena, sempre, o significante é significado de alguma coisa e assim, na medida em que o significado imediato é destruído, um novo significado se constrói. Porém, o significante e o significado anterior continuam existindo no mesmo significado. Essa, notadamente, não é uma relação de negação mas de coexistência. Dessa forma, a máquina fotográfica não se transforma em metralhadora, mas assume a condição de também ser metralhadora devido ao seu hibridismo. Essa relação é a circunstância que permite a criação de metáforas que relacionam a vida com a morte, o instante com a eternidade.

Jean Baudrilhard em seu livro $O$ sistema dos objetos, diz:

“...as relações do homem com os objetos resumem as integrações do homem com o mundo e com as relações sociais..." 55

Antes de $A$ classe morta, Kantor pregava que a única forma de entrar na realidade era através das latas de lixo, dos objetos que foram descartados pela sociedade que são produtos dos desejos humanos. Assim, o objeto criado para uma necessidade inexistente de nada serve. Para a civilização, os objetos quando não satisfazem uma necessidade imediata, geralmente não são bem vindos. No entanto, a arte, sobretudo a arte de Kantor, burla esse ideal da existência prática. Até 1973, os objetos que mais lhe

\footnotetext{
${ }^{54}$ Mango, L. Appunti per uma lettura icônica del teatro di Tadeusz Kantor. In. Tadeusz Kantor - Cricot 2. Milano: Oedipus edizioni, 2001, p. 31.

${ }^{55}$ Baudrillard, J. O sistema dos objetos. São Paulo: Perspectiva, 2002, p. 54.
} 
interessavam eram aqueles esquecidos nas lixeiras e, compadecido deles, Tadeusz Kantor sentia a necessidade de proteger esses objetos que, segundo ele, estavam no limite entre o lixo e a eternidade.

Pois bem, se as relações do homem com o objeto são definitivas na construção do seu conjunto de relações no interior da sociedade definindo o seu modo de ser, Kantor construiu a sua linguagem a partir das privações impostas pela Segunda Guerra Mundial. Afinal, o que sobrara para se fazer arte na Polônia nesse período? É evidente que cada objeto encontrado passou a ser cultuado como um depositório de energias oriundas da memória que o impregnava. Cada objeto encontrado, sem nenhuma utilidade, descartado das suas funções de uso, trazia em si o significado de civilização incrustado na sua aparência. Esse é um dos motivos pelo qual Kantor, na construção de objetos e cenários, fazia uso de uma espécie de reciclagem de matéria prima. Essa matéria prima que carregava em si energia histórica e conforme comenta Jean Baudrillard:

“...o objeto antigo, este, é puramente mitológico na sua referência ao passado. Não tem mais resultado prático, acha-se presente unicamente para significar. O objeto antigo significa o tempo."56

É exatamente esse o ponto. Os objetos funcionais existem somente na atualidade, e ainda Baudrillard:

“...não se asseguram no tempo."57

\footnotetext{
${ }^{56}$ Ibid, p. 82.

${ }^{57}$ Ibid, p. 84.
} 


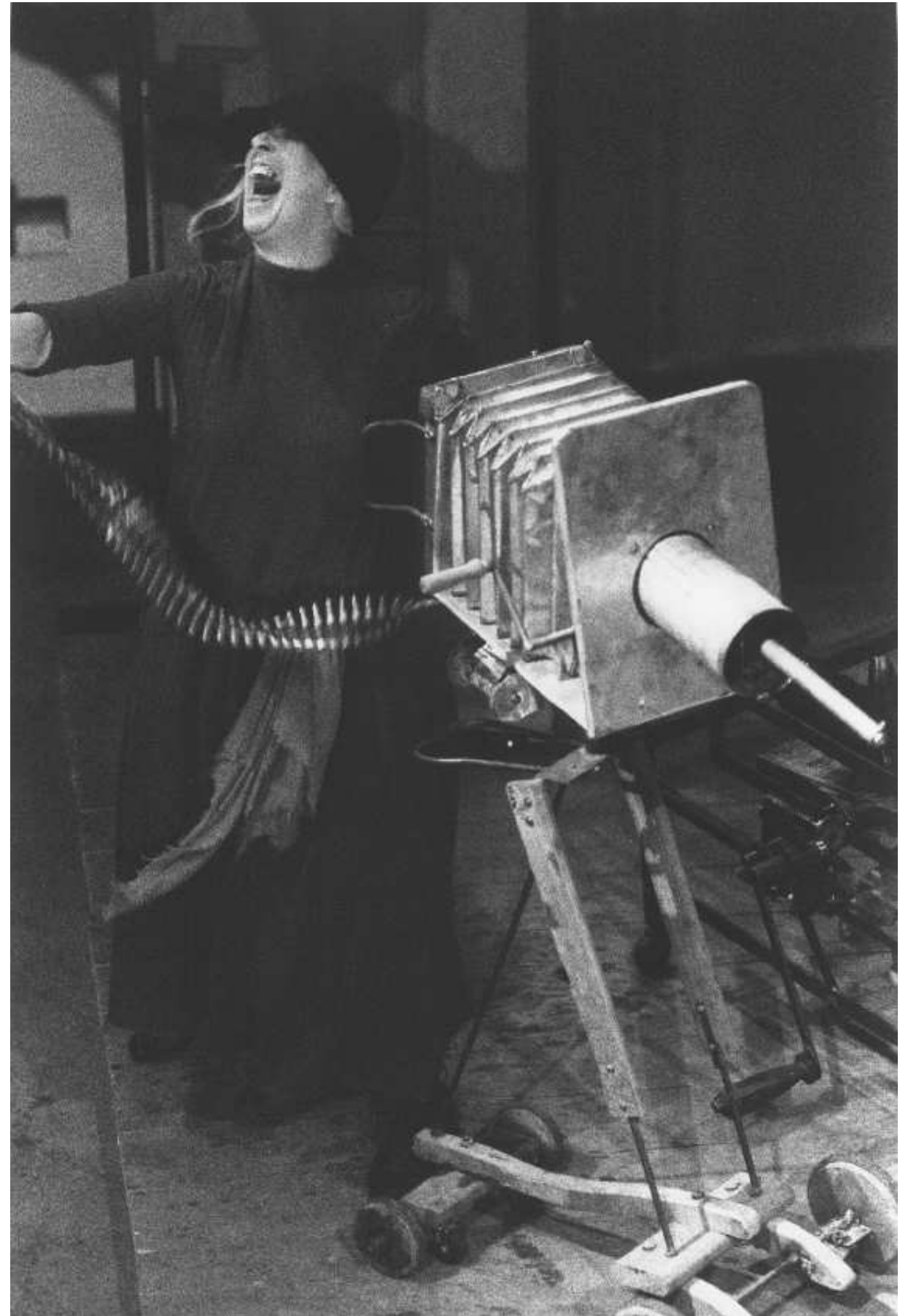

Wielopole Wielopole. Na cena, a Fotografa-viúva com seu objeto. Foto: Romano Martinis.

Em Wielopole Wielopole, a máquina-fotográfica-metralhadora não faz mais parte da categoria da "realidade de classe mais baixa"; apesar da matéria prima utilizada na sua confecção poder ser classificada como tal, esse instrumento trata-se de um objeto construído para um fim muito específico. Um objeto que só é capaz de existir no universo artístico e que constitui o seu próprio sistema de referências. Um objeto que 
consegue sua verdadeira e própria vida, paralela, autônoma. Um objeto mensageiro, condutor de significação. A máquina fotográfica nos possibilita um aprofundamento da eficiência da visão a fim de torná-la fonte de um conhecimento obscuro. Ao criar um objeto híbrido, Kantor, através da fotografia nos induz a um olhar, o seu olhar sobre o mundo e, simultaneamente, a metralhadora sugere uma troca de mundo, algo novo se cria e um novo significado se institui. Nesse sentido, o objeto não é mais visto no imediatismo do uso, mas na sua natureza de evento se transforma em "objeto da visão" ${ }^{58}$ através da mediação de Kantor. Assim, o espetáculo passa a ser lido como um jogo de imagens presas na memória coletiva, as quais, ao saltarem de uma imagem a outra, em uma linha de tempo não linear, possibilitam um movimento do jogo das lembranças vividas de Kantor a uma emoção que o espectador a faz sua.

\section{O violino-realejo}

Uma das imagens mais melancólicas do teatro de Kantor trata-se do velho soldado com seu violino. Um estranho instrumento musical, mudo, que não ressona som de qualquer espécie, assegura unicamente a existência da personagem que o manipula. Esse instrumento, mais um entre tantos, cuja existência somente é possível dentro de um universo artístico, é feito de madeira leve, um tipo de compensado. Ele sugere a forma de um violino, mas não possui cordas, tarraxas para afinação, as coisas características de um objeto real. Além da caixa, esse instrumento possui apenas uma manivela, que lembra outro instrumento movido por um mecanismo semelhante, ou seja: um realejo. O seu caráter híbrido, na cena, garante apenas a existência da personagem que o manipula. O Deportado, essa é a maneira como Kantor se refere a essa personagem em uma das suas notas, trata-se de mais um dos seus parentes que saltam para a cena a partir das suas lembranças. Um tio, tio Stasio, violinista, que durante a Primeira Guerra Mundial era oficial do Império Austríaco e foi preso pelos russos. Alguns anos após o término da guerra, ele volta para a Polônia. Inicialmente, Kantor não tinha nada escrito

\footnotetext{
${ }^{58}$ Bellasi, P. e Lalli, P. Recitare con gli oggetti - microteatro e vita quotidiana. Bologna: Cappelli edittore, 1987, p.23.
} 
sobre ele, sobre o seu desenvolvimento na cena. O que mais lhe chamava a atenção era a imagem daquelas pessoas que foram deportadas dos campos de prisioneiros quase no final da sua vida e que tentavam retornar para as suas pátrias. Essas figuras espectrais, no limite da vida, carregam em si a aparência da morte, semelhantes aos velhos de $A$ classe morta, mendigavam por toda a Europa. Kantor sintetizou todo esse universo de dor e esquecimento na personagem do tio músico que vaga pelas ruelas da sua memória e, principalmente, da sua imaginação. Ao que me parece, Kantor nutre por essa personagem um sentimento muito especial. Isso pode ser percebido em um dos seus escritos de 1984, bem posterior à estréia do espetáculo, quando ele se refere a essa personagem que ainda é uma incógnita.

“O violinista deportado prova ser, no final das contas, um simples e pobre tocador de realejo. Sua caixa de violino que parece anunciar um concerto extraordinário, não passa de um simples realejo, se apoiando sobre uma prótese de inválido (...) A ilusão do figurino romântico e do personagem patriótico é quebrada pelo tipo miserável de artista da BARRACA DE FEIRA. Nós não sabemos quais são os seus verdadeiros sentimentos. Talvez ele acredite ser um artista virtuoso; na sua imaginação ele vê a multidão que o aplaude, ele saúda o público após cada "número", e talvez, ao final, a loucura se aposse dele. Mas ele pode ser também um LOGRADOR VAZIO como o seu violino. A melodia natalina, sobre o tema de um scherzo de Chopin, deformada por esse patético instrumento, que deve recordar o ambiente de todas as noites de natal que a nossa infância pertence, ela assim, no mesmo gênero pobre da BARRACA DE FEIRA, ao VERDADEIRO TEATRO DAS EMOÇÕES.”,

Existe um fato notório que é o olhar romântico que Kantor deposita sobre os artistas de rua. Isso faz muito sentido pois a Cracóvia foi o mais importante entreposto cultural da Europa Oriental até as primeiras décadas do século XX. Hoje, como no passado, a antiga capital da Polônia possui uma vida cultural muito intensa e é palco de exibição de uma grande variedade de artistas de rua vindos de diversos lugares do mundo. Como estão sempre de passagem, esses são os artistas viajantes, um modelo que Tadeusz Kantor utilizou para definir o seu próprio teatro, os artistas viajantes do teatro Cricot 2. Isso pode ser percebido através de um objeto que é recorrente a todas as suas encenações: a mala. Signo da viagem, ao que parece, ela não está associada a nenhum personagem específico. Ela passa pelas personagens que a manipulam; em se tratando de Wielopole Wielopole, ela funciona como uma preciosidade fortemente protegida

\footnotetext{
${ }^{59}$ Kantor, T. Wielopole Wileopole. Kraków-Wroclaw: Wwydawnictwo Literackie, 1984, p. 60. (arquivo da Cricotéka).
} 
pelos tios que cruzam a cena logo no início do espetáculo, até marcar o retorno de Mariam Kantor, que volta da guerra. A mala também tem uma outra significação: ela pode assumir a conotação de mensagem da morte como aquela que acontece quando o padre entra para comunicar a morte de $\operatorname{Adas}^{60}$, ele entra com uma mala na mão que é colocada ao lado do monte de terra que suporta uma cruz em pé. É a mesma terra que cobrirá Adas quando as portas de fundo se abrirem e lá o soldado morto for depositado.

"Signo de viagem, ela também se torna o signo da morte, da grande viagem sem retorno"

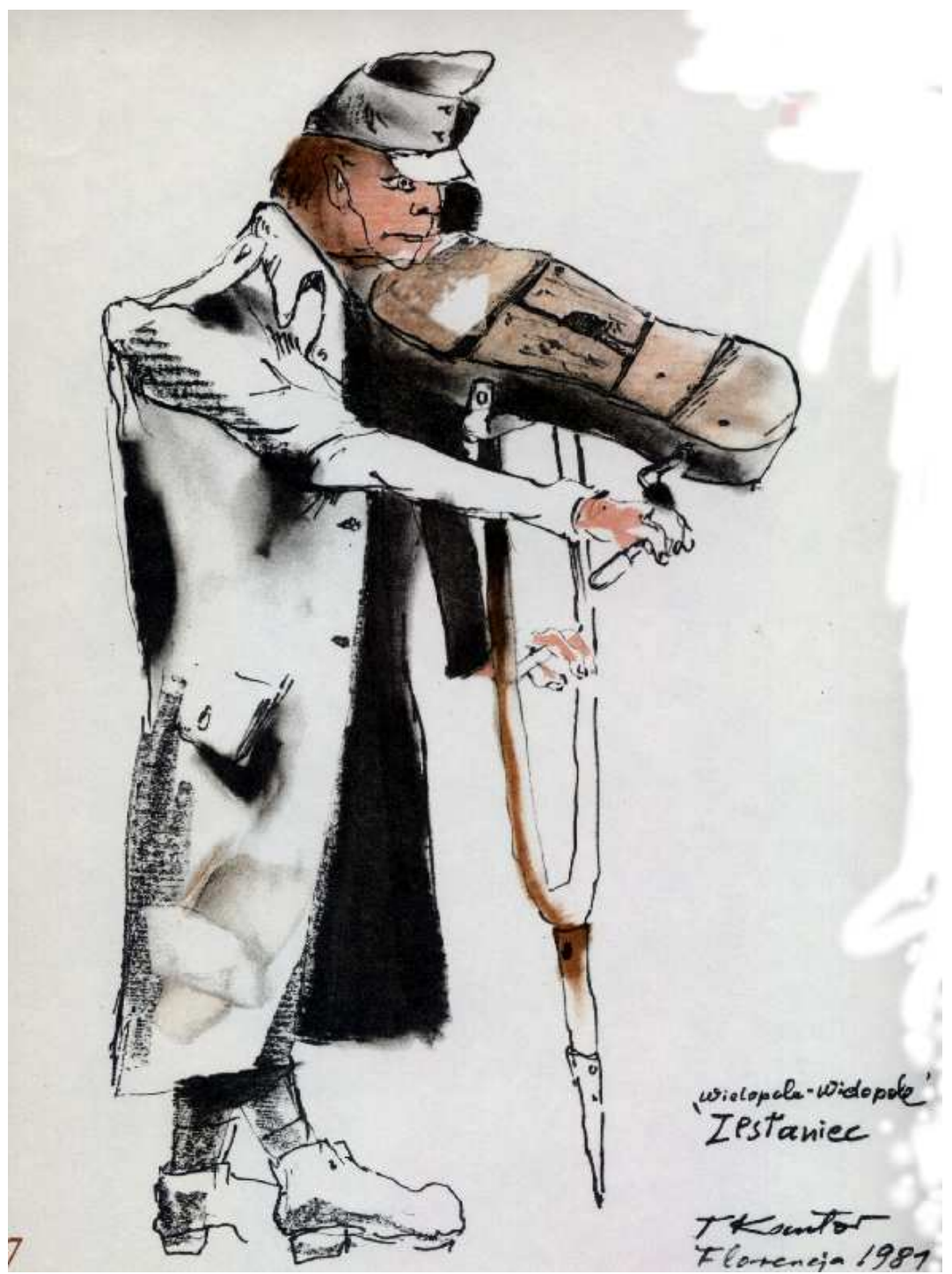

Tadeusz Kantor - projeto do violino-realejo. Imagem impressa gentilmente cedida pela administração da Cricoteka.

\footnotetext{
${ }^{60}$ Adas, o soldado que é trazido para a cena, em Wielopole Wielopole, na cruz obliqua sobre rodas. O soldado que parte para o front tem a morte e o sepultamento antecipados pelo padre Smietana. Nesse circo-grotesco de Kantor, a morte está sempre um passo adiante da vida.

${ }^{61}$ Erulli, B. In. Kantor, T. Les voies de la création thèâtrale - études de Denis Bablet et Brunella Eruli, réunis et présentés par Denis Bablet. Paris: C.N.R.S. Vol. XI, 1983, p. 250.
} 
A idéia da viagem em Kantor começou na sua obra, teatral e pictórica, nos anos sessenta. Nesse período, a sua concepção de arte estava diretamente associada à idéia de viagem, como ele mesmo disse em uma entrevista concedida a Michal Kobialka em 1986:

"Nessa época, nos meus escritos teóricos, eu definia a arte como uma viagem, a vida como uma viagem." ${ }^{62}$

Essa definição era sustentada pela presença, no seu trabalho, de elementos significativos que faziam referências expressas à viagem, como uma bicicleta e malas diversas. A galinha d'água, por sua vez, não era concebida como uma cena tradicional de teatro, mas como um longo corredor, um longo caminho no qual os personagens da peça não paravam de se deslocar. O surpreendente dessa concepção da arte como viagem irá se transformar em memória, uma viagem ao passado. A memória como a grande "embalagem" 33 da história.

No universo cênico de Wielopole Wielopole, de um objeto a outro se tem uma circulação de funções e significações das mais variadas. Nesse universo se morre, não somente pelas estocadas das baionetas dos soldados, mas também através de um aparelho fotográfico. Quando as portas se abrem para a partida dos jovens soldados para a guerra, também se abrem as portas das câmaras de gás de Auschwitz. Assim, o violinista com seu violino também é condutor de significações diferentes. É um ser sem voz e sem palavras, o seu instrumento parece falar por ele através da melodia que é repetida insistentemente. Em alguns momentos do espetáculo, como comenta Brunella Eruli:

\footnotetext{
${ }^{62}$ The drama rewiew, no. 30, automne 1996, p. 177-183. New York University and Massachusetts Institute of Technology.

${ }^{63}$ No "manifesto das embalagens", Kantor fala sobre a necessidade de proteger os objetos que estão no limite entre o lixo e a eternidade. A embalagem corresponde ao processo de ocultação de alguma coisa, de proteção de um conteúdo que pode ou não ser revelado. Em Christo, por exemplo, o ato de esconder implica necessariamente chamar a atenção para as propriedades do objeto que passam desapercebidas do olhar cotidiano. Para Kantor, o corpo humano é uma embalagem por excelência, porque esse corpo está no limiar entre a morte e o lixo. Assim, para ele, é preciso embalar o corpo humano e salvaguardá-lo da ignorância e da vulgaridade, pois não existe nada mais precioso do que o conteúdo que ele abriga.
} 
“...se tinha a impressão que a sua aparência parecia se animar, mas ele voltava a ficar inerte, como se em tudo aquilo que ele observava, nada o estimulasse a dar um novo élan à sua música..."64

Esse personagem pode ser lido como um mensageiro de esperança e também como o próprio sentido da incapacidade de realização de qualquer ato que sugira esperança. Seu olhar é ausente e distante de todas as situações. Está sempre presente, mas não interfere na ação. Na cena final, homem e objeto criam a impressão da sugestão de um momento de fraternidade e esperança, no entanto, a melodia que lhe é característica constantemente é interrompida por um acorde dissonante que é acompanhada por uma breve pausa do movimento da manivela do instrumento; a música nunca chega ao fim. Subsiste apenas, no final do espetáculo, um discurso que se torna vazio e insuportável, o violinista e seu objeto insistentemente provocam o olhar do espectador se mostrando indiferente a qualquer reação que possa ter despertado pela cruel falta de objetividade da sua presença na cena.

Esse violinista, no espetáculo, possui uma zona de ação muito precisa que está situada próxima à porta de fundo. Praticamente todas as suas intervenções acontecem nesse local, a não ser pela última cena em que ele está próximo à mesa na qual a família está reunida para ser fotografada como a imagem da Última ceia, de Leonardo Da Vinci. Brunella Erulli faz um comentário muito interessante sobre a personagem e seu instrumento. Ele diz, que em alguns ensaios da peça, o deportado apoiava o violino sobre uma muleta que perdia a sua função:

“...o violino tornou-se a verdadeira muleta desse misterioso personagem, condutor do destino de todo um povo."

O violino a manivela reflete a sua própria condição de objeto híbrido, não somente pela abstração que o envolve ao sugerir duas formas, mas principalmente por ser um objeto que é extensão do seu manipulador. É um dos exemplos mais claros do bio-objeto. A sua hibridez não se restringe a sua forma e à matéria da qual ele é feito. $\mathrm{O}$ seu caráter híbrido decorre de dois outros importantes fatores. A extensão do braço do

\footnotetext{
${ }^{64}$ Erulli, B. In. Kantor, T. Les voies de la création thèâtrale - études de Denis Bablet et Brunella Eruli, réunis et présentés par Denis Bablet. Paris: C.N.R.S. Vol. XI, 1983, p. 250.

${ }^{65}$ Ibid, p. 249.
} 
ator que movimenta a manivela e a música de Chopin, que aciona esse movimento. Em resumo, um instrumento musical que não produz som algum, no entanto dialoga com um som externo a ele e que o insere na ação.

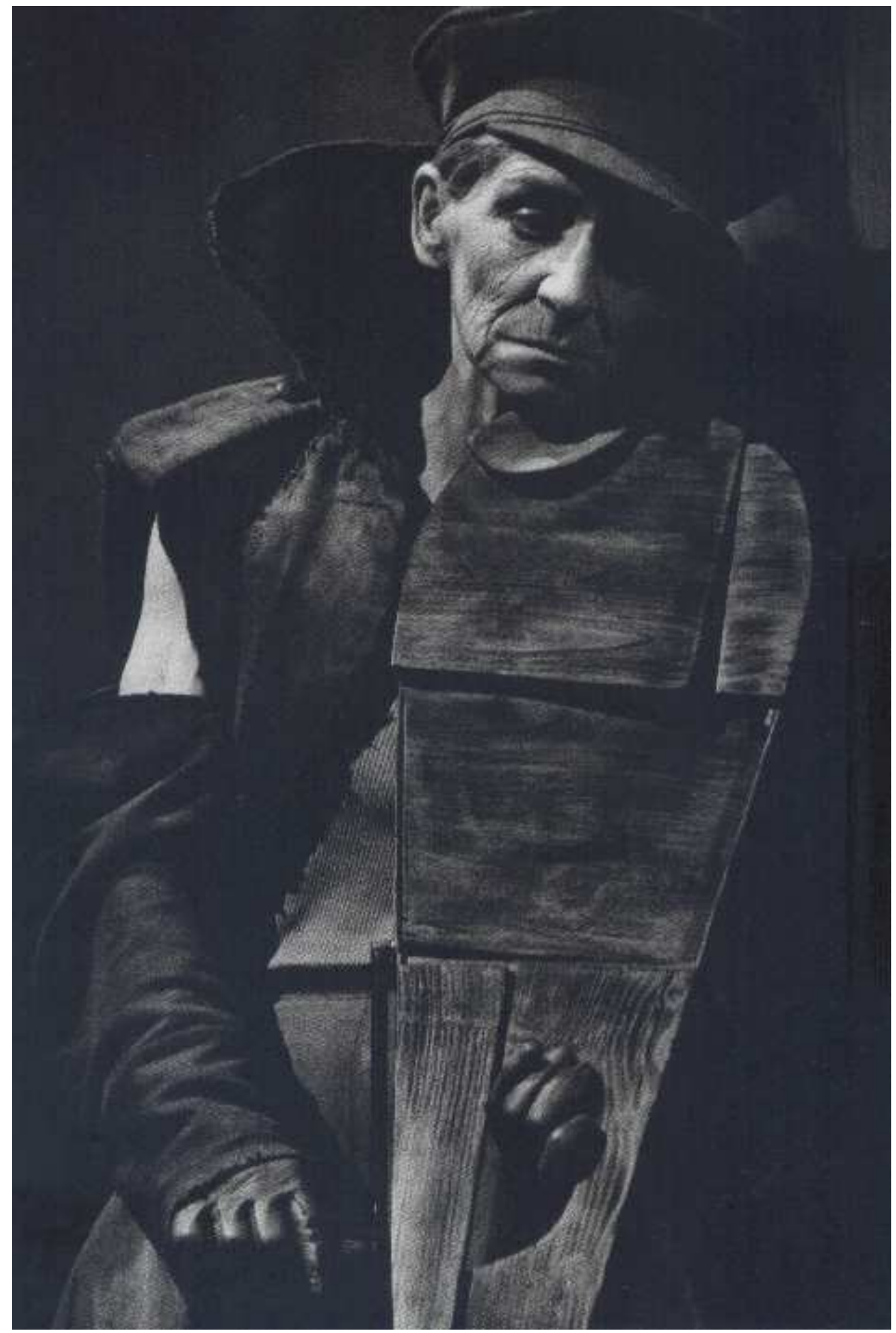

Wielopole Wielopole. O deportado e seu instrumento. Foto: Maurizio Buscarino. 
O movimento rítmico das mãos na manivela deste instrumento inatingível pela razão prática, cotidiana, torna-se o elemento significativo do movimento circular do tempo no qual as situações não se desenvolvem linearmente. As situações apenas acontecem e independem da ordem cronológica. Tudo se passa como em um lapso de tempo contido na memória do diretor polonês e que se constitui em uma dimensão patética e perturbadora na qual os significados da vida são exumados pelos significantes da morte. O insistente tocar do violino/realejo mudo, as dimensões do tempo (imutabilidade e imobilidade), definição de um instante eterno se constituem em uma peculiar percepção da eternidade: a arte é o lugar da eternidade. E para a eternidade o tempo não existe, ele apenas se configura como um instante. Assim, através dos elementos retirados diretamente da vida, e transformados em estruturas de uma obra de arte, a vida coexiste como objeto, como elemento de uma obra de arte, a vida tem seu significado reconstituído, deixando o estado de efêmero se elevar à condição de eternidade. O passageiro associa-se ao eterno. A vida, ela mesma, é a própria obra de arte.

\section{OS OBJETOS CÓPIAS}

Existe no teatro de Tadeusz Kantor uma espécie de contaminação dos organismos vivos por organismos inanimados, do movimento orgânico, biológico, pela repetição mecanizada, do real pelo simulacro. Os objetos cópias, são assim chamados por mim, devido ao fato de se repetirem no teatro de Kantor, ou seja: de serem reinterpretados a partir de objetos já utilizados em espetáculos anteriores, ou por serem recriações de objetos que fazem parte da sua história pessoal. No primeiro caso, esses objetos que fazem parte de um momento muito particular da sua memória, aquela destinada à criação artística, são reconstruídos para seus dois últimos espetáculos: Não voltarei jamais e Hoje é meu aniversário. Nesse caso, os objetos reinterpretados, devido à quantidade, são menores do que os originais, isso para facilitar a sua movimentação pela cena. Essa é a situação dos bancos escolares que já foi comentado anteriormente, 
que embora sejam cópias dos bancos de $A$ classe morta, optei por falar sobre eles em um único bloco temático. A segunda situação trata-se dos objetos reproduzidos da memória de Kantor. Nessa situação, os objetos se apresentam desestruturados pela imaginação do artista. Em geral, são objetos construídos de forma a serem apenas uma referência ao passado histórico. Esse é o caso do violino a manivela, das metralhadoras, do canhão, dentre outros.

\section{A banheira com rodas}

Na perspectiva do teatro kantoriano, o ato de criar está sempre associado à necessidade de um engajamento total, um processo contínuo de descobertas. Em $A$ Galinha D’Água, por exemplo, na encenação que se fundava sobre o happening, a função dos objetos era a de colocar os atores em uma situação difícil, uma espécie de constrangimento. Em uma banheira cheia de água, que fora encontrada em um edifício em demolição, a atriz deveria dizer o texto em uma posição de desconforto. Os demais atores jogavam água sobre ela chegando ao ponto de tentar afogá-la, empurrando-a continuamente para o interior da banheira. A atriz deveria tentar a todo custo sair para continuar a jogar. Segundo Mira Rychlicka ${ }^{66}$, a graça da cena estava no fato de que tudo era muito real. Isso se explica pelo fato de Kantor não trabalhar com a noção de representação imitativa, mas a de jogo. Nesse período, Kantor proclama o "jogo sem representar"67, e, por conseguinte, a desarticulação do ator privando-o de sua posição confortável e respeitável do teatro profissional. Kantor, como comenta Guy Scarpetta:

“.... contribuiu como nenhum outro para liberar a arte da encenação de sua função ilustrativa, para fazer dela um lugar de exploração de territórios desconhecidos, jamais vistos, e que não existem fora desse teatro...."68

\footnotetext{
${ }^{66}$ Atriz que trabalhou com Kantor por cerca de 30 anos.

${ }^{67}$ Skiba-Lickel, A. L'Acteur Dans Le Thèâtre de Tadeusz Kantor. Bouffoneries, n. 26-27. France. 1991, p. 74.

${ }^{68}$ Scarpetta, G. Kantor au Présent. Arles: Actes Sud, 2000, p. 15.
} 
A banheira é utilizada no espetáculo de forma a estabelecer as relações, não mais de utilidade cotidiana de um utensílio destinado ao banho das pessoas, mas para deslocar as pessoas para outra realidade na qual um objeto prosaico assume a condição de elemento do jogo, sem deixar de ser banheira. Em resumo, esse objeto não metamorfoseia a sua natureza. Apesar de não ser utilizada como objeto de banho, a relação homem, objeto e água, continuam a existir, ou seja, é conservada a mesma relação de elementos da vida cotidiana. A diferença aqui é que a banheira está destinada ao jogo dos atores, e no interior desse jogo o objeto assume uma nova conotação simbólica: opressão, tortura, humilhação e morte.

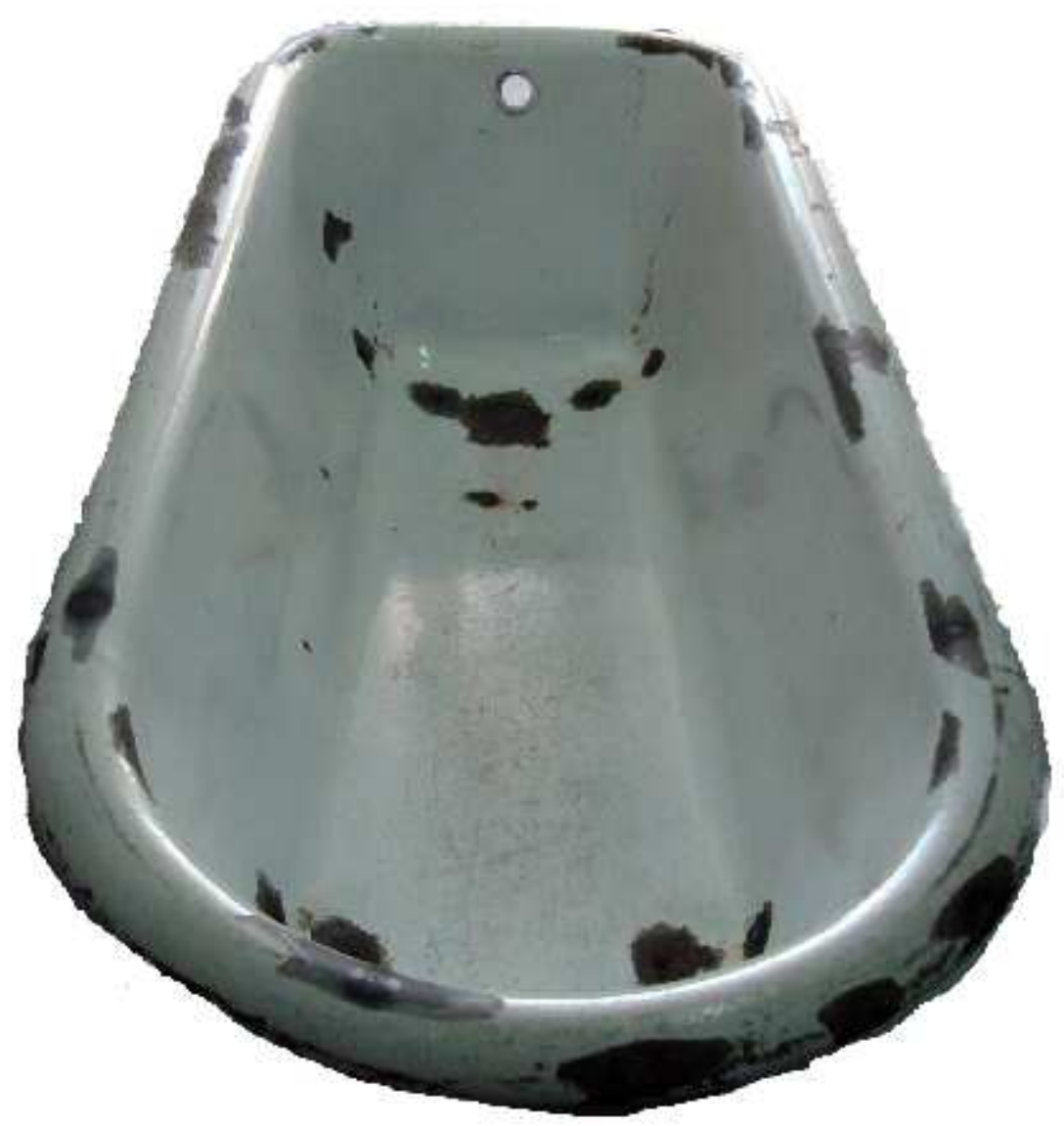

Banheira usada por Kantor em $A$ galinha d'água. Foto e tratamento gráfico: Wagner Cintra.

Essa estrutura desenvolvida por Kantor em A galinha d'água contrasta com o espetáculo Akropolis dirigido por Grotowski e que foi encenado no mesmo período. 
Para o segundo, o objeto deve ser entendido como distante do ator para que esse possa estabelecer com ele apenas relações essenciais e que são fundamentais para o desenvolvimento da ação dramática. $\mathrm{O}$ valor do objeto cênico em Grotowski está muito mais associado à dinâmica da peça do que ao interesse pela criação de algum significado. Isso pode ser observado em Akropolis, em que é utilizado um objeto semelhante ao usado por Kantor em A galinha d'água. A banheira em Akropolis exemplifica um aspecto essencial do objeto em Grotowski que é a utilização variada. Cada objeto no espetáculo tem uma utilidade múltipla e pode até chegar a ter um significado simbólico, dificilmente não o teria, já que em cena todo objeto se torna signo de alguma coisa. Entretanto, aquilo que Grotowski faz, de fato, é explorar no objeto o seu potencial de mutabilidade.

Em Akropolis ${ }^{69}$, a banheira é um objeto real que fora concebida para se tomar banho, mas quando virada para cima, esse mesmo objeto transforma-se em altar, diante do qual um personagem da peça entoa uma oração. Quando colocada em outra posição pode assumir a condição de ser outro objeto, como um leito nupcial por exemplo. Para Grotowski, o objeto deve ser explorado na sua capacidade de transformação da sua identidade real, ao passo que para Kantor, nesse mesmo período, o objeto deve ser explorado no seu potencial de objeto real. Assim, para Grotowski, uma banheira não é somente uma banheira, ela pode ser muitas outras coisas, e por não possuir um caráter essencial enquanto objeto real no processo de sua utilização, poderia facilmente ser trocada por outro objeto. Isso já não seria possível em Kantor, pois esse objeto não esconde ou dissimula a sua realidade. Kantor mostra o objeto como ele é. Seu potencial de jogo está exatamente na valorização da sua identidade enquanto objeto real. Se a banheira de Grotowski tem o seu potencial como objeto real fragmentado pelas estruturas nas quais ela se metamorfoseia, em Kantor existe uma concentração da potência do objeto real que é acentuada pelo uso dos atores e pelo jogo que se desenvolve no seu interior e ao seu redor. Quando Kantor quer atribuir uma outra função a um objeto, ele o reinterpreta, recria, criando um simulacro da idéia principal, ou seja, ele constrói um novo objeto a partir do anterior. Com esse procedimento, ambos os objetos mantém a sua individualidade e autonomia na cena.

\footnotetext{
${ }^{69}$ Grotowski. Jerzy. Em busca de um teatro pobre. Rio de Janeiro: Civilização Brasileira, 1976, p. 52.
} 
Em Não voltarei jamais, a banheira é reinterpretada e não se trata mais de um objeto encontrado ao acaso, retirado dos dejetos da vida utilitária. É um objeto reconstruído a partir da memória de um espetáculo antigo. Sua estrutura é feita de metal, uma espécie de zinco ou latão. Na parte de baixo dois pares de rodas situados próximos às extremidades lhe proporcionam movimento retilíneo a partir do contato dos remos com o chão. A galinha d'água, no seu interior, não é mais submetida ao flagelo do afogamento. Ela não precisa mais se livrar dos seus algozes. A galinha d'água, assim como o seu objeto característico, nesse outro espetáculo, também é reinterpretada. A personagem do espetáculo de 1968 agora é a condutora dos mortos, o barqueiro Caronte que faz a passagem do mundo dos vivos para o mundo dos mortos. No entanto, na cena, são os mortos que voltam, que povoam o mundo dos vivos. Evidentemente, também se conserva, em essência, a idéia do teatro como viagem.

Cada vez mais, nos seus espetáculos, a partir do ciclo do Teatro da Morte, a morte ganha materialidade na cena. Isso anteriormente já acontecia mas de outra forma. Em As belas e os feios, por exemplo, a morte era representada por um esqueleto humano que era manuseado pelos atores em uma espécie de Dança Macabra ${ }^{70}$. A partir de $A$ classe morta, Kantor associa a morte à figura humana. Foi assim com a faxineira de $A$ classe morta, com a fotógrafa-víuva de Wielopole Wielopole, a prostituta que se revela o anjo da morte em Que morram os artistas!, e em Não voltarei jamais, Caronte é personificado pela Galinha d'água. Em Hoje é meu aniversário, por sua vez, a morte se realiza como a suprema abstração, a ausência de Kantor em cena, a sua cadeira solitária traduz, através do vazio, o efeito devastador da morte que consome a matéria humana. Kantor foi material e literalmente consumido por ela.

Em Não voltarei jamais, a banheira com rodas, o veículo do barqueiro dos mortos, inicia a sua passagem pela cena na frente do batalhão dos violinistas-mortos que entram em um típico desfile nazista. A música tema para essa cena trata-se daquela utilizada para conduzir os prisioneiros às câmaras de gás. Caronte, ao trazer, com seu

\footnotetext{
${ }^{70}$ Dança Macabra refere-se à criação medieval que mostrava a Morte em pessoa à frente de figuras representativas da sociedade da época (um imperador, um rei, um Papa, um monge, uma criança, etc.) dançando como, ou com esqueletos. Essas criações artísticas, gravuras e pinturas, na sua maioria, foram feitas após a devastação na Europa causada pela epidemia conhecida como peste negra ocorrida no século XIV.
} 
barco/banheira, os personagens históricos do teatro Cricot 2, também traz as lembranças do trauma histórico do povo polonês durante a Segunda Guerra Mundial. Ao que me parece, aquilo que fica evidente nesse espetáculo, como já foi dito em outra passagem, Kantor não tem mais o domínio sobre os personagens de sua memória que se manifestam de maneira autônoma. Quando isso acontece, lembranças que estão associadas a eles também se manifestam. Lembranças que são impossíveis de esquecer. A banheira sobre rodas, ao adentrar a cena na condição de barco dos mortos, aciona imediatamente uma memória profunda, ligada ao terror dos campos de extermínio.

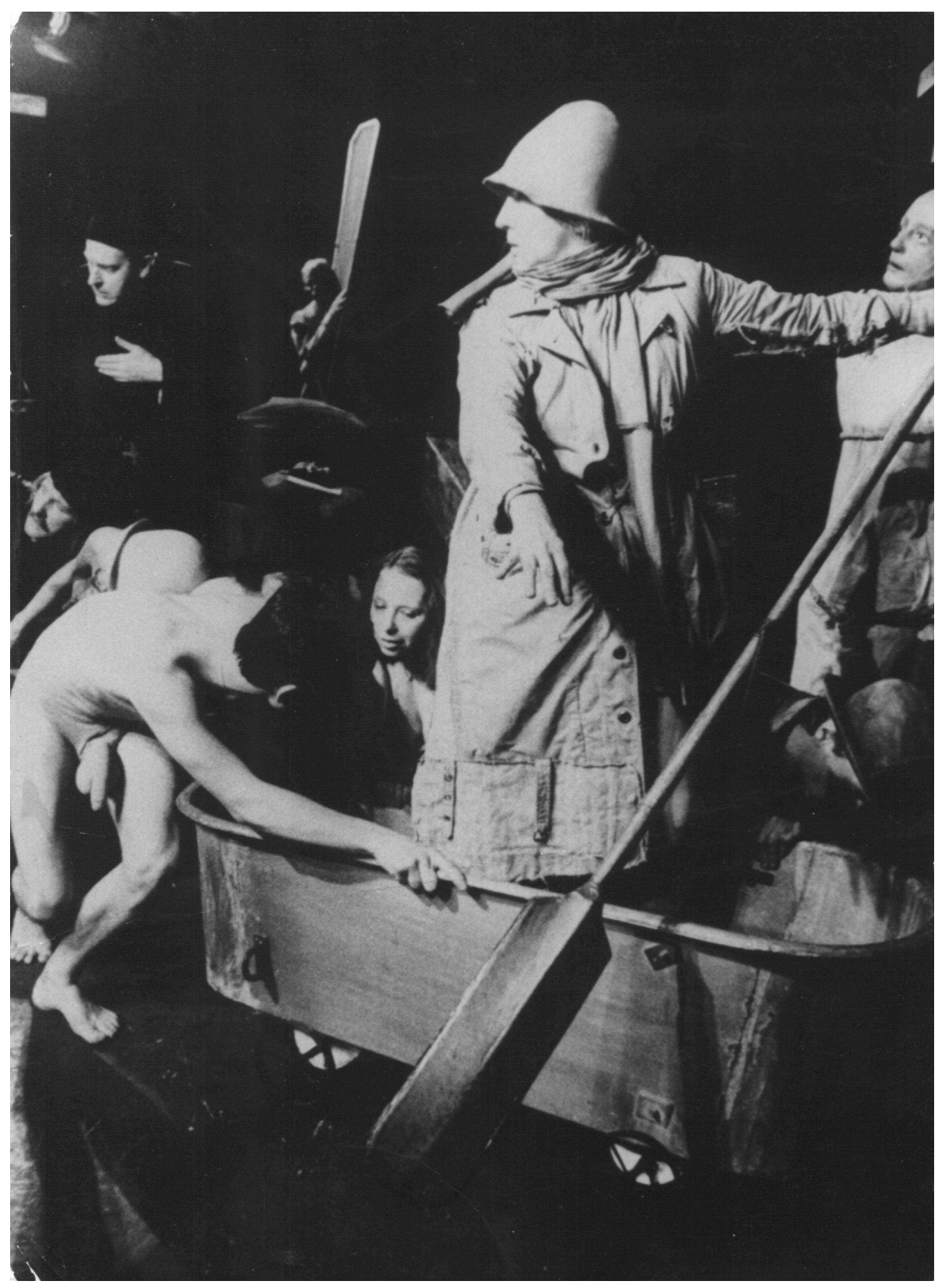

Não voltarei jamais. Na cena, a Galinha d'água no interior da banheira com rodas. Foto: G.K. Kuhnel. 
Fica evidente, em se tratando das banheiras, uma característica dos objetos no teatro de Kantor de serem eles portadores de todas as significações que lhes forem atribuídas no curso de suas transformações, embora essas transformações não signifiquem metamorfoses. O objeto em Kantor se destina essencialmente ao fim para o qual foi concebido. Insisto que a banheira de A galinha d'água é uma banheira e é utilizada como banheira, ao passo que a banheira com rodas de Não voltarei jamais, é uma nova concepção, não uma transformação da anterior; é outro objeto, construção autônoma, própria para o espetáculo a que se destina, apesar da sua referência se situar na banheira original. Ou seja: Kantor potencializa o objeto real na sua natureza como objeto real. Quando ele quer que esse objeto assuma outra função, ele o cria novamente, concebido através da vontade poderosa do demiurgo que é. O objeto recriado, no caso a banheira sobre rodas, é forjado a partir do modelo anterior que se revela no objeto presente apenas como idéia e nas relações que também são reinterpretadas. Em Não voltarei jamais, a tríade relacional ator, água, objeto se conserva no simulacro como ator, objeto, água, sendo que a água é apenas uma ilusão que pode ser percebida pelo movimento dos remos provocado pelo barqueiro.

Na França, na cidade de Nantes, existe um importante grupo chamado Royal de Luxe $^{71}$, cujo trabalho, em geral feito na rua, se utiliza de diversos objetos concebidos para fins unicamente cênicos. Esses objetos possuem as mais variadas formas. Dentre tantos, um que me chamou especial atenção, trata-se de uma espécie de reutilização de um objeto real. Uma banheira, semelhante àquelas utilizadas por Kantor e Grotowski, é reaproveitada como elemento de uma nova concepção de um veículo automotivo. Essa banheira, a exemplo de Grotowski, torna-se o "cockpit" desse veículo. Por outro lado, essa máquina também se apresenta como banheira, a exemplo de Kantor, pois no seu interior o piloto, à medida que se movimenta com o insólito veículo, também é envolto por água e sabão, sendo que a água é constantemente despejada sobre ele através de um chuveiro situado atrás do acento. Nessa situação, mais uma vez a exemplo de Tadeusz Kantor, a relação homem, água e banheira, também se mantém, sendo que, apesar de toda a maquinaria destinada à concepção do objeto carro, o fato mais importante, a meu

\footnotetext{
${ }^{71}$ Royal de Luxe é uma companhia de teatro de rua que se caracteriza por usar objetos variados, máquinas e marionetes gigantes em suas produções. Foi fundada em 1979 por Jean Luc Courcoult, e desde então, tem se apresentado em diversos países de todo o mundo.
} 
ver, é que o objeto real ganha em potência expressiva e é o responsável por concentrar todas as atenções.

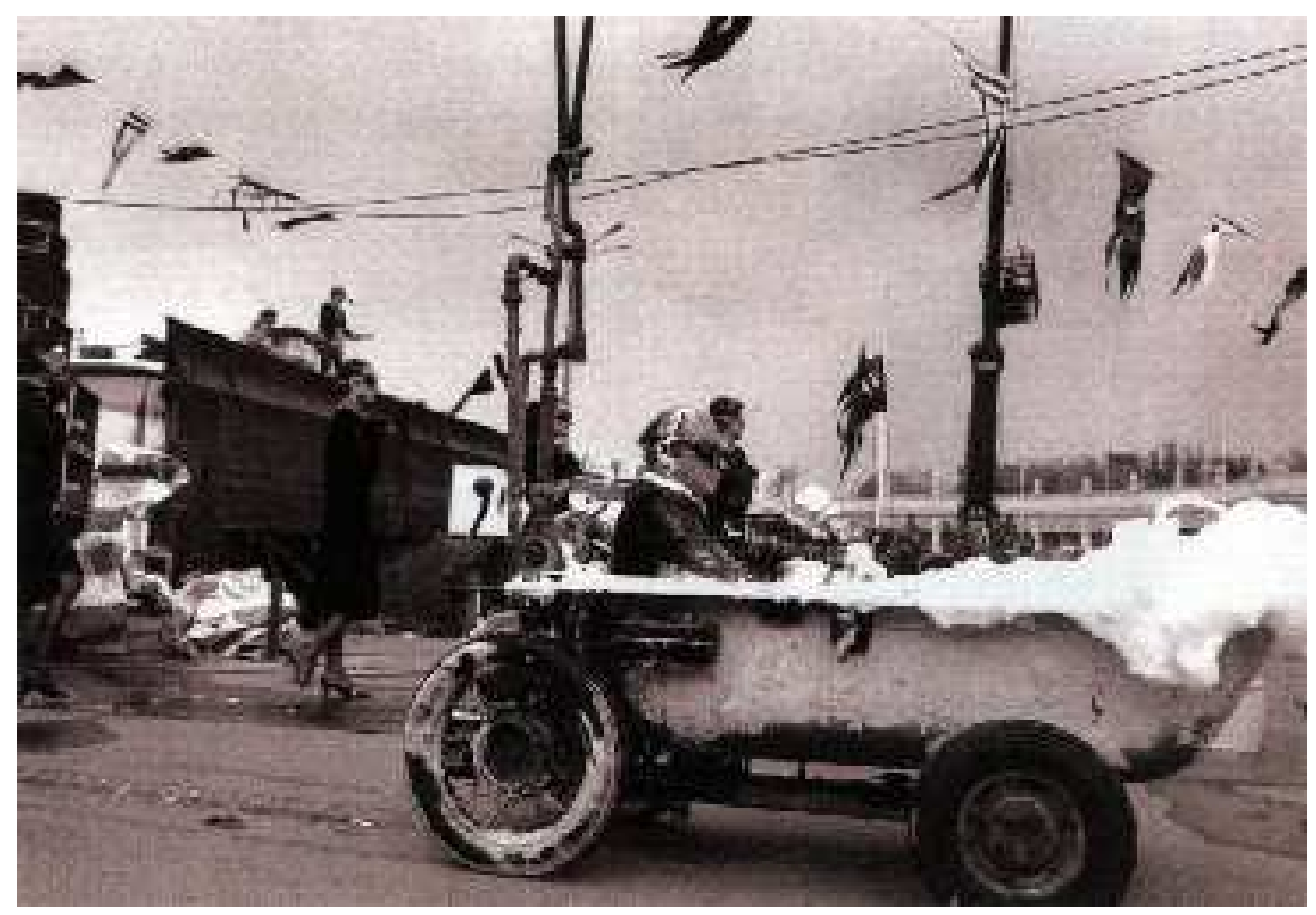

A banheira sobre rodas no espetáculo La demi-finale du waterclash. Foto: Jordi Bover.

Para o Royal de Luxe existe evidentemente uma questão ideológica associada a essas máquinas extravagantes que estabelece constantemente uma relação entre o progresso da sociedade e a alienação do indivíduo. Em Kantor, a questão proeminente, não menos ideológica, talvez seja o seu desejo de fazer do teatro um lugar no qual se formulassem questões para a vida, um local que fosse mais repleto de significado do que a própria morte que dá significado ao seu teatro. Se para o Royal de Luxe, o objeto cênico é destinado ao propósito de levantar questões relativas ao consumo e à futilidade extrema na sociedade moderna, para Kantor os objetos estão livres de uma narrativa ilusionista, o que realmente importa são as relações que esses estabelecem na cena com os demais elementos. Essas relações, inteligentemente construídas ou destruídas, acionam um dispositivo de composição de imagens que estão repletas de significados. A banheira sobre rodas de Não voltarei jamais, apesar de autônoma no espetáculo, capaz 
de construir significados próprios, traz em si uma significação anterior, a de ser representação, no sentido de "representatio", como semelhança de um objeto que, ao trazer em si a idéia da coisa, traz necessariamente, para a forma em representação, o princípio da coisa representada e suas significações. Assim, a banheira com rodas de Não voltarei jamais, carrega um conjunto duplo de significados: aqueles próprios do momento da encenação que se manifestam através da aparência e aqueles que estão atrelados às lembranças do espetáculo anterior.

\section{As metralhadoras}

As metralhadoras fazem parte de um grupo de objetos chamados instrumentos do poder. Como essa concepção está totalmente conectada à história da Polônia em seu processo de dominação por outros povos e à luta do país pela liberdade, faz-se necessário que, nesse momento, eu faça um breve comentário sobre a história da Polônia, principalmente a história do século XX.

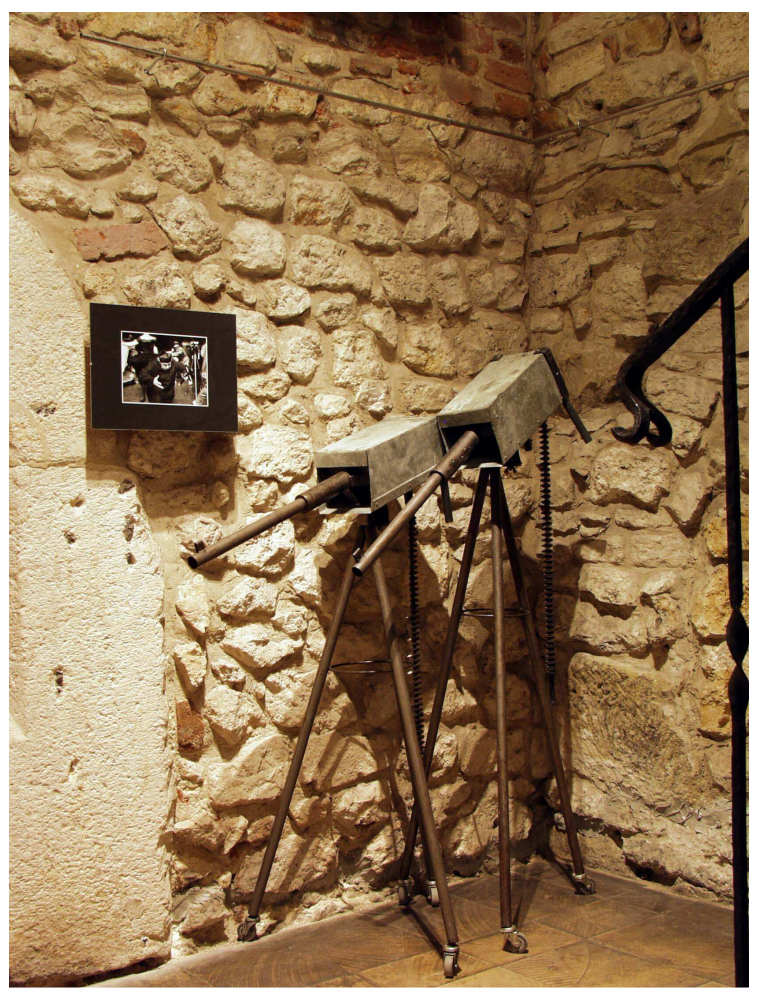

As metralhadoras usadas em Hoje é meu aniversário. Foto: arquivos da Cricoteka. 
A Polônia, devido à sua geografia, por estar situada entre dois grandes países, até o século $\mathrm{XX}$ foi submetida a constantes invasões de diferentes povos que se impuseram através das armas. Para alcançar a tão esperançada liberdade nacional, a Polônia teve que esperar pela "desgraça" dos seus vizinhos, sobretudo Alemanha e Rússia, ocorrida ao final da Primeira Guerra Mundial (1914-1918), para que fosse possível a proclamação de uma república polonesa totalmente autônoma. Entretanto, após a guerra, a Polônia era uma terra arrasada devido aos estragos provocados pelo conflito que deixaram as suas marcas por todas as partes. Com o duro processo de reconhecimento da independência e a conseqüentemente reestruturação do país, a Polônia viu-se novamente subjugada pelo poder das armas, foi invadida pela Alemanha nazista em 1939 dando início à Segunda Guerra Mundial, mergulhando o país em um dos períodos mais negros da história da humanidade. A Polônia ocupada pelos alemães serviu de palco para as batalhas brutais entre os exércitos de Hitler e Stalin. Além disso, o país foi o local escolhido para a política de extermínio em massa desencadeado pela ocupação nazista contra judeus e outras minorias. Milhares de operários poloneses também foram remetidos, enfiados em vagões de trem, e obrigados a trabalhar na indústria de guerra alemã.

Paralelamente a isso, foi planejado e cumpriu-se um massacre das elites polonesas, executado pela "Einsatztruppe" (tropa de extermínio) que visou à liquidação de políticos, intelectuais, acadêmicos, professores, padres, artistas, dentre outros - a Polônia também se viu vitimada pela guerra racial nazista. Com o final da guerra, a Polônia estava quase ferida de morte, e foi com o cheiro da pólvora e a putrefação dos corpos apodrecidos misturados aos escombros herdados dos combates que o país começou a sair do abismo para o qual foi empurrado. Entretanto, a ocupação aliada colocou a Polônia e os poloneses sob o jugo autoritário da União Soviética de Stalin. Nenhum outro povo da Europa moderna, desde o século XVIII até o século XX, travou tantas batalhas e combates para conseguir o direito pela liberdade e pela autonomia nacional como os poloneses o fizeram. Durante mais de dois séculos, empenharam-se em defender-se das intromissões e das ocupações, das violentas repressões, das matanças, seguidas pelo exílio forçado de centenas de cidadãos submetidos pelas potências vizinhas. 
Pois bem, esse cenário conturbado da história da Polônia serviu de nutriente para o teatro e para a arte de Tadeusz Kantor. Algumas das suas lembranças mais remotas, antes de passar pela família, passam necessariamente por personagens que marcaram um determinado momento da sua vida. Sobre essas lembranças, Brunella Eruli ${ }^{72}$ comenta que, ao falar delas, Kantor dizia que ele se lembrava dos soldados que tinha visto, quando criança, atravessarem o seu vilarejo, Wielopole, situado na fronteira entre a Rússia e a Áustria; ele se lembrava dos exércitos mudando de posições, assim como o uniforme dos soldados. No entanto, segundo ele, o destino do vilarejo era sempre o mesmo: destruição. Não é de se estranhar que o seu teatro esteja forrado de imagens tão perturbadoras. Kantor diz ainda sobre os clichês que estão guardados na sua memória, que através de um ele chegava a outro, ou seja:

“...através de um general ele via a sua mãe ou o seu tio"73.

Certamente, a Segunda Guerra Mundial é a obsessão de Kantor. É por isso que ele insiste no constante retorno ao tema e a cada vez que essa obsessão é repetida, ele espera que percebamos o que está acontecendo. Em Hoje é meu aniversário, existe uma constante invasão do espaço da representação pelos instrumentos do poder. Se em Wielopole Wielopole, o poder estava associado ao exército, o mesmo exército que ele via quando criança se movimentando pela sua vila, o poder do coletivo que se manifesta unamente, em Hoje é meu aniversário, esse está associado aos instrumentos que garantem e que impõem o poder. De um lado, as armas de guerra. Do outro, a polícia secreta russa.

As metralhadoras, alguns dos objetos militares, são pequenas caixas feitas de zinco com um cano na sua frente e estão apoiadas sobre um tripé de metal com pequenas rodas.

\footnotetext{
${ }^{72}$ Kantor, T. Entretiens - Arts \& Esthétique. France: Carré, 1996, p. 21.

${ }^{73}$ Ibid.
} 


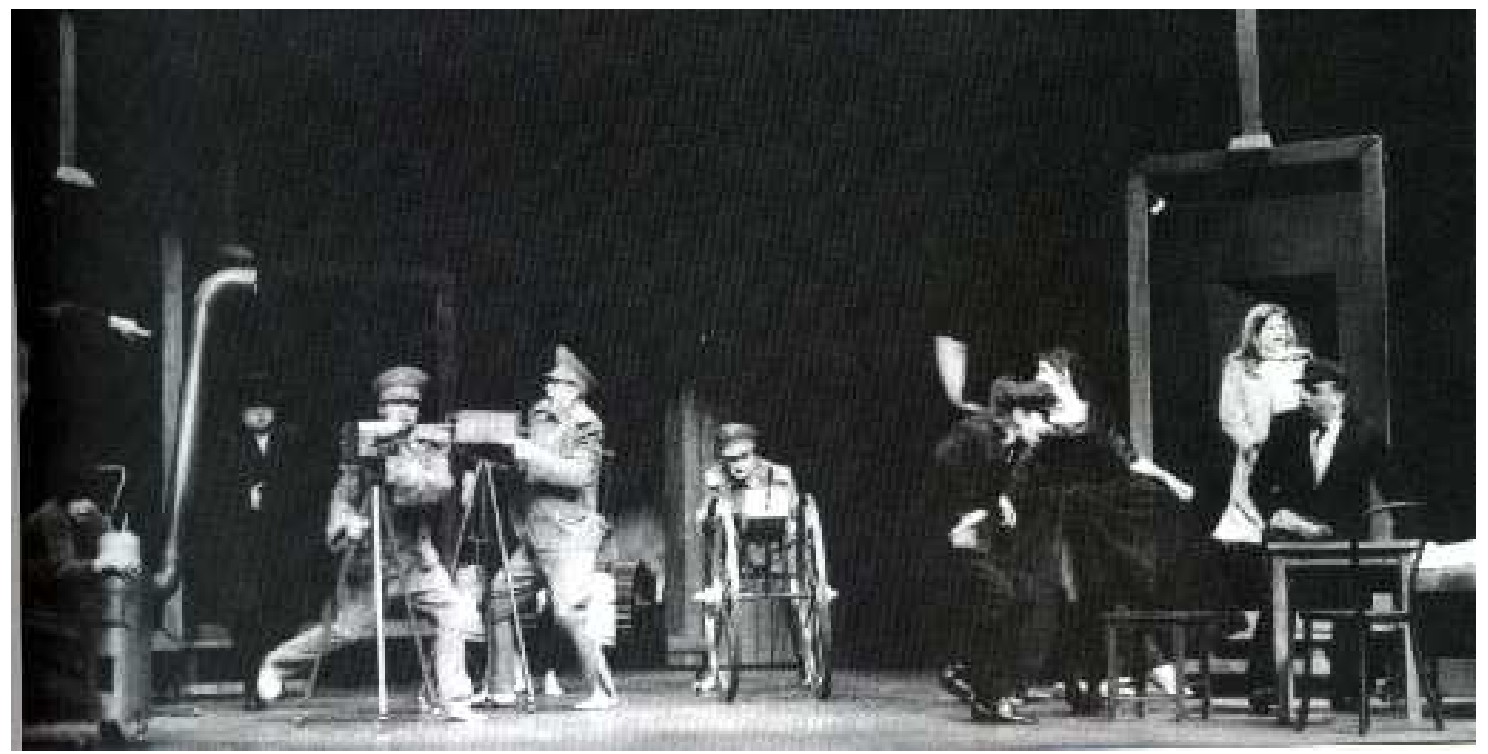

As metralhadoras em uma cena de Hoje é meu aniversário. Foto: arquivos da Cricoteka.

Se a polícia secreta simboliza a opressão, principalmente no que diz respeito à proibição da arte abstrata na Polônia nos primeiros anos da década de cinqüenta, as metralhadoras tornaram-se o símbolo máximo do desprezo pela vida, pelos assassinatos, pelo genocídio ocorrido na Polônia nos tempos da Segunda Guerra. Não somente nos tempos das guerras mas também daquele momento opressivo pelo qual a Polônia estava passando. Em um de seus ensaios, Kantor fala sobre isso:

“Eu pertenço à geração surgida na época dos genocídios e dos atentados mortíferos contra a arte e a cultura.

Eu não quero salvar o mundo com a minha arte.

Eu não acredito na "universalidade".

Após todas as experiências do nosso século, eu sei como isso termina, e a quem e a que serve essa célebre "universalidade", tanto mais perigosa que hoje ela atingiu a dimensão do globo terrestre.

Eu quero SALVAR A MIM MESMO,

não egoisticamente, mas somente com a fé

no VALOR INDIVIDUAL!"74

\footnotetext{
${ }^{74}$ Kantor, Tadeusz. Leçons de Milan. Paris: Actes Sud - Papiers, 1990, p. 66.
} 
Ao que me parece, o poder de Kantor está exatamente na sua individualidade, no seu espírito livre, na sua capacidade de se opor, com sua arte, à autoridade conquistada pelas armas. Em Hoje é meu aniversário, ele comenta:

“...contra o poder,

contra a política,

contra a ingerência,

contra a ignorância,

contra a vulgaridade

e a bobagem,

minhas armas são:

minha imaginação,

a memória da infância,

minha pobreza,

a solidão...

E a morte que aguarda.",75

A luta de Kantor é contra a autoridade, mas também contra as convenções artísticas e suas instituições. Ao colocar em cena as metralhadoras e também os secretários do partido com os soldados, conjunto que ele chama de gentalha, ao se referir à cena, ele está se referindo não somente ao exército e à guerra, mas aos atentados contra a arte e aos artistas no século XX. Não é por acaso que na seqüência, na homenagem a Meyerhold, a leitura da carta desse a Molotov trata-se do desabafo referente ao seu sofrimento na prisão. Sem dúvida, essa foi a primeira manifestação aparente de Kantor em relação à contestação do regime, contra a polícia secreta russa que atuava livremente na Polônia durante os anos da Guerra Fria. Anteriormente, a sua indignação, o seu discurso contra o poder estavam escondidos por entre as imagens e se manifestavam sob determinadas condições. Não havia um confronto aberto. Por outro lado, a sua reação contra a arte e a cultura oficial, através dos happenings e cricotages, denunciavam um artista profundamente inteirado com a sua história e, sobretudo, com a sua contemporaneidade. Nesse momento, penso que não cabia mais a ele camuflar qualquer possível crítica, isso porque a Polônia alcançou a tão sonhada liberdade ao romper com a URSS com a eleição democrática de Lech Walesa, um operário, líder do Sindicato Solidariedade.

\footnotetext{
${ }^{75}$ Kantor, Tadeusz. Les voies de la création théâtrale. Vol. II. Paris: CNRS, 1983, p. 203/204.
} 
Por outro lado, com a idade já avançada, Kantor, o guerreiro de tantas batalhas, parece estar certo de que a morte está perto. Aliás, ela, a morte, sempre esteve ao seu lado desde a mais tenra idade quando ele acompanhava o movimento das tropas pela sua cidade natal. E como ele mesmo apontou em A classe morta, os velhos estão a cada dia mais perto da morte. Coincidentemente, em Hoje é meu aniversário, ao encenar a sua própria morte, apesar de ter morrido antes da estréia, o espetáculo também marca, pela primeira vez, uma crítica aberta de Kantor em relação a uma determinada forma de dominação e poder. Se na recente história da Polônia Lech Walesa combateu as metralhadoras com poder do direito individual de lutar por melhores condições de vida, Kantor, com sua individualidade, combateu as armas com o seu teatro.

\section{$O$ tanque de guerra}

Uma das coisas mais singulares em Tadeusz Kantor é a sua hostilidade a todo tratamento realista da história. Após muito tempo, ele se empenhou em realizar um espetáculo que afrontasse o poder geral. Mesmo com o fim do comunismo, Kantor não acreditava que o poder tivesse desaparecido. Para ele, o poder apenas mudou de forma. Ele não sabe exatamente qual é essa outra forma mas ele crê na sua existência. Diante disso Kantor, incansavelmente, sempre nos força a olhar para o seu teatro de uma maneira diferente. Em hoje é meu aniversário, a cena é continuamente invadida pelos monumentos do poder e seus instrumentos. Já não são mais os exércitos da Primeira ou da Segunda Guerra Mundial, mas são os exércitos que agora são transformados em monumentos e esses monumentos estão por todos os lados e foram divididos entre oeste e leste, ou seja; entre Estados Unidos e União soviética.

No espetáculo não existe diretamente um objetivo político ou social. Trata-se de um desabafo que se materializa de uma forma completamente teatral. Kantor se opõe à elevação da política a um nível superior à arte. Ele se opõe ao poder, mas não de uma maneira política mas pela vontade de criar uma realidade diferente daquela reinante. Kantor não está interessado em analisar o poder do ponto de vista da sua racionalidade 
interna, como o fez Foucault ${ }^{76}$ ao sistematizar as relações de poder através de seus antagonismos e estratégias. Não, a visão do poder em Kantor passa necessariamente por uma reflexão sobre o exercício da liberdade, sobretudo a liberdade na arte.

"Existe uma liberdade suprema, que é exigida pela arte, e que não é a mesma coisa que a liberdade "concedida" pelo mundo político... "77

Se existe alguma coisa a qual Kantor resiste, obstinadamente, é a compreensão equivocada dessa noção de liberdade suprema na arte. A liberdade artística, quando mal interpretada, induz à tendência de se conceber a arte como supérflua, inútil, insignificante em relação à vida política e social. Mas como a arte poderia ser considerada de tal maneira se o desenvolvimento político e social da civilização conduziu à Segunda Guerra Mundial e à Auschwitz? Essa é a pergunta que acredito que Kantor tenha feito insistentemente durante toda a sua vida e ao que me parece com maior intensidade nesse último espetáculo, no sentido da relação do poder das instituições políticas, sociais, e culturais, no final do século XX, que acabaram por determinar formas de sujeição da subjetividade individual à vontade coletiva. Essa é a liberdade concedida pelo poder do Estado. No entanto, conforme o pensamento de Foucault, a liberdade desaparece em todo lugar onde o poder é exercido. Assim, a liberdade artística, concedida pelas instituições de poder e pelo fato do poder sempre ser uma forma de atuar sobre um determinado sujeito, de impor uma ação sobre outra ação de maneira direta ou indireta, a arte institucionalizada necessita de requisitos para ser exercida, ou seja: o artista precisa ser submisso para que a sua arte seja alforriada e ganhe a condição de ser livre, apesar dos grilhões ainda estarem presos aos seus tornozelos. Kantor se recusou determinantemente a ser oficial e a receber subsídios do Estado.

É a partir da necessidade que Kantor possui em resistir contra o agenciamento do poder das instituições e da crescente vulgaridade na arte, que o seu discurso também se torna um discurso de poder. Um poder que emerge da sua memória e das experiências da sua história pessoal, que o categoriza como indivíduo e determina a sua própria individualidade, uma identidade artística capaz de reconhecer a si mesmo no

\footnotetext{
${ }^{76}$ Foucault, M. Microfísica do Poder. Rio de Janeiro: Graal, 1979.

${ }^{77}$ Kantor, T. In. Scarpetta, G. Kantor au Présent. Arles: Actes Sud, 2000, p.166.
} 
percurso de suas transformações, ao mesmo tempo em que é reconhecida por outros como sujeito autônomo. O poder do teatro de Kantor é a sua capacidade de fazer jogar as relações entre os indivíduos ou entre os grupos. É um poder de resistir ao cosmopolita mercado da arte no qual tudo é uniformizado e para o consumo. Como consumir uma cadeira quebrada? Essa é outra característica de poder do teatro de Kantor que já foi por vezes repetida nesse trabalho: fazer obra de arte com aquilo que a civilização destinou às latas de lixo.

Para Foucault, o poder se exerce entre relações de pessoas, grupos e instituições de forma não excludentes, e poder é ação e ação pressupõe liberdade. Liberdade que foi mascarada pelo mito do Estado moderno. Entretanto, o objetivo da luta de Kantor não é atacar uma instituição de poder, grupo ou elite, mas uma maneira de se fazer pensar sobre o centralismo do poder, não somente o estatal, diálogo direto com a história recente da Polônia, propriamente a segunda metade do século XX, mas toda e qualquer forma de dominação que induz à submissão da subjetividade e da liberdade na arte. Kantor está necessariamente falando da sua crença no valor individual. De uma certa maneira, ele está tentando dizer que no Estado moderno o poder estatal precisa ser repensado mas o exercício desse poder pelo indivíduo, fragmentado no interior do Estado, também.

Certamente, as armas de guerras criaram as principais metáforas da ação do poder no teatro de Kantor. $\mathrm{O}$ tanque de guerra, seguindo o mesmo princípio das metralhadoras, é mais um dos instrumentos característicos e representativos do poder. Feito de metal, o mesmo material das metralhadoras, esse objeto possui uma estrutura de ferro sob as esteiras, na qual se encontram pequenas rodas que permitem a sua movimentação na cena. 


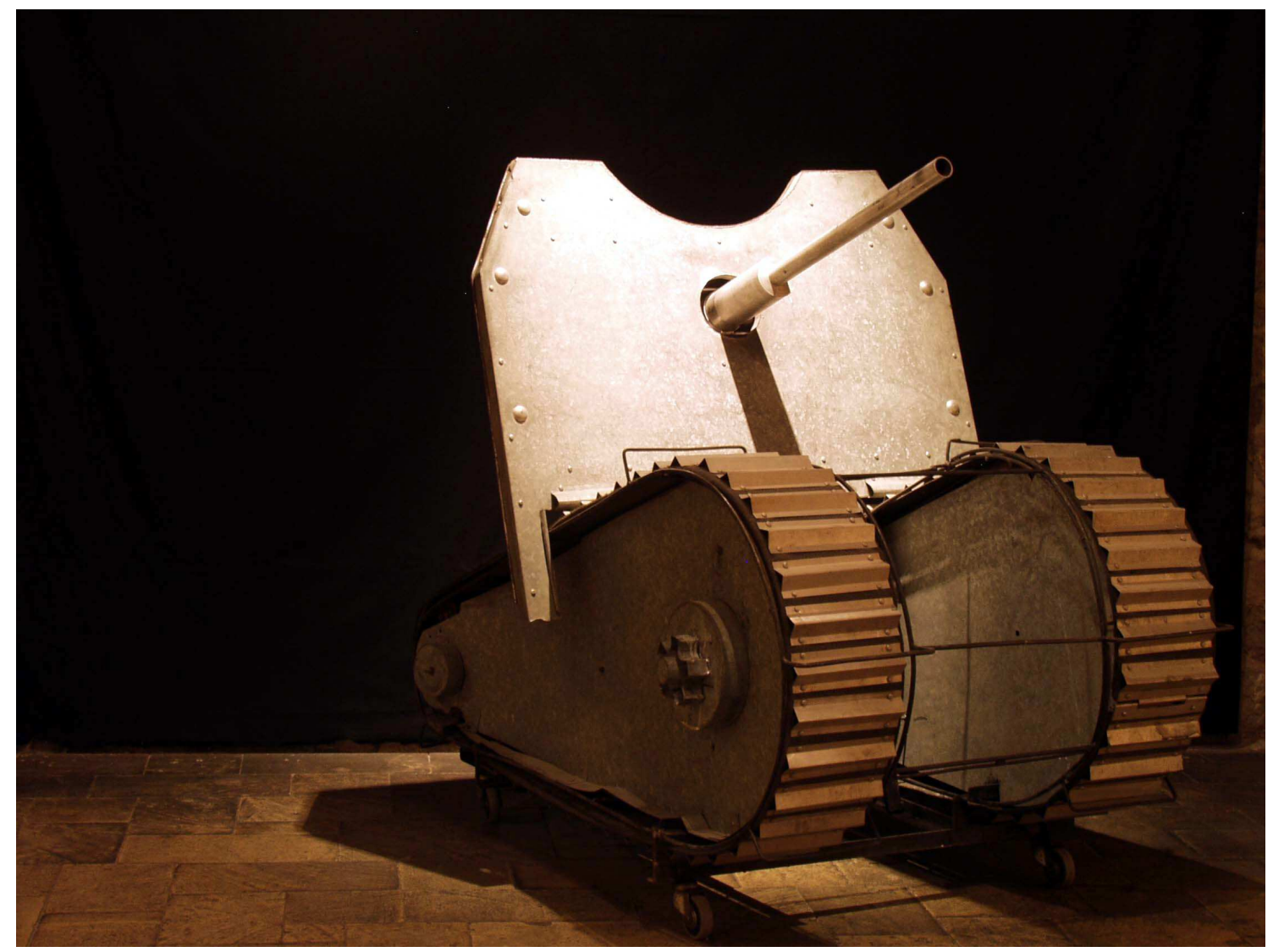

O tanque de guerra usado em Hoje é meu aniversário. Foto: arquivos da Cricoteka.

A presença desses objetos, sempre de uma forma ameaçadora, colocava o espectador em um constante estado de ansiedade. Para Kantor, o mais importante era que o público fosse perturbado interiormente, que ele fosse abalado, não somente no sentido poético mas como se estivesse no limiar da morte. Assim, a constante referência à Segunda Guerra Mundial e aos campos de concentração, quando o espectador é levado ao confronto com os elementos dos seus espetáculos e convidado a neles entrar, é possível que ele esteja entrando em Auschwitz, o limiar da morte. Não qualquer morte, mas a morte sem dignidade através da qual muitos artistas foram submetidos. A morte de Meyerhold por exemplo. No palco, o tanque de guerra atira contra as personagens mas também contra o público. O artista plástico Jonasz Stern, que veio para cena na bagagem de Maria Jarema, vestido com farrapos e com a estrela de David em um dos braços, é vitimado, submetido por esse cruel objeto de destruição. 


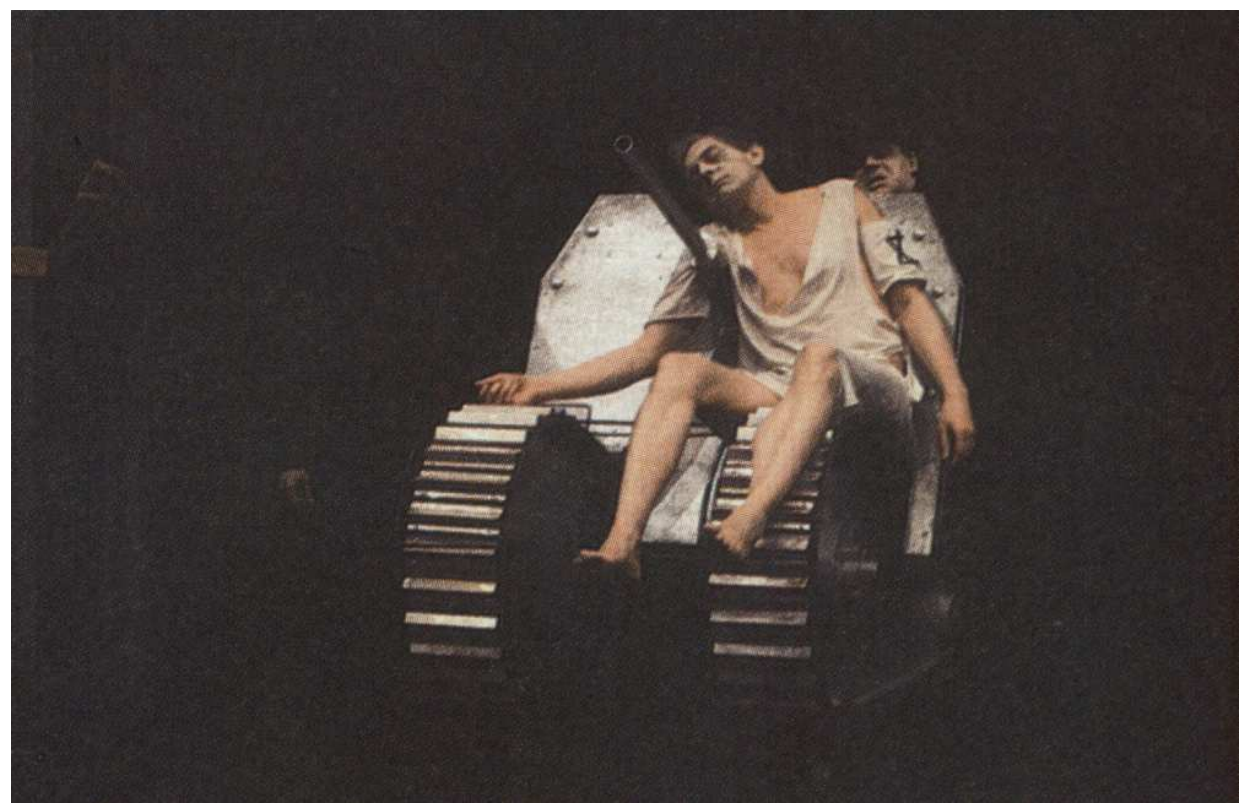

Hoje é meu aniversário - na cena, Jonasz Stern vitimado pelo tanque de guerra. Foto: arquivos da Cricoteka.

Acontece nessa cena um diálogo com diversos sentidos metafóricos que se sobrepõem uns aos outros. Nesse contexto, temos a presença transfigurada das figuras "estéticas" simbolizando as vanguardas, a exemplo de Meyerhold - cuja idéia inicial de Kantor era colocar em cena a sua perseguição e morte - e Maria Jarema, na cena a "comissária do povo para a abstração".

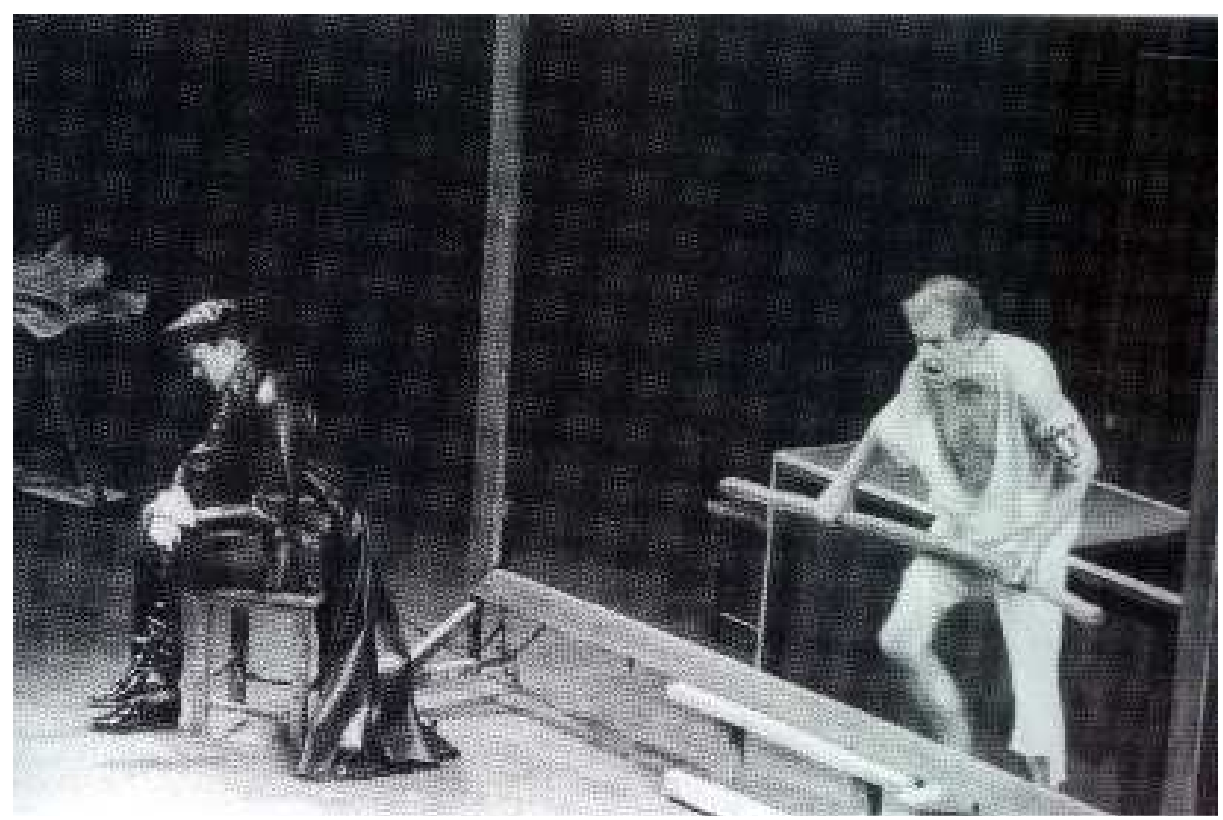

Hoje é meu aniversário. Na cena, Maria Jarema e Jonasz Stern. Foto: arquivos da Cricoteka. 
A arte abstrata, que fora proibida na Polônia comunista, surge no discurso de Maria Jarema como a única possibilidade de cura da realidade e também a única maneira de transcender essa mesma realidade. Nessa passagem, Kantor recorda o seu encontro com Maria Jarema nos anos cinqüenta, quando o abstracionismo foi proibido no país. Ao serem atingidos pelos tiros de tanque de guerra e metralhadora, essas figuras trazem para a cena um momento histórico de intensa perseguição aos artistas abstratos, não somente na Polônia, mas também na antiga $\mathrm{URSS}^{78}$. Nesse contexto, o artista plástico de vanguarda, Jonasz Stern, associado a Kantor e Maria Jarema, ao ser subjugado pelo poder do tanque de guerra, traz em si duas metáforas sobrepostas: uma relativa à condição de artista abstrato e perseguido pelos dignitários do poder comunista e outra, a condição de judeu, representante de todo um povo submetido ao terror nazista nos campos de concentração.

\section{O casaco de Ulisses}

Em Não voltarei jamais, o casaco de Ulisses não é o mesmo da encenação de 1944, e nem mesmo é uma reprodução do figurino original que se perdeu, mas como os outros, obedece a um processo de reinterpretação da forma, o que necessariamente leva a um novo conteúdo ou a um conteúdo mais profundo. Pode parecer estranho eu estar falando de uma peça de figurino, um artefato feito de pano que será usado na caracterização de um personagem do espetáculo e chamá-lo de objeto. No entanto, para Kantor, esse figurino especificamente, nesse espetáculo, trata-se de um objeto ou melhor: de um bio-objeto.

\footnotetext{
${ }^{78}$ União das Repúblicas Socialistas Soviéticas.
} 


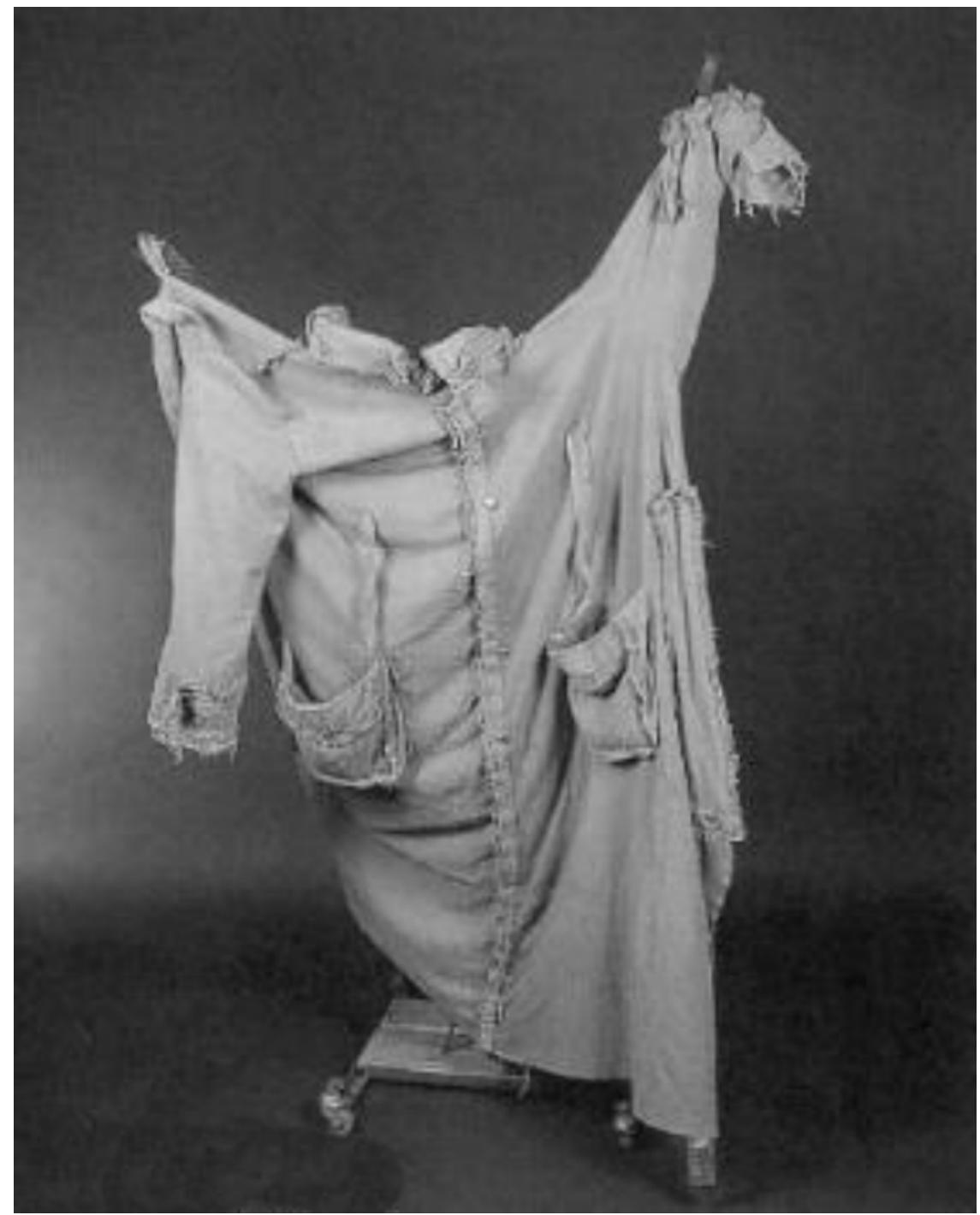

O casaco de Ulisses usado em $O$ retorno de Ulisses. Foto: arquivos da Cricoteka.

Em um dos seus ensaios ${ }^{79}$ Kantor referindo-se ao figurino teatral, diz que se entendermos que o corpo do ator, assim como o corpo de qualquer ser humano é, em suas proporções e em sua estrutura, formado conforme certas funções práticas e vitais, uma concepção de figurino que vise a mudar essas proporções, para ele, é particularmente muito tentador, justamente pela possibilidade de se transmitir os conteúdos que estão além dessas funções, e que, segundo ele, nos invadem por todos os lados. Kantor não se convence que o corpo do ator não possa ser estruturado livremente.

\footnotetext{
${ }^{79}$ Kantor, Tadeusz. Metamorfozy, Teksty o latach 1938 - 1974. Métamorphoses, textes des années 19381974. Ośrodek Dokumentacji Sztuki Tadeusza Kantora CRICOTEKA, Księgarnia akademicka, Kraków 2000, p. 235.
} 
Para ele, essa é uma concepção do corpo do ator como conceito do sagrado, foi herdado da antiguidade e ainda é sustentado por todos os selos acadêmicos. Ele diz ainda, nesse ensaio, que o figurino, seja ele histórico, seja ele moderno, deforma o corpo humano, já que somente o fato de se colocar qualquer coisa sobre o corpo engendra uma deformação mais ou menos significativa. Assim, o figurino é colocado em cena em forma de ator, já que do seu encontro com a individualidade do intérprete, que até então, conforme os preceitos do realismo/naturalismo, se limitava à mímica da aparência, aos gestos, e às reações do sistema nervoso que resultavam em experiências vitais convencionais, é agora capaz de lhe atribuir uma maior dimensão, uma espacialidade amplificada e uma maior mobilidade das tensões. Da união de ator e figurino, sobressai uma estrutura livre que se justifica única e exclusivamente como objeto de arte mas muito mais potente do que qualquer experiência vital convencional devido à sua força de expressão. Esse novo organismo deve constituir uma fusão íntima da matéria do corpo humano e das formas cênicas que se desenvolverão no espaço.

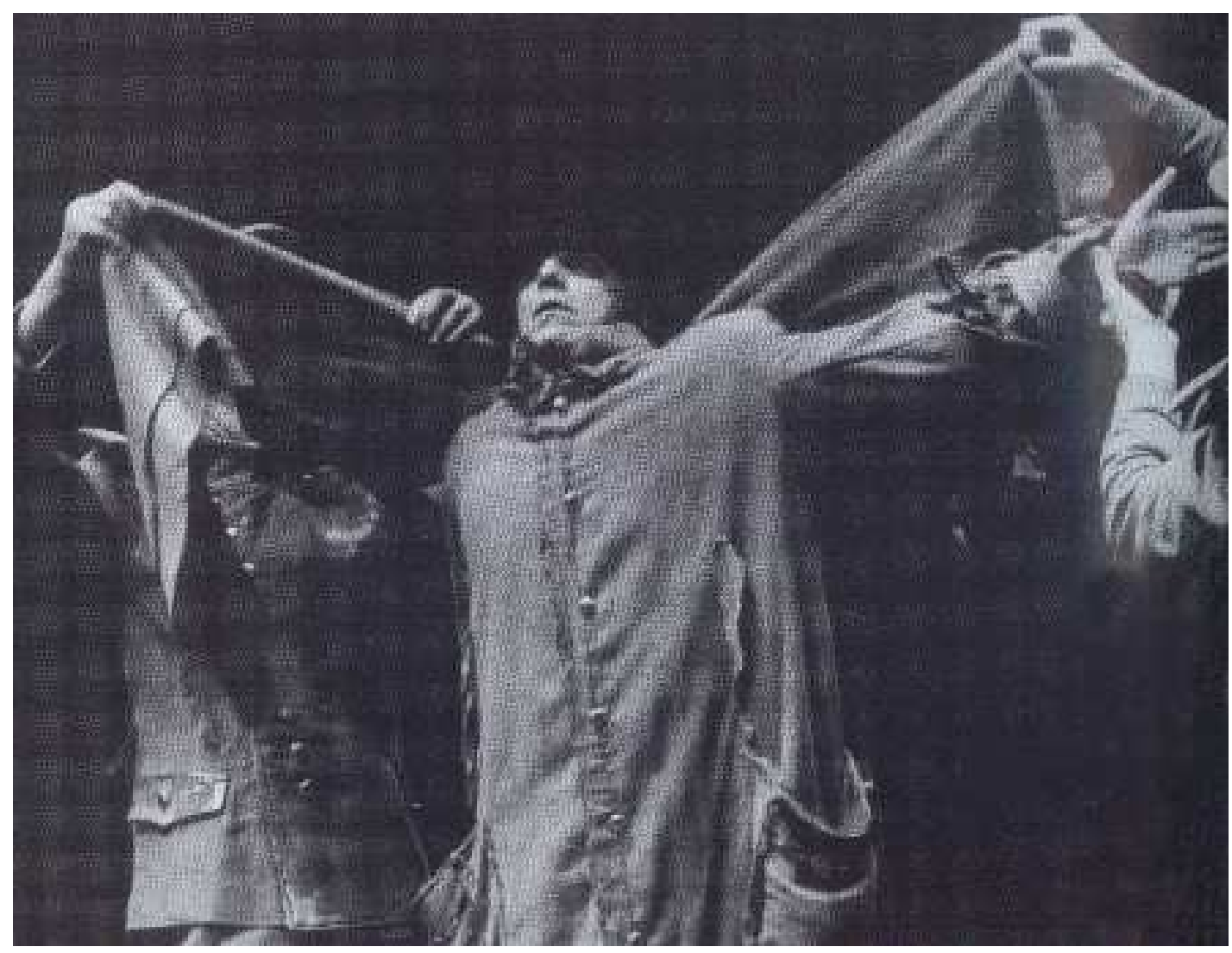

Não voltarei jamais. Na cena, o proprietário do albergue está sendo preparado para representar Ulisses. Foto: arquivos da Cricoteka. 
Pois bem, o bio-objeto no teatro de Kantor é uma extensão do seu entendimento do objeto real, sobre o qual muito já foi dito, em passagens anteriores. Entretanto, em Não voltarei jamais, o objeto está no mesmo nível do ator. Em sua concepção, esse objeto muda o comportamento do ator de uma maneira tal que um novo ator surge a partir de um processo de fusão entre dois organismos, ou seja, o objeto faz nascer um novo ator. Assim, se o objeto é habitado pelo ator, com esse procedimento o ator se torna as vísceras do objeto. Seu sangue, sua alma.

Ao ser interpelado pelo Padre e preparado para representar Ulisses, o proprietário do albergue e jogador de cartas compulsivo, muda totalmente o seu comportamento quando colocado dentro desse objeto. Há aqui, notadamente, uma inversão de valores, pelo menos em relação ao teatro de imitação tradicional - não é o ator que usa o objeto para expressar o seu personagem mas é o objeto que se apropria do ator para expressar a sua própria autonomia.

Feita a transposição de um personagem ao outro, Ulisses aparece durante uma canção entoada pela faxineira, a mesma música que era cantada pelos prisioneiros judeus quando se dirigiam para as câmaras de gás. Em determinado momento, a porta ekkiklema se abre e por ela surge o manequim de Mariam Kantor preso ao pilar dos mortos, mais uma referência à morte do pai em Auschwitz. A cena é toda marcada pelo canto lamentoso da faxineira. Nos bancos escolares, os personagens de todos os espetáculos repetem as brincadeiras infantis ${ }^{80}$, feitas em $A$ classe morta. Ulisses atira em direção a eles. À rajada de metralhadora é sobreposto o tema do violino à manivela de Wielopole Wielopole. O deportado de Wielopole Wielopole é agora o músico ambulante de Não voltarei jamais que acompanha a cena com seus movimentos característicos. Em “off”, a voz de Kantor lê as anotações do seu caderno de diretor de 1944.

Nesse espetáculo, o uniforme de Ulisses está além dos limites do tempo e do espaço. O tempo passado, o tempo futuro e o tempo presente se desdobram em um único tempo. Em 1944, com O retorno de Ulisses, havia no espetáculo uma associação da figura do herói grego com a imagem do pai de Kantor que, conforme constava naquela época, teria morrido em Auschwitz em 1942 de um ataque do coração. Essa

\footnotetext{
${ }^{80} \mathrm{Um}$ jogo de caretas e de sons feito pelos velhos/alunos, personagens do espetáculo.
} 
relação até certo ponto conflituosa com a memória do pai desaparecido, o atormentou por muitos anos. Em $O$ retorno de Ulisses, o pai era apenas uma referência associativa. Em Wielopole Wielopole, o pai está em cena. Essa foi a primeira vez que Kantor deu materialidade à memória que tinha do seu pai. O interessante é que em Não voltarei jamais, o ator que fez seu pai em Wielopole Wielopole, é o mesmo que irá representar Ulisses nessa nova encenação. No espetáculo, o personagem que mais tarde se tornará Ulisses, é o dono do albergue, local para onde as personagens vieram ao encontro de Kantor. Esse personagem também é um jogador de cartas que insistentemente exerce a sua obsessão pelo jogo da mesma maneira que em Wielopole Wielopole, o soldado, pai de Kantor, insistia a tudo medir com um metro ${ }^{81}$.

Essa visão do figurino como objeto, como bio-objeto, embora tenha adquirido sua estruturação definitiva em Não voltarei jamais, com o casaco de Ulisses, essa estrutura já vinha sendo utilizada, de uma maneira menos organizada, em outros espetáculos. Em A galinha d'água, por exemplo, as "personagens viajantes", em suas viagens incessantes, os errantes sem casa, sem pátria, são condicionados por sua paixão a embrulhar seu corpo com vários casacos em um processo de sobreposição de peças, a fim de, na anatomia complicada do figurino, proteger, não somente os corpos do sol, da chuva e do frio, mas principalmente os segredos que estão envoltos por essa embalagem que se move. Embalagens humanas, "viajantes e suas bagagens", reiteram a idéia da arte como viagem. Esses personagens, cujo figurino é completado por malas, sacolas, mochilas presas ao corpo, propiciaram a Kantor, a criação de toda uma série de personagens que são encontrados em sua obra de uma maneira geral, pobres artistas ambulantes que ele observou por toda a Europa, são os modelos que ele chamou de "pessoas incompreensíveis para os outros" ${ }^{82}$, não em razão da sua aparência pitoresca mas por sua filosofia humana autônoma.

\footnotetext{
${ }^{81}$ Toda essa cena do aparecimento de Ulisses está diretamente conectada com a história de seu pai. Um fato muito peculiar sobre isso trata-se de que até 1988, Kantor acreditava, como já foi descrito anteriormente, que seu pai havia morrido em Auschwitz no ano 1942. Entretanto, aos 73 anos ele descobriu que o pai sobreviveu ao holocausto e viveu em uma pequena cidade da Polônia trabalhando como professor de matemática até o final da sua vida.

${ }^{82}$ Kantor, T. Metamorfozy, Teksty o latach 1938 - 1974. Métamorphoses, textes des années 1938-1974. Ośrodek Dokumentacji Sztuki Tadeusza Kantora CRICOTEKA, Księgarnia akademicka, Kraków 2000, p. 360 .
} 
Ao olharmos as transformações sucessivas do teatro de Tadeusz Kantor, seja como linguagem, seja na sua atitude com seu posicionamento pessoal da vida em relação a arte, perceberemos que desde $O$ retorno de Ulisses já se anunciava aquilo que iria sobrevir nos anos sessenta e que se estenderia até Hoje é meu aniversário, o conceito de figurino fundado sobre a idéia da "realidade pronta", um ready-made, usando a terminologia de Marcel Duchamp, com exceção de $O$ polvo, e $O \operatorname{circo}^{83}$ que tiveram os figurinos criados e confeccionados por Maria Jarema.

Kantor que tinha particular atração pelo Dadaísmo explorou diversas possibilidades oferecidas pelo "objeto pronto", ou pelos "objetos encontrados ao acaso", maneira como ele gostava de se referir a esses objetos e que, necessariamente, faziam parte da chamada "realidade de classe mais baixa". As roupas, que eram muito apreciadas pelo artista, eram aquelas quase que totalmente destruídas, em farrapos, que estavam guardadas no fundo de malas escondidas nos cantos mais remotos das casas. $\mathrm{O}$ repertório basicamente era composto por saias surradas, chapéus amassados e cobertos de poeira, em conformidade com a realidade do desgaste provocado pelo tempo. A propósito dos figurinos de Kantor pode-se dizer exatamente a mesma coisa acerca dos seus objetos, porque em efeito, conforme comenta Piotr Krakowiski:

“...trata-se de arrancá-los e de fazê-los ressaltar de sua dominação e de suas relações vitais para deixá-los sem nenhum comentário." 84

O figurino deve permanecer uma metamorfose particular do ator na qual as formas de expressão criadas por esse são aquelas próprias do circo,

“aquelas associadas ao lado perverso das situações que tendem para o escândalo, para a surpresa, para o choque e para as associações de idéias contrárias ao bom senso, além de uma pronúncia enganosa e artificial", 85 .

\footnotetext{
${ }^{83}$ O circo - peça de Kazimier Mikulski encenada por Kantor em 1957. Trata-se, desde a fundação do Teatro Cricot 2 em 1955, até 1975 com A classe morta, da única montagem que não se referia a um texto de Witkiewicz.

${ }^{84}$ Krakowski, Piotr. Kantorowskie kostiumy (Les costumes de Kantor). Catalogue de l'exposition Tadeusz Kantor Fantomy realności (Tadeusz Kantor. Les fantômes de la réalité), Cricoteka 1996.

${ }^{85}$ Id. ibid.
} 
O figurino é um objeto que abriga no seu interior o organismo vivo do ator conforme a concepção kantoriana do bio-objeto, capaz de determinar o jogo e as funções desse ator. Assim, o dono do albergue, ao ser colocado no interior do casaco, assume a condição de também ser Ulisses em um complexo simbiótico de relações de coexistência. O figurino bio-objeto funciona como uma forma de exoesqueleto, uma estrutura que protege e salvaguarda o organismo vivo interior, ao mesmo tempo em que dá a ele uma nova dimensão de força em uma nova realidade. O exemplo claro disso, como já foi dito, trata-se do casaco de Ulisses.

Para Kantor, todos os elementos do espetáculo deveriam ser elevados a uma condição de autonomia como obra de arte para que pudessem até mesmo ser expostos como peças únicas e genuínas em um museu. Em As belas e os feios também havia alguns figurinos cujas estruturas também se comportavam como bio-objetos e que posteriormente passaram a ser expostos como objetos de arte. A "nieletnia",86, não é autêntico, é a cópia de um figurino utilizado no espetáculo de 1973. Essa peça que foi reconstruída em 1978, e está exposta no atelier do artista situado na rua Siena, na Cracóvia, trata-se de uma escultura em tecido, ou seja; esse objeto é uma escultura que revela que o figurino para Kantor era tão importante quanto qualquer outro objeto ao ponto de ser elevado à categoria de escultura.

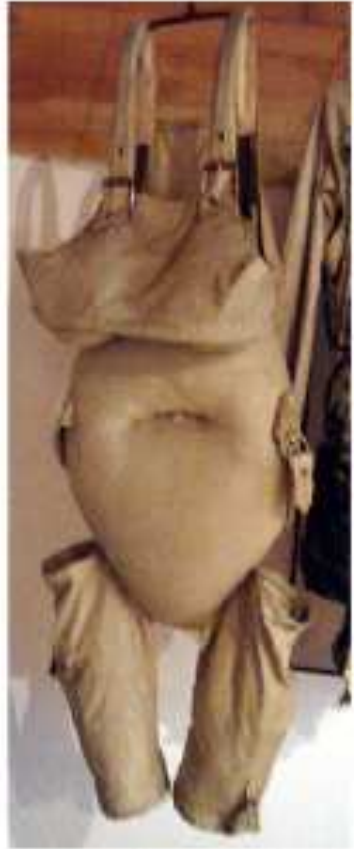

Nieletnia. Foto: Wagner Cintra.

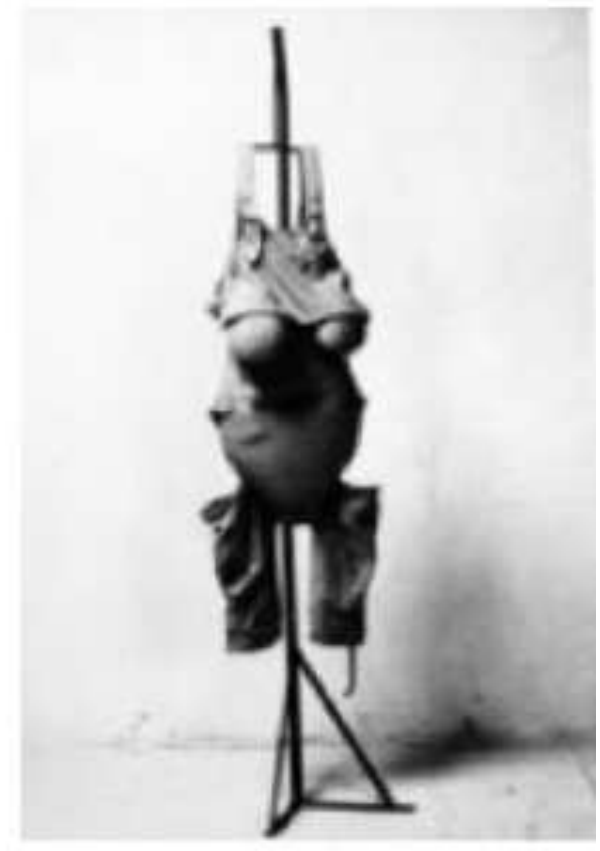

Nieletnia. Foto: arquivos da Cricoteka.

\footnotetext{
${ }^{86}$ Não consegui uma tradução adequada para esse objeto, por isso utilizo o nome em polonês.
} 
Muitos desses figurinos foram transformados em obras de arte autônomas, como o figurino do deportado de Wielopole que também virou escultura e também está exposto na Cricoteka. Tanto o figurino do deportado, quanto o casaco de Ulisses são espécies de armaduras, armaduras confeccionadas com o mais pobre tecido encontrado. Armaduras, como as demais peças de roupa que traduzem no esgotamento da sua aparência e na grosseria da sua confecção, as batalhas históricas enfrentadas pelos atores e demais elementos do teatro Cricot 2. Batalhas que em Não voltarei jamais, observamos a síntese.

\section{O pequeno carro}

No processo de reconstrução da memória de Kantor em cena, o pequeno carro ou carro infantil, tem um papel definitivo na consolidação desse processo de criação que tem início com A classe morta. Entretanto, a idéia de tal objeto que foi concebida inicialmente para Wielopole Wielopole, Kantor havia feito alguns croquis preparatórios para a sua construção, mas devido a uma série de dificuldades na execução do projeto e também pela falta de precisão das suas lembranças, a idéia só viria a ser concretiza em 1985 em Que morram os artistas!

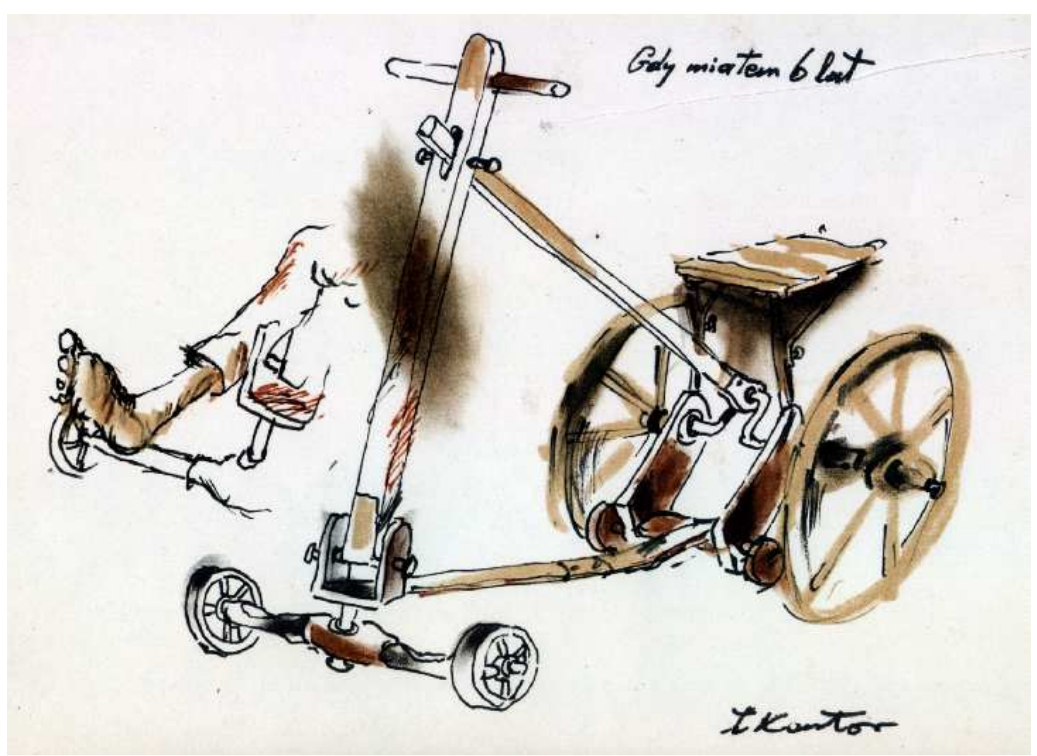

Tadeusz Kantor - projeto do pequeno carro. Imagem impressa gentilmente cedida pela administração da Cricoteka. 
Esse brinquedo de criança, que Kantor se empenhou em reconstruir, foi dado a ele de presente pelo seu tio, o padre, quando retornou de uma viagem feita à Viena. $\mathrm{O}$ presente foi para a comemoração do seu sexto aniversário ${ }^{87}$. De início, Kantor se empenha em reconstruir fielmente o brinquedo de sua infância. Tudo é muito semelhante, exceto o sistema de conexão do acento com as rodas. Assim, um objeto surge pela primeira vez em um espetáculo seu, extraído diretamente das suas lembranças pessoais e com muita verossimilhança. A presença do pequeno carro, construído conforme o modelo estacionado em sua memória, se constituirá em uma espécie de confissão individual, a sua própria vida em cena. Com a materialização cênica dessa memória específica, Kantor empreende definitivamente a sua viagem de retorno a si mesmo.

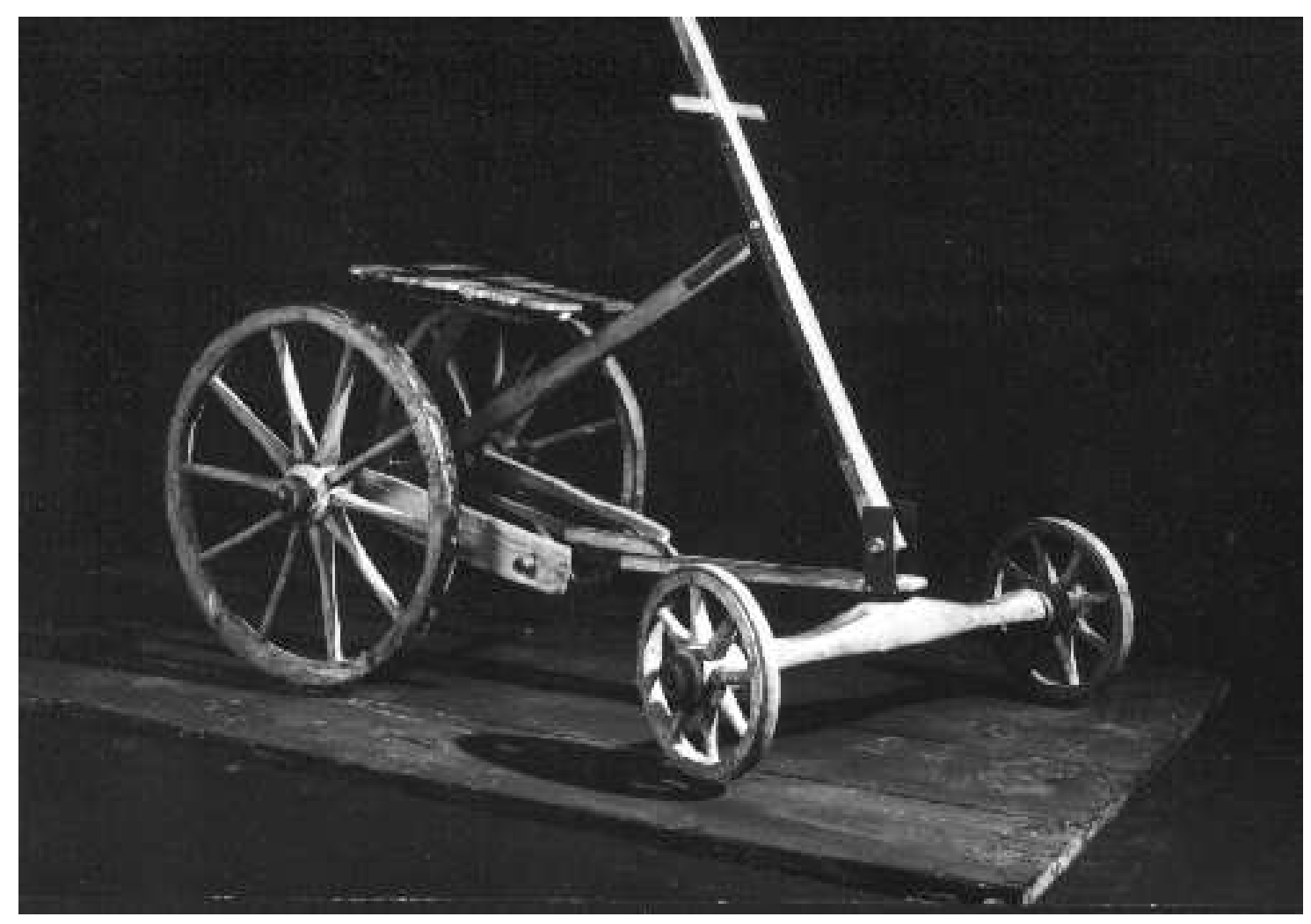

O pequeno carro. Foto: Janusz Podlecki.

No teatro de Kantor existe uma impossibilidade de se prever os acontecimentos a partir do momento em que as portas se abrem. Em uma das vezes em que a porta de

\footnotetext{
${ }^{87}$ Quando o pai de Kantor parte para lutar na Primeira Guerra Mundial, ele, a mãe e as irmãs vão morar com um tio materno que era padre em Wielopole.
} 
Que morram os artistas! se abre, Kantor, com a idade de seis anos, aparece em seu veículo de infância vestindo uma roupa de soldado. Em seguida, após acionar um mecanismo, o pequeno soldado retorna, com o movimento contrário, ou seja; de marcha ré, já que o objeto permite que isso seja feito e sai pela porta principal. Em seguida, mais uma vez a porta se abre e o pequeno soldado com seu carro, Kantor com seis anos, aparece e se dirige para frente da cena seguido pelas suas memórias de infância, pelos soldadinhos de brinquedo que, no presente da cena, representam o cortejo militar do marechal Pilsuldski e seus soldados mortos. Essa figura emblemática da história da Polônia vem montada em seu animal apocalíptico, um esqueleto de cavalo com crina e rabo, armado em uma plataforma de madeira sobre rodas que o movimenta pela cena.

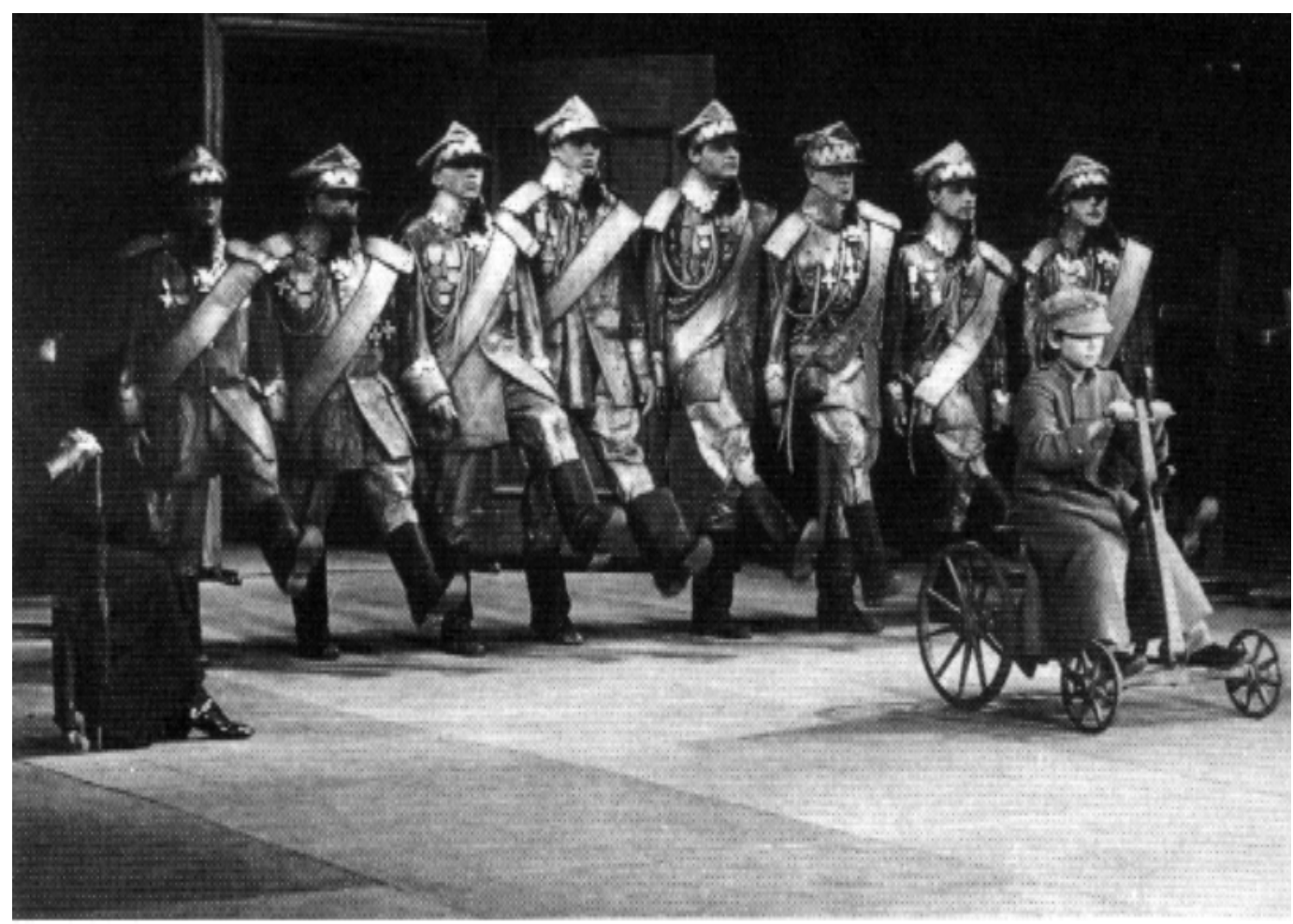

Que morram os artistas! - na cena, Kantor, a criança de seis anos com seu brinquedo, na frente do desfile militar dos soldados mortos do Marechal Pilsuldski. Foto: arquivos da Cricoteka.

Kantor possui uma fascinação muito grande pelos soldados que ele havia brincado quando criança, mas ao mesmo tempo ele é muito consciente de como o exército é desumanizado pelo poder. $\mathrm{O}$ exército é um regime de ordem que Kantor quer desafiar. O soldadinho de seis anos, montado em seu brinquedo, agora feito de madeira rústica e envelhecida pelo tempo de uso, tornar-se-a o soldado adulto que evocará a 
personagem histórica do grande herói polonês. Assim, a figura do grande marechal polonês será representada por dois personagens: a pequena criança de seis anos que Kantor era em Wielopole e que sonhava com a glória militar, como todas as crianças polonesas antes dos anos quarenta, e o marechal Pilsuldski adulto.

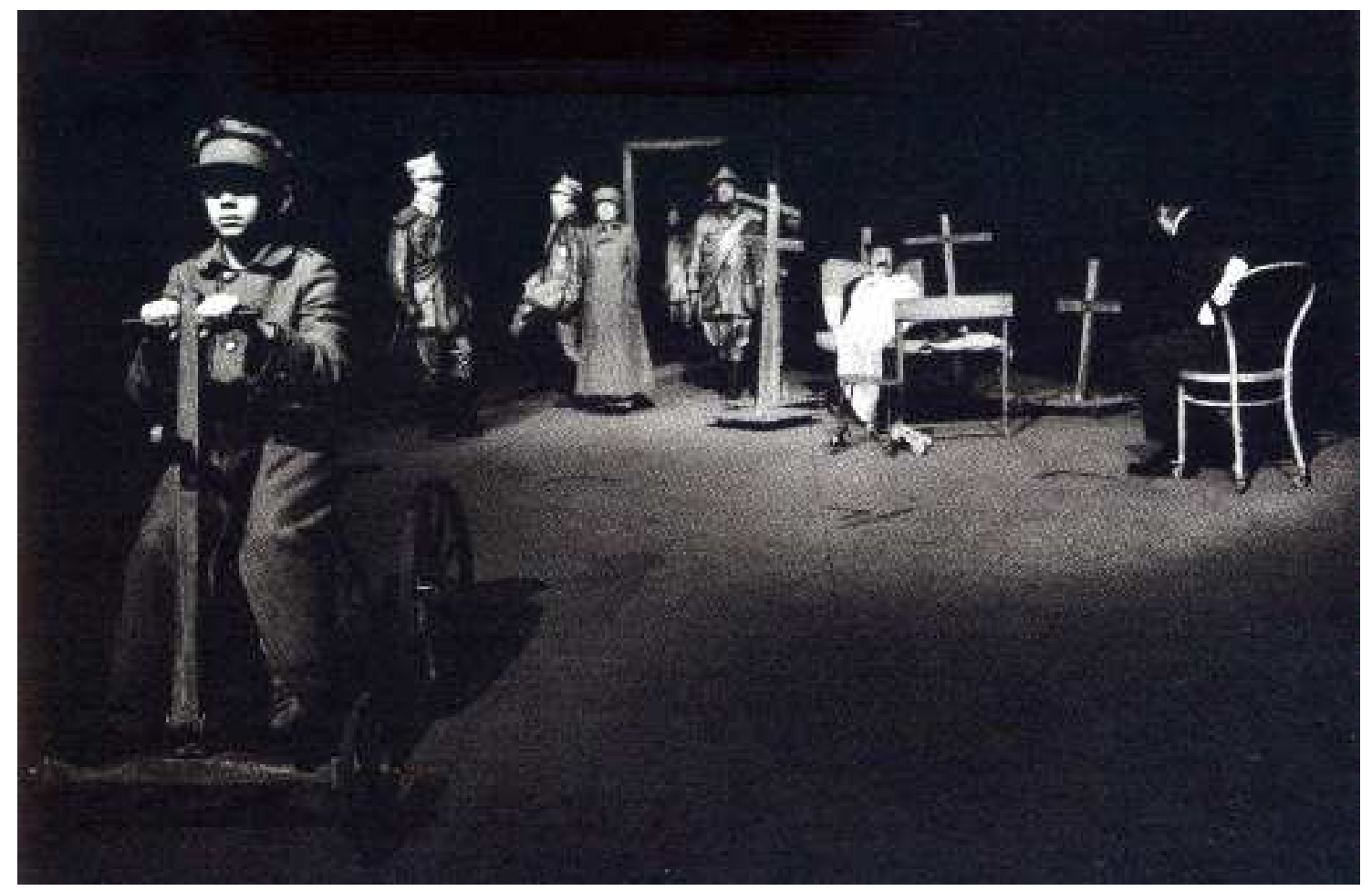

Que morram os artistas! - Na frente da cena, Kantor aos seis anos. Ao fundo, diante da porta, o Marechal Pilsuldski. Foto: Maurizio Buscarino.

Esse cortejo entra na peça com os soldados cobertos de poeira como se tivessem saído das suas tumbas. Na cena se encontram com outros personagens: os artistas ambulantes, as beatas, as prostitutas, Veit Stoss, o próprio Kantor à beira da morte. Ele a pequena criança de seis anos, está a um passo de morrer à frente dos exércitos que se movimentavam pela sua cidade nos tempos de guerra, ao mesmo tempo em que Kantor está agonizando na cena sobre a cama. Entretanto, Kantor, ele mesmo, o artista vivo, sobrevivente de duas grandes guerras, como nos outros espetáculos desde A galinha d'água, está no palco junto com os atores encarnando o passado, o presente e o futuro. Nesse espetáculo, temos simultaneamente muitas personalidades de Kantor em um processo de tentar descobrir as relações entre as suas diferentes identidades. Ao utilizar os atores para representar o seu personagem, Kantor está somente tentando afirmar a sua 
existência enquanto ser real, produto de movimentos históricos. Nesse jogo de relações, no confronto entre o eu real de Kantor com os dados presentes na sua memória e na sua imaginação, retorna a si mesmo, como produto histórico da civilização ocidental e vai ao encontro de fatos e pessoas a fim de discutir a vida, a morte e a arte.

“Eu - eu me componho de um número infinito de personagens, da mais tenra infância até os nossos dias, toda uma loucura vinda das profundezas do tempo. Eles todos e eu. Eu estou assim em cena: o Eu real. A cama - um dos dois personagens se parece como dois gêmeos: Eu morrendo. Eu o faço vir do futuro - um desejo tão humano: se coloca em face do inimaginável: do Eu morrendo. Em um instante aparecerá o pequeno soldado - Eu - aos 6 anos de idade, com um pequeno carro (meu carro) um desejo imperioso de reviver aqueles anos, ainda uma vez o faço vir." ${ }^{, 8}$

Que morram os artistas! é uma obra construída ao redor de temas e ações que se concretizam em imagens sonoras e visuais. A relação entre imagem e significação dramática é um ponto crucial no teatro de Kantor. Nesse espetáculo existe o fato de as personagens não terem nomes. Elas são tratadas pelas funções na cena. O nome do marechal Pilsuldski não é citado e a personagem é representada por uma mulher. No entanto, a maneira como a cena é montada, com a pompa militar, as roupas que sugerem uma época, essa imagem remete a um significado muito específico. Kantor, que nesse momento está tecendo uma reflexão sobre reputação e glória, vai dizer que essas estão necessariamente associadas à morte e que esse é um aspecto da cultura polonesa ${ }^{89}$. Através dessa discussão sobre os atributos da reputação e da glória, Kantor queria tratar, a partir da morte como sujeito, a questão de saber porque, por exemplo, os artistas não atingem jamais o reconhecimento e a notoriedade concedida aos generais. Esse é um tema que sempre o fascinou e que no entanto ele nunca encontrou ou pelo menos nunca ofereceu, uma resposta.

\section{AS MÁQUINAS CÊNICAS}

\footnotetext{
${ }^{88}$ Kantor, Tadeusz. Les voies de la création théâtrale. Vol. II. Paris: CNRS, 1983, p. 59.

${ }^{89}$ Kantor, T. Entretiens - Arts \& Esthétique. France: Carré, 1996, p. 81.
} 
As máquinas existem no teatro de Kantor há muito tempo, entretanto elas diferem umas das outras de acordo com a especificidade do seu momento histórico. Aquilo que estou chamando de máquinas cênicas, dentro da minha visão, são objetos que não são passíveis de ser encontrados na realidade, mas que podem se mostrar como deformações muito contundentes de algum aspecto da realidade.

As máquinas cênicas são um caso especial do objeto cênico. Primeiro pela sua forma, em geral de aparência assustadora, e segundo pelo conceito que ela representa, ou seja: de ser esvaziada de qualquer significação a partir da forma mas cujo conteúdo, antes de tudo, é o de impressionar, de ser unicamente um objeto de arte, utilizado unicamente para os fins da arte, no caso o teatro.

Normalmente as máquinas cênicas de Kantor estão associadas a funções estritamente teatrais; no entanto, ele pode romper com isso e transformar essas máquinas em objetos que podem ser expostos como esculturas. Isso aconteceu com o "carro de lixo" usado em A pequena mansão, espetáculo de 1961, que se tratava de um objeto feito em ferro que pertencia ao serviço de limpeza da Cracóvia. Esse objeto horrível servia de berlinda para duas crianças. Kantor diria, em 1984, que esse foi o seu “primeiro local móvel”,90.

\footnotetext{
${ }^{90}$ Kantor, Tadeusz. Wielopole Wielopole - Wydawnictwo Literackie. Kraków/Wroclaw, 1984, p. 134.
} 


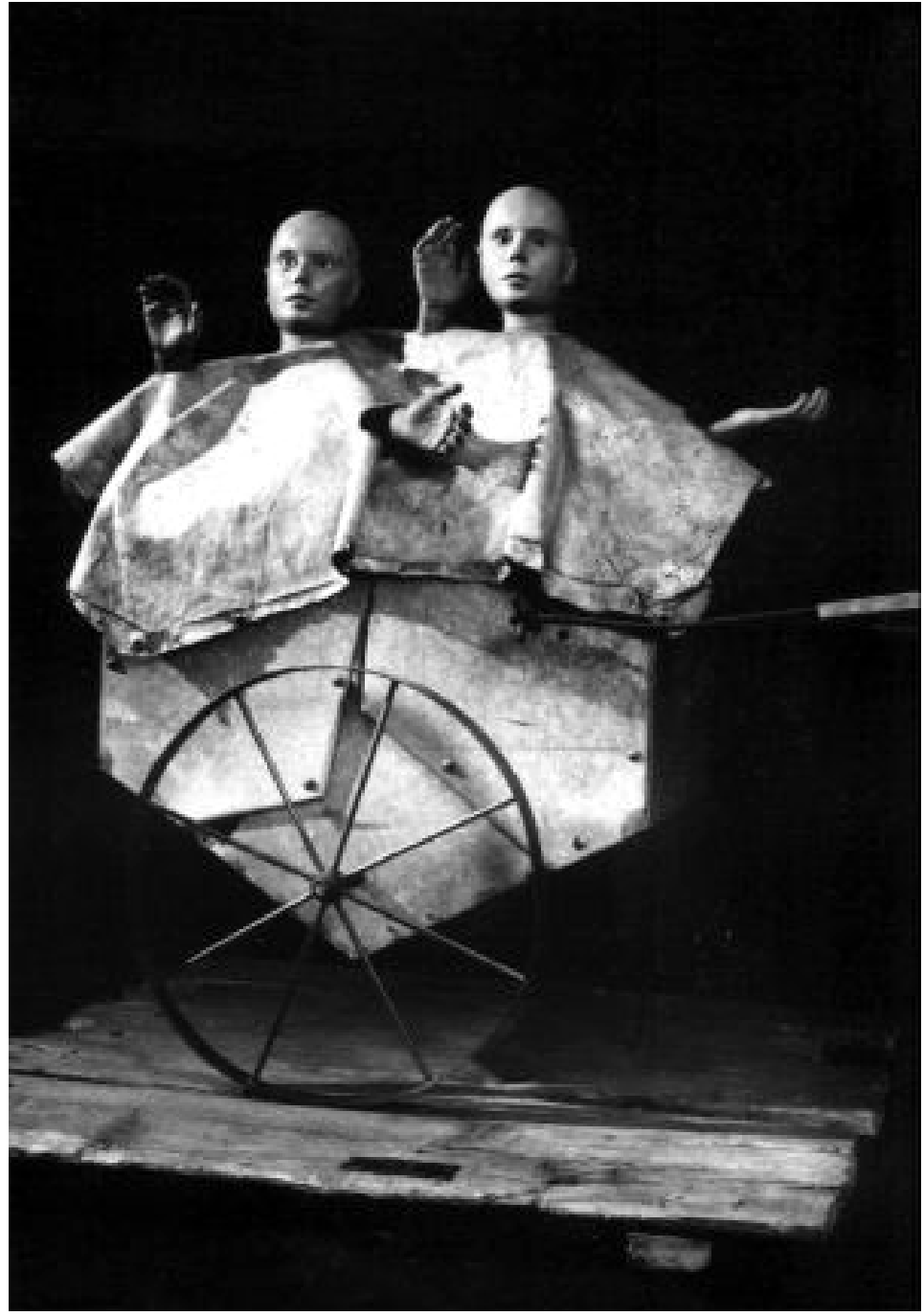

O carro de lixo usado em $A$ pequena mansão. Foto: arquivos da Cricoteka.

A grande pilha de cadeiras, utilizada em $O$ louco e a freira, chamada no espetáculo de "máquina de aniquilamento", tinha por objetivo, através dos seus espasmos, anular a interpretação emocional dos atores. Essa obra, que foi realizada em 1963, é composta de uma estrutura em metal que sustenta várias cadeiras velhas de dobrar. Esse objeto foi reconstruído por Kantor no início dos anos oitenta para se tornar parte do acervo da coleção da Cricoteka. 


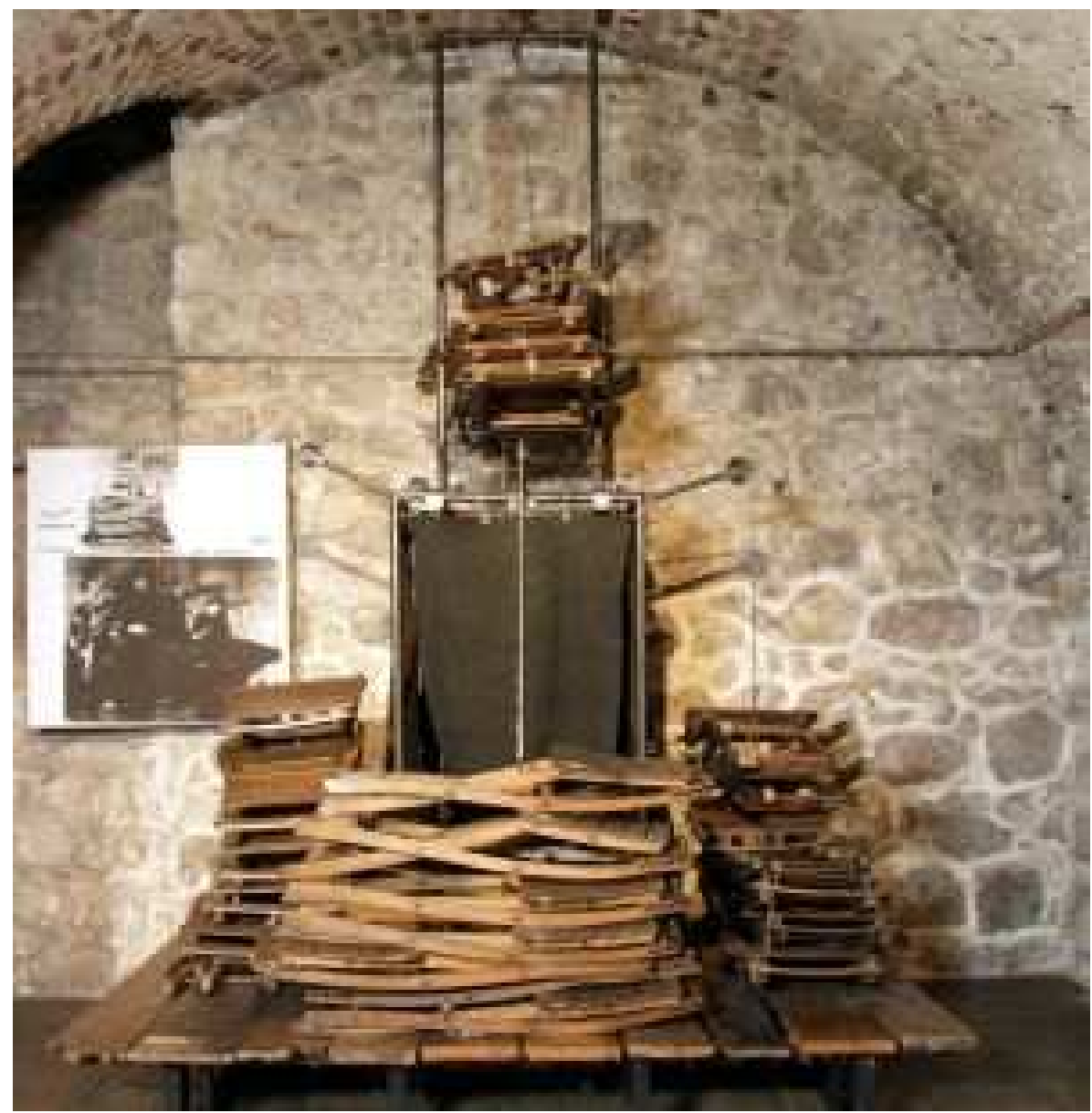

A máquina de aniquilamento usada em $O$ louco e a freira. Foto: arquivos da Cricoteka.

A máquina de tortura, por sua vez, que suscita a impressão de um corpo torturado, esticado e submetido a um alongamento mortal; na encenação de 1967 da peça de Witkiewicz, A galinha d'água, é semelhante a uma "caixa ziguezague", objeto muito utilizado pelos mágicos para serrar as pessoas ao meio, cria a sensação de que o corpo no seu interior foi supliciado e esticado ao extremo da sua resistência. Esse objeto também foi reconstruído por Kantor, no início dos anos oitenta, para também fazer parte do acervo da Cricoteka. 


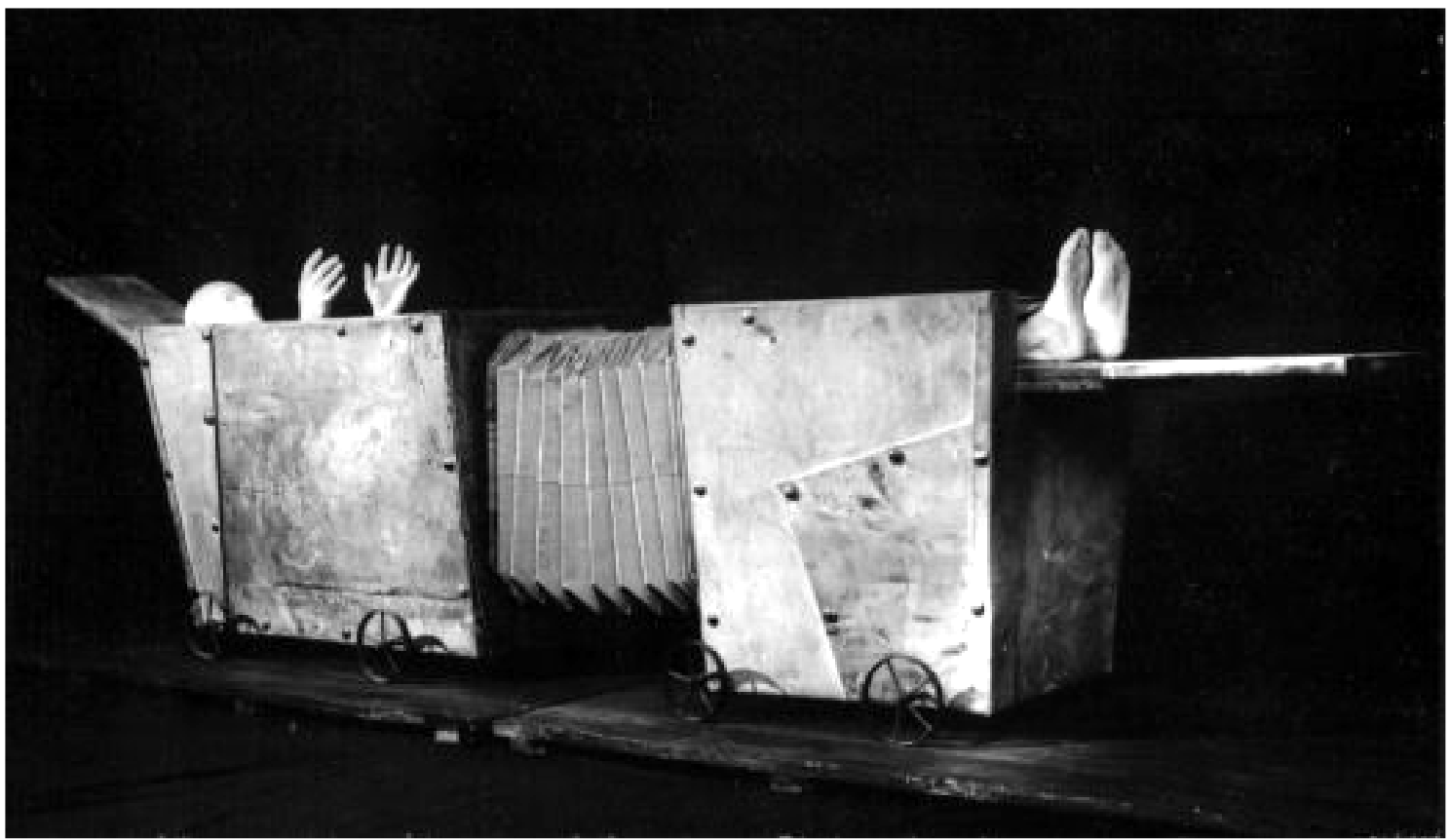

A máquina de tortura criada para a encenação de $A$ galinha d'água. Foto: arquivos da Cricoteka.

Não somente as máquinas mas praticamente todos os objetos de Kantor ganharam essa condição de também serem obras de arte autônomas, apesar de serem todos esses objetos profundamente equivocados na essência da sua natureza. De um lado, são estruturas funcionais cujo papel é essencial no desenvolvimento do ritmo do espetáculo, principalmente no sentido de imprimir os estados de convulsões ao contaminar os corpos vivos dos atores. Por outro lado, são objetos inúteis, visto que é impossível lhes atribuir alguma significação estável. Trata-se, entretanto, de uma força incontestável que possui diversas conotações: a tortura, a guerra, a loucura, a mutilação da vida. Essas máquinas que constrõem a sua própria realidade estão inevitavelmente associadas à morte a ao desconhecido.

\section{O velocípede}


A classe morta é a primeira produção de Kantor que foi reconhecida fora da Polônia e do leste europeu. No mundo ocidental o espetáculo foi considerado uma realização teatral incrível, o que deu a Kantor toda a sua notoriedade e reconhecimento mundial. Uma das facetas mais espetaculares dessa produção são as imagens, independentemente de se entender a língua ou não, que são construídas durante todo o espetáculo e cuja capacidade de choque não se limita ao local de exibição mas continuam ressoando por muito tempo dentro do espectador. Esse espetáculo combina diversos tipos de objetos que podem ser divididos entre objetos reais e objetos inventados, ou máquinas cênicas. Como já foi visto, entre os objetos reais estão os bancos escolares, as cruzes e também os livros empoeirados. Entre as máquinas cênicas, está o velocípede.

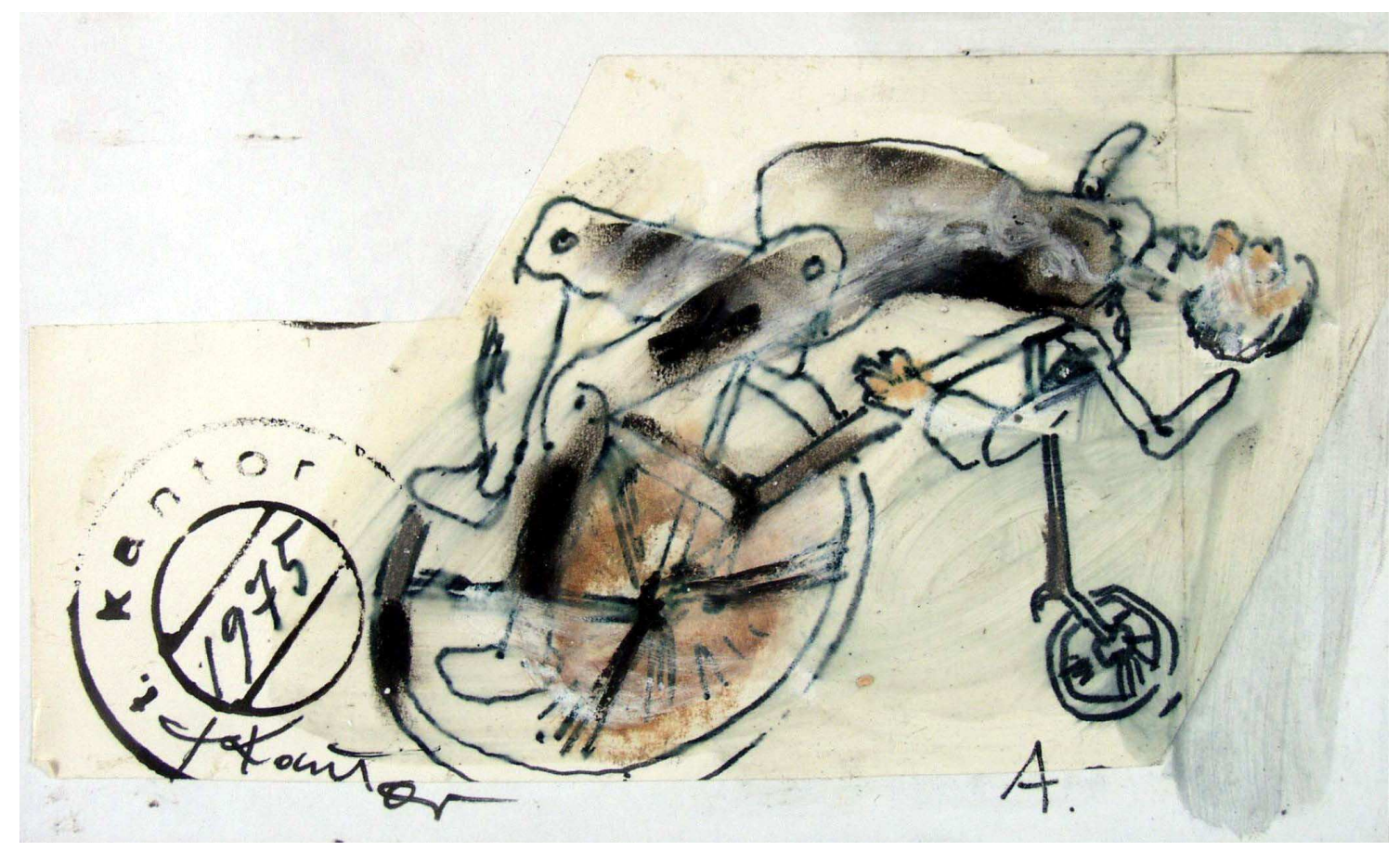

Tadeusz Kantor. Projeto inicial para o velocípede. Foto: arquivos da Cricoteka.

A este objeto está associado um manequim de criança, aquela que os velhos de $A$ classe morta já foram um dia. O manequim está ligado ao mecanismo do objeto de forma a fazer com que o movimento da máquina seja sugerido por ele, provocando assim, gestos absurdos e não sincronizados. Trata-se de um veículo complicado que 
parece uma bicicleta sobre a qual está crucificado o manequim de um garoto vestido com uniforme escolar. São vários os componentes desse veículo: uma grande roda suspensa está apoiada, na frente, a um seguimento de metal com um pequeno rodízio na sua extremidade e, atrás, uma roda menor que sustenta uma espécie de banco. Essa roda traseira é torta, um pouco oval, o que dá ao movimento do objeto um tom muito mais estranho e característico. As duas rodas são unidas por uma barra de ferro e do lado direito existe uma engrenagem, algo como uma manivela, que ao ser movimentada pelo Velho condutor, dá a ele uma movimentação semelhante ao movimento do objeto: desconexa e estranha.

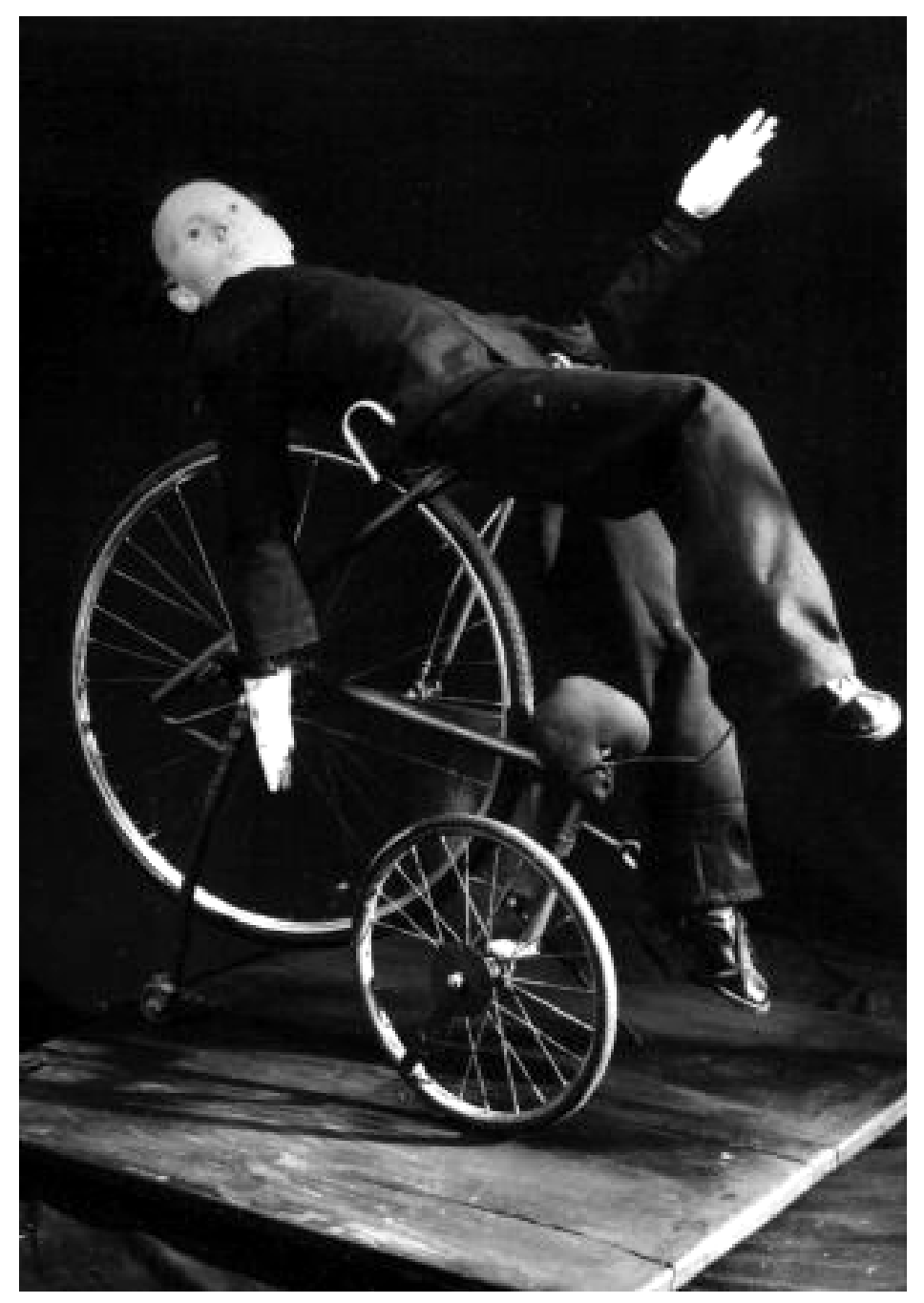

O velocípede com manequim. Foto: arquivos da Cricoteka. 
Em A classe morta se encontram diversos elementos anteriores presentes na obra de Kantor, entretanto eles assumem um significado completamente novo. Esse velocípede, por exemplo, com a grande roda suspensa, distante do solo por uma vara de ferro, trata-se de uma reinterpretação da roda de tanque de guerra de $O$ retorno de Ulisses. Essa, por sua vez, utilizada como objeto real, como um “objeto encontrado" em um espaço real, será mais tarde transformada em uma peça de museu reinterpretando o famoso ready-made a Roda de bicicleta de Marcel Duchamp - notadamente, essa máquina, criada para o espetáculo, também é um diálogo com Marcel Duchamp e com os dadaístas - mas ao mesmo tempo é um brinquedo de criança, um brinquedo do qual o Velho não quer se separar, mesmo se lamentando por estar alterado o seu objeto de infância. O Velho não reconhece mais o seu velocípede que foi deformado pelo tempo da mesma maneira que seu corpo e sua memória também o foram.

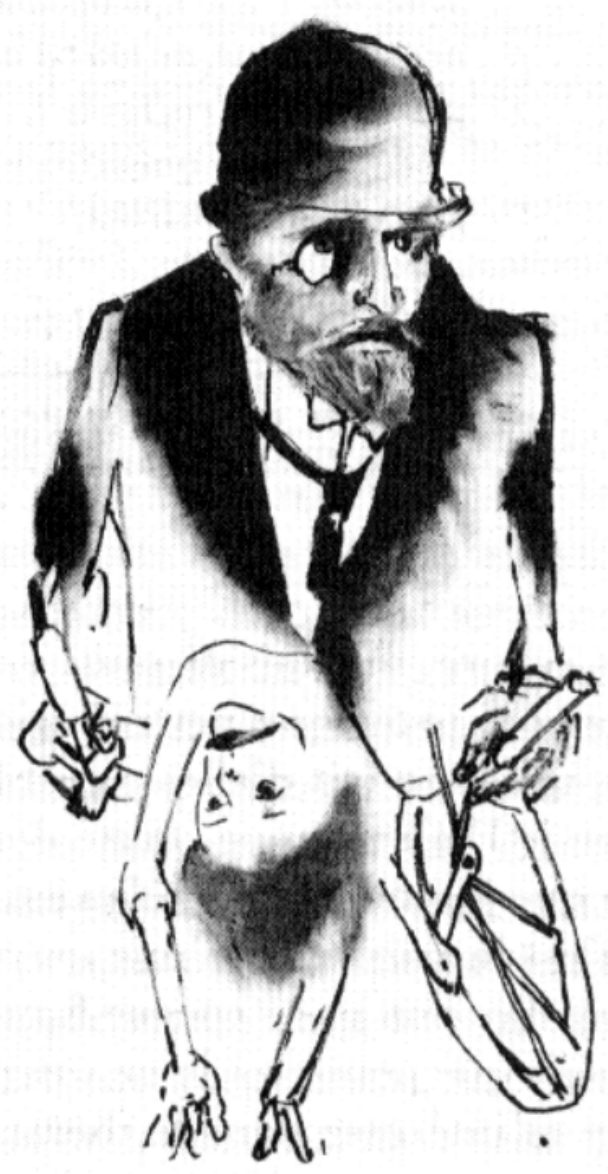

Tadeusz Kantor. O velho com o velocípede. Foto: arquivos da Cricoteka. 
A principal função desse aparelho na cena é existir como objeto autônomo, sem qualquer possibilidade de interpretação racional ou de qualquer aproximação com a realidade prática. Esse objeto foi construído por Kantor exatamente para afrontar a racionalidade, para que os movimentos do seu condutor tornem-se não convencionais e, de certa forma, até mesmo opressivos.

Sobre o velocípede está o manequim de uma criança vestida com roupa escolar, uma roupa preta de gala, que está afixado em uma espécie de crucifixão sobre ele; representa exatamente a infância morta, o tempo que cuidou de assassinar a criança que o Velho condutor já fora. Não é à toa que A classe morta é um retorno dos velhos que estão à beira da morte para a sala de aula, momento no qual a vida se manifesta na sua forma mais poderosa. Nesse caso específico, essa máquina que é empurrada pelo Velho também assume a condição de carro fúnebre. Um veículo que conduz a morte, um estado que o velho ciclista tenta dissimular atribuindo ao manequim, o seu manequim de criança, movimentos para simular a vida. O manequim, a mensagem da morte.

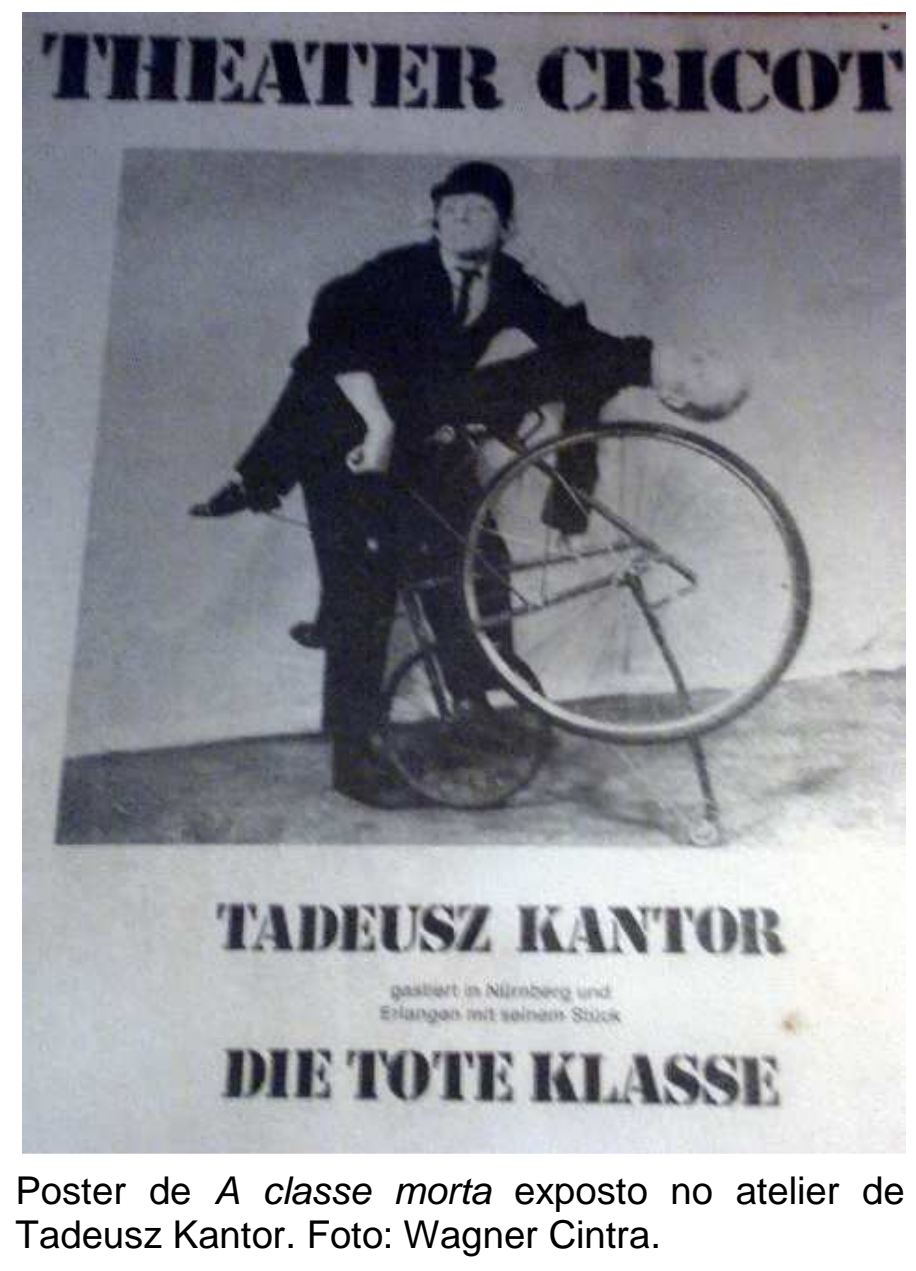


A idéia dominante do espetáculo é fazer as pessoas velhas retornarem à escola para reencontrarem a sua infância perdida que é simbolizada pelos manequins de crianças em uniforme escolar que são carregadas como tumores pelos velhos. A situação metafórica possui duplo sentido tal qual, temos visto, é muito comum em Tadeusz Kantor. O primeiro sentido reside no pensamento de que a criança está unida ao velho para sempre; o segundo, é aquela de que os adultos assassinam a sua infância. Assim, sendo os velhos indissociáveis dos seus manequins, temos um contágio, uma estranha contaminação do presente pelo passado e dos vivos, ou aparentemente vivos, pela mecânica dos manequins que, da sua ausência de vida, exalam um profundo sentimento da morte.

Em um dos seus ensaios, Kantor diz que essa relação dos cadáveres com as criaturas humanas é uma espécie de "relação antropológica" porque se desenvolve e continua a crescer para além da idade adulta. Esses bonecos são como que dimensões extra-biológicas, ou seja:

"a sua materialidade é apenas um fator deliberadamente simbólico para localizar, no plano da arte, uma ocorrência, por assim dizer, que se prolonga até o fim da vida."91

Assim, existe no espetáculo um esforço próprio da velhice que é a necessidade de ressuscitar a memória do passado e é através dessa necessidade que A classe morta irá se desenvolver e se estruturar como base do futuro teatro de Kantor e do seu Cricot 2, ou seja: ele realiza um exame ético sobre si mesmo, movido pelo impacto registrado em sua memória pela Segunda Guerra Mundial. A partir de A classe morta, todo o seu trabalho no teatro estará ancorado na reconstrução da memória.

\section{Máquina familiar}

\footnotetext{
${ }^{91}$ Cintra, Wagner F.A. O circo da morte - A especificidade do jogo entre o humano e o inanimado no teatro de Tadeusz Kantor. Dissertação de mestrado. São Paulo: ECA-USP, 2003. p. 91.
} 
Existe ainda em A classe morta, ao lado da memória, a noção de ação paralela. Essa estrutura trata-se de uma única ação que se desenvolve ao mesmo tempo em dois planos diferente. No caso desse espetáculo, o plano das ações da encenação de Kantor agindo em concomitância com a peça de Witkiewicz. Para explicar essa situação, a máquina familiar faz-se o melhor exemplo.

No espetáculo, existe o encontro de duas realidades: uma autônoma, real, livre no seu desenvolvimento que se trata das ações desenvolvidas em A classe morta de Tadeusz Kantor; a outra é aquela imaginária, fictícia, que possui uma estrutura literária estilizada da peça Tumor Cervical de Witkiewicz. Em efeito, esse é um meio através do qual se torna possível situar uma realidade dentro de outra realidade. Com essa estratégia, Kantor consegue libertar os personagens da peça da submissão da fábula, criando indivíduos independentes, imersos em nuances e complexidades muito mais profundas. Assim, a realidade da encenação de Kantor, autônoma, desliza em direção à peça de Witkiewicz e essa profere um movimento contrário. Nesse sentido, essa máquina, também chamada de "máquina de fazer nascer", atendendo aos mesmos desígnios dos demais objetos, possui mais de uma possibilidade de existência.

A primeira leitura desse instrumento nos leva a acreditar tratar-se de um instrumento ginecológico, uma mesa na qual as mulheres são colocadas para um eventual exame. No entanto, essa cena está evidentemente, dada às circunstâncias, situada em um plano infernal, um mundo de pesadelo do qual parece ser impossível sair. Essa máquina bizarra, feita em madeira e metal, possui, além de um encosto para apoio das costas, dois suportes em forma de braços nos quais as pernas de uma das personagens são afixadas. O movimento desses braços faz com que as pernas da personagem se abram, levando ao mesmo tempo à uma leitura imediata que é aquela relativa ao ato sexual, recorrente à ação da peça Tumor cervical. E a outra, devido à maneira cruel como é desenvolvida, induz à leitura de sofrimento, da dor da tortura. A ambigüidade da cena é evidente. A ação forte e violenta não impede a velha supliciada de trocar um diálogo ambíguo com outros personagens. O interessante dessa situação é que o texto proferido pelos personagens não possui nenhuma relação com a ação que está se desenvolvendo. A ação aparente é aquela do espetáculo de Kantor localizado em uma suposta sala de aula, e a outra provém do texto de Witkiewicz, que, no entanto, não é literal, ele é recomposto de uma maneira perceptivelmente dadaísta. As frases desse 
diálogo são repetidas de uma maneira artificial, plena de sentimentos, mas contraditórios. Não existe a preocupação com a lógica. Na medida em que uma ação intensa, expressa no texto Tumor cervical, é dita, a intensidade da cena aparente pode se desenvolver no sentido de realçar a penúria da personagem que está sendo torturada. A alegoria metafórica da cena está certamente associada à questão vida e morte, que basicamente é o grande tema da peça. Assim, a abertura das pernas da vítima, sem nenhuma dúvida refere-se a um monstruoso jogo de parto.

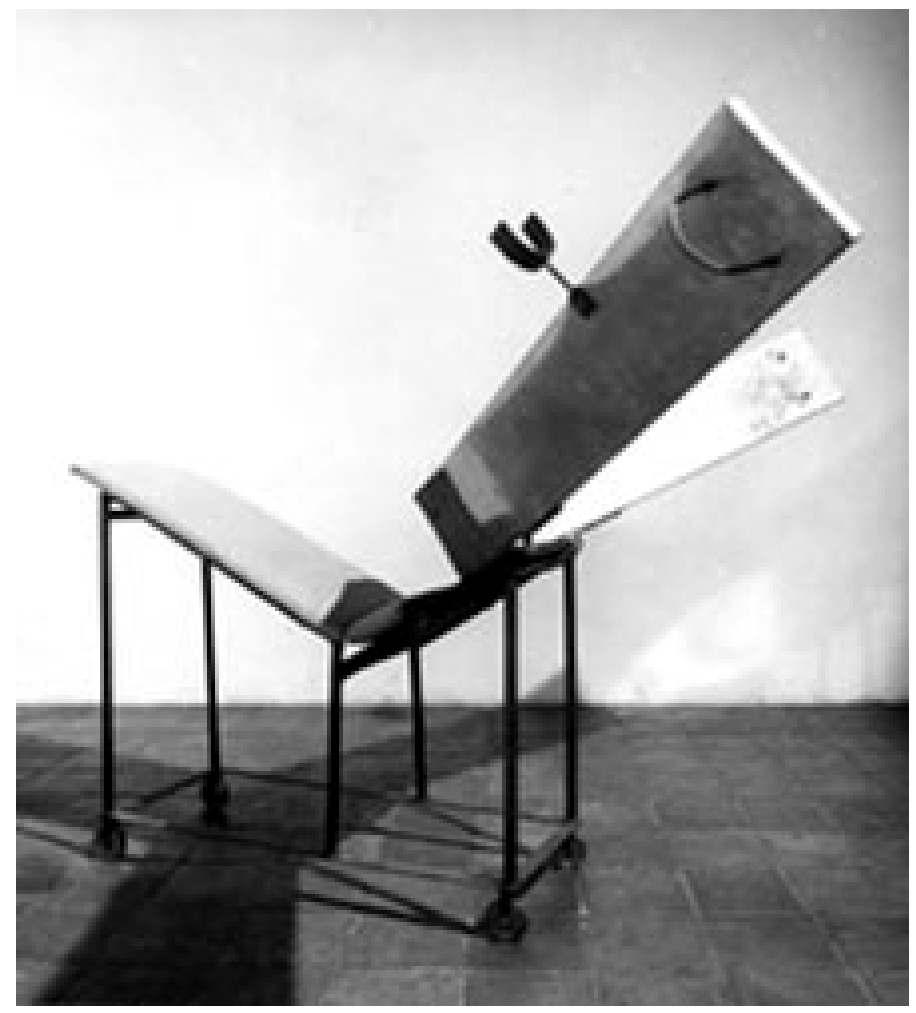

A máquina familiar. Foto: arquivos da Cricoteka.

Convém lembrar que o espetáculo funciona como um quadro que retrata um pesadelo no qual homens e mulheres velhos, próximos da morte, possuem uma aparência cadavérica e estão em busca da infância destruída pela idade adulta. Cada um deles carrega, unido ao corpo, um manequim de criança cadavérica, o seu próprio manequim sobre os quais estão depositadas as lembranças da época da sua infância acabada. Infância abandonada pelo pragmatismo da vida social. De volta à sala de aula, eles se comportam como se fossem crianças: sopram lições uns para os outros, fazem conversas paralelas, pedem para sair para fazer suas necessidades, ou seja, desenvolvem 
um típico repertório de ações comuns àqueles em idade escolar. Nesse universo composto pelo definhamento do corpo humano na sua relação com a vida e a morte, percebe-se, ironicamente, um contraponto fascinante entre o horror trágico e o humor circense. Essa contradição se desenvolve em um constante transformar do movimento que vai da infâmia ao sublime, da perversão à reflexão sobre a existência humana.

Dos vários temas que se sucedem, um que obviamente atravessa todo o espetáculo é o conflito entre a infância que se opõe à velhice. Muitas são as variações sobre essa temática. Uma diz respeito exatamente ao uso da máquina familiar. A cena na qual essa máquina está inserida é nomeada por Kantor de "a cena familiar" e a partir do seu desdobramento acontece uma mudança no seu interior. A sala de aula dá lugar a um divertido jogo de crianças. Divertido mas cruel. A idade avançada dos velhos traz aparentes traços de loucura no desenvolvimento desse e de outros jogos de crianças. Existe uma troca de martírio e opressão entre eles que dá vazão ao aparecimento de uma crueldade infantil que surge de algum germe profundamente escondido nos seus desejos. Tudo isso, misto de terror e humor hilariante, revela uma ação forte e violenta composta de sofrimento e dor que é reforçado por um humor negro extremamente violento, realça vorazmente a tortura e humilhação por qual a personagem está sendo submetida.

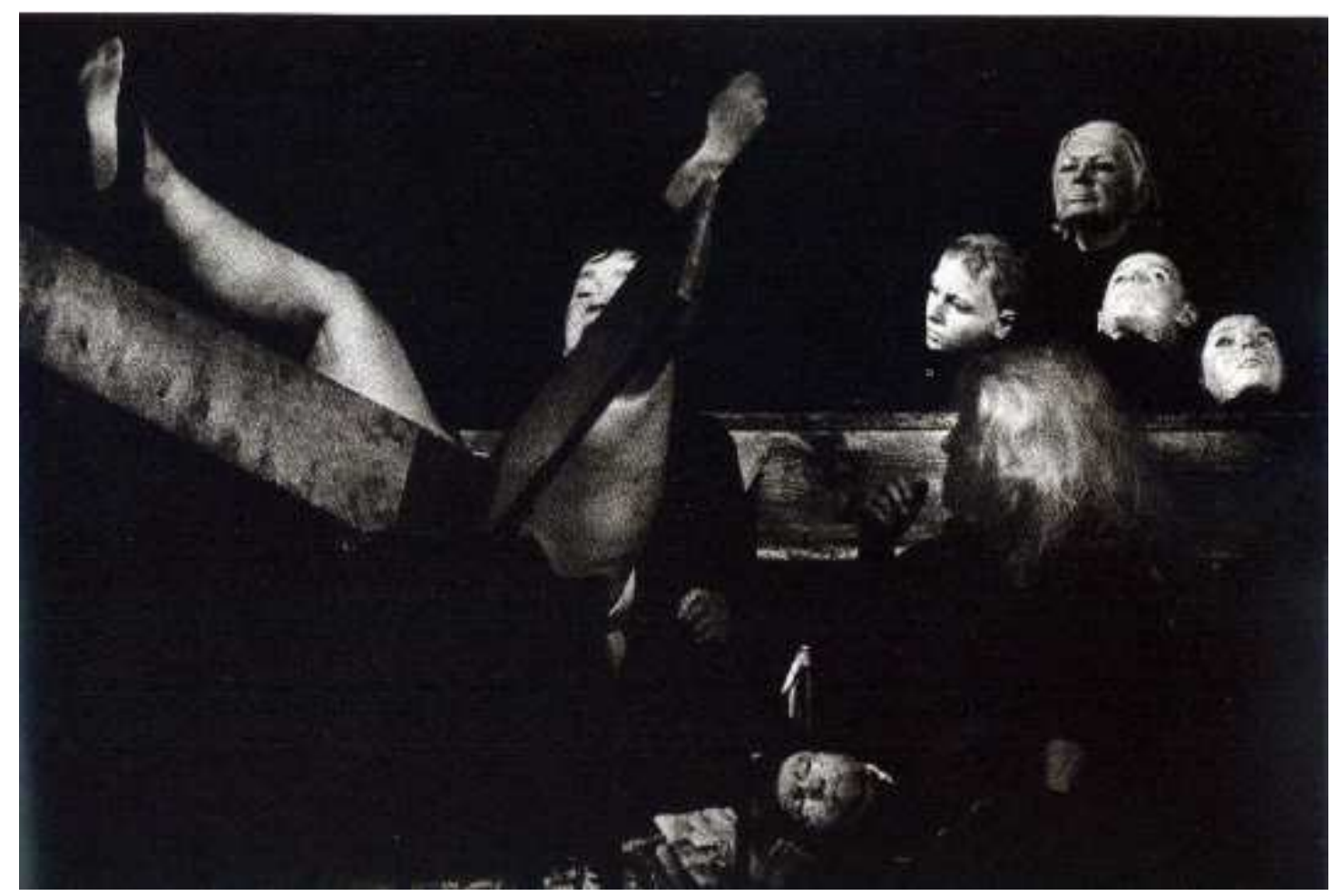

A máquina familiar em uma cena de $A$ classe morta. Foto: Maurizio Buscarino. 
Por outro lado, existe outro contexto quando pensamos no segundo nome que Kantor dá a esse objeto, "máquina de fazer nascer". Nesse contexto exatamente, Kantor está dando ao ato do nascimento, tema da peça de Witkiewicz, uma conotação de sofrimento e dor, tema de A classe morta, peça de Tadeusz Kantor. Ao que me parece, Kantor está fazendo uma leitura paralela, que se dá através do objeto, sobre um tema relativo à vida e morte naquilo que diz respeito ao surgimento da vida a partir do ato sexual, mais uma vez a peça Tumor cervical, uma vida que é apenas abstração, com o sofrimento da materialização dessa vida no mundo concreto. Kantor parece estar dizendo: nascer é começar a sofrer para morrer em seguida. Isso ficará evidente no desdobramento dessa cena quando a máquina familiar for associada outra, uma máquina complemento, tão bizarra quanto a primeira, que mergulhará mais ainda o espetáculo nas suas relações com a existência humana e suas implicações metafísicas. Esse novo objeto: o berço mecânico.

\section{O berço mecânico}

Tanto a máquina familiar quanto o berço mecânico pertencem a uma série de objetos que parecem ser dotados de vida biológica. Conforme a definição de Tadeusz Kantor:

“...por seu caráter mecânico e brutal, eles fazem parte dos objetos máquinas teatrais, cruéis e trágicas”. ${ }^{92}$

Objetos que se chocam constantemente com a vida humana presente no espetáculo.

No final da cena familiar, sob as pernas abertas da Velha torturada na "máquina de fazer nascer", é colocado um berço de metal com engrenagens que estão ligadas a um motor elétrico e, quando esse mecanismo é acionado, ele dá ao objeto um movimento mecânico de embalar que movimenta o pequeno berço de um lado para o outro.

\footnotetext{
${ }^{92}$ Kantor, Tadeusz. Przedmioty, klisze pamieci. Wroclaw: BWA, 1990, p. 20.
} 


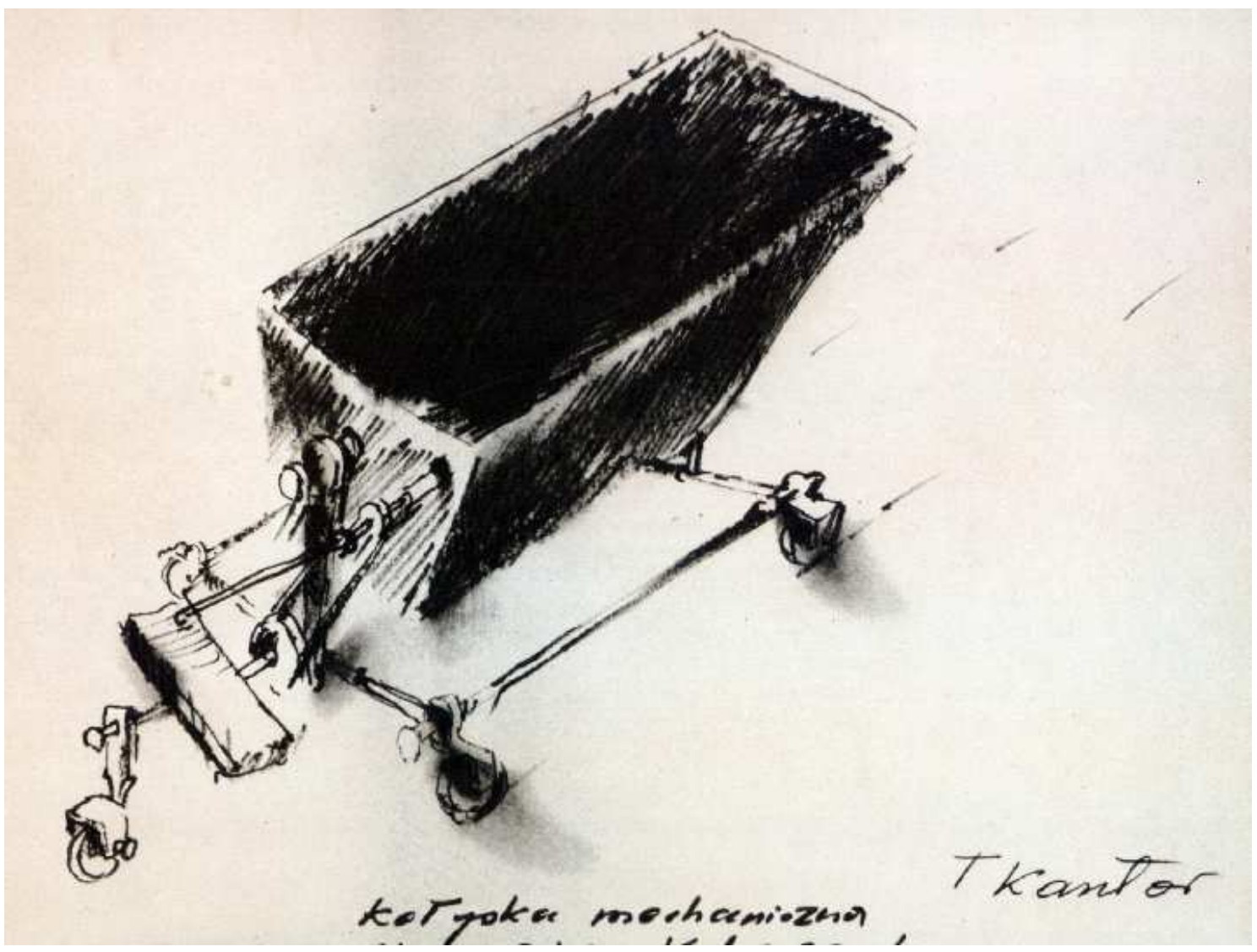

O berço mecânico. Imagem impressa gentilmente cedida pela administração da Cricoteka.

O berço é colocado cerimoniosamente no espaço da encenação pela Faxineira, personagem que personifica a morte no espetáculo, e o início da cena do berço se movimentando coincide exatamente com o final da cena anterior que termina com um grito de uma mulher dando a luz:

“...eu não sobreviverei a essa felicidade.",93

Além dos mecanismos que movimentam esse aparelho, outra peculiaridade desse objeto trata-se da sua aparência se assemelhar a um pequeno ataúde. Esse objeto tem impregnado, na sua forma, a aparência da vida por se tratar de um berço, local destinado aos cuidados da vida que se inicia e, ao mesmo tempo, a aparência da morte por se assemelhar a um caixão, local destinado a cuidar dos restos deixados pela morte.

\footnotetext{
${ }^{93}$ Kantor, Tadeusz. Les voies de la création thèâtrale. Études de Denis Bablet ET Brunella Eruli. Textes réunis et presentes par Denis Bablet. Paris: CNRS, Vol. XI, 1983, p. 119.
} 
Nesse contexto, aquela reflexão sobre a vida e a morte que fora iniciada na cena anterior como uma sugestão abstrata, desenvolve-se nessa cena como materialidade simbólica já que o produto do nascimento não existe no plano da realidade. Existe apenas o bater de duas bolas de madeiras no interior do berço/ataúde que, no jogo mecânico dos elementos, o som produzido em nada se parece com o choro de uma criança recém nascida. O som produzido pelo choque das bolas de madeira contra as paredes de ferro do objeto acentuam a tensão ao se fundirem com os lamentos e as súplicas dos Velhos. Esse congestionamento sonoro ao chegar ao máximo da tensão desliza para o inevitável: o silêncio, que em toda a sua letárgica frieza acentua a precariedade da vida nesse mundo.

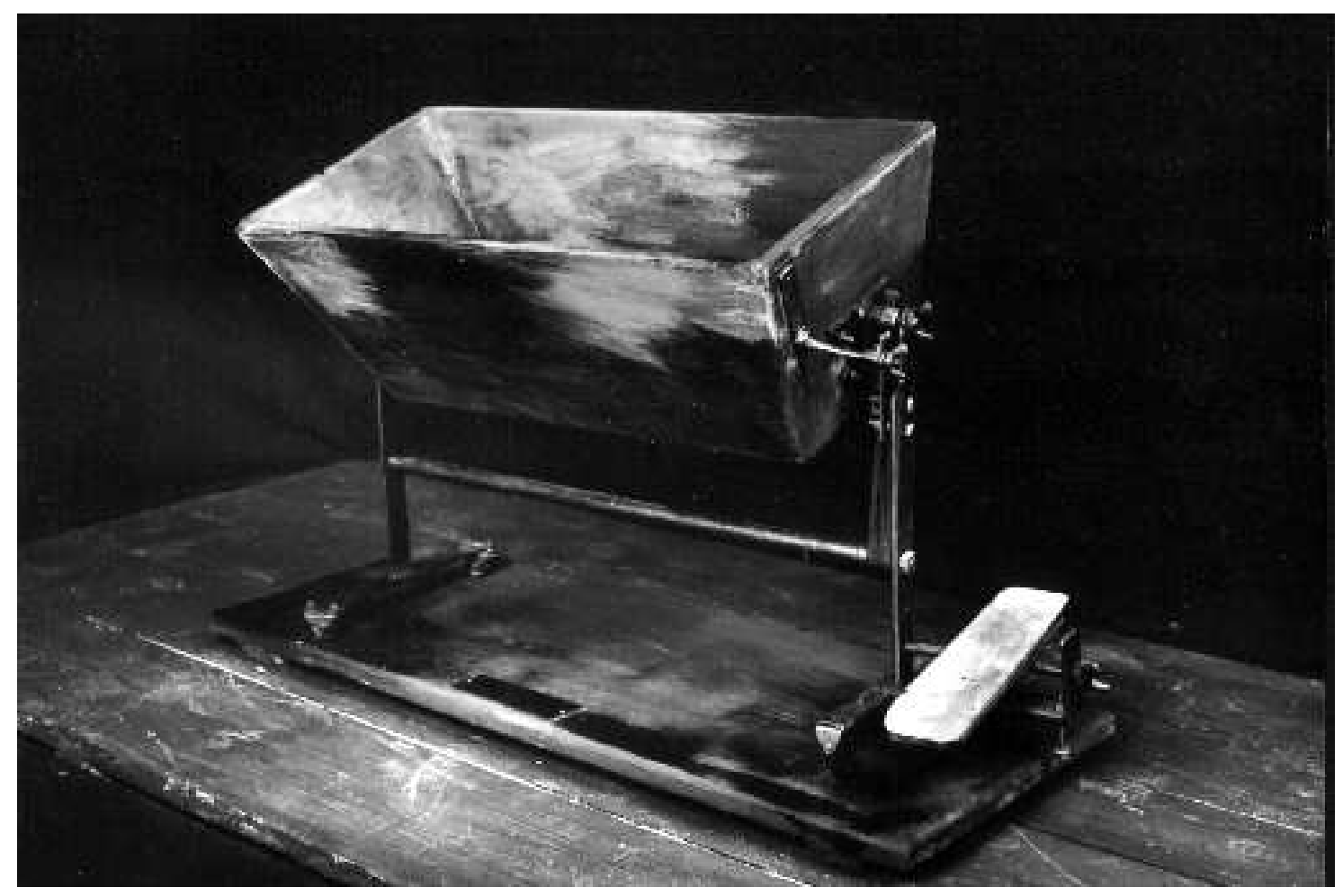

O berço mecânico. Foto: Janusz Podlecki.

Assim como as máquinas, as personagens que habitam a cena são seres autômatos, seres cuja vida se esvai a todo instante. Para eles nada mais resta a não ser desenvolver um intenso jogo com o pouco de vida que ainda pulsa em suas carcaças. As repetições, as ações mecânicas irão se constituir no contraponto ao estado de inércia encontrado na morte. Dessa forma, toda ação é levada ao extremo como condição essencial da vida sobre a morte. Entretanto, em certo momento do espetáculo não se 
sabe mais a diferença entre os vivos e os não vivos. Por vezes, os manequins que trazem em si a aparência da morte, parecem mais vivos que os próprios vivos. Essa dicotomia entre morte e vida torna possível a percepção de outra realidade que está situada além do espetáculo.

A cena familiar é de fundamental importância porque nela existe um diálogo intenso entre dois objetos inventados, objetos que só podem existir no teatro de Kantor ou em um universo de pesadelo, apesar de a sua essência residir na realidade prática da vida cotidiana. Em A classe morta, os objetos assumem um papel de fundamental importância no processo de organização e constituição desse universo insólito, que por menor que seja a sua significação na vida prática, quando acoplado aos diferentes elementos presentes na cena, ganham o poder de criar a sua própria realidade e possivelmente serem elevados ao status de obra-de-arte.

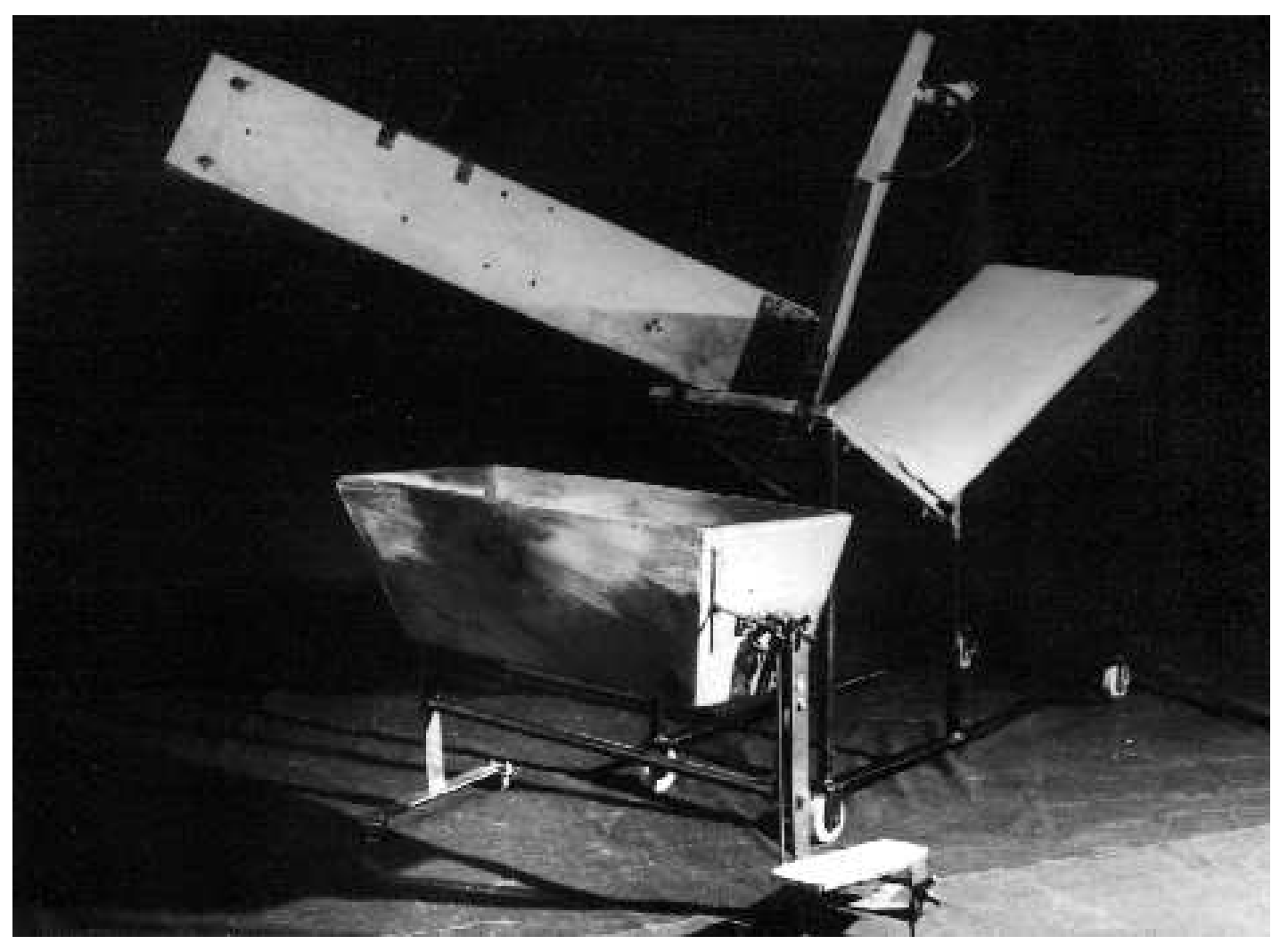

Composição entre a máquina familiar e berço mecânico. Foto: Janusz Podlecki.

O espetáculo resulta, então, na concepção de uma nova existência na qual um novo complexo de relações passa a existir, uma nova existência que só é conhecida 
pelos seres que habitam a cena e é intuída pelo espectador. A Faxineira, por exemplo, tem sua existência associada ao seu escovão e ao seu balde, objetos destinado à limpeza de espaços cotidianos. No entanto, ao som das batidas das bolas de madeira nas paredes do berço, essa personagem limpa com muita cerimônia os corpos dos mortos que estão espalhados pelo espaço. O berço/ataúde, de maneira monótona, balança insistentemente de um lado para o outro, movimentado pela engrenagem mecânica. No lugar do choro de criança, o bater das bolas de madeira. No lugar do primeiro banho, a Faxineira/morte processa a lavagem ritual dos cadáveres. Em um comentário sobre o espetáculo, naquilo que diz respeito a essa cena, Kantor diz que tudo acontece como em um pesadelo no qual:

“...de um lado as bolas ressecadas atravessam o espetáculo criando uma imagem qualquer, ou até mesmo o símbolo da infância. E de outro, por seu papel de objeto inferior, ou por sua subjetividade, elas reduzem essa infância ao estado de objeto morto, elas matam e mutilam."94

Essas bolas, por estarem inacessíveis ao olhar do espectador, ao mesmo tempo em que sugerem algo de sagrado, inviolável, também sugerem o sacrilégio por sua falta de humanidade. Invisíveis no interior do objeto, elas parecem estar unidas a ele ao ponto de serem inseparáveis.

No final do espetáculo os velhos organizam um jogo de baralho em que as cartas são substituídas por obituários nos quais estão escritos nomes de pessoas falecidas. $\mathrm{O}$ engraçado da situação é que esses nomes foram retirados da lista telefônica e de livros de recenseamentos. São nomes sem nenhuma importância, freqüentemente ridículos, emprestados das classes mais humildes da população, dialogando uma vez mais com uma das bases do seu teatro, ou seja: "a realidade de classe mais baixa".

\footnotetext{
${ }^{94}$ Kantor, Tadeusz. Les voies de la création thèâtrale. Études de Denis Bablet et Brunella Eruli. Textes réunis et presentes par Denis Bablet. Paris: CNRS, Vol. XI, 1983, p. 164.
} 


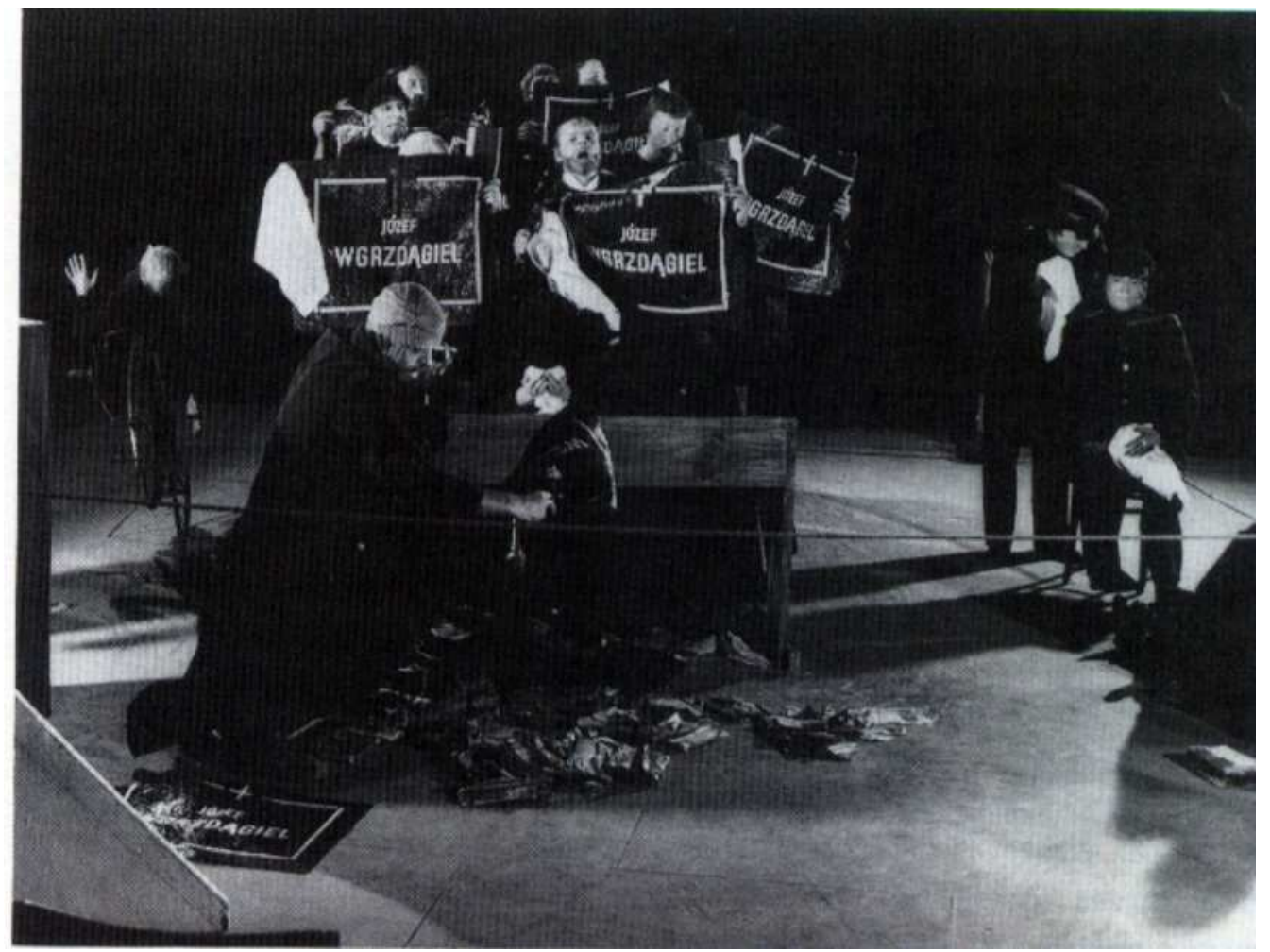

A classe morta. Na cena, o jogo de cartas com os obituários. Foto: arquivos da Cricoteka.

Existe muita paixão nesse jogo de cartas. É como se todas as paixões de uma vida se manifestassem naquele momento expondo todos os desejos da vida humana. Os obituários passam de mão em mão. Eles os colam uns nos outros. O bater das bolas se mistura com uma música, uma valsa francesa que soa muito alto, ao mesmo tempo em que os velhos brincam entoando uma rima infantil muito conhecida na Polônia e, dessa maneira, permanecem até o final. O som desaparece, o que permanece são os gestos que são repetidos com contumácia mecânica como se estivessem aprisionados neles para sempre.

\section{As máquinas de tortura}


Sobre certo ângulo de visão, é possível entender Que morram os artistas! como a condição e o lugar do artista na sociedade contemporânea do final do século XX. Conforme um esclarecimento de Kantor feito a Michal Kobialka em 1986, para a revista The Drama Rewiew, não teria sido a sua intenção falar sobre isso. Kantor diz que a confusão aconteceu, e acontece, pelo fato das traduções, sobretudo a inglesa: Let the artist die!, não possuírem o mesmo conteúdo e o mesmo sentido do idioma original.

Em língua polonesa, morrer é um significado que possui sua existência atrelada a dois verbos distintos. Um desses verbos é destinado ao ato de morrer que é exclusivo aos homens, e o outro é reservado especificamente aos animais. Assim, as traduções não possuem a mesma força, a mesma complexidade, nem o mesmo impacto do seu equivalente em polonês. Segundo Kantor, apesar do título da obra não fazer referência direta à situação do artista na sociedade, ao se pronunciar "Que morram os artistas!", obviamente questões acerca do lugar dos artistas na sociedade moderna evidentemente aparecem.

O título da peça surgiu acidentalmente. Kantor trabalhava na montagem do espetáculo e não sabia como iria chamá-lo. Em uma exposição anteriormente realizada em Paris, ele ouviu do diretor da galeria na qual as suas obras estavam expostas, a história de uma mulher que era a proprietária do imóvel e que se opunha aos planos de ampliação do espaço de exposição. Combatendo o projeto, a mulher freqüentemente gritava para que todos ouvissem: que morram os artistas! Kantor se interessou muito pelo fato, pois a notoriedade do imóvel, e conseqüentemente a valorização desse, só foi possível graças aos artistas que ela queria que morressem. Diante desse fato, Kantor utilizou-se do protesto da proprietária para nomear o seu espetáculo, cuja estréia aconteceria em Nuremberg um ano depois, em 1985. Nesse período ele relutou muito em assumir definitivamente esse título, pois ele considerava a expressão muito provocativa. Talvez, uma das razões de Kantor para manter o nome tenha a sua origem na história recente da Polônia.

Logo nos primeiros anos após o término da Segunda Guerra, propriamente em 1948, ano em que o Ministério da Cultura Polonesa, subsidiário da política cultural da antiga União Soviética, mandou uma mensagem aos artistas: "abandonem todas as esperanças!". Essa citação feita por Dante na Divina comédia foi impressa em todas as 
primeiras páginas de todos os jornais poloneses. Para Kantor, essa expressão é muito mais perversa do que "que morram os artistas!" porque se trata de uma forma de negação da liberdade de expressão artística individual em função de um modelo chamado de arte oficial. Para ele, a condição do artista contemporâneo sempre foi ilegal e suspeita; mesmo aquele que está sob o amparo da cultura oficial, isso pela sua condição de submissão, pois, sem que eles saibam, as instituições culturais, os fundos privados, dentre outros, extirpam a sua autonomia criativa. De certa maneira eles também são encarcerados, só que não sabem.

Os artistas autônomos por sua vez, conforme o pensamento de Kantor, tornam-se fora da lei e, marginalizados, são excluídos da sociedade e "deixados mortos" entre as suas criações. É bem possível que essa seja a visão de Kantor sobre o seu próprio trabalho. A crítica, caso exista no espetáculo, e faça justiça ao título, caminha na direção de um determinado grupo de artistas, os quais ele chama de malditos, que são exatamente aqueles que recorrem constantemente ao reconhecimento oficial. Por outro lado, a autonomia do artista o enclausura, o retém como em uma prisão.

Para Kantor, as condições de um prisioneiro são comparáveis àquelas do artista, pelo menos os da sua atualidade, uma pessoa que é forçada permanentemente a ter que aceitar as regras e os compromissos oficiais. Isso se trata de uma ingerência na arte do final do século $\mathrm{XX}$, sobretudo naquilo que diz respeito à necessidade de transformação da arte e de seu processo evolutivo. É muito provável que Kantor também esteja se referindo à crise das vanguardas a partir da década de setenta.

Desde o início do século XX a arte de vanguarda era identificada como um processo ininterrupto de inovações formais. As vanguardas ampliavam exaustivamente as fronteiras da criação artística. Esse processo de transformação e inovação aparenta chegar até o início dos anos 70 sendo que, de lá para cá, aparentemente nenhuma tendência se manifestou efetivamente, a não ser aquelas ligadas às repetições fragmentárias de elementos desvirtuados da arte do passado. O próprio Kantor afirma que no entardecer do século $\mathrm{XX}$ as vanguardas deixaram de existir. 
Nesse contexto de possibilidades que o espetáculo apresenta, as máquinas de tortura funcionarão como tema da derradeira grande obra do final do século. A elas estarão anexados os personagens do espetáculo, os mártires que se sacrificam pela arte:

“...se é verdade que o artista queima por sua obra, a criação são as suas cinzas." 95

$\mathrm{Na}$ esfera da arte marcada pela morte, os artistas condenados se revoltam com a sua condição e se libertam dos pelourinhos nos quais estão amarrados e amontoam pelo chão os instrumentos do seu martírio. Esses instrumentos são feitos com os mais variados formatos. De uma maneira geral possuem um poste em madeira sobre o qual estão afixadas engrenagens, cordas e todo tipo de sugestão de suplício. Esse poste, que será apoiado sobre as costas dos atores, também assume a dimensão da cruz e do sofrimento de Jesus. Assim, os artistas condenados carregam o peso da cruz, o martírio pela autonomia ou o peso da sua submissão. Kantor, em toda a sua história, sempre se recusou a ser oficial. Ele nunca aceitou qualquer subsidio do Estado para a realização dos seus espetáculos.

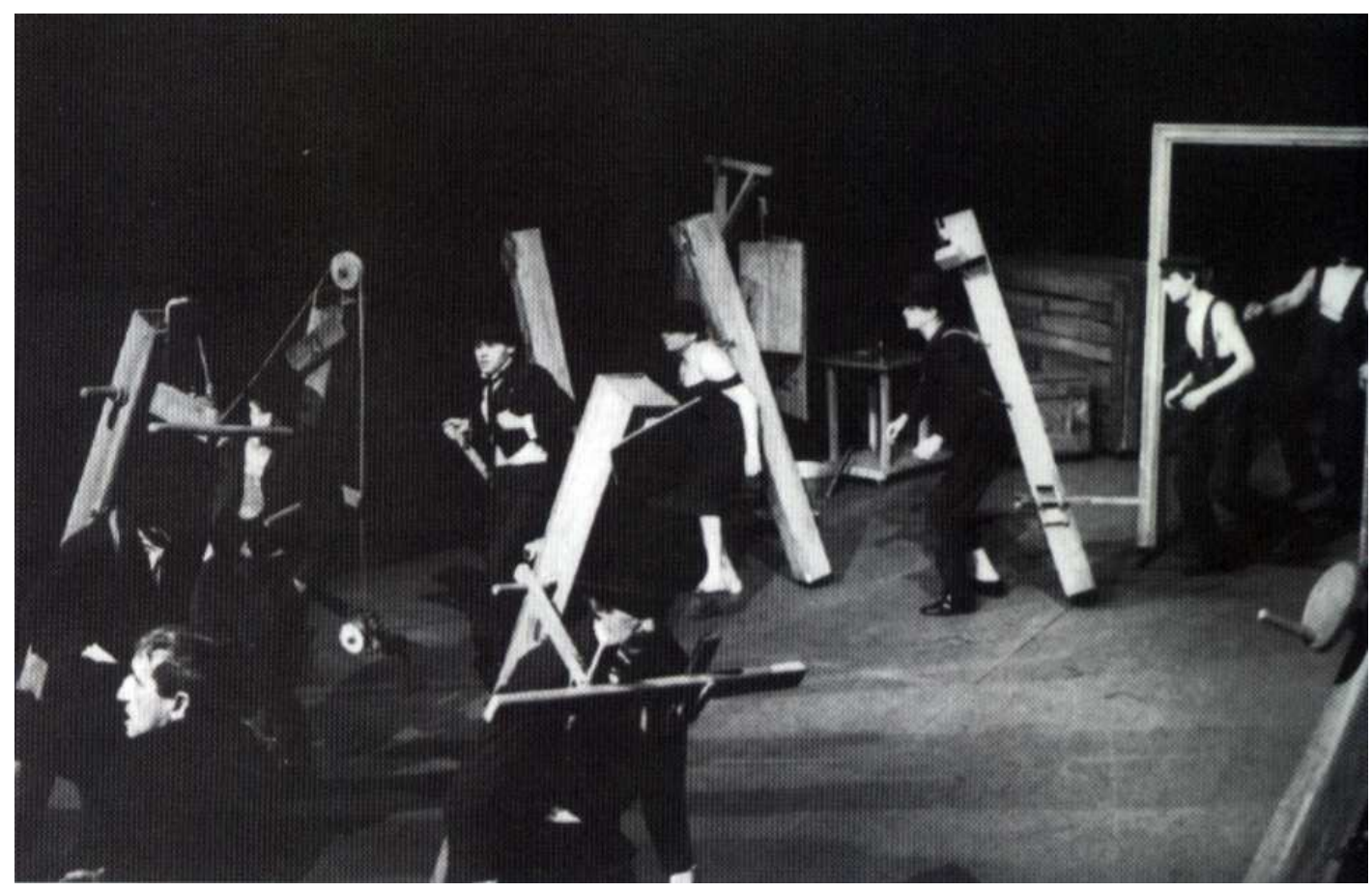

Que morram os artistas! - Na cena, a dança dos artistas condenados. Foto: arquivos da Cricoteka.

\footnotetext{
${ }^{95}$ Kantor, T. Les voies de la création thèâtrale. Paris: CNRS, 1993, vol. 18, p. 65.
} 
A entrada dos artistas condenados configura a cena como uma "Dança Macabra" movida pelo som de um tango. Em face do poder extenuante da indústria cultural e de seus agentes culturais, a prisão, a tortura e a morte são metáforas comuns a todos os artistas que se colocam à margem da cultura oficial. Ao que me parece, existe nessa parte do espetáculo uma paráfrase de Kantor à Dialética do esclarecimento ${ }^{96}$ de Adorno e Horkheimer, no capítulo sobre a indústria cultural, no sentido das observações de Kantor dizerem respeito à questão da arte oficial que é patrocinada pelos diversos poderes, não possuir nenhuma necessidade artística objetiva a não ser aquela de ser um mero instrumento do Estado ou do capital. Para Kantor, a arte não pode viver de decretos, e para cada decreto, conforme os autores Adorno e Horkheimer, "maior é o grau da impotência"97, e conseqüentemente menor a autonomia do artista. Assim, o pensamento sobre o declínio da arte em Kantor está diametralmente associada à Dialética do esclarecimento pelo fato da submissão à indústria cultural que, além de "condenar tudo à semelhança"98, também institui um processo de homogeneização da produção artística. Por esse caminho, Que morram os artistas! assume uma dimensão crítica que está direcionada à industria da cultura e ao mercado de arte.

Como Kantor desejava reconstruir o mundo com os detritos de uma explosão, dessa forma, ao introduzir na cena algumas das personagens míticas da história da Polônia, ele responde à indagação de Adorno sobre como fazer "poesia"99 após Auschwitz? Com a dor e com sofrimento causadas pela Segunda Guerra Mundial. Dessa forma, com os destroços que sobraram dos "campos da morte", com o esvaziamento das relações humanas que determinam as relações com as coisas, as máquinas de torturas, signo maior da sordidez e do desrespeito à vida, tornar-se-ão simbolicamente a matéria de criação da última grande obra do mestre Veit Stoss.

Com o esmorecimento das vanguardas, essa será a última grande obra do final do século XX. Veit Stoss, o artista do final do século XV, um personagem convocado por Kantor, construirá com os dejetos da história recente da Polônia, e também da humanidade, um altar inspirado na sua obra-prima, o altar da Catedral da Cracóvia. Essa obra é construída com a matéria causadora de dor e sofrimento às personagens e

\footnotetext{
${ }^{96}$ Adorno, T. W/Horkheimer, M. Dialética do esclarecimento. Rio de Janeiro: Zahar, 2006.

${ }^{97}$ Ibid. p. 43.

${ }^{98}$ Ibid.

${ }^{99}$ Entenda-se poesia como arte de uma maneira geral.
} 
também com o material das diversas batalhas do Teatro Cricot 2. Nesse sentido, esse novo altar se transformará em uma cela de prisão, uma câmara de tortura, pois os objetos de que ele se serve garantem a existência dos personagens e dos próprios membros do Cricot 2 devido à autonomia da sua produção. Em uma simbiose temporal, o altar é construído com objetos e pessoas, um monumento apocalíptico de um teatro de morte, cuja mensagem ao mundo deixada pelo artista cabe a cada expectador descobrir as suas significações:

“Quando as pessoas vêm ao meu espetáculo (...) graças à estrutura do meu teatro, elas param de se comportar como em um teatro convencional. Pode ser que elas se tornem testemunhas (...) mas é bom que os espectadores não consigam decifrar o sentido do espetáculo. É bom que as pessoas se sintam em uma tempestade e sacudidas quando deixam a sala. É somente quando saem do teatro que as conclusões aparecerão. Os espectadores podem ser desconcertados pelos acontecimentos do meu quarto da imaginação, mas tais acontecimentos são insignificantes. A mensagem lhe é primordial. Uma mensagem jogada sobre o muro à maneira dos prisioneiros. Cada um de nós deve conceber a sua própria concepção das imagens vistas em cena..."100

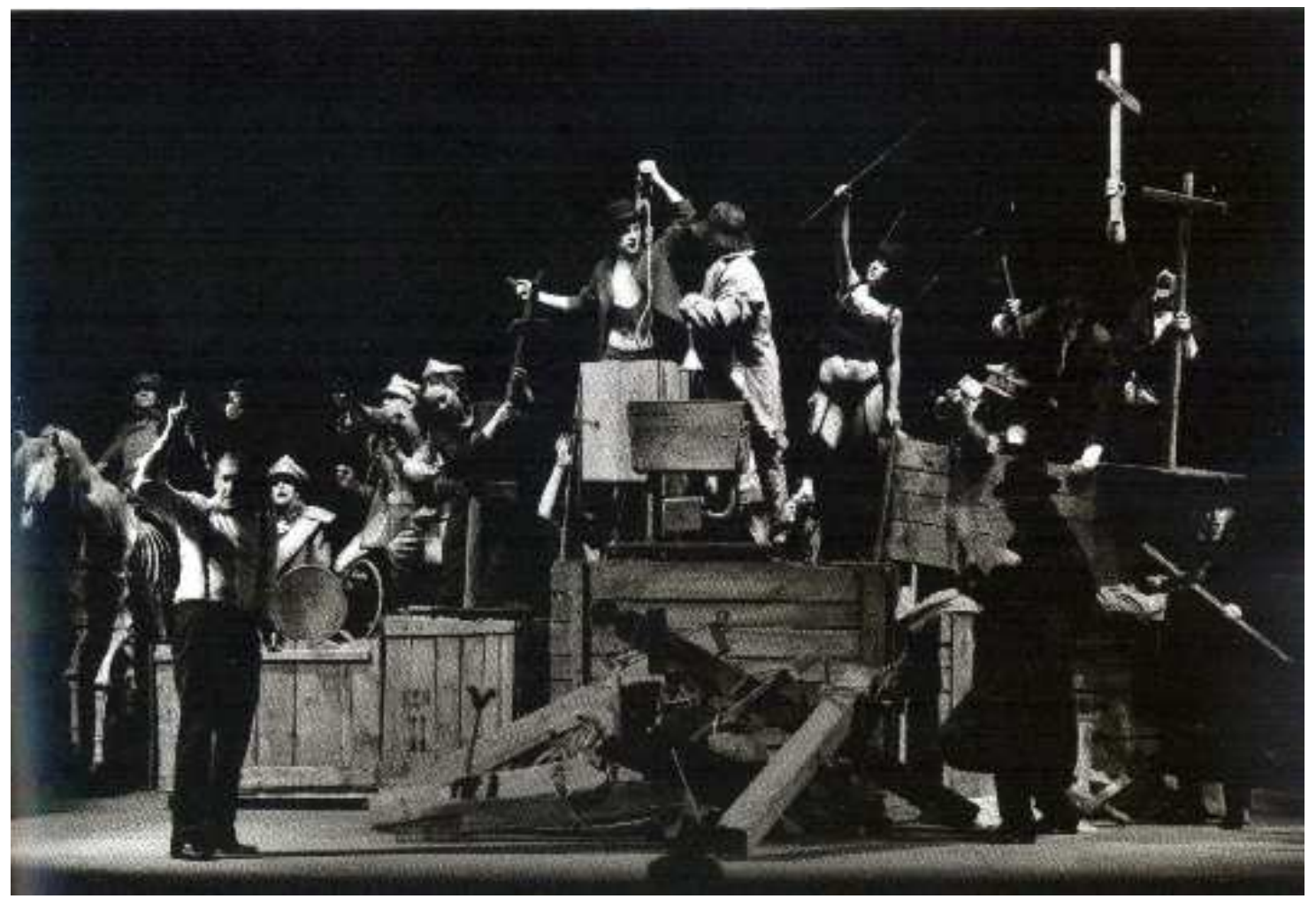

Que morram os artistas! Na cena, a obra do mestre Veit Stoss. Foto: Maurizio Buscarino.

${ }^{100}$ Kantor, T. Entretiens, Arts e Esthétique. France: Carré, 1996, p. 86/87. 
A escultura do novo altar feita por Veit Stoss trata-se da cena capital da peça. É uma espécie de barricada que simboliza além da separação da vida, também a barreira entre o público e o ator. Em A classe morta, essa separação era a noção da morte; Em Que morram os artistas! é a noção de prisão, que no entender de Kantor ${ }^{101}$, é o lugar onde o ser humano está inacreditavelmente só. Kantor sempre acreditou que ele podia se servir dessa noção desumana como signo de criação de uma obra de arte.

\section{A trombeta de Jericó}

De todos os objetos criados por Kantor, talvez a trombeta de Jericó seja o mais bizarro e insólito de todos, feito para uma cricotage, a forma kantoriana do happening, intitulada Onde estão as neves de antanho? ${ }^{102}$, que se trata de um espetáculo no qual os signos culturais e algumas de suas conotações polonesas estão dispostos em um dispositivo cênico ${ }^{103}$ abstrato. Nessa produção, a encenação acontece ao longo de uma corda fixa que divide o palco ao meio e no sentido da lateral da cena. Diante do olhar do espectador, os movimentos dos atores acontecem em paralelo a essa linha, seja da esquerda para a direita ou no sentido oposto, da direita para a esquerda. Ao longo dessa corda de separação ocorre uma série de contrapontos, como movimentos que provocam choques de velocidades ou as ressonâncias das cores utilizadas conforme a variação das suas intensidades.

Em um contexto que mistura pesadelo e bufonaria, a trombeta de Jericó surge como uma máquina sobre rodas, quase que um brinquedo de criança, um carrinho de puxar sobre o qual um instrumento de sopro, semelhante àqueles usados pelas bandas para a produção de sons graves, um contrabaixo entre os instrumentos de sopro, comumente chamado de tuba entre nós brasileiros, está afixado. Esse instrumento

\footnotetext{
${ }^{101}$ Ibid. p. 73.

102 Produção de 1979.

${ }^{103}$ Dispositivo cênico no sentido da organização de todos os elementos presentes na cena que definem o espaço mas sem representá-lo. Difere de cenário por não criar a realidade visual ou a atmosfera na qual se desenvolve a ação dramática.
} 
musical está preso ao chassi do carro através de algumas barras de metal que deixam o instrumento suspenso e com a abertura da sua caixa de ressonância voltada para baixo. Dessa abertura sai um tecido em forma de saco que se conecta a um balde de latão; esse, por sua vez, está associado a um sarrafo de madeira constituindo, com um suporte preso no chassi, uma espécie de alavanca com o formato de gangorra. Quando se coloca uma tensão na extremidade do sarrafo, inicia-se um movimento de subir e descer do balde de latão. Esse movimento, ao mesmo tempo em que produz um som metálico devido às suas repetidas batidas contra a base do chassi do carro, também cria uma movimentação do tecido que sugere o inflar e o esvaziar do saco, como se fosse um instrumento de "fole". No entanto o som que se ouve é aquele produzido mecanicamente pelo choque do metal contra a madeira; algo semelhante àquilo que foi anteriormente visto em $A$ classe morta, com as bolas de madeira no interior do berço mecânico. A cena é completada sonoramente por uma música instrumental cujo tema principal é marcado por um instrumento de sopro de som grave. Ao lado da corda de separação, que não é violada em nenhum momento, temos o acontecimento de cenas autônomas, sem a aparente conexão de umas com as outras. A única coisa que é comum é a composição sonora e musical, através da qual, em um processo de justaposição, as músicas e os diversos sons insistentemente se sobrepõem uns aos outros.

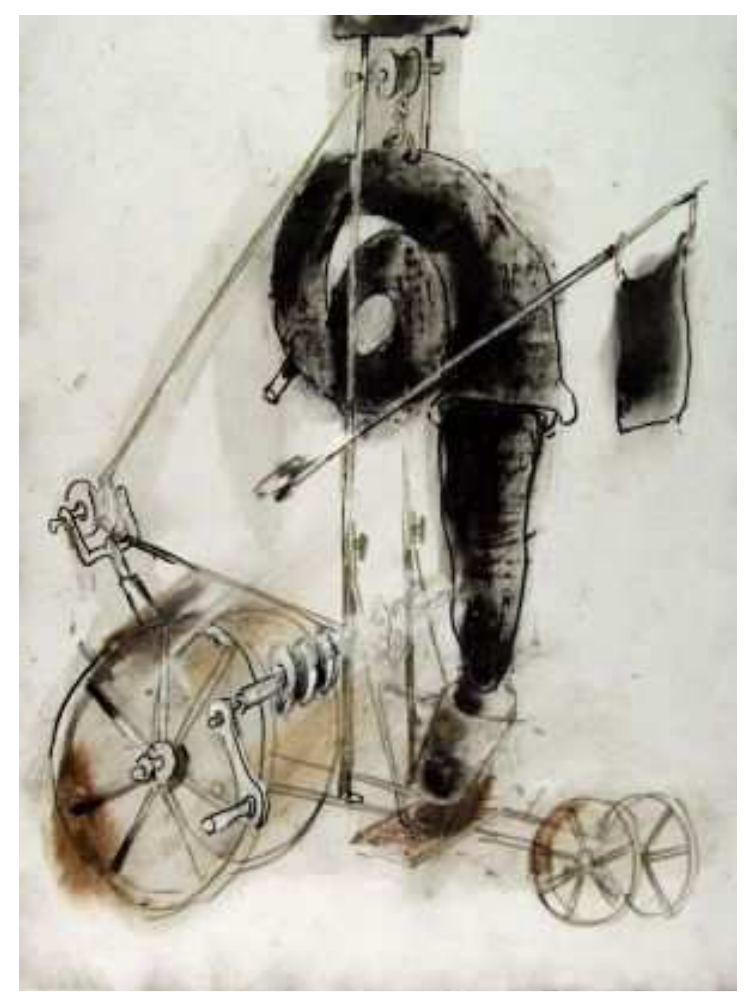

Tadeusz Kantor. Projeto da trombeta de Jericó. Foto: arquivos da Cricoteka. 
Nessa produção, feita em intensas variações de preto e branco, a única cor encontrada é o vermelho escarlate dos hábitos dos Bispos que dançam ao som de um tango e que contrasta com o negro das roupas dos dois Hassindins ${ }^{104}$, vestidos com roupa tradicional e que agem do outro lado da corda. Os Hassindins têm muita dificuldade para movimentar a máquina. Eles se movem como se estivessem arrastando o peso do mundo nos ombros. Ao se esforçarem para dar movimento a esse bizarro objeto, constantemente eles param e clamam ao céu por alguma compaixão ou entendimento. Mas o quê esperar dessa máquina? Ao que me parece, não existe nenhuma exigência formal no sentido da constituição de algum significado aparente, apesar desse significado existir subsumido no contexto da abstração. Aparentemente essa máquina possui unicamente a sua existência atrelada à condição de ser mais um elemento nesse aparelho cênico abstrato.

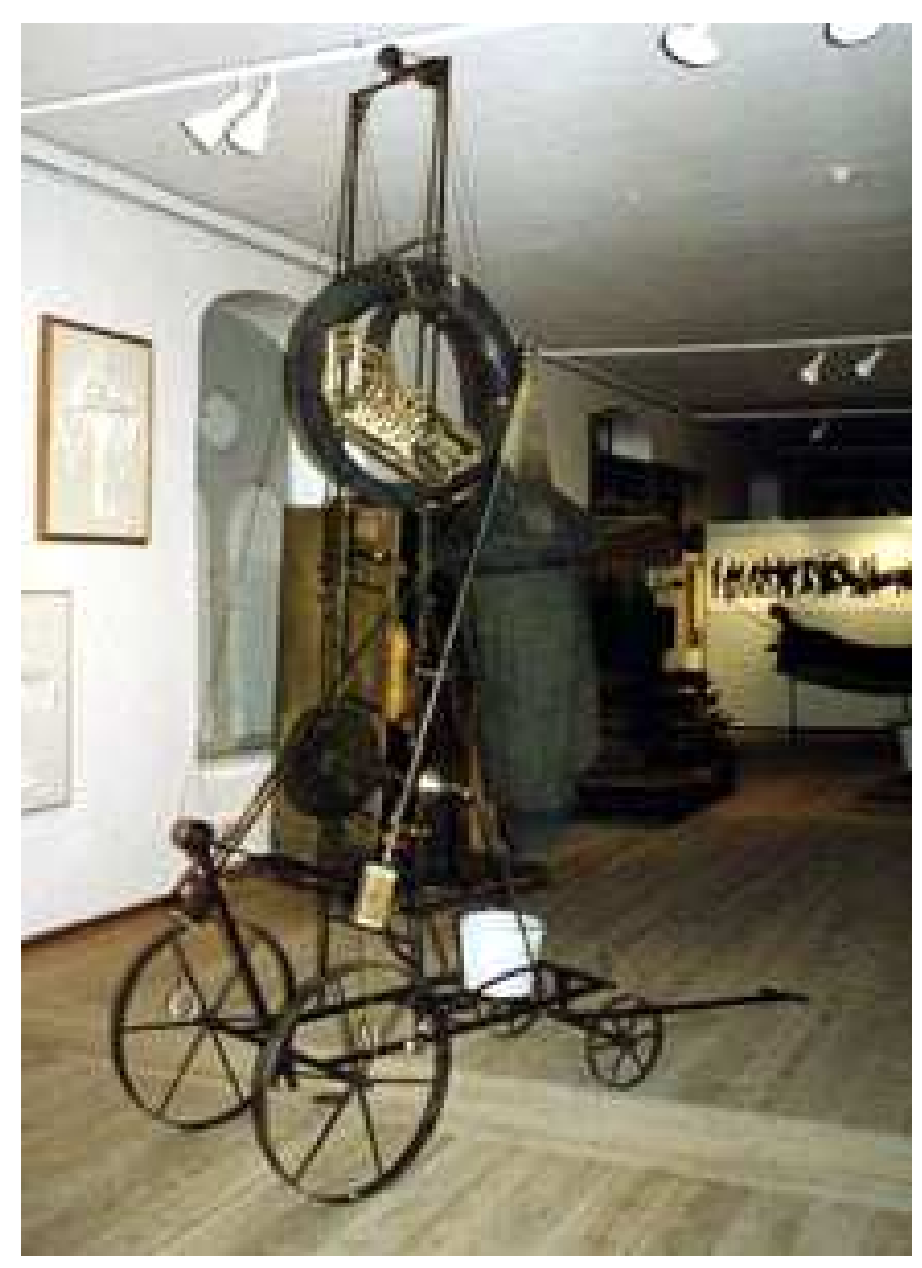

A trombeta de Jericó. Foto: arquivos da Cricoteka.

\footnotetext{
${ }^{104}$ Judeus ortodoxos que vivem a pregar o fim do mundo.
} 
Essa máquina-objeto, cuja existência só é possível em um universo de pesadelo, submete os personagens a uma situação de constrangimento, de opressão e de sofrimento. Eles não sabem para que ela serve. Eles estão intimamente ligados a ela mas desconhecem a sua utilidade. Quais obscuros mistérios ela esconde? Não há uma resposta para isso. Kantor não se preocupa em equacionar os códigos. Eles existem por si mesmos. Por outro lado, essa corda divisória que revela a possibilidade de observação de duas realidades distintas e concomitantes tem seu ponto de fuga em uma das suas extremidades, saindo de um ponto situado sobre a cabeça de um esqueleto sentado em uma cadeira com pequenas rodas. $\mathrm{Na}$ aparência do esqueleto, que tem todos os dentes a mostra, observa-se um tom de escárnio, como se estivesse rindo de tudo e de todos. Evidentemente o esqueleto nos remete de imediato ao significado da morte. Contudo, ao contrário de A classe morta, encenada anteriormente, e de Wielopole Wielopole, feita em seguida, a morte nessa produção não é personificada por um ator, mas por um objeto inanimado. Aqui, a morte está desprovida de "anima", ela está presente o tempo todo mas não age, apenas observa. Nessa caixa de imagens dinâmicas e sincopadas, temos a constatação de que a morte está à espera, espreitando cada movimento.

Como em A classe morta não havia a possibilidade de salvação, nessa encenação Kantor acena para uma possível redenção. Mas de quem virá? De Deus? O mesmo Deus, dos cristãos e judeus, que não ouviu as súplicas dos seus escolhidos a caminho das câmaras de gás e que se associou à indiferença dos Bispos a tudo que acontece do outro lado da corda? Kantor, mais uma vez, oferece dúvidas a respostas. No entanto ele tem esperança e é exatamente esse o ponto. Se na produção anterior ela inexistia, em Onde estão as neves de antanho? a esperança irá ganhar uma materialidade específica e se tornará um objeto.

Vários são os temas que podem ser apreendidos desse pequeno espetáculo. Dentre tantos, observamos a emergência metafórica da esperança e do perdão associados ao lamento pelo desaparecimento das neves brancas. Esse tema foi extraído do Salmo 51, no qual o Rei Davi clama a Deus:

“Compadece-te de mim, ó Deus, segundo a tua benignidade; apaga as minhas transgressões, segundo a multidão das tuas misericórdias. 
Lava-me completamente da minha iniqüidade, e purifica-me do meu pecado.

Pois eu conheço as minhas transgressões, e o meu pecado está sempre diante de mim.

Contra ti, contra ti somente, pequei, e fiz o que é mau diante dos teus olhos; de sorte que és justificado em falares, e inculpável em julgares.

Eis que eu nasci em iniqüidade, e em pecado me concedeu minha mãe.

Eis que desejas que a verdade esteja no íntimo; faze-me, pois, conhecer a sabedoria no secreto da minha alma.

Purifica-me com hissopo ${ }^{105}$, e ficarei limpo; lava-me, e ficarei mais alvo do que a neve.”

Como se pode observar na passagem do Salmo acima transcrito, o arrependimento devolve ao homem a inocência branca da neve. Mas por que os homens deverão se arrepender para tornarem-se puros, se eles cometerão os mesmos erros novamente? ${ }^{106}$. Então, para que a redenção? Será que a esperança na renúncia à violência pelos homens não é uma esperança absurda?

Por mais pessimistas e sombrios que possam aparentar os temas trabalhados no interior do teatro de Tadeusz Kantor, certamente a renúncia completa da esperança não é um deles. Aqui, as considerações de Dante no prólogo de a Divina comédia "abandonai todas as esperanças, ó vós que entrais..." não encontram integral ressonância. É possível estarmos, sim, diante dos portões de Auschwitz mas a fé nos homens parece existir. A esperança de iluminação dos homens, sem nenhuma conotação mística ou religiosa, encontraria a arte como caminho e resposta para a salvação da humanidade. Maria Jarema repetira por diversas vezes que só a arte abstrata poderia salvar o homem. Mas qual o sentido dessa afirmação? Talvez porque na arte abstrata se encontra o princípio de todas as coisas representadas. No mais simples se encontra a essência da totalidade do universo. No Quadrado preto sobre fundo branco de Malevich, no princípio mais claro da abstração, encontramos o zero absoluto, encontramos Deus e a alegórica fundamentação de todas as coisas. Assim, se encontramos Deus em uma representação abstrata, a trombeta de Jericó, a estranha

\footnotetext{
${ }^{105}$ Espécie de planta medicinal.

${ }^{106}$ Como já foi visto anteriormente, só que de uma maneira menos abstrata Kantor utilizou essa mesma temática para a criação de Ô douce nuit durante o Festival de Avignon em 1990.
} 
materialização do desconhecido, da crença e da fé no outro mundo, torna-se a forma material do desconhecido e do incompreensível fardo carregado pelos judeus nas provações históricas como povo. Todavia, a Jericó de Kantor está muito longe de ter os muros derrubados. O anti-semitismo não desapareceu com o fim da guerra.

Apesar da intolerância, a humanidade sonha em ser branca e inocente como a neve,

“...mas da neve verdadeira, nada resta do seu brilho". 107

Isso é representado no espetáculo por um grande pedaço de papel branco que é manuseado pelos atores no espaço e no sentido delimitado pela corda. A inclinação dadaísta de Kantor em representar com materiais e objetos diversos de forma a desviar o seu uso, sugere através da brancura do papel uma história que ainda não foi escrita devido às lembranças da agonia de uma catástrofe que todos temem repetir. De certa maneira, trata-se de um tempo passado que necessita ser revisto. Assim, o papel branco, as neves artificiais, revelam a oportunidade de a história ser reescrita ou pelo menos de ser compreendida para que possa, no seu devir, alcançar o alívio da provação e do martírio e assim reencontrar a inocência e pureza perdidas. É exatamente por isso que no espetáculo, o soldado, ainda que de maneira mecânica aparente seus movimentos, está vestido de branco e sua roupa é feita com o mesmo papel que foi anteriormente manuseado pelos atores. Kantor, em sua relação pessoal com o exército e com a perda da individualidade instituída por esse, traz para a cena um soldado individualizado e distinto da generalidade institucional. O soldado, o poder totalitário na sua mais íntima individualidade, pode recuperar as neves que o abandonaram.

Como o papel branco esticado feito toalha de mesa sob a corda que acaba unindo os dois espaços representa a idéia dos valores que foram perdidos e, ao mesmo tempo, o intenso desejo do seu retorno, esse objeto notadamente traz em si a mensagem material da esperança e, conseqüentemente, a abstração adquire a forma de objeto. Isso quer dizer exatamente que a esperança se tornou uma folha de papel e sua especificidade, a pureza e inocência, o branco da folha. Evidentemente, no espetáculo, essa busca pela pureza através da simbologia da brancura da neve se mostra falseada pois o papel é um

${ }^{107}$ Scenes - Revue de l'espace Kiron. Paris: ALPHA FNAC, no. 2 Avril, 1986, p. 22. 
simulacro, é a representação sensível de um determinado aspecto de uma representação inteligível, obviamente, sem matéria. Apesar dessa representação se instituir como "falsa noção" da apreensão do valor representado, em Kantor a percepção desse valor é determinado por um "pathos" individual o qual determina a situação que o estado desse valor tem para a sua vida.

Algumas das digressões feitas nessa cricotage terão a sua forma desenvolvida na cena final de Wielopole Wielopole na qual a esperança está associada a uma toalha de mesa, um signo típico polonês utilizado nas mesas durante as refeições feitas no natal. Se o teatro de Kantor recorre insistentemente à lembrança histórica da condição humana em face da constante ameaça de dor e sofrimento imposto pela guerra, em Wielopole Wielopole, Kantor retira da toalha branca todas as leituras imediatas do seu repertório lingüístico para atribuir a ela a referência à fraternidade e à esperança. $\mathrm{O}$ branco nas duas produções contrasta com a condição humana de degradação e morte. Entretanto, o sentimento de esperança é totalmente fugidio. Em Wielopole Wielopole, após um lampejo de esperança que surge com a cena que lembra as ceias de natal e, conseqüentemente, as conotações significativas que a ela estão associadas, a cena se transforma em eucaristia, a última ceia a qual antecede a agonia, o martírio e a morte de Jesus Cristo. Nesse contexto, a esperança dura um breve instante. Semelhante ao que foi encenado em A classe morta, quando, através da máquina familiar e do berço mecânico, Kantor associa a morte como condição inexorável da vida, em Wielopole Wielopole, os códigos presente na mensagem de natal sugerem que um nascimento pode redimir a humanidade. Kantor imediatamente desconstrói essa noção, fazendo derivar dela a conotação de que a redenção que conduz à pureza é fatalmente sobrepujada pela intolerância e suas ramificações. A esperança no teatro de Kantor existe, mas ela é frágil e delicada como a neve. 


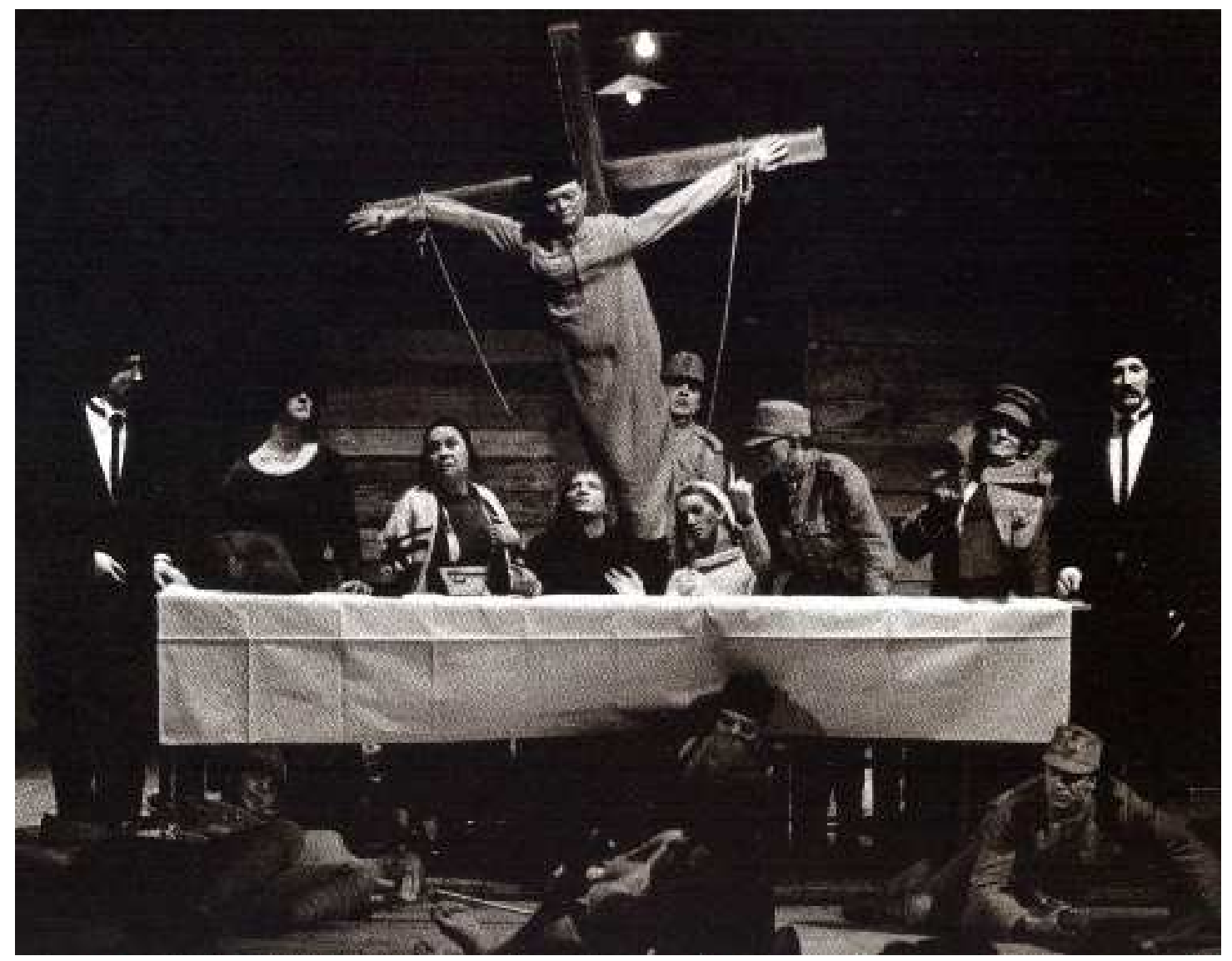

A cena como eucaristia no final de Wielopole Wielopole. Foto: Maurizio Buscarino.

Onde estão as neves de antanho? antecipa muitas das situações temáticas que serão realizadas em Wielopole Wielopole. Os signos históricos que são convocados para essa cricotage são simultaneamente desrealizados, devorados em um redemoinho de situações que extrai a sua significação simbólica ou referencial através do humor, no sentido quase de uma farsa provocativa. Assim, a trombeta de Jericó, com sua bizarra aparência, não tem por objetivo destruir os muros da cidade bíblica; aqui, ela procura, de uma maneira burlesca, desestruturar a objetividade de leitura direta do espetáculo, introduzindo na cena um elemento desconhecido e que desestrutura toda a construção referencial do teatro tradicional. Tradicional no sentido da representação mimética e de um teatro de conflitos. Temos aqui, não um diálogo em primeiro grau, cotidiano, mas um diálogo que é essencialmente intuído, o que pode nos fazer pensar em uma poética simbolista em Tadeusz Kantor. Evidentemente esse raciocínio procede em alguns aspectos, sobretudo naquilo que diz respeito à construção das imagens. Em uma peça sem contexto, sem forma dramática, o conflito é substituído por uma série de vibrações 
internas. Não existe o conflito pois esse é substituído pela tensão. Tensão que, por sua vez, está alicerçada na avassaladora expectativa da morte. Assim, qualquer perspectiva de crise é solucionada pela morte, pois essa resolve tudo, independentemente de tudo e de todos.

Em Onde estão as neves de antanho?, o tema é abstrato: a salvação pelo arrependimento. Diante da morte, as personagens não têm nenhum controle sobre qualquer acontecimento. O sentido do trágico em Kantor, pelo menos desde A classe morta, não resulta do fracasso das paixões humanas ou do esforço divino mas se revela como no simbolismo, e principalmente como em Schopenhauer, do choque com as forças exteriores que fogem ao controle do homem colocando-o entre a vida e a morte $^{108}$. No caso específico dessa produção, é a lembrança da morte que estabelece a dimensão do trágico. A máquina misteriosa, inexplicável para os Hassindins, também institui o tempo como elemento que está além do controle humano. O clamor dos Hassindins é pelo passado, mas também é pelo esclarecimento do presente e do futuro. Talvez a trombeta de Jericó seja o signo representativo através do qual ruíram todos os projetos do Iluminismo. Quais preces clamorosas deverão ser entoadas para que a barbárie não se repita? E mais uma vez, uma pergunta sem resposta. Tudo é mistério.

Ao que me parece, como na pintura de Goya, em muitas das suas gravuras que retratavam aparições e figuras sobrenaturais, muitas saídas dos sonhos e pesadelos do artista, o teatro para Kantor, através do desastre, do horror e da fantasmagoria, motivadores da erupção de um outro mundo, é um meio para se chegar ao mistério ao mesmo tempo em que o mistério é um meio para se chegar ao teatro. Uma peculiaridade nessa relação de Kantor com a pintura barroca, principalmente com Goya, trata-se do fato de que na sua pintura, Kantor não representou o terror nazista e a ocupação da Polônia pelo exército alemão. Indiretamente ele realizou isso através de Goya, do

\footnotetext{
${ }^{108}$ De acordo com o peculiar pessimismo da filosofia de Schopenhauer, toda a vida é sofrimento porque é um constante querer eternamente insatisfeito, que leva ao amor, ao ódio, ao desejo ou à rejeição. Schopenhauer elimina Deus da sua visão de mundo e em seu lugar coloca uma "vontade universal" que é a força voraz e indomável da própria natureza. A vontade aqui nada tem a ver com a decisão racional por uma opção de agir, mas trata-se de um ser absoluto, essência primeira, a coisa em si que gera todas as coisas deste mundo. Essa vontade, que é também um substrato, a coisa em si, no homem, é responsável pelos seus apetites incontroláveis. Ao final o homem encontra a morte, o golpe fatal que recebe a vontade de viver.
} 
passado do pintor espanhol em uma Espanha ocupada pelo exército napoleônico que cometia todas as formas de desmandos e que, paradoxalmente, atuava sob as ordens dos representantes dos ideais iluministas. Foi sobre esse contexto que ele pintou a série sobre os soldados de Napoleão, em que, metaforicamente, a Espanha de Goya se torna a Polônia de Kantor.

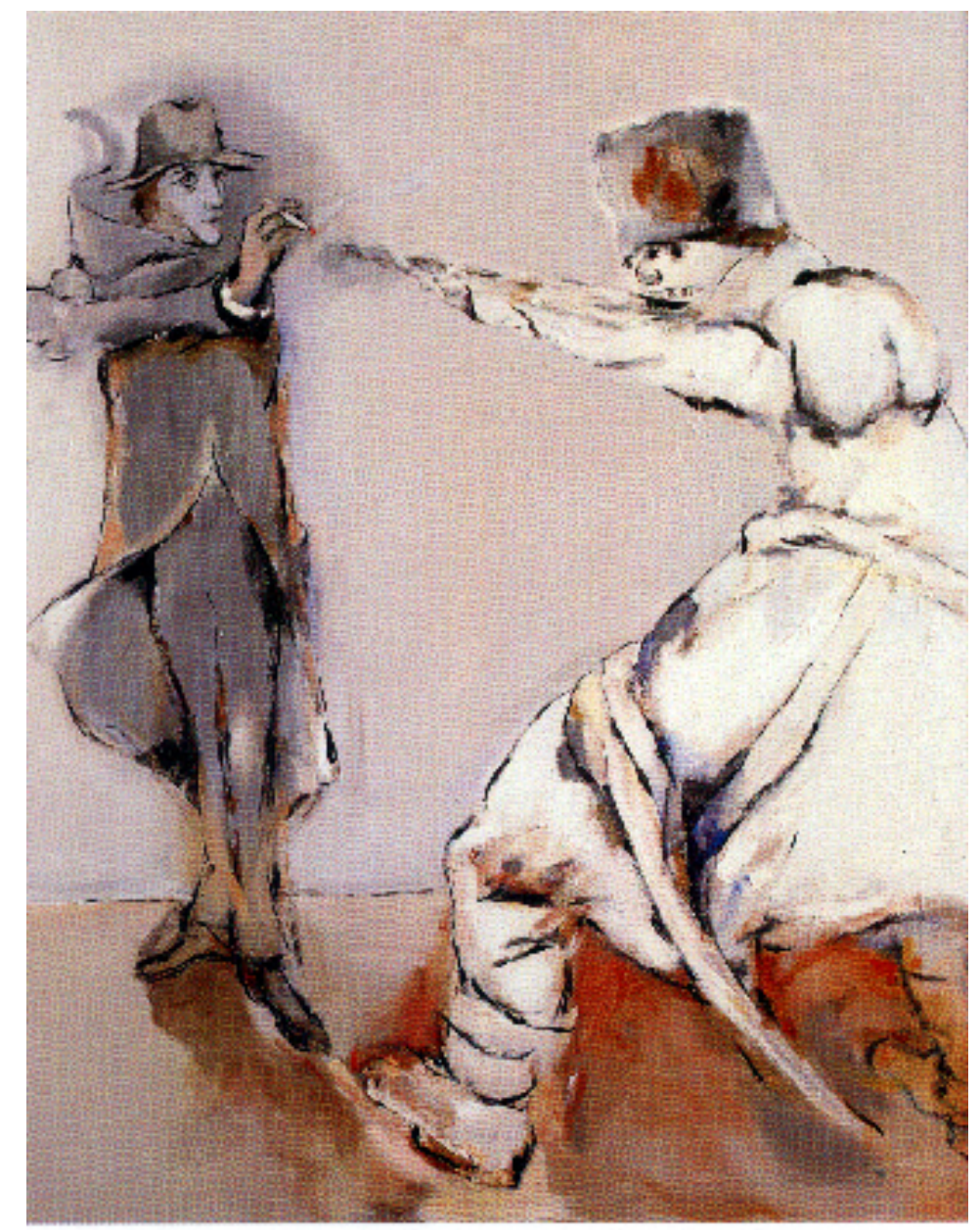

Tadeusz Kantor - Certo dia o soldado napoleônico do quadro de Goya invadiu o meu quarto da imaginação. Acrílico sobre tela, 1988. Foto: Janusz Podlecki.

Evidentemente, a relação entre dois universos que se contaminam vão além das relações entre o teatro e a pintura e se estendem para os diversos temas, metáforas ou alegorias que se sucedem nas produções: os adultos que assassinam a sua infância, o passado tornado presente, o vivo confrontado com a mecânica dos manequins, entre outros. Esses, dentre tantos elementos que em um contexto suscitam insistentemente um mundo invadido por outro através das máquinas insólitas, dos objetos prontos ou 
construídos, suscitam situações que sempre degeneram em contos absurdos cujos elementos estão conjugados em uma espécie de poesia estranha, com um certo coeficiente de nostalgia, mas turbulenta e corrosiva e que consegue, ao mesmo tempo, ser insolente e hilariante, repletas de momentos de extrema energia; paroxismos, como se cada espetáculo fosse decomposto e se recompusesse infinitamente diante dos olhos do espectador. O teatro de Kantor trata-se de uma tela viva na qual todos os elementos, formas e imagens, sem cessar, não se cansam de se formar e de se desagregar. Enfim, os espetáculos se constituem em uma espetacular galeria em que as imagens, como que fixadas em uma tela, transpostas das visões de Kantor, tornam-se a quintessência do movimento e do arranjo, na cena, dos diferentes elementos que; apesar da aparente desconexão, as cenas que são por eles compostas se comportam como em uma espécie de silogismo simbiótico. A conjugação das cenas é perfeita. Existe uma minúcia na organização dos signos que são próprios à poética de pintor e esse talvez seja o maior paradoxo do seu teatro. Ele funciona como se quisesse se lançar no tempo rompendo com as convenções de efemeridade a que o teatro está submetido. Dessa forma, os limites entre o teatro e a pintura tornam-se indistintos. As telas se comportam como cenas autônomas ao passo que cada cena se constitui como uma tela. Resumindo, as imagens estão além da forma e o teatro está além do teatro.

Como na poética simbolista, a ambigüidade do discurso, em Kantor, substituído pela imagem, é representada por uma relação de vários sentidos entre as personagens e os objetos. Da mesma maneira que ocorre no teatro simbolista, nenhum objeto no teatro de Kantor é decorativo. Ele existe no espetáculo para acentuar um efeito e tornar externa uma visão interior. Outra característica que aproxima o teatro de Kantor do teatro simbolista se trata do valor atribuído à música como elemento de comunicação não racional, como forma de condução para uma visão subjetiva. Isso é próprio do teatro de Kantor a partir do período do Teatro da Morte.

A ambigüidade da imagem em substituição à ambigüidade do discurso simbolista, associa-se necessariamente ao processo de conhecimento irracional trabalhado por muitos dos surrealistas, como Salvador Dalí e Magritte, que se por um lado contribuíram para o total descrédito do mundo da realidade e questionaram os nossos pressupostos acerca do mundo e das relações entre um objeto representado e um objeto real, por outro, no Segundo manifesto surrealista, escrito em 1930, conforme 
comenta André Breton, a principal finalidade do Surrealismo, pelo menos naquele momento, era o de determinar a existência daquele ponto, situado na mente humana, em que a morte e a vida, real e imaginário, passado e futuro, comunicável e incomunicável, e todas as contradições deixam de ser percebidas como contraditórias. Essa percepção das finalidades do Surrealismo apontadas por Breton não tinham em vista o estabelecimento de estados contraditórios em relação ao real expressos nas imagens. Aquilo que André Breton propõe e que será, a meu ver, de maneira semelhante, encontrado na obra de Kantor, mais intensamente após $A$ classe morta, será a resolução das contradições em um estado, um universo de "supra-realidade". Em Kantor, esse estado de supra-realidade, a melhor inspiração do Surrealismo visual, constituir-se-á a partir da imagem, como um buraco realidade. Esse buraco, essa fenda no espaço-tempo, desde $O$ retorno de Ulisses, como venho insistentemente afirmando, dentre todos os elementos do seu teatro, o objeto, como veremos, é o meio através do qual essa realidade outra se configura. Entretanto, antes de entrar efetivamente na demonstração desse ponto, acredito ser de necessária importância uma observação mais pontual acerca de algumas questões que foram insistentemente citadas nesse capítulo por serem recorrentes ao universo poético de Tadeusz Kantor transpassando toda a sua obra. Questões como o tempo, a morte, e o objeto como estrutura de construção da imagem. 


\section{CAPÍTULO III}

\section{A ESPECIFICIDADE DO TEMPO, DA MORTE E DO OBJETO- IMAGEM NA POÉTICA KANTORIANA}

\section{O EU DIVIDIDO E O TEMPO INVARIÁVEL}

Nesse trabalho, ao falar do objeto no teatro de Kantor, optei por não pensar no objeto em sua perspectiva filosófica de desenvolvimento por acreditar que, especificamente no teatro de Kantor, não existe o interesse em questionar as funções do objeto do ponto de vista da sua existência enquanto entidade, seja na cena, seja na vida cotidiana. Por esse caminho, a opção feita foi por não me prender a questões e interpretações, como em Freud por exemplo, sobre o seu conceito de objeto pois a única relação a qual acredito possa existir, trata-se, em relação ao teatro de Kantor, do objeto usado como elemento da construção da subjetividade, em que as figuras do sujeito e do objeto, ou melhor, entre um eu e um outro, encontrarão sua base de sustentação e também de divergências ${ }^{1}$. Essas são questões que, embora pertinentes enquanto questionamentos filosóficos e psicanalíticos, fugiriam, acredito, do objetivo primordial desse trabalho pois o objeto em Kantor não pretende ser nada além daquilo que é. Ele não está destinado a qualquer processo de reificação da sua condição de objeto, mesmo quando ele se torna protagonista que apesar dessa condição, a ele não é atribuída nenhuma humanidade.

Mas por outro lado, se na sociedade capitalista o trabalho é a essência constitutiva do homem e o fetichismo da mercadoria está diretamente relacionado ao

\footnotetext{
${ }^{1}$ A relação sujeito objeto em Freud é um dos pontos chaves para a compreensão daquilo que hoje chamamos de ego. Na medida em que Freud aprofundou a sua pesquisa sobre o funcionamento e constituição da psique do sujeito, se pode observar, na relação entre sujeito e objeto, que ambos fazem parte de um quadro maior que se chama subjetividade. Essa temática é vista, não somente em Freud, mas em muitos de seus seguidores, principalmente Lacan.
} 
processo de reificação das relações humanas, os objetos fetiches, que não são ilusões, possuem de fato uma existência real e uma influência concreta sobre os indivíduos. Por esse caminho, é evidente que podemos pensar, em Marx, dentro do conceito de reificação, um princípio através do qual os objetos tornam-se cada vez mais sujeitos e através deles se dá a ligação, a comunicação do homem com a realidade, e através desse processo, a utilização cada vez maior de um elemento intermediário no processo de construção dessa mesma realidade.

Processo semelhante acontece em Kantor, algo como uma "reificação às avessas", em que a realidade torna-se a própria realidade do objeto que passa a ser percebida também como sujeito. No entanto, em Kantor, o objeto, apesar de também ser intermediário, elo de ligação com outra realidade, a ele não é atribuído nenhuma condição de valor. Valor que se institui como abstrato, que não tem potencial para troca e que pode ser única e somente utilizado como objeto de arte. Mas uma arte que não pode e não deve ser consumida; pelo menos não do ponto de vista do trabalho e do capital. Em Kantor, o objeto é sempre aquilo que é enquanto objeto real, da mesma forma como o ator continua sendo o homem que é como homem real.

Existe um mito de que o ator, no teatro de Kantor, é apenas um objeto ${ }^{2}$. Eu pessoalmente acredito que essa é uma concepção equivocada já que, da mesma forma que um objeto qualquer é usado na cena como um objeto qualquer, em um determinado momento do teatro de Kantor o mesmo se aplica ao ator que passa a ser visto como um homem real na sua condição de homem real. Também não existe, acredito, o processo de reificação do ator já que se esse homem é utilizado na condição de homem real com todos os seus atributos reais e cotidianos; esse ator não se torna um objeto no sentido que Marx atribuía ao processo de transformação da força de trabalho humana em mercadoria, pois a arte de Kantor, a priori, não é destinada ao consumo. Por esse caminho, se o ator, nessa fase do teatro de Kantor, nada mais é do que um homem comum, cotidiano, a sua condição de ator não se justifica já que, em tese, a sua produção também não poderia ser consumida. Isso fica ainda muito mais evidente quando Kantor atribui aos seus atores a aparência de um morto. Se o ator carrega em si a aparência da morte, ele torna-se, da mesma maneira que uma cadeira quebrada, sem

\footnotetext{
${ }^{2}$ Convém destacar que essa concepção do ator como objeto, no teatro de Kantor, passou a ser utilizada pelos críticos a partir dos espetáculos que foram encenados após a fase do Teatro da Morte.
} 
valor nenhum para a civilização do consumo e seus destinos, conseqüentemente, são endereçados ao lixo, ou seja, à lixeira e à cova respectivamente.

Dessa forma, o ator torna-se mais um elemento do diálogo, semelhante em grau de importância a qualquer outro elemento que compõe a cena, assim como o objeto também passa a ser entendido como sujeito essencial para o desenvolvimento da ação. Ação que é uma perfeita simbiose entre os dois elementos. Evidentemente, essa é uma técnica de pintor e é por isso que se atribui ao "ator" a condição de objeto. Aquele que perde a autonomia enquanto ser criador para se tornar unicamente elemento, como uma cor ou um traço da criação demiúrgica de Tadeusz Kantor.

Por outro lado, sob determinado aspecto, também é possível entender esse processo do ponto de vista da construção da subjetividade, como uma espécie de dissolução do eu individual de Kantor no meio da totalidade histórica. Como comenta Renato Palazzi:

“...o eu hebraico dissolvido no holocausto e na diáspora, é o eu polonês suprimido em sua própria identidade nacional e constrangido por uma outra diáspora, mais moderna, na qual, ser judeu ou polonês não é uma referência étnica, mais o símbolo de uma condição universal. Em suma, isso é o conceito de um eu meta-histórico e, entretanto, profundamente comprometido com a história que o engole como um buraco negro ou vazio cósmico as tragédias do nosso século, grandes ou pequenas, pessoais ou coletivas, reativando-as em imagens teatrais." ${ }^{3}$

Nesse sentido, mesmo o eu individual de Kantor, em cena, que vive e se movimenta em um espaço real, está diluído, a partir do seu "quarto da memória”, nas diferentes etapas e elementos que compõem a cena. No palco, Kantor, o eu real, observa a dissolução do seu próprio eu, da sua própria história nas personagens que ele cria em relação ao passado, ao presente e ao futuro. É por isso que em determinado momento da sua carreira, mais no final da sua vida, ele irá dizer que toda a sua criação nada mais foi do que reflexo da sua vida frente aos acontecimentos e situações nas quais ele viveu. Assim, quando ele se propunha a rever a sua infância, por trás dos bancos, ou sentado no seu carro infantil, não era ele, mas outra pessoa que estava em seu lugar. Da mesma forma, quando ele queria morrer, algum outro representava a sua morte. Nessa luta

\footnotetext{
${ }^{3}$ Palazzi, Renato. Le théâtre du moi partagé et du moi reconstruit. In. Kantor, l'artiste à fin du XXe. Siècle. Org. Georges Banu. Paris: ACTES SUD - PAPIERS, 1990, p. 98.
} 
titânica consigo mesmo na tentativa desesperada de organizar o seu ser multiforme, Kantor se serve de materiais muito pessoais, de determinadas ferramentas de trabalho que são a ele incansavelmente associadas, a exemplo da morte e da memória.

A morte e a memória são as coordenadas através das quais Kantor prepara o terreno para o drama escarnecedor da derradeira angústia do eu. A relação entre sujeito e objeto se dá evidentemente através da ação do eu de Kantor situado em todas as dimensões do seu ser, em concordância ou dissonância com os objetos das suas lembranças. Em Kantor, a história é o objeto. Dessa forma, a subjetividade artística de Kantor será erigida a partir de si mesmo e os objetos materiais se tornarão os vínculos da sua consciência presente com o passado e com o futuro. Ainda, nesse processo de construção da subjetividade, ao lado da memória, também existe o tempo que é outra noção fundamental do seu teatro.

Em se tratando do tempo, no teatro existe uma espécie de dupla natureza do tempo no qual o tempo histórico é uma realidade que se insere necessariamente no texto e na representação. Devido a suas temporalidades e de seu modo de produção, o teatro é sempre situado na história. De um lado, temos o tempo representado que está associado ao desenvolvimento da fábula - trata-se do tempo dramático. De outro, temos o tempo da representação, o tempo cênico, que segundo Patrice Pavis:

“...é o tempo vivido pelo espectador confrontado ao acontecimento teatral, tempo eventual, ligado à enunciação, e ao desenrolar do espetáculo..."4

A representação acontece sempre no presente e da mesma forma se desenrola o tempo. A representação fornece todos os dados que se passam diante de nós em função da nossa temporalidade como espectadores. Isso nos dá a noção de início e fim da representação. O tempo dramático, por sua vez, "é o tempo da ficção da qual fala o espetáculo",5, está ligado à realização de que algo acontece, aconteceu, ou acontecerá no universo da ficção. Muitos autores chamam de tempo teatral a correlação entre aquilo que acontece entre o cênico e o dramático, ou seja, entre o real e a ficção. No entanto, diferentemente disso que foi indicado acima, em Kantor, existe uma espécie de tempo

\footnotetext{
${ }_{5}^{4}$ Pavis, Patrice. Dicionário de teatro. São Paulo: Perspectiva, 2001, p. 400.

${ }^{5}$ Ibid.
} 
mítico, estrutura semelhante àquilo que também pode ser observado no teatro de outro importante diretor polonês da atualidade, Leszek Madzik ${ }^{6}$, que recebeu muita influência de Kantor, e também no espetáculo Dicotomias - fragmentos squizofrê $\hat{e}^{7}$, de Ana Maria Amaral.

Existe na obra dos três artistas uma espécie de tempo mítico, um tempo que está intrinsecamente associado aos acontecimentos primordiais que faz com que o espetáculo aconteça em um único instante, em uma fenda no espaço-tempo, sobrepondo-se constantemente a si mesmo. Dessa forma, a ação do tempo não acontece de maneira linear, mas ciclicamente, em que as situações, duplas e paralelas, justapõem-se constituindo uma narrativa fragmentada que organiza o entendimento de cada observador individualmente.

Em um jogo de contrastes, Kantor, Madzik e Ana Maria Amaral, não fornecem ao observador uma ação temporal na qual os acontecimentos se sucedam linearmente. As situações são resolvidas em si mesmas pois o processo está diretamente ligado à criação de imagens e como já foi dito no primeiro capítulo, as imagens são capazes de desenvolver atividades inconscientes no pensamento do espectador. Assim, a fragmentação das cenas associadas às tentativas frustradas de pensamento consciente, possibilita a não repetição do tempo pois ele funciona como um constante retorno a um momento presente. O tempo não se desenvolve, ele somente acontece. Em função do tempo, os espetáculos de Tadeusz Kantor e os de Leszek Madzik, assim como Dicotomias - fragmento skizofrê, funcionam como uma cerimônia imagética situada fora do tempo histórico. Nesse sentido, as imagens fixadas pelo observador tornam-se símbolos puros.

\footnotetext{
${ }^{6}$ Diretor do Scena Plastyczna (Cena Plástica) - KUL (Katolickiego Uniwesytetu Lubelskiego) - Grupo mantido pela Universidade Católica de Lublin. Leszek Madzik (1945) é formado em história da arte nessa mesma universidade, e ainda como jovem pintor, também passou a se dedicar ao teatro por entender, entre outras coisas, que uma tela é insuficiente para obter do observador a mesma intensidade de reações, sentimentos e emoções, que é capaz de produzir um espetáculo realizado ao vivo diante de um espectador. Madzik abandona a palavra, se apega à imagem que é fortemente amparada pela exploração da luz no espaço. Se utiliza ainda de objetos, bonecos, e da presença silenciosa do ator que é usado como mais um elemento na criação das imagens. Em seu teatro existe uma certa relação com o sagrado que leva o espectador a refletir acerca da sua existência e sua relação emocional com a realidade.

${ }^{7}$ Dicotomias - fragmentos skizofrê é uma produção realizada pelo O Casulo BonecObjeto, que através de sons, sombras, máscaras, bonecos, ou objetos, atua diretamente sobre as emoções do espectador. Os personagens do espetáculo são imagens agem diretamente na nossa subjetividade a fim de nos transportar para um outro tempo, um outro espaço. A peça que teve a sua estréia no ano de 2003, permaneceu em cartaz em viagens por diversos festivais pelo Brasil até 2007.
} 
Dessa forma, o tempo no teatro de Kantor se modela como a estrutura ideal através do qual ele pode ativar toda a atividade do seu ser. O tempo se constitui no elemento que corta, transforma e multiplica a ação cênica ativando a presença simultânea de momentos em que o indivíduo se perde na totalidade. Ou seja: na dissolução do eu de Kantor entre os vários momentos do espetáculo.

O tema dessa identidade fragmentada em segmentos temporais pode ser observada em diversos momentos da jornada artística de Kantor, entretanto, a mais explicita trata-se de Que morram os artistas!, em que a negação do eu individual é colocada em evidência pela sua presença na cena como o eu real que observa simultaneamente o encontro do seu "eu criança", reconstrução do passado de uma maneira aparentemente deformada pela memória, com o seu "eu morrendo", "projeção da memória atávica do futuro"8. Tudo isso acontece diante do olhar do verdadeiro Kantor que se constitui, com sua presença em cena, como o agente ativo de uma construção poética, a qual participa ao mesmo tempo em que fica ao lado da construção. A sua memória age de maneira livre, em estado puro, autônoma, independente de qualquer estado de verossimilhança. Trata-se de uma memória que apenas recorda, não se tratando, freudianamente, da manifestação de uma vontade ou de um sentimento reprimido que encontra na arte, no teatro, um meio para sublimação. Trata-se, porém, da memória de um sujeito que age em relação aos objetos de sua história privada constituindo um terreno no qual o eu acredita realizar a sua vida. Dessa forma, a memória se apropria do espaço impondo seu caráter transformador e transitório para celebrar, conforme as palavras de Renato Palazzi:

"seu banquete de felicidade entre as cinzas de uma vida que cegamente se acreditava aberta para as energias do futuro"9.

Todo o teatro de Kantor, não importando qual a perspectiva de análise, sempre nos conduzirá a determinadas profundezas inquietantes. As imagens, principalmente aquelas construídas a partir de A classe morta, foram se perfilando continuamente uma após a outra, constituindo-se como metáforas amedrontadoras desse eu dividido, estratificado entre a memória e o sentimento de outro mundo, de forma que o eu se

\footnotetext{
${ }^{8}$ Palazzi, Renato. Le théâtre du moi partagé et du moi reconstruit. In. Kantor, l'artiste à fin du XXe. Siècle. Org. Georges Banu. Paris: ACTES SUD - PAPIERS, 1990, p. 96.

${ }^{9}$ Ibid.
} 
constrói como resíduo do passado e, ao mesmo tempo, como estado premonitório do futuro fatal e inelutável. Por esse caminho, somos levados a pensar que com seus desfiles de máscaras macabras e clownescas, dos simulacros dolorosos dos personagens, objetos e manequins, Kantor se coloca em frente do espectador como espelho cujo reflexo é deformante e impiedoso, destruidor de toda certeza sobre a continuidade real da existência. Na face desse espelho, toda a visão do existir fica obscurecida.

Diante de todas essas considerações, e diante das diversas possibilidades de interpretações do objeto a partir do pensamento poético e uso cênico desses, acredito ser o mais importante a compreensão desse fenômeno no teatro de Kantor. Antes de qualquer outra coisa, penso que é necessário se conhecer os mecanismos que determinaram o surgimento desse fator na sua produção artística. De uma maneira geral, eu insisto novamente nisso, o objeto, em Kantor é somente um objeto que deve ser utilizado como objeto real. O objeto para ele deve ser constantemente lembrado, reconhecido como tal. Nesse sentido, há uma concordância com a afirmação de Adorno $^{10}$ sobre a reificação ser esquecimento. Isso quer dizer que, ao ser reificado o homem e, ao ser humanizado o objeto, deixam a condição de ser aquilo que são e passam a ser vistos como coisa e sujeito respectivamente. Em resumo, a meu ver, a reificação do homem-sujeito, trata-se da sua "coisificação", ao passo que a humanização, "reificação às avessas", da coisa-objeto, seria a sua transformação em sujeito. Esse processo, no entanto, não acontece dessa forma no interior do teatro de Kantor. Caso possamos falar em reificação e humanização em Kantor, essa relação entre sujeito e objeto, apesar de homem e coisa serem entendidos e colocados lado a lado, reconhecidos como o mesmo grau de valor, não existe o esquecimento da sua condição de objeto real. A lembrança e a memória são fatores de fundamental importância para o entendimento do objeto em Kantor. Para ele, e isso já foi dito insistentemente por mim, em passagens anteriores, o objeto deve ser protegido, salvaguardado do esquecimento. A própria história como objeto necessita insistentemente ser lembrada e os objetos são os meios mais eficazes para isso. O teatro de Kantor é uma luta incessante da memória, da mesma forma que Adorno irá conceber em Educação após Auschwitz. ${ }^{11}$ como um

\footnotetext{
${ }^{10}$ Adorno, T. W/Horkheimer, M. Dialética do esclarecimento. Rio de Janeiro: Zahar, 2006, p. 190.

${ }^{11}$ Adorno, T. W. Educação após Auschwitz. In: Educação e emancipação. Rio de Janeiro: Paz e Terra, 1995. p. 119-138.
} 
princípio de não esquecimento - lembrar para que a história não se repita - lembrar sempre da dor, da humilhação, do sofrimento e da morte.

\section{A MORTE COMO POÉTICA}

Mesmo a morte sendo recorrente em toda a sua obra, Tadeusz Kantor nunca esteve interessado em explicá-la como fenômeno. Por se perceber finito mediante a consciência da própria morte, a arte de Kantor se mostra como sublimação da vida à espera do inevitável e é através da arte que ele realiza a sua crença na imortalidade da vida depois da morte, e de certa maneira a notória recusa da própria destruição e o anseio pela eternidade.

Deixando o ponto de vista de um artista imbuído de um forte sentimento de dor e de catástrofe e passando para os domínios do desenvolvimento da civilização, é possível perceber, desde os seus primórdios, que a morte é a responsável pelo aparecimento das primeiras angústias existenciais e metafísicas do homem. Disso decorre, evidentemente, o culto aos mortos em todas as culturas. Assim, a morte se mostra, desde o princípio da civilização, como uma fronteira que não significa somente o fim da vida mas o começo de outra realidade, na maioria das culturas: desconhecida e aterradora. Desde o início dos tempos, a consciência religiosa sempre ofereceu um conjunto de convicções que indicaram os rumos do comportamento humano frente ao mistério da morte, fosse através dos primitivos rituais, fosse através de religiões mais organizadas. É exatamente por isso que a angústia da morte criou a crença na imortalidade através da aceitação do sobrenatural e da admissão do divino e do sagrado como verdade fundamentada na fé.

Em Kantor, a morte é um processo que está muito distante do sobrenatural. Ela é a condição finita da temporalidade que fundamenta o sentido da existência e que permeia o tempo todo a vida humana. Lembrando, em A classe morta, na cena familiar, o nascimento se institui como a primeira morte no sentido de perda, a primeira perda, a primeira separação. Podemos também observar a oposição entre os velhos e os 
manequins de crianças, o velho e o novo, que continua a repetir indefinidamente o primeiro rompimento, o que explica a angústia presente nas personagens diante do esfacelamento da vida física no tempo. Dessa forma, é possível observar no teatro de Kantor, a divisão do homem entre corpo e espírito, deixando esse de ser mero objeto da natureza para se tornar possibilidade de transcendência ${ }^{12}$ para alguma coisa além dele mesmo.

Para Kantor, o transcender significa conquistar outra dimensão na qual a arte se institui como realidade sensível e, ao mesmo tempo, desconhecida daquilo que está oculto dos sentidos, mas que é patente à consciência. Isso remete Kantor mais uma vez de encontro a Malévich cujas:

“...formas elementares pretendiam anular as respostas condicionadas do artista ao seu meio ambiente e criar novas realidades não menos significativas do que as realidades da própria natureza..."13

Assim como em Malévich, o quadrado, que nunca se encontra na natureza, institui-se como repúdio ao mundo das aparências e da arte passada; em Kantor, por sua vez, ao trazer para o seu teatro a aparência e os fundamentos da morte, repudia o teatro como imitação da vida. Dessa maneira, tanto o quadrado de Malévich quanto a morte em Kantor, em nenhuma circunstância se configuram como estruturas "nadificadas". Pelo contrário, transbordam significados, exatamente por aparentarem "nada ser", parafraseando Jean Paul Sartre ${ }^{14}$ sobre a consideração de que do nada se chega às coisas. Dessa forma, o conhecimento sensível é substituído pelo inteligível já que as possibilidades de existência de representação, nos dois casos, encontram-se fora do alcance dos sentidos. Nas Lições de Milão, Kantor fala sobre isso:

\footnotetext{
"Minha criação e minhas obras cujas fontes provém do subconsciente "compreendem" esta voz interna e comanda bem mais cedo e bem mais rapidamente.

Nesse caminho o intelecto realiza mais claramente as NOVAS RAZÕES:

ESPIRITUALISMO

IMPERATIVO DA ALMA.

SENSAÇÃO DE UM OUTRO MUNDO.

${ }^{12}$ No sentido moderno mais usual definido por Heidegger que estabelece como transcendente a relação entre o homem e o mundo.

${ }^{13}$ Scharf, Aaron. Suprematismo. In. Conceitos da arte moderna. Rio de Janeiro: Zahar, 2000, p.121.

${ }^{14}$ Sartre, Jean-Paul. O ser e o nada. Petrópolis: Vozes, 2005.
} 
CONCEPÇÃO DA MORTE.

DO "IMPOSSÍVEL".

"DA ESPERA PACIENTE DIANTE DA PORTA" ATRÁS

DA QUAL SE ESTENDEM

OS ESPAÇOS INACESSÍVEIS AOS NOSSOS SENTIDOS E CONCEITOS..." ${ }^{15}$

Para Kantor, somente os artistas são capazes de enfrentar o desafio da morte através da sua arte, tanto no sentido literal como no simbólico. Isso acontece exatamente pelo fato de serem os artistas, mas os "verdadeiros artistas", usando o seu vocabulário, capazes de romper com a ordem estabelecida, a velha ordem, para, a partir dela, construir algo novo baseado em princípios distintos da convenção. Em um dos seus ensaios, Kantor comenta:

“Eu compreendi que era necessário propor uma correção

urgente na maneira convencional

de conceber a arte.

Que era necessário suprimir entre os anos

as fronteiras rígidas, consagradas pela tradição..."16

No mesmo ensaio, que se trata de um comentário sobre a "Anti-exposição",17 realizada em 1963, ele irá dizer que através das cartas, bilhetes de viagem, endereços e das demais coisas que compunham a obra, que já poderia ser chamada de "instalação", pela primeira vez ele experimentou intensamente a noção do vazio, do nada, e que toda a realidade incomensurável da vida era plena de acontecimentos os quais a qualquer instante poderiam se tornar obra de arte. Essa era a época do Teatro Zero, chamado assim pelo temor que ele tinha em pronunciar a outra palavra que estava escondida atrás da palavra "nada", ou seja, morte.

Assim, a morte se refere ao zero absoluto, ao nada, da mesma forma que o quadrado negro de Malévich também é associado, entre outras possibilidades, ao número zero, na medida em que, a fim de obter a anulação das formas objetivas da

\footnotetext{
${ }^{15}$ Kantor, T. Leçons de Milan. Paris: ACTES SUD - PAPIERS, 1990, p. 82.

${ }^{16}$ Kantor, Tadeusz. Ma création, mon voyage. Commentaires intimes. Paris: Editions Plume, 1991, p. 100.

${ }^{17}$ Detalhes sobre a "Anti-exposição” serão expostos no próximo capítulo.
} 
realidade, Malévich depurou a geometria até a absoluta aniquilação de qualquer referencial, permanecendo apenas aquilo que pode ser chamado de percepção intuitiva de algum objeto ou de alguma coisa ${ }^{18}$. No mesmo passo, Kantor se opôs ao mundo objetivo abstraindo da vida em direção à realidade da morte, a garantia absoluta da vida, e conseqüentemente chegando à mesma conclusão que Ariano Suassuna em uma passagem de $O$ auto da compadecida, de que "tudo o que é vivo morre", o que determinará a edificação de uma nova realidade que está além das prioridades práticas da vida e além dos objetivos lingüísticos tradicionais e cuja lógica se orientará na construção de outras necessidades e objetivos, tantos formais quanto de conteúdo. Evidentemente, dentro dessa percepção recém descoberta por Kantor da incomensurabilidade da realidade da vida como objeto de representação poética, aquilo que se mostra mais expressivo e mais significativo dentro desse universo desmedido, trata-se notadamente do seu antagonismo, a morte. Kantor percebe que a morte é imbuída de infinitas possibilidades para a criação artística, muito mais do que a própria vida.

Apesar de a morte estar indissociável ao teatro de Kantor desde 1944, e já aparecer fortemente em $O$ retorno de Ulisses, é graças a Witkiewicz que essa noção iniciará o percurso como elemento centralizador da sua poética. Em um de seus ensaios ele comenta sobre isso:

\begin{abstract}
“A noção da morte emerge em mim através de Witkiewicz e de outros "destruidores": porque quando dizemos: destruição; quando dizemos: colapso, também devemos pronunciar a palavra que se segue. Primeiro eu criei o Teatro zero, isso quer dizer nada (...) mas ainda eu não tinha pronunciado tanto a tal palavra, por assim dizer, banal: morte. Mais tarde eu falei: Morte. Em seguida pronunciei a palavra passado. Sequer isso foi permitido porque todos me consideravam um homem velho, aquele que começou a inventar o seu passado, e em seguida juntou esta outra palavra: memória.”19
\end{abstract}

Inicialmente Kantor se recusava a assumir abertamente a morte como elemento poético. Ele dizia que até o momento da Arte Informal, ao contrário de outros artistas, ele se recusava a utilizar-se de lembranças como processo de criação, ele dizia não estar preparado para empreender uma viagem às terras do passado onde ele deveria criar com

\footnotetext{
${ }^{18}$ Malévich absorveu idéias de filósofos como Upenski, que em sua obra defendia a existência de uma espécie de "razão intuitiva".

${ }_{19}$ Tadeusz Kantor: apud Silvia Parlagreco. L'assente presenza di Tadeusz Kantor. In. Martinis, Romano. Tadeusz Kantor-Cricot 2. Salerno/Milano: Oedipus Edizioni, 2001, p. 37.
} 
a ajuda do tempo que escorria, da sua nostalgia e de sua inutilidade, com fragmentos pobres, a tela trágica do tempo presente. Ele não conhecia ainda a relatividade do tempo e seu ultimato.

"Eu perguntava a mim mesmo - "O retorno de Orfeu é possível?"

Dos Infernos - Lá embaixo, em meu "Infernum", eu senti pela primeira vez o contato dessa Bela Dama - a Morte - e o poder que ela exerce sobre a arte. Nada era maior e nem mais magnífico."20

Nesses anos havia nele algo que ele mesmo não conseguia explicar, uma espécie de vazio que, no seu "infernum",21, a palavra "nada" possuía uma significação estranha, significado que alguns anos mais tarde, Kantor, após a desmascarar, assumiu a sua presença em seu teatro como elemento da sua poiesis, ou seja: a morte como linguagem. E nada mais incomensurável na realidade da vida do que a realidade da morte. Assim, a morte é elevada ao status de obra de arte. Verdadeiramente uma afronta, um ato blasfematório, frente às tradições e instituições artísticas.

No teatro de Kantor, os pólos opostos, morte e vida não se excluem mutuamente. Eles são estruturas dialéticas inseparáveis, negam-se e se confirmam incessantemente. Evidentemente, como na própria história, o sentido da morte nem sempre é o mesmo. De uma maneira geral, a forma como alguém ou um povo enfrenta a morte ou o significado que a ela é atribuído, indica, de alguma maneira, o sentido que também lhe confere a vida. Kantor, desde a Segunda Guerra Mundial, enfrentou a morte através do seu teatro. A sua ligação com a morte se justifica evidentemente pelas experiências adquiridas nesse período, o que justifica também a sua relutância, após a queda da Alemanha nazista até o início dos anos setenta, apesar do intenso sentimento da morte, de não haver qualquer ação da memória no seu processo de criação, exatamente pelo fato de que isso implicava necessariamente a renovação direta da dor e do sofrimento vivenciado durante a guerra. Essa situação se tornará inevitável com a descoberta da morte como potência criadora que já estava subsumida à "realidade de classe mais baixa", a morte, também entendida como dejeto da civilização, foi escondida,

\footnotetext{
${ }^{20}$ Kantor, Tadeusz. Ma création, mon voyage. Commentaires intimes. Paris: Editions Plume, 1991, p. 112-113.

${ }^{21}$ Título de um de seus ensaios.
} 
escamoteada, afastada das vistas do mundo e da arte. A morte fora, apesar da sua inevitabilidade, esquecida do seu aspecto real e cotidiano. Coube a Kantor retirar a embalagem que a protegia e trazê-la para o teatro como forma, como elemento poético.

Para Kantor a arte habita o território inexplorado da morte e ele insiste em despertar a consciência para esse fato. Isso não deve ser entendido como um desejo por um assunto mórbido tratado por um artista que vive obcecado pela morte inevitável. Esse comportamento, pessimista no sentido shopenhauriano, seria uma atitude estanque no processo de construção da realidade. No entanto, Kantor, ao contrário, ao aceitar a sua própria finitude, reavalia o seu comportamento e suas escolhas. Segundo Heidegger, em Tempo e ser ${ }^{22}$, somente o homem autêntico enfrenta suas angústias e assume a construção da sua vida. Essa autenticidade, em Kantor, é reforçada cada vez mais pela autonomia do seu teatro. Assim, em Kantor, a existência está condicionada a uma sucessão infinita de possibilidades, entre as quais se encontra justamente a morte como elemento artístico significante que possibilita a imersão do olhar crítico sobre a vida habitual. Kantor assume, por esse caminho, a condição de um "artista para a morte", no mesmo sentido que Heidegger pensava o "dasein", como um "ser para a morte"; homem cujo ser como possibilidade o introduz na temporalidade. Isso significa que o homem passa a ser reinterpretado em relação ao passado e ao futuro, não mais como uma sucessão de momentos que se alternam uns aos outros de maneira passiva, mas como um futuro para o qual a existência é projetada, sendo o passado aquilo que a existência transcende. Obviamente, tanto em Kantor quanto em Heidegger, a morte é algo que dá sentido à vida, e a meu ver, em nenhum outro artista, desde o século XIV, com a Dança Macabra, o enfrentamento da própria finitude foi tão intenso na arte como no teatro de Tadeusz Kantor. Aceitar a morte para Kantor é aceitar uma realidade dentro da história, é demonstrar uma verdade que é parte integrante da sua vida, seguramente a verdade dos campos de extermínio. Kantor aceita a morte como necessidade de transcendência do pensamento para que a história não seja esquecida e para que a realidade da morte se mantenha como consciência do devir. Assim, a morte deixa de ser uma prerrogativa dos seres vivos para se tornar a essência da consciência do homem.

\footnotetext{
${ }^{22}$ Heidgger, M. Ser e tempo. Petrópolis: Vozes. 2006.

23 "O ser ấ", ou seja: o ser lançado no mundo e que tem a sua existência garantida pela realidade cotidiana.
} 
Como é possível perceber, a morte é um elemento indispensável ao teatro de Kantor. É claro que essa não é a morte ritual mas uma verdade humana. Tudo aquilo que Kantor fez na arte é reflexo da sua atitude em relação aos eventos que o cercaram, em relação às situações nas quais ele se encontrava: seus medos, sua fé, sua descrença, ceticismo e esperança. Para expressar tudo isso, ele cria a idéia de realidade como uma forma de colocar em debate a própria realidade. E sendo essa realidade fundamentada na especificidade da morte como realidade, todos os questionamentos de Kantor necessariamente dialogam insistentemente com a dicotomia morte e vida. Por esse caminho, Kantor dialoga com o passado através de um intenso sentimento de dor ao mesmo tempo em que projeta no futuro questionamentos sobre o seu próprio destino.

A isso Guy Scarpetta se refere:

“...o teatro de Kantor é pós-histórico (a história terminou, nada resta além dos fragmentos, dos dejetos), teatro póstumo, é a morte, a "pulsação da morte" que deforma sem fim a representação.",24

Aos poucos o teatro de Kantor irá se constituir em um alucinante cortejo saído de um mundo sepultado através de uma memória às vezes individual, às vezes coletiva, retrato de família de uma Europa desaparecida, restituída em uma dimensão concomitantemente patética e burlesca:

“...como se a própria morte colaborasse com as imagens exumadas". ${ }^{25}$

Existe em Kantor, em seu teatro, uma espécie de equilíbrio instável, que conduz à representação, ao jogo teatral, a um ponto no qual ela se torna totalmente patética e caricatural, ao mesmo tempo em que é sagrada e profana. Esse desequilíbrio penetra no interior do coração do sagrado no qual ele faz manifestar todo o seu poder de desestruturação. Isso quer dizer que em relação à morte e suas dimensões manifestas, tais como o horror e a agonia, Kantor introduz o humor como um elemento desafiador do real. Desafio que tem, evidentemente, seu ponto de apoio fora do mundo convencional. É exatamente nesse sentido que se estabelece a sua relação com os temas mais duros que estão presentes na sua memória. Através do burlesco, Kantor desacraliza o martírio do povo judeu nos campos de concentração. Isso não significa que o processo

\footnotetext{
${ }^{24}$ Scarpetta, Guy. Kantor au présent. Arles: Actes Sud, 2000, p. 46.

${ }^{25}$ Ibid. p. 51.
} 
de dessacralização da história deva ser entendido como irreverência, não, pelo contrário, ao introduzir o humor burlesco nos domínios da morte, Kantor deixa evidente toda a fragilidade da vida. Isso é aquilo que Guy $\operatorname{Scarpetta}^{26}$ chama de o ponto secreto, ardente, decisivo na organização subjetiva de um criador na dimensão de Tadeusz Kantor. Nesse sentido, a morte realiza a sua principal condição. Deixar de ser o que é para ser colocada noutro mundo, para mudar inteiramente de ser.

\section{A IMAGEM CONDENSADA}

Uma das características da imagem no teatro de Kantor trata-se do fato de cada imagem, individualmente, trazer em si uma significação concentrada daquilo que trata o espetáculo como todo. Essa significação pode estar única e exclusivamente associada à produção de estados emocionais no observador. Essas imagens, fascinantes e perturbadoras são produtos do repositório da memória de Kantor como se estivessem afixadas em uma fotografia, o que faz com que os jogos observados em cena sejam percebidos como uma sucessão de imagens. Isso ocorre inevitavelmente porque a construção dos jogos está totalmente fundamentada na construção da imagem. $\mathrm{O}$ teatro de Kantor é, antes de tudo, um teatro de imagens fortes e avassaladoras. Essas imagens podem ter sua origem na imaginação de Kantor ou como produto da sua memória poderosa. A memória pode se manifestar por meios diretos ou indiretos, ou seja, a imagem, a situação, vivida e experimentada, dá seguimento à cena que se materializa no palco. Por outro lado, essa memória pode aparecer por meios indiretos, como é o caso de Wielopole Wielopole, na qual uma parte essencial do espetáculo foi baseada em imagens retidas em fotografias antigas. A foto dos soldados, recrutas, provavelmente prestes a partir para o front, mobilizou a memória pessoal de Kantor, referente à criança de seis anos que via o movimento das tropas do Marechal Pilsuldsk em ação pelas ruas da sua pequena vila natal. A transferência dessa imagem estática fixada pela fotografia,

\footnotetext{
${ }^{26}$ Ibid. p. 31 .
} 
desbotada pela ação do tempo, acionando a sua memória pessoal, concebeu para o palco figuras dolorosas de homens em cinza, empoeirados - revestimento da morte antecipada.

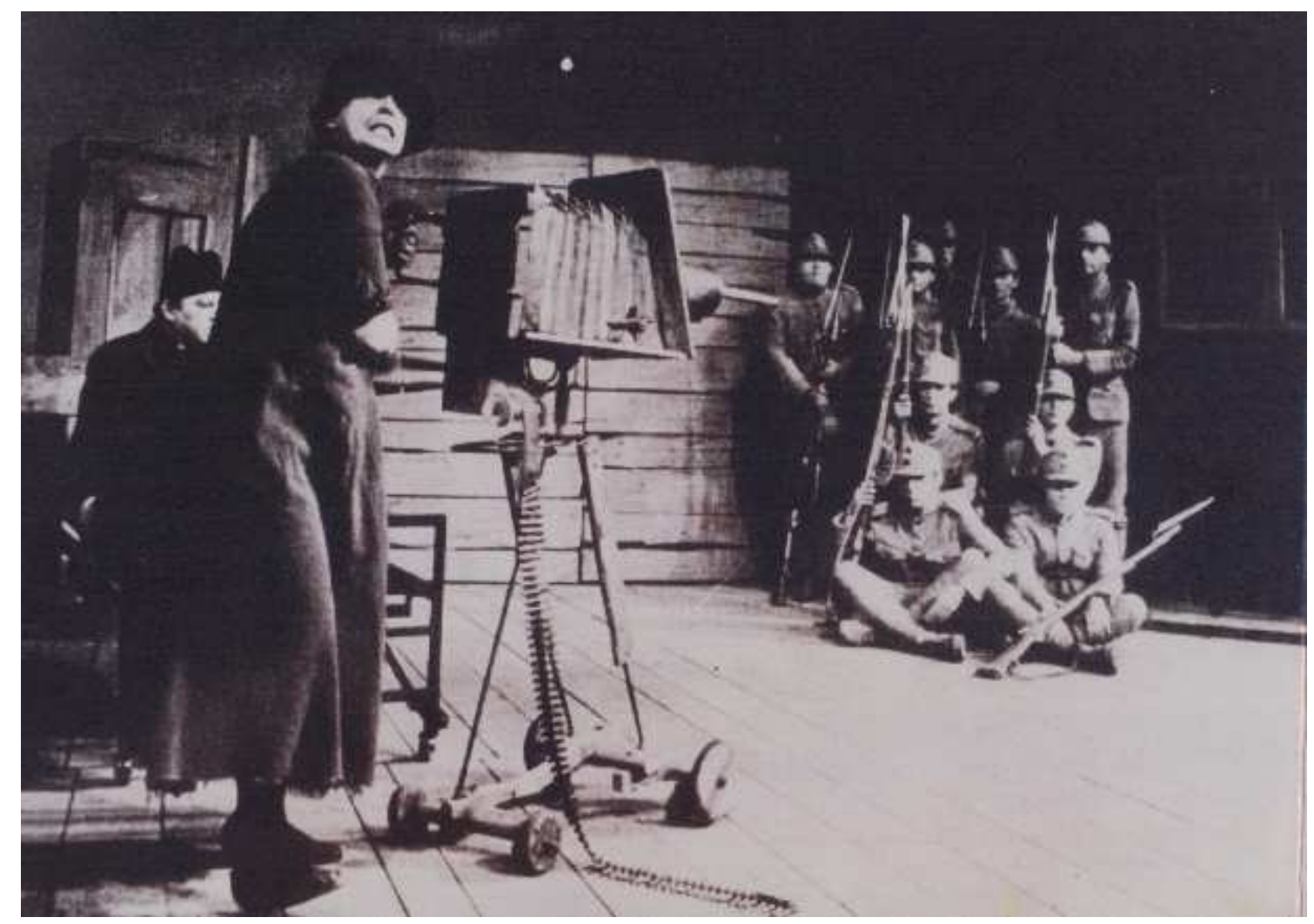

Wielopole Wielopole. Na cena, a fotografa-viúva e os soldados da Primeira Guerra Mundial. Foto: arquivos da Cricoteka.

$\mathrm{Na}$ aparência da imagem inerte, Kantor viu o desenvolvimento de uma história, a tragédia de homens reais, a manifestação de algo que aconteceu e que estava destinado a acontecer novamente no palco. Uma nova criação, original, única, como vista pela primeira vez. Além dos soldados em uniformes da Primeira Guerra mundial, em pose, posando para uma fotografia, a última recordação antes da partida sem volta, temos também uma série de carteiras escolares feitas de madeira velha, usada, na qual estão sentados velhos decrépitos, pessoas estranhas, pálidas, todos vestidos de negro, como que prontos para um funeral; temos também um quadro, uma moldura enorme em cujo centro, em pose, pessoas estão reunidas para uma fotografia familiar; uma ratoeira gigante que devora homens; um monumento enorme - uma escultura feita com os objetos degradados de vários formatos e funções. No alto desse monumento, o anjo da 
morte, a puta do cabaré, como A liberdade guiando o povo, obra do pintor francês Delacroix, e também como a clássica fotografia que marca a tomada do "reichstag",27 pelo exército vermelho em 1945, movimenta a sua bandeira negra. Essas, dentre inúmeras outras, são imagens memoráveis do teatro de Tadeusz Kantor: Wielopole Wielopole; A classe morta; Hoje é meu aniversário; As belas e os feios; Que morram os artistas!. Essas são imagens poderosas, imagens que trazem em si uma vasta gama de significados relativos ao repertório gramatical kantoriano.
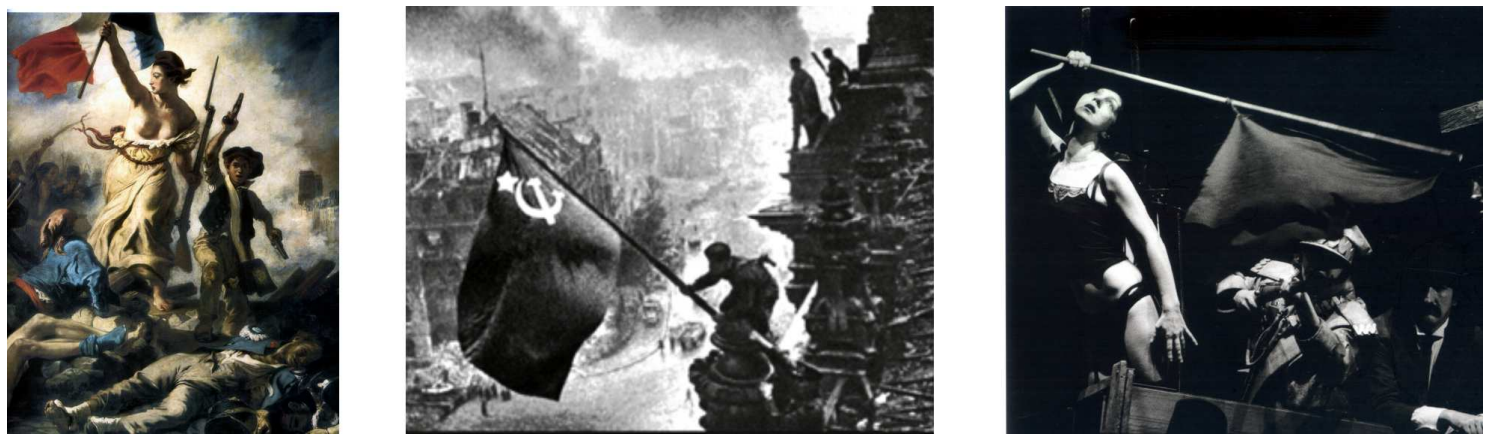

A liberdade guiando o povo - Delacroix (obra de 1830). Foto: Coleção Folha Grandes mestres da pintura; $A$ tomada do Reichstag pelo exército vermelho em 1945. Foto: www.anovademocracia.com.br; A puta do cabaré empunha a bandeira da resistência em Que morram os artistas!. Foto: Maurizio Buscarino.

A imagem no teatro de Kantor trata-se de uma estrutura imobilizada em um momento que não poderá jamais evoluir, vivendo eternamente em um único instante de emoções condensadas. A imagem, afastada da vida, como uma fotografia, transforma-se em ícone, em emblema, em metáfora e alegoria. É isso que a Kantor interessa. O poder da imagem como vocabulário que age diretamente na estrutura psíquica do observador desestabilizando-o de todos os seus instrumentos de reconhecimento da realidade como constructo da sua consciência.

A relação entre imagem e significado dramático são os nós essenciais dos trabalhos teatrais de Tadeusz Kantor. O componente visual, que é uma espécie de escritura, de dramaturgia da imagem, é extremamente forte e está repleto de sinais, que ao serem observados, derivam a dúvida entre teatro e pintura. Kantor, por sua vez,

\footnotetext{
${ }^{27}$ Edifício em Berlim que abrigava o Parlamento alemão durante a Segunda Guerra Mundial.
} 
insiste em afirmar que o seu teatro não é um teatro de pintor, mas que a pintura é uma espécie de escrita para o teatro. Em resumo, essa escrita cênica trata-se, de uma forma autônoma e específica, de um meio de expressão. Mas esse componente visual não se resolve somente através da pura ilustração, nem vai se sustentar como um plano dramatúrgico preexistente. Essa estrutura visual, no plano cênico, emergirá como uma realidade dramatúrgica própria e verdadeira. Essa estrutura dramática, evidentemente muito particular, é mais icônica do que narrativa, que traduz, através da imagem apresentada, níveis desconhecidos da realidade. Ele é capaz de ver dentro da imagem, de uma imagem que ainda é estática, imóvel, e através da sua ação criativa, liberar aquilo que está escondido dos olhos e fazer teatro com isso. Um exemplo claro dessa situação trata-se dos soldados de Wielopole Wielopole. Ao olhar uma fotografia velha e desbotada, Kantor foi capaz de observar os vícios, as vicissitudes, expressões de surpresas, de felicidade, de desespero e de terror de cada um deles. A imagem traz em si o seu destino, a sua lógica, ícone exato da sua própria história. Trata-se de um processo de criação na qual a imagem como recurso dramatúrgico se constrói em cena e com a cena, constituindo assim o movimento narrativo e simbólico do espetáculo. Lorenzo Mango $^{28}$ atribui a esse processo de construção da imagem, uma manifestação dividida em três níveis diferentes: personagem ícone (a caracterização do personagem); o espaço opaco (organização da cena); a construção dramática (construção da narrativa).

Os personagens ícones seriam, usando como exemplo os soldados de Wielopole Wielopole, aqueles que são marcados pela morte, que estão “infectados por esse bacilo" ${ }^{, 29}$ e que estão mortos antes mesmo de terem morrido. A sua aparência é o próprio emblema da morte. Para conseguir essa aparência, Kantor se utiliza de diversos recursos: a maquiagem esbranquiçada e a deformação expressiva da face que transforma os rostos em máscaras, as roupas velhas e empoeiradas, os movimentos desconexos, mecânicos, seguimentados como em uma marionete, etc. De uma maneira geral, Kantor intervém na matéria visível com os recursos de outro material visível. Esse recurso de adicionar uma imagem sobre outra imagem faz com que exista uma separação, um distanciamento da realidade real da imagem, fazendo dela, através de um processo de

\footnotetext{
${ }^{28}$ Mango, Lorenzo. Appunti per uma lettura iconica del teatro di Tadeusz. In Marines, Romano. Tadeusz Kantor - Cricot 2. Salerno/Milano: Oédipus, 2001, p.32.

${ }^{29}$ Kantor, Tadeusz. Wielopole Wielopole. In. Les voies de la création théâtrale, études de Denis Bablet et Brunella Eruli, réunis et présentés par D. Bablet. Paris: C.N.R.S. Vol. XI, 1983. p. 149.
} 
recomposição, não somente um indicador expressivo emocional da cena, mas principalmente como um estado dramático localizado no interior da cena.

É na imagem dramática que reside o conteúdo dos personagens do teatro de Kantor. A imagem funciona como síntese, como elemento condensador icônico que transcende a sua própria realidade como imagem, indo muito além da sua história original, cotidiana, para revelar elementos e situações que variam do imprevisível ao misterioso de histórias e aventuras que nunca foram contadas. Essas histórias contêm um segredo, sombra e reflexo daquilo que percebemos condensado na imagem que se realiza no espaço. Essas imagens que são pertencentes à imaginação, aos delírios, às alucinações e fantasmagorias de Kantor, são constituídas por um tecido de gestos, de ações pequenas e grandes, por jogos repletos de humor e terror, especificidades que conferem ao teatro de Kantor o recorrente uso de um signo negativo associado à estrutura dramática das imagens criadas. Isso quer dizer que, para cada cena, para cada imagem, existe posteriormente o seu contraponto, a sua negação como expressão dramática simbólica. Dessa forma, diante um tema duro e traumático como o holocausto e a morte dos judeus nos campos de extermínio, na seqüência da cena, Kantor insere uma paródia jocosa, quase burlesca. Assim, nessa situação específica, Kantor dessacraliza a história introduzindo um elemento de humor em uma estrutura aceita e sacralizada como absoluta e imponderável de ser observada de outra forma:

“A arte de Kantor é antes de tudo um desafio ao real. O real, em Kantor, quando é evocado, está sempre afetado de um signo negativo. Isto porque o humor em sua arte, representado pela relação ao real, quer dizer ao horror, à agonia, ao triunfo inelutável e generalizado da morte, uma espécie de desafio positivo, e ao desafiar o real dessa maneira; isso supõe evidentemente um ponto de apoio fora do mundo. É esse o ponto secreto, ardente, decisivo na posição subjetiva de um criador da dimensão de Kantor.”30

A "iconização" da imagem flui como subtração do transcurso do tempo e imersão no universo do simbólico através de um intenso diálogo com a morte que encontra através das imagens e dos personagens que constituem essas imagens, e por isso também são icônicos, um caminho e um meio para se manifestar. A morte como abstração encontra materialidade na imagem como forma concreta. Esse tempo que teve

\footnotetext{
${ }^{30}$ Scarpetta, Guy. Kantor au Présent. Actes Sud, Arles 2000, p. 131.
} 
o seu percurso alterado, condensado em uma imagem, para a eternidade, como já foi visto, trata-se de um tempo mítico, um tempo que vive eternamente o instante da ação.

Outro aspecto do componente icônico da imagem no teatro de Tadeusz Kantor trata-se da utilização dos manequins como recurso expressivo. A presença do manequim nos espetáculos é, segundo Lorenzo Mango, na obra já citada, o exemplo mais tangível da manifestação da morte e conseqüentemente da transformação dessa em ícone, ou seja: o manequim nada mais é do que a expressão absoluta da morte, do vazio e da vacuidade. Em A classe morta, os Velhos carregam os manequins das crianças que foram um dia, como excrescência, um tumor supurado do passado morto. Em Wielopole Wielopole, a imagem do Padre duplicada no manequim de látex desperta o interesse na descoberta da condição da sua humanidade. Assim, a partir do temor da morte, surge a clareza última da vida que é traduzida em imagem pura, emblematicamente fechada como ícone.

No processo de organização da cena, nesse espaço opaco, conforme a definição de Lorenzo Mango ${ }^{31}$, a cena é o local no qual o ícone do personagem se materializa. Isso será iniciado nos anos setenta quando Kantor, a partir do Teatro da Morte, começa a desenvolver a tendência de concentrar a ação teatral em um único lugar cênico - isso após, durante anos de frequiência assídua de lugares inusitados e situados nas dimensões do happening. O seu teatro chegará então a um lugar, do ponto de vista da utilização do espaço físico, a algo parecido com a "cena italiana", mais uma vez lembrando da corda de separação adicionada em $A$ classe morta, estrutura que irá se fortalecer e ganhar estabilidade em Wielopole Wielopole e que prosseguirá assim nas demais produções. Em um comentário feito por Luigi Allegri acerca de Wielopole Wielopole, ele dirá:

“...enquanto os olhos observam a transparência da cena que age feito janela que se abre como visão para um mundo ilusório, somos conduzidos a ver além da matéria afetiva que temos diante de nós, assim, o espaço de Kantor se torna opaco...,"32

\footnotetext{
${ }^{31}$ Mango, Lorenzo. Appunti per uma lettura iconica del teatro di Tadeusz Kantor. In Marines, Romano. Tadeusz Kantor - Cricot 2. Salerno/Milano: Oédipus, 2001, p.34.

${ }^{32}$ Luigi Allegri. Lo Spazio medievale di Wielopole Wielopole. In. Kantor. Protagonismo registico e spazio memoriale. A cura di Lido Gedda, Liberoscambio, Firenze, 1984.
} 
No interior dessa construção opaca da cena, os objetos assumem uma proeminência particular, sendo que a relação que Kantor tem com eles é levada a ser reconhecida como uma experiência próxima aos ready-made de Marcel Duchamp. Não tanto porque o objeto esteja totalmente pronto mas porque ele é análogo ao processo mental que é a base da sua criação. Em Duchamp, o ready-made, o objeto privado de sua função original, de certa forma, como em Kantor, é exposto em um contexto no qual ele é visto como se fora pela primeira vez. O objeto, nesse processo, a "coisa em si" irá ocupar o lugar da imagem, que anteriormente, antes do Cubismo e da Colagem, eram entendidas como desdobramento da idéia em imagem composta na tela. Com o Dadaísmo, propriamente com o ready-made, o objeto se tornou imagem sem ser ele mesmo imagem, o que no contexto do teatro de Kantor é percebido exatamente como imagem. Disso decorre a averiguação do teatro feito por Kantor como um teatro fortemente amparado pelas bases da arte pictórica. Uma das definições do ready-made que acredito sirva prontamente ao objeto no teatro de Kantor, trata-se daquela na qual o filósofo José Arthur Giannotti se refere a ele como:

“...um objeto posto fora do seu contexto de uso, deixa de ser coisa a mão para vir a ser coisa que não se contempla quando nela nada pode ser contemplado..."33

A banheira de A galinha d'água, assim como a cadeira de Penélope em $O$ retorno de Ulisses, nega a sua realidade cotidiana para ser vista como diferença em um museu imaginário que se configura como a realidade artística na materialidade do teatro e, graças a isso, um efeito de estranheza paradoxal é produzido: o objeto torna-se finalmente visível.

Em Kantor, a construção dramática, se assim posso dizer, é um procedimento através do qual aquilo que chamamos de dramaturgia tem sua lógica baseada, mais uma vez, na produção de imagens icônicas, nas quais a lógica das combinações e das seqüências, lembrando que essa é uma lógica da imagem, trata-se de um procedimento fundamentado na construção e na desconstrução. A construção se dá exatamente através da agregação lógica dos fragmentos que são incongruentes uns entre os outros em uma imagem homogênea. A desconstrução, ao contrário, destrói a coerência da imagem dentro de um plano narrativo alheio à imagem. É por isso que a memória, pessoal e

\footnotetext{
${ }^{33}$ Giannotti, J.A. O jogo do belo e do feio. São Paulo: Companhia das Letras, 2005, p. 135.
} 
abrangente, no palco, a partir do seu "quarto da imaginação", é desconstruída e reconstruída em ícones "dramáticos" individuais. Nesse contexto, as imagens como ícones, são apresentadas como sínteses de um passado vivo na memória. As imagens de Kantor são túrgidas de emoções. É por isso que em Que morram os artistas!, o monumento final construído por Veit Stoss, ao mesmo tempo que se refere ao altar da Igreja de Santa Maria, também se refere aos artistas marginais que buscam a liberdade, daí a referência a Delacroix, em cuja pintura, a Liberdade representada por uma mulher de seios de fora, evidentemente uma ousada reação ao violadores dos ideais da revolução de 1789, é também ao Anjo da Morte, cujos ideais iluministas se esfacelaram diante da barbárie nazista e do terror stalinista. Ao observarmos a imagem construída no espetáculo, estamos ao mesmo tempo nos reportando ao século XV, ao século XIX, e ao século XX. Vemos através da imagem construída, a obra de Veit Stoss, ao mesmo tempo em que percebemos a defesa e o esfacelamento do Iluminismo. Todas as imagens em uma única imagem.

Esse processo de criação, de certa forma, está ligado a algumas considerações de Freud sobre o sonho. O sonho como linguagem que, através da estratégia da condensação e movimento, re-nomeia as coisas e as redefine, ou seja, a realidade e sua compreensão. A linguagem dos sonhos, segundo Freud, é uma linguagem icônica que atua no inconsciente como imagem chave, absoluta, estranha, ilógica; contudo, são excepcionalmente capazes de se expressar como símbolos, de se exprimir amplamente em um universo simbólico. A imagem no teatro de Kantor, por sua vez, age, não somente a fim de definir uma dramaturgia icônica, em que o ícone representa sozinho a imagem central, mas ainda, e com isso, a sua capacidade de antagonizar a linguagem lógica, racional, cotidiana. Por outro lado, a imagem icônica em Kantor também está repleta de teor lírico.

O lirismo das imagens criadas por Kantor que conjuntamente com a música operam um retorno a si mesmas, promovem um constante multiplicar dos significados, de forma que a ação expressa no presente imediato, configura-se, como comenta Anatol Rosenfeld, a respeito do imediatismo do lírico:

“A isso se liga a preponderância na voz do presente, que indica a ausência da distância, geralmente associada ao pretérito. Esse caráter do imediato que se manifesta na voz do presente não é, 
porém, o de uma atualidade que se processa e se distenda através do tempo (como na dramática), mas de um momento eterno" ${ }^{34}$.

O lirismo desse momento eterno na obra de Tadeusz Kantor, que também pode ser observado em Dicotomias - fragmentos skizofrê e nas produções de Leszek Madzik, realiza-se de uma maneira muito específica ao associar a imagem à poesia. As imagens e as figuras constituem o espaço que só é possível se representar através dos objetos e formas. Por sua vez, a poesia se articula através dos signos que se sucedem no tempo e os signos, conforme especifica Benedito Nunes ao citar Lessing:

“...só podem representar objetos sucessivos que se chamam ações, eis o domínio próprio da poesia.”35

O teatro de Kantor, ao mesmo tempo em que está repleto de terror e humor macabro, também está repleto de poesia na qual a realidade afetiva despertada pelo espetáculo é a medida interna do sentimento interno de oposição entre os contrastes, entre o permanente e o provisório, a exemplo da relação entre o humano com o inanimado. Nada mais poético do que o melancólico movimentar da manivela do instrumento híbrido utilizado pelo soldado músico que volta da guerra apresentado em Wielopole Wielopole ou, no mesmo espetáculo, o encontro entre o Padre Smietana e o Rabino Smull, em uma atitude de reconciliação entre as culturas; através de um se observa a generalidade. Esses, dentre inúmeros outros exemplos. Assim, o momento de eterna poesia presente, nos outros artistas citados acima, mas sobretudo em Tadeusz Kantor, realiza-se na efemeridade temporal do espectador suscitando sentimentos diversos e na impossibilidade de configuração concreta do tempo e do espaço, dentro de uma estrutura normativa e linear, os espetáculos vão muito além da realização artística e muito mais do que somente suscitar no observador percepções estéticas, a arte de Kantor se configura como uma profunda experiência afetiva que coloca o humano em relação ao jogo com as imagens e objetos na busca de significados. Significados esses que se não estão ligados ao conhecimento de questões relativas à existência humana, constituem-se, com certeza, nas dúvidas de realização humana da nossa própria individualidade.

\footnotetext{
${ }^{34}$ Rosenfeld, A. O teatro Épico. São Paulo: DESA - Coleção Buritis, 1965, p.12.

${ }^{35}$ Nunes, Benedito, O tempo na narrativa. São Paulo: Ática, 2003, p.10.
} 
De uma maneira geral, a imagem no teatro de Tadeusz Kantor é uma estrutura fortemente articulada com os objetos e também com os homens, mas principalmente com os objetos. Essas imagens, em cujo tempo é invariável, que não evoluem cronologicamente, não podem ser medidas em uma relação de causa e efeito entre uma e outra. São imagens independentes, autônomas, que trazem em si um profundo sentimento de dor, de catástrofe, referendadas pela presença inexorável da morte, refletem a invariabilidade do tempo e, conseqüentemente, um constante e intenso retorno a esses sentimentos, o que causa, no espectador, a impressão de que o espetáculo nunca termina, tratando-se, pois, de uma experiência que se inicia com a entrada na sala de espetáculo, cujo final funciona como uma interrupção, jamais como epílogo. A imagem, em Kantor, é uma realidade em si, que pode e deve ser entendida como uma realidade alternativa concebida em outra percepção de tempo e também de espaço. Assim, para entrar efetivamente na demonstração desse princípio, deverei falar um pouco acerca da ilusão e da realidade no teatro de Kantor. 


\section{CAPÍTULO IV}

\section{A REALIDADE RELATIVA - O JOGO ENTRE REALIDADE E ILUSÃO, ESPAÇO E MEMÓRIA}

Sobre a ilusão, no teatro de Kantor, existem dois momentos fundamentais no que se refere ao tratamento destinado a essa estrutura. $O$ primeiro inicia-se com $o$ nascimento do Teatro Cricot 2 e continua até 1973, com a negação da ilusão como única forma de entrar na realidade. O segundo, após 1973, e mais especificamente a partir da encenação de A classe morta, na qual há uma retomada da ilusão por Kantor como condição essencial para a entrada e conhecimento da realidade. Realidade que irá de espetáculo em espetáculo se constituir como uma superposição de estados de consciência.

\section{A NEGAÇÃO DA ILUSÃO - O ESPAÇO REAL E O OBJETO REAL}

Antes de 1973, a arte de Tadeusz Kantor era praticamente a imagem refletida da sua atitude em relação aos acontecimentos que estavam ao seu redor, em relação às suas crenças, aos seus medos e à expectativa do seu destino. Para expressar todas essas situações, Kantor cria a idéia de realidade em detrimento da idéia de ilusão e, conseqüentemente, a renúncia do conceito de representação, ou seja: da reprodução mimética do drama. O teatro de Kantor irá se constituir como uma ruptura com a realidade formal moldada pelas convenções não somente artísticas, mas também sociais e políticas.

É muito difícil falar do trabalho de Kantor em relação às práticas teatrais dominantes. O seu teatro, a meu ver, acontece em um lugar de transição entre dois mundos. Um lugar cuja lógica do espetáculo tradicional não encontra ressonância. É 
nesse local de transição, onde a "marginalidade" tem direito à existência digna, que Kantor explora, através de um auto-exame de suas introspecções mais profundas, coisas que estão escondidas do resto do mundo. Essas coisas que poderiam ser definidas como um profundo sentimento de catástrofe são marcas que emergem desse outro mundo como frutos de sensações muito pessoais. Sensações que não são organizadas, ao contrário, são confusas, mas que na sua enganosa aparência de casualidade reside um sistema de relações artísticas muito complexas que é marcado por um intenso e profundo sentimento da morte.

Talvez o maior problema em relação ao teatro de Kantor seja a dificuldade de contextualização, já que aquilo que acontece no palco, essa experiência de outro mundo ${ }^{1}$ para a linguagem habitual, é insuficiente para uma definição satisfatória de uma poética que se expressa no teatro de maneira irracional e acidental. Descrever os acontecimentos que ocorrem no palco de Tadeusz Kantor torna-se um exercício de ultrapassar as fronteiras da língua e do pensamento lógico em busca de outros níveis de entendimento do acontecimento teatral. Mas, por outro lado, essa linguagem convulsiva é exatamente o elemento que nos permite a compreensão desse outro mundo ou dessa outra realidade que tanto já fora mencionada. Esse mundo outro, não se trata de um local construído pela fé ou por qualquer crença religiosa. É antes de tudo o mundo do abstrato. Como já foi dito nos capítulos anteriores, para Kantor a arte abstrata nada mais é do que a existência da imagem de um objeto material em um universo cujo nível de existência não pode ser visto ou tocado a não ser através da arte. Para desenvolver essa idéia, é preciso falar um pouco sobre a anexação da realidade.

A realidade que Kantor se empenha em anexar não se trata da realidade das convenções sociais cujos objetos possuem um valor estabelecido. Pelo contrário, Kantor se apega à realidade que perdeu sua significação e não apresenta mais, para a sociedade, nenhum valor reconhecido. Essa realidade desprezada pela civilização e pela arte se tornará o propulsor que possibilitará a emergência desse outro mundo, que no teatro de Kantor, como já foi visto, está associada ao período do Teatro Autônomo, do Teatro Informal, do Teatro Zero, do Teatro Happening, do Teatro Impossível, ou seja: aos diversos momentos da sua criação que antecedem o Teatro da Morte. Todos os

\footnotetext{
${ }^{1}$ É preciso lembrar que utilizo o substantivo mundo no mesmo sentido de realidade.
} 
procedimentos dessas estruturas teatrais desenvolvidas por ele se empenharam em negar o valor da realidade através de iniciativas de exploração de determinadas coisas que poderiam estar escondidas da singularidade da visão cotidiana. Essa idéia de anexação da realidade, como já foi anteriormente falado, está baseada no entendimento de Kantor na arte abstrata.

Após a guerra e durante o processo de reconstrução da Polônia, Kantor inicia um trabalho de exploração da matéria. Para ele, toda matéria é detentora de uma força inimaginável. Ele via na destruição das cidades polonesas através dos ferros retorcidos das pontes bombardeadas, do concreto dos edifícios em ruínas, ou seja, das formas comprimidas da matéria, um novo status para uma nova convenção artística. Tudo isso estava muito próximo, no final dos anos quarenta e início dos cinqüenta, daquilo que iria se constituir nas célebres "Compressões" de automóveis feitas por César Baldaccini ${ }^{2}$ nos anos sessenta.

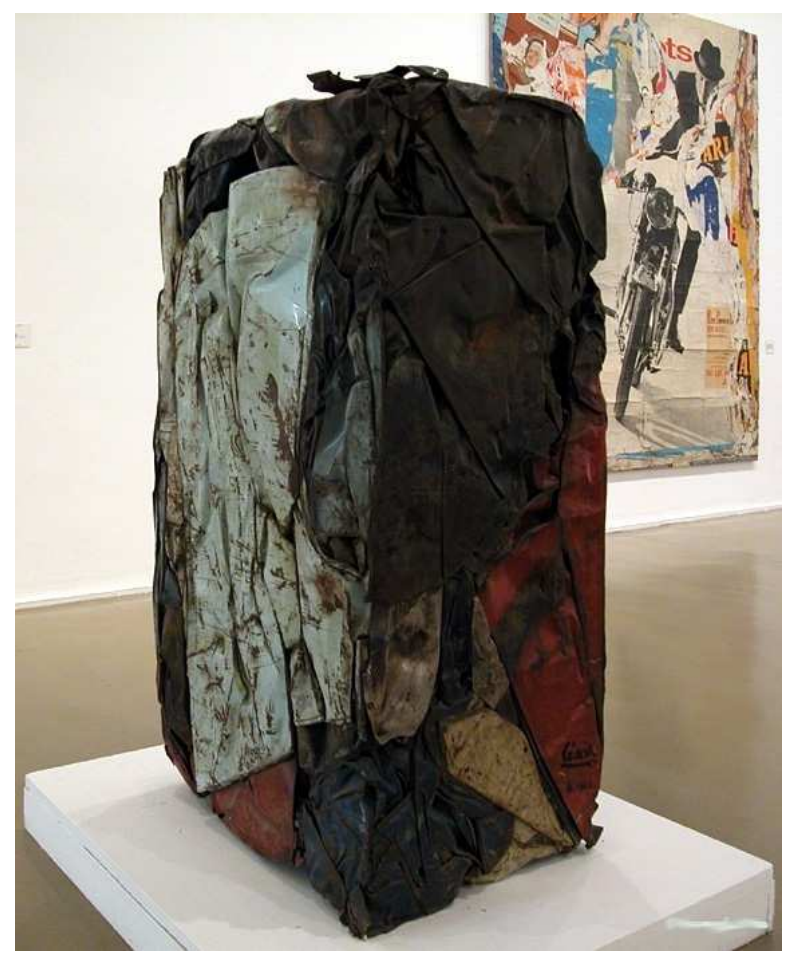

César Baldaccini - Compression automobile. Musée d'Art Moderne de la Ville de Paris. Foto extraída do site do museu.

\footnotetext{
${ }^{2}$ César Baldaccini (1925 - 1988) Escultor francês que entre 1960 e 1965, com partes de automóveis e de sua prensagem em blocos, o artista realiza suas famosas Compressões. Seguindo os princípios de Marcel Duchamp e de seus ready-made, mas de forma absolutamente particular: em sua obra há uma transformação do objeto apropriado, um elemento cênico, e o estabelecimento de uma relação com o processo de consumo de mercadorias. Trata-se de uma arte que está diretamente ligada ao real e que preconiza a utilização de objetos existentes, por isso foi chamada de Novo Realismo, uma arte de junção, acumulação e modificação do objeto real. Contemporânea da Pop Art americana, o Novo Realismo será reconhecido como uma das múltiplas tendências da arte de vanguarda dos anos 60.
} 
Usando um carro comprimido, completamente esmagado por um compressor, César Baldaccini questiona a essência do objeto artístico trazendo para os espaços rarefeitos dos templos sagrados dos museus e das galerias, aquilo que noutro contexto seria chamado de sucata. A opção por materiais não utilizados habitualmente para o contexto artístico ilustra outra das características que viriam a definir o espaço conceitual da arte contemporânea. Antes do Novo Realismo dos anos sessenta, em 1947 Kantor já era atraído pela força da compressão e era exatamente essa força aquilo que estava escondido dos olhos, que o interessava.

Em algumas de suas pinturas, Kantor explora o interior da matéria. Por esse caminho, a imagem do ser humano começa a desaparecer. Ele tenta revelar aquilo que está no seu interior. Em 1948, ele realiza uma exposição na qual é exposta a imagem interna de um ser humano através de chapas de raio X. Essa exposição acaba sendo o motivo para o início da exploração mais acentuada do interior do homem e das coisas. Isso significa, antes de tudo, o abandono da arte representacional que estava fundamentada na experiência da Segunda Guerra Mundial. Mais tarde, com a Arte Informal, Kantor se interessa somente pelo interior. Ele estava interessado pelas entranhas do corpo humano, pela sensação que essas entranhas provocam. Existe uma familiaridade na pintura de Kantor, nessa fase, com o Expressionismo Abstrato de Jackson Pollack. Essa busca pela exploração táctil da mão que entra no interior da matéria se estende com a Arte Informal até 1955, momento em que conjuntamente com Maria Jarema, Kantor funda o Teatro Cricot 2. É exatamente nesse momento que ele se volta intensamente para o teatro.

Nesse período, Kantor presume o teatro simplesmente como uma reprodução de formas sem pensamento. Em tal contexto, o Teatro Autônomo surge como uma ruptura com o teatro tradicional pelo fato desse se orientar na direção da tradução, da interpretação ou na busca de algum significado novo. Já a cena kantoriana não possui uma relação lógica com os fatos expostos. No palco existe uma total liberdade da imaginação no processo da criação de fatos que rompem definitivamente com a aparência e a lógica do drama. 


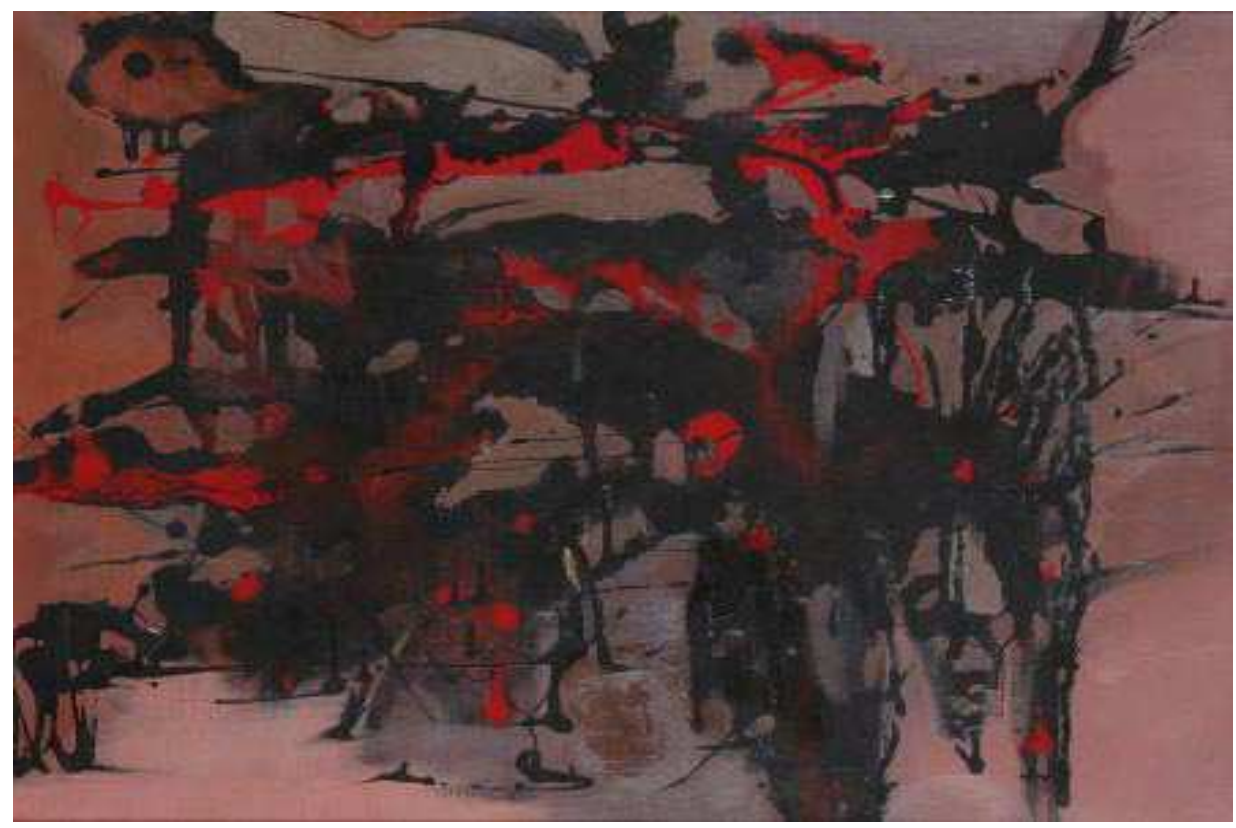

Tadeusz Kantor - Kompozycja, 1958. Foto: arquivos da Cricoteka.

O Teatro Autônomo é uma resposta à realidade e não uma representação da realidade. Na encenação de $O$ Polvo, que é uma peça que fala sobre a função e o significado da arte na sociedade, especificamente sobre a crise da arte moderna, é impossível se observar qualquer interpretação de um drama. Aquilo que existe é a tensão entre um texto literário com as situações que estão ocorrendo no palco. É a tensão a responsável pela destruição da estrutura do drama. Kantor quer demonstrar que o drama nada mais é do que invólucro vazio. No espetáculo, a primeira providência é a criação do ambiente de uma maneira que o palco seja despojado de toda a ilusão e foi exatamente por isso que a encenação da peça aconteceu em um ambiente real, ou seja: a apresentação foi feita em um Café e o público entrava para o espetáculo vindo diretamente da rua.

As peças de Witkiewicz, autor que foi o principal representante da vanguarda polonesa dos anos 20, são estranhas por natureza e foram censuradas na Polônia durante o período mais intenso da influência soviética, isso porque os textos lidavam com um conceito de realidade que não se encaixava no modelo dominante entendido como Realismo Socialista. Diante dessa realidade sugerida pelos textos de Witkiewicz, Kantor inicia um rompimento com a ideologia oficial. Ele propõe um mergulho nas profundezas da realidade proposta por Witkiewicz como alternativa para um ideal de 
realidade que, de certa maneira, ecoa a sociedade surgida com a era da razão e do esclarecimento do século XVIII, mas que demonstrou seu fracasso ao conduzirem a civilização à Auschwitz e outros campos de concentração.

Todos os valores encontrados nessa realidade alternativa e ilógica são hipervalorizados por Kantor de uma maneira que se faz impossível perceber qualquer padrão no desenvolvimento dos diálogos, o que conduz à existência de uma intensa e surpreendente mudança de pensamento e de tensões entre os personagens. Subsiste então, nesse trabalho, um diálogo, sem desenvolvimento, que é reminiscência da tradição dadaísta de criar choque e escândalo. E deste conjunto de elementos em um constante transformar das relações, a única relação que permanece com certa estabilidade, lembrando, são as relações que se estabelecem no espaço entre os objetos e os atores. Assim, o espaço que não é sagrado como em Grotowski, que não é teológico como em Artaud, que nada imita e nada traduz, torna-se objetivamente um ambiente dinâmico que visa unicamente o desenvolvimento das mais variadas possibilidades de relações entre sujeito e objeto.

Dentre as relações estabelecidas nesse espaço, podemos observar em $O$ louco e a freira, a forma como o trabalho do ator é definido como uma estrutura em constante transformação, metamórfica e fluída em um fluxo ininterrupto, não visando à construção de um personagem mas naquilo que o ator é capaz de liberar em forma de jogo, de criação autônoma. Nessa produção, a máquina de aniquilamento se comporta como um elemento que frustra toda iniciativa dos atores de exploração de qualquer fator emocional. Assim, eles são obrigados a se dirigir para outra zona, de se colocar em contato com os próprios sentimentos que surgem a partir das emoções frustradas pela máquina. Nesse contexto, temos situações de jogo com resíduos emocionais tais como: melancolia, frustração, neuroses de toda espécies, esquizofrenia, dentre outras. Esse tipo de procedimento retira o ator do espaço tradicional e conseqüentemente das formas tradicionais de atuação, sobretudo aquelas definidas por Stanislavski ${ }^{3}$, para introduzi-lo em um novo conceito de atuação definido como anti-atividade, estrutura que corrobora com o desejo de Kantor de destruir a ilusão enaltecida pelo teatro convencional. Esse

\footnotetext{
${ }^{3}$ No sentido de um teatro de ilusão e da criação do real em cena. Em Stanislavski, o ator representa um papel e se engaja no desenvolvimento das ações e das emoções que estão subsumidas a ele. No teatro stanislavskiano, através da imitação o ator representa o "outro", distanciando-se da sua verdadeira natureza individual, ao passo que em Kantor o ator joga com si mesmo e sobre a sua própria natureza.
} 
empreendimento em desbancar a ilusão do seu trono dourado irá se constituir no principal artifício de Kantor para dar uma resposta à realidade.

Nos anos sessenta, o objeto virá a se estabelecer como o elemento central do teatro de Kantor. Isso quer dizer que ele começará a pensar o objeto vulgar como fundamento da obra de arte, lembrando que as bases disso já se encontravam em 1944 em $O$ retorno de Ulisses. O objeto desprovido de qualquer valor monetário e por isso jamais seria apropriado pelos museus e pelo mercado da arte. Em 1963 ele faz uma exposição de pintura na Cracóvia, mas os quadros jamais foram expostos. Aquilo que foi exibido foram contas de restaurante, passagens de trens, tickets de espetáculos, cartas, dentre outros - elementos que foram pendurados em varais pelo espaço.

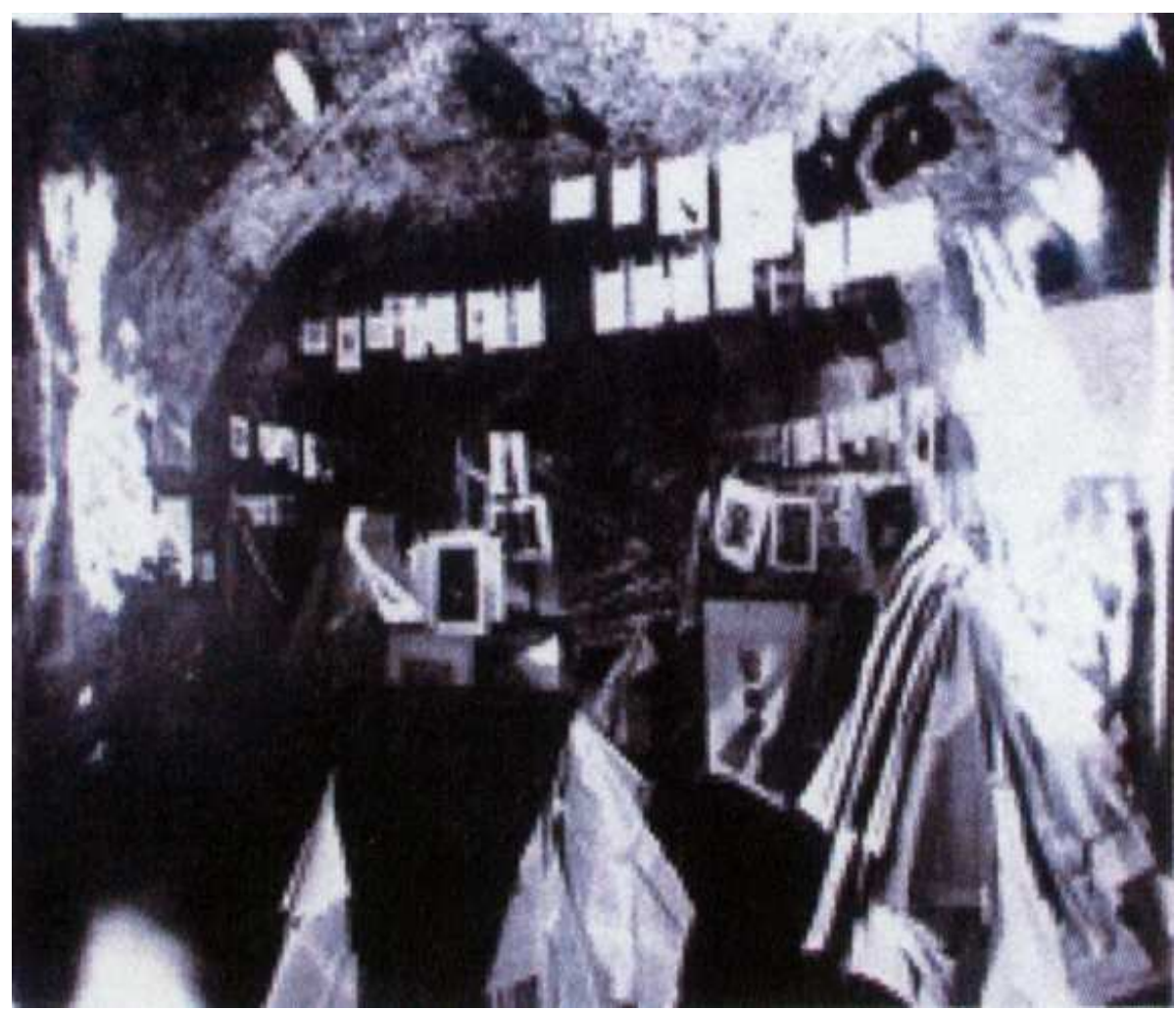

Anti-exposição ou exposição popular - realizada na Galeria Krzysztofory na Cracóvia em 1963. Foto: Tadeusz Chrzanowski.

Ao entrar no ambiente da suposta exposição, o espectador, inicialmente movido pela ilusão da busca pelas pinturas, depara-se com a mais trivial realidade. A movimentação por esse espaço obriga o contato direto com os objetos que jamais serão 
considerados obras de arte e, por isso, são inapropriados para o consumo, acabam por revelar outro contato com a criação artística que induz a percepção de aspectos desconhecidos da realidade. A ilusão, por sua vez afixa-se na impressão de imutabilidade da obra em relação ao seu processo de criação. No entanto, segundo Kantor, o verdadeiro processo de criação reside no estado de fluidez, mudanças e efemeridade da obra. Assim, esse ideal do constante "vir a ser" da obra de arte determinará os rumos do teatro de Tadeusz Kantor.

Nesse processo de transformação do espaço e das relações nesse espaço exemplificado pela exposição de 1963, encontramos a síntese e os traços das estruturas características do Teatro Autônomo, do Teatro Informal, do Teatro Zero e também do Teatro Happening, já que Kantor acredita que imagens e objetos existem em função do espaço e de sua mutabilidade. O espaço se torna, na concepção de Kantor, um objeto de criação. Talvez isso deva ser entendido como uma mudança no seu teatro, já que o espaço deixa de ser o local no qual o ator e objeto se confrontam e evoluem, deixando de ser somente um receptáculo da ação para se tornar o próprio agente da ação. $\mathrm{O}$ espaço está repleto de energia que será capaz de múltiplas transformações e variações de formas:

"O espaço tem para mim um valor autônomo

Elástico;

Dinâmico;

Animado de movimento de contração e de extensão.

Ele é vivo,

Esse é o espaço que forma e deforma os objetos..."4

Embora essa consideração sobre o espaço tenha sido escrita após o período ao qual estou me referindo no momento, é possível perceber que o teatro de Kantor trata-se de uma experiência espacial que coloca em choque constante espaço, atores e objetos. Essa associação entre esses elementos pretende liberar a energia comprimida e retida no interior da matéria através de diferentes arranjos e de diferentes estados de tensão. Nesse espaço coisas, da vida cotidiana são adicionadas para que seus valores possam ser desarticulados através da revelação de elementos imprevisíveis que reagem e destroem a

\footnotetext{
${ }^{4}$ Kantor, T. Les voies de La création théâtrale. Études de Denis Bablet ET Brunella Eruli, reunis et présentés par D. Bablet. Paris: CNRS, vol. XI, 1983, p. 20.
} 
sua ligação com as atividades diárias, atribuindo a esses objetos um caráter desconhecido.

A Segunda Guerra Mundial, na visão de Kantor, devido à bestialidade humana que colocou em "xeque" os ideais iluministas, também destruiu a idéia de encanto e beleza da obra de arte. É exatamente por isso que ele se apegou à realidade, àquilo que estava mais próximo, o objeto real que era trazido para o espaço real não para o espaço teatral. Diante do genocídio e da barbárie incomensuráveis, Kantor desafia a tradição do teatro ilusionista como reação à história oficial e à civilização; ele se recusa a trabalhar dentro de uma ordem estabelecida e de conceitos esquemáticos. A realidade era excepcionalmente forte e dela não havia escapatória, ela o encontraria onde quer que ele estivesse. Dessa forma, para que criar a impressão de realidade se lidar com a própria realidade era tão "mais fácil"? Para que explorar aspectos singulares da realidade, passando pela estrutura deformante da ilusão, se era possível entrar na realidade através dela mesma? Diante dessas questões, Kantor se apega, então, aos objetos reais e ao espaço real, iniciando seu processo de investigação com $O$ retorno de Ulisses na encenação de 1944. Esses elementos, já vistos, mais tarde serão denominados de "realidade de classe mais baixa" e se tornarão os principais elementos desafiadores da tradição teatral; a sua estrutura de utilização busca, antes de tudo, destruir o entendimento do conceito de ilusão do teatro aristotélico e stanislavskiano em uma clara reação de protesto contra os dogmas do espaço sagrado.

Não é por menos que, desde $O$ retorno de Ulisses até As belas e os feios, ele encena seus espetáculos em espaços não convencionais nos quais ele pode explorar as idéias e noções do Teatro Autônomo. Idéias que conduzem à criação de tensões entre o espaço, o texto e o ator. Essa exploração do espaço passa pelo Teatro Informal de 1963 no qual ele usa um guarda-roupa para a investigação do outro aspecto da realidade da matéria; pelo Teatro Zero no qual a máquina de aniquilamento reduz a zero a possibilidade de interpretação dos atores, restando somente o espaço como elemento de estruturação do jogo; no Teatro Happening a movimentação no interior da banheira em A galinha d'água, conjuntamente com o intenso movimentar na cena, procuram desfazer a tensão da realidade existente jogando-a para o interior de outra realidade pronta. Já em 1973, essa era a fase do Teatro Impossível, observa-se a crise do espaço real relacionado à maneira como a platéia reagia aos acontecimentos ligados a esse 
espaço. Essa mudança de registro foi a última transformação do Teatro Cricot 2 que será inaugurado com A classe morta e prosseguirá até Hoje é meu aniversário. Essa última transformação, marcada pelo surgimento do Teatro da Morte, determinará o retorno da ilusão ao teatro de Kantor e, através dela, uma nova maneira de se entrar na realidade.

\section{O RETORNO DA ILUSÃO - MEMÓRIA: OUTRO ESPAÇO, OUTRO OBJETO}

É importante lembrar que as classificações, todos os momentos do teatro de Kantor, não devem ser entendidas como atividades estilísticas mas como um processo que buscava explorar as coisas que foram esquecidas e encobertas pelas convenções e dogmas da cultura oficial; tais como a matéria bruta, os objetos marginalizados e degradados, as atividades cotidianas, etc. Esse processo de desafio, a sua necessidade de expôr as entranhas da realidade e de tentar reeducar os olhos do espectador para outra compreensão da arte, o conduz, de certa maneira, na medida em que suas próprias atitudes se tornavam tão estáveis quanto a estrutura oficial que ele tanto se empenhou em desafiar, para uma armadilha. Armadilha essa em que, consciente dos perigos, ele se empenha agora em escapar. E é exatamente nesse ponto que ocorre uma transformação no seu pensamento e, conseqüentemente, uma nova concepção do seu teatro. Na minha interpretação, essa transformação que tem A classe morta como ponto de referência, dará início àquilo que se constituirá nas características mais marcantes do teatro de Tadeusz Kantor: a morte e a memória.

Em A classe morta havia uma corda de separação entre o espaço da encenação e o espaço destinado ao público. Isso não acontecia nos espetáculos anteriores nos quais existia uma assimilação da platéia pelo espetáculo. Essa assimilação era motivada pela inserção dos espectadores no mesmo espaço de jogo. Em A classe morta, a corda propõe distância, o olhar do espectador será encaminhado por Kantor na direção da experiência de observação de uma obra de arte exposta em um museu. Uma obra que não pode ser tocada, apenas vista, e cuja linguagem textual não faz sentido, sendo que o ponto de importância é a tensão, é a criação do espaço. Esse é um momento muito 
importante na mudança do teatro de Kantor. Se antes de $A$ classe morta, a propósito da investigação da realidade, a noção de espaço real era de fundamental importância para a sua criação, sendo por isso que as suas encenações deveriam ser realizadas em locais específicos, não podendo ser encenadas em outros lugares. Sem dúvida, o mesmo não acontece com essa produção e as subseqüentes. Isso permitiu a Kantor levar a sua criação teatral para diversos lugares do mundo a partir de 1975.

Muitos dos elementos do espetáculo estão diretamente relacionados com o Manifesto do teatro da morte e muitos são prolongamentos de conceitos anteriormente formulados. Os livros velhos, amontoados, empoeirados, presentes em uma das cenas de $A$ classe morta estão se desfazendo, são considerados inúteis e como os objetos em $O$ retorno de Ulisses, também são libertos da escravidão da utilidade para atingirem, nessa peça, a condição de unicamente existirem como objetos no espaço e nele exibirem a sua "objetualidade".

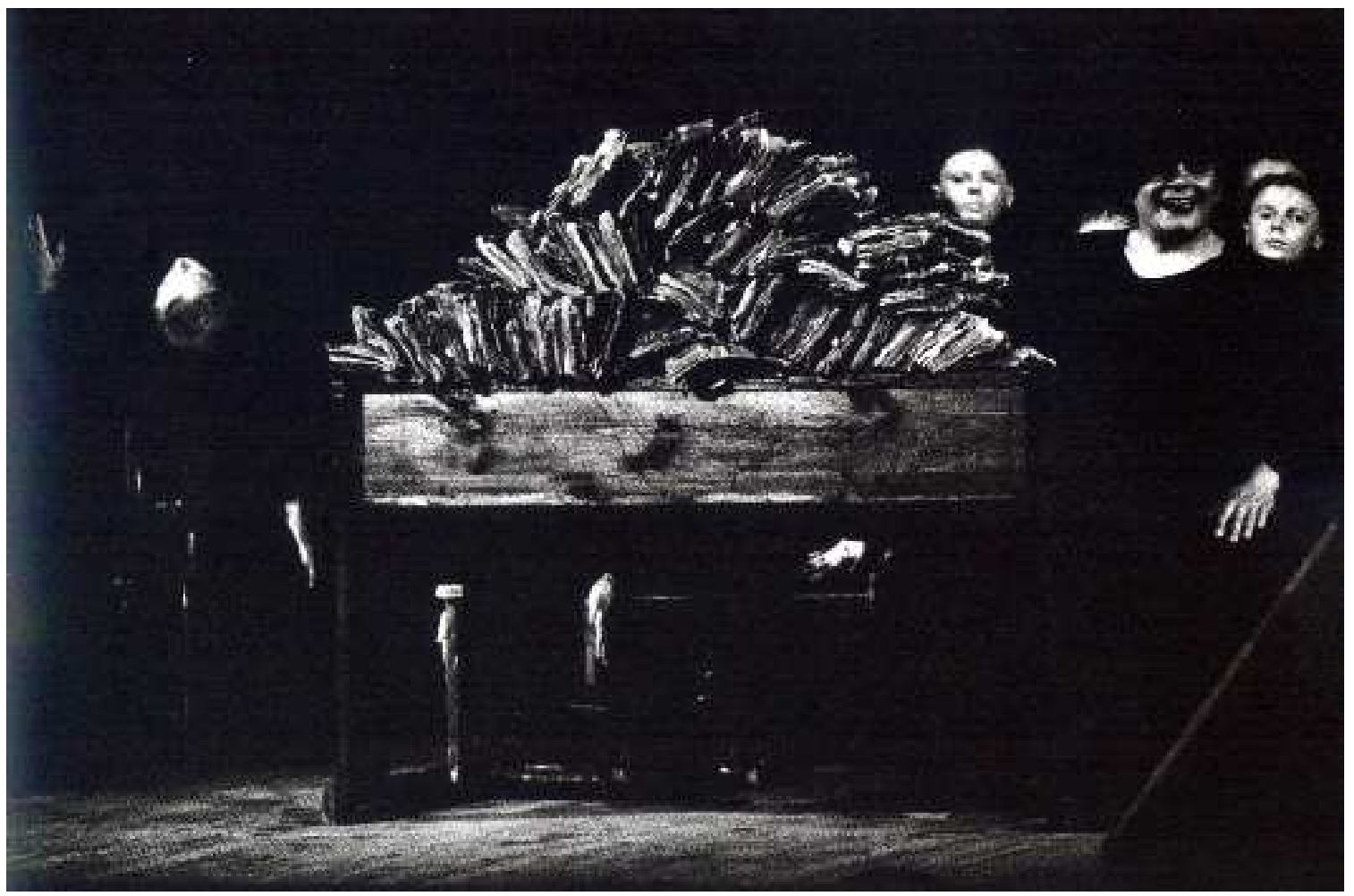

A classe morta. Na cena, sobre os bancos escolares, os livros empoeirados. Foto: Maurizio Buscarino. 
A partir de A classe morta, Kantor não desafia mais a arte tradicional, e tudo que a ela se refere. Ele não se lança mais para o interior da realidade; ele se coloca separado, atrás daquela barreira intransponível a qual ele faz referência no Manifesto do teatro da morte, para promover uma investigação voltada para si mesmo em um processo de busca dos elementos que se configurarão como a sua mais profunda intimidade. É por isso que, como comenta Michal Kobialka ${ }^{5}$, a corda de separação surge como o primeiro elemento visível no espaço de representação, que é precisamente aquilo que separa o espaço da platéia do espaço da ação.

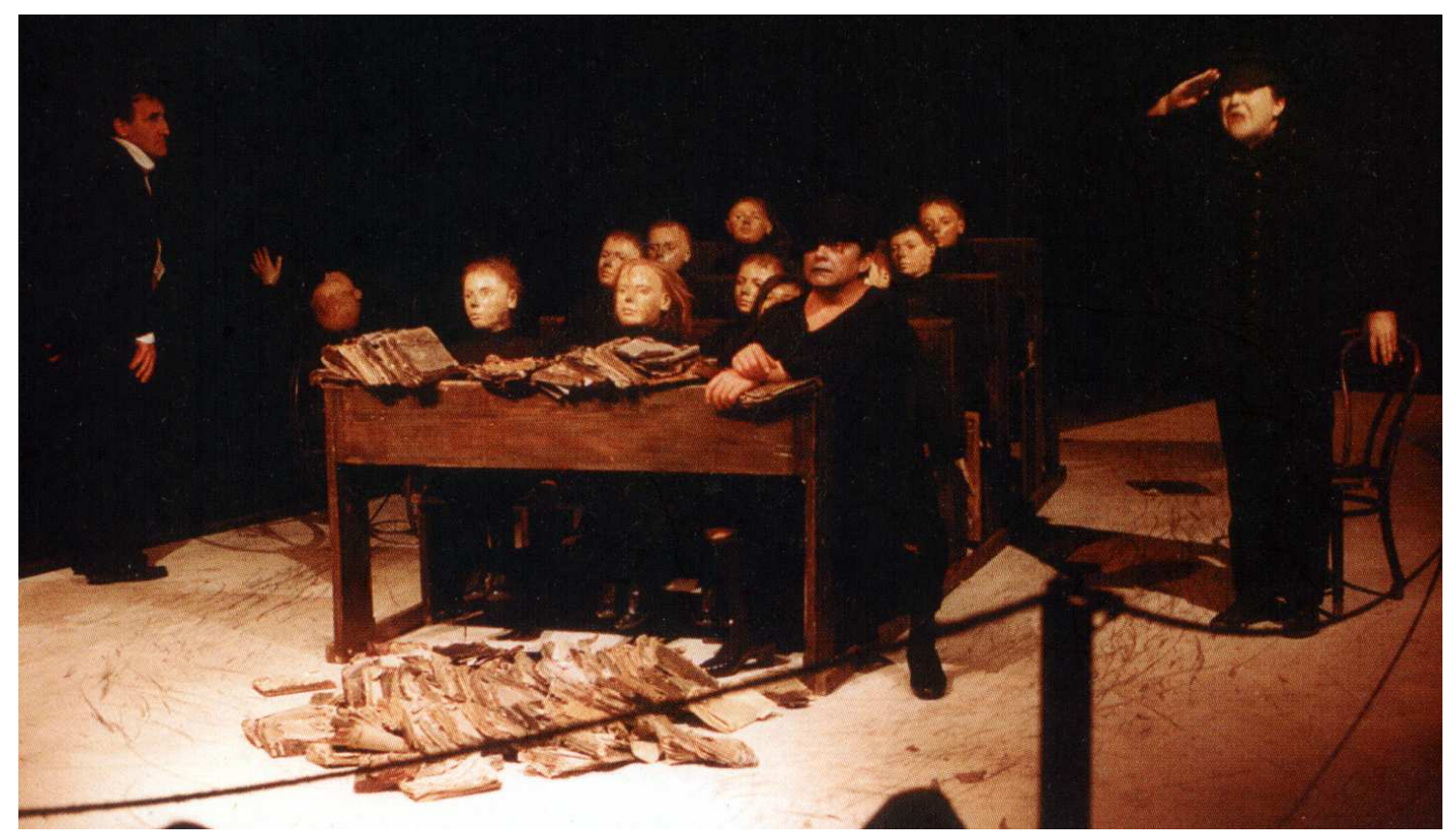

A classe morta. Na imagem do espetáculo realizado em Nova lorque em 1979, a corda que delimita os espaços do público e da cena. Fotografia extraída do programa da exposição sobre Tadeusz Kantor organizado pela Galeria Sztuki, em Lublin, Pôlonia em 2003.

Desde a Renascença com a redescoberta da perspectiva ${ }^{6}$ no teatro tradicional, $o$ palco é uma extensão da platéia que introduz a terceira dimensão em um plano de duas dimensões. Isso quer dizer que ao olhar para um quadro o observador tem a ilusão de

\footnotetext{
${ }^{5}$ Kobialka, Michal. A journey through other spaces. Essays and manifestos, 1944-1990 - Tadeusz Kantor. Los Angeles: University of California Press, Ltd. 1993, p. 325.

${ }^{6}$ Brunelleschi redescobriu a perspectiva, Alberti a teorizou em 1436.
} 
que a tridimensionalidade realmente existe no plano da obra que é bidimensional. Ela nos indica como era a relação do homem com o mundo ${ }^{7}$. Até então, o espaço de representação medieval que na maioria das vezes era um espaço real, uma igreja, por exemplo, foi substituído pela forma de proscênio em arco, o que facilitava a construção da perspectiva e também possibilitou o desenvolvimento de um processo de imitação da vida e de construção de um espaço de representação, no qual a platéia pudesse ser capaz de decifrar os códigos e significados das situações que estavam sendo apresentadas diante dos seus olhos. $\mathrm{O}$ artista que adota a perspectiva como condição essencial da sua arte não está interessado em uma visão abstrata e nem mesmo absoluta da realidade. Ele apresenta um ponto de vista de algo que está acontecendo em um determinado momento. Nesse sentido, a perspectiva é uma inovação na história da arte. Ela introduz na arte a dimensão do tempo e aquilo que o artista reproduz não se trata mais de uma estrutura imutável mas de uma percepção individual da realidade. Essa estrutura que nasce com a Renascença permanece até os dias atuais. Kantor, por sua vez, ao diferenciar o espaço da representação do espaço do espectador, sugere que aquilo que está no palco está protegido, o acesso está muito além do simples olhar. Aquilo que é visto em cena não é algo que se possa decifrar inteiramente; exatamente por não ser o ponto de vista de uma situação em particular localizada em um momento específico. Trata-se apenas de uma situação que nada imita e nada pretende imitar.

Nesse momento de transformação do teatro de Kantor, a cena irá se constituir como a materialização das suas memórias, processo que se tornará cada vez mais sólido e contundente na sua produção teatral, mas trata-se de uma materialização a cuja memória apenas Kantor tem acesso. A platéia é deixada de lado nesse processo. Evidentemente, o espetáculo transforma-se em um constante retornar a si mesmo, não há possibilidade de qualquer extensão ao espectador. A corda impede, simbolicamente, que o espectador entre no espaço da representação. A angústia é evidente para o espectador que se vê diante do fato de não enxergar a cena como reflexo da sua própria vida. A cena continua a não imitar nada se tornando somente o espaço de ação para as memórias de Kantor, apenas as suas memórias que podem até ter alguma possibilidade de alinhamento com as do expectador mas esse alinhamento ou aproximação jamais será completado.

\footnotetext{
${ }^{7}$ Mantovani, Ana. Cenografia. São Paulo: Editora Ática, 1989, p. 9.
} 
Essa idéia de separação simbolizada pela corda também se refere à concepção de Kantor sobre o ator e da sua separação do espectador:

“Tentaremos representar essa situação fascinante: em frente àquele que desse lado, um homem se ergue exatamente semelhante a cada um dos demais, entretanto, (pela virtude de qualquer operação misteriosa e admirável) infinitamente distante, terrivelmente estranho, como habitado pela morte, separado deles por uma barreira, que por ser invisível, não parecia menos assustadora e inconcebível, tal que o sentido verdadeiro e a honra, só podem nos ser revelado pelo sonho.",

Para Kantor, o aparecimento do ator é um ato revolucionário pois através da semelhança se percebe a mais profunda diferença. Essa barreira a qual Kantor se refere está conectada com o ideal de uma ação que está sendo realizada pela primeira vez. A semelhança entre os homens, quando um deles se encontra do outro lado, percebe-se a existência do homem, que apesar de ser homem, não é exatamente homem enquanto semelhança. Evidentemente, trata-se de uma noção que contraria a perspectiva renascentista de imitação da vida, já que essa é uma imitação por semelhança. Em Kantor, se em algum momento fora do Manifesto do teatro da morte se possa falar em imitação, certamente essa não será por semelhança, mas por diferença. Talvez isso explique a atitude de Kantor em $O$ retorno de Ulisses, ao destinar às personagens a utilização de objetos sem nenhuma utilidade para a vida prática, como uma cadeira quebrada, mas que no espetáculo passam a ser utilizados exatamente pela diferença, como uma nova "genesis", um primeiro ato de criação. O objeto, tal qual o homem, como se vistos pela primeira vez.

Mas essa idéia da semelhança e diferença introduzida em A classe morta vai muito além da agonia e da aflição do espectador por não ser capaz de reconhecer o seu reflexo na cena. Aquilo que ele observa em termos de semelhança é exatamente o que o torna infinitamente diferente. Aquilo que o espectador observa no palco não é o reflexo da sua vida mas a projeção da sua morte. No palco, a semelhança ocorre através da diferença, assim como a vida através da morte.

\footnotetext{
${ }^{8}$ Manifesto do teatro da morte, in. Kantor. Tadeusz. Les voies de la création théâtrale, études de Denis Bablet et Brunella Eruli, réunis et présentés par D. Bablet. Paris: C.N.R.S. Vol. XI, 1983, p. 64.
} 
"Assim que na luz ofuscante de um raio, eles percebem repentinamente a imagem do homem, barulhento, tragicamente clownesca, como se eles o vissem pela primeira vez, como se eles vissem a si mesmos. Esse foi com certeza, uma percepção que se poderia qualificar de metafísica.

Essa imagem viva do homem saindo das trevas, colocando sua marcha adiante, constitui um manifesto irradiante, de sua nova condição humana, somente humana, com sua responsabilidade, e sua consciência trágica, determinando o seu destino em uma escalada implacável e definitiva, a escalada da morte. "9

Essa "nova condição humana" apontada por Kantor é exatamente o centro dessa outra etapa do seu teatro. Nesse contexto, somente quando nos confrontamos com um morto é que percebemos as diferenças existentes entre eles e os vivos e como conseqüência os questionamentos sobre a morte e a vida. Com o Teatro da Morte Kantor propõe um novo modelo para o ator cujas referências não estão nas semelhanças encontradas desse lado, o lado da platéia, mas que nos força a olhar de uma maneira mais apurada e atenta para a diferença que está latente do outro lado da barreira intransponível.

"Foi aos espaços da morte que esse manifesto foi endereçado, revelador que provocou no público (utilizando um termo atual) esse acesso ao metafísico. Os meios e a arte desse homem, o ator (empregando nosso próprio vocabulário), ligando-se assim à morte, a sua trágica e horripilante beleza.

Nós devemos devolver à relação espectador/ator a sua significação essencial. Nós devemos fazer renascer esse impacto original do instante no qual um homem apareceu pela primeira vez diante de outros homens, exatamente semelhante a cada um de nós, e, no entanto, infinitamente estranho, além dessa barreira que não pode ser transposta. $" 10$

Assim, até $A$ classe morta, Kantor utilizava atores que tinham uma formação de teatro convencional. Diante dessa nova concepção, as pessoas que alimentavam as cenas do seu teatro não precisavam necessariamente ter formação de ator. Esse é um elemento muito importante, embora, durante a fase do Teatro Impossível, ele já houvesse

\footnotetext{
${ }^{9}$ Ibid.

${ }^{10}$ Ibid.
} 
utilizado pessoas nas suas vidas reais, como em Cassino, por exemplo, uma cricotage realizada em $1969^{11}$.

A partir dessa nova fase, essas pessoas não profissionais que ele passa a utilizar, muitas delas tiveram com ele encontros casuais, tratavam-se de pessoas reais, com suas pessoalidades e trejeitos cotidianos mas que, de alguma maneira, foram capazes de reorganizar o seu pensamento em relação à poética de Kantor. Poética que desde então se fundamenta sobre a materialização da memória de Kantor no palco e é a partir dela que esses atores e não-atores desenvolvem os jogos que se transformarão em cenas. Esses jogos e essas cenas, especificamente em A classe morta, os atores que estão do outro lado da corda de demarcação do espaço e ao mesmo tempo do outro lado dessa barreira metafórica, em um ambiente que se poderia qualificar de metafísico, essas pessoas se tornam os geradores das memórias de Kantor tanto quanto da ação paralela da peça de Witkiewicz ${ }^{12}$.

Desde o Teatro Zero, Kantor afirma que é impossível para o ator representar algo além de si mesmo. Disso decorre o conceito do "ator dibuk" e, por inferência, a revelação da existência de um lugar de transição entre "um e outro mundo". O "ator dibuk" nada mais é do que uma pessoa que é "possuída", metaforicamente, por um morto $^{13}$. Essa idéia no teatro de Kantor não tem nenhuma relação com qualquer fator místico ou religioso. Esses mortos, aos quais Kantor se refere, são aqueles que habitam a sua memória e que encontrarão nos atores do Cricot 2 um meio para retornar a esse mundo não por possessão, mas por correspondência. Esse processo ficará mais claro

\footnotetext{
${ }^{11}$ No Teatro Impossível não existia um local definido para a encenação. Os atores circulavam por diversos lugares reais nos quais se produziam os acontecimentos, ultrapassando, por seu caráter extraordinário, os limites do possível. Em Cassino, além dos atores, havia pessoas reais que exerciam na cena as funções que realizavam no dia a dia. Havia, dentre outros, um Crupiê que comandava a roleta e jogadores verdadeiros, já que se tratava de um Cassino verdadeiro, que apostavam na roleta e um grupo de Hippies ambulantes reunidos ao acaso. Em determinado momento, o limite do possível era ultrapassado pela ameaça de um rebanho de carneiros que tentava entrar na sala. Feno era trazido e empilhado ao redor da roleta ao mesmo tempo em que galinhas entravam na sala, voavam e cacarejavam sem parar. Os atores se colocavam em perseguição dos animais. Essa situação era uma das medidas do impossível.

${ }^{12}$ É importante esclarecer que essa barreira de separação não significa, em nenhum momento, desconhecimento do público pelos atores. Não, pelo contrário, existe total consciência sobre isso, mas também, eles são muito conscientes de que não estão interpretando um texto literário, mas sim que são agentes dos comentários mais pessoais e interiores de Tadeusz Kantor.

${ }^{13}$ Dibuk é o nome da alma errante de um morto. Em certas circunstâncias, um dibuk penetra no corpo de um vivo. (...) Essa crença permaneceu viva durante muitos anos em amplas camadas dos guetos judaicos do leste europeu - Trecho do prefácio de Anatol Rosenfeld para a peça $O$ dibuk de Sch, Na-ski. São Paulo: Brasiliense, 1965.
} 
com a encenação de Wielopole Wielopole, espetáculo que se caracteriza por ser fundado nas memórias de Kantor. Esse retorno se dá evidentemente sob duas bases. A primeira, estritamente formal, reza que o retorno aconteça através da materialização da aparência da morte. A segunda, conceitual, solicita que ele se realize em um espaço intermediário. Esse novo espaço se configura como um espaço paralelo situado entre a morte e a vida.

Com A classe morta, Kantor mergulha muito mais profundamente nos pesadelos da vida. O abandono do espaço real produz uma imersão na realidade através dos mecanismos da morte. Mas como lidar com a morte no teatro se não através da ilusão? É por isso que, ainda que discretamente, a ilusão faz o seu retorno ao teatro de Kantor. A realidade nos é apresentada através dos objetos, sobretudo os bancos, e também pelos Velhos. Os bancos de escola, devido à sua robusta materialidade física, aludem à permanência, à supremacia do objeto sobre brevidade da matéria humana. Os bancos escolares tratam-se daquilo que é mais real no espetáculo e é exatamente através deles que a ilusão se manifesta com maior força, ou seja: os bancos criam a ilusão da sala de aula. Por outro lado, na peça, os Velhos que trazem em si a aparência da morte, a inexorável realidade da existência humana reforçada pela aparência degradada pelo tempo, insistem em negar a morte através do recurso dos manequins que materializam suas próprias memórias do período mais vivo das suas histórias, o período escolar.

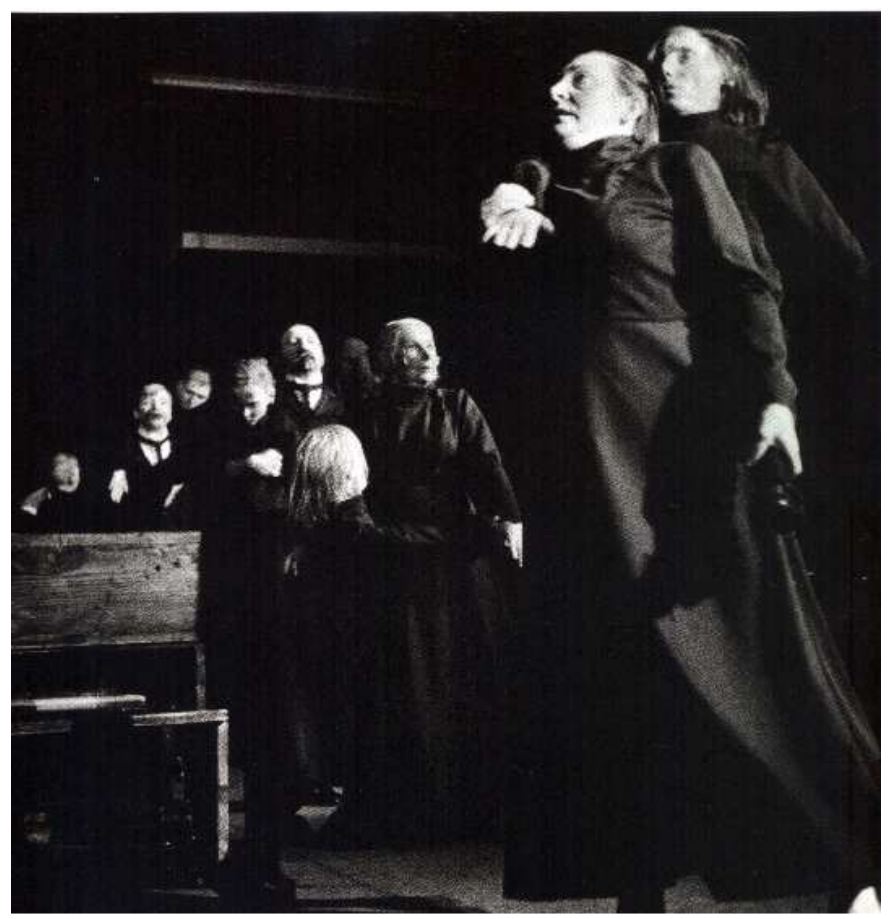

A classe morta. Na cena, os Velhos com os manequins de crianças. Foto Maurizio Buscarino 
Mas de que maneira a peça de Witkiewicz se encaixa nesse processo? Kantor não está interessado em representar a peça Tumor cervical, mas sim em criar uma tensão entre os velhos de $A$ classe morta com a peça de Witkewicz. Existe no espetáculo um processo de reduplicação da realidade. Isso quer dizer que temos a realidade de $A$ classe morta e a realidade de Tumor cervical. Assim, ocorre constantemente uma mistura entre os Velhos que estão constantemente dando vida às suas memórias, mas essas jamais se completam com a ação da peça de Witkiewicz. Isso significa que as memórias dos Velhos não são reconstruções nostálgicas do passado porque as imagens que se formam são retiradas das palavras da peça de Witkiewicz e, dessa maneira, as imagens entram em colapso devido ao excesso de elementos em choque. Por outro lado, os personagens da peça de Witkiewicz são "habitados" pelos Velhos de A classe morta. Em alguns momentos, a cena parece apresentar alguns elementos do texto de Witkiewicz mas nenhuma das cenas jamais se completa. Uma das maneiras de reagir à tentação de completar logicamente a cena é através das lembranças dos Velhos que se recordam dos seus tempos de escola. Toda vez que a peça Tumor cervical ameaça se impor pelos campos da narrativa lógica e contínua, os Velhos, que estão presos à imaginação de Kantor não à de Witkiewicz, voltam a si mesmos e à realidade da classe que expõe a sua condição de degradação e proximidade da morte.

\section{A RELATIVIDADE DO ESPAÇO, DA MEMÓRIA, DA ILUSÃo}

Como eu já antecipei em alguns parágrafos anteriores, Kantor não percebe o espaço como um valor absoluto como preconizava Isaac Newton, mas como um espaço motivado por diversos valores relativos. Esse espaço que surge com A classe morta passou a ser explorado através de uma perspectiva fora das definições tradicionais, sobretudo a compreensão neo-realista ${ }^{14}$ de Aristóteles. O espaço em Kantor é uma estrutura dinâmica no qual tudo que nele existe está em um processo contínuo de mudança. A partir de A classe morta, a noção de espaço real se esvaziou, noção que era

\footnotetext{
${ }^{14}$ Referindo-me ao termo aristotélico habitualmente utilizado pela crítica contemporânea e anteriormente já utilizado por Brecht para designar um teatro baseado na ilusão e na identificação.
} 
de supra-importância para o aparecimento da tensão dentro da realidade. Nesse momento da sua obra, Kantor voltou todo o seu interesse para a investigação da tensão que ocorre entre o choque da memória com a realidade.

O jogo de tensões entre memória e realidade em seus espetáculos ficará mais evidente em Wielopole Wielopole. O espaço desse espetáculo certamente não é o mesmo espaço de $A$ classe morta, que era um espaço constantemente desafiado pelos personagens da obra de Witkiewicz. O espaço de Wielopole Wielopole é o espaço que se estrutura através da repetição, da possibilidade de ação constante da memória na cena. Isso é aquilo que Kantor chama de "espaço da memória", em que ele usa de uma realidade, não uma realidade literária como foi o caso de Tumor cervical para desestabilizar suas lembranças, mas a realidade das suas experiências pessoais, das recordações mais íntimas que encontrarão na cena as condições essenciais para a sua materialização. A cena se tornará o espaço de ação da sua memória, o espaço da sua infância com todos os seus habitantes. Esse espaço é construído infinitamente pela memória, no qual seus habitantes - parentes, amigos, personagens públicos - vivem e morrem insistentemente a cada reconstrução. É um espaço que se transforma por ser maleável, da mesma maneira que maleável é a memória de Kantor. Os personagens que nele são depositados repetem insistentemente os mesmos gestos como se estivessem presos a uma pose em uma fotografia. Nesse espaço somente Kantor tem o domínio, e é exatamente por isso que no início do espetáculo é ele quem está em cena arrumando, posicionando os objetos de suas lembranças. A cena se constituirá, então, não na reprodução das coisas como eram mas da maneira como ele julga se lembrar. Assim, as situações não precisam ser apresentadas através de uma estrutura linear, elas ocorrem independentemente umas das outras; o que leva ao resultado de cada cena individualmente se resolver em si mesma e distante de qualquer possibilidade de verossimilhança com o real. É por isso que encontramos em Wielopole Wielopole a cena da crucificação antes da santa ceia, a morte dos soldados antes de partirem para o combate. A linearidade histórica e o tempo cotidiano não têm a menor importância. $\mathrm{O}$ principal trata-se do processo de desestabilização da memória interna de Kantor que ocorre quando as personagens intervêm no espaço de representação, já que esse espaço é a sua própria memória materializada. 
Como já foi dito, entre 1944 até 1973, Kantor rejeita abertamente a ilusão por acreditar que a única possibilidade de se chegar à verdade era através do manuseio da realidade. A realidade era a única coisa que interessava ser explorada e cuja entrada se dava através dos objetos marginalizados, degradados, esquecidos nas latas de lixo. Já em 1973, com a crise da "realidade de classe mais baixa", Kantor se volta para a ilusão como uma nova maneira de lidar com a realidade, processo contra o qual ele havia lutado durante a maior parte da sua vida artística. Assim, por esse caminho, Kantor percebeu que no seu teatro, por trás da barreira intransponível, emerge outra realidade, uma realidade que é elevada a outro nível, ou seja: o teatro passou a ser entendido como um local onde os registros da realidade e da ilusão são expostos, sendo que a ilusão possui a propriedade de transferir a realidade para outro tempo e para outro espaço.

Uma vez que esse outro espaço é criado e organizado por ele à maneira das suas lembranças, evidentemente, no momento que lhe melhor interessar, ele permitirá que os personagens surjam, vindos de um "outro mundo" através das portas e intervenham no espaço da sua memória. Por serem as suas ações desconexas e ilógicas, esses seres "memoriais" tentam organizar seus atos através de ações repetidas, mas eles não conseguem, exatamente porque as suas memórias não são as corretas; é importante lembrar aquilo que foi descrito a propósito de $\hat{O}$ doce noite, quando após o Holocausto os mortos, ao ressuscitarem, tentaram reconstruir o mundo através dos objetos mas eles não sabiam para que eles serviam exatamente. Por mais que os personagens tentem, é sempre a memória de Kantor que persevera. Mesmo que suas memórias não sejam totalmente verossímeis, a similaridade existe e é exatamente isso que prende os personagens no espaço, através do jogo, não com a verossimilhança, mas com a similitude. O que está em cena são fragmentos de personagens e situações, tais como: os membros da sua família, a Primeira e Segunda Guerras Mundiais, passagens bíblicas, etc. Tudo isso, produto da memória, está misturado de forma caleidoscópica, o espaço se re-arranja a partir de cada abertura das portas. Segundo Michel Kobialka ${ }^{15}$, a memória de Kantor não possui uma estrutura linear de desenvolvimento, aquilo que se vê no palco é a própria consciência do artista, ou seja: o "espaço da memória" trata-se exatamente da consciência dos fatos da sua própria história pessoal. Por outro lado, se há consciência, é possível intuir que muitas dessas situações criadas por Kantor também

\footnotetext{
${ }^{15}$ Michal Kobialka. Palestra realizada no Teatro Fábrica São Paulo em julho de 2005.
} 
podem ser produzidas por digressões oriundas do inconsciente. Nessa situação, não existe nenhuma garantia de que as ações de Kantor, apesar de criadas a partir da consciência, não entrem na cena através do inconsciente. É exatamente por isso que é impossível determinar alguma relação de causa e efeito entre uma cena e outra nos seus espetáculos. Quando é visto pela primeira vez, é impossível prever o que irá acontecer quando a porta se abre e o espaço se transforma. Por esse caminho, é possível perceber que o espaço de Kantor não é absoluto como o espaço de Newton e também não é uma metáfora. Trata-se de um espaço que é multidimensional, relativo na sua organização espaço temporal, o que torna muito difícil prever como as situações e os jogos irão se desenvolver. Mais uma vez, o teatro de Kantor se mostra como uma atividade em constante transformação.

Em sua memória, as personagens e situações de Wileopole Wielopole já aconteceram. No palco, essas memórias se constituem como outro ato de criação, como repetição de um fato no tempo. No palco, personagens e situações se repetem uma vez mais mas sempre como uma atitude criativa genuína. E como os fatos se desenvolvem na medida das suas lembranças, e essas nunca são precisas, estão em constantes transformações, reforçadas eventualmente por um ou outro detalhe que lhe interessa no momento, na cena, tudo ocorre como se fosse feito pela primeira vez. Nesse sentido esse espaço de criação anula a realidade que aconteceu em outro tempo e noutro espaço, constituindo assim, diferentes possibilidades de exploração das relações entre tempo e espaço. É exatamente por isso que o obsessivo tema da Segunda Guerra Mundial é uma constante no seu trabalho. Para cada repetição do tema, ele espera que o espectador perceba os acontecimentos e a trabalhe na sua memória através das imagens que são lançadas no espaço e que essa insistência na repetição estimule o espectador a não sucumbir ao esquecimento. Kantor acredita que completar é esquecer, é não dar possibilidade para a ação da imaginação e produção de novas imagens ou conhecimentos. Essas imagens produzidas afetam as experiências sobre aquilo que o espectador sabe da realidade. Assim, a avaliação daquilo que se vê em cena está diretamente relacionada com as suas experiências passadas e com as suas emoções. Dessa forma, no palco, tudo está envolto por um enorme peso emocional.

Durante muito tempo Kantor se debateu contra a ilusão em proveito da promoção do "objeto real"; a isso ele chamou de a descoberta da realidade, que nada 
mais era do que a sua maneira de se opôr ao naturalismo e, de certa maneira, também à abstração. Segundo ele, a abstração também pode suscitar a ilusão através do gesto criador, através da ilusão do pensamento que constrói formas. Entretanto, pouco a pouco, ele foi vencido pela materialidade da realidade e seu teatro ganhou um novo impulso ao trazer de volta a ilusão para a cena, ao reintroduzi-la de outra maneira, como uma dimensão específica da sua arte. Em determinado momento desse processo, ele declara que a realidade não pode existir por ela mesma, necessitando sempre de alguma coisa que a coloque em perigo, nesse caso: a ilusão. Ilusão que está além do significado corrente do termo, assume, para ele, uma dimensão metafísica. Dimensão essa muito próxima de um ritual, que por sua estrutura de repetição, lhe atribui esse aspecto metafísico. Disso decorre o paradoxo do teatro de Kantor: ser ao mesmo tempo antiilusionista, no sentido de que os atores são percebidos como signos, e pelo fato do diretor estar em cena, no meio deles, observando e corrigindo a sua disposição, mas também revelam esse outro aspecto metafísico da ilusão que é capaz de acionar a realidade através da repetição, como em Wielopole Wielopole.

Mas esse aspecto, digamos ritualístico, suscitado pela repetição, não possui a mesma dimensão de um verdadeiro ritual, como no teatro oriental, como em Artaud ou em Grotowski. Essa idéia se manifesta, como assinala Guy Scarpeta ${ }^{16}$, como um apontamento, como uma indicação, assim é o caso das roupas vermelhas dos Bispos que dançam tango em Onde estão as neves de antanho? ou as músicas em Wielopole Wielopole; Que morram os artistas!; e Não voltarei jamais. Em se tratando de Onde estão as neves de antanho?, Guy Scarpeta comenta:

“...há uma mistura de rituais. O tango é um ritual, as roupas vermelhas dos cardeais pertencem a um ritual, mas são dois cardeais em roupa vermelha que dançam tango, isto é verdadeiramente outra coisa., ${ }^{17}$

\footnotetext{
${ }^{16}$ Scarpetta, Guy. Kantor au présent. Arles: Actes Sud, 2000, p. 89.

${ }^{17}$ Ibid.
} 


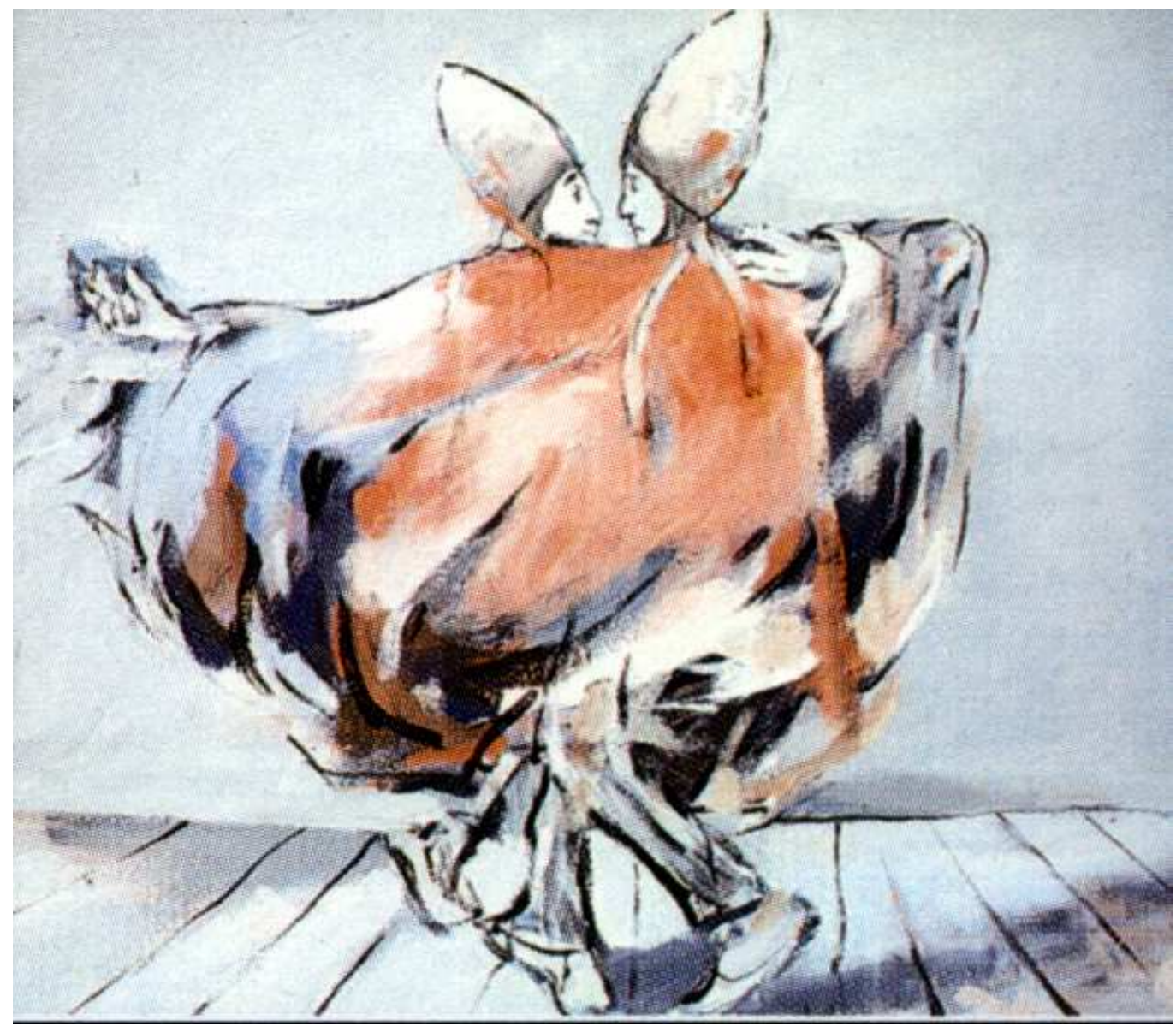

Bispos dançando tango - projeto inicial feito para Onde estão as neves de antanho e que também foi usado em Não voltarei jamais. Foto: arquivos da Cricoteka.

O mesmo acontece com os rituais escolares, com o exército, com o casamento, as fotos de família, etc., que são transformados ao mesmo tempo em que são esvaziados dos seus significados imediatos para serem redimensionados em uma nova forma de existência. 


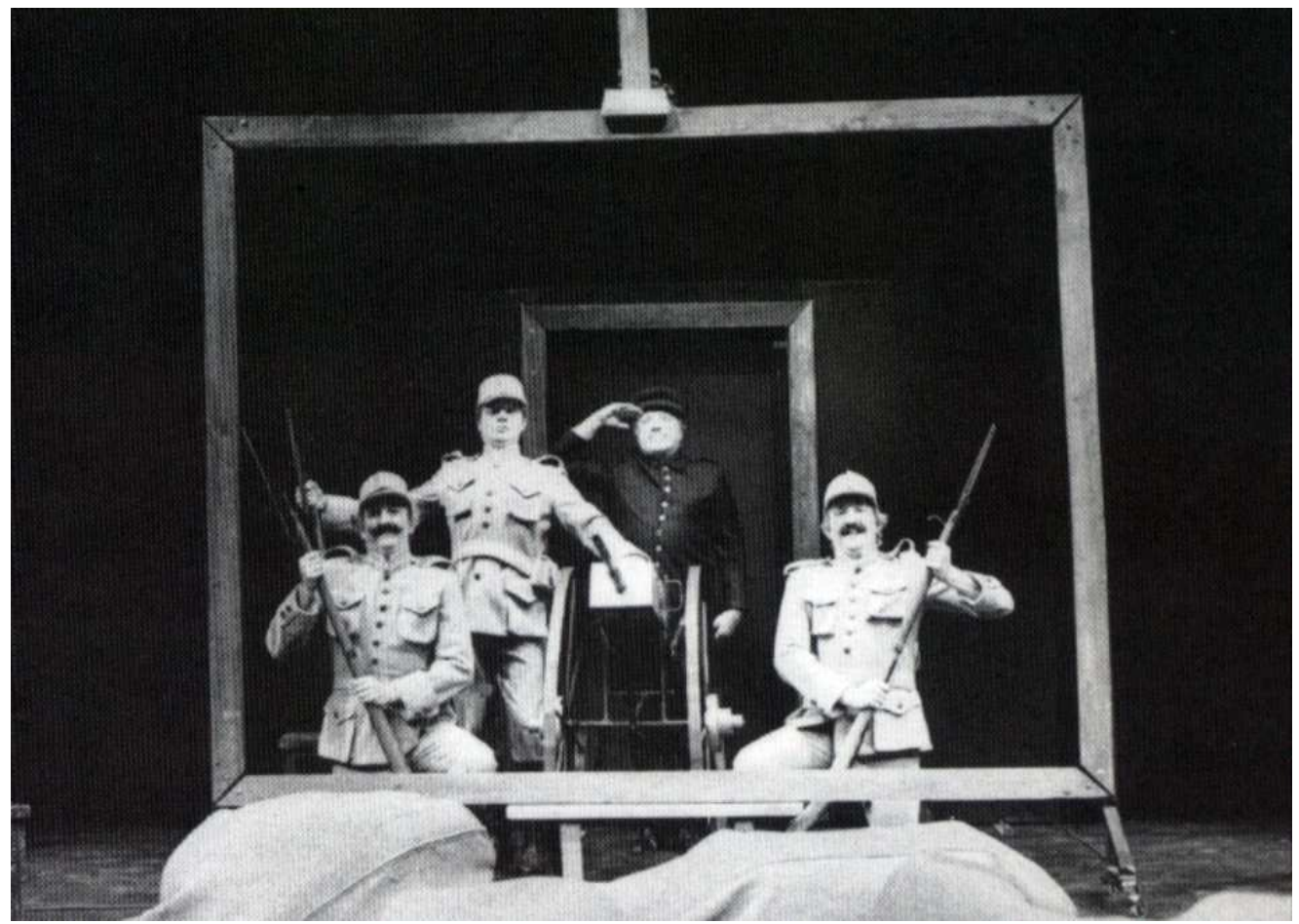

Hoje é meu aniversário. Na cena, os soldados posam para a fotografia. Foto: arquivos da Cricoteka.

O palco é o espaço da memória de Kantor. Trata-se de um local onde somente ele pode interferir. Se em Wielopole Wielopole ele trabalha com a idéia da repetição como um ato de criação, não criação divina, mas criação humana capaz de construir e desconstruir o espaço a partir da sua memória, em Que morram os artistas! por sua vez, ele irá trabalhar com uma nova forma de utilizar a memória no espaço, ou seja: através da exploração de múltiplos desdobramentos de Kantor no tempo. A exploração dessa multiplicidade de tempo e espaço ocorrerá, evidentemente, no mesmo tempo e no mesmo espaço. Se em Wielopole Wielopole o "espaço da memória" é único e estava sujeito a constantes transformações devido à inferência dos personagens que alteravam os aspectos aparentemente estáveis do espaço, em Que morram os artistas!, Kantor irá desenvolver a idéia do espetáculo como uma seqüência de negativos fotográficos colocados um sobre o outro, o que leva a concluir que ao olhar o primeiro, necessariamente se observará todas as personagens e situações simultaneamente. Nesse sentido, o espaço de ação ou espaço da memória, pode ser definido também como um espaço híbrido, não uno, um espaço que traz em si a qualidade de ser o que é, ou seja: local da representação, mas também a materialização de múltiplos espaços da memória 
de Kantor. Dessa forma, temos esse espaço se constituindo ao mesmo tempo como um cemitério, um albergue, uma câmara de tortura, dentre outros. E nesse espaço serão observados diferentes estados de Kantor: Kantor aos seis anos, Kantor morrendo, Kantor ele mesmo, que na realidade do espetáculo gera, através da memória, o passado; e através da consciência, a projeção do futuro. Assim, simultaneamente teremos na cena vários "Kantors", e ao olharmos para um, conforme a organização em negativos, necessariamente estaremos olhamos para os outros, sendo que cada um desses negativos pode produzir a sua própria memória, o que amplia as relações no tempo e no espaço.

Esse jogo com o espaço-tempo encontra paralelismo nas teorias da física quântica no sentido de que no mundo quântico tudo está em superposição. No universo quântico existem várias possibilidades de existência para o mesmo objeto, ao passo que no mundo convencional estas múltiplas possibilidades, ao que me parece, se resumem a escolhas muito específicas e definidas, ou seja: tudo é determinado e está em um lugar específico. O teatro de Kantor, assim como a mecânica quântica, é oceano de genuína potencialidade de existências distintas.

Existe um preceito na teoria da física quântica chamado de "entrelaçamento" que diz que a conectividade entre as coisas é o fundamento básico do tecido da realidade. Dessa forma, é preciso estabelecer novos paradigmas para aquilo que chamamos de realidade. A realidade não se sustenta mais na aparência daquilo que sabemos sobre o real. Existe um nível de existência que acontece em um mundo que não é percebido pelos sentidos. O espaço, por sua vez, fornece apenas a ilusão de que as coisas estão separadas. Através dessa percepção, e a partir de experimentos realizados no mundo subatômico, foi demonstrado pelos físicos que nesse nível, uma partícula (um dos componentes da matéria), pode estar em vários lugares ao mesmo tempo. Elas, ao que parece, podem estar ligadas apesar de aparentarem estar separadas. Na realidade, elas podem estar ligadas pelo espaço, por um espaço muito grande. Um espaço composto de várias dimensões. No caso de Que morram os artistas!, isso é observado através do desdobramento de Kantor em várias dimensões temporais.

Para a teoria da relatividade, o tempo não é absoluto e de acordo com a "simetria reversa do tempo", na qual uma das suas bases teóricas e também controversa, trata-se do fato de podermos influenciar o passado na mesma medida em que podemos 
influenciar o futuro, e mais controversa ainda, a possibilidade de que o futuro pode ter um efeito causal no presente. No mundo quântico, as coisas podem se mover para frente e para traz. Dessa forma, a simetria de reversão do tempo destrói a nossa percepção e todas as noções que possuímos sobre o tempo e, por outro lado, o "entrelaçamento" acaba por destruir toda a nossa experiência com o espaço. Assim, conforme esses princípios, é possível vermos Kantor no passado, no presente e no futuro.

Em uma das metamorfoses do espaço, a entrada de Veit Stoss é muito significativa pois ele irá recriar o seu famoso retábulo esculpido para a Catedral de Santa Maria, na Cracóvia. Os objetos que entram em cena, os quais constituirão a nova obra que será construída pelos atores que estão no albergue, transformam o espaço em um local de tortura no qual os artistas são supliciados. A construção realizada, inspirada na obra do século XV, no momento em que os objetos são agrupados, assume a dimensão de barricada, um local de resistência de onde será lançada uma mensagem ao mundo, uma mensagem que contradiz a idéia de que os artistas devem morrer. Essa contradição está alicerçada no pensamento de Kantor de que o artista deve viver e criar, e somente assim, através da verdadeira criação artística, a humanidade alcança a tão sonhada eternidade. Evidentemente, ao trazer Veit Stoss para a cena, Kantor está associando a idéia de obra de arte ao conceito de eternidade. Através da obra, da verdadeira obra de arte, não aquela destinada unicamente ao consumo, o artista não morre, ele vive eternamente. Dessa forma, Veit Stoss, assim como os vários momentos de Kantor, existe no presente, determinado pela arte, no mesmo instante em que existe no passado determinado pela história, ou melhor, pela memória. Seguindo os princípios do "entrelaçamento", Veit Stoss, Kantor e o espectador, estão ligados pelo espaçotempo, mesmo que separados pelo espaço e pelo tempo. Assim, aquilo que liga o passado, o presente e o futuro e permite o rompimento com o espaço absoluto é exatamente a arte de Veit Stoss e os objetos do espetáculo, os objetos de Kantor, com os quais o artista do século XV recriará no presente a sua obra mais importante. Em resumo, o retorno se dá através da matéria, do objeto artístico. O teatro de Kantor ignora o relógio e suas convenções. Ele funciona como um organismo, um tipo especial de organismo altamente conectado com suas partes e que se estende pelo espaço e pelo tempo. 


\section{OS NÍVEIS RELATIVOS DA ILUSÃO E DA REALIDADE}

É muito difícil restringir a arte de Kantor a alguma síntese pois um dos elementos que impõem essa dificuldade trata-se da intensa necessidade que Kantor possui em descrever a realidade na qual ele está inserido. Em Que morram os artistas! a relação com o espaço não se dá da mesma maneira como aquela ocorrida em Wielopole Wielopole na qual, no seu processo de exploração, ele sugere que a memória funciona não somente como um desdobramento linear da narrativa mas que ela possui aptidão para o espaço. Em Que morram os artistas! aquilo que interessa a ele é a coexistência de diferentes memórias em um mesmo espaço e no mesmo instante. Nessa encenação, Kantor, a exemplo de Wielopole Wielopole, também inicia o espetáculo organizando os objetos no espaço da cena: as camas, as cruzes, cadeiras, portas etc. Somente quando o espaço estiver organizado e pronto é que os personagens entrarão. Uma das cenas que considero muito esclarecedora sobre a ação da memória no espaço e que enfatiza a idéia dos negativos, trata-se, logo no início da peça, do momento quando Kantor, a criança de seis anos entra em seu brinquedo infantil. Nessa cena ele, a criança de seis anos, é seguido por outra de suas memórias que diz respeito aos seus soldadinhos de brinquedo, mas ao mesmo tempo trata-se das suas lembranças sobre o movimento das tropas do exército comandadas pelo Marechal Pilsuldisk. Nesse espaço, os soldadinhos, ao brincarem com Kantor, a criança, também materializam a memória de um importante momento da história da Polônia no seu processo de conquista da independência.

De certa maneira, nesse espetáculo, a memória, a tradução cênica das suas lembranças mais íntimas, o conduzirá para a intensificação do processo de transparência da ilusão. Diferentemente dos espetáculos anteriores nos quais ela estava escondida no texto de Witkiewicz. Sobre isso comenta Guy Scarpetta:

“...a ilusão é elevada ao seu ponto culminante de saturação, de exasperação, aquele onde os corpos vivos imitam os manequins, onde a oposição entre o real e a aparência acaba por se decompor - estado do maisque-real." 18

\footnotetext{
${ }^{18}$ Scarpetta, Guy. Kantor au présent. Arles: Actes Sud, 2000, p.46.
} 


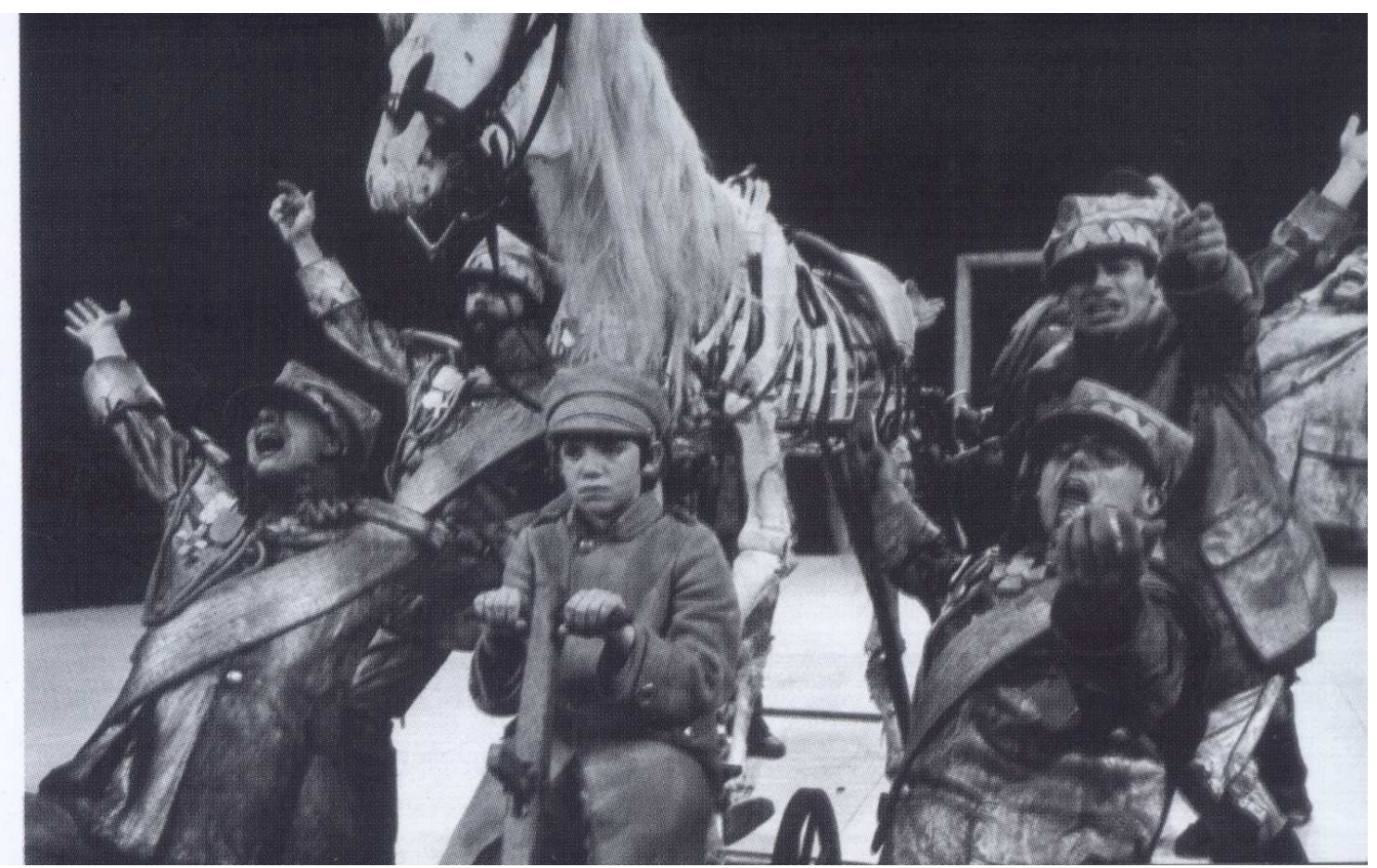

Que morram os artistas! Na cena, os soldados brincam com Kantor, a criança de seis anos. Foto: Romano Marinis.

Em Que morram os artistas!, o seu desejo de mostrar a realidade no palco o conduz a outra armadilha, algo que o aproxima do tão combatido teatro tradicional. Isso quer dizer exatamente que a criança que Kantor era aos seis anos é representada por outra criança de seis anos, não pelo Kantor real. Na sua morte, outro morria no seu lugar, um ator representava o seu papel de morrer. Em síntese, aquela estrutura que ele havia confrontado toda a sua vida, nesse espetáculo, conforme a minha interpretação pessoal, funcionava perfeitamente bem. Sobre esse processo de retorno da ilusão ao seu teatro, em uma entrevista a Guy Scarpetta, Kantor diz:

“A realidade e a ilusão são problemas capitais para mim. No início, eu era um ortodoxo, ou seja: eu recusava completamente a ilusão. Eu queria que somente a realidade existisse. Posteriormente eu comecei a duvidar, pois a ilusão, em meus espetáculos, aparecia cada vez mais. Quando eu pego um objeto, ou um personagem da vida real, eu privo esta realidade do passado e do futuro. Eu pego, por exemplo, no teatro, uma ação que é útil na vida, e privo esta ação de sua causa, de seu motivo, assim como de sua meta, de 
sua eficácia, é isto que eu chamo a "realidade pura", aquela que eu posso manipular. Mas em certos momentos esta realidade acaba por tornar-se uma "ilusão" (...)"

Já em Não voltarei jamais, diante do dilema estabelecido entre a realidade e a ilusão, Kantor desenvolverá uma estrutura na qual ele estará em cena como o eu real que se direciona ao encontro das situações e pessoas que criaram com ele a sua história artística. É um retorno a si mesmo através da memória, mas é um retorno de confronto, uma espécie de "passar a limpo" a história do seu teatro. Ele está em cena, não mais como um organizador do espaço. Ele não está mais interessado em criar o seu espaço da memória que é apresentado no palco. A cena se realiza através do confronto de Kantor, o Eu verdadeiro, com os objetos da sua criação. Mesmo aqui a teoria dos negativos se mostra eficiente para explicar o que acontece. Por se tratarem de memórias dos espetáculos anteriores, e muitas dessas memórias por si já são memórias, a densidade da cena acontece exatamente pela fusão de diferentes níveis e estados da memória aplicada sobre a própria memória que, em confronto com a memória dos atores, os mesmos que Kantor utilizou anteriormente para materializar o seu espaço da memória, lembrando que a maioria desses atores trabalhou com ele por mais de vinte anos, a tensão que surge imediatamente é exatamente o confronto entre Kantor, o Eu verdadeiro, com os atores que com ele se encontram nesse espaço.

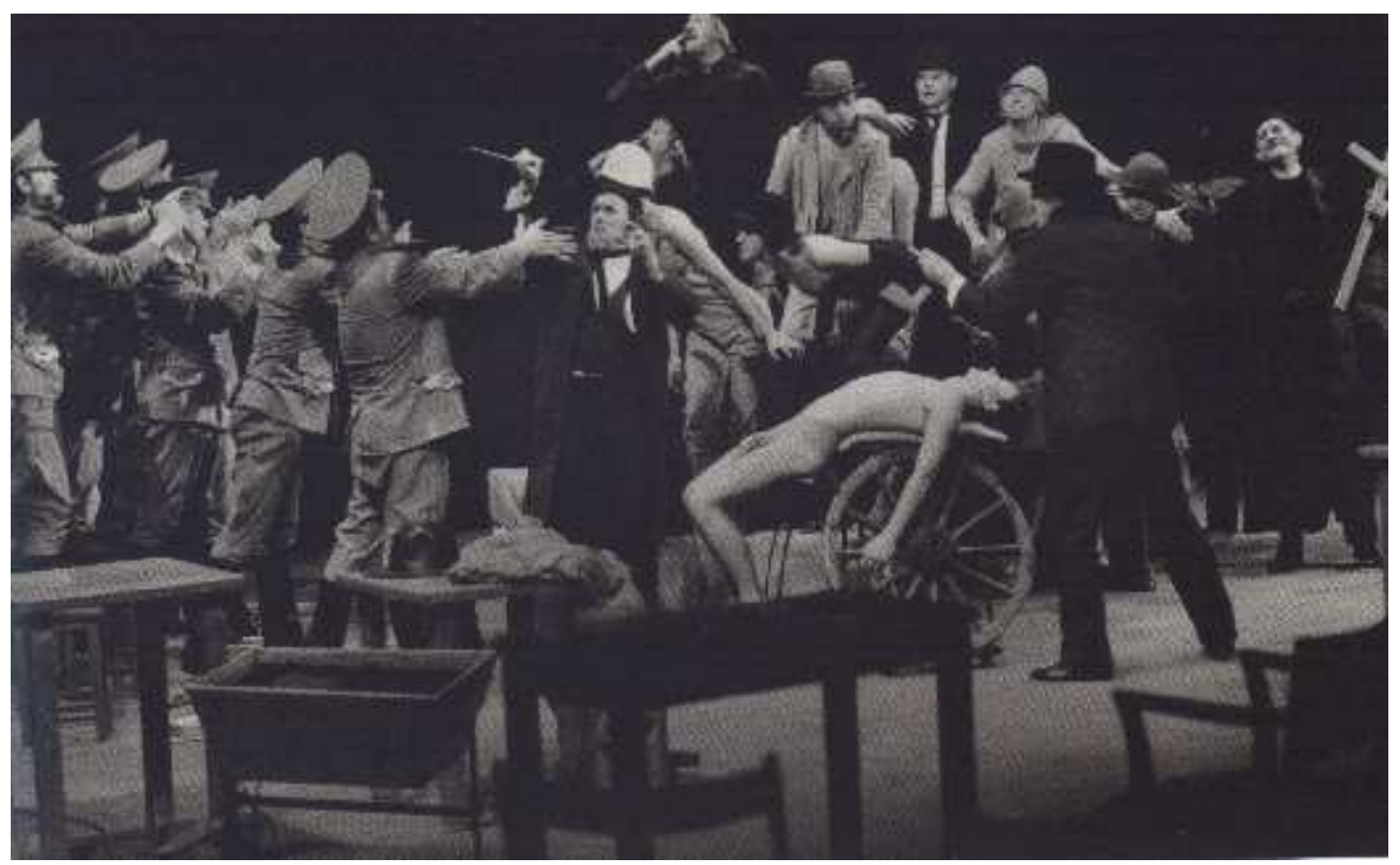

Não voltarei jamais. Na cena, Kantor (de costas) junto dos atores no espaço. Foto: Maurizio Buscarino.

\footnotetext{
${ }^{19}$ Ibid. p. 84.
} 
Mais do que a teoria dos negativos, eu vejo Não voltarei jamais como um bom exemplo de "calidoscopia" no teatro de Kantor. A teoria dos negativos se ajusta perfeitamente bem a Wielopole Wielopole, mas principalmente a Que morram os artistas!. No entanto, em Não voltarei jamais, existe algo mais que diante do confronto do criador com os objetos de sua criação há a ocorrência de um processo de mistura dos fragmentos da memória. À medida que Kantor remexe a sua memória, não só as cenas se reorganizam, mas os próprios elementos constituintes da memória original, ou seja: a cena original se reorganiza em outros parâmetros. Isso quer dizer que os elementos não estão mais presos à memória original e se apresentam independentes dela. É por isso que nessa produção, uma espécie de colagem de diferentes momentos da criação de Kantor, tudo está sempre mudando e os personagens de determinada peça, como já antecipei em um capítulo anterior, falam textos ou usam objetos de outra. Se no teatro de Kantor, de uma maneira geral, o óbvio é um equívoco, Não voltarei jamais, é o exemplo perfeito dessa singularidade.

Desde A classe morta os espetáculos são compreendidos como um procedimento criativo que tem sua fonte de expressão originada a partir da memória que se volta sobre si mesma a fim de explorar os seus diferentes atributos. A teoria dos negativos mostra a maneira como as memórias são sobrepostas e cuja simultaneidade permite lidar com o passado, presente e futuro. Em Hoje é o meu aniversário, haverá prontamente um tratamento da memória que mostra outro aspecto do engajamento de Kantor com a realidade.

Durante toda a sua vida, Kantor foi motivado pela crença de que a única verdade na arte é a representação da vida de alguém em um processo de descoberta do seu destino e da sua fé: a vida e o destino de Kantor se confundem com a sua arte. A sua casa sempre foi o seu trabalho, ou seja, a pintura e o teatro. Hoje é meu aniversário é essencialmente um resumo das várias mudanças no trabalho artístico de Kantor, seja em relação à sua pintura, seja em relação ao seu teatro. Em síntese, esse espetáculo define toda a sua obra como pintor e criador teatral colocando em cena o próprio atelier do artista, o seu espaço de trabalho, o seu "quarto da imaginação".

Com a morte de Kantor, esse espetáculo se tornou a memória ativa da sua presença no palco. A cadeira na qual ele se sentava ficou vazia dessa vez. Inicialmente 
foi cogitado, para dar continuidade às apresentações agendadas para o ano de 1991, colocar na cadeira o manequim de Kantor. No entanto essa situação se converteria em falseamento da realidade, proposta que foi recusada pelos membros do Teatro Cricot 2. Por outro lado, até então, a cadeira vazia não possuía uma história imediata de ação no palco, e essa opção, mesmo que ao acaso, veio enfatizar a ausência de Kantor na cena. A cadeira na qual ele deveria se sentar, próxima à mesa, permaneceu vazia, habitada apenas pela sua memória e consequientemente pela sua abstração. Nesse sentido, o objeto torna-se o receptáculo da memória ao mesmo tempo em que sugere Kantor em outro contexto de existência. O interessante nessa situação é que essa cadeira vazia pode ser interpretada como um ato original, da mesma maneira como a cadeira quebrada de $O$ retorno de Ulisses se constitui, através da ação de Penélope, em um ato que está acontecendo pela primeira vez. Nesse caso específico, pela primeira vez na jornada artística de Kantor.

No prólogo do espetáculo havia uma gravação com a voz de Kantor na qual ele se referia sob quais situações essa produção foi erigida:

"Eu estou novamente em cena,

e sem dúvida...

para:

o magnífico resumo de minha

teoria e de meu método."20

Evidentemente, existe aí uma contradição, ou seja: originalmente Kantor não estava verdadeiramente no palco mas no seu limite. Na frente da platéia, conforme o seu vocabulário - na realidade - e diante dele a cena, a ilusão. Esse é um espetáculo cujo movimento acontece na direção da ilusão para o mundo real e esse acontecimento deve ser uma revelação cênica única, original, como que acontecendo pela primeira vez:

“...sem pathos, sem milagres ou procedimentos cênicos pretensiosos... ${ }^{21}$.

Essa produção, em particular, não se trata mais da ação da sua memória sobre fatos e situações das suas lembranças pessoais e da história da Polônia. Mas é sobre a

\footnotetext{
${ }^{20}$ Kantor, Tadeusz. Les voies de la création théâtrale. Paris: CNRS, 1993, vol. 18, p. 170.

${ }^{21}$ Ibid.
} 
sua vida na arte. São as memórias da sua evolução artística. É um momento através do qual ele quis perceber e resumir aquilo que foi feito da sua própria vida e como a sua vida se confunde com a sua arte. Assim teremos no palco a sua pintura e o seu teatro. É por isso que o cenário é composto basicamente por três molduras de quadros e pequenos palcos atrás dessas.

Nesse espetáculo, Kantor mergulha nas turbulências das suas reflexões, das suas dúvidas, dos seus sentimentos, e de todos os clichês da sua história artística. É uma tentativa de colocar seu passado em ordem revendo-o no contexto do presente. Dessa maneira, ele procede limpando, exumando a sua história tentando organizar a sua memória a fim de dar forma às idéias para esse que foi o seu derradeiro espetáculo.

Nesse trabalho ele se apropria do palco como o seu espaço íntimo. Nele se encontram os seus objetos mais pessoais: a cama, a cadeira, a mesa, sobretudo os seus quadros, além dos personagens mais próximos da sua vida e da sua criação, como é o caso dos membros da sua família e a Infanta de Velázquez, respectivamente. De uma maneira geral, Kantor transfere o seu quarto, o atelier onde suas idéias surgem, para o palco. Por diversas vezes ele comentou com seus amigos e com seus estudiosos que ele imaginava o seu quarto em um teatro, no palco mais do que em qualquer outro lugar. Então, em Hoje é meu aniversário, o seu "quarto da imaginação" está situado no palco e não deve se parecer como um quarto no palco mas como um quarto real, o seu quarto pessoal, que pertence a ele e somente a ele. Assim, aquilo que se vê no palco é o desejo de Kantor em completar a exumação da sua arte que começou com Não voltarei jamais.

Se em Não voltarei jamais Kantor cria o espaço para a sua memória encontrar as suas criações que vêm a ele, em Hoje é meu aniversário ele mora no palco atribuindo uma nova dimensão para a realidade. Ele mostra a sua vida, as suas idéias, as suas lembranças, revelando todos os detalhes da sua história a fim de desvendar o seu próprio destino. Parece que ele está dizendo que aquele é o seu limite. Isso já podia ser observado na pintura feita dois anos antes, em 1988, intitulada Eu não sairei mais dessa tela, na qual ele antecipa o seu destino que se realizará dois anos depois em Hoje é meu aniversário. Sobre isso ele comenta em um ensaio escrito no mesmo período: 
"E afim de que esse

TEATRO DA VIDA

termine conforme as regras:

o epílogo,

a derradeira tela:

“LÁ, EU PERMANECEREI”.

Porque, finalmente

a tela deve vencer."22

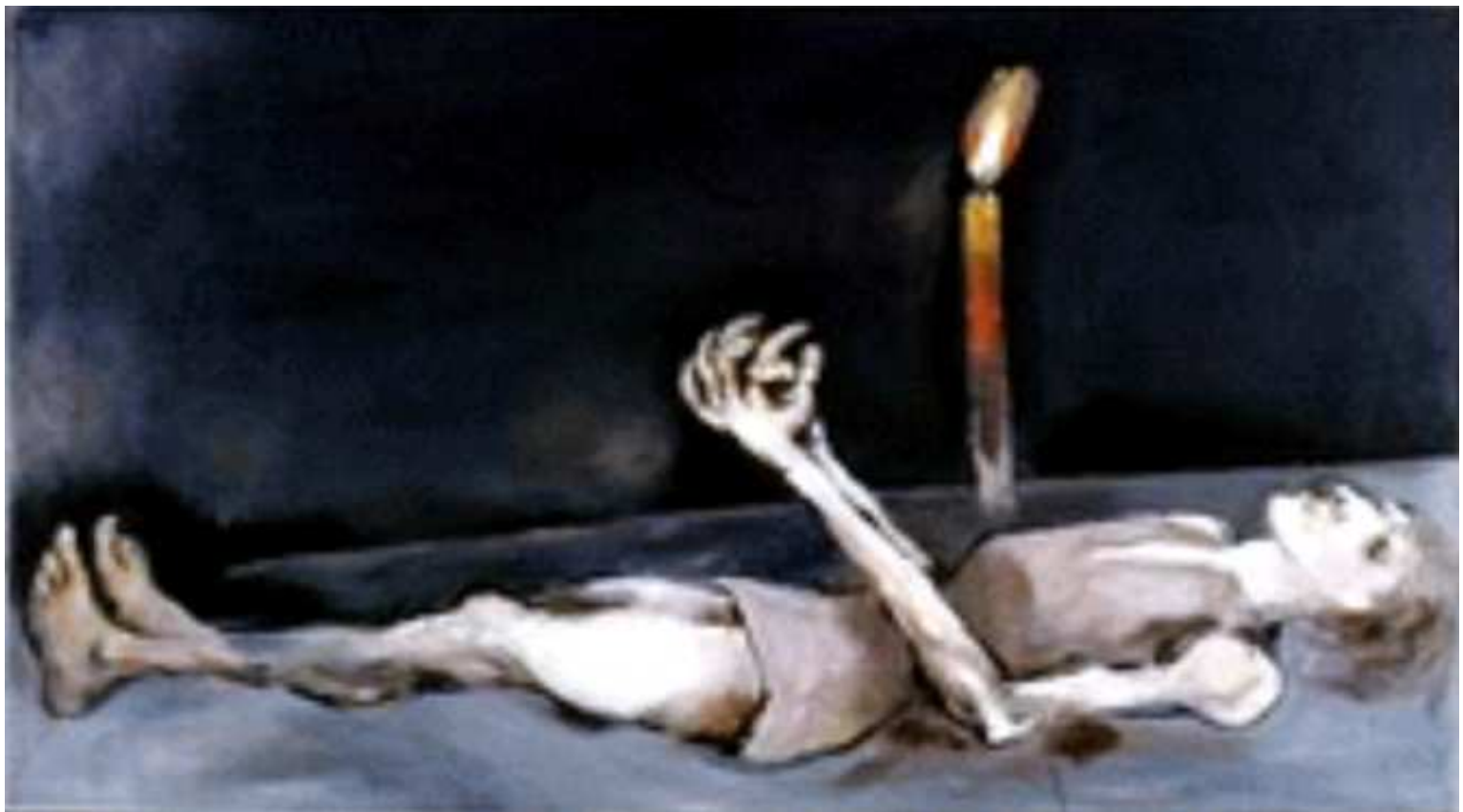

Tadeusz Kantor. Eu não sairei mais dessa tela - 1988. Obra pertencente aos herdeiros do artista. Foto: arquivos da Cricoteca.

Assim, Hoje é o meu aniversário se constituirá no seu grande altar, exatamente por estar o seu destino subsumido às circunstâncias inexoráveis da existência. $O$ palco como tela, como tumba, expõe um mundo desaparecido, engolido pelo tempo e que, no entanto, retorna constantemente. E na medida em que é retorno, repetição, a criação de situações ilusórias permite a ele olhar a realidade através de outro ângulo e, consequientemente, torná-la clara.

\footnotetext{
${ }^{22}$ Kantor, Tadeusz. Ma création, mon voyage. Commentaires intimes. Paris: Editions Plume, 1991, p.220.
} 
Através das molduras vemos, em um processo de composição fotográfica, alguns aspectos da vida e do trabalho de Kantor. Vemos a Infanta, vemos os soldados, vemos a família. Essa estrutura fotográfica não é algo estanque mas uma composição que está em contínua mutação. Na moldura central estão as portas de A classe morta, de Wielopole Wielopole, de Que morram os artistas! - as portas da morte. Por elas, diferentes personagens entram e encontram a sua vida exatamente entre as molduras e as portas, entre a morte e a ilusão. O interessante é que constantemente os personagens atravessam a moldura em direção ao espaço central onde, assim como a cadeira vazia, nenhum deles tem uma história de palco. Isso quer dizer que personagens como Maria Jarema, Jonasz Stern, Meyerhold, a Infanta, ao deixarem as pinturas, agem no palco como memórias autônomas. Elas não têm uma história de palco para contar. A única coisa que existe é a relação das memórias com o espaço. Esse novo espaço que não pertence a Kantor é construído através das relações entre as personagens e as molduras quando elas estão no espaço central. Essa autonomia que isenta os personagens de qualquer sentido, induz a uma existência apenas em termos das relações estabelecidas nesse espaço. Isso quer dizer que os personagens não controlam a representação e aquilo que acontece entre as molduras e a porta da morte deixa de ter qualquer significado quando a moldura é retirada para revelar uma porta completamente diferente, e isso se dá em todas as relações. Quando, em uma das seqüências, a moldura central é removida, os personagens que surgiram do passado entram na cena da maneira como eles pensam ser, não através da memória de Kantor.

Nesse espetáculo, a exemplo de todo o seu trabalho teatral, Kantor, mais uma vez, propõe a necessidade de se pensar o seu teatro através de outros canais de observação. Um exemplo disso se trata do fato dele sugerir a existência no espetáculo de dois níveis de ilusão, ou seja: um nível secundário que é composto pela tela e seu interior, e outro nível anterior, reconhecido no palco como o seu "quarto da imaginação". Nesse contexto, a presença da ilusão na tela diante da ilusão primária do seu quarto materializado no palco, faz com que o "quarto da imaginação" se torne realidade.

Originalmente Kantor, o observador que estava presente nessa realidade construída, estava constantemente gerando as suas memórias, ou seja: as memórias são geradas nessa realidade e é por isso que é possível perceber que no seu processo de 
criação a memória está no mesmo plano da realidade. Isso vai um pouco mais longe. Se pensarmos que existe outro plano de realidade anterior a essa, que é a realidade do espectador, perceberemos que essa é a realidade que faz com que a realidade do "quarto da imaginação" de Kantor, criada a partir do contraste com a ilusão e que é gerada pela ação da memória no espaço da tela, também possa ser compreendida como outro espaço de ilusão. Assim, da mesma maneira que observamos diferentes níveis de ilusão, também observamos diferentes níveis de realidade e isso está diretamente relacionado à presença do observador. Dependendo do observador, os registros entre a realidade e a ilusão podem ser alterados. Aquilo que acontece no espetáculo é uma espécie de interrelação entre observador e objeto observado que torna as coisas reais conforme a percepção individual da realidade exterior. Isso faz com que a maneira do observador de perceber, sentir, pensar as coisas, ou seja, a maneira como o mundo é percebido, esteja em constante mudança pois depende essencialmente da posição do observador em relação ao objeto em observação. Mais uma vez a física quântica.

Essa é uma situação paradigmática na relação entre o espaço e o tempo e que dificulta a compreensão da realidade como um sistema de relações absolutas. Nesse sentido, a forma de observar o mundo, conforme Newton afirmava, como um sistema de relações baseadas no movimento e que podem ser descritas a partir e pelas leis do movimento, só funcionam bem na realidade imediata. Mas como vimos, a realidade é dependente do observador, assim a realidade deixa de ser absoluta e passa para o plano da relatividade, pelo menos na maneira de Kantor pensar e se relacionar com ela.

É possível ainda perceber na estrutura do espetáculo uma moldura metafórica que separa o espectador dos diversos níveis de existência da ilusão que acontecem no palco. Trata-se de uma tela composta nos mesmos moldes ilusionistas de As meninas do pintor espanhol Velázquez. 


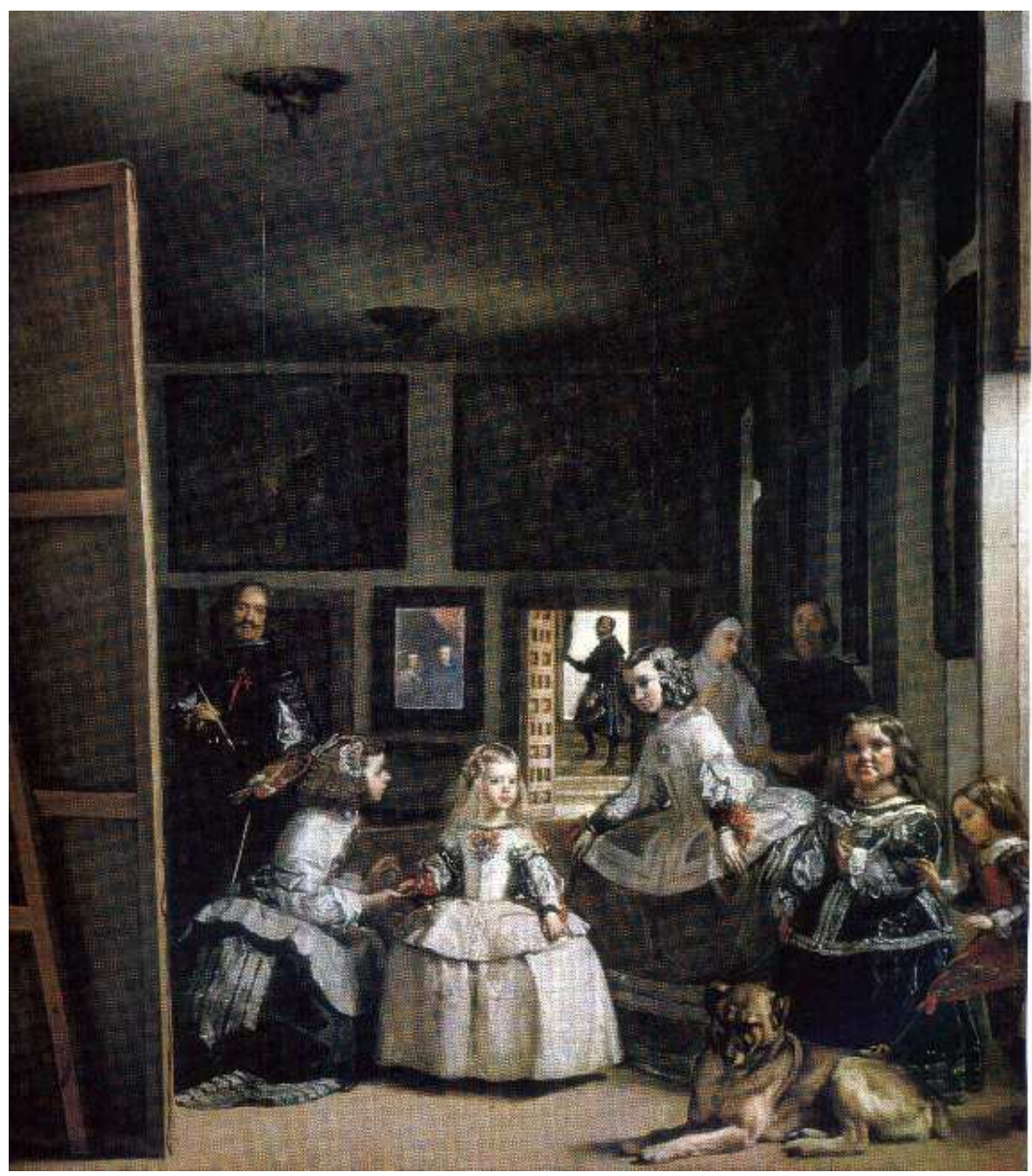

Velázquéz. As meninas (1656) - óleo sobre tela. Museu do Prado, Madri (Espanha). Imagem extraída do volume 7 da coleção Folha Grandes mestres da pintura.

Na obra de Velázquez, um instante da vida cotidiana do pintor é capturado de uma forma quase que fotográfica que também sugere a ausência do objeto pintado, no caso os Reis de Espanha: o objeto real não está na tela. Eles existem em outro espaço, sugerido apenas por um tênue reflexo em um espelho situado ao fundo da pintura. Algo interessante nessa obra trata-se da porta localizada no fundo do quadro e que é a responsável pelo desdobramento de toda profundidade e toda perspectiva da pintura. A exemplo dessa porta, a porta situada na moldura central de Hoje é meu aniversário também funciona como indutor de perspectiva. Constantemente Kantor brinca com o movimento da moldura e da porta no sentido de aumentar ou diminuir o espaço entre elas com a nítida intenção de desestabilizar as regras através das quais a ilusão se configura. 


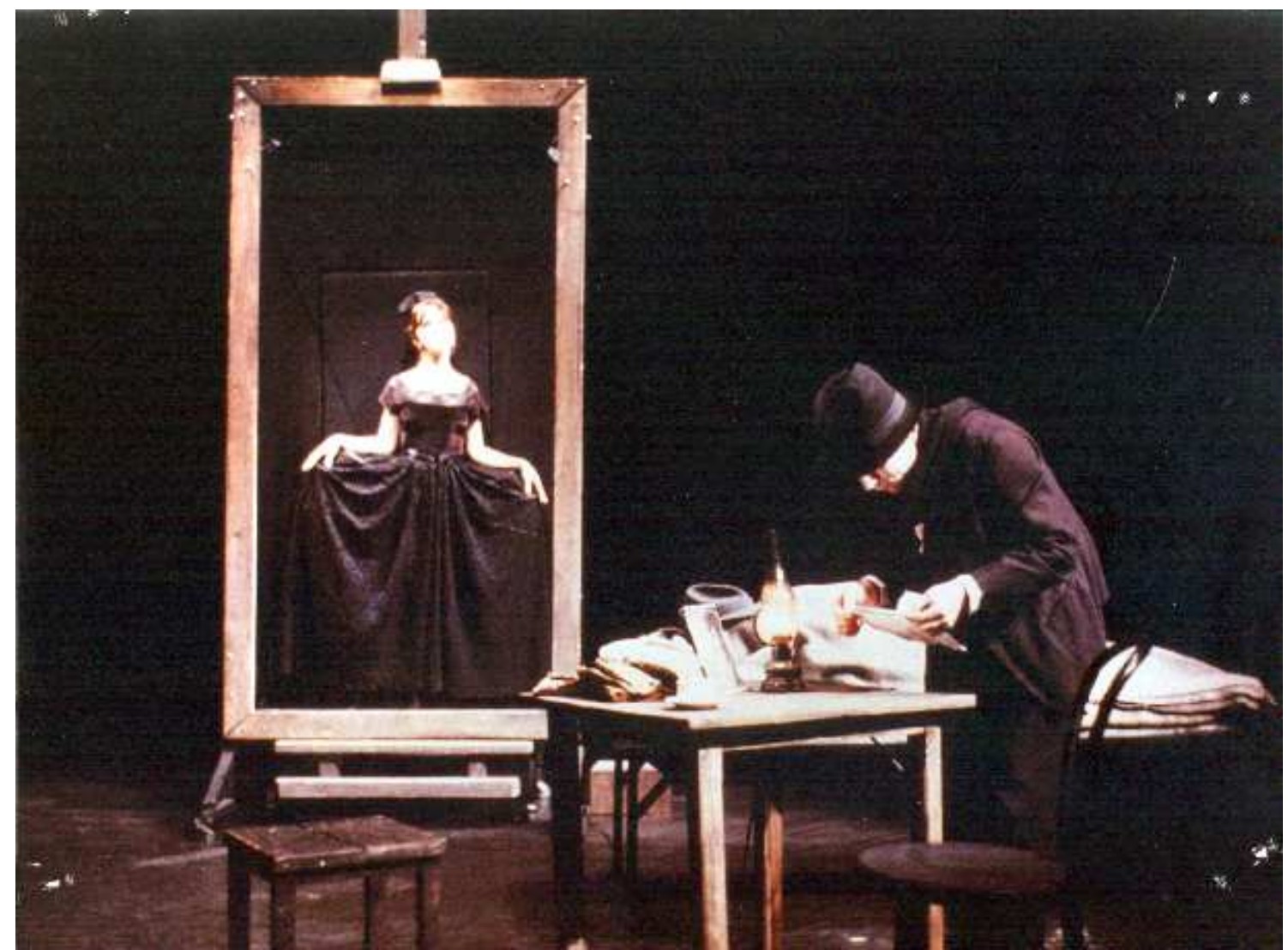

Hoje é meu aniversário. Na cena, a Infanta e o Auto-retrato. Foto: arquivos da Cricoteka.

De uma maneira geral, Kantor está afirmando, com esse trabalho, que a existência da realidade depende da existência da ilusão. Mesmo antes de 1973, quando ele se empenhou em desmascarar a ilusão para bani-la da arte, a negação da ilusão garantia indubitavelmente a sua existência nos meandros da criação. Kantor se empenhou então, não em eliminá-la, mas em bloquear a sua influência na cena. Daí a sua opção pelo objeto real, pelo espaço real. A ilusão, por mais que Kantor se esforçasse em negá-la, agia subterraneamente e constantemente ele tinha que encontrar meios para evitá-la. Quando Kantor cria a idéia de realidade iniciando a intensa luta contra a ilusão, imediatamente ele irá desestabilizar a noção tradicional de representação propondo a falta de representação. Essa ausência não significa absolutamente uma total negação da representação, mas sim daquelas forças que agem na representação como uma estrutura rígida e imutável. 
Pois bem, se a constituição da realidade depende necessariamente da posição do observador em relação ao objeto observado, nessa situação, na qual temos uma realidade se sobrepondo a outra, no caso de Hoje é meu aniversário, é possível verificar nesse espetáculo que nessa sobreposição a memória de Kantor está sendo gerada no plano da realidade que é configurada pela ilusão criada pelas telas. Dessa forma, é possível perceber que para Kantor a memória é a própria realidade e essa realidade não existiria sem a ilusão; e por esse caminho a idéia de que a ilusão está situada no mesmo nível da realidade. Assim, originalmente, no palco, no plano da realidade, Kantor estaria olhando em direção à porta central, a porta da morte, gerando suas memórias ao mesmo tempo em que elas convergem, inevitavelmente, para o seu futuro irrevogável. Trata-se pois de uma maneira muito peculiar de tornar evidente esse processo de revelar a verdade sobre a vida de alguém nas dimensões do passado, do presente e do futuro.

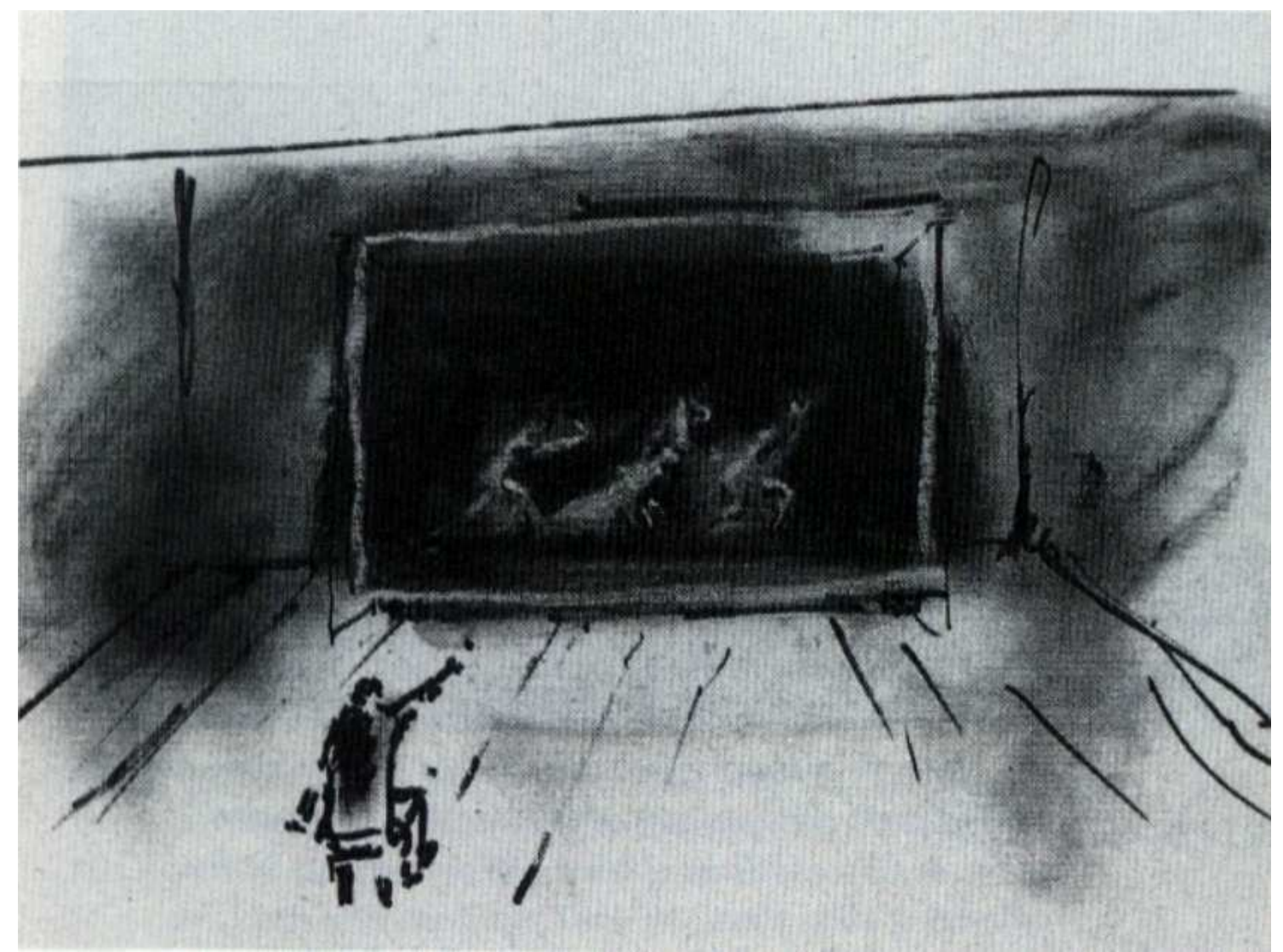

No desenho, projeto de cena para Hoje é meu aniversário, Kantor está sentado na cadeira olhando para a moldura central e para a porta que está situada no seu interior. Foto: arquivos da Cricoteka. 
No espetáculo, após a morte de Kantor, a realidade se transformou na sua ausência na cena; paradoxalmente a cadeira vazia induz à ilusão de existência ao mesmo tempo em que a abstração, conforme os postulados de Kantor, garante a sua existência nesse universo que só pode ser alcançado pelos meios da arte, vem justificar a sua afirmação de que a ilusão também se encontra na abstração pois, ao percebermos a cadeira vazia, também percebemos a presença de Kantor. Ou seja, a alteração da nossa percepção da realidade através de um objeto real que nos lança, como veremos a seguir, para o interior de outra realidade.

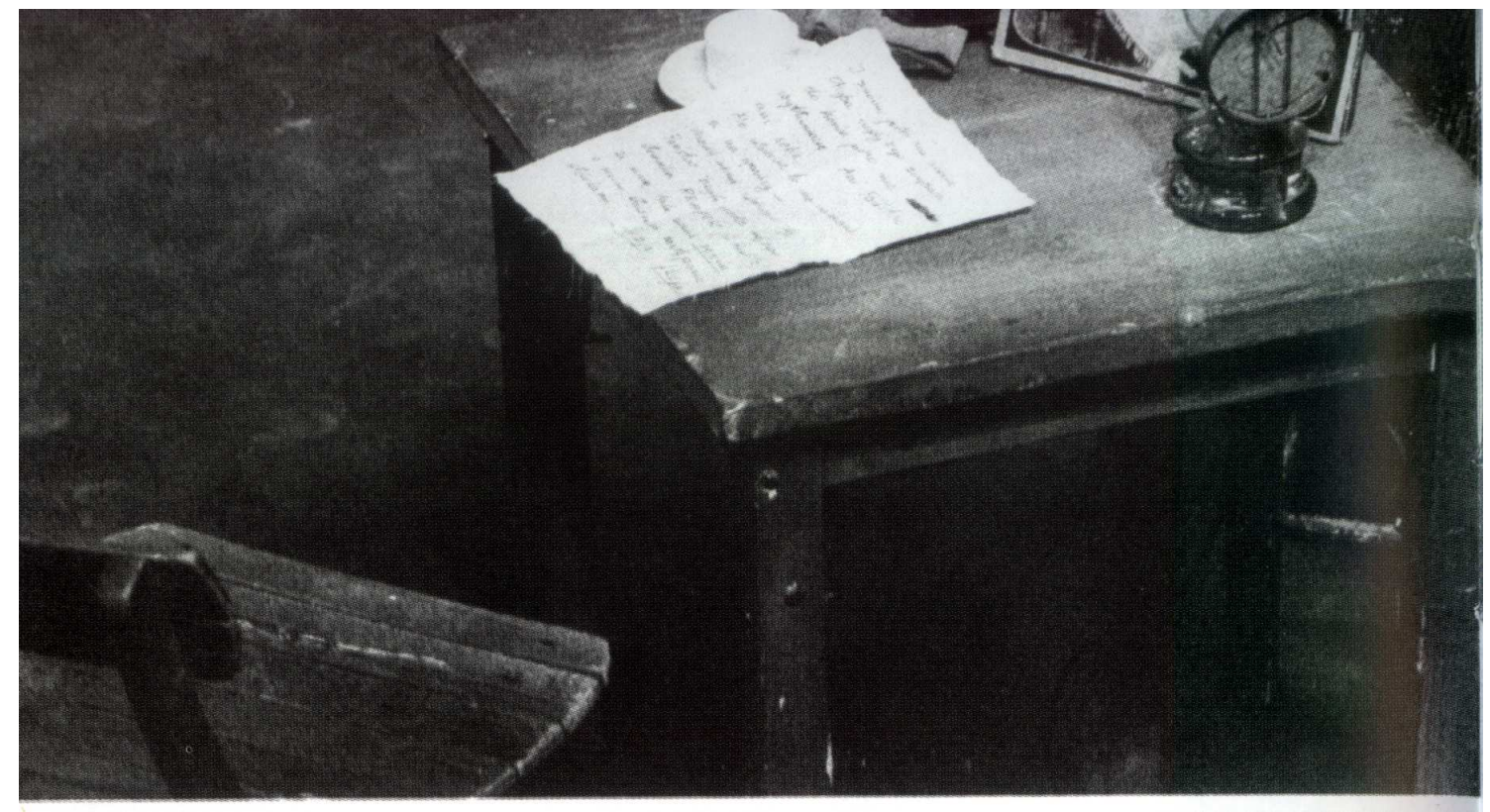

Hoje é meu aniversário. Na imagem, a cadeira vazia ao lado da mesa com algumas anotações de Kantor. Foto: Romano Marinis. 


\section{CAPÍTULO V}

\section{ILAÇÕES ACERCA DA VARIABILIDADE DO REAL DENTRO DA REALIDADE VARIÁVEL}

\section{OS ESPAÇOS MULTIDIMENSIONAIS}

A manipulação da memória é capaz de criar, no mesmo tempo e no mesmo espaço, espaços multidimensionais. Por outro lado, esse processo de desestabilização do espaço a partir da memória também altera as relações entre realidade e ilusão. Evidentemente tudo o que acontece no palco estará diretamente relacionado à posição do observador. Isso necessariamente diz respeito à questão do espectador no teatro de Kantor. Diferentemente de Grotowski, para Tadeusz Kantor, o espectador é um elemento essencial da criação e parafraseando a sua máxima, assim como Witkiewicz representa com o Cricot 2, o espectador também o fará como elemento do espetáculo. Em uma entrevista realizada em 1975, ele concordará que o objetivo final do teatro é ganhar o público:

"Esta é a função do teatro. Não pode ser a mesma coisa com a pintura, mas o teatro... a palavra em si tem esse significado. É por isso que não posso crer absolutamente nisso quando alguém me diz que o teatro é um laboratório."

Antes de 1973 esse espectador tinha uma presença muito ativa nas encenações de Kantor exatamente por essas acontecerem em espaços reais. Com A classe morta e depois dela, não mais com a necessidade do lugar real, o espectador adquiriu outra especificidade no processo de criação. Afastado pela corda de separação adicionada no espetáculo e que continua metaforicamente até Hoje é meu aniversário, o espectador, na

\footnotetext{
${ }^{1}$ O objeto se torna ator - conversa com Tadeusz Kantor. In. Cadernos de teatro n. 68. Rio de Janeiro: O Tablado, 1976, p. 10. - No texto, claramente uma crítica a Grotowski e sua concepção do Teatro Laboratório.
} 
sua condição de observador, será o responsável, através da sua consciência ${ }^{2}$, pela definição do espaço.

Apesar de Kantor acreditar na existência de muitos espaços multidimensionais, o seu teatro ocorre em um espaço muito específico que é determinado pelo espectador no momento da observação. Isso quer dizer que tudo aquilo que acontece no palco depende necessariamente do observador pois é esse que está constantemente definindo aquilo que é realidade e aquilo que é ilusão. Mesmo antes de $A$ classe morta isso já acontecia. Se recordarmos a encenação de As belas e os feios, perceberemos que o jogo, que era real, feito em determinados momentos com os espectadores que participavam ativamente do espetáculo, criava constantemente uma tensão entre a realidade do espectador e a realidade dos artistas. Embora sobre o mesmo tempo e sobre o mesmo espaço, o espectador era forçado, por sua natureza de observador, a redirecionar a sua atenção para a narrativa da peça, já que os atores "simulavam" ou jogavam, na ausência de uma palavra melhor, com as personagens de Witkiewicz. Mesmo que isso ocorresse em um momento muito breve. Dessa forma, a atividade do espectador exigia também a sua participação no processo de constituição dos seus próprios referenciais para que ele pudesse participar ativamente do espetáculo. E essa é uma atitude real que, através da ação da consciência sobre a realidade do momento, define a arte como a própria realidade.

Voltando um pouco mais atrás, no primeiro espetáculo do Cricot 2, O polvo, de 1956, no qual, o espaço real de um Café, com suas mesas e com seus fregueses, chocava-se com os personagens históricos que eram arremessados para o interior desse espaço; o espectador, ao tomar sua bebida, sentado em uma cadeira real, encostado em um balcão real, bebia uma bebida real diante do manequim de três metros de altura do Papa Julius II. O espectador, através da consciência, via-se em um Café mas ao mesmo tempo em um teatro. Ou seja: apesar de um único espaço físico, esse espaço era capaz de se alterar conforme a forma de observação. Sobre essa capacidade que o espaço possui de se transformar, Kantor escreveu anos mais tarde:

\footnotetext{
${ }^{2}$ Convém lembrar que estou me referindo ao termo consciência com o significado que a filosofia moderna e contemporânea lhe atribuiu, ou seja: a relação da alma consigo mesma, o que possibilita ao homem conhecer-se de modo direto e objetivo - "...relação puramente privada do homem consigo mesmo, na qual o homem se desliga das coisas e dos outros e "retorna para si mesmo", testemunhando de si para si e criando uma indagação puramente "interior", na qual possa conhecer-se com absoluta verdade e certeza.”, in. Abbagnano, Nicola. Dicionário de filosofia. São Paulo: Martins Fontes, 2003, p. 185.
} 
“O ESPAÇO

Esta UR-MATÉRIA é o espaço!

Eu sinto como ele pulsa.

O espaço,

que não tem nenhum ponto de apoio e nem fronteira,

que com igual velocidade se afasta e foge,

ou se aproxima,

por todos os lados, sobre as bordas e pelo meio,

se eleva para o alto, cai nas profundezas,

gira sobre um eixo vertical, horizontal, obliquo...

Não crendo poder penetrar na muralha de uma forma fechada,

sacudindo-a de maneira brutal,

diminuindo-lhe a sua aparência cotidiana...

Os personagens, os objetos alteram as funções do espaço e de suas peripécias...

...o espaço não é um recipiente neutro,

no qual nós misturamos os objetos, as formas...

O ESPAÇO é o próprio OBJETO (de criação)

E o espaço principal!

O espaço carregado de ENERGIA.

$\mathrm{O}$ espaço que se contrai e se estica.

Estes são movimentos que adornam as formas e os objetos.

O espaço GERA as formas!

O espaço condiciona os encontros entre as formas e suas TENSÕES.

A TENSÃO é o ator principal do espaço.

MULTI-ESPAÇO...”

Como a tensão é o principal elemento do espaço e é originada através do choque entre as formas que são criadas por esse mesmo espaço, o observador ao entrar no Café altera substancialmente aquilo que já estava no espaço, reestruturando o desenvolvimento das ações através de outro grau de percepção desse mesmo espaço, ou seja, o espaço passa a se comportar a partir do seu ponto de vista. Isso porque a imagem remonta à idéia que determina o rumo das coisas. Evidentemente, esse espaço, mutável, contraria a noção de espaço imóvel de Newton que, por séculos, dominou a maneira de encarar a física no Ocidente. Kantor rejeita o espaço e o tempo absoluto da mesma maneira que Einstein demonstrou na teoria da relatividade os fundamentos que seriam

\footnotetext{
${ }^{3}$ Kantor, Tadeusz. Leçons de Milan. Paris: ACTES-SUD-PAPIERS, 1990, p. 25-26.
} 
utilizados pelos teóricos ${ }^{4}$ da física quântica, dentre esses fundamentos, os princípios da incerteza e imprevisibilidade como contraponto ao mecanismo estável da física clássica. Princípios que são encontrados ativamente no teatro de Tadeusz Kantor.

O principio da incerteza é próprio da condição do observador como elemento do espetáculo ${ }^{5}$. Isso quer dizer que a coisa só passa a existir a partir do momento em que é observada. Dessa forma, é possível concluir que a observação tem um efeito direto no mundo. Ou seja, a realidade deixa de ser estável como na mecânica clássica. Isso significa que o real é flexível a ponto de qualquer coisa que não esteja no mundo possa se materializar a partir da consciência. Dessa forma, como a realidade exterior está constantemente sendo construída a partir da nossa consciência, qualquer alteração nessa realidade se dá através da percepção que temos dessa mesma realidade. É exatamente essa situação que levou o físico austríaco Anton Zeilinger ${ }^{6}$ a dizer que a idéia de que o mundo existe independentemente do observador está errada. Ou seja: realidade e observação são coisas diretamente proporcionais.

Isso quer dizer que no teatro de Kantor, desde o momento da adição da memória como fundamento da sua criação, Kantor está constantemente gerando a realidade a partir da sua observação da cena a partir de si mesmo, da sua própria consciência, já que consciência pode ser entendida como a percepção que o indivíduo tem de si mesmo através de uma relação intrínseca com o seu próprio interior. E como através da consciência o indivíduo pode conhecer a si e julgar a si mesmo, o teatro de Kantor, com a inferência da memória, constituir-se-á como um processo de auto-exposição dos seus comentários íntimos a partir das suas lembranças. Assim, se a realidade é criada a partir do momento em que é observada, Kantor, ao observar a cena, ao depositar no palco as suas memórias, está ao mesmo tempo exibindo o seu auto-julgamento. Então, aquilo que o espectador vê na cena trata-se basicamente da consciência de Kantor, ou seja, o

\footnotetext{
${ }^{4}$ Werner Heisemberg; Erwin Schrödinger; Marx Born; Niels Bohr.

${ }^{5}$ Em 1939, Edmond Bauer sugeriu que a consciência humana é capaz de influenciar o processo de observação de elétrons. Isso não significa que se pensarmos que o elétron está em determinado lugar que deverá nele aparecer. Não é isso. Antes de ser observado, o elétron tem uma posição indefinida, é como se estivesse em mais de um lugar ao mesmo tempo. É somente ao ser observado pela consciência que ele aparece em um determinado lugar. Essa idéia levou o físico americano Hugh Everett, em 1957, a sugerir, a partir das estranhas propriedades quânticas, a existência de universos paralelos sem comunicação uns com os outros.

${ }^{6}$ Zeilinger, Anton. A face oculta da natureza. São Paulo: Editora Globo, 2005.
} 
seu processo de tornar evidente a vida de alguém, no caso a sua, nas dimensões do passado, do presente e do futuro.

Na física não newtoniana, um dos modos de deformar a estrutura do espaçotempo é através da presença de massa, de matéria no espaço. Isso faz com que onde haja matéria, haja gravidade, que pode ser interpretada, conforme a física, como uma deformação no universo que causa interferências nas medidas de espaço e de tempo. No caso dos buracos negros, são muitos os indícios teóricos de anomalias que poderiam transportar a matéria a pontos incomuns, como ao passado, ao futuro ou a lugares que sequer estão no universo. Se tais coisas forem reais e puderem ser controladas com precisão, isso significa que viagens a longas distâncias poderão ser realizadas sem depender do eixo temporal. A física quântica por sua vez nos apresenta fenômenos que sugerem estranhas conexões físicas entre todos os pontos do universo, como se de certa forma existissem atalhos invisíveis a ligar tudo - relembrando a teoria do "entrelaçamento". Toda essa reflexão sobre a existência de universos múltiplos acaba por nos proporcionar uma investigação sobre aquilo que de fato é a realidade e sobre qual o nosso papel individual na vestimenta do mundo como o percebemos. Questões que também são intrínsecas ao teatro de Kantor.

Tudo isso pode parecer não realizável do ponto de vista prático. Que tudo não passa de pura especulação imaginativa. Entretanto, os avanços no campo da informática possibilitam, principalmente naquilo que se refere aos jogos de computador do tipo "location based mobile games"7 que, ao contrário dos universos paralelos, nos quais teoricamente seria permitida a passagem de um para outro mundo, nesse tipo de game, estaríamos simultaneamente em duas realidades.

Essa situação pode ser explicada através de uma proposta conhecida no meio cibernético como "espaço cíbrido", ou seja, um local que se situa em um espaço de transição entre os objetos concretos e os dados virtuais. Nesses games, as pessoas se locomovem no mundo real ao mesmo tempo em que se locomovem no mundo virtual ${ }^{9}$. Como em todo jogo, o jogador terá desafios para resolver mas ao invés de ficar sentado

\footnotetext{
${ }^{7}$ Tem esse nome por dependerem da localização do jogador que está em movimento.

${ }^{8}$ Palavra que surge dos termos "ciber e híbrido".

${ }^{9}$ Isso é possível através da conexão de inúmeros sensores com o corpo do jogador.
} 
em frente ao computador, o jogador terá de deslocar-se e atuar em lugares reais, como ocorre em jogos ou atividades de rua. A diferença para um jogo tradicional se estabelece no fato de que o jogo ocorre nesse espaço distinto, nessa outra realidade que, apesar da ação ter lugar no mundo real, os desafios são resolvidos no mundo virtual. Um observador externo que tenha acesso simultâneo ao jogador e ao programa no qual o jogador está conectado, será capaz de perceber as duas realidades, a real e a virtual, sendo que o movimento do jogador no mundo real será percebido como o movimento do mesmo jogador ou do seu personagem no mundo virtual.

A situação descrita possibilita uma reflexão paralela com o tema central desse trabalho que procura demonstrar que, no teatro de Tadeusz Kantor, o objeto é o responsável pela entrada na tal dimensão na qual acontece o espetáculo, no sentido de que a entrada ao mundo virtual do game, onde me referi no breve trecho acima, só é possível a partir do conceito dimensões múltiplas que no jogo é exercitado do ponto de vista prático, não como mera imaginação, mas como uma nova realidade que se cria no mundo virtual e que está em total conexão com a realidade do mundo real. Evidentemente, o processo de entrada, nessa outra dimensão, dá-se necessariamente através de um objeto, uma máquina, no caso, um computador e seus acessórios.

O teatro de Kantor, por sua vez, em sua última fase, através da desestruturação do espaço-tempo pela ação da memória sobre a matéria, faz com que o objeto funcione como um orientador da percepção imaginativa do observador na direção de perceber o espetáculo como uma variável dentro da sua realidade. Mesmo que isso seja questionável do ponto de vista prático, já que a realidade depende necessariamente do ponto de vista do observador, a imaginação humana nos leva a conceber aquilo que aparentemente parece impossível. É nesse sentido que a arte se manifesta como constructo da imaginação, como pura existência abstrata; como consciência abstrata através da qual as pessoas e as coisas surgem no vasto universo que observamos. Por outro lado, o universo que somos está sempre a escorrer por entre os nossos dedos. A vida que se esvai a todo instante nos torna sempre mais abstratos até o ponto em que chegamos à pura abstração. A morte, o vazio da cadeira em Hoje é meu aniversário.

Algumas das teorias da física moderna sustentam a existência de universos múltiplos, que a realidade tal qual a conhecemos é questionável pois tanto sujeito como 
objeto, ambos, estão em constante mudança, de forma que aquilo que já foi aceito como realidade pode deixar de ser. Por esse caminho, o teatro de Kantor, como potencialidade para o "vir-a-ser", nos leva a intuir a existência de realidades distintas que coexistem em uma variável de espaço e tempo que deixa de ser oculta para nós e será nessa variável que o espetáculo se realizará e as tensões entre os elementos se manifestarão e serão esgotadas.

\section{O DESLOCAMENTO DO REAL NO INTERIOR DA REALIDADE}

Anteriormente vimos que a negação da ilusão se institui como uma estratégia que propõe que essa nova realidade seja construída com objetos reais e em um espaço real, que é unicamente diferenciada pela maneira como a relação acontece entre os homens e os objetos, aconteça como realidade própria e independente. Assim, essa outra realidade que surge como um deslocamento na realidade do espectador/observador que está inserido no espaço real, torna possível que uma cadeira quebrada seja percebida, não como um objeto de uso descartado mas, pelo contrário, como um objeto de necessária e substancial importância para a existência da personagem no universo que se configura como uma realidade intermediária e concomitante à realidade da vida. Essa é a realidade na qual Kantor acreditava que a arte deveria acontecer e encontrar os seus fundamentos. Enfim, esse é o modelo do teatro de Kantor antes de 1973, em que no seu processo de criação, as raízes já se mostravam desenvolvidas desde $O$ retorno de Ulisses. Durante esse período, o objeto real, pertencente, sobretudo à "realidade de classe mais baixa", é o principal instrumento desse deslocamento do real que se institui como uma realidade alternativa na qual o teatro de Kantor encontra a sua existência.

No teatro de Kantor não existe qualquer necessidade de alterar a natureza do objeto, alteração que só seria possível através da ilusão, como é o caso da banheira utilizada por Grotowski em Akropolis. Em Kantor, sobre o objeto jamais existirá a possibilidade de surgimento de qualquer estrutura ilusionista que impeça o objeto de ser conhecido como objeto real. 
Durante o período da negação, Kantor travou uma intensa batalha para desbancar a ilusão que tentava sorrateira e insistentemente se impôr como relevante aos espetáculos. Nas encenações, na medida em que a ilusão ameaçava se fortalecer, Kantor lançava mão de estratégias para destroná-la e evitar que o espetáculo degenerasse na direção do teatro tradicional. Um bom exemplo disso trata-se de uma cena em A galinha d'água, na qual existia uma máquina de costura no palco. Essa máquina, quebrada, como a maioria dos objetos reais utilizados por Kantor, era utilizada unicamente para produzir barulho através das suas engrenagens. Entretanto, com o repetir da cena nas várias apresentações, a ilusão se depositava sobre o ator no sentido de defini-lo como personagem e induzindo-o para uma narrativa que sugerisse uma ligação histórica, e até emocional com o objeto. Mesmo o ator, cujo único objetivo era produzir som movimentando o pedal da máquina, motivado pelas repetições do espetáculo, acabava por se deixar envolver pela situação, possibilitando assim o aparecimento de estados emocionais na cena. Para bloquear qualquer envolvimento emocional do ator com a cena, Kantor substituía constantemente o ator que movimentava o pedal da máquina. Essa é a principal razão pela qual, no meu entendimento, o ator não pode ser considerado, nessa fase, um instrumento de deslocamento do real, exatamente pelo fato de ser sobre ele que a ilusão procurava insistentemente se manifestar. $\mathrm{O}$ objeto por sua vez estava livre dessa ameaça pois tratava-se de um objeto real utilizado em sua condição de objeto real.

Outra situação interessante ocorre ao se observar a cadeira vazia em Hoje é meu aniversário. Isso nos leva a pensar imediatamente na ação da ilusão sobre o objeto que está em cena e que conduz o observador a imaginar a presença de Kantor no palco. A cadeira, diferentemente dos bancos de $A$ classe morta, que criam a ilusão da sala de aula, não cria a ilusão de Kantor. Essa ilusão não é motivada pelo objeto mas pelo vazio da cadeira, vazio que representa a ausência do sujeito/objeto e cuja presença agora se encontra na cena sem forma. O sujeito ausente trata-se de uma abstração que exatamente por manifestar através da sua ausência a sua presença na cena, o vazio, que tem a cadeira como agente, faz com que a abstração, nesse caso específico, torne-se o receptáculo da ilusão. Assim, Kantor será referendado por Hoje é meu aniversário na sua crença na existência de uma dimensão que só pode ser atingida através da arte. 
Em toda a história do teatro de Kantor é possível perceber que todo objeto está atrelado, de uma maneira ou de outra, a um personagem. Dessa forma, quando Kantor afirma que os homens passam mas os objetos permanecem, veremos que um dos aspectos de entrada nessa dimensão é através dos objetos que estão carregados de energia vivida, de memória, e é através deles que ocorre a passagem.

Mesmo a cadeira vazia, em Hoje é meu aniversário, que até a morte de Kantor, não tinha nenhuma existência significativa no palco, passa a ser de significante relevância pois, através dela, observa-se a existência de Kantor em outra realidade, em outra dimensão. Obviamente, nesse caso, uma realidade distinta da realidade da vida e também da realidade da morte. É exatamente nessa congruência que o seu teatro acontece após 1975. A cadeira, nesse caso, seguindo as proposições sobre a arte abstrata colocadas por Kantor em Lições de Milão, torna-se necessariamente o elemento que possibilita o acesso a esse outro universo. Em O retorno de Ulisses, Kantor manuseava a realidade através daquilo que era mais real, ou seja, a Segunda Guerra, o terror nazista, os campos de concentração. Enfim, a realidade da vida era a realidade da morte, um ready-made, um deslocamento do real dentro da realidade, através do qual se tornava possível a observação mais profunda da natureza da vida. Por esse caminho, no seu teatro, o uso de objetos comuns transfigurados em obra de arte coloca em discussão a existência de lugares desconhecidos e ainda não habitados pela arte. Assim, em Kantor, o objeto vulgar, ao ultrapassar os limites da fronteira com o desconhecido, inaugura uma nova existência como objeto único.

Esse ultrapassar as fronteiras do desconhecido em busca de lugares ainda não habitados pela arte encontra sua maior expressão no Teatro da Morte. No entanto, em relação ao objeto, nos anos sessenta, com as suas "embalagens", Kantor irá se relacionar com o objeto através daquilo que está escondido dos olhos, propondo ainda uma digressão em relação à natureza da embalagem com a sensação do pecado oriundo das profundezas religiosas da sua infância que, em contraste com o seu lado herético, fez desse jogo, pecado e heresia, um excelente campo para a ação artística - de um lado a pobreza e a eternidade; e do outro, o objeto pobre como monumento de arte.

\footnotetext{
"A POBREZA foi por muito tempo, e talvez seja definitivamente o sujeito da minha arte.
} 
Eu volto ao meu discurso sobre o OBJETO,

no instante no qual eu tinha um pobre saco nas mãos

sem saber o que fazer com ele.

E eu devia lhe confiar o meu futuro.

Eu sabia que não poderia reiterar meu gesto

do ano de 1944, embora a realidade e o objeto

deixou de contar e tem, ao contrário, todas as chances

de persistir.

Eu sabia que isso que durante a guerra se criava contra toda estética se tornava, em 1963,

um simples gesto refinado e de... esteticismo.

Assim, eu fiz algo que decidiria o meu futuro:

Eu cobri rapidamente e quase "furtivamente" esse objeto."10

Essa atitude de cobrir o objeto significa tornar invisível para que se possa ver alguma coisa além do visível. Assim, tratando-se o mundo exterior, conforme a concepção de Kantor da realidade do objeto, na medida em que o objeto é oculto, embalado, invisível para a visão, outro mundo se abre diante do observador. Isso quer dizer que ao cobrir o objeto, que foi concebido para ser visto, Kantor retira do observador a possibilidade da leitura imediata, excluindo qualquer possibilidade de conhecimento por meio dos sentidos, necessariamente a visão. $\mathrm{O}$ fato de estar o objeto encoberto não significa que ele não exista. Evidentemente ele existe, só que em outras condições, com outras regras, ou seja: as regras que se estabelecem sob a realidade que está abaixo dos panos e longe do acesso do olhar. Dessa forma, o objeto embalado, que não é visto, tem a sua existência plena na sua condição de objeto em uma situação de realidade que está em desacordo com a realidade do observador. Esse, ao perceber a realidade da embalagem, percebe simultaneamente o objeto em uma existência paralela com a sua realidade. E é exatamente nessa realidade paralela que a obra está acontecendo em todo o seu esplendor. Assim, a embalagem, seja na tela, seja no palco, constitui-se como uma estrutura performática que, através do elemento que encontra-se encoberto, também produz um deslocamento do real na realidade. O objeto, que é real, torna-se estranho para a realidade cotidiana assim como a morte que só pode ser atingida através da arte.

\footnotetext{
${ }^{10}$ Kantor, Tadeusz. Ma création, mon voyage. Commentaires intimes. Paris: Editions Plume, 1991, p.115.
} 


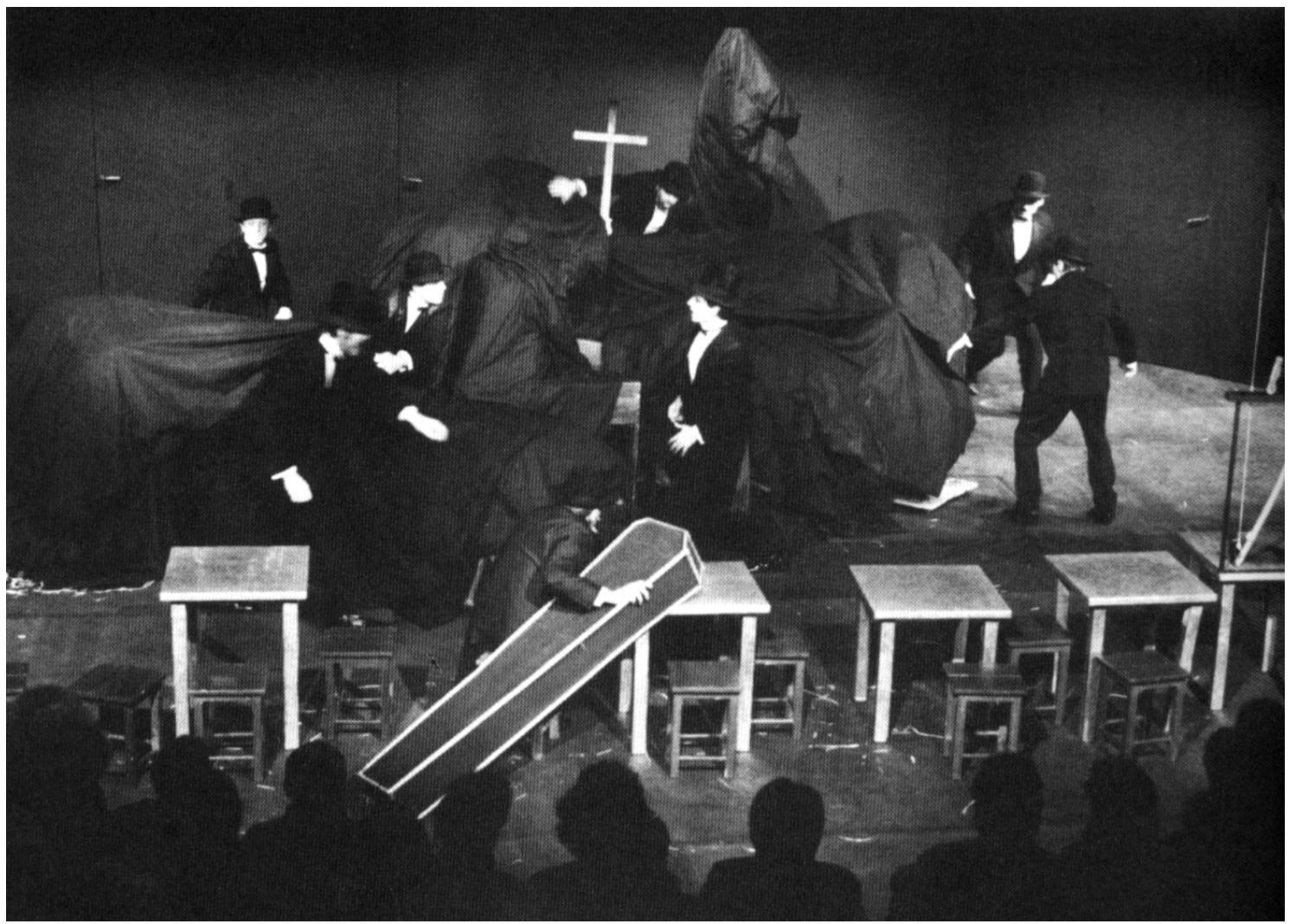

Não voltarei jamais. Na cena, a grande embalagem. Foto: arquivos da Cricoteka.

A existência de objetos no mundo que nos rodeia é, de certa maneira, o testemunho icnográfico de um determinado momento na história. Afinal, a história das civilizações é contada através dos seus objetos: a arqueologia é o exemplo mais contundente disso. No entanto, existe um momento em que o objeto deixa de ser histórico. Esse momento é exatamente aquele no qual o objeto passa a usufruir de uma carga de significados que ele não possuía anteriormente, passando a ser definido semanticamente como obra de arte e, nesse instante, a passagem do objeto vulgar para outro território que define a criação de objetos artísticos em um mundo existente em paralelismo com a realidade do mundo real. Nesse outro território, nessa outra dimensão, o uso de uma cadeira quebrada passa a ser entendida pelo espectador como essencial, como verossímil, sendo o espectador, obrigado a abandonar a análise lógica e o pensamento racional para uma situação que abre caminho para a atuação da imaginação como ação criadora, que é capaz de garantir a existência de coisas as quais não se encontram no mundo das coisas. Dessa forma, a cadeira quebrada de Penélope, mais do que ignorada, que está morta para a civilização, tem a existência garantida nessa nova realidade artística. Assim, o acesso a essa realidade pelo teatro de Kantor, já 
nesse momento, faz-se através do objeto que em nenhum momento deixa de ser aquilo que é, falseando a sua condição de cadeira quebrada. Ao ser percebido como objeto essencial, ele é transposto para outra dimensão de existência que assegura a ele a sua autonomia enquanto objeto de arte essencial. Essa é uma das inúmeras situações que se repetirão por toda a jornada artística de Kantor.

De uma maneira geral, em todas as civilizações, os objetos são sempre os responsáveis pela orientação da consciência nos trâmites da lógica ou nos domínios da fé que conduzem à crença de possibilidades de existências que estão além da vida cotidiana. Determinados objetos, em toda a história, manifestam o seu poder de transcender a realidade para outras dimensões. Podemos observar essa situação em objetos que já trazem em si o estigma de outro mundo. A cruz, por exemplo, no mundo cristão nos remete imediatamente à idéia da morte e da existência de outro universo, de um possível outro estágio da vida, normalmente chamado de paraíso. Muitos objetos, devido à sua peculiaridade cultural, como é o caso da cruz no Ocidente ou a imagem de Buda entre os orientais, institui-se imediatamente na consciência como objetos que lembram, o tempo todo, outra realidade que se fundamenta em outras formas de existência moral. Esses são ícones religiosos, símbolos que são responsáveis pelo questionamento metafísico de diversos povos. No entanto, outros objetos, cuja existência material, até prova ao contrário, existem apenas como materialidade na história das civilizações e na imaginação das culturas, também trazem em si a idéia de outra realidade. A Arca da Aliança, o objeto mítico mais importante entre os judeus, trata-se de um objeto que, conforme a crença, estabelecia uma ligação direta entre os homens e Deus. Entre o mundo das coisas e o princípio da própria coisa.

Tal qual a Arca da Aliança, outros objetos trazem em si conteúdos de existências semelhantes. O Santo Graal ${ }^{11}$ é outro objeto mítico que estaria imbuído de poderes que lembram, a todo instante, a existência de outra realidade. $\mathrm{O}$ cálice sagrado que além de ter sido usado na sua última ceia também serviu para guardar o sangue de Jesus derramado pela lança do centurião Longino; aliás, a lança também se trata, conforme a tradição, de outro objeto dotado de poderes sobrenaturais. De qualquer maneira, a lenda do cálice sagrado está necessariamente associada à possibilidade de outro mundo

\footnotetext{
${ }^{11}$ No sentido mais tradicional conforme as lendas arturianas que estabelecia o Graal como o cálice utilizado por Jesus na última ceia.
} 
através do qual o poder emana para o objeto. Nas representações pictóricas e na literatura, o Graal aparece muitas vezes associado a efeitos que sugerem uma experiência extra-real, à maneira dos surrealistas. A lança de Longino, também chamada de A Lança do Destino segundo a mítica histórica, trata-se de um objeto que possui poderes espantosos e que muitos homens poderosos teriam se beneficiados da sua força, dentre eles, Napoleão Bonaparte e Adolf Hitler. Enfim, toda relíquia divina, em qualquer cultura, está inevitavelmente associada a uma realidade distinta da realidade cotidiana.

Esses objetos mágicos, por serem detentores de um poder cuja origem deve estar situada em outro estado de realidade, são passíveis de serem considerados divinos exatamente pelo fato da origem de seus poderes estarem localizadas fora do nosso mundo. Assim, a força sobrenatural providenciada por um objeto sagrado só é possível porque o seu poder vem de outra fonte que não se localiza na realidade da vida. $\mathrm{O}$ objeto sagrado é somente o intermediário entre o humano e o divino e, através desse objeto, a percepção de um mundo distinto do nosso mundo. Assim, o objeto ascende, mesmo que na forma de ídolo ou máscara, como o principal elemento mágico presente na história das civilizações.

Essa situação do objeto como condutor, como ligação com o mundo do "além de", foi amplamente utilizado pelo cinema, sobretudo o "hollywoodiano". Nas telas é muito comum o sobrenatural se manifestar através, não somente de objetos icônicos, mas também através de simples objetos cotidianos que ao serem tocados pelo divino ou pelo o maligno, passam a se apresentar como agentes de uma força misteriosa que se manifesta de maneira a expressar o bem ou o mal. Além dessa maneira de "iconizar" o objeto através de forças sobrenaturais, Hollywood através da ficção e da fantasia geralmente atribui ao objeto a condição de ser a chave ou o caminho para realidades paralelas. Dentre muitos, podemos observar isso em produções recentes como As crônicas de Nárnia ${ }^{12}$ e Matrix ${ }^{13}$. No primeiro filme, os heróis encontram uma passagem dimensional que está situada em um guarda-roupa e é nessa outra dimensão que a trama se desenvolve e os conflitos, cuja origem é anterior ao ultrapassar das portas do guarda-

\footnotetext{
${ }^{12}$ As crônicas e Nárnia - o leão, a feiticeira e o guarda-roupa. 2005. Direção: Andrew Adamson.

${ }^{13}$ A trilogia Matrix é composta por - Matrix (1999); Matrix reloaded (2003); Matrix revolutions (2003). Direção: Larry Wachowski, Andy Wachowski.
} 
roupa, serão resolvidos. A série Matrix, por sua vez, utiliza-se de um computador para entrar na realidade virtual e de um telefone antigo para voltar ao mundo real. Na trilogia Matrix, os conflitos, pelo menos a maioria, também acontecem no mundo paralelo, no entanto existe uma co-relação entre os mundos. $\mathrm{O}$ mundo real se prolonga no mundo virtual da mesma maneira que o virtual faz seu prolongamento no real, como se a existência de um dependesse necessariamente da existência do outro.

Em 1862, Lewis Carroll, em Alice no país das maravilhas, um clássico da literatura universal, já lidava com o conceito de realidades paralelas. O texto de Carroll é aberto a várias possibilidades de leitura que seduz o leitor à uma série de questionamentos a partir do momento em que Alice atravessa o buraco do coelho iniciando sua viagem, uma aventura que até poderia ser chamada de surrealista, tem a realidade que conhecia alterada a partir desse momento para uma outra na qual as coisas acontecem em função de outra lógica e de outros códigos lingüísticos. Por esse caminho, através dos exemplos acima citados, somos levados a perceber que, de uma maneira geral, seja cultural, seja meramente um recurso artístico, o objeto torna-se o principal elemento no processo de percepção e construção dos universos paralelos. Mesmo através de situações que podem ser comprovadas na prática, como as viagens interplanetárias, ou pelo menos até Marte, das naves exploradoras que viajam pela galáxia atrás de informações sobre o desconhecido sabe-se que, no espaço, as leis não são exatamente as mesmas da realidade do nosso planeta. Quanto mais distante, mais frágil a nossa compreensão do universo em que vivemos a partir das nossas experiências. O macro-universo é regido por leis que desconhecemos. Nós apenas intuímos a partir da compreensão que temos do nosso próprio mundo. Quando se fala em viagens dessa natureza, estamos falando necessariamente de máquinas que se movimentam dessa realidade para outra totalmente desconhecida. De qualquer forma, seja para viagens no mundo da ficção, seja para pequenas viagens, em escalas astronômicas, em nosso sistema solar, tanto a fantasia quanto a realidade estão submetidas ao poder do objeto para que o ser humano possa cogitar alguma possibilidade de conquista e conhecimento de universos que não estão à vista dos nossos olhos. Enfim, o universo trata-se de uma grande embalagem.

Para Kantor, o objeto é alguma coisa que está além dele. É algo que ele pode desenhar sua imagem e garantir a sua existência na tela. Mas isso não é o suficiente. 
Não se trata somente de uma imagem mas de algo que se fosse possível ele o comeria a fim de ligá-lo ao seu organismo. Mas essa relação do objeto em Kantor terá necessariamente dois momentos distintos no seu procedimento de estabelecer os vínculos do objeto com o "além de", com a dimensão paralela situada entre a vida e a morte. A primeira, e já venho antecipando isso, diz respeito ao uso do objeto real degradado, que se inicia com a idéia da pobreza em 1944, fazendo dessa a característica fundamental do objeto nas suas encenações. A segunda, através da ação da memória sobre o objeto. Assim, através dessa nova realidade que surge na obra teatral de Tadeusz Kantor a partir de A classe morta, e na qual acontecem seus espetáculos, nesse espaço intermediário entre a vida e a morte, é importante lembrar que o acesso e conhecimento da dimensão da morte não é possível, da mesma maneira que não é possível o retorno dos mortos e seus adereços para a realidade cotidiana. Dessa forma, esse espaço intermediário funciona de maneira semelhante ao "espaço cíbrido" acrescentando que, no espaço cíbrido, não há passagem do indivíduo de uma realidade para a outra, mas a existência simultânea do mesmo em duas realidades diferentes, ou seja, a real e a virtual. Em Kantor, o objeto, que é real, nos leva para essa realidade intermediária na qual o espetáculo se realiza da mesma forma em que guia os personagens, que estão perdidos nas várias dimensões da memória, para esse lugar de encontro. Entretanto, do ponto de vista do observador, esse objeto é visto na realidade do teatro ao mesmo tempo em que é percebido na realidade paralela.

Por várias vezes Kantor se perguntou se o retorno do mundo dos mortos era possível. Em um dos seus ensaios, ele conclui que é impossível, e atribui a isso a grande tragédia humana.

\footnotetext{
“...após alguns anos, após ter obtido muito de mim mesmo, eu comecei a pensar no retorno. Eu me perguntava se o retorno de Orfeu era possível. Para o nosso mundo.

"Infelizmente não existe retorno.

Esse é o destino trágico do homem."14
}

Dessa constatação, a sua ligação com o objeto se desenvolverá por novos caminhos. Por caminhos desconhecidos por ele até então, principalmente motivado pelo fato dele perceber no objeto a capacidade de se conservar materialmente no tempo, mais

\footnotetext{
${ }^{14}$ Kantor, Tadeusz. Ma création, mon voyage. Commentaires intimes. Paris: Editions Plume, 1991, p.118.
} 
do que o ser humano. Lembrando que na sua concepção os homens passam, mas os objetos permanecem.

"O tempo do objeto.

Isso é "algo" que existe na outra extremidade da minha consciência,

do meu "eu".

Inacessível.

E todos esses esforços, após os séculos, para o "tocar"

Custou muito.

O objeto, profundamente ancorado em mim..."

Notadamente, Kantor reconhece a impossibilidade de se conhecer a dimensão da morte. No entanto, ele atribui à memória, ao passado - possivelmente inspirado por Maeterlinck $^{16}$ - esse status. Porém, aquilo que está na memória, apesar de estar morto, paradoxalmente, também está vivo. Assim, ao trazer a memória para o palco, o palco se transforma em um local de recepção de personagens e situações. Kantor tem uma maneira muito peculiar de se referir a isso. Ele chama o palco de a sua casa e por ser a sua casa, os personagens que habitam a sua memória, o seu passado, são os locatários desse imóvel e que encontram no palco a sua morada. Em um dos comentários a respeito de Wielopole Wielopole ele escreve:

“...é difícil de definir as dimensões espaciais da lembrança.

Eis o quarto de minha infância,

que eu arrumo sempre

e que sempre morre.

Com seus locatários de alhures.

Os locatários são os membros da minha família.

Todos repetem ao infinito

seus atos,

impressos como em um clichê.

Para a eternidade." $" 17$

\footnotetext{
15 Ibid.

${ }^{16}$ Maeterlinck, em $O$ pássaro azul, se refere ao passado como o mundo dos antepassados, dos mortos.

17 Kantor, Tadeusz. La mémoire comme processus de création. In. Kantor, l' artiste à la fin du Xxe. Siècle. Paris: ACTES SUD,1990, p. 61.
} 
Para poder entrar nesse local que é lugar de encontro entre um mundo e outro, faz-se necessário o uso de uma energia muito intensa, uma energia que possa unir o passado com o presente. Dessa forma, aquilo que é capaz de resistir com muito mais solidez as intempéries do tempo trata-se do objeto. $\mathrm{O}$ objeto permitirá que as personagens que são atores reais associados aos objetos e às lembranças de Kantor se apresentem em um teatro ou um espaço artístico, mas ao mesmo tempo, que esse local se declare como uma ruptura em relação ao espaço e tempo cotidiano. Nessa realidade paralela ou alternativa, o tempo deixa de ter relevância pois como na memória tudo acontece ao mesmo tempo, em um processo de sobreposição de imagens e situações, o tempo se caracteriza pelo instante em que é observado. O tempo cronológico é uma prerrogativa do observador que não se encontra na cena. Aquilo que existe no palco de Kantor, como foi visto em outro momento desse trabalho, trata-se de uma forma específica de tempo que se define em outros parâmetros. Ou seja, um tempo mítico.

Se o palco é o ponto de confluência das memórias de Kantor que estão latentes em sua imaginação, o jogo do ator nessa outra realidade se dá necessariamente, para que ele possa ser arremessado para lá, através de algo que o caracteriza como necessário. Dessa forma, um objeto colocado no palco, o arco de Ulisses por exemplo, imediatamente, através da força da sua energia histórica, retirará Ulisses do ano de 1944 e o conduzirá para 1988 - evidentemente estou falando de uma situação que envolve $O$ retorno de Ulisses e Não voltarei jamais. Trata-se pois de um objeto em uma situação de um espetáculo do passado que se desdobra no tempo para acontecer no espetáculo do presente:

“O TEMPO PASSADO QUE DESLIZA SECRETAMENTE

NO TEMPO PRESENTE." ${ }^{\prime 18}$

Nesse mesmo momento o objeto que é real, que está ligado à consciência do espectador, ao promover a entrada da personagem na dimensão paralela, também conduz o espectador para essa zona na qual os jogos se realizarão e as tensões serão estruturadas e sublimadas. Nesse contexto, o espectador/observador estará constantemente definindo esses limites já que Kantor, que está no palco, não é produto

\footnotetext{
${ }^{18}$ Kantor, Tadeusz. La mémoire comme processus de création. In. Kantor, l' artiste à la fin du Xxe. Siècle. Paris: ACTES SUD,1990, p. 62.
} 
da sua memória ou da sua imaginação. Kantor é o ser real, histórico, artista criador que está construindo a sua memória no palco. O observador, ao sentir a presença do real é levado a se desvencilhar momentaneamente dele e será obrigado a compartilhar com Kantor os seus comentários mais íntimos. O objeto, por sua vez, permanece estável o tempo todo. Ele existe enquanto objeto real tanto no presente, quanto no passado e até mesmo no futuro. Mesmo se tratando de um objeto cópia do real, como é o caso do arco-metralhadora de Ulisses, esse objeto, construído no presente, estranho para a realidade do espectador, é o objeto através do qual Ulisses é guiado para a sua outra Ítaca e com o qual os pretendentes de Penélope serão assassinados. Ulisses voltará para a terra natal, não após vinte anos perdido em lutas pelas terras gregas, mas por quase meio século de perambulações pela Europa devastada pela guerra e pelas almas congeladas em pedra pelos olhos frios da Medusa stalinista. Ulisses retorna não para a diplomacia mas para reafirmar a sua identidade como o herói que supera as intempéries e derrota os inimigos. Seja no passado grego, na obra de Homero, seja na montagem de Kantor sobre a obra de Stanislaw Wyspianski ou em Não voltarei jamais, o retorno de Ulisses está diretamente associado ao seu arco, símbolo do seu poder sobre os pretendentes de Penélope. No seu retorno, antes da esposa, é o arco que Ulisses tem em suas mãos.

O arco-metralhadora, mais do que o manto (o casaco do herói), determinará a condição na qual Ulisses será observado como Ulisses na realidade do espetáculo e que é a realidade do espectador/observador. Entretanto, concomitantemente, a consciência do espectador/observador é transferida, através do objeto, do real para a realidade paralela na qual Ulisses se encontra com esse objeto, que é um desafio ao entendimento consciente, pois a sua natureza híbrida, produto das sobreposições de memórias de Kantor, e também das suas alucinações, terá sua existência justificável nas mãos do astuto general grego. Mais uma vez, o objeto como sustentáculo de existência do personagem.

O objeto no teatro de Kantor é sempre uma estrutura real que está constantemente desafiando a realidade na qual ele está inserido. Muito já se falou sobre a cadeira quebrada de $O$ retorno de Ulisses, da maneira como esse objeto é capaz de se colocar como objeto real em outra realidade que está em total conexão com a realidade do observador. Diferentemente da memória como processo de criação, que através da 
sua ação no espaço real desestabiliza esse espaço e provoca o surgimento de uma realidade alternativa, os objetos do Teatro Independente, o qual é anterior à fundação do Teatro Cricot 2, e aqueles encontrados no Teatro Autônomo, no Teatro Informal, no Teatro Zero, no Teatro Happening, e alguns momentos do Teatro Impossível, irão, a exemplo da cadeira quebrada de Penélope, promover a ruptura com a realidade através de um redimensionamento do valor do objeto real na realidade. Lembrando que essa é sempre a realidade do observador.

Esse redimensionamento do objeto faz com que o armário de $A$ pequena mansão, um velho guarda-roupa, sirva na realidade do espetáculo, de local não para pendurar roupas, mas para sustentar seres humanos presos a cabides, seja percebido como estranho, como único para a realidade na qual ele está inserido. Isso quer dizer que na realidade do observador haveria de se presumir que quando as portas do objeto se abrissem, roupas penduradas é que seriam vistas, não homens. Disso decorre a estrutura que se tornará inerente a todas as demais fases do teatro de Tadeusz Kantor, como já apontado anteriormente, de que é impossível se prever o que irá acontecer nos seus espetáculos a partir do momento em que as portas se abrem. Esse guarda-roupa, que também foi utilizado em Wielopole Wielopole, em A pequena mansão será o responsável pela desconexão do objeto com a realidade do observador, posto que ao observar o guarda-roupa o espectador é forçado a configurar uma outra realidade na qual aquela situação seja verossímil. Evidentemente essa busca acontece a partir da consciência, no entanto, se aceitarmos a consciência como o entendimento da realidade exterior a partir do entendimento e conhecimento que o sujeito tem de si mesmo, o conjunto de relações entre esse objeto com a realidade do observador não é passível de acontecer. Dessa forma, através de uma percepção puramente intuitiva, o espectador observa esse objeto em outra realidade que não é a sua realidade cotidiana, mas que está acontecendo, a partir de aspectos desconhecidos da sua consciência, aos quais Kantor já havia se referido em uma passagem descrita anteriormente e que também faz parte do mundo exterior que por ele é construído no instante da observação. A diferença entre as situações de entendimento surge do fato de ser o mesmo objeto observado e, apesar disso, ele se apresenta distinto em duas realidades que não são opostas, mas similares. Trata-se, portanto, de um fato semelhante ao apontado por Kantor no Manifesto do teatro da morte, quando ele comenta sobre o surgimento do ator ser percebido de uma maneira completamente diferente quando colocado além da barreira instransponível. 
Seguindo esse princípio, em 1969, Kantor realizou um happening na exrepública da Iugoslávia, nos Alpes, que se tratava de uma nova concepção de A pequena mansão. Nesse happening, um guarda-roupa similar ao utilizado no espetáculo de 1961 foi erguido por um helicóptero a uma altura de mil e quinhentos metros, e de lá foi solto para se chocar contra o solo em um local próximo a uma estação de esqui. Os observadores/espectadores, informais nesse caso, não entendiam exatamente o que estava se passando. Aquele objeto pendurado pelo helicóptero criava uma situação estranha para a sua experiência de observador, ainda mais por se tratar de um local cuja possibilidade de que algo a mais do que esportes de inverno acontecesse praticamente não existia. Entretanto, ao perceber aquela situação inusitada, o observador casual intuitivamente percebe aspectos da realidade que estavam escondidos da sua visão cotidiana. Na sequiência, após o objeto ser derrubado e se arrebentar contra as pedras, alguns atores se colocavam em jogo com os fragmentos daquilo que restou do armário, cuja concepção e arranjo da situação deveria determinar a simplicidade da realidade da vida. Evidentemente isso só foi possível através do objeto. Temos também no contexto desse acontecimento aquilo que iria se tornar o célebre pensamento de Kantor sobre o happening, como uma maneira de situar a arte na realidade da vida. Obviamente, toda a estrutura do seu teatro apresenta essa dicotomia entre arte e realidade, de modo que a arte acontece no interior da realidade, mas que esse acontecimento se dá como ruptura com essa mesma realidade na medida em que a arte não pode ser determinada pelas mesmas regras de construção que regem a realidade cotidiana.

De uma maneira geral, o teatro de Kantor, em todas as suas fases, de acordo com aquilo que foi apresentado nesse trabalho, pode ser sintetizado conforme a tabela que se segue: 


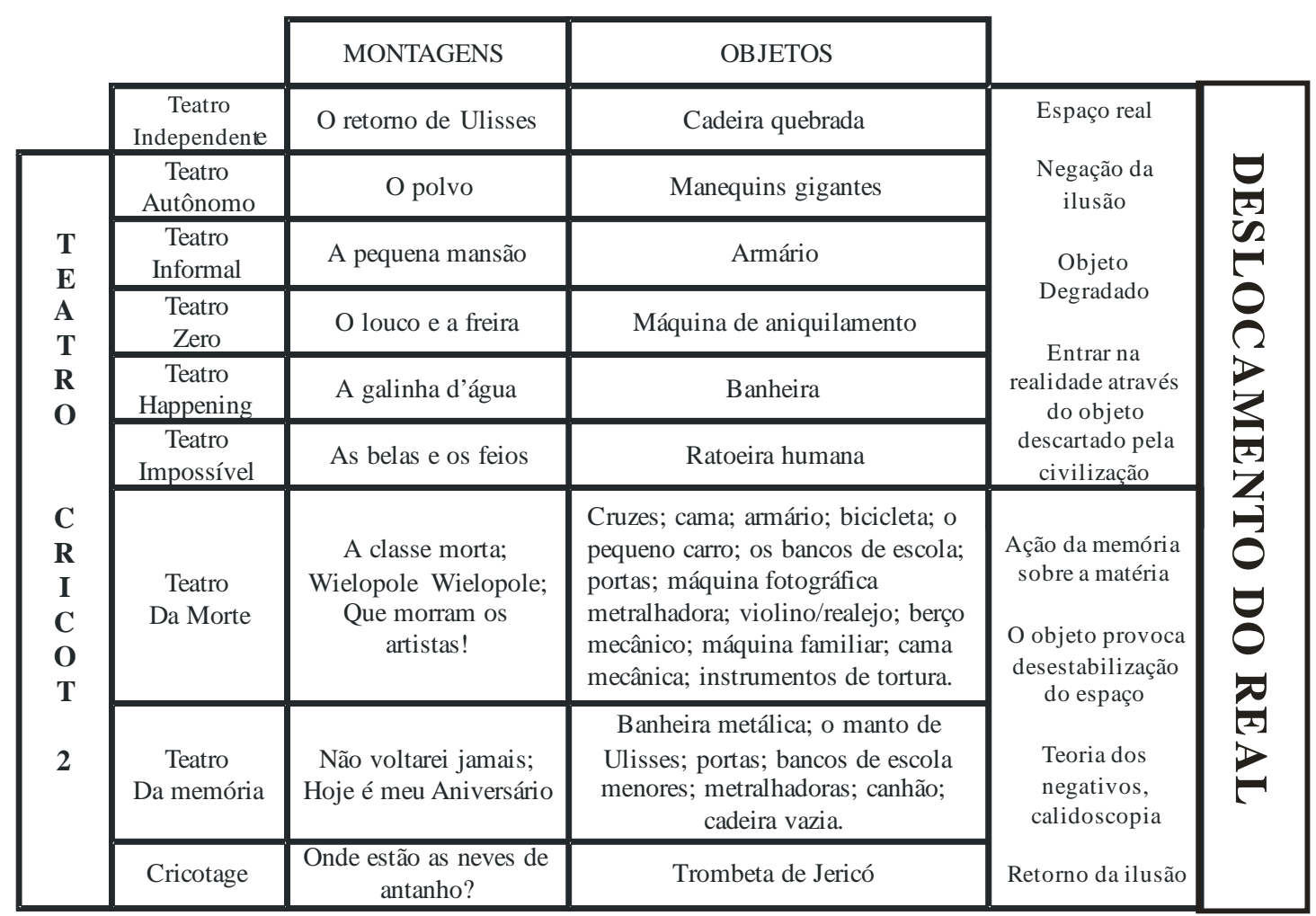

Resumindo, a relação de Kantor com a realidade, sintetizada no quadro acima, acontece em dois momentos. O primeiro acontece antes de A classe morta, no qual a entrada na realidade se dá através dos objetos degradados, renegados pela civilização. $\mathrm{O}$ objeto é real mas inútil, morto para a "sociedade do espetáculo" e do consumo. Esse objeto, como a cadeira quebrada na qual Penélope se senta constituindo o ato de sentar como uma nova gênese, ou seja, algo que está ocorrendo pela primeira vez, o objeto é o elemento que permite que o espetáculo não degenere nos domínios da ilusão e se mantenha na realidade específica da sua condição de objeto degradado. Isso quer dizer que, na cadeira quebrada, Penélope a rainha de Ítaca, ao tecer pacientemente sua tapeçaria à espera do retorno do marido da Guerra de Tróia, essa cadeira quebrada não ostenta na realidade do espectador a condição de ser própria para uma rainha, principalmente por se tratar de um objeto impróprio para o uso de qualquer pessoa. Por outro lado, a cadeira quebrada de Penélope na realidade do espetáculo, torna-se a cadeira da heroína e não existe nenhum interesse no falseamento dessa realidade. Penélope utiliza um objeto sem nenhum valor para a sociedade de consumo, que é percebido pelo espectador como algo sem utilidade, mas a rainha de Ítaca desconhece esse dado. Ela reconhece a cadeira como essencial no ato de esperar por Ulisses. Essa é 
a única cadeira que Penélope conhece e, é exatamente por isso, que o ato de sentar nessa cadeira quebrada se constitui como um primeiro ato de criação, original, genuíno.

No segundo momento, o objeto se comportará como um agente através do qual a memória de Kantor encontrará substrato para desestabilizar o espaço e, dessa forma, pelos meios da ação da memória sobre o objeto, decorre a memória como matéria, como substância; e sendo matéria e sendo substância, a memória ocupa lugar no espaço, e assim, na medida em que os objetos, por serem depositórios da memória, ocupam a cena e o espaço altera substancialmente a sua configuração inicial, o que modifica intrinsecamente a realidade na qual o objeto está inserido. Dessa forma, do choque entre um e outro espaço, teremos um teatro que desde a sua origem não se caracteriza por ser reflexo do observador diante do espelho, mas sim uma espécie de "deslocamento do real dentro da realidade", já que aquilo que é observado, seja em O retorno de Ulisses, seja em Hoje é meu aniversário, constitui-se como uma realidade própria, embora intensamente amparada pelo real cotidiano.

“... a ação "artística” deve ser extraída

do cotidiano prosaico, da realidade que permanece POBRE pela relação com a imaginação "rica”.,"19

Kantor insiste continuamente que a arte precisa de leis e de uma moral próprias. Por esse caminho, o teatro e a arte de Kantor, de um modo geral, se desenvolverão sobre os parâmetros da transgressão e do pecado em relação aos dogmas artísticos. Algo parecido com Marcel Duchamp no sentido de retirar da arte o valor de utilidade, no caso do teatro, da presença dos gestos sem motivação e sem objetivo, sem origem e sem efeito, desprovidos de toda função utilitária e emancipado de toda ação. Nessa realidade alternativa, o sentido do pecado e da transgressão são prerrogativas morais próprias e necessárias à sua criação. Na arte, a nuance é fundamental. A "descoberta da realidade", a promoção do objeto real é distinta de Duchamp. Em Kantor existe algo de muito mais religioso:

\footnotetext{
"Eu sinto isto como uma transgressão, um pecado, este sentido do pecado é decisivo, em toda a minha criação."20

${ }^{19}$ Kantor, Tadeusz. Ma création, mon voyage. Commentaires intimes. Paris: Editions Plume, 1991, p.119.

${ }^{20}$ Tadeusz Kantor. In. Scarpetta, Guy. Kantor au present. Arles: Actes Sud, 2000, p. 34.
} 
Para ele, através dos objetos se observam fragmentos de vida, objetos que tinham o status de ready-mades e que no seu vocabulário eram chamados de "objetos encontrados", cuja utilização desse material em seu teatro, e também na sua pintura, implicavam uma relação de fé, de crença na condição do objeto como algo a ser preservado. Para Kantor, o objeto, igualmente como o homem do pós-guerra, era produto do sofrimento, do desespero, da vergonha, da humilhação, da zombaria e da dor. Disso decorre uma problemática que se trata da maneira como uma arte que é fortemente carregada de emoção pode se situar, entretanto, nas antípodas de toda sentimentalidade? Talvez seja por isso que ele, certa vez, escreveu em seu caderno de notas que cada noite, que cada representação se constitui como um ato de sacrifício. $\mathrm{O}$ seu sacrifício retificado no palco a partir da memória do sofrimento, da humilhação, da dor e da morte. A exemplo da pintura barroca, principalmente de Goya, que na tela promoveu a erupção de "outro mundo", o teatro também se tornará definitivamente em Kantor, um meio para atingir o mistério. Evidentemente, a morte é o maior mistério e o seu sacrifício se trata da luta contra o esquecimento, mesmo que a cada noite seja renovada a experiência da dor, da humilhação, e da morte.

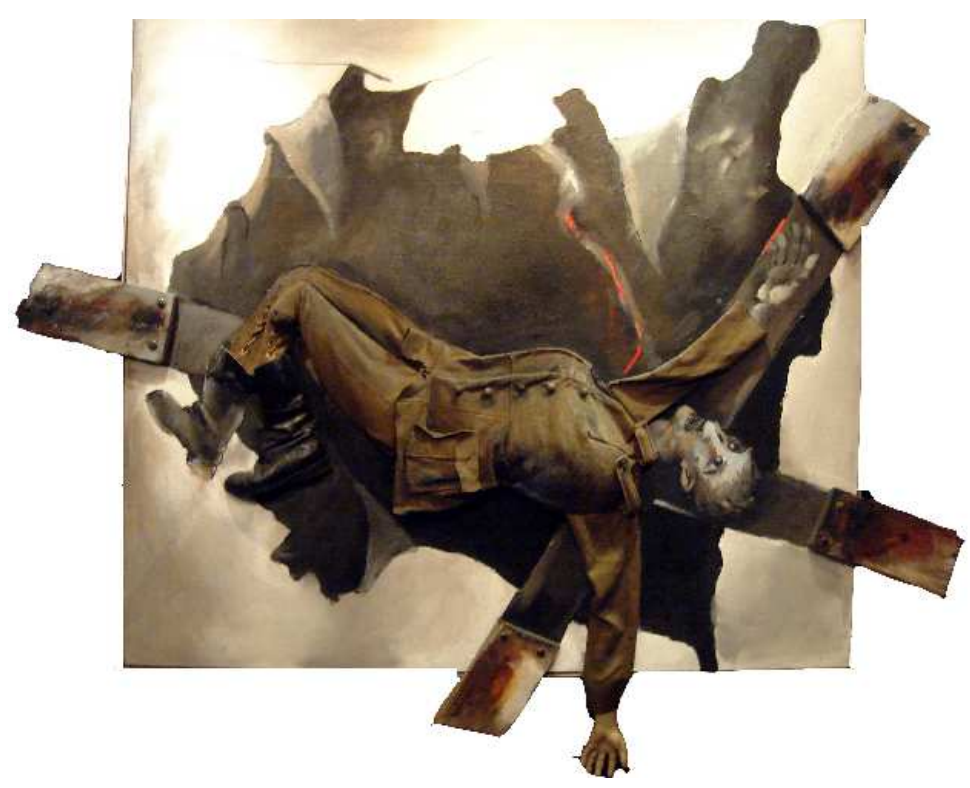

Tadeusz Kantor. Auto-retrato. Na cruz, o soldado de inúmeras batalhas. Foto: Wagner Cintra. 


\section{CONCLUSÃO \\ UM TEATRO DE FRONTEIRAS}

O teatro de Tadeusz Kantor é um teatro de sentimentos extremos, de paixões extremadas. Como um grand-guignol, é um teatro de excessos em primeiro grau. Um teatro que institui a sua intensidade própria, que cultiva as suas próprias ferramentas de poder - eis a originalidade do grand-guignol kantoriano. Um teatro marcado pela alternância entre temas cômicos e trágicos que cria uma constante sucessão de momentos de relaxamento e de tensão.

O teatro de Kantor rompe definitivamente com os limites impostos pela convenção cênica em direção a uma maior capacidade expressiva da ação. Assim, o teatro de Kantor se apóia na premissa da necessidade de outra reorganização da realidade da cena. Trata-se então, esse teatro, de um meio em que a cena se apresenta de maneira carregada, na qual as situações são levadas ao extremo da tensão pontuando como "representação" exasperada de uma suposta degeneração moral da arte e de seus representantes, agentes do mercado que, conforme o pensamento de Kantor, acabaram:

\section{"ENTORPECENDO O ESPÍRITO E A ALMA HUMANA.}

Os enormes magazines de pesadelos tornaram-se os santuários do novo deus do consumo e da vida material.

(...)

É NECESSÁRIO A TODO CUSTO PERMANECER ATEU DIANTE DESSES SANTUÁRIOS E A ESSE DEUS!

Em uma atmosfera, misto de barroco e pesadelo, oscilando entre o grotesco de um grand-guignol e o mais complexo lirismo, Kantor nos revela um mundo absurdo no mais puro sentido kafkiano, ele faz conhecer ao espectador a sua própria condenação, o seu mais íntimo sentimento de solidão. Existe nesse universo uma obsessão pelo mistério, pelo homem misterioso e pelas forças incontroláveis que regem o seu destino. Trata-se de um terrificante testemunho da precariedade da condição humana, do 
abandono do paraíso e da prematura entrada no asilo dos loucos perigosos. Com Kantor, como comenta Guy Scarpetta:

“...o teatro deixou de ser inofensivo."

De uma forma instigante e perturbadora o teatro de Kantor também é, de uma maneira geral, definitivamente divertido e engraçado. $\mathrm{O}$ grand-guignol de Kantor não cultiva o extremo pelo extremo, mas estabelece um feixe de relações que permite reinterpretar a realidade através da experiência poética, na qual o espectador é confrontado com um espetáculo extremamente rico e complexo que surge como resultado do choque de forças antagônicas e contraditórias. Kantor cria em cena um caleidoscópio de referências e associações que mostram uma visão de mundo fragmentado no qual se acentua a relatividade das coisas e a ambivalência do homem, dividido entre realidade e ilusão, luz e trevas, vida e morte. O público é fortemente atingido pelo desnudamento das anomalias psíquicas provocadas pela força das imagens. Mas, ao mesmo tempo, a tensão é relaxada pelo contraponto do riso, embora esse riso seja intencionalmente desconfortável, pois se trata de um riso que tem o gosto amargo da constatação e da revelação das verdades essenciais da condição humana degradação e morte. Um riso que se faz presente diante do sofrimento, da dor e da morte, no mais puro espírito do grotesco cuja construção de imagens está relacionada a uma história pessoal, vivida e experimentada, sobretudo no período em que a Polônia, durante a ocupação nazista, tornou-se a própria expressão da morte concretizada na bizarra materialidade dos campos de extermínio. No entanto, Kantor retrata a morte, não de uma maneira cerimonial mas como produto de sua memória. Entretanto, essas lembranças não são amargas, pelo contrário, se materializam nas cenas que estão repletas de humor e ironia que invadem os domínios da morte, da dor e do sofrimento, para se constituírem nos elementos mais significativos na estrutura da imagem do seu teatro. Tadeusz Kantor faz da degradação a sua bandeira poética e a morte torna-se um instrumento da sua arte.

\footnotetext{
${ }^{1}$ Scarpeta, Guy. Kantor au présent. Arles: Actes Sud, 2000, p.53.
} 
Por outro lado, a idéia da morte também está associada àquilo que podemos chamar de a tragédia da vida cotidiana, da qual os artistas são como sobreviventes residuais do cosmopolita mercado de arte, onde:

"Tudo se tornou marchandise,

o marchandise tornou-se o deus sanguinário

de assustadoras quantidades de alimentação

que alimentam o mundo inteiro,

e a metade da humanidade morre de fome;

Das montanhas de livros que jamais chegaremos a ler;

os homens devorando os homens,

seus pensamentos, seus direitos, seus hábitos,

sua solidão

e sua personalidade.

Dos mercados de escravos organizados em uma formidável escala

se vende pessoas,

se compra,

se negocia,

se corrompe.

Criação,

esta palavra deixa de ser

um argumento sem apelo",2.

Obviamente Kantor tece nessa passagem de Lições de Milão, uma crítica ao comércio da arte que brutalmente submeteu a criação à necessidade de venda. Assim, os atores como os demais elementos do seu teatro, são resistentes, mesmo degradados continuam a existir. Subjugam a morte a fim de afrontar a vida, uma vida que existe além do consumo que a tudo uniformiza, que a tudo nivela e a tudo deixa sem significado. Na verdade, Kantor está falando sobre a maneira como o mercado da arte engoliu e passou por cima dos ideais surrealistas e de seus autores. Para ele, o ato de criar, a liberdade infinita da criação liberada pelo Surrealismo, foi aprisionada pelo escuso interesse comercial. A criação foi substituída pela reprodução:

"Hoje o surrealismo está vulgarizado

maciçamente e - o que é pior -

\footnotetext{
${ }^{2}$ Kantor, T. Leçons de Milan. Paris: ACTES SUD - PAPIERS, 1990. p.69-70.
} 
de maneira "interessada"

e utilizado de uma forma inacreditavelmente grosseira

em todo lugar onde se quer

SURPREENDER.

IMPOR COMERCIALMENTE, ATERRORIZAR.

ATRAIR PELA FORÇA,

E ENFIM... VENDER.

Em todo lugar onde

pela falta de idéias precisas

SE SIMULA ESTADOS ALUCINATÓRIOS, ONÍRICOS E DELIRANTES,

HOJE EFICAZES E RENTÁVEIS...”3.

Kantor chama os artistas que se submetem e que vivem pelo mercado de pseudo-poetas:

"SIMULADORES QUE TENTAM ENCANTAR POR SUA HISTERIA

CUJA POBRE IMAGINAÇÃO É SALVA

PELA TÉCNICA

E SEUS ULTRAMECANISMOS,

EXTERMINANDO SEM ESCRÚPULOS

O PENSAMENTO E A EMOÇÃO.

(...) “GRAFISTAS” QUE OSTENTAM A HABILIDADE OCA

DE SUA PROFISSÃO,

TENTANDO PELA VIOLÊNCIA NOS CONVENCER QUE ELES ATRAVESSARAM

“O ESPELHO DE ALICE NO PAÍS DAS MARAVILHAS”.

NA REALIDADE ELES PERMANECEM DIANTE DELE" $"$.

Em Kantor, como em um grand-guignol, a conjunção dos diversos elementos que compõem a cena aparenta uma perspectiva de bagunça, de caos, de deboche, de displicência, de subversão, de aparente desconexão entre os meios e os fins. Os acontecimentos apresentam uma narrativa às avessas, imprecisa que suscita muitas dúvidas. Esse detalhe da aparente imprecisão, quando do jogo com os objetos, cria ao mesmo tempo situações brutais e grotescas no qual se infiltra, pela finura da poesia, uma lógica humorística pontuada perspicazmente por um diálogo irônico. Ironia que tem nos objetos uma função muito específica, ou seja: iluminar as zonas sombrias do real abrindo uma passagem para um universo paralelo, onde o que está dentro, ao

\footnotetext{
${ }^{3}$ Ibid. p. 73-74.

${ }^{4}$ ibid.
} 
primeiro olhar, é viscoso e repulsivo, mas passado o primeiro impacto, através das associações dos signos criados, os acontecimentos parecem dispostos a restaurar no palco o ideal sonhado por Antonin Artaud de:

“...uma arte liberta de toda preocupação com a imitação, uma "poesia para os sentidos”, uma linguagem antes de tudo "psíquica e plástica", na qual os códigos reunidos na polifonia teatral possam se emancipar de toda função pura e simplesmente ilustrativa; onde o texto deixe de ser a instancia superior ao qual todo o resto está subordinado, (...) onde o diretor se imponha como o verdadeiro criador; onde a arte não seja o reflexo da vida, mas se situe do mesmo lado, onde cada espetáculo seja percebido como uma ação real, e não a reprodução de uma ação."5

Com efeito, o teatro de Kantor, como um grand-guignol, é sempre um teatro de limites, um teatro de fronteiras que a partir de A classe morta, a observação da cena é feita à distância pois uma barreira separa o observador dos seres que estão em jogo na área de encenação. É um teatro de objetos no sentido de serem numerosos, e apesar de apresentarem uma aparente desordem, seu funcionamento mobiliza toda a atenção. Nesse sentido:

“... esse é um teatro de objetos sem ser "objetal.",

Na cena kantoriana nada é definitivo. A cena é uma matéria tal qual os objetos que a constituem. A cena existe por seus movimentos e sua metamorfose. $\mathrm{O}$ espaço se converterá então em uma espécie de superfície que se forma ao redor dos objetos e dos homens. Nesse espaço, Kantor não está propriamente interessado na criação de metáforas. O que importa realmente é o sentimento do impossível, a tensão na direção de tudo aquilo que é considerado irrealizável e até utópico. Para Kantor, é precisamente a tensão provocada pelo impossível que dá sentido à sua arte, ou seja, um meio criativo que fosse capaz de ultrapassar os estreitos limites do senso comum.

Esse desejo de ir além do senso comum, ou melhor, de ir muito além do senso comum, faz com que os elementos do seu teatro se posicionem de maneira autônoma na cena de forma que não se encontra qualquer espécie de hierarquização nos espetáculos. Todavia, o objeto tem especial destaque no sentido da comunicação com o "além de".

\footnotetext{
${ }^{5}$ Scarpeta, Guy. Kantor au présent. Arles: Actes Sud, 2000, p.40.

${ }^{6}$ Dort, Bernard. In. Kantor, l'artiste à la fin Du XXe. siecle. Paris: Actes-Sud-Papiers, 1990, p. 24.
} 
Nas classificações do objeto em Kantor, apontadas por mim: objeto real; objeto cópia; objeto híbrido; objeto máquina, todos aqueles que pertencem a essas classificações estão diretamente relacionados ao processo de construção da realidade na qual o espetáculo se realiza. Já muito se falou sobre a cadeira de Penélope e como através da realidade degradada do objeto, esse é percebido como único em um universo distinto do cotidiano no qual esse objeto jamais serviria para civilização, pelo menos não na condição de objeto real. Isso só é possível através do deslocamento do real no interior da realidade que atribui a esse objeto significado e utilidade no mundo da arte. Dessa forma, é possível afirmar, que para Kantor, a arte nada mais é do que esse deslocamento do real.

Pois bem, outros objetos reais, assim como a cadeira quebrada, como a cadeira vazia, as carteiras, a cama e as portas, todos esses funcionam como fator de desequilíbrio do real, seja pela sua condição de degradação, seja pela sobreposição da memória sobre eles. Por sua vez, os objetos cópias do real, por serem reinterpretações de objetos utilizados na história da vida cotidiana ou em espetáculos anteriores, trarão em si, a memória do seu estado anterior. A banheira utilizada em Não voltarei jamais, se comporta como objeto autônomo, mas ao mesmo tempo está totalmente atrelada à banheira velha de A galinha d'água. As duas banheiras se comportam da mesma maneira que os arcos de Ulisses. A banheira de A galinha d'água, na sua condição de objeto real, na sua relação com a água e o ator, mostra-se como objeto real. Entretanto, em relação à ação, que também é real que acontece no seu interior pois a atriz é impedida de sair de dentro dela, essa banheira deixa de ser um objeto vulgar, cuja utilidade foi desprezada, para se tornar a imanência da ação na realidade do espetáculo. A banheira se torna o protagonista na medida em que conserva a sua estabilidade no processo da anexação pelos atores.

“O objeto não se trata assim de um acessório ou algo que simboliza alguma coisa, mas é acima de tudo, um antagonista". ${ }^{2}$

De uma certa maneira, Kantor destrói os referenciais do observador para em seguida lhe indicar outras possibilidades. Uma dessas possibilidades trata-se exatamente a de deslocar a percepção do observador para uma realidade distinta daquela na qual ele

\footnotetext{
${ }^{7}$ O objeto se torna ator - conversa com Tadeusz Kantor. In. Cadernos de teatro n. 68. Rio de Janeiro: O Tablado, 1976, p. 11.
} 
vive e está acostumado. A banheira com rodas por sua vez, na sua condição de cópia só tem sua relação estabelecida com a anterior através da memória de Kantor que cita o espetáculo passado. Essa citação se dá evidentemente com a Galinha d'água no interior da banheira. Para o espectador, mesmo aquele que não foi iniciado no teatro de Kantor, ao se defrontar com a imagem do objeto no espaço, tenta encontrar parâmetros para a interpretação da cena. No entanto, o jogo entre os elementos impossibilita o estabelecimento de qualquer relação comparativa. Dessa forma, o objeto se estabelece na consciência do observador como um elemento de desafio à sua compreensão em busca de resultados lógicos pois esses, se existem, pertencem obviamente à memória e à imaginação de Kantor. Toda e qualquer tentativa de interpretação isolada torna-se frustrada.

No século XX, sobretudo após os anos 50, a obra de arte não atua mais como um valor absoluto mas como uma estrutura combinatória. Dessa forma, na estrutura de organização dos objetos híbridos em Kantor se observa a ação de duas realidades: a verdadeira condição de objeto enquanto tal e a sua utilização como objeto de arte. Por esse caminho, a cena do teatro kantoriano é invadida por objetos estranhos da mesma maneira que tem invadido o mundo contemporâneo desafiando a razão nos obrigando ao exercício de uma possível nova antropologia que dê conta das suas naturezas. O objeto híbrido trata-se de um vocabulário dentro de outro vocabulário, de uma ação dentro de outra que através da associação de idéias distintas sobressai infinitas possibilidades de interpretações na forma de objetos autônomos. Os objetos máquinas, por sua vez, constituem-se como um dos elementos que mais estão presentes na vida contemporânea. Se a história da humanidade é contada através dos seus objetos, as máquinas, sem dúvida, são as responsáveis pelos momentos mais impressionantes da história da humanidade, desde o "Cavalo de Tróia", concebido por Ulisses, até a chegada à lua pela “Apolo 11" que, em minha opinião, é um dos se não o feito mais notável da raça humana na sua relação com a máquina. O homem é indissociável dos seus objetos, e ao que me parece, a existência da racionalidade humana e sua evolução está condicionada à existência deles. Esse tema foi tratado, no filme 2001 - uma odisséia no espaço ${ }^{8}$, em que fica evidente, através da descoberta de um pedaço de madeira como ferramenta e que se transforma em arma de guerra, evoluindo para naves espaciais, percebe-se a

\footnotetext{
${ }^{8}$ 2001: A Space Odyssey, 1968 - Direção: Stanley Kubrick.
} 
síntese da evolução da razão humana associada à evolução dos objetos e máquinas. Enfim, desde A guerra do fogo 9 até o filme Stanley Kubric, os objetos nos sugerem transcendência quando utilizados fora da vida prática. É por isso que quando um objeto, como um pequeno pedaço de madeira passa a ser utilizado como ferramenta, esse deixa de ser somente madeira para se tornar um objeto que facilita a vida cotidiana estimulando o surgimento da agricultura e outras formas de domínios da razão sobre a natureza. No momento em que esse pedaço de madeira se torna cotidiano, o seu ideal de transcendência deixa de existir por se inserir na vida prática diária. A relação com o transcendente se perde na praticidade do cotidiano. Por outro lado, quando esse mesmo objeto é utilizado como arma, a transcendência ocorre através da distinção daquilo que é cotidiano e vulgar, e que passa, em um momento muito específico, para uma condição na qual se estabelecem relações de poder e submissão, mais uma vez o pedaço de madeira em 2001: uma odisséia no espaço.

As máquinas em Kantor estão necessariamente associadas à idéia de poder, seja o poder concreto das metralhadoras e canhões que se impõem como intermediadoras entre a vida e a morte, seja o poder abstrato, oriundo do desconhecido, das dúvidas e incertezas sobre o próprio destino, como é o caso da trombeta de Jericó - o abstrato é tão ou mais poderoso do que as armas de guerra. Evidentemente, as máquinas de guerra são objetos que muito nos impressionam pois, além da sua forma, algumas vezes estranha e bizarras, a elas está associada a idéia de morte, dor e sofrimento. As máquinas de Kantor se constituem, sempre, como um artifício de alteração da realidade e de criação de outra em um novo contexto. As máquinas em Kantor estão associadas à idéia de poder e o poder, mesmo surgindo da realidade cotidiana, se opõe, a essa mesma realidade se constituindo como realidade própria, autônoma; haja visto a ascensão do nazismo na Alemanha. A manutenção do poder que se institui como algo que está além da realidade cotidiana, que não pode ser encontrado na vida simples e vulgar e que habita outras regiões que não são acessíveis às pessoas comuns. Mesmo a Apolo 11, ao tocar o solo lunar, com transmissão ao vivo para todo o nosso planeta, aquela realidade se revelava como uma realidade alternativa, possível, mas distinta da vida utilitária do dia-a-dia. Viagens espaciais, embora hoje sejam possíveis a curtas distâncias, constituem uma realidade que só é acessível a algumas pessoas. Essa realidade,

\footnotetext{
${ }^{9}$ La Guerre du feu, 1981 - Direção: Jean-Jacques Annaud.
} 
mensurada em macro-escalas, ou seja, escalas astronômicas, instituem-se na realidade do observador como uma realidade alternativa, possuidora de outros valores, não fictícia, mas cujo acesso só é permitido através da tecnologia, da alta tecnologia, manifesta nas naves espaciais. As leis desse outro universo se manifestam como valores independentes e autônomos da realidade do observador, embora esse possa, no processo de organização do seu pensamento, intuir possibilidades de relacionamentos nesse universo a partir da sua própria experiência pessoal. O comportamento dos objetos realizados na realidade terrena tiveram o seu aprofundamento na nova realidade na qual ele foi inserido. Disso podemos estabelecer um paralelismo com o pensamento de Tadeusz Kantor naquilo que se refere à sua definição de teatro:

"Poesia e misticismo (...) Trabalho teatral é criação, um procedimento demiúrgico cujas raízes se aprofundam em outro mundo..."10

O teatro de Kantor nasce do real, nas condições do real, assim como as naves espaciais nascem na Terra e são submetidas, lançadas, introduzidas, na realidade do espaço relativo. Os objetos de Kantor, por serem constructos da consciência sobre o real, ao negarem o espaço real como absoluto, deslocam-se para esse outro espaço no qual a sua arte acontece, e tal qual as determinações astronômicas, novas leis regerão os homens e os objetos. Assim, essa nova realidade, esse novo espaço, constituir-se-á como uma nova arte, uma poética autônoma, como que acontecendo pela primeira vez.

\footnotetext{
${ }^{10}$ Tadeusz Kantor citado por Roberto Tessari no artigo: Il teatro di Kantor: oltre Il simbolismo, sino al símbolo del rango più basso. In. Martinis, Romano. Tadeusz Kantor - Cricot 2. Salerno/Milano: Oedipus Edizioni, 2001 p. 24.
} 


\section{BIBLIOGRAFIA}

1. ABBAGnANO, N. Dicionário de filosofia. São Paulo: Martins Fontes, 2003.

2. ADES, D. O Dadá e o Surrealismo. Rio de Janeiro: Labor, 1976.

3. ADORNO, T. W/HORKHEIMER, M. Dialética do esclarecimento. Rio de Janeiro: Zahar, 2006.

4. ALEXANDRIAN, S. L'art Surréaliste. Paris: Fernand Hazan, 1975.

5. AMARAL, A. M. Teatro de Animação. São Caetano do Sul: Ateliê Editorial, 1997.

6. O Teatro de Formas Animadas. São Paulo: EDUSP - 1993.

7. O Ator e seus Duplos. São Paulo: EDUSP/SENAC, 2002.

8. ARGAN, G.C. Arte moderna. São Paulo: Companhia das Letras, 2004.

9. ARISTÓTELES. Arte Poética. Porto Alegre: Ed. Globo, 1996.

10. ASLAN, O. Le Masque: du rite au théatre; études de Odette aslan, D. Bablet et alii. Paris: CNRS, 1995.

11. BABLET, D. Tadeusz Kantor y el teatro Cricot 2. Madrid: 'El Publico', 1986.

12. Les revolutions scéniques $d u \quad X X e$. Siècle. Paris: Socièté Internationale d'Art, 1975.

13. BACHELARD, G. Poética do Espaço. São Paulo: Martins Fontes, 1993.

14. BARCO, L. Arte e matemática. São Paulo: Cultura, 2001.

15. BAUDRILLARD. Le system des Objets. Paris: Gallimard, 1968.

16. BELASI, P. E LALLI, PINA. Recitare com Gli Oggetti, microteatro e vita quotidiana. Bologna: Capelli, 1986. 
17. BOIE, B. L'homme et ses simulacres. Paris: Corti, 1979.

13. BRETON, A. Manifestos Surrealistas. São Paulo: Brasiliense, 1995.

18. BUSCARINO, B. Kantor Cyrk Smierci. Sturzfluge, Polska. 1997.

19. CARSON, M. Teorias do Teatro. São Paulo: Unesp. 1995.

20. CH, HAMON-SIREJULS. Le construtivisme au théâtre. Paris: CNRS, 1992.

21. COELHO NETTO, J.T. Semiótica, Informação e Comunicação. São Paulo: Perspectiva, 1983.

22. CORVIN, M. Dictionnaire encyclopédique du trèâtre. Bordas: Larousse, 1988

23. CRAIG, E. G. Da arte do Teatro. Trad. de Redondo Jr. Lisboa: Arcádia, 1963.

24. DEPUIS, J. F. História Desenvolta do Surrealismo. Lisboa: Antígona, 1979.

25. ELIADE, M. Imagens e símbolos. São Paulo: Martins Fontes, 1991.

26. FERNANDES, S. Gerald Thomas em cena - Memória e invenção. São Paulo: Perspectiva, 1996.

27. FEYNMAN, R. Física em 12 lições. Rio de Janeiro: Ediouro, 2006.

28. FOUCAULT, M. Microfísica do Poder. Rio de Janeiro: Graal, 1979.

29. GENETTE, G. Discours du récit. Paris: Seuil, 1972.

30. GIANNOTTI, J.A. O jogo de belo e do feio. São Paulo: Companhia das Letras, 2005.

31. GLEISER, M. A dança do universo. São Paulo: Companhia das Letras, 1997.

32. O fim da terra e do céu. São Paulo: Companhia das Letras, 2002.

33. GOMBRICH, E.H. A história da arte. Rio de Janeiro: Guanabara Koogan, 1993.

34. GORDON, M. The grand guignol: Theatre of fear and terror. New york: Da Capo Press, 1997. 
35. GRAY, C. O grande experimento da arte russa 1863 - 1917. São Paulo: Worldwhitewall Editora Ltda, 2004.

36. GROPIUS, W. The teater of the Bauhaus. London: Methuen, 1961.

37. GROTOWSKI, J. - Em Busca de Um Teatro Pobre. Rio de Janeiro: Civilização Brasileira, 1976.

38. HEIDEGGER, M. Ser e tempo. Petrópolis: Vozes, 2006.

39. HUGO V. Do Grotesco e do Sublime. São Paulo: Perspectiva, 2002.

40. INNES, CH. El teatro sagrado. El ritual y la vanguardia. Trad. de J. J. Utrilla. México: F.C.E. 1992.

41. JUNG, C.G. O Homem e seus Símbolos. Rio de Janeiro: Nova Fronteira, 1964.

42. JURKOWSKI, H. Métamorphoses - La marionnette au XX siécle. CharlevilleMézières: Éditions Instiut International de la Marionnette, 2000.

43. KAISER, W. O grotesco. São Paulo: Perspectiva, 2003.

44. KANT, IMMANUEL. Crítica da razão pura. São Paulo: Martin Claret, 2001.

45. KANTOR, T. El teatro de la muerte. Buenos Aires: Ediciones de la Flor, 2004.

46. Entretiens, Arts e Esthétique. France: Carré, 1996.

47. Les voies de la création théâtrale, études de Denis Bablet et Brunella Eruli, réunis et présentés par D. Bablet. Paris: C.N.R.S. Vol. XI, 1983. 48. Leçons de Milan. Paris: ACTES SUD - PAPIERS, 1990.

49. Le Theatre de La Mort - Textes Réunis et Rassemblés par Denis

Bablet. Lausanne: L'Age D’Home - 1977

50. Les voies de la création théâtrale, textes réunis par Denis

Bablet. Paris: C.N.R.S. Vol. 18, 1993.

51. Ma création, mon voyage. Commentaires intimes. Paris:

Editions Plume, 1991. 
52.

$\hat{O}$ douce nuit - Les classes d'Avignon. Paris: Actes Sud

Papiers, 1991.

53. KOBIALKA, M. A journey through other spaces. Essays and manifestos, 19441990 - Tadeusz Kantor. Los Angeles: University of California Press, Ltd. 1993. 54. The Milano Lessons by Tadeusz Kantor. The drama review 35, 1986.

55. LALANDE, A. Vocabulaire Technique et critique de la philosophie. Paris: Press Univ. de France, 1951.

56. MANTOVANI, A. Cenografia. São Paulo: Editora Ática, 1989.

57. MARTINIS, R. Tadeusz Kantor - Cricot 2. Milano: Oedipus edizioni, 2001.

58. MINK, J. Marcel Duchamp - l'art contr l'art. Paris: Taschem, 2004.

59. NUNES, B. O Tempo na Narrativa. São Paulo: Atica, 2003.

60. PANOFSKY, E. O Significado nas artes visuais. São Paulo: Perspectiva, 1979.

61. PAVIS, P. Dicionário de teatro. São Paulo: Perspectiva, 2001.

62. A análise dos espetáculos. São Paulo: Perspectiva, 2003.

63. RICKEY, G. Construtivismo - Origens e evolução. São Paulo: COSAC \& NAIF, 2002.

64. ROSENFELD, A. O teatro Épico. São Paulo: DESA - Coleção Buritis, 1965.

65. O dibuk de Sch, Na-ski. São Paulo: Brasiliense, 1965.

66. ROUBINE, J.J. A Linguagem da Encenação Teatral. Rio de Janeiro: ZAHAR, 1980.

67. SARTRE, J.P. O ser e o nada. Petrópolis: Vozes, 2005.

68. SCARPETTA, G. Kantor au present. Arles: Actes Sud, 2000.

69. SCHULZ, B. Traité des mannequins. Paris: Julliard, Les Lettres Nouvelles 15, 1961. 
70. SEGRE,C. As estruturas e o tempo. São Paulo: Perspectiva, 1986

71. SKIBA-LICKEL, A. L'acteur dans le thèâtre de tadeusz kantor. France: Bouffoneries, n. 26-27. 1991.

72. UBERSFELD, A. Le thèâtre et la cite - de Corneille à Kantor. Bruxelles: AISS-IASPA, 1991.

73. VÁRIOS AUTORES. Kantor, l' artiste à la fin du Xxe. Siècle. Paris: ACTES SUD, 1990.

74. Le grand guignol: le théâtre es peurs de la Belle-époque.

Paris: Bobert Laffont, 1995.

75. Conceitos da arte moderna. Rio de janeiro: Zahar, 2000.

76. WALTHER, IF; METZGER, R. Van Gogh - L'oeuvre complet - pinture. Köln: Taschen, 2006.

77. WITIKIEWICZ, ST. L'art Théâtral dans le système esthétique de Stanislas Ignacy Witkiewicz. Lausanne: Cahier Witkiewicz, n. 1 - L'Age Homme, 1976.

78. ZEILINGER, A. A face oculta da natureza. São Paulo: Editora Globo, 2005.

\section{ARTIGOS:}

BABLET, D. “Tadeusz Kantor et le Théâtre Cricot 2". In J. Jacquot. Les voies de la création théâtrale. Vol. II. Paris: CNRS, 1983.

Théâtre/Public, Festival d' Automne à Paris 1988, n. 84, Gennevilliers, novembre-décembre 1988. 
BELL, J. Theater of the thwentieth century as theater of the performing objects. In Puppetry Yearbook. Ed. By James Fischer. Vol. 1. New York: Mellen Press, 1995.

ERULI, B. “Wielopole-Wielopole”. In J. Jacquot. Les voies de la création théâtrale. Vol. II. Paris: CNRS, 1983.

HALCZAK, A. Ostatnie cricotages Tadeusza Kantora. Kraków: Didaskalia, 2000.

KANTOR, T. Kantor, du théâtre à la peinture et inversemente. in: Puck - Éditions Institut International de la Marionnete, no. 2, 1989. Metamorfozy, Teksty o latach 1938 - 1974. Métamorphoses, textes des années 1938-1974. Ośrodek Dokumentacji Sztuki Tadeusza Kantora CRICOTEKA, Księgarnia akademicka, Kraków 2000.

Wielopole Wielopole - Wydawnictwo Literackie. Kraków/Wroclaw, 1984, p. 134.

KOBIALKA, MICHAL. O trabalho de Kantor. São Paulo: Camarim/Cooperativa Paulista de teatro. Ano 8, n.35.

KRZEMIEN,T. L'objet devient acteur. Varsovie: Le Thèâtre in Pologne, 1978.

LECOQ, J. “Rolê du masque dans la formation de l'acteur. In O. Aslan et alii. Paris: CNRS, 1985.

LEONARDINI, J.P. La morte objet trouvé. Paris: Temps Actuels, 1982.

METZ. C. Remarques pour une Phenoménologie du narrative, Revue d'esthétique. Nouvelle série, 3-4, juil./dec. 1996.

\section{CATÁlOGOS:}


Tadeusz Kantor. Motivos Españoles - Catálogo, Muzeum Narodowe w Krakowie Kraków 1999.

Katalog obrazów i prac na papierze. Muzeum Narodowe Krakowski, P.

Kantorowskie kostiumy - Catalogue de l'exposition Tadeusz Kantor Fantomy realności (Tadeusz Kantor. Les fantômes de la réalité), Cricoteka 1996.

Wirydarz Galeria Sztuki - Tadeusz Kantor (1915 - 1990). Ze "smietnika” Krzystofa Miklaszeskiego.

\section{REVISTAS:}

Cadernos de teatro n. 68, 87, 128. Rio de Janeiro: O Tablado, 1976.

The drama rewiew, no. 30, automne 1996, p. 177-183. New York University and Massachusetts Institute of Technology.

La Marionnette et les autres arts. Interférences. PUCK - Éditions Institut International de la Marionnete, n. 11.

Moin-Moin - Revista de estudos de teatro de formas animadas. Jaraguá do Sul: Sociedade Cultura Artística de Jaraguá do Sul e Universidade de Santa Catarina. Vol. 1 (2005); vol. 2 (2006).

Scenes - Revue de l'espace Kiron. Paris: ALPHA FNAC, no. 2 Avril, 1986

\section{VÍDEOS:}


Onde estão as neves de antanho? De A. Sapija, W.F.O., Lodz: 1984.

Wielopole Wielopole. De A. Sapija, W.F.O., Lodz: 1984.

Le thèâtre de Tadeusz Kantor - de Deis Bablet, C.N.R.S.. 1985.

Que morram os artistas! de N. Lilenstein, prodution La Sept. Paris: 1987.

A classe morta - De Wajda.

Teatro de Tadeusz Kantor. Produção T.V.P. Cracóvia, 1990. Intrevistas de Tadeusz Kantor, documentário sobre seus espetáculos: As Belas e os feios, A classe morta, Onde estão as neves de antanho? , Wielopole Wielopole, Que morram os artistas!. 


\section{$\underline{\text { ANEXOS - ÍNDICE }}$}

CONSIDERAÇÕES AOS ANEXOS 305

AS PEQUENAS ENCENAÇÕES - COMENTÁRIOS ACERCA DE ALGUMAS CRICOTAGES 308

UM CASAMENTO ENCENADO À MANEIRA CONSTRUTIVISTA E SURREALISTA 308

A MÁQUINA DO AMOR E DA MORTE 315

UMA LIÇÃO MUITO CURTA 319

Ô DOCE NOITE 322

LIÇÕES DE MILÃO 327

NÃO VOLTAREI JAMAIS 410

APRESENTAÇÃO 411

TRADUÇÃO 414

HOJE É MEU ANIVERSÁRIO 483

APRESENTAÇÃO 484

TRADUÇÃO 487

MANIFESTO DO TEATRO DA MORTE 563

CRONOLOGIA 576 
Wagner Francisco Araujo Cintra

\section{NO LIMIAR DO DESCONHECIDO \\ - Reflexões sobre o objeto no teatro de Tadeusz Kantor -}

Volume II

- Anexos -

Tese apresentada à Escola de Comunicações e Artes da Universidade de São Paulo, como exigência parcial do Curso de Pós-Graduação, para obtenção do título de Doutor em Artes.

Orientador: Profa. Dra. Ana Maria de Abreu Amaral

Departamento de Artes Cênicas

Escola de Comunicações e Artes

Universidade de São Paulo

SÃO PAULO

2008 


\section{CONSIDERACÕES AOS ANEXOS}

Basicamente, o material apresentado neste anexo é composto por traduções de obras de Tadeusz Kantor. A opção por um texto teórico e pelas suas duas últimas peças, deu-se em função da minha visão pessoal de que Lições de Milão se constitui como a obra teórica mais organizada feita pelo artista polonês que, praticamente, sintetiza o seu pensamento artístico nos seus diversos períodos. Principalmente esclarecimentos muito significativos acerca das principais vanguardas que influenciaram o seu trabalho, assim como estruturas recorrentes à sua obra como espaço e objeto.

Kantor não produziu nenhuma obra teórica. A sua poética resume-se a pequenos ensaios e manifestos. Esses escritos elaborados por ele foram reunidos em algumas publicações que se tornaram notórias fora da Polônia, tratando-se da primeira e obra mais expressiva $O$ teatro da morte ${ }^{1}$, organizada por Denis Bablet, que se tornou um dos seus principais estudiosos. Mesmo as Lições de Milão, cujo conteúdo foi elaborado para uma finalidade didática, ou seja, um seminário que ele proferiu em Milão, na Escola Municipal de Arte Dramática, no ano de 1986, somente alguns anos mais tarde é que foi publicado em francês e italiano.

Já a tradução das peças: Não voltarei jamais e Hoje é meu aniversário, deu-se pelo fato de que esses dois trabalhos, a meu ver, são sínteses de toda a sua produção teatral, um retorno às obras do passado. Os textos não são trabalhos de dramaturgia que mereçam, em minha opinião, um estudo literário aprofundado. Tratam-se, esses textos, de descrições de acontecimentos e da organização de elementos cênicos diversos. $\mathrm{O}$ texto falado, quando existente, é o produto final dos jogos que se desenvolveram

\footnotetext{
${ }^{1}$ Kantor, Tadeusz. Le Theatre de La Mort - Textes Réunis et Rassemblés par Denis Bablet. Lausanne: L'Age D'Home - 1977.
} 
durante o processo de criação dos espetáculos e que estavam sujeitos a constantes transformações. A publicação feita pelo C.N.R.S ${ }^{2}$ em 1993, para o volume 18 de Les voies de la création théâtrale, trata-se de uma das versões escritas dos espetáculos que foram traduzidas para o francês com muita fidedignidade por Marie-Thérèse VidoRzewuska, o que facilitou muito o meu trabalho, pois não exigiu de mim muitos conhecimentos da língua polonesa. Assim, a tradução, que agora apresento, tem por finalidade única a ilustração de determinados pontos do meu trabalho acadêmico, para que possam auxiliar o leitor na articulação de um pensamento mais amplo que envolva o teatro de Tadeusz Kantor em suas dimensões mais diversas.

Além das referidas traduções, também acrescento neste anexo, a tradução que fiz do Manifesto do Teatro da morte e que faz já estava presente na minha dissertação de mestrado. O motivo de acrescentá-lo novamente se deve ao fato de que, por várias vezes neste trabalho, eu me refiro a ele e à sua importância para a fase do Teatro da morte. Acrescento também uma cronologia para que o leitor possa acompanhar o desenvolvimento da história artística de Kantor, desde as primeiras manifestações na Escola de Belas Artes da Cracóvia (1934-1938), até as últimas apresentações de Hoje é meu aniversário em 1992. Apresentações que aconteceram sem a sua presença física em cena, já que, lembrando, Kantor morreu na madrugada do dia 8 de dezembro de 1990, na véspera da estréia do espetáculo.

Acrescento ainda, como ilustração, alguns comentários acerca de algumas de suas cricotages: Um casamento à maneira construtivista e surrealista; A máquina do amor e da morte; Uma lição muito curta; $\hat{O}$ doce noite. Esses comentários que tiveram como base um artigo escrito por Anna Halsack ${ }^{3}$ e que me foi apresentado, na cricoteka, durante minha estada na Cracóvia em 2006, uma versão, não publicada, do artigo em francês, tem por finalidade tornar mais visível alguns dos procedimentos de Kantor na realização dos seus espetáculos.

Durante esses comentários, tento demonstrar a forma como Kantor se relacionava com a criação, com os atores, com os objetos, com a dramaturgia e toda

\footnotetext{
${ }^{2}$ Centre National de la Recherche Scientifique.

${ }^{3}$ Halczak, A. Ostatnie cricotages Tadeusza Kantora. Kraków: Didaskalia, 2000.
} 
espécie de material utilizado na cena, além do que, muitas dessas, que eram chamadas de pequenas peças, serviram como suporte poético para espetáculos como Não voltarei jamais e Hoje é meu aniversário. 


\section{AS PEQUENAS ENCENACÕES}

\section{COMENTÁRIOS ACERCA DE ALGUMAS CRICOTAGES}

\section{UM CASAMENTO ENCENADO À MANEIRA CONSTRUTIVISTA E SURREALISTA}

Em 1986, durante quatro semanas, Tadeusz Kantor dirigiu um seminário na "escola primária de arte dramática", nome que ele mesmo deu ao seu trabalho realizado na Escola Municipal de Arte Dramática, em Milão, Itália. O curso começou com a apresentação de um plano de trabalho, ou ainda, do programa dessa estranha escola na qual o artista representava o papel de professor. O elenco era composto por doze alunos do terceiro ano. Essa foi a primeira vez que Kantor trabalhou com atores que não pertenciam ao Teatro Cricot 2.

Kantor falou aos alunos acerca de determinados fenômenos artísticos usando a sua própria experiência artística como exemplo. Esse trabalho não se tratou exatamente de um curso teórico sobre uma determinada linguagem, mas de um pensamento que foi depositado sobre uma prática. Ou seja, a própria prática dos alunos. A teoria foi rapidamente transposta para a cena. Lá os estudantes que preparavam pequenas apresentações descobriam os princípios essenciais da abstração.

Conforme Kantor, o Construtivismo foi a origem do teatro contemporâneo. Assim, em cena, se instala uma construção, uma “máquina de representar”. Após alguns 
dias, o diálogo entre o "professor" e os alunos torna-se mais vivo, intenso. Os atores elaboram uma espécie de desenho do espetáculo e, como tema, eles escolheram o casamento. Os figurinos tratavam-se daqueles que estavam disponíveis na escola. Kantor observa os trabalhos dos alunos com interesse mas, no fim, ele conclui que os alunos não dominavam os princípios essenciais do Construtivismo. Dessa forma, ele propôs repensar o trabalho adotando uma outra hipótese:

“...nós estamos em 1917, no tempo da revolução e, tudo isso que o teatro pode adquirir no passado desapareceu e foi destruído"4.

Diversas observações foram feitas por Kantor respeitando os princípios do Construtivismo e como resultado dessa discussão, desenvolvida com os alunos, deveriase chegar a um espetáculo construtivista.

As primeiras observações e correções de Kantor foram sobre o espaço do espetáculo. O casamento deveria se passar em uma catedral e em cena haveria uma “construção-máquina para representar”. Inicialmente, os atores não perceberam que a máquina para representar estava em cena e eles não se serviam dela. Eles se comportavam de uma maneira naturalista e apresentavam a cerimônia do casamento do ponto de vista religioso e familiar. A ação não tinha nada a ver com a construção e o jogo dos atores não correspondia ao espaço por não estar adaptado ao cenário.

Os personagens do espetáculo deveriam ser espécies de locatários dessa construção que determinaria seus comportamentos e as suas ações. Os membros da família que participavam da cerimônia deveriam representar os papéis dos personagens que criaram em cena essa estrutura: pedreiros, carpinteiros, encanadores e seus serventes. Eles deveriam se apropriar dos gestos e das atitudes desses trabalhadores que ergueram, nesse local, tal construção, para em seguida incluí-los no ritual. A realidade

\footnotetext{
${ }^{4}$ Tadeusz Kantor citado por Anna Halczak em Ostatnie cricotages Tadeusza Kantora. Kraków: Didaskalia, 2000.
} 
do ritual do casamento deveria ser destruída pelas ações ligadas ao ato de construir. O padre, o organizador desse "canteiro de obras" deveria falar como um mestre de obras. Oposto a essa construção haveria o conteúdo, o material do drama a ser encenado intitulado $O$ casamento.

Os protagonistas, deixando de lado a intriga naturalista, deveriam se servir da construção como apoio para a criação. E assim, partindo de cada detalhe da intriga inventada pelos alunos, dias após dia, se tentava incorporar essa história nos moldes do Construtivismo. Kantor ensinava não somente o jogo do ator, mas também os princípios da arte dramática tal qual eles haviam sido concebidos pelos construtivistas. Com precisão, e permanecendo fiel ao olhar dos seus próprios mestres, Kantor apontava as correções no espetáculo naturalista inventado por seus jovens aprendizes.

No espetáculo os atores entravam pela porta situada no fundo da cena que dava para o jardim. Eles se encontravam na sala assim como os espectadores e permaneciam em cena como as pessoas responsáveis pelo acontecimento e pela máquina-construção. Os figurinos e acessórios encontrados nos armários da escola não correspondiam em quase nada à época na qual se desenrolaria a ação do espetáculo. A roupa deveria ser a mais simples possível: figurinos negros, coletes, uniformes dotados de algum acento característico, como o chapéu dos bispos ou o quepe dos soldados etc. Os atores podiam se preparar para o espetáculo em cena se vestindo e se maquiando. Durante todo o tempo Kantor falava em eliminar a ilusão, mas não se podia levar isso ao infinito pois senão não existiria o espetáculo.

Evidentemente, a ilusão podia reaparecer a qualquer momento e todos os personagens dessa máquina se empenhavam em destruí-la. É exatamente essa destruição que se constituirá no jogo mais importante. Mais importante do que a própria representação da intriga. O casamento proposto pelos estudantes deveria se desenvolver em uma catedral. Os atores, nesse caso, os funcionários que se ocupam da cultura, construíam essa catedral em cena. Um Bispo celebrará a cerimônia do casamento e 
também será o mestre do canteiro de obras. Uma cruz ${ }^{5}$ é aquilo que ele deverá construir. E assim, a justificativa de Kantor em relação à sua intervenção, pela sua necessidade de se referir aos meios utilizados pelo Construtivismo que, pouco a pouco, ele transformava a cerimônia do casamento em pretexto que lhe permitia em seguida introduzir na cena os elementos que contribuíram, segundo ele, para a criação do teatro contemporâneo.

Em seguida, é com o jogo do ator que Kantor se preocupa. Observando os atores em cena, ele desenha e explica a necessidade de dar vida, através de cada movimento, a todos os elementos que estão presentes na cena, como por exemplo, a rampa. O movimento sobre a rampa (as escadas da catedral) deveria ser ritmado, cadenciado, contrastado e os atores deveriam adaptar constantemente seu comportamento e sua atitude em função dos outros atores e do local no qual eles se encontravam. $\mathrm{O}$ ator deveria insistentemente adaptar o seu jogo à forma do objeto, nesse caso, a construção. $\mathrm{O}$ ator deveria de alguma maneira dar vida a essa máquina, a esse espaço.

O ator, para Kantor, deve sempre se colocar de encontro aos outros personagens; suas pernas devem estar flexionadas porque assim ele pode mais facilmente e mais rapidamente mudar de postura. Sua aparência, segundo ele, deve sempre estar voltada para o espectador. Seu passo, alongado, deve ser duas vezes mais longo que na vida cotidiana. Cada gesto, cada ação deve conduzir a uma meta precisa. Para poder determinar o que quer que seja, é importante que o movimento seja o mais simples possível. Após cada sequiência, os atores devem se imobilizar por um instante como se eles não soubessem o que fazer em seguida.

\footnotetext{
${ }^{5}$ Nesses pequenos espetáculos, Kantor se servia de objetos que eram freqüentemente utilizados pelo Teatro Cricot 2: móveis como mesas, como camas, cadeiras, dentre outros. Por exemplo, a cruz de madeira usada em Wielopole Wielopole, também se encontra em $O$ casamento e $\hat{O}$ doce noite. Evidentemente eles eram insistentemente trabalhados pelo artista ao longo da preparação do espetáculo o que levava à adequações conforme as necessidades de cada espetáculo. A cruz em Wielopole Wielopole quando fincada em um monte de terra caracterizava a tumba do soldado que parte para a guerra. Em $O$ casamento, essa cruz era um objeto imponentemente sólido.
} 
Para melhor destruir a ilusão, o espetáculo começa com uma repetição do casamento. Desde então, o casamento deverá ser celebrado em uma catedral. Por isso a necessidade de que essa fosse construída diante do espectador. O Bispo e o Padre, entre o público; ao fundo, o barulho de batidas de martelo que são amplificadas por um altofalante, montam uma cruz e, em seguida, a levam para a cena. Os momentos trágicos, cômicos, as emoções nascem no instante da surpresa devido a essa situação que não é anunciada pelas situações que a precedem. Assim, a construção da cruz é reduzida apenas ao ato de construir, uma ação cotidiana e neutra. Mas graças a isso, uma cruz e uma catedral são criadas. Quando os espectadores se dão conta, a emoção se apossa deles.

A impressão é amplificada por uma música sublime, elemento importante na estrutura do espetáculo. A cerimônia do casamento, onde a estola do padre foi substituída por uma corda que une o jovem casal com tal força que eles quase são estrangulados, será freqüentemente interrompida por comunicados vindo do alto-falante que afirmava o Construtivismo ter nascido com a revolução e, com esse acontecimento, a destruição de toda transposição duradoura da ilusão. Essa informação localiza o espectador na época na qual a cena se desenvolve.

O ritmo não é perceptível. A idéia de murar o jovem casal, construindo uma tumba ao redor deles, foi uma cena inventada pelos alunos para substituir a cena da noite de núpcias. Mas no lugar desse fim catastrófico (o casamento terminaria com a morte dos noivos) foi adotada a convenção do circo. Dessa forma foram elaboradas com precisão todas as etapas e o ritmo da construção da parede: no início com muito mais energia, pois o trabalho foi efetuado com uma cadência moderada e no final todos foram tomados pela fadiga. $\mathrm{O}$ efeito cômico era um recurso muito utilizado pelos construtivistas para reforçar um aspecto trágico ou catastrófico em cena.

Graças à imaginação dos estudantes que, por vezes, era difícil de dominar e que, ao final, foi aceita por Kantor, apareceram muitos elementos cômicos em cena. Os movimentos, os gestos, os figurinos eram mais importantes do que a palavra. Os assuntos tratados pelos protagonistas foram elaborados somente no final dos ensaios. 
$\mathrm{Na}$ segunda parte do espetáculo, os atores mudaram de roupa, a nova maquiagem envelheceu suas aparências transformando-os em velhos. Tudo isso foi feito seguindo as concepções do Construtivismo. Mas dessa vez, toda ação se passa sob uma $\mathrm{luz}^{6}$ tênue. $\mathrm{O}$ teatro deve, dessa maneira, tornar o mistério evidente. $\mathrm{O}$ espectador deve descobrir os mistérios que envolvem as famílias.

Esse é um mundo criado pela imaginação. A época mudou. $\mathrm{O}$ tempo agora é o do Surrealismo, uma nova época importante na arte do século XX. Os destinos das famílias após o casamento serão revelados, suas histórias serão contadas alguns anos mais tarde. Os membros da família estão mais velhos, saem, um após o outro de uma tumba. Tudo desaparece, permanecendo apenas a cruz e a silueta curvada do Cronista. Sua memória funciona melhor do que aquelas dos outros personagens: ele consulta a sua obra na qual, no passado, escrevia tudo. Mas aquilo que permanece na cena são apenas fragmentos de lembranças dos fatos, dos quais ele não se lembra quase nada porque o tempo já fez sua devastação no passado. É nesse momento que Kantor faz aparecer todos os elementos do inconsciente, do sonho, da alucinação.

Foi também elaborada, na segunda parte do espetáculo, a idéia de segunda realidade que, após a morte, o tempo é uma total solidão levando ao esquecimento: os membros da família não se reconhecem mais, a mãe passa ao lado de seu filho e não o reconhece. Mas como eles passaram uma boa parte da sua vida juntos, os fatos que eles rememoram os unem por um curto instante. O Cronista os ajuda a colocar ordem sobre os fatos, mas a verdade não interessa a ninguém.

No cemitério, onde eles passeiam, eles falam frases desconexas. Eles esqueceram, não somente os fatos de suas vidas, mas também a estrutura das frases, de maneira que os assuntos parecem mais balbucios repetidos com obstinação. Os diálogos

\footnotetext{
${ }^{6}$ A luz, no Teatro Cricot 2, tinha uma função muito específica que era unicamente a de iluminar de uma maneira uniforme a cena. Entretanto, nas cricotages, em certas cenas, graças à música, Kantor, em alguns momentos, construía um ambiente bem determinado pela luz. Por exemplo: em A máquina do amor e da morte, durante as apresentações, a cena era iluminada por raios imóveis de luz. Na segunda parte de Uma lição muito curta, a frente da cena era mergulhada na penumbra para que o mundo cheio de luz fosse melhor visto através da janela.
} 
são automáticos e a única coisa de que eles ainda se lembram são as antigas disputas: os gestos característicos para a querela, uma entonação muito marcada, a repetição das mesmas palavras. O Cronista tenta transpor o sonho, o comportamento da família e os fragmentos da memória em linguagem acessível para o público e ele ajuda os espectadores a articularem os enunciados incoerentes enquanto se refere ao seu livro. É dessa maneira que o espectador descobre porque o jovem noivo, na cerimônia do casamento, se apoiava sobre muletas. Ele foi ferido durante a guerra. Mas agora ele não se lembra de nada: seja ele o soldado, seja toda uma unidade de soldados.

A irmã da noiva não pára de jogar com o círculo de metal. Ela volta a uma fase da infância. Não se sabe se o Bispo é realmente um Bispo ou um louco que caminha pelas ruas com um chapéu vermelho na cabeça. A mãe do noivo chora não somente por causa da cadeira sobre a qual ela tenta em vão se sentar, porque a sua construção é imperfeita, mas ela chora também pensando em seu filho morto na guerra. Na outra vida ela era uma lavadeira. Hoje a única atividade que ela se lembra é aquela de lavar: com um balde que está em cena, ela a tudo lava.

No desenvolvimento, um cadáver aparece reproduzindo a seqüência da cena da batalha na qual o noivo encontrou a morte na guerra. Os funerais acabam e o corpo do herói é colocado na tumba; o pretexto para a festa foi enfim encontrado. A tumba passa a ser utilizada como mesa e os atores, no lugar de cantar um canto fúnebre, cantam uma canção militar. Os membros das famílias, vendo-se na impossibilidade de se comunicarem entre si, jogam uns nos outros o prato principal do banquete: espaguete.

Essa bagunça é interrompida por um breve instante pela aparição dos noivos e pelo silêncio que se instala por um curto momento. A noiva, nua, olha a cena e observa os personagens. Ela renuncia à idéia de voltar para esse mundo e leva com ela o seu esposo de volta para a tumba. Os outros personagens, pouco a pouco, desfalecem de 
fadiga. Somente o soldado continua em cena marchando ao ritmo de uma música ${ }^{7}$ cadenciada.

Apesar da primeira parte da apresentação terminar com as palavras do Cronista: e eles, por muito tempo, viveram felizes, na segunda parte ele revela que a construção habilmente agenciada da totalidade do espetáculo, abre novas possibilidades à nossa imaginação. Os destinos das famílias dos noivos não se realizam como era de se esperar. A atividade da "escola primária de arte dramática" de Tadeusz Kantor termina com uma representação pública do espetáculo Um casamento à maneira construtivista $e$ surrealista, cujos procedimentos teóricos foram chamados de Lições de Milão.

\section{A MÁQUINA DO AMOR E DA MORTE}

Um ano mais tarde, Kantor não deixou de pensar na separação dolorosa com o Construtivismo e as diferentes tendências nas artes que desempenharam um papel importante no seu desenvolvimento artístico: o Surrealismo, o Dadaísmo, a Bauhaus. Em Milão, dirigindo-se aos alunos da sua turma, ele disse que tudo aquilo que foi dito por ele nada mais era do que a transmissão do seu conhecimento e do seu saber pois ele queria, concomitantemente, colocar ordem no seu olhar acerca dessas correntes artísticas. Ele queria as analisar uma vez mais, as resumir e fazer disso um ponto de reflexão. Por outro lado ele também desejava se beneficiar disso para fazer um balanço da sua vida individual e pessoal. Em seus pensamentos germinaria então, uma nova idéia que estaria doravante presente em seu teatro e em sua pintura. Essa idéia levou à encenação de um novo espetáculo chamado A máquina do amor e da morte, encenado em 1987, que tem a duração de pouco mais de meia hora e é de fundamental

\footnotetext{
${ }^{7}$ A música no teatro de Kantor tem um papel estruturante para o espetáculo no sentido de amplificar as emoções. Durante os preparativos dos espetáculos, se procurava por um tema musical concreto que correspondia ao ambiente e ao clima definido por Kantor. Permanecendo fiel à sua idéia de realidade, ele optava, sempre, pela "música pronta".
} 
importância na última etapa de criação de Kantor. Esse trabalho se constituirá no desenvolvimento dos estudos iniciados em Lições de Milão, e ao mesmo tempo, uma espécie de reencontro de Kantor com a criação de outros artistas.

A máquina do amor e da morte é uma homenagem prestada à arte do século XX, e ao mesmo tempo é uma confissão muito pessoal de aspectos da sua vida. Nessa cricotage, Kantor nos convida a penetrar no universo misterioso e inquietante do drama de Maeterlinck: A morte de Tingatiles. Ele retoma dessa maneira o material que ele havia trabalhado antes da guerra no seu teatro de marionetes no ano de 1937. Ou seja, ele retorna aos princípios de sua fascinação pelo Construtivismo, pela Abstração, pela Bauhaus. Em cena, Kantor constrói um círculo de madeira que terá sobre ele, à meiaaltura, uma porta de metal. Uma voz cheia de afeição que se ouve de um alto-falante, conta a história do pequeno príncipe Tingatiles.

Essa história comentada pelos manipuladores das marionetes (atores em roupas negras que manipulam as marionetes de madeira que estão instaladas na cena sobre cadeiras móveis) que enquanto fazem comentários à propósito do drama, destroem a seriedade da história lhe conferindo novas significações. Todavia, o autor não lhe permite esquecer o lado patético do drama que se desenvolve sobre o palco.

Uma música ritmada e ameaçadora, a abertura da porta e os movimentos das "super-marionetes" construtivistas dos três manipuladores, interrompem o texto do drama amplificando o sentimento de inquietude. Esse aspecto de ameaça e de inquietude é amplificado pelo Tipo Suspeito que durante toda a duração do espetáculo observa os acontecimentos que se desenvolvem em cena. $\mathrm{Na}$ sua terceira aparição, o Tipo Suspeito joga para os manipuladores longos bastões de madeira com os quais, a partir desse momento, eles colocarão em movimento as marionetes. Essa cena é quase uma citação da Bauhaus. Neanmoins, a cruel rainha volta vitoriosa. Sua chegada conduz a morte das irmãs de Tingatiles e do velho e fiel cavaleiro Alobade. A rainha aprisiona Tingatiles em uma mala de pano. Ele percebe então que a Rainha é a personagem que veste o mesmo figurino usado no espetáculo encenado pelo Cricot 2: A galinha d'água. 
No final do drama de Maeterlinck, o espetáculo se encontra em uma outra época. Os manipuladores das marionetes das irmãs de Tingatiles param diante da porta de metal. Eles a abrem e descobrem o pequeno Berger. É assim que termina o tempo da Santa Abstração, maneira como Kantor se refere ao Abstracionismo e à Bauhaus, e começa a segunda parte do espetáculo: meio século mais tarde, no ano de 1987.

Uma música sentimental faz surgir dois coveiros vestidos de negro. Eles trazem um pequeno cavalo feito de pano. Esses personagens, saídos das telas nostálgicas de Wojtkiewicz ${ }^{8}$, farão Tingatiles-Berger montar nesse cavalo e andarão pela cena. Do lado oposto, chega a escolta fúnebre composta de três bruxas megeras que puxam o carro junto com a jovem noiva, cantando um canto funerário italiano. Tingatiles-Berger e sua esposa são representados por crianças. Os dois cortejos que caminham em direções opostas se encontram várias vezes no centro da cena. Em alguns momentos, o casal se olha com ternura. A caminhada do cortejo é interrompida por um comunicado vindo de um alto-falante que ordena que todos deixem a cena. Os coveiros trazem um grande pacote negro que é colocado no palco. Os manipuladores da máquina do amor e da morte acendem grandes velas que são colocadas ao lado dos pacotes. Tadeusz Kantor, que esteve em cena desde o início, dirigia quase que imperceptivelmente o ritmo, nesse momento importante ele estava no meio da cena, mas ele não está só. Existe ainda a presença de um Sujeito de Olhar Suspeito, que é um personagem que está presente nas duas partes do espetáculo que em certos momentos se coloca no meio da cena junto com Kantor. Estar em cena é aparentemente a sua única função.

A máquina do amor e da morte movimentada pelos maquinistas mostra em seu círculo dois personagens que se encontram nos dois pontos situados nas extremidades do seu eixo. A aparição do manequim do Belo Homem Jovem, é acompanhada por uma música muito forte, considerando que a aparição do segundo personagem é amplificada pelo ritmo monótono de uma melodia lírica. O Autor, pouco a pouco, desvenda diante de nós o mistério que oculta a embalagem negra: uma jovem mulher nua - o manequim

\footnotetext{
${ }^{8}$ Witold Wojtkiewicz (1879 - 1909), pintor polonês geralmente associado ao expressionismo. Inicia seus estudos na Escola de Desenho de Varsóvia e, em seguida, ingressa na Academia de Belas Artes da Cracóvia. Fascinado pelo desenho de marionetes, ele cria um universo pleno de símbolos onde se pode observar uma espécie de simbolismo que conjuga o mundo infantil com a angústia da existência humana.
} 
desconhecido - personagem totalmente indiferente ao funcionamento da máquina do amor e da morte. $\mathrm{O}$ artista recupera então o fundo da cena deixando os espectadores tocados pela descoberta.

Essa cricotage foi criada durante duas semanas de ensaios em Kassel. Antes, na Cricoteka, na Cracóvia, foram construídos as super-marionetes dos servidores, a porta de metal e o círculo de madeira da máquina. Kantor trabalhou com os atores italianos que já haviam participado de dois outros espetáculos do Teatro Cricot 2. O papel do Sujeito de olhar suspeito foi confiado a um dos atores do Cricot 2, Stanislaw Richlicki. O papel de uma das Bruxas-megeras foi representado por uma aluna da Escola de Milão. As crianças só apareceram nos últimos ensaios. O espetáculo foi preparado para a abertura do festival de Kasel na Alemanha.

Os preparativos foram muito intensos, todos os elementos do espetáculo foram criados ao mesmo tempo: o texto, os figurinos, a música, e toda a construção cenográfica. A concepção do espetáculo também se transformava à medida em que a produção evoluía. Foram duas semanas de trabalho ferozmente efetuadas pelos atores, pelos técnicos, e pelo próprio Tadeusz Kantor. O maior problema técnico acontecia com as cadeiras que deveriam se mover todas juntas na última sequiência da primeira parte do espetáculo. A realização das diferentes instalações e mecanismos levava dias inteiros, o que deixava Kantor cada vez mais impaciente. Assim, um dia antes da estréia do espetáculo, os trabalhos terminaram, e não criaram o efeito que ele desejava.

As mais importantes modificações foram feitas no personagem do Manequimdesconhecido. Durante os ensaios em Milão teve que ser o personagem do Soldado do espetáculo Wielopole Wielopole representado por uma mulher que, nesse momento, carregava uma cruz até o meio do círculo da máquina. Assim, na estréia em Kassel, o Manequim-desconhecido aparecia em cena vestido de negro saído do público. Tadeusz Kantor se sentava em sua cadeira no meio do círculo e, fumando um cigarro, observava com indiferença o funcionamento da máquina do amor e da morte. Após o retorno para 
Milão, por ocasião da apresentação do espetáculo e, após outras tentativas, ele decide, enfim, colocá-la em uma embalagem.

A máquina do amor e da morte marca o início do "Teatro do Amor e da Morte", que está totalmente articulado com a última etapa da criação artística de Kantor, o Teatro da Memória. Essa cricotage foi concebida durante os ensaios do espetáculo Não voltarei jamais, cuja primeira representação aconteceu um ano mais tarde. $\mathrm{O}$ personagem do Manequim-desconhecido foi transformado naquele da Jovem Noiva que esposa o manequim de Tadeusz Kantor e uma embalagem negra recobre todos os personagens e objetos do Teatro Cricot 2.

\section{UMA LIÇÃO MUITO CURTA}

Em 1988, no Institut International de la Marionnette em Charleville-Mézières, Kantor realiza uma outra cricotage: Uma lição muito curta. Nessa encenação ele utiliza alguns jovens atores que já tiveram as suas primeiras experiências artísticas. Os primeiros encontros aconteceram em uma sala de conferência que rapidamente o cansou. Após alguns dias foi decidido levar o curso para a sala de teatro do instituto. Kantor havia ido à França com a idéia de realizar um espetáculo consagrado a casa. Ele trouxe o desenho de uma de suas telas intitulado A casa representando uma chaminé, o solitário elemento dessa casa que sobreviveu após a catástrofe. Entrevistas e discussões destinadas a casa precederam os trabalhos de cena.

Velhas roupas compradas no mercado se tornaram os figurinos dos personagens do espetáculo. No início ele encontra os moradores dessa casa, isso quer dizer: os atores. Esses encontros aconteceram em um Café vizinho. Após litros de café e da espessa fumaça dos cigarros, pouco a pouco começava a se desenhar a idéia do 
espetáculo. A apresentação feita pelos atores era interessante a tal ponto que ele a utilizou no início do espetáculo. O "Autor da peça", um personagem cênico, tem a intenção de apresentar a sua obra, "a morte do poeta", em um quarto. Assim, aparecem os personagens que ele havia inventado. Eles vivem a sua própria vida e falam seus próprios textos. Eles não se submetem às regras do drama criado pelo autor que não está certo de onde quer chegar e se justifica insistentemente diante do público. Os atores colocam em cena as suas obsessões, seus objetos. As proposições dos atores, submetidas à opinião do artista que faz uma síntese e que as abrevia para não as reduzir a um só instante, constituem a primeira parte do espetáculo representado ao ritmo de um tango.

Uma certa inquietude se instaura porque, "Ela", chega e toma conta da cena. As outras intervenções que essa personagem faz e, a mudança do tango para uma melodia comovente cria um ambiente repleto de tristeza e de nostalgia que anuncia a segunda parte do espetáculo. O Autor explica pacientemente que ela representa perfeitamente o seu papel, mas que está enganada porque ela não deveria interferir a não ser na segunda parte do espetáculo. Em seguida, o Poeta que durante todo o tempo estava sentado à mesa, volta-se ao público, está enfim convencido de apresentar o texto. Ele também desaponta o Autor. Ele declama o poema de Arthur Rimbaud Le dormeur du Val no lugar de recitar o texto previsto. O Autor tenta a todo preço organizar a situação e o caos que invadiram a cena. Torna-se impossível a continuação do espetáculo, mas ele tenta assim mesmo. Um dos jovens atores representa esse personagem com a predisposição para improvisar papéis cômicos, elementos que não foram modificados por Kantor.

A cenografia foi elaborada ao longo do desenvolvimento dos ensaios. Os cenotécnicos construíram os muros do quarto, a janela e, na cena, foram colocadas cadeiras, mesas e uma cama. Os atores escutavam diferentes formas musicais e registravam o barulho de diferentes elementos sonoros, como o som da chuva, por exemplo. Todos esses elementos eram, nos momentos apropriados, utilizados conforme as necessidades do espetáculo.

\footnotetext{
${ }^{9}$ A Jovem Noiva.
} 
Os comportamentos, assim como os textos dos atores, eram minuciosamente observados e refletidos por Kantor que em seguida os adaptava propondo uma forma definitiva dos personagens. A idéia da casa, dos comportamentos primários dos homens, mudava constantemente. O Autor, as peripécias de sua obra de arte, o personagem do "Poeta" local Arthur Rimbaud, aos poucos vai ganhando importância na cena. Também existe nessa cricotage, um casamento, a Jovem Noiva, que carrega um véu branco e que deverá esposar alguém no desenvolvimento do trabalho. Um casamento para sempre, até ao fim, como se tornou um hábito no Teatro Cricot 2 e, como pode ser observado em: Onde estão as neves de Antanho; Wielopole Wielopole; Não voltarei jamais, a temática vai sempre e necessariamente ao encontro da morte. Nesse trabalho, a noiva, acentuando esse aspecto, coloca uma corda ao redor do pescoço. A cerimônia do casamento é completada por formas grotescas de eventos funerários.

Ao ritmo de um tango, o cortejo composto pelos locatários do quarto aparece em cena dançando com um caixão ${ }^{10}$. Após se movimentar várias vezes ao redor da mesa, sobre a qual foi celebrado um lamentável casamento, os personagens levam a corda para o Jovem Noivo, eles o despem e deixam suas roupas com a sua esposa e o conduzem até o caixão. A Jovem Noiva continua, durante um certo tempo, a sua dança para se unir em seguida aos outros personagens. A maioria dos atores não continua o jogo e se recoloca em cena. Tudo isso é feito de maneira dócil. Eles encontram o muro do quarto e revelam aquilo que se esconde atrás. O quarto se transforma em sala de teatro. Os atores tornamse espectadores. A luz muda, a Noiva também. Agora, a luz é tênue mas não encobre aquilo que está se passando atrás da janela-cena, ou seja, uma dança sonambúlica da Jovem Noiva com as roupas do Poeta que se eleva lentamente do caixão.

Os espectadores-atores fazem comentários sobre o espetáculo e sobre a música que o acompanha; eles falam dessa dança de amor e de morte que se passa do outro lado da vida. O Autor não reconhece mais a sua peça de teatro sobre a qual ele não tem mais domínio.

\footnotetext{
${ }^{10}$ O caixão utilizado em Uma lição muito curta, que aparecerá em Não voltarei jamais e $\hat{O}$ doce noite, já estava presente em $O$ polvo, primeiro espetáculo realizado pelo Teatro Cricot 2 em 1956.
} 
O casamento torna-se um enterro e a Jovem Noiva oferece a morte no lugar do amor. O Poeta, que desde o início devia morrer na mesa sobre a qual havia uma corda suspensa, levanta-se totalmente do caixão. Os personagens do drama, ao invés de desenvolver a intriga, provocam incessantemente um caos cada vez maior. Na cena, a vida é reduzida a alguns instantes e a um só gesto. Apenas uma palavra é enunciada, não importa qual, permanece apenas a necessidade de repetição das mesmas palavras e das mesmas frases.

Essa cricotage é um ensinamento para os artistas de como fazer teatro, mas também uma lição-mensagem dirigida por um artista experimentado a jovens atores: qual é a condição do artista; o que é uma obra de arte; o que é a arte como tal?

Esse tema será utilizado por Kantor com o Teatro Cricot 2 na encenação de Não voltarei jamais, apresentada alguns meses mais tarde, em 1988. Na preparação do novo espetáculo, muitas cenas que compunham Uma lição muito curta serão trabalhadas, desenvolvidas ou modificadas de acordo com a especificidade organizacional dos códigos que sustentariam Não voltarei jamais.

\section{Ô DOCE NOITE}

Quando Kantor iniciava uma oficina com jovens atores, normalmente ele começava pedindo para que os participantes falassem um pouco das suas vidas pessoais. Para o espetáculo que viria a ser encenado em Avignon, França, em 1990, ele ouviu vinte narrações, o número de participantes da oficina, acerca do acontecimento mais importante das suas vidas. 
Após isso, Kantor instala em cena uma chaminé, tema de muitas das suas telas. Uma em especial estava pendurada no seu atelier acima da cabeceira da sua cama. Notadamente, uma clara evidência aos campos de concentração e, simbolicamente, a evidência de que o genocídio e a barbárie nazista habitavam insistentemente os seus pensamentos. A introdução desse elemento já havia sido tentada em CharlevilleMézières, na preparação de Uma lição muito curta, mas não surtiu efeito desejado na cena. A idéia foi abandonada, mas não esquecida, tornando-se a base de $\hat{O}$ doce noite.

A idéia principal do trabalho seria a criação de um espetáculo que se tornaria uma espécie de retorno ao início de todas as coisas. Um retorno através do qual os alunos aprenderiam novamente o que é um objeto que mostraria o extermínio da humanidade e, ao mesmo tempo, a maneira como essa humanidade ressuscita insistentemente.

$\hat{O}$ doce noite se tornou o momento no qual Kantor poderia escrever textos em movimentos acerca dos gestos de todos os dias, que ele podia falar das impressões da infância. Esse último texto é o desenvolvimento das reflexões do artista acerca do seu trabalho iniciado em Wielopole Wielopole. Ele também levou para a cena, nessa ocasião, um dos temas que ele não chegou a realizar em Wielopole Wielopole: a véspera de natal, com a Virgem Maria, José e o Menino Jesus na manjedoura.

Em cena, em uma casa, encontravam-se os objetos e os acessórios habituais do Teatro Cricot 2: uma mesa, cadeiras, uma cama, além da grande chaminé. O espetáculo se iniciava com os personagens deitados pelo chão cobertos com um pano branco. Muito docemente, eles se colocam a contar as histórias mais importantes das suas vidas. Eles escutam uns aos outros acerca de um fato atual. Kantor percebe que cada um deles está preocupado com a sua própria história.

Iniciando, no quarto, entra o Menino Jesus carregado por um personagem que avança com ele no colo, cuja aparência é meio anjo, meio palhaço. Incidentalmente, ao 
fundo, soa uma cantiga de natal: Noite feliz. Um ator e uma atriz representam os papéis de José e Maria. Isso acontece durante um breve instante, pois o mais importante para eles é a exposição dos seus cotidianos, dos seus problemas pessoais. O que permanece é aquilo que eles consideram ser o mais importante para si mesmos. Mas a Bíblia não quer se fazer esquecer. Aparece então um soldado com um fuzil. Ele aponta a sua arma na direção do Menino Jesus. Ajoelhado, o Anjo anuncia a boa nova. Coberto de bandagens, ele eleva uma das mãos. Ele permanece assim, imóvel, durante um longo tempo. Um ator lê a Bíblia em voz alta. Ele nos fala da sequiência dos acontecimentos dessa história que novamente penetra no quarto: Jesus será crucificado.

Ao som de uma espécie de réquiem, os atores trazem uma cruz para a cena, e o locatário do quarto torna-se a primeira vítima. Um julgamento unânime é pronunciado contra o Pequeno Rabino. Na verdade ele é que será crucificado. E o Padre, que é testemunha dessa cerimônia, retira as roupas do seu corpo. O Anjo terminou sua missão porque a história que ele propôs chegou ao fim. Ele é colocado em um caixão. Os locatários da casa, em um cortejo solene, participam das exéquias e retiram-no da cena. Os locatários-vítimas desse cataclisma - novamente representam seus papéis. O Pequeno Rabino desce da cruz e senta-se em uma cadeira. Os outros personagens voltam do enterro e contam, individualmente, a sua história pessoal e repetem os mesmos movimentos que são desconexos e absurdos.

Em cena aparece uma guilhotina, e com ela um fundo musical, a música trata-se de um canto da revolução francesa. Sob a melodia de Ca ira, uma outra história será contada na casa. Uma mulher, muito vulgar, com uma aparência lasciva, segurando uma corda, movimenta a lâmina da guilhotina para cima e para baixo. É o Padre que ordena o movimento dessa máquina da morte.

Após a primeira tentativa que fracassa, ou seja, a vítima sai incólume, aparece em um cesto a imitação de cabeça de mulher, a cabeça da vítima; um recurso utilizado pelo teatro de feira e pelo circo. Os acontecimentos históricos não têm nenhuma importância para a humanidade que, de toda maneira, renasce constantemente. Outra 
música, um tango, dá aos personagens o lado cotidiano da vida. A melodia de Noite feliz os faz pensar novamente na Bíblia. Ça ira é apenas história. Ao ritmo dessa música o comportamento dos atores se transforma. A civilização aparece por um breve instante sob a forma de um canhão". Após a primeira prece, "Pai Nosso", dita por um dos personagens, essa máquina de guerra atira. E novamente os locatários são as vítimas. Todos caem por terra. Após alguns instantes alguém diz: é o fim.

Um fim pelo qual o espetáculo começou. A história dos locatários dessa casa vítimas da civilização - pode recomeçar novamente. Mas a versão dos mesmos acontecimentos poderá, entretanto, ser completamente diferente.

Essa palavra dos atores-vítimas encaixa-se com aquelas do artista, é a última lição proposta por Tadeusz Kantor aos jovens atores. Uma lição que consistia em lhes mostrar como estar presente em cena, como criar personagens, como representar com objetos, como construir um diálogo e, principalmente, como ultrapassar o diálogo.

$\hat{O}$ doce noite foi concebida durante os ensaios de Hoje é meu aniversário onde, em cena, apareciam os mortos, dessa vez, os mais próximos: a família e os amigos. A história e a civilização destroem seu universo individual.

Durante os ensaios com os estagiários, Kantor não queria se limitar ao papel de um teórico da arte. Ele preferia mostrar o processo de criação artística e queria que os alunos participassem desse processo. Assim, o acento foi, não sobre o ensino ou a instrução, como ele dizia, mas acerca de uma criação comum. O objetivo dessas ações conjuntas era a realização de um pequeno espetáculo. Pequeno, mas intenso.

${ }^{11} \mathrm{O}$ canhão, que também foi utilizado em $O$ casamento, se tornará, mais tarde, um dos objetos representativos dos "organismos do poder" em Hoje é meu aniversário. 
Durante o trabalho, Kantor falava de teoria, mas ela era apresentada sobre a forma verbal e informal, não à maneira de um curso magistral. Essa fórmula escolhida era considerada por ele o melhor método de ensino. Ao longo dos encontros com os alunos, ele sustentava as idéias apresentadas pelos jovens atores reforçando suas concepções. Kantor sabia como estabelecer um contato com seus parceiros e como os incitar à ação. Ao mesmo tempo, ele tentava não ofendê-los e evitava também não os sobrecarregar demais com a sua personalidade. Essa era a medida de definir rapidamente e assim respeitar o caráter específico e individual de cada ator. Com isso, Kantor queria sensibilizar os jovens. Ele gostava muito do contato com eles. No entanto, ele era consciente da fadiga e da impaciência dos atores provocadas pelas fortes tensões devido a sua atividade durante a criação, tensão que o próprio Kantor sentia pelo fato que, de uma maneira geral, esses atores não chegavam sempre a se adaptar e a acompanhar o seu ritmo.

Tadeusz Kantor tinha o dom da observação e ele sabia apresentar de forma clara e simples os fenômenos e questões difíceis no domínio da arte. Ele mostrava aos alunos o seu próprio universo artístico, levando-os a alcançá-lo, permitindo a eles tocá-lo e senti-lo como se eles fossem íntimos. Para esses jovens, ele era, sem nenhuma dúvida, um verdadeiro mestre. E era com confiança e com engajamento que eles partiam com ele em intensas viagens artísticas. O método de trabalho acerca desses pequenos espetáculos está diretamente articulado com aquele que Kantor adotou e utilizou intensamente com o Teatro Cricot 2 desde 1955. 


\section{TADEUSZ KANTOR}

\section{LIÇÕES DE MILÃO}

Tradução feita a partir da versão francesa publicada em: Kantor, T. Leçons de Milan, ACTES SUD - PAPIERS, Paris, 1990. Também foi utilizada a versão em inglês publicada em: KOBIALKA, M. A journey through other spaces. Essays and manifestos, 1944-1990 - Tadeusz Kantor. Los Angeles: University of California Press, Ltd. 1993, pg. $208-265$. 


\section{LIÇÕES DE MILÃO - TADEUSZ KANTOR}

\section{LIÇÃO 1}

Eu quero apresentar o programa de nosso trabalho.

Eu devo dizer essa palavra: instruir. Se instruir.

Eu não tenho vergonha dessa palavra. Eu estudo desde o início, desde o momento que decidi tornar-me pintor.

Eu sabia que a pintura francesa era uma grande pintura.

Mas não havia pintura francesa na Polônia.

Eu tive que estudar nos livros a partir de reproduções.

Esse não era um estudo "escolar". A imaginação e a vontade de imaginar eram importantes! Eu me encontrei com a pintura francesa após a guerra, em 1947.

Eu não sei se esse encontro físico teve mais importância do que o encontro imaginário. Foi outro material. Este encontro foi uma verificação. Mas pessoalmente eu prefiro sempre a imagem da minha imaginação.

A minha criação foi sempre a descoberta de acontecimentos que eu não conhecia. Esses acontecimentos eram espécies de estudos.

Uma viagem, descoberta de novas terras; mas o objetivo se afastava sempre. Eu deixava atrás de mim o país conquistado...

Os artistas devem estudar, descobrir, reconhecer e deixar para trás as regiões conquistadas... Eu os auxiliarei...

Eu gostaria que vocês aprendessem alguma coisa durante esses encontros comigo.

Eu falarei de certos fenômenos da arte contemporânea através da minha experiência, e através da minha interpretação.

O estudo de vocês não será "escolar". Ele deve ser criativo. Eu tentarei transmitir claramente a essência do fenômeno e da tendência do movimento artístico. 
Essa compreensão deve possuir um grau equivalente ao engajamento daqueles que no passado descobriram e criaram esse fenômeno.

Este engajamento é quase uma utopia pois ele diz respeito ao passado. Mas tentaremos! O passado, suas descobertas vibram sempre em nossa cultura e no nosso tempo.

Nós nos aproximaremos do teatro através do domínio de outras disciplinas.

É necessário abraçar toda a arte para compreender a essência do teatro. A profissionalização teatral conduz o teatro a sua derrota. Isto é uma opinião particular.

O teatro não tem pontos de apoio específicos.

Ele se apóia na literatura, no drama, na arte visual, na música, na dança, na arquitetura.

Tudo isso "caminha" para o teatro mas não provém dele.

Tudo isso servirá igualmente ao teatro como matéria.

Assim, tentaremos descobrir a matéria original, "a UR-MATÉRIA", a PROTOMATÉRIA do teatro, o "ELEMENTO ESPECÍFICO” do teatro.

Independente! Autônomo!

Se tivermos êxito, isso será paradoxalmente a consequiência do conhecimento de TODA A ARTE contemporânea, de sua idéia, de sua problemática, de seus conflitos...

\section{ABSTRAÇÃO}

A abstração, no sentido mais radical, foi um fenômeno raro no teatro. Ela foi plenamente realizada na Bauhaus, no teatro de Oscar Schlemmer.

ELEMENTOS DA ABSTRAÇÃO: o quadrado, o triângulo, o círculo, o cubo, o cone, a esfera, a linha reta, o ponto, as concepções do espaço, as tensões, os movimentos, são os elementos do drama. 
Elementos estes possíveis de serem traduzidos em categorias filosóficas, humanas, psicológicas.

Cada um deles tem a sua essência, a sua irrevogabilidade e sua finalidade.

A linha infinita, o círculo contínuo, o ponto solitário, se pode com esses, assim como com todas as peripécias da vida, conflitos e catástrofes, criar um drama também interessante, tal qual uma tragédia grega.

A criação abstrata nasce, desenvolve-se, conquista o mundo, reina.

\section{A IDÉIA DE UMA OBRA INDEPENDENTE DA NATUREZA, AUTO- SUFICIENTE.}

Pura criação do espírito e do cérebro humano,

suportando a escravidão e o reinado do mundo do objeto,

passando sobre a ajuda da natureza,

não se ajoelhando diante dela e não buscando nela a sua salvação,

mas erguendo-se acima dela.

O espírito humano nasceu no limiar da nossa época e que não hesitou em se chamar a época do "homem-mestre" da criação.

Parecia que a vitória estava próxima e segura.

Hoje nós estamos inclinados a fazer uma grande revisão...

Mas nós não podemos nos afastar da história do homem. Da abstração.

MINHA DEFINIÇÃO DE ABSTRAÇÃO ao olhar a estreita definição corrente, talvez seja uma blasfêmia. 
A abstração é conforme minha convicção a ausência do objeto.

Esta ausência é muito importante pois parece-me que todo grande drama de abstração reside nessa falta.

$\mathrm{Na}$ ausência da figura humana.

Como se nós tivéssemos transgredido o limite do visível.

Como se das forças antigas representassem a antiga tragédia.

\section{MAS A FIGURA HUMANA RETORNOU, O OBJETO IGUALMENTE.}

Imaginemos que nessa cena de abstração entre um homem nu que carrega uma cadeira...

O homem e o objeto.

Isto não é o retorno de um desterro. Isto não é a derrota da abstração como pensavam os primitivos adeptos do realismo.

Os movimentos diversos, surgidos de princípios e pensamentos contrários não seguem uma linha reta ascensional. Parece-me que aquela assemelha-se aos dos abalos, a uma formação espontânea, às numerosas direções, às causas surpreendentes e mal identificadas. Se qualquer coisa desaparece, isto não significa que ela morreu, mas que ela está mais longe, em profundidade, que ela pulsa...

\section{UM OUTRO OBJETO APARECE.}

Não aquele para o qual o artista oferece os seus serviços, imitando-o fielmente em sua tela. Surge um objeto ARRANCADO DA REALIDADE DA VIDA, SUBTRAÍDA A 
SUA FUNÇÃO VITAL, QUE MASCARAVA A SUA ESSÊNCIA, SUA OBJETIVIDADE.

Isto acontecia em 1916.

Marcel Duchamps fez isto.

Ele o despiu de todo o sentido estético.

Ele o chamou de "OBJETO PRONTO”.

O objeto puro.

Se poderia dizer: ABSTRATO!

A abstração agia assim "subterraneamente".

27 anos são passados, no caminho dos quais se esqueceu a grande descoberta.

ANO DE 1944. CRACÓVIA. TEATRO CLANDESTINO. O RETORNO DE ULISSES DE STALINGRADO.

A abstração existiu na Polônia até a explosão da guerra (isto não significa um fenômeno tardio).

$\mathrm{Na}$ época do genocídio bestial, ela desapareceu. Isto se produz sempre em tais circunstâncias.

A crueldade que veiculava esta guerra era demais estranha à esta idéia purista.

A realidade era mais forte.

Toda idealização torna-se igualmente impotente,

a obra de arte, a "estetizante" reprodução tornaram-se impotentes.

O furor do homem encurralado pelo monstro humano excluiu A ARTE.

Nós tínhamos força somente para agarrar

AQUILO QUE ESTAVA SOB A MÃO, O “OBJETO REAL”, 
e o proclamar como obra de arte!

No entanto era:

um objeto miserável, POBRE, incapaz de servir na vida, bom para ser jogados às sujeiras. Liberto de sua função vital, protetora,

nu, desinteressado, artístico!

Apelando à piedade e à EMOÇÃO!

Este era um objeto completamente diferente do outro.

Uma roda lamacenta de carroça.

Um pedaço de madeira podre.

Um andaime de pedreiro borrado de cal.

Um horrível alto-falante urrando comunicados de guerra...

sem voz...

Uma cadeira de cozinha...

\section{QUEM REALIZOU A ABSTRAÇÃO}

e sua intervenção, sempre vivaz apesar do seu retrato em primeiro plano?

Pela primeira vez na história, o objeto aparece liberto de sua função vital.

Ele torna-se vazio.

Ele não se justificava mais pelas circunstâncias estranhas, mas por ele mesmo.

Ele revelou a sua existência.

E se uma ação, decorrente de sua função estava a ele ligada, isto era de tal forma que esta ação teve lugar pela primeira vez após a criação do mundo. 
Em O Retorno de Ulisses, Penélope sentava sobre uma cadeira de cozinha, manifestando, mostrando ostensivamente - o estado de estar sentado - como um primeiro ato "humano".

O objeto adquire uma função histórica, filosófica, artística!

O objeto deixa de ser um acessório da cena,

ele torna-se o concorrente do ator.

\section{LIÇÃO 2}

26 de junho de 1986

\section{SEQÜÊNCIA DA ABSTRAÇÃO.}

(Em cena se encontram duas personagens, uma branca e outra negra.

A personagem branca marcha traçando um CÍRCULO.

O negro vai e vem traçando uma LINHA RETA.

No encontro da cena na direção do fundo, ao lado do círculo.).

Os personagens não executam nenhuma atividade prática da vida.

Eles não tratam de motivos psicológicos ou emocionais.

Eles pertencem, pois a uma composição abstrata.

Estas atividades se repetem e podem não ter fim.

Desta maneira, elas afirmam e se definem sempre mais fortes. A repetição obriga à reflexão, à interpretação dramática. Estudo: "o círculo e a linha reta".

Um personagem faz um círculo. O outro faz qualquer coisa de contrário, que está em oposição ao CÍRCULO: A LINHA.

Quando a linha reta se aproxima do círculo, o drama se intensifica. 
Quando ela o ultrapassa e se afasta: o perigo desaparece pouco a pouco.

A repetição nos sugere o pensamento

do infinito, o pensamento de nossa vida em relação com

o infinito,

da iminência de QUALQUER COISA

de passagem e do desaparecimento...

AINDA UMA VEZ A ABSTRAÇÃO.

Estudo: "A imobilidade do objeto".

No centro da cena se encontra uma caixa e uma moldura de quadro retangular.

Durante todo este tempo, o objeto permanece imóvel.

A esquerda aparece o personagem humano branco.

Avança, não mecânico, e se aproxima do objeto.

Ele se detém diante dele, como se além dele o caminho estivesse interditado.

Ele retorna e parte no mesmo passo (ritmo) para o lugar de onde veio.

No momento onde ele se volta e começa o caminho do retorno, aparece, do lado direito, o personagem humano negro. Ele avança em um passo mecânico na direção do objeto.

Ele espera exatamente o momento em que o BRANCO desaparece do lado esquerdo.

O homem NEGRO retorna e volta. Desaparece. Neste momento o branco aparece e começa a marchar.

IMOBILIDADE DO OBJETO 
O objeto imóvel é SAGRADO. Ele está impedido de mover-se. Está impedido de saltar para o alto.

O objeto inacessível ao pensamento humano.

O objeto estranho ao pensamento humano.

Nesta ESTRANHEZA se encontra a noção do drama. Imitar um objeto na tela é acreditar ingenuamente no conhecimento. Na possibilidade de conhecer o objeto através deste um método.

Nos anos sessenta, os neo-realistas tentaram "tocar" o objeto pela sua destruição. (O escultor francês Cezar, realizou célebres compressões de veículos. O italiano Rotella arrancava cartazes e avisos e formava quadros com os pedaços).

Minhas "embalagens" eram uma tentativa de "tocar" a natureza do objeto. Ocultando-o, embalando-o. Era o ano de 1962.

O MISTICISMO DA ABSTRAÇÃO

Alguém entre os ouvintes colocou esta questão.

Eu respondo: sim, existe misticismo na abstração.

$\mathrm{Na}$ abstração autêntica.

O "Quadrado negro sobre fundo branco" de Malevitch é um mundo.

O "fundo" branco é igualmente uma realidade.

Dois elementos formam a unidade.

Dois iguais a um!

O quadrado em Malevitch é uma realidade. Ele é o objeto.

Seus imitadores não eram mais que estetas.

Este quadrado real existe como conceito em geometria. 
Na linguagem religiosa, este quadrado é DEUS.

Através deste quadrado, nós podemos, hoje, formular uma definição paradoxal: não existe diferença entre a abstração e o objeto.

E isto é uma UNIDADE MÍSTICA.

A ABSTRAÇÃO é talvez o conceito do OBJETO em um outro mundo, que existe e cuja arte nos dá a intuição.

LIÇÃO 3

27 de junho de 1986

A ABSTRAÇÃO, O ESPAÇO, A TENSÃO, O MOVIMENTO

Nós falamos das noções da abstração que se definem por noções geométricas: $O$ CÍRCULO, O TRIÂNGULO, O QUADRADO, A LINHA, O PONTO...

Nós abordamos uma noção de abstração mais geral: O ESPAÇO, A TENSÃO, O MOVIMENTO.

Estas noções são indispensáveis ao teatro.

O ESPAÇO

A UR-MATÉRIA

Eu sou fascinado pela idéia e a suposição, talvez mística ou utópica, que em cada obra de arte, existe uma UR-MATÉRIA independente do artista, que toma forma isolada e na qual vive toda a infinidade das variantes possíveis da vida. Isto não diminui absolutamente o mérito do artista na criação da obra, nem diminui sua imaginação. 
Bem ao contrário! Aquela dirige unicamente seus talentos em uma justa direção. A melhor. Me parece que é justamente nesta camada profunda do processo da criação que nasce a existência autônoma da obra.

Eu acredito nesta SIMULTANEIDADE e nesta EQUIVALÊNCIA de minha ação individual. E desta MATÉRIA ORIGINAL. NESTA “UNIDADE” permanece, contudo o mistério inexplicável da criação.

\section{O ESPAÇO}

Esta UR-MATÉRIA é o espaço!

Eu sinto como ele pulsa.

O espaço,

que não tem nenhum ponto de apoio e nem fronteira,

que com igual velocidade se afasta e foge,

ou se aproxima,

por todos os lados, sobre as bordas e pelo meio,

se eleva para o alto, cai nas profundezas,

gira sobre um eixo vertical, horizontal, obliquo...

Não crendo poder penetrar na muralha de uma forma fechada,

sacudindo-a de maneira brutal,

diminuindo-lhe a sua aparência cotidiana...

Os personagens, os objetos alteram as funções do espaço e de suas peripécias...

...o espaço não é um recipiente neutro,

no qual nós misturamos os objetos, as formas... 
O ESPAÇO é o próprio OBJETO (de criação)

E o espaço principal!

O espaço carregado de ENERGIA.

O espaço que contrai e se estica.

Estes são movimentos que adornam as formas e os objetos.

O espaço GERA as formas!

O espaço condiciona os encontros entre as formas e suas TENSÕES.

A TENSÃO é o ator principal do espaço.

MULTI-ESPAÇO...

O alcançar é no fundo infantil.

Isto exige, contudo, a intervenção constante de uma vontade.

De bruscas mudanças.

Nós conduzimos o ESPAÇO a um PLANO.

Nós imprimimos diversos movimentos a este plano.

MOVIMENTO DE ROTAÇÃO,

Ao redor de um eixo cuja inclinação varia em relação ao plano da tela:

vertical, horizontal, obliquo...

Este movimento exige uma OPOSIÇÃO constante.

MOVIMENTO PENDULAR

cujos afastamentos

pela ruptura

e o retorno do EQUILÍBRIO,

condicionalmente o desenvolvimento, 
O CRESCIMENTO do espaço.

MOVIMENTO DE DESLIZAMENTO (dos planos)

DESLIZAMENTO PARA FRENTE.

DESLIZAMENTO PARA TRAZ,

cobrindo e descobrindo,

MOVIMENTO DE QUEDA E DE ELEVAÇÃO.

MOVIMENTOS REPELIDOS para os lados, até o desaparecimento.

MOVIMENTO DE APROXIMAÇÃO E DE AFASTAMENTO.

a BRUTALIDADE e a RAPIDEZ destes movimentos

criam outros valores:

TENSÃO

e

mudança de ESCALA.

A tradição pictural que começa com o renascimento, com a aplicação de leis ópticas da perspectiva, conhecia a tela como um só espaço que se impunha em todo o campo do quadro.

Se criava a TENSÃO graças justamente a estas leis da perspectivas e da unidade deste espaço único.

A ABSTRAÇÃO descobriu e utilizou as leis do MULTI-ESPAÇO.

(Esta é a minha interpretação do novo espaço.)

No parágrafo precedente eu defini todos estes aspectos.

Se forma, neste caso, a TENSÃO na tela.

(eu sublinho: na tela - a pintura), 
não mecanicamente, como adiante, pelas razões da ilusão ótica, de diminuição e de aumento de escala dos objetos e dos personagens.

A TENSÃO aqui se cria graças a dinâmica, a energia, graças a vida do ESPAÇO.

Mas, sendo dado que isto se relaciona e está transposto como a característica de uma superfície de tela plana, e que é fácil em uma tal situação de misturar os efeitos da dinâmica de um espaço vivo com os efeitos da ilusão da perspectiva, eu estabeleci (conforme eu me lembro, a minha interpretação pessoal do espaço múltiplo) que a TENSÃO é criada pela energia do espaço que "manipula o criador do quadro", que torna-se assim, quase que um demiurgo.

Este ESPAÇO, dirigido pela vontade do criador,

se encolhe, se distende, se eleva, cai, perde o equilíbrio, se distancia e se aproxima.

No teatro a TENSÃO tem semelhantes valores e semelhantes causas.

Ela é criada pelas relações entre os personagens, pela direção das mãos, dos pés, de todo o corpo,

pela distância entre os personagens, que diminuem ou aumentam...

pela utilização de objetos apropriados...

Estudo: "O HOMEM E SUA SOMBRA"

Um homem se encontra no centro. Imóvel. A luz é móvel.

A luz provem de diversas direções e de diversas alturas.

A sombra muda. As vezes ela é muito longa, as vezes curta e larga, ela se retrai e se estende...

A sombra está viva! 
Algumas vezes agressiva, ameaçadora, as vezes abaixado, inquietante, em seguida, divertido, deformado por uma careta de dor ou o próprio grito...

Segunda parte: não existe mais a luz, um ator se projeta sobre o sol, tal qual a sombra de um homem em pé: o homem em pé executa sucessivamente movimentos das mãos, dos pés, do corpo, da cabeça; outro ator faz a mesma coisa, ele repete os movimentos, mas na posição horizontal da sombra, em um segundo o ator se lança sobre o sol como uma segunda sombra.

Em seguida um terceiro. Existem agora três sombras: homem em pé executa seus movimentos sucessivamente em relação a cada um dos três atores-sombras alongadas, mais e mais rápido. Finalmente ele "se funde" com os outros em uma só entidade...

\section{LIÇÃO 4}

27 de junho de 1986

(Os estudantes mostram seus estudos:

"Imobilidade do objeto".

"O círculo e a linha reta".

"O círculo que corre"

"O homem e sua sombra".)

Eu os encontro todos bem, de mais, simples e sem pretensões. O drama cênico existiu bem expresso nas categorias puramente abstratas - e isto já é enorme. Minha observação: me é difícil exprimir uma opinião sobre a obra de um outro artista. Eu acredito que um artista não tem o direito de julgar outro artista . Publicamente. Por isso eu jamais fui membro de qualquer júri. Isto é um principio de moralidade artística.

Eu tenho o direito de não me interessar por uma outra obra. E eu o faço muito freqüentemente. Muitas vezes. 
Segunda observação: nos estudos citados, existe uma certa dose de humor especial. Isto é muito bom.

Eu não confio na ausência do humor, no sério e na sua presença importante. Isto indica sempre uma falta de inteligência.

Oscar Schlemmer, cujo nome trato freqüentemente aqui, executava seus estudos abstratos com um rigor não habitual, com roupa e maquiagem de palhaço!

\section{CONSTRUTIVISMO}

(Se instala sobre a cena construções de elementos encontrados no depósito: uma plataforma em viés, tábuas de madeira, postes, cavaletes, uma roda de bicicleta, aros de metal....).

Antes que os estudantes "escrevessem a peça" para esta construção que parece com uma máquina para jogar, eu li meu ensaio sobre o construtivismo que constitui uma parte dos textos intitulados "O lugar teatral".

A cena de um teatro tradicional, um espaço no qual tudo é ficção, tudo é artificial, fabricado a fim de conceber somente a ilusão.

As instalações que servem a isto estão cuidadosamente escondidas e inacessíveis aos olhos do público.

O espectador olha para miragens de paisagens, de ruas, de casas, de interiores.

Porque por trás, todo este mundo se revela artificial, de fancaria, em "papel maché", fabricado de uma só vez. E penetrando mais ainda nesta selva, nós veremos que além desta imitação e desta fachada pomposa, existe o

ATRÁS.

A verdadeira cena.

Enorme e ameaçadora. ESTRANHA.

Primitiva. Como subjugada por este rico encadeamento de balcões, de camarotes e poltronas de ouro e de veludo. 
Um muro é erguido às cegas. Atrás um céu de azul idílico. Em seguida o verde ensolarado das árvores e os mármores dos palácios, "trabalham" enormes cordas, e pesados e espessos contrapesos de precárias escadas horizontais, de pequenos pontos de ferro suspensos acima de sombrios abismos, das carcaças dos refletores, dos cabos, das cordas, das linhas.

Todo este inferno, esta maquinaria, sustentam com o auxílio das mãos sujas dos operários, este aparato "soberano", esta magnificência, esta arrogância, esta forma de se pavonear, de requebrar, das afetações, esta medíocre camada de ilusão que não pode acontecer de um só lado. Aquele destinado ao público.

Esta explicação para a tendência revolucionária explica porque ao mesmo tempo que a revolução, também apareceu o construtivismo que destrói toda a pompa dourada da ILUSÃO e mostrará o que existe por trás, O ATRÁS, o fundo "LABORIOSO", sem vergonha radicalmente ele arranca esta medíocre camada "aristocrática" sob a qual se escondia um vazio medíocre.

\section{Esta foi realmente a DESTRUIÇÃO DO “PALÁCIO DE INVERNO” DA ILUSÃO.}

Os construtivistas acreditavam fanaticamente que sua revolução artística era paralela à revolução social, e que nela estava a única verdade equivalente.

Que a arte penetrando na vida a tornaria perfeita e justa.

Este postulado de uma penetração material da arte na vida apagou a barreira que até então os separava.

A arte deixou de ser o reflexo e a ilusão da vida.

Ela torna-se um projeto, uma proposição, um manifesto, uma estrutura análoga àquela da vida. Ela não exigia a contemplação, mas o conhecimento.

No teatro, a ribalta e a cortina formavam esta barreira.

Suprimidos. Os gritos que acompanharam esta supressão lembravam a destruição da Bastilha. 
Destruída realmente toda a ILUSÃO da cena. A fé em sua magnificência e em sua força provavelmente também caiu com o antigo regime.

Se descobria antecipadamente a RETAGUARDA severa da cena e seus mecanismos. Os muros do Château d' Elseneur desabam sobre a cena. O seu lugar se eleva com o entusiasmo das construções dos "operários", das plataformas, das escadas, das correias de transmissão - servindo na organização dos movimentos e da ação.

A terminologia corrente dos historiadores do teatro chamam esta mudança de a supressão da divisão entre a cena e a platéia.

Esta supressão exigida por uma época revolucionária que desejava e previa a ingerência ativa de um público até então passivo, além da possibilidade e da necessidade de um contato direto entre o ator e o espectador.

Importava em suprimir a distância entre a platéia e a cena, isto foi feito. A ilusão que exige a distância e o condicionamento para a separação devia aparecer.

Ela cedeu lugar aos dispositivos que chamei "instalações", às estruturas que organizam a transmissão do drama, da ação e do jogo dos atores.

Nos é difícil hoje imaginar e conceber qual impressão chocante podiam produzir nas obras e nos cenários dos teatros os ANDAIMES que ocupavam descaradamente e sem escrúpulos estéticos o lugar das antigas formas, refinadas e sublimes.

Lamacento, sujo de cal, desfigurando as vistas dos palácios e dos santuários clássicos, descartando o BELO.

A construção, com o auxílio de andaimes, de um memorial à revolução, devia ser considerado como a suprema arrogância.

Um NOVO BELO nascia apesar de tudo.

Os artistas de vanguarda se intitulavam de REVOLUCIONÁRIOS. Meyerhold se fazia fotografar em traje de comissário: uma veste negra e curta, com joelheiras, e um boné militar. 
Os artistas de vanguarda acreditavam firmemente que a revolução tinha criado a arte de vanguarda e que a arte devia servir à Revolução.

Ninguém supunha que em pouco tempo a revolução iria trair a sua arte.

A tragédia dos artistas-revolucionários tornou-se sacrifício.

O CONSTRUTIVISMO tornou-se FORMA PURA, ao preço de sua vida!

E ele deu vida à outras manifestações de arte.

\section{LIÇÃO 5}

30 de julho de 1986

(Conforme meu plano, se construiu em cena uma "instalação" tipicamente "construtivista com materiais que encontrei no depósito do teatro. Uma foto ou um desenho darão uma idéia desta instalação).

(Os estudantes apresentaram a sua própria proposição do espetáculo para esta instalação sob o título: “O CASAMENTO”).

Minhas observações:

Dos elementos de construção da cena foram realizados para os quais é difícil de adotar o nome de cenário.

Trata-se da utilização de elementos que não representam objetos, por exemplo: o muro de um quarto de um palácio, as árvores de um jardim, etc. 
1. Estes são os elementos que servem para mover os atores sobre diferentes níveis, sobre as escadas, nas superfícies obliquas, ampliando assim as possibilidades de movimentos limitados de uma cena plana.

(Contudo não os considero como cenários representando uma rua e um andaime circundando uma casa burguesa em construção).

2. Isto também tem um lado provocador: a utilização de uma estrutura, não como imitação de uma realidade qualquer (muro, janela, coluna, árvores, etc.) mas como a representação de uma construção sem "máscara", pior: uma construção "operária".

Esta palavra perdeu hoje, a sua força e a sua significação revolucionária.

Restou a concepção formal: A CONSTRUÇÃO.

Minha correção está conduzida ao nome, diria eu, do verdadeiro construtivismo.

A ação representada pelos estudantes se desenvolvia conforme um modelo retirado da realidade da vida.

Nesta também se desenrola a ação do casamento, na igreja, de acordo com as normas do ritual religioso.

A construção não esteve presa nessa condição.

Aquela que existe afim de impor à ação suas leis.

As leis do construtivismo.

As noções substituem os objetos.

Noções de equilíbrio, de gravitação, de peso, de tensão.

No lugar de PAPÉIS VIVOS, DE PERSONAGENS,

dos OPERADORES que acionam estas instalações-máquinas,

o bispo não pode dar o sacramento do casamento das cerimônias religiosas, porque não existe o altar. 
O que permanece são os aspectos mais vivos, os mais essenciais do ritual.

Eles são freqüentemente substituídos pelas agitações contrárias àquelas da vida, comprometendo, escandalizando as normas.

Este não será mais o modelo do ATOR, “O HOMEM DA CENA”, este será um gênero inferior:

UM COMEDIANTE, UM SALTIMBANCO.

A palavra exata enfim surgiu: O CIRCO!

Portanto não às roupas ricas, naturalistas ou estilizadas, sim À MALHA DO SALTINBANCO.

Daí então as gags, os processos dos jogos populares, os truques, a mistificação.

O CIRCO se misturará aos ecos da realidade presente e aos elementos compatíveis com a natureza dos andaimes.

Resumos:

Consideremos que o espetáculo "apresentado" é a realização de uma peça teatral, de um drama escrito, realização de um tema composto de acontecimentos da vida cotidiana (aqui: um casamento).

O postulado do teatro construtivista (e não somente o seu) ressoa portanto:

A REALIDADE DO TEMA VIVO, DAS AÇÕES QUE ACOMPANHAM A ATMOSFERA, DEVE SER QUEBRADA PELAS AÇÕES LIGADAS AO CARÁTER DO LUGAR, DE SUA DESTINAÇÃO, DE SUA FUNÇÃO.

Em consequiência, o curso naturalista da atividade vital busca as formas que nas categorias da vida podem parecer bizarras, absurdas, desprovidas de sentido lógico, provocantes, incompreensíveis, 
mas nas categorias da arte, elas tornam-se AUTÔNOMAS, não reproduzem, dissemos claramente:

nada informam, e pela segunda vez sobre isto, que a partir de agora é dito, isto que é o original, é reconhecido como tal.

FORMAS AUTÔNOMAS, OBRAS AUTONÔMAS

LIBERTAS, NÃO SUBMISSAS!

LIÇÃO 6

30 de junho de 1986

Na primeira representação do espetáculo $O$ Casamento, no fundo da cena se abriram as portas dando sobre a corte, e de repente, através de uma fresta, nós vimos que atrás da cena sombria, existia uma paisagem ensolarada, o céu, as árvores verdes...

Isto era surpreendente, mas longe do "espírito" do construtivismo.

Me pareceu, no espaço de um instante, que isso era a resposta improvisada destes jovens, mas cuja severidade dos construtivistas, não concernia.

Quando mais tarde, escandalizado, eu disse que eles deviam guardar na memória o testamento dos artistas mortos na luta por um NOVO BELO, eu senti que eles acolheram isto com reserva.

O que virou este "Novo Belo"?

Hoje?

Nenhum traço do espírito revolucionário. A uniformização técnica, eu não sei porque me vem na memória uma outra abertura de porta.

Wyspianski, A Liberação, abriu as portas da cena.

Sobre as trevas trágicas da servidão.

Mas um curso é um curso. Ele deve estar em acordo com o seu sujeito. 
O cortejo do casamento entra em cena por esta porta, vindo dos bastidores. Mas os bastidores foram suprimidos porque A ILUSÃO ai encontrava seu último refúgio. A ilusão é um adversário!

É preciso destruí-la! Se isto não é totalmente possível, O PROCESSO DE SUA LIQUIDAÇÃO E DO BLOQUEIO DE SUA EXPRESSÃO É MAIS IMPORTANTE QUE O TEMA PRESENTE! O CASAMENTO.

Os atores estarão inicialmente sentados na sala e terminarão sua transformação em personagens do espetáculo.

A coisa se passa na igreja - será preciso preparar esta igreja diante dos olhos do público.

Nada a esconder!

Na sala, se reúne a cruz, qualquer coisa entre o jogo dos atores e uma ação prática.

Em seguida a cruz é montada em cena pelo bispo e o sacerdote. Eles procuram um lugar.

O cortejo do casamento se forma em cena. Sobre o plano inclinado a jovem noiva é empurrada em um carrinho de mão, feito de metal e borrado de cal. Isto é feito com crueldade. A situação está em contradição com a realidade da vida.

Interpretação lúdica de uma cerimônia convencional.

No espírito do construtivismo.

A jovem noiva fica atrás, esquecida.

A mãe da jovem chora o tempo todo.

Ela não se separa de sua cadeira, que é uma paródia de construção e prova que o construtivismo no teatro deve se colocar às margens do cômico.

A construção é complicada a cada vez que a Mãe, em pranto quer se sentar, ela se curva e desaba quase como um trejeito de circo CONSTRUTIVISTA.

É obvio, à cada vez, a mãe cai por terra e chora. Este choro, no momento da queda "compromete" o outro choro, aquele que todas as mães derramam no casamento de seus filhos. 
A irmã da jovem noiva salta através de um arco cantando ulalala... ulalala...ulalala...

O sacristão puxa uma corda que está no lugar do sino do campanário. Esta corda está esticada sobre uma roda de bicicleta e faz o papel de uma correia de transmissão. Apesar disto, se entende o som de um sino de igreja.

O Bispo dirige esta cerimônia ambígua.

Eu retorno constantemente às reflexões acerca do construtivismo.

Esta corrente influenciou, sobretudo o teatro e o drama.

Ele destruiu o antigo mundo estreito da cena tradicional, e abriu o infinito horizonte da livre imaginação humana.

O construtivismo nasceu do espírito da revolução, da fé na transformação do velho mundo petrificado em um grande mundo novo, da fé no desenvolvimento da humanidade, da convicção de que a arte representa um papel capital na construção deste mundo.

Se podia, e valia a pena então ser fanático. Para uma melhor compreensão, se bem que isto seja uma grande simplificação histórica, eu chamarei construtivistas todos estes revolucionários que costearam a arte da época, o construtivismo e seus métodos de ação e seus processos artísticos.

O construtivismo exigia a liberação da arte da servidão naturalista da reprodução da vida.

Esta liberação era a condição indispensável para tornar possível a criação de uma obra autônoma, independente, criação situada sobre o mesmo plano hierárquico como a natureza ou Deus.

Obra humana, não obra da natureza ou obra "divina". 
Esta era uma ambição que justificava todos os sacrifícios, aí inclusos aqueles da sua própria vida.

A nova obra dos construtivistas conduzia à estatura da vida, onde tudo está em acordo com as normas do cotidiano, sua própria junção autônoma, na qual agem as leis de uma causalidade surpreendente e de uma eficiência inesperada e onde o curso dos acontecimentos, que na vida é abraçado de maneira servil no leito do pragmatismo e da estreita e mesquinha causalidade, se transforma em tempestade de liberdade.

Estas eram as terras secretas e inexploradas desta UR-MATÉRIA, desta PROTOMATÉRIA da vida.

Se acionava os ataques mais e mais fortes contra as convenções que se apropriavam do direito de explicar a vida conforme seus pequenos métodos que não iam além da ponta do seu nariz.

HOJE, NESTA SOCIEDADE DE CONSUMO UNIVERSAL EM VIAS DE DEGENERAR, ESTE ENTUSIASMO DOS CONSTRUTIVISTAS, SUA LUTA DE MORTE PELA VITÓRIA DA ARTE SOBRE O MUNDO DA VIDA PRÁTICA, NATURALISTA E INSENSATA - FOI RECUPERADO PELO MERCADO DA ARTE, OU CONSIDERADO PELA OPINIÃO GERAL COMO UMA ÉPOCA ACABADA.

NA SITUAÇÃO ONDE O ESPÍRITO DO PRAGMATISMO BURGUÊS REAPARECE INCESSANTEMENTE EM NOSSA CIVILIZAÇÃO, É INDISPENSÁVEL NÃO ESQUECER A LIÇÃO DOS CONSTRUTIVISTAS E DE REALIZAR CLARAMENTE AQUILO QUE ERA MAIS ESSENCIAL, AQUILO QUE ELES MESMOS, TALVEZ, NÃO CONHECESSEM TOTALMENTE.

TRATA-SE DE QUALQUER COISA DE INABITUALMENTE GRANDE E SIGNIFICATIVO PARA O DESENVOLVIMENTO POSTERIOR DA HUMANIDADE: 
ASCENSÃO AO NOVO, ÀS CAMADAS ORIGINAIS DA VIDA,

E TRATA-SE SEMPRE DELA.

E HOJE AINDA MAIS!

É PRECISO INCESSANTEMENTE COMPROMETER E DESMASCARAR ESTE MISERÁVEL PEQUENO MATERIALISMO, ESTA OFICIALIDADE RIDÍCULA, ESTE ESTILO DE VIDA, DAS MANEIRAS DO “HIGH-LIFE”.

PARA A ZOMBARIA, A IRONIA, A PROVOCAÇÃO, A MISTIFICAÇÃO DO CIRCO DE NOSSA ÉPOCA, APOCALÍPTICA.

\section{A LEMBRANÇA DA ATITUDE DOS CONSTRUTIVISTAS E DO GRANDE FRANÇOIS VILLON!}

PRIMEIRA COMPOSIÇÃO: ESQUEMÁTICA

As pessoas entram na igreja, em pares com muita cerimônia. Nós supomos que seremos as testemunhas de um funeral.

Mas, neste momento, a jovem noiva entra com um véu branco. Agora nós sabemos com certeza que isto será um casamento. Estas duas alternativas se reaproximam fora de nossa consciência convencional. Casamento e funeral. Amor e morte.

Todos se dirigem na direção do altar. As famílias rodeiam os jovens noivos.

O padre executa o ritual de união dos dois jovens.

Esta cerimônia imemorial dá às palavras e aos gestos esquemáticos uma significação quase trágica.

Os instrumentos musicais. As felicitações. Todos deixam a igreja. 
Este é o simples esquema de uma situação habitual.

De tais esquemas tradicionais são numerados: nascimento, morte, casamento, funeral, festas, guerra, disputa, manobras amorosas, conversas, roubo, ataques, etc.

SEGUNDA COMPOSIÇÃO: NARRATIVA

A dramaturgia de nossa cultura nos habituou a unir à composição esquemática uma outra composição complementar. UMA SEGUNDA.

A composição da vida individual, muito mais complexa.

Como se penetrando no interior de uma casa privada, e lá se descobriria a vida. Se poderia narrar e nós teremos então nos ocupado de uma narração e de um relato, se pode colocar em diálogos e nós obteremos um drama. Uma peça de teatro.

Eu me ocuparei um pouco mais tarde desta composição.

Eu contarei e esboçarei a história dessa casa, ou ainda, dessas duas casas, dessas duas famílias, eu descobrirei seus segredos.

Entre parênteses, eu devo avisar que jamais fui um conhecedor acadêmico das convenções teatrais, eu sempre tive a impressão, lendo ou assistindo uma peça de teatro, a impressão do verdadeiro contar primitivo, que o teatro deixa de fato o descobrimento aos olhos do público, curioso e ávido de sensações, os segredos da família, as tragédias privadas ou suas vergonhas.

\section{TERCEIRA COMPOSIÇÃO: CONSTRUTIVISTA}

Na seqüência eu quero apresentar a terceira composição, que está ligada à primeira. 
Esta é uma composição que pode se passar da segunda, de sua fábula "privada", das tragédias "privadas", dos dramas cotidianos, dos acontecimentos, das sensações "doentias" que tanto estimulam a curiosidade do público, que eu confesso, trago a este primeiro esquema árido, quase oficial em consistência e da vida.

Os construtivistas (repito; eu simplifico este termo) estimularam, com sua severidade característica, que esta composição narrativa privada, era a expressão de um pragmatismo mesquinho, limitado e pouco elevado, que não tocava a essência da vida e se contentava em mostrar a superfície e a aparência.

Era preciso, conforme os construtivistas, arrancar esta epiderme e descobrir as camadas profundas da vida.

Esta camada profunda, eu chamei: UR-MATÉRIA da vida, proto-matéria da vida.

Os construtivistas proclamavam que esta superfície, esta zona convencional camuflava, obstruía, mascarava e ocultava a verdadeira matéria bruta da vida.

Esta terceira composição opera nos domínios da filosofia, da metafísica, da moral, da psicologia das profundezas.

\section{DIGRESSÃO}

Uma pequena observação e uma digressão são aqui necessárias: destruindo cientificamente a superfície do nosso cotidiano, e nossos hábitos, de nossas convenções habituais, o construtivismo foi acusado de blasfêmia, de grosseria, de ausência de psicologia e de refinamento.

Esta opinião é compreensível lembrando que o início do século XX, apesar das idéias revolucionárias, era o herdeiro do naturalismo do século XIX, de um sentimentalismo e de um psicologismo simplório, em grande parte puritano-burguês, cujas manifestações refinadas eram o mais distanciado possível da matéria bruta da existência, postulado pelo construtivismo revolucionário. 
Hoje nós sabemos que não se pode afastar da história do teatro as descobertas do século XIX.

Porque isso era uma descoberta em relação à época antecedente. Ela consistia em:

isolar o destino do individuo de sua vida privada, dos seus dramas privados, das suas tragédias, de sua psicologia privada.

Diante da avalanche massiva posterior dos "produtos destas descobertas" a contestação revolucionária dos construtivistas é compreensível.

Nós o sabemos muito bem hoje.

O teatro da época construtivista substituiu os PERSONAGENS-INDIVIDUOS pelos TIPOS, pelos personagens que eram portadores, ou mesmo símbolos da IDÉIA DO ESTADO, da CONDIÇÃO - das camadas profundas da matéria da vida.

Esses personagens eram despojados de seus pequenos problemas privados, de seus dramas individuais, afim de não mascarar o DRAMA DA EXISTÊNCIA, O ESSENCIAL.

Dessa proto-matéria da vida.

Eu defini o caráter das três composições: esquemática (espécie de dicionário), narrativa (passagem para a ideologia do séc. XX), e construtivista.

É sobre este terceiro ângulo que eu tentarei examinar o sujeito que nos interessa: $\mathrm{O}$ CASAMENTO.

ESTUDO SOBRE O TÍTULO O CASAMENTO NA INTERPRETAÇÃO CONSTRUTIVISTA 
A austera "definição-divisa" do esquema tradicional do casamento, com sua seqüência de atos fixados pelas convenções não é nem pode ser um material necessário à realização de um espetáculo, obra de arte.

Ela não possui efeito algum "impulsão dinâmica" DA EMOÇÃO, indispensável para poder falar de CRIAÇÃO.

O momento da emoção é indispensável.

Sobre esta severa definição-divisa, saída do dicionário, eu redescobri, indo na direção das profundezas, uma sequiência de REFLEXÕES

no domínio do INFERNO.

Uma energia e uma dinâmica das mais potentes aparentemente.

O CONTEÚDO INTERIOR, se poderoso e se inquietante, torna natural e indispensável a exigência decisiva da EXPRESSÃO!

Cênica, pelo jogo dos atores.

Nós podemos ser tranqüilizados. Isso será um drama!

\section{O CASAMENTO.}

Fato excepcional na vida.

Qualquer coisa aconteceu na vida de duas personagens cuja cerimônia não fala.

A cerimônia nada faz que "confirmar" administrativamente o sentimento de amor.

Alguma coisa termina.

Nós estamos no limiar do desconhecido

Pelos séculos!

Para sempre!

Para o melhor e para o pior!

Até a morte. 
Atrás deste para "para sempre", "pelos séculos"

se encontra a noção da morte.

Um dia se depositarão dois corpos

em uma mesma tumba.

Desconhecido.

Pavor diante do desconhecido.

E decisão desesperada.

Como se chamasse o destino à luta.

Desconhecido: a felicidade futura e a tragédia futura.

Todas as paixões, os prazeres e as dores.

A bondade e a crueldade.

INFERNO.

O choro da mãe, o choro de todas as mães que colocam no mundo e perdem seus filhos.

E ainda uma reflexão:

Diante do drama desses dois jovens - a cerimônia torna-se um exercício administrativo, o padre, um funcionário da igreja.

Essa reflexão trouxe uma certa dose de ceticismo e de ironia. Elas são necessárias.

Sobre a PALAVRA: casamento

Nós descobrimos um mundo de idéias, de reflexões polissêmicas, quase simbólicas, metafóricas... 
O conceito de casamento tornou-se uma plataforma que nos permitirá exprimir nossas inquietudes, nossos medos, nossas dúvidas, nossos protestos, nossas acusações, nossas esperanças...

Os construtivistas reconheceram estes domínios como a matéria da existência, a matéria bruta da existência.

Os surrealistas, em sua tradução, chamaram este inferno de o mundo do sonho.

Por honestidade, eu devo usar o nome que eu lhe dou em meu teatro: A realidade liberada.

Nós estamos no ano da graça de 1986.

Mais de meio século escoou desde aquela época.

Nós não vivemos no tempo da revolução social de outubro, nem na época da revolução espiritual surrealista.

Hoje essas idéias e esses princípios, se importantes para a nossa época, se justificam freqüentemente em uma só estimativa do nosso mundo contemporâneo.

Nosso ensaio buscou a "reconstrução do espírito construtivista" não pretendendo a fidelidade.

Certamente ele está "poluído" pelas experiências e as contribuições que foram acumuladas durante esse meio século.

Sendo dado que eu tenho seriamente "esfregado os dedos" neste ensaio, eu quero indicar, para terminar, as modificações que apareceram em razão da minha idéia de "realidade liberada", e da minha idéia da "realidade de classe mais baixa". 
Em efeito à esta "ortodoxa” terceira construção construtivista (até aqui descrita).

à seus domínios da "matéria bruta da vida", de metáforas, de símbolos exprimindo JULGAMENTOS,

penetraram ou se somaram aos elementos da REALIDADE COTIDIANA.

Isto significa, nem mais, nem menos, os "componentes" da SEGUNDA CONSTRUÇÃO, inflamados pelo Construtivismo.

Eles são provenientes da minha criação do pós-guerra, criação de "happenings", também revolucionária tal qual os construtivistas em seu tempo.

Porque estes não são elementos ligados à função naturalista.

Sua função de vida cotidiana foi suprimida.

Restando: o objeto mesmo, seu aspecto, sua situação, seu estado, autônomo, sem causas e sem conseqüências.

Uma nova situação, desconhecida do construtivismo no teatro, uma situação criando uma esfera de mistério, do inexplicável, até metafísico (desculpem-me pela palavra).

\section{INTERVENÇÃO DA REALIDADE}

Tal qual ela apareceu nos estudos sob o título "CASAMENTO”.

Nós nos introduzimos nas casas e nas famílias do jovem casal.

O cronista, bisbilhotando incansavelmente no velho "livro das lembranças", nós aprendemos que o marido da mãe do jovem noivo faleceu, "está morto!".

Porque as lágrimas da mãe-viúva são duvidosas, visivelmente artificiais? Pelas pessoas? Eles sabem muito sobre a vida dessa família.

O filho, o jovem noivo, como nós veremos mais tarde, foi morto na guerra.

O casamento se desenvolve antes do acidente com uma granada que lhe atingiu a perna. 
Para comprovar isso, o noivo vem ao casamento mancando.

Como se o TEMPO o tivesse submetido a profundas perturbações.

As semelhanças misteriosas serão freqüentes nesta casa.

A irmã da Jovem Noiva pula sem interrupção através do aro de metal.

Como ela o fazia na infância.

Ela permaneceu imutável no seu desenvolvimento? Ou o tempo é que é restrito?

A Mãe da Jovem Noiva tem crises de risos loucos.

Doença mental?

Seu marido, ao contrário, está distinguido, irradia saúde, de excelente humor.

Toda a realidade parece suspensa na vida.

Sem passado, sem causas e sem conseqüências.

Tudo vem "DE LUGAR ALGUM" e vai "NA DIREÇÃO DE NENHUM LUGAR"

OBRA DE ARTE!

AUTÔNOMA!

LIÇÃO 7

01 de julho de 1986

Os ensaios do espetáculo $O$ Casamento, cujo conteúdo é uma idéia dos estudantes, começa.

O Casamento, conforme foi estabelecido, deve ser representado de uma maneira construtivista e em seguida surrealista. Os mesmos personagens devem aparecer.

Se ignora ainda qual será a relação entre os dois espetáculos.

Por um instante, o "cenário" para $O$ Casamento "construtivista" está no lugar. 
Durante a lição e o ensaio se cria uma situação, se corrige e se discute sobre as formas de se representar, os meios de expressão cênica, os movimentos, reunir uma esfera verbal e sonora. Faz-se a sincronia de todos estes elementos.

Nessa descrição serão percebidos que os elementos do ensaio que introduzem outros meios de montar o espetáculo com os meios convencionais.

Com efeito, isto deve ser uma lição para o "futuro".

1 - Primeiro "insegnamento"12

O comportamento teatral convencional e profissional saiu da convicção geral de que a peça (o drama) é o primeiro motor e a razão de ser do teatro.

Por isso é que se atribui tal importância à sua escolha e à isso que se chama o repertório. Os ensaios e os cuidados de toda espécie que rodeiam sua "representação" formam a parte e o sujeito essencial do trabalho teatral.

NÃO RESTA MAIS TEMPO NEM CONHECIMENTO PARA A PESQUISA DA FORMA E DA FUNÇÃO DO TEATRO.

O TEATRO É UMA CRIAÇÃO DEMIÚRGICA.

O ESPETÁCULO É UMA OBRA DE ARTE.

A ESSÊNCIA DE UMA OBRA DE ARTE É A SUA AUTONOMIA.

A OBRA DE ARTE NÃO PRECISA DE UM MODELO QUE A LIGUE A SUAS

LEIS.

A OBRA DE ARTE POSSUI AS SUAS PRÓPRIAS LEIS.

"O REFLEXO DO MUNDO E DA VIDA (SHAKESPERIANO) SE

MATERIALIZA NA OBRA DE ARTE EM SUA PRÓPRIA MATÉRIA, SUA

LÓGICA, SUA AUTONOMIA".

O POSTULADO DO TEATRO AUTÔNOMO É UM POSTULADO DE VANGUARDA RADICAL.

\footnotetext{
${ }^{12}$ Mantenho a palavra em italiano conforme a versão francesa.
} 
O TEATRO AUTÔNOMO NÃO PRECISA DO TEXTO LITERÁRIO

PREEXISTENTE COMO UM DRAMA QUE LHE DARIA, NA OPINIÃO

PROFISSIONAL CONVENCIONAL, UMA RAZÃO DE SER.

ISTO NÃO É VERDADE!

É NECESSÁRIO CLARAMENTE O CONSTATAR.

ELE REDUZ A FORÇA DEMIÚRGICA DO TEATRO.

Nós não apresentaremos uma peça escrita anteriormente.

O drama nasce durante a criação do espetáculo.

Nós eliminaremos a estrutura reprodutiva.

Nós construiremos um espetáculo obra de arte.

Nós não pensamos na peça que devemos apresentar

Mas a FORMA DO TEATRO.

2 - segundo "insegnamento"

Os atores querem entrar em cena a partir dos bastidores.

NÃO EXISTEM BASTIDORES!

ESTAS ESPÉCIES DE SEGURANÇAS ONDE A ILUSÃO DRAMÁTICA E OS PERSONAGENS DO AUTOR ENCONTRAM FACILMENTE LUGAR E PROTEÇÃO.

NÃO EXISTE ESCAPATÓRIA DA CENA.

QUE PARA A SALA

NA DIREÇÃO DA REALIDADE!

O ATOR ESTÁ EM CENA COMO NUMA ARMADILHA, NUMA EMBOSCADA, OU EM UMA FORTALEZA FECHADA. 
NÓS TEMOS AS MESMAS EXIGÊNCIAS PARA O ESPECTADOR.

O ESPECTADOR ASSUME PLENAMENTE A RESPONSABILIDADE DE SUA ENTRADA NO TEATRO.

ELE NÃO PODE SE RETIRAR.

A CENA E A PLATÉIA ESTÃO UNIDAS!

OS ATORES E OS ESPECTADORES SE ENCONTRAM EM “UM MESMO SACO”. O PERIGO É O MESMO PARA AS DUAS CATEGORIAS.

Diante da cena, no meio dos espectadores, se forma um lugar livre.

Os atores, neste lugar, vestirão a sua FANTASIA ritual.

Deste lugar eles entrarão em cena,

COMO PARA UMA EXPEDIÇÃO PERIGOSA. COMO OS CONQUISTADORES DE OUTRORA.

3 - Terceiro "insignamento"

a) O Bispo e o padre entram em cena afim de recolher e de examinar os lugares do jogo. Novamente a ELIMINAÇÃO DA ILUSÃO.

Os atores não entram em um lugar familiar em relação a sua aparência, por exemplo, em um salão, em uma igreja....

Eles entram em um lugar ESTRANHO, que existe independentemente deles. Eles entram afim de anexá-lo ao seu jogo e de imaginar uma maneira de se comportar com ele.

Mais uma vez a REALIDADE. 
O padre sublinha com ostentação essa idéia, iluminando o bispo com uma vela. Muito de "gags" cômicas.

b) No mesmo tempo, dessa maneira, nós retiramos do bispo o seu papel de ficção de Padre da igreja.

Ele se torna organizador. Mestre de Cerimônias, Experiente "em casamentos".

No espírito revolucionário construtivista. Assaz cínico.

É blasfemador como ordenava a revolução.

4 - Quarto "insegnamento”

No final os atores devem subir ao palco. Eles vêm da platéia. Eles pertencem, sem nenhuma dúvida, a mesma categoria que os expectadores; nenhuma ILUSÃO!

Apesar da impressão que eles sobem ao palco para JOGAR.

REPRESENTAR.

Eles não têm essa intenção (isso é muito importante porque eles são brutalmente empurrados em direção da cena pelo sacerdote).

Isto tem uma profunda significação para a condição do ATOR.

Privado da "dignidade" convencional própria aos expectadores.

Dolorosa mas verdadeira DISTINÇÃO da condição do artista.

5 - Quinto “insegnamento”

O Bispo-organizador tem diante dele todo o Conjunto. 
Ele ordena, por intermédio do Padre, de fazer a apresentação dos Personagens.

$\mathrm{Na}$ medida que os atores chamados se apresentam ao público, eles tornam-se os convidados dos espectadores e não o contrário!

Se aumenta assim a REALIDADE DO EXPECTADOR.

Tudo isso é acompanhado de muitos momentos cômicos.

Mas ao mesmo tempo existe alguma coisa de bizarro, de curioso, quase que metafísico.

Como SE UM OUTRO GRUPO INVISÍVEL DE PERSONAGENS DE UM OUTRO MUNDO ESCORREGASSEM PELAS PERSONAGENS REAIS DOS ATORES E SE FIZESSEM SENTIR!

E ELES MESMOS COMO SE NÃO FOSSEM MAIS DO QUE INTERMEDIÁRIAS. OS EXPECTADORES APRENDEM O SEGREDO DAS DUAS FAMÍLIAS, EXISTINDO QUALQUER COISA ABAIXO, PARA ALÉM DA CENA.

(Isso foi explicado mais precisamente na lição 6.)

6 - Sexto "insegnamento”

É bom na obra de arte a possibilidade de se apresentar uma realidade através de uma outra, totalmente diferente da primeira.

A primeira realidade é a verdadeira, aquela da qual nós desejamos transmitir o conteúdo,

mas como não queremos "reproduzir" diretamente e de maneira "naturalista", nós nos servimos de uma outra realidade, diferente e de maneira chocante.

Não existe o processo de reprodução.

A descrição dessa primeira realidade pelo espectador, tem lugar na sua imaginação que deve descobrir as ligações entre esses dois mundos.

Aumentar a atividade da imaginação do expectador é muito importante. 
Isso que no processo de "reprodução" é convencional, torna-se POESIA pura.

(Por exemplo, os papéis de condes, de barões, de bispos, de generais, representados pelos vagabundos, bêbados, marginais, desencaminhados, ou o papel da morte representado por uma vulgar faxineira...) (exemplos tirados do meu próprio teatro).

Aqui, a imaginação do expectador deve "descobrir" a Igreja onde se desenrola o Casamento em uma... usina.

O campanário é uma roda sobre a qual uma CORDA é enrolada tal qual uma CORREIA DE TRANSMISSÃO.

O Padre tira a corda. Se percebe o som de um sino.

Isso não é um símbolo, mas uma SUBSTITUIÇÃO.

O PLANO INCLINADO para o alto é o CAMINHO.

O caminho deve ser longo e difícil.

Quase a vida.

O casamento será o ÁPICE.

Mais longe, nada se eleva.

7 - Sétimo “insegnamento”

As formas e as construções que criam o espaço cênico não podem permanecer inertes.

Elas o são quando formam somente um fundo para os atores.

Elas existem no teatro convencional.

Se esse fundo cria uma potente atmosfera exigida pela ação, se pode, como último recurso, a aceitar. 
Mas no nosso caso, essas formas e esses fundos devem viver, "jogar".

Esta vida lhe é dada pelos movimentos dos atores.

Os movimentos dos atores devem jogar com estas formas e estas construções.

8 - Oitavo “insignamento”

O problema do OBJETO.

No teatro, o objeto é quase sempre um acessório.

Nessa denominação existe alguma coisa de humilhante para o OBJETO.

De servil.

\section{O HOMEM E O OBJETO. Duas CORRENTES.}

Quase hostis, em todo caso estranhas.

O homem tenta conceber o OBJETO, de o "tocar", de o fazer "seu" (isto se chama a "apropriação", domesticar).

Deve existir uma ligação precisa, quase biológica entre o ator e o objeto. Eles devem ser indissociáveis.

De maneira mais calma, o ator deve tudo fazer para que o objeto seja visível, que ele exista; no caso mais radical, o ator deve constituir com o objeto um só organismo.

Eu chamo este caso de BIO-OBJETO.

Aqui, a irmã da jovem noiva joga sem cessar com uma roda que diz mais sobre ela mesma e sobre o estado deficiente de seu espírito do que ela própria. A mãe do jovem noivo não se separa jamais de uma cadeira deficientemente construída, que provoca seus incessantes CHUTES.

O arquivista com seu inseparável metro e o Livro das lembranças. 
O metro indica a sua mania de tudo medir e de tudo verificar.

9 - Nono "insignamento"

Esta é a volta do problema do FIGURINO nesta estrutura construtivista.

Os construtivistas amavam vestir os atores em combinações, roupas como uniformes de operários.

Eles os ligavam às construções cênicas, deixavam iguais os atores e os espectadores (período da revolução).

Nisto que nos concerne, nós rejeitamos o figurino "total", ilustrando de maneira naturalista ou estilizada o caráter do personagem, seu papel, sua profissão.

Nós produzimos um figurino único: a malha.

O figurino do circo.

Toda a "seriedade" naturalista da cerimônia é desmontada pelo circo, pela palhaçada.

Os espectadores atingirão a essência e o sujeito profundo do casamento através dos “OBSTÁCULOS” necessários para chamar a atenção da sua imaginação.

O figurino torna-se OBSTÁCULO e BARREIRA.

A IMAGINAÇÃO deve transpô-los.

10 - Décimo “insegnamento”

Não esqueçamos a emoção.

A emoção aparece em um momento determinado.

Ela é precedida pela ação que dura um certo tempo. 


\section{A PREPARAÇÃO.}

Ela dura assaz muito tempo.

Nós aceitamos qualquer duração, que se arrasta, contanto que ela dure!

Contanto que não chegue àquilo que nós sabemos,

que desejamos repousar no tempo.

E de repente a ação que mantinha a nossa esperança cessa.

Não existe mais nenhuma ajuda.

Se completa aquilo que deveria acontecer.

Evidentemente trata-se de uma concepção extrema.

Aqui:

O Bispo-organizador arruma um ensaio do CASAMENTO.

Um ensaio da cerimônia. Nós não estamos seguros que o verdadeiro espetáculo será a cerimônia, ou se o espetáculo começou mais cedo, no momento onde começou o ensaio.

O ensaio é por si mesmo EXPECTATIVA do verdadeiro ACONTECIMENTO.

Nós ficamos impacientes.

Excessivamente o Bispo e o Padre prolongam esta expectativa.

Eles deixam a cena e, no meio do público, começam a preparar uma CRUZ com pedaços de madeira.

Isto dura muito tempo. A junção da Cruz é "representada" como puro trabalho de marcenaria executado por pessoas incompetentes: Não por marceneiros, mas por um Bispo e por um Padre. Portanto, muito de CIRCO.

De repente a CRUZ está pronta, erguida do solo, ela torna-se

ILUSÃO.

Nós sabemos que as zombarias terminaram. 
E que o CASAMENTO real será trágico.

E a EMOÇÃO aparecerá então.

O Bispo e o Padre levam a CRUZ para a cena.

11 - Décimo primeiro “Insegnamento”

Mas porque a ILUSÃO não domina,

é preciso derrubá-la de tempos em tempos.

Esta função aqui é cumprida pelo extrato de qualquer Manifesto Construtivista repetido mecanicamente como as informações nos aeroportos.

Por um alto-falante.

E isso nos momentos, onde levantados pela emoção, nós queremos acreditar naquilo que se passa em cena.

LIÇÕES 8, 9, 10, 11.

2 de julho de 1986 - Seqüências de ensaios.

12 - Décimo segundo “insegnamento"

Não é que agora nós nos demos conta que se tratava do "primeiro ato" da peça $O$ Casamento e que o ensaio da cerimônia que observamos era o sujeito desse "ato".

Ato assaz ambíguo:

porque nós não sabemos muito bem se a peça (drama) representa o meio e um grupo de atores de um teatro qualquer que preparam um espetáculo com o título $O$ Casamento - 
nós conhecemos desde já o primeiro ato: ele nos mostra um ensaio, conforme toda verossimilhança, o segundo nos mostrará o espetáculo pronto -

ele pode contudo possuir outra eventualidade do tipo de "ilusão":

A peça apresentará duas famílias, talvez conhecidas por suas bizarrices, que, por obterem um desencadeamento impecável da cerimônia, realizam, com o acordo do Bispo livre pensador, um ensaio do ritual (no primeiro ato). Após o qual tem enfim o "verdadeiro" casamento (no segundo ato).

Parece que a primeira interpretação tem melhor chance de chegar a um epílogo para todo este empreendimento.

Seremos então convencidos que a peça fala de um “CASAMENTO”, representado pelos ATORES.

Mais precisamente: fala de um GRUPO DE ATORES que realizam um espetáculo sob o título O CASAMENTO.

Mas o sujeito desse acordo será sempre exposto pela ambigüidade já assinalada.

E é isto que o torna mais interessante.

Assim, os atores da "Escola Elementar" representam o papel dos atores de um teatro qualquer, que ao seu redor repetem e representam um espetáculo com o título $O$ Casamento.

Mas como sempre no teatro, o convencionalismo dessa concepção (do tipo commedia dell' arte) se perde por instantes, se transformam em "ilusão da realidade da vida". Assim nós teremos, uma vez: Os atores representando o papel de atores, e em seguida brutalmente os atores representando verdadeiros personagens da vida.

Conforme minha convicção: está muito bem!

Nos chegamos aqui ao sujeito do nosso décimo segundo "insegnamento":

Eu quero falar da noção do "verdadeiro", da verdade.

$\mathrm{Na}$ arte, na obra de arte. 
O problema é o seguinte:

após a cena, "ensaio de um casamento", deve continuar logicamente a cena do "casamento pronto", isso quer dizer do verdadeiro casamento.

Isto significa que nós deveremos olhar novamente a primeira cena, mas como se diz: apurada.

Isto seria tedioso, estúpido, e não poderia ser o sujeito de um "drama".

Nós nos encontramos em completa conta.

Se desenha agora as perspectivas ou as peripécias, não "da vida" mais "elaborada", isto é, CONTRÁRIAS às concepções da vida.

Os surrealistas anexaram essa situação para sua meta, e conforme sua idéia, começaram a falar de visão onírica.

Hoje isso não nos constrange mais.

Nós vivemos 70 anos após a Revolução Construtivista.

\section{UM VERDADEIRO CASAMENTO! PRONTO!}

QUANTO DE ACONTECIMENTOS BIZARROS E IMPREVISTOS PODEM OCORRER NO ESPETÁCULO PRONTO DE UM “VERDADEIRO” CASAMENTO!

Quanto de "IMPOSSÍVEL" e de "INCOMUM" podem intervir, originados das misteriosas REGIÕES DA IMAGINAÇÃO!

Como se um vento violento atravessasse a cena, rompesse e varresse tudo aquilo que proviesse da vida e parecesse VERDADE.

NA ARTE A VERDADE É OUTRA COISA!

Porque, com toda a certeza, os caracteres e os instintos da família mudam. 
Os familiares, eles tornam-se cruéis, brutais e dementes.

A grossa corda nas duas extremidades terminadas pelos nós corrediços é passada pelo pescoço dos AMANTES pelos seus parentes - ela serve de estola religiosa ligando as duas mãos. As palavras do sermão nupcial, repetidas depois do Bispo, provém das gargantas estranguladas dos jovens noivos em agonia.

A música do órgão acompanha esse ritual mortífero.

A família deixa rapidamente a cena em silêncio, envergonhada.

Permanecem as duas Mães.

Elas enlaçam as suas duas crianças com a corda que encurta mais e mais, terminando por unir um ao outro os dois Amantes.

Elas colocam, com solenidade, os dois corpos, um ao lado do outro, sobre o plano inclinado, como em um LEITO NUPCIAL.

O arquivista da família mede os corpos com precisão.

Ele chama todos para a cena.

Última cena: Misericórdia e Comédia Humana.

Após o início, uma pilha de tijolos está disposta diante da cena.

Como ela acaba sobre o andaime de pedreiro.

Os membros das famílias formam uma "corrente".

Eles passam os tijolos de mão em mão etc...

Emparedam os dois corpos.

\section{LEMBREMOS NÓS:}

A VERDADE É OUTRA NA VIDA E OUTRA NA ARTE. 


\section{LIÇÃO DE MILÃO}

\section{ANTES DO FIM DO SÉCULO XX.}

Esta será uma lição sobre o surrealismo.

Evidentemente em um grande atalho.

Será preciso nos movermos não somente nos limites da estética mas também, antes de tudo, nos limites da civilização, naqueles das transformações da alma e do espírito do homem e da sociedade.

Porque tal era o sentido do movimento surrealista que não desejava ser uma corrente puramente artística.

O surrealismo definiu o papel da arte em seu sentido mais vasto e extenso.

Sua influência, conforme os postulados do surrealismo, não devia se deter no domínio das emoções nem no domínio do estético, mas ir mais longe; formar as aspirações e as ações humanas. As transportar afim de que elas formem ao seu redor um sistema social baseado sobre a PLENA LIBERDADE DO HOMEM, o mais alto dos valores.

O surrealismo proclama sua palavra de ordem:

A MAIOR META DA ARTE É

\section{A LIBERDADE DO HOMEM!}

A liberdade não funciona unicamente nos limites de um remexer das convenções artísticas, a liberdade não funciona unicamente no quadro de um sistema social postulado pelo comunismo - sistema de igualdade e de justiça, mas

\section{a LIBERDADE}

reconhecendo a CONDIÇÃO HUMANA TOTAL

em suas mais profundas camadas, reconhecendo este lado da natureza humana, que jamais havia sido considerado no movimento social:

a ESFERA PSÍQUICA DO HOMEM, 
suas profundezas, a imensa força de ação, que até aquele momento era pressentida pelos poetas, e agora estudada pela inteligência (a ciência) e a imaginação (a arte).

Essa atitude é incontestavelmente a maior descoberta do século XX.

Nós não podemos contestar nem a substituir por uma outra.

Nós somos os herdeiros.

Assim, após o período surrealista, a ciência, e aquilo que é mais curioso, a arte, misturaram-se nos movimentos sociais.

O movimento surrealista era sim

fascinante e se evidenciou no

desenvolvimento de uma civilização autenticamente humana

que finalmente

se submeteu às leis da

integração e (desculpem-me a palavra)

da vulgarização.

Ao mesmo tempo era um movimento totalmente intelectual e

refinado,

que toda "vulgarização" e toda "integração"

tornavam-se vulgares.

Sobretudo em nossa época de total mecanização.

É por isso que eu devo começar as lições sobre o surrealismo

por um capítulo de estimação

geral (se bem que é totalmente pessoal) 
da situação na qual eu vivo e acredito.

Na qual vocês vivem

e acreditam.

Quaisquer observações e quaisquer reservas

antes que eu não chegue ao sujeito

de minha lição, que lentamente

tornou-se um manifesto.

Eu não sinto em mim a vocação para salvar o mundo e o

reformar.

Bem ao contrário, eu observo atentamente seus defeitos

que estimulam fortemente o meu processo criativo.

Aquilo que direi não será a palavra de um profeta irritado do antigo testamento.

Eu detesto proferir ensinamentos, ordens e proibições.

Sobretudo em arte.

Eu tenho a impressão, e talvez a consciência (trágica)

que nessa época do pesadelo

da santa consumação geral,

da produção,

da comunicação,

da técnica e da política onipotentes,

o mundo gira e girará só,

independentemente da voz da ARTE

e mesmo contra ela, e que o poder pertence às FORÇAS MATERIAIS, 
hostis à arte e à alma humana.

Estas palavras não são a expressão do fatalismo ou do pessimismo, elas provêm da minha profunda experiência, elas decorrem do subconsciente e são verdadeiras.

Eu não posso ter vergonha nem os mascarar.

Eu as quero explicar afim de conhecer as conseqüências e de definir claramente minha própria atitude.

Não existe nelas

nenhuma fé revolucionária em um "luminoso" ou "perfeito" futuro;

nem

uma fé revolucionária nas palavras de ordem da organização do mundo conforme as leis da razão e da justiça.

Apesar da enorme carga de entusiasmo investida nestas idéias,

eu vejo hoje

a sombra de uma perigosa "gigantomania"

atribuindo-se a pretensão de abraçar todo o universo.

Hoje nós sabemos muito bem como isso termina.

Ao mesmo tempo eu estou longe do espírito catastrófico da filosofia e da arte

na qual eu descobri um maneirismo, uma espécie de megalomania do ceticismo e um pathos indiferente.

O ceticismo não me convém mais. Ele não pode agir na arte.

Procurando a essência dessa atitude, eu ainda me referi aos sentimentos de desprezo pelas forças que governam o mundo

e a esse estado de alma, ao meu ver, da classe intelectual e artística elevada, na qual nós decidimos reconhecer A EXISTÊNCIA DO MAL, quando anteriormente nós rejeitamos conscientemente a noção mais fácil do BEM e, aquela, a mais convencional, do BELO. 
O MAL é evidente, tangível, nós o vemos ao nosso redor, pior:

Nós nos habituamos a ele.

Voltemos a esse "credo" fatalista e a esse julgamento quase bíblico do nosso século XX.

Eu não me desespero.

Ao contrário, eu estimo que essa consciência pessimista tem paradoxalmente, para mim (e para muitos outros), uma grande importância.

Ela desperta, como sempre despertou no passado,

a NECESSIDADE DE UMA RESISTÊNCIA.

e uma reação de ACUSAÇÃO.

Já se sabia da enorme FORÇA que reside nas reações:

A FORÇA DA OBRA DE ARTE.

Eu pertenço à geração surgida na época dos genocídios e dos atentados mortíferos contra a arte e a cultura.

Eu não quero salvar o mundo com a minha arte.

Eu não acredito na "universalidade".

Após todas as experiências do nosso século, eu sei como isso termina, e a quem e a que serve essa célebre "universalidade", tanto mais perigosa que hoje ela atingiu a dimensão do globo terrestre.

Eu quero SALVAR A MIM MESMO,

não egoisticamente, mas somente com a fé no VALOR INDIVIDUAL!

Eu me tranco no meu estreito quarto da imaginação.

E LÁ 
E SOMENTE LÁ

EU ARRANJO O MUNDO.

COMO NA INFÂNCIA.

EU ACREDITO FIRMEMENTE QUE NESSE PEQUENO QUARTO DA INFÂNCIA SE SITUA A VERDADE!

E HOJE, TALVEZ COMO NUNCA, ESSA E A VERDADE EM QUESTÃO!

Escrevendo isto, eu vejo a que nível eu me distanciei do espírito surrealista.

Eu continuo, entretanto, a me sentir o herdeiro.

Isso não é retroceder.

EU VOU SEMPRE NA FRENTE.

EU PROTESTO.

Eu não aceito o conformismo a adaptação,

Eu destruo os princípios do passado,

Inúteis.

Este é o traço essencial do surrealismo.

ESTA É A MINHA PRIMEIRA “CORREÇÃO” DO SURREALISMO.

Haverá outros mais.

Para colocá-lo por mais tempo em evidência, eu me reportarei ao texto do meu "Pequeno Manifesto", redigido pela ocasião do Premio Rembrandt que me foi atribuído em 08 de abril de 1978.

"Permitam-me, senhores e senhoras, de lhes apresentar meu pequeno manifesto (eu continuo a escrever manifestos), que eu escrevi em sua homenagem". 
Mas antes de ler, para um esclarecimento posterior, eu me permito de voz lembrar que o principio fundamental (se eu posso me exprimir assim pateticamente) de meu trabalho era e é sempre a idéia da realidade que eu defini como a REALIDADE DE CLASSE MAIS BAIXA.

É ela que explica meus quadros, minhas embalagens, objetos pobres como o são meus pobres personagens que, tal como o filho pródigo retorna após uma longa viagem, à sua terra natal. Hoje, eu quero aplicar esse método a mim mesmo: não, não é verdadeiro que o homem moderno é um espírito que venceu o medo diante do mundo exterior, o medo diante do destino, diante da morte, diante do desconhecido, o medo diante do nada, diante da vida.

Não é verdade que o artista é um herói, um intrépido conquistador, como ensina a lenda convencional.

Creiam-me, este é um homem pobre e sem armas que escolheu seu posto, face a face com o medo, com toda a consciência.

É na consciência que nasce o medo.

Eu estou aqui, amedrontado, acusado diante de vocês, juízes severos, mas justos.

E está é uma diferença entre mim e os dadaístas dos quais me sinto o descendente.

“Em pé!” Exclamava o grande humorista Francis Picabia.

"Você é acusado".

Eis a minha correção atual à esta imponente invocação: eu estou aqui diante de vocês, julgado e acusado. Este é o momento de me justificar. De procurar provas. Eu não sei se isso é da minha inocência ou da minha falta... Eu estou aqui diante de vocês como antigamente... Em uma carteira de escola... Na sala de aula... E digo: Eu esqueci. Eu sabia. Eu sabia certamente. Eu lhes asseguro senhoras e senhores... 
Nesses tempos de apocalipse moderno,

quando os potentes deuses da nossa época arrastam a arte

ao campo do seu império submisso a leis brutais,

seja à leste ou à oeste,

quando parece que a arte morreu, aparecem

repentinamente,

eu estou seguro - isso é sempre assim -

vindo não se sabe de onde

das pessoas, parecidas com antigos santos, aos eremitas,

aos ascetas,

dos artistas cujos atributos e a arma serão a

POBREZA

e o RIDICULO.

A pobreza e o ridículo com seus meios.

Os descendentes desses GRANDES

que começaram o nosso século $\mathrm{XX}$

NA POBREZA

e no RIDÍCULO!

Suas obras tornaram-se as FOGUEIRAS desses sintomas "APOCALÍPTICOS" de nossa época e que parecem triunfar.

Eu aspiro os reunir e os ordenar.

Como em uma fogueira! 
Isolados da vida, eles não despertam de seus reflexos assustadores.

Sobre a fogueira, se pode os queimar.

Tudo, ao menos na obra de arte.

E esses são elas,

essas diversas espécies de FUROR da nossa época:

\section{O CONSUMO ONIPOTENTE}

Tudo tornou-se marchandise

o marchandise tornou-se deus sanguinário

de assustadoras quantidades de alimentação

que alimentam o mundo inteiro,

e a metade da humanidade morre de fome;

Das montanhas de livros que jamais chegaremos a ler;

Os homens devorando os homens,

seus pensamentos, seus direitos, seus hábitos,

sua solidão

e sua personalidade;

Dos mercados de escravos, organizados em uma formidável escala,

se vende pessoas,

se compra,

se negocia,

se corrompe.

Criação, 
Esta palavra deixa de ser

um argumento

sem apelo.

Esses que virão e talvez já tenham chegado,

nos quais se repetirão os nomes dos GRANDES:

Pablo, Chaim, Paul, Marc, Henri...

Da sua POBREZA e do RIDÍCULO, de quando começaram o que significavam eles em face da Grande PRODUÇÃO

das Grandes Corporações,

que fazem cálculos de mercados quilométricos,

mercados-museus

mercados-teatros

mercados-festivais

mercados-galerias.

Eis uma outra aparência do FUROR do nosso final de século:

A COMUNICAÇÃO ONIPOTENTE.

Se a falta de lugar,

pelos excêntricos que andam a pé,

parece um meio de locomoção que ajuda a pensar

nos rios de carros que flutuam por nossas casas e apartamentos,

se a falta de água, de ar, de florestas e de plantas,

a quantidade de seres vivos cresce de maneira espantosa: dos 
homens...

Continuamos:

A COMUNICAÇÃO

que concorda perfeitamente

com as estradas de ferro, os bondes, os ônibus,

foi julgada como o conceito mais adequado e o mais salutar

para o espírito humano

e para a ARTE.

COMUNICAÇÃO onipotente!

Sua primeira palavra de ordem:

\section{A VELOCIDADE}

rapidamente transformada em um grito de guerra selvagem de colônias primitivas.

O lema tornou-se ORDEM.

O mundo inteiro,

toda a humanidade,

todo o pensamento do homem

e toda a ARTE

devem a executar docilmente.

O mundo breve em sua privação com um grito selvagem.

Eles querem reunir a luz e o pensamento?

Não totalmente!

Não existe lugar para o pensamento neste curso assustador. 
A luz? Sem dúvida “eterna” após a catástrofe!

A comunicação é sustentada pela força e o poder da

BUROCRACIA.

Com seus mecanismos sem almas

a COMUNICAÇÃO transformou os LUGARES do pensamento humano

e da arte

(eu não quero chamá-los de santuários ou de monumentos) nos

ESCRITÓRIOS DE COMUNICAÇÃO

e das ESTAÇÕES DAS REDES DE COMUNICAÇÃO.

As velhas reivindicações permaneceram para semear a confusão.

E não existe mais mistérios

nem continentes desconhecidos, nem vielas,

para a ultra-velocidade tudo esta

codificado e comunicado

pelas linhas telefônicas

pelas ondas etéreas,

pelos aparelhos mais sofisticados

ao mesmo tempo, em todos os cantos do mundo,

apagando toda diferença.

Tudo torna-se obrigatoriamente uniformizado,

nivelado

e... SEM SIGNIFICAÇÃO! 


\section{A SANTA TÉCNICA ONIPOTENTE}

Não, eu não sou contra a técnica.

Eu não sou um partidário

da idéia ingênua de um retorno à natureza

ou a um modo de vida primitivo.

Eu não tenho confiança na ressurreição

de pretensiosos e vazios

rituais

artificialmente preparados

e celebrados com seriedade

que se esforçam em nos provar à nós, os homens,

o lugar perdido entre o homem

e a terra,

a água,

o fogo,

o ar,

e a matéria

Este é o momento de desmascarar esses

Chamans e "gurus" de todas as espécies

Sombrios e obtusos,

Feiticeiros,

Exorcistas, 
Curadores,

Rituais de strip-tease.

Abraãos pseudo-bíblicos

sangrando

porcos, retirados

dos açougues urbanos,

chafurdando nas

vísceras e nas entranhas,

depositando uma oferenda

não ao Deus Cruel

da bíblia,

privado de espírito (cérebro) humano,

mas simplesmente e banalmente

o Onipotente Mercado de Arte

e ao Santo Comércio.

A esses falsos

Padres do Comércio e do Mercado

apareceram os "oportunistas",

calculadores insensatos

que

com uma astúcia extraordinária

obtém aparências de grandeza

servindo-se desse objetivo 
da grandeza da natureza,

das cadeias de montanhas,

da areia dos desertos, que eles

recobrem de cores,

que eles exculpem com a ajuda de escavadeiras,

nada que para ser visto

na vitrine do mundo.

A última dessas manifestações

de FUROR de nossa época

se percebe

um perigoso anti-intelectualismo

e uma brutal eliminação do pensamento.

Eu sou pela palavra de ordem

"a inteligência ao poder"

para a técnica e a ciência

que ajudem

no desenvolvimento intelectual

do homem,

para a esfera metafísica

cuja ironia, o sentimento de humor

e a imaginação 
são o lado humano,

e - o horror! - para

a emoção

E aí começa meu

"contra"

meu protesto dirigido

contra a TÉCNICA.

Hoje o surrealismo está vulgarizado

maciçamente e - o que é pior -

de maneira "interessada"

e utilizado de uma forma inacreditavelmente grosseira

em todo lugar onde se quer

SURPREENDER.

IMPOR COMERCIALMENTE, ATERRORIZAR.

ATRAIR PELA FORÇA.

e enfim... VENDER.

Em todo lugar onde

Pela falta de idéias precisas

SE SIMULA ESTADOS ALUCINATÓRIOS, ONÍRICOS E DELIRANTES, HOJE EFICAZES E RENTÁVEIS...

Nós conhecemos bem esses CRIADORES DE ESPETÁCULOS, SEGUROS DE SI MESMOS, 
PSEUDOPOETAS CAPRICHOSOS.

SIMULADORES QUE TENTAM ENCANTAR POR SUA HISTERIA.

CUJA POBRE IMAGINAÇÃO É SALVA

pela TÉCNICA

E SEUS ULTRAMECANISMOS.

EXTERMINANDO SEM ESCRÚPULOS

O PENSAMENTO E A EMOÇÃO.

Nós conhecemos bem esses

"DESENHADORES", esses "GRAFISTAS", QUE OSTENTAM A HABILIDADE OCA

DE SUA PROFISS ÃO.

TENTANDO PELA VIOLÊNCIA NOS CONVENCER QUE ELES ATRAVESSARAM

“O ESPELHO DE ALICE NO PAÍS DAS MARAVILHAS".

MAS QUE NA REALIDADE,

ELES PERMANECEM DIANTE DELE - como dizem delicadamente os franceses "bouche bée ${ }^{13}$ ".

A SANTA TÉCNICA, onipotente, reina hoje em todos os TEATROS e MEIOS DE COMUNICAÇÃO.

A TELEVISÃO, com a banda magnética, produz esse "maravilhoso" surrealista de forma mecânica.

Nas produções musicais visuais

de potentes mecanismos sem alma

nos submergem em uma inundação

${ }^{13}$ Boquiaberto. 
de efeitos quase "surrealistas"

completamente privados

de toda FORÇA DE EXPRESSÃO

de toda EMOÇÃO.

Os executores enraivecidos utilizam dos meios

descobertos outrora pela

GRANDE REVOLUÇÃO SURREALISTA

reduzindo-os

a um clima brutal de um jogo de futebol.

Das exceções, algumas vezes se produz uma força espiritual extraordinária.

Mas a "VAGA" permanece em uma onda cuja força é aquela do DILÚVIO

e da... DESTRUIÇÃO!

Devido à importância do tema que representa o problema do surrealismo, eu chamei esta aula de "XII Lição de Milão".

Eu queria que vocês conhecessem as "ordens" do surrealismo, que absorvessem os conteúdos para que estejam presentes em sua criação e se tornem para vocês um painel indicador.

Essa não é uma situação “escolar” nem um curso,

É algo mais que um ensinamento.

Eu quero que vocês descubram as suas origens!

O surrealismo nasceu no limiar do século XX,

aqueles foram os anos de sua juventude.

Nós todos pertencemos a este século. 
Sua juventude é a nossa.

Nós estamos ligados a ele geneticamente.

A dinâmica e a força da nossa criação provém daí!

Nós não nos liberamos da nossa juventude.

Nós não podemos a trair.

E não podemos a dilapidar.

Vocês não são obrigados a aprender.

Vocês não sabem mesmo que pertencem à mesma família.

Somente o que eu posso lhes aconselhar, é isso,

de adquirir a plena consciência

de suas origens, de sua genealogia.

Afim de poder claramente diferenciar o espírito autentico

do

surrealismo de seus

miseráveis imitadores,

da elegância sedutora,

do conformismo confortável,

do carreirismo

e da... queda.

Bom, mas chega dessas minhas advertências!

Se tem escrito milhares de dissertações e de livros sobre o surrealismo. 
Leiam-nos. Aprendam a vida de seus pais,

suas vitórias, seus fracassos,

suas peripécias aventureiras,

seus pecados, seus delitos, seus amores, seus perigos,

tudo: os prazeres e as paixões,

a miséria e o luxo, a vaidade e a nobreza...

Isso é indispensável. Tanto pior se isso for livresco, qualquer coisa

"escolar". Vocês não têm outra saída.

Leiam estes livros como as crianças lêem, pudicamente, as cartas de famílias descobertas no meio dos álbuns familiares.

Para ter, ao menos um pouco, a consciência tranqüila para

vocês e esta Lição de Milão,

eu serei um livreiro, em um sebo...

Não esperem de mim um curso sobre o surrealismo.

Quando em 1947, eu o encontrei em Paris, eu o conheci pelas

exposições, pelos livros, pelos manifestos.

Pelo ar e pelo clima que estavam impregnados.

Eu posso dizer que o "caminho" pessoal de minha juventude me

me conduziu infalivelmente na direção do grande caminho,

onde marchava esse exército revolucionário.

Desde então, de acordo com minha convicção,

nos genes de nosso século, em seus genes 
o surrealismo deixou profundas marcas.

estudem-no como eu indiquei à poucos instantes, na época

da minha "prática nos mestres do surrealismo".

Assim eu serei liberado do papel de professor o qual não é o meu.

Isso que você entenderam será ainda um confronto entre o

surrealismo e as minhas próprias concepções, idéias e "descobertas",

que marcaram o nosso tempo, mais e mais distanciadas disso

que eu chamo a "quintessência" original do surrealismo.

Eu peço que aceitem

a minha "revisão" individual,

ou ainda a revisão do nosso tempo. Nós temos o direito, nós vivemos na oitava década do

nosso século que chega rapidamente ao seu término.

Durante minha "peregrinação" individual, certas "ordens"

do surrealismo perderam sua força e sua eficácia.

Nós devemos perguntar: hoje, o que herdamos do surrealismo,

o que nós podemos, com uma paixão e uma fé igual a àquelas dos

surrealistas, aceitar essa infância, manter e utilizar como arma em nossa arte e nossa luta.

Falando do surrealismo e dos surrealistas, eu penso igualmente,

sempre, no dadaísmo e nos dadaístas pois, estes dois MOVIMENTOS, eram uma só TENDÊNCIA no seu início. 
Então, após a guerra, nos anos 60, eu encontrei, pela primeira vez, as obras dadaístas e, desde já elas representavam posições e valores de museu. Elas envelheceram ou estavam mortas. Mas eu sentia que o espírito de suas manifestações, de seus escândalos, de seus protestos e revoltas vivia sempre.

Eles eram a geração da Primeira Guerra mundial, eu (nós), eu carregava sobre os ombros o não menor e horrível fardo da Segunda.

Então eu notei e compreendi a relação notável entre as suas atitudes e as minhas.

Esta atitude que se definiu em mim e para mim durante a guerra.

Nada conhecendo deles, eu cheguei a um "comportamento" artístico similar e a uma similar semelhança com o mundo da arte.

Eu tentarei comparar essas duas épocas, essas duas atitudes, de encontrar as diferenças devido a distância das épocas e enfim de fazer as "revisões", minhas e suas revisões do fim do SÉCULO, revisões de um MOVIMENTO que foi o início desse SÉCULO e talvez se poderia dizer: seu pai.

ANO DE 1914

Primeira Guerra mundial:

os milhões de cadáveres

em uma hecatombe absurda.

Após a guerra:

os tronos abolidos,

as patentes, as medalhas de generais, 
as coroas de imperadores e de reis,

lançadas ao lixo,

das pátrias em falência,

os patriotismos nacionais que revelaram

comportamentos selvagens...

Frente a este gigantesco compromisso com um mundo que até então organizado para reconhecer sua existência como legalmente admissível,

somente a atitude dos dadaístas era a reação e o único reflexo saudável:

BRINCADEIRA

IRONIA

REVOLTA

PROTESTO

NEGAÇÃO DE TUDO

BLASFÊMIAS lançadas contra todas as SANTIDADES.

REVISÃO de todos os valores os quais se baseava o funcionamento da sociedade.

Se ridicularizou as noções até então veneradas, de arte.

A CONSCIÊNCIA que, conforme o antigo ponto de vista, volta a condicionar a obra de arte, foi substituído pelo ACASO.

A FORMA e sua perfeição, que deveria EXPRESSAR

conteúdos importantes, foram substituídos pela REALIDADE bruta

que não expressam nada, que simples é.

Um quarto de século se passou.

Segunda Guerra Mundial. 
Genocídio,

Campos de concentração,

Crematórios,

Bestas Selvagens,

Morte,

Torturas,

O Gênero humano transformado em lama, em sabão, em cinzas,

Aviltamento,

O tempo do desprezo...

E eis a minha (nossa) resposta:

NÃO EXISTE OBRA DE ARTE

(mais tarde, se rotulou isso de uma maneira mais intelectual: negação da obra de arte).

NÃO EXISTE A “SANTA” "ILUSÃO”,

NÃO EXISTE A “SANTA” FUNÇÃO DE REPRESENTAÇÃO.

EXISTE SOMENTE UM OBJETO ARRANCADO

DA VIDA E A REALIDADE.

(A história da arte chama isso de uma

maneira mais refinada: o objeto pronto).

A RODA DE UM CARRO COBERTA DE LAMA torna-se obra de arte. 
NÃO EXISTE O LUGAR ARTÍSTICO

(como os museus, os teatros).

EXISTE SOMENTE O LUGAR REAL (um quarto destruído pela guerra,

uma estação de estrada de ferro, uma escadaria por onde Ulisses retorna de Tróia)

OS VALORES ESTÉTICOS REFINADOS SÃO SUBSTITUÍDOS PELA POBREZA!

O OBJETO POBRE (roda lamacenta, madeira podre, cadeira de cozinha sobre a qual se senta a rainha Penélope).

A ATITUDE ARTÍSTICA É:

O PROTESTO

A REVOLTA.

A BLASFÊMIA PARA

A SANTIDADE ESTABELECIDA.

A PALAVRA DE ORDEM: CONTRA O PHATOS, CONTRA TODA CELEBRAÇÃO

E TODA SANTIDADE.

Hoje eu reivindico minha atitude de 1944 como minha própria descoberta ${ }^{14}$.

\footnotetext{
14 Após meu encontro com o dadaísmo nos anos 60, que já era uma peça de museu, eu realizei meu protesto de 1944. Era o gesto dos dadaístas de 1914.

Eu me sentia descendente do Dada, e como acontece freqüentemente, meu "pai" me era então desconhecido.
} 
Para diferenciar essas duas atitudes, em referência ao ACONTECIMENTO teatral (e não o espetáculo) $O$ Retorno de Ulisses, eu dou a esta etapa de minha criação o nome de: TEMPO DE ULISSES.

A Morte inevitável que era a característica dessa guerra e o pressentimento do meu TEATRO DA MORTE, 30 anos mais tarde, deram a esta etapa e a este tempo um traço METAFÍSICO, longe do espírito Dada.

A noção de POBREZA que, alguns anos depois, foi mais amplamente definido em minha IDÉIA DA REALIDADE DE CLASSE MAIS BAIXA, carregava com ela um tom LÍRICO e (horror!) SENTIMENTAL, que era estranho aos dadaístas.

Essas eram as diferenças que fazem do TEMPO DE ULISSES o meu próprio.

De 1944 para o presente.

Essa atitude, as manifestações escandalosas que eu quero enumerar e que me são muito queridas, deveria, logicamente, ter desaparecido com o fim da guerra.

Passaram os anos $40 \ldots, 50 \ldots, 60 \ldots, 70 \ldots$,

as idéias artísticas se desenvolveram,

mas eu percebo continuamente como dos distantes signos de advertência, é talvez uma voz interior me ordenando, me ditando tal atitude e não outra,

PROTESTO,

REVOLTA,

CONTRA AS SANTIDADES PREGADAS OFICIALMENTE, CONTRA TUDO ISSO QUE “CONFIRMADO”

PELA REALIDADE.

PELA POBREZA. 
O tempo

do desprezo

sanguinário, dos instintos selvagens,

do poder absurdo que não quer a nenhum preço se "civilizar"

e que se mantém como no primeiro ano da história,

esse tempo dura ainda...

A resposta para estas questões é incontestavelmente dada pela

arte das décadas citadas.

Falta somente ter um "bom ouvido" para entender.

Em 1948

O poder atenta contra a

Liberdade da arte.

Em meu estreito pequeno quarto da imaginação eu compreendo as "ORDENS" desse outro tempo, mais e mais claras e mais e mais apuradas (urgentes).

Elas se tornam mais queridas, mais próximas e mais pessoais

A única verdade.

Fascinantes,

Eu percebo que devo torná-las precisas, torná-las evidentes, as intensificar, dar-lhes uma força de agressão!

E ao mesmo tempo realizar as "revisões" assaz audaciosas

Para que o espírito DADA

E o espírito do TEMPO DE ULISSES, estejam vivos. 
Porque com o tempo, outros sintomas que ameaçam nossa época, chegou a degraus de potencia enorme:

UMA BUROCRACIA OBTUSA

UMA TÉCNICA ONIPOTENTE

UM CONSUMO CANIBAL

UMA VIDA PRÁTICA UNIVERSAL E OBRIGATÓRIA

ENTORPECENDO O ESPÍRITO E A ALMA HUMANA.

Os enormes magazines de pesadelos tornam-se os santuários do novo deus do consumo e da vida material.

Eu escuto atentamente esta "Voz Interior":

É NECESSÁRIO A TODO CUSTO PERMANECER ATEU DIANTE DESSES SANTUÁRIOS E A ESSE DEUS!

Minha criação e minhas obras cujas fontes provem do subconsciente "compreendem" esta voz interna e a comanda rapidamente.

Nesse caminho o intelecto realiza mais claramente as NOVAS RAZÕES:

ESPIRITUALISMO

IMPERATIVO DA ALMA.

SENSAÇÃO DE UM OUTRO MUNDO.

CONCEPÇÃO DA MORTE.

DO “IMPOSSÍVEL”.

"DA ESPERA PACIENTE DIANTE DA PORTA" ATRÁS

DA QUAL SE ESTENDEM

OS ESPAÇOS INACESSÍVEIS A NOSSOS SENTIDOS E CONCEITOS... 
Eu não tenho tempo de me perguntar se por acaso esta não habitual “junção", não está, após tanto tempo, inscrito no meu subconsciente e em meu caráter.

“Revisão", não sem importância. Sinceramente anti-dada.

Mas somente na aparência. Os Dadaístas eram contra seu tempo e seu mundo. Essa "revisão" é igualmente contra nosso tempo. Contra o mundo cuja a força atingiu uma dimensão absurda.

ao mesmo tempo, a loucura dessa vida material provoca um retorno da louca convenção artística hiper-barrocas, uma licença da ilusão, um delírio de bizarrices.

Se utiliza sem escrúpulos os meios surrealistas para ações sem o menor conteúdo ou motivação intelectual, somente com a intenção de assustar e de manifestar sua excentricidade.

A imaginação, esta região inquietante e herética do psiquismo humano descoberta pelos surrealistas, é transformada e assimilada a mecanismos produtores de pirotecnia.

Os charlatões e os medíocres fingem ser os pais do

MARAVILHOSO.

Neste tempo da aterrorizante tendência pelas BIZARRICES (longe desse "maravilhoso" surrealista)

é preciso coragem para sugerir:

A REALIDADE

QUOTIDIANA

BANAL

POBRE

SEVERA. 
DELA SOMENTE PODE NASCER HOJE:

O NÃO HABITUAL,

"O IMPOSSÍVEL",

O SUPERNATURAL.

O SUFICIENTE PARA A PRIVAR DE CAUSAS E DE CONSEQÜÊNCIAS!

ELA SE TORNARÁ AUTÔNOMA E NUA!

Isso também é uma "revisão".

Após numerosos anos, as palavras de ordem dos dadaístas e dos surrealistas se confundem.

Novas configurações aparecem.

Novas forças que ameaçam a liberdade crescem.

Se nós permanecemos fieis ao espírito não conformista, devemos encontrar em nós um Novo Estado de Oposição, mesmo se estranho às antigas palavras de ordem.

De onde a necessidade de uma constante "revisão".

Os surrealistas se diferenciavam dos dadaístas porque às suas palavras de ordens destruidoras, eles juntavam os valores positivos da observação científica.

Eles não acreditavam na função da arte de prover servilmente e docilmente as impressões sensoriais e estéticas, mas de revolucionar a consciência humana estimulada pelos estereótipos e pelos esquemas do espírito prático,

de destruir a experiência pragmática e prática do mundo real, de ampliar a consciência à novos espaços psíquicos, não levado em conta até o presente,

e enfim, de atender um nível mais elevado da existência humana. 
Frente ao argumento do desenvolvimento lógico perfeito, nós reagimos hoje com um sentimento de desconfiança, quase uma sensação de culpa: nós não acreditamos mais em uma argumentação demais racional.

A EXPERIÊNCIA DO SÉCULO XX NÓS CONHECEMOS QUE:

A VIDA EM SEU DESENVOLVIMENTO

\section{NÃO CONHECE ARGUMENTOS}

\section{RACIONAIS.}

Nessa afirmação nós somos mais irracionais do que o surrealismo irracional.

Essa é a primeira revisão.

Hoje nós sabemos também como A Motivação Social É Perigosa Para A Arte.

Essa é uma segunda correção.

O sentido didático da arte e sua inclinação à universalidade não são hoje convincentes.

A inscrição em seu programa da percepção universal da arte, do emprego universal pelo seu espírito e

a criação "universal" conforme a palavra de ordem dos surrealistas

"todos podem ser artistas",

advogam a

MEDIOCRIDADE!

E eis aqui a terceira revisão:

O IMPORTANTE É O MUNDO INDIVIDUAL,

CRIADO NO ISOLAMENTO E SEPARAÇÃO, 
QUE É CAPAZ DE OCUPAR

O MAIOR ESPAÇO DO

ESPAÇO DA VIDA!

Nessa concepção,

O ESPAÇO DA VIDA É TUDO AQUILO QUE CONTEM ESSA PALAVRA,

EXISTE AO LADO DO

OUTRO ESPAÇO,

DO ESPAÇO DA ARTE,

JUNTO E CONJUNTAMENTE

SE MISTURAM E SE INTERPENETRAM

COMPARTILHANDO UMA PARTE COMUM...

ISTO É SUFICIENTE!

E eis aqui minhas últimas reflexões. Eu não sei se elas estão ligadas ao surrealismo ou se elas se distanciam. Mas isso não é o mais importante. Essas são minhas próprias reflexões, para meu uso pessoal. Eu não tenho a intenção de impô-las a ninguém.

Isso que a vocês e a mim encantou no surrealismo, durante os anos do após guerra, era

\section{A ULTRAPASSAGEM DA REALIDADE MATERIAL PRAGMÁTICA E} LIMITADA.

Para essa "ultrapassagem" os surrealistas procuravam ajuda na esfera do SONHO, nas visões oníricas, nas camadas mais profundas do psiquismo humano, onde as imagens reais da vida se misturam às criações cegas das forças vitais. 
A capacidade em utilizar esses encontros é o que nós chamamos imaginação.

Também para os surrealistas.

Hoje essas afirmações despertam em mim hesitações, dúvidas. Eu as devo agarrar porque elas ditam minha vida atual.

Primeira heresia

EU NÃO ACREDITO NO PODER DOS SONHOS,

onde conforme os surrealistas nasce a imaginação.

Eu estou certo que DAS FUNÇÕES PSÍQUICAS MULTIPLICADAS, UMA REFLEXÃO INTENSIFICADA ENGENDRA UMA LIBERDADE DA IMAGINAÇÃO, DE CONOTAÇÃO, FAZEM COM QUE NÓS NOS DESVIEMOS DAS LIGAÇÕES E ASSOCIAÇÕES RACIONAIS, DAS FUNÇÕES VITALMENTE UTILITÁRIAS DOS ELEMENTOS REAIS:

A máquina de costura, o guarda-chuva e a mesa de operação não estão ligadas no sonho do Senhor de Lautréamont. Disto estou seguro.

É o negócio de uma liberdade do pensamento em formação.

Os surrealistas afirmavam que o PSIQUISMO É UM ESTADO QUE É NECESSÁRIO ESTUDAR E QUE OS RESULTADOS DO ESTUDO SERVIR AO DESENVOLVIMENTO DA CONSCIÊNCIA.

Nesse ponto eu tenho dúvidas.

MAS A INCERTEZA FAZ QUE NÓS ENTENDAMOS MAIS CLARAMENTE A IMPORTÂNCIA DA “VOZ INTERIOR”.

A ARTE NÃO É PSICOLOGIA. O PROCESSO DE CRIAÇÃO ESTÁ LONGE DA OBSERVAÇÃO CIENTÍFICA.

NA ARTE É NECESSÁRIO ACOLHER O PSIQUISMO E NÃO OBSERVÁ-LO. 
ACOLHER COMO UMA NOÇÃO SUPRASENSORIAL

O PSIQUISMO - ESTE “ÓRGÃO” IMATERIAL.

“TRANSPLANTADO” SOBRE UM ORGANISMO PSÍQUICO.

CONCESSÃO DA NATUREZA OU DE DEUS -

É ELA QUE REVELA SUAS VERDADEIRAS ASPIRAÇÕES, NÃO DE

"ULTRAPASSAR A REALIDADE MATERIAL",

MAS DE SE

SEPARAR DELA.

O PSIQUISMO ESTÁ EM CONTRADIÇÃO COM A REALIDADE MATERIAL.

ELE SOMENTE A TOCA.

ELE CRIA SEU MUNDO PRÓPRIO, FECHADO, QUE É COMO O PRESSENTIMENTO

DE UM OUTRO MUNDO.

É DELE QUE EMANA A FORÇA CHAMADA IMAGINAÇÃO.

É ELE QUE CRIA OS DEUSES.

OS ANJOS,

O CÉU E O INFERNO.

OS ESPECTROS..

E agora eu entro no meu pequeno quarto

da minha imaginação e digo:

O PSIQUISMO É CAPAZ DE CRIAR E DE MOSTRAR A REALIDADE TAL COMO A VIMOS PELA PRIMEIRA VEZ. 
E isso é tudo.

E meu último conselho:

"lembrar de tudo,

e tudo esquecer..."

- Iniciado em Milão em julho e terminado na Cracóvia em 01 de novembro de 1986. 
TADEUSZ KANTOR

\section{NÃO VOLTAREI JAMAIS}

Tradução feita a partir da versão francesa publicada em: Kantor T. Les voies de la création théâtrale. Paris: C.N.R.S. Vol. 18, 1993. 


\section{APRESENTACÃ̃}

Após a encenação de $A$ Classe Morta, Kantor reivindica para suas indagações pessoais, um lugar central no seu percurso intelectual e artístico. Por esse caminho, a sua obra torna-se definitivamente autobiográfica, não somente no sentido daquilo que se refere à sua família e dos elementos pessoais que denunciam uma face da memória coletiva de uma nação, mas também pela apresentação em cena das sobras de uma "vida pessoal" a procura de uma "verdade", cujo conteúdo é difícil de se compreender e ainda mais em se representar. Seguindo esses princípios, em 1988, acontece a encenação de: Não Voltarei Jamais (NIGDY TU JUZ NIE POWRÓCE). Nesse momento, Tadeusz Kantor estava plenamente consciente das transformações que ocorreram em seu teatro, tanto que no programa de Não Voltarei Jamais ele escreve:

"Meus espetáculos:

A Classe Morta,

Wielopole Wielopole,

Que Morram os Artistas!,

e esse último,

Eu Não Voltarei Jamais,

são todos confissões pessoais

Confissão pessoal...

Gênero raro e insólito hoje em dia

A nossa época

Essa, de uma vida mais e mais coletiva

De uma coletividade que cresce de uma maneira surpreendente,

Gênero antes

Constrangedor e embaraçoso. 
Hoje eu quero trocar a razão

de minha paixão maníaca

por esse gênero.

Eu sinto que ele é importante,

Que existe nele qualquer coisa de definitivo,

Qualquer coisa que surge da percepção do

FIM.

O sentido que captura a consciência

Da substância dessa razão

Talvez, nós nos tornemos

Capazes de sermos salvos da

Dúvida completa"15.

Não Voltarei Jamais é uma espécie de reconstituição autobiográfica. Nele encontramos elementos dos espetáculos anteriores com um acento todo especial para a sua presença em cena. Após As belas e os feios, a presença de Kantor no palco junto com os atores, torna-se um verbete essencial do seu trabalho, ou seja, o encenador presente no centro da sua criação, um criador onipresente e onipotente que joga, insistentemente e incansavelmente, com a realidade e com a ilusão. É um encenador que no momento da realização do espetáculo, estimula os atores, impõe o ritmo, corrige a movimentação e o gesto, confrontado-se a todo instante com as leis da verossimilhança. No entanto, em Não voltarei Jamais, não contente em ser esse personagem, pela primeira vez, ele está em cena como ator, um ator representando a si mesmo. Um "objeto pronto", um objeto real que se opõe aos elementos de ficção. Todas as personagens, quanto o próprio Kantor, são personagens encontradas, mais do que isso, são personagens reencontradas nas suas lembranças e que estabelecerão as relações entre o passado e o presente. Neste espetáculo Kantor faz uma espécie de exumação de figuras antigas, como a Galinha d’Água, a Duquesa Kremlinska e Ulisses sobretudo. Ulisses é o último personagem a ser reencontrado, mas Ulisses não voltará realmente. Kantor não respeita a cronologia das lembranças. A peça é composta de imagens,

\footnotetext{
${ }^{15}$ No salvar do esquecimento - texto escrito para o programa de "Não Voltarei Jamais
} 
imagens vindas de todos os tempos de sua carreira. Ulisses na verdade não está no palco a não ser através da idéia do herói, do mito. Ele não aparece de fato. Apenas o seu casaco está presente. O casaco do herói cuja a cor foi corroída pelo tempo. Os trapos carregam em si a força de terem descoberto caminhos secretos e viajado por terras distantes. Entretanto, um ator é necessário para fazer existir a personagem. Para o novo Ulisses, o casaco se tornará uma camisa de força e pouco importa se Ulisses retornara verdadeiramente. O mito é muito mais forte que o acontecimento real. Assim, por esse caminho, Ulisses realmente não voltou. Entretanto um homem veio. Tadeusz Kantor, o "eu-real", metaforicamente, tornou-se Ulisses na imagem do ator que veste o casaco do herói. Ulisses na camisa de força da história. Denis Bablet, comenta em um artigo:

“... mais que todas as obras anteriores de Kantor, Wielopole Wielopole, Que Morram os Artistas!, e Não Voltarei Jamais, se situam no encontro da vida cotidiana, da história e da mitologia. Ainda falta entender melhor sobre a sua significação de "história". Conforme a concepção de Kantor, ela não o conduz na direção de um teatro político no sentido tradicional do termo, com seus engajamentos, suas lutas, suas teses, suas mensagens e suas denúncias, mas o reconhecimento de que em nosso mundo e na nossa vida toda, ato ou criação, é e só pode ser político. Se existe um humanismo em Kantor, este consiste em recusar a massificação, as ideologias e os movimentos de massa e as destruições de massas. Consiste em agir para salvar a individualidade que determina o valor de cada homem."16.

Para Kantor, a cena é o único local, uma espécie de lugar isolado, onde se pode exercer um questionamento fundamental sobre si mesmo através da encenação no espaço. Associado à manipulação das tensões criadas a partir das revelações permanecidas em suspense, as imagens surgidas na sua memória, incansavelmente projetados, flutuam no tempo suspenso. Longe de ser um trabalho de condensação da experiência individual, as imagens projetadas pela força da lembrança congelam uma história em um enigma incessantemente repetida pelo narrador. A incerteza sobre a sua própria identidade, seja no presente, seja no passado, nos coloca a dúvida quanto a autenticidade dos fatos; esses, suscetíveis de serem manipulados, permitem ao narrador contar e conseqüentemente continuar a existir.

\footnotetext{
${ }^{16}$ Denis Bablet, extraído de um artigo para Théâtre/Public, Festival d' Automne à Paris 1988, n. 84, Gennevilliers, novembre-décembre 1988, p. 15-23.
} 


\section{TRADUCÃ̃}

\section{Não Voltarei Jamais}

\section{Tadeusz Kantor}

Guia (Roteiro)

Em um instante eu entrarei

em um bar miserável e suspeito.

Eu andei muito em sua direção.

Durante muitas noites.

Sem sono.

Eu andava para um encontro,

com espectros ou pessoas, eu não sei.

Dizer que após muitos e muitos anos eu os

criava,

seria exagero.

Eu lhes dava vida, mas eles colocavam de si.

Eles não eram fáceis nem obedientes.

Eles caminharam muito tempo comigo 
e progressivamente eles aprenderam acerca dos diversos caminhos e das diversas paradas.

Agora nos devemos nos reencontrar.

Talvez pela última vez.

Como para a "Festa dos Mortos" polonesa.

Ainda uma vez eu os verei.

Após tantos anos.

Todos eram pobres,

saídos das profundezas,

desencaminhados,

corroídos (atormentados) pela vida.

Todos estão mortos.

Eles virão para esse bar

como que para o

julgamento final,

afim de dar testemunho

de nosso destino,

de nossas esperanças, de nossos entusiasmos

"sobre as ruínas",

de nosso inferno e de nosso céu

do nosso

final de século... 
Eu não questiono para

também me "fiar"

nesta ocasião.

Eu sei tudo

sobre este bar.

Eu sei também que isto se passa no momento

antes da minha chegada.

Como todos os bares, os bistrôs,

ele desenvolve-se em qualquer parte em uma

rua do sono

esquecido.

Tudo se passa

à margem do tempo.

Adiante, nós poderemos

nos encontrar

além dele.

O cotidiano se transforma imperceptivelmente

em eternidade.

Tudo perde a sua verdadeira significação,

se mistura, se agita

se destrói... 
Aqui nada está de acordo com ele.

Com as vulgares mesas de bar,

como que retiradas de um frio necrotério.

Separados, aqui não existe nada

que permita o bar

de funcionar de maneira

"barzesca".

Uma vida sepulcral exala.

Ai perdido

o proprietário

executa todos os gestos conhecidos

de um típico proprietário de bar.

Mas eles de nada servem.

Inúteis.

Uma espécie de abstração de bar

aparece

dando a ele quase que as dimensões

do inferno,

além da última fronteira,

que logo correrá o rio Estíge

de Ulisses, retornando a sua

moradia. 
Durante a guerra do ano de 44.

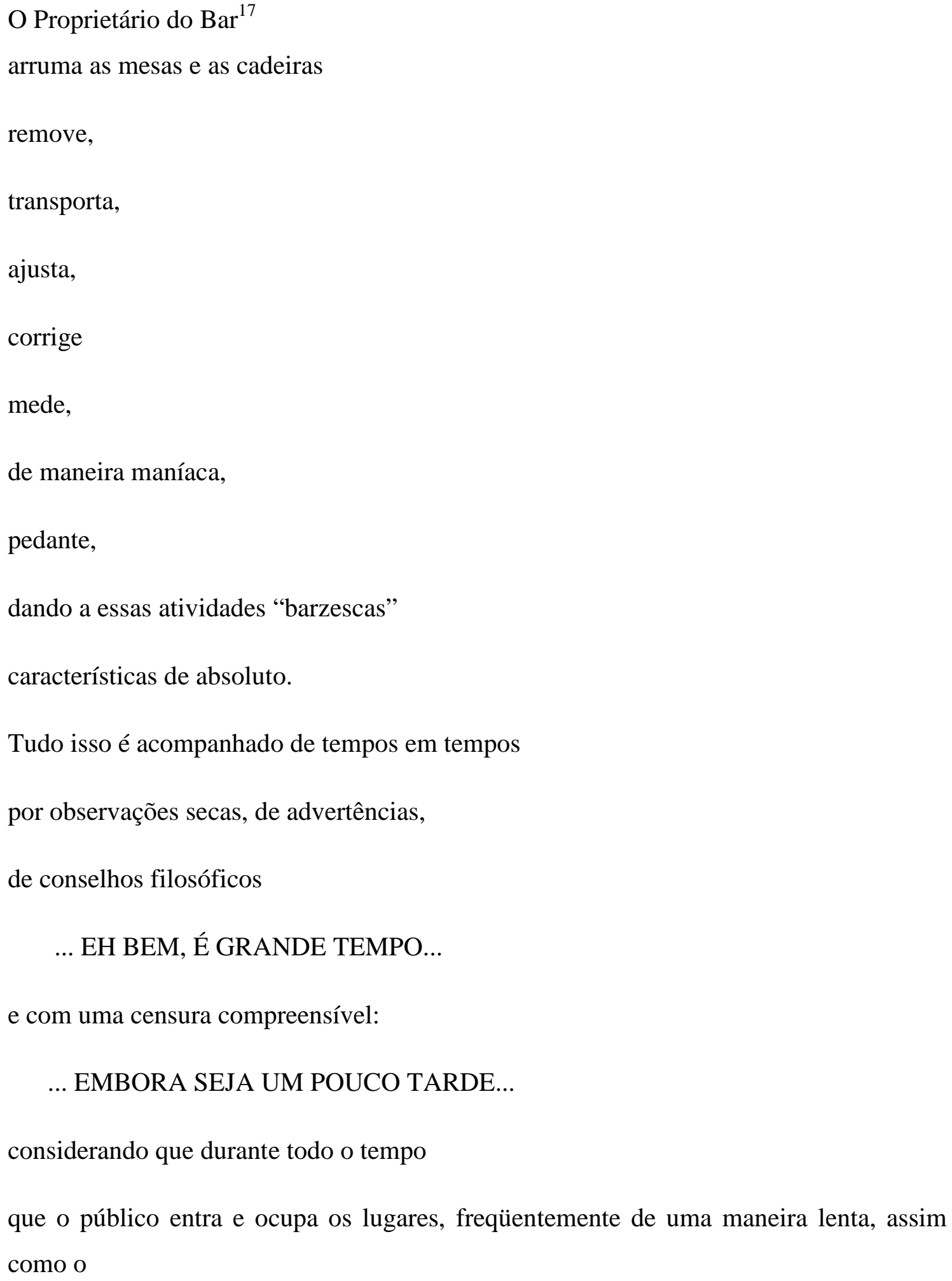

${ }^{17} \mathrm{O}$ traço vertical indica a parte verbal do espetáculo, monólogos e diálogos. 
barman, ou como as duas pessoas que estão "dormindo", tudo ocorre "cenicamente", de forma simples e evidente.

A extinção do fogo na sala "revela" o Barman. Começa a jornada do bar, e... o espetáculo.

Tranqüilizador:

TUDO AINDA ESTÁ DIANTE DE NÓS

Ele não esconde mais o seu pedantismo maníaco:

UMA LOCALIZAÇÃO PRECISA!

DISCIPLINA E SUBORDINAÇÃO!

E novamente:

TUDO AINDA ESTÁ DIANTE DE NÓS

de repente ele se ergue,

ele eleva o dedo e o aponta para o alto

e quase "o guarda para você"

ele articula como um severo pregador:

INTEGRIDADE! 
Palavra símbolo

E agonia do purista diante da realização de um erro;

E AGORA CONTAR

E SOBRETUDO NÃO SE ENGANAR

E SOBRETUDO NÃO COMETER GRANDES ERROS...

O Padre também está sentado em uma mesa

parece ser um hábito

deste lugar

de renome pouco glorioso,

distante de toda santidade e de toda a virtude.

Mas sejamos tranqüilos,

será seu instante de grandeza.

Só "no o seu lugar"

está esta "maltrapilho",

está uma Moça que a tudo

suja, usada para os prazeres da carne.

Em breve ela também obterá

seu momento de glória,

quando

dessa profundeza ela entoara a canção 


\section{AQUELES QUE VÃO PARA AS CÂMARAS DE GÁS,}

e se tornará o símbolo da

Terra Prometida.

Existe ainda o Orador de Feira,

bêbado,

contratado afim de exibir seu talento oratório duvidoso

no casamento

em preparação.

Permitiremos a ele

de pronunciar este

discurso repetido.

Ele é,

como todos os discursos oficiais feitos pelo mundo,

surdo ao destino do homem.

Que fala.

Ele é necessário.

A grandeza da cena

tem sempre necessidade

de seu palhaço. 
O Orador de Feira

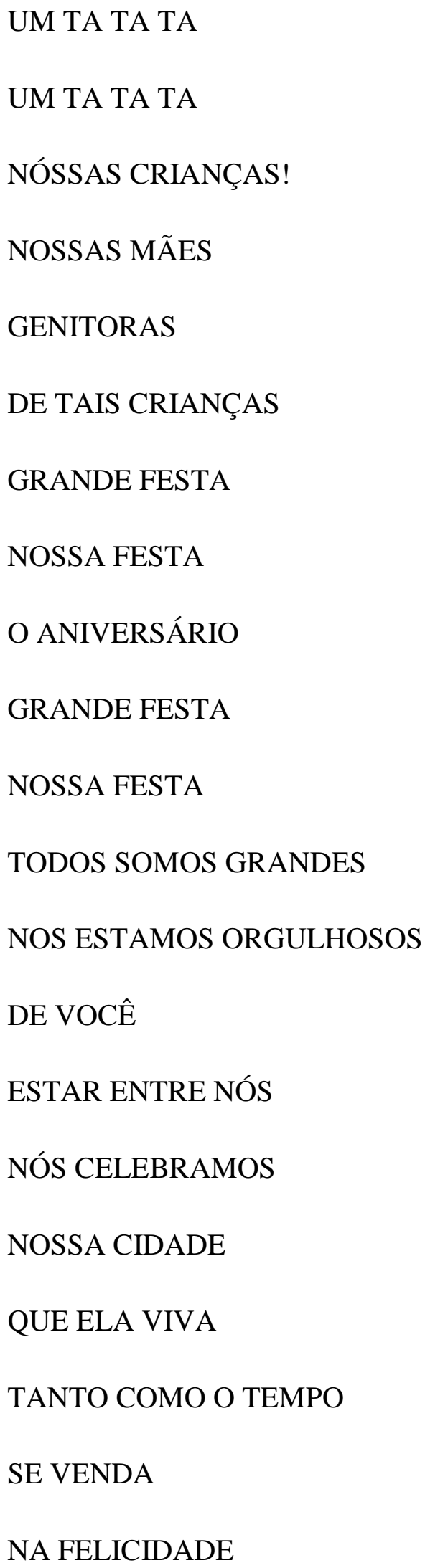




\begin{tabular}{|c|}
\hline DA NOSSA CIDADE \\
\hline CIDADE DE REIS \\
\hline DE POETAS \\
\hline DOS BISPOS \\
\hline CARDEAIS \\
\hline GENERAIS \\
\hline E ARTISTAS \\
\hline MÁRTIRES \\
\hline ENSANGÜENTADOS \\
\hline SANTOS POLONESES \\
\hline ENTERRADOS \\
\hline NESSA TERRA \\
\hline TORTURADOS \\
\hline TODOS OS SANTOS \\
\hline NOSSA CIDADE \\
\hline BEM AMADA \\
\hline E DOS MALDITOS \\
\hline DOS EXCOMUNGADOS \\
\hline DE NOSSOS FILHOS \\
\hline SANTAS MATRONAS \\
\hline PROSTITUTAS \\
\hline ILUSTRES \\
\hline ENTERRADOS \\
\hline
\end{tabular}




EM MÁRMORE
SOBRE OS MONUMENTOS
AOS HERÓIS
BEM AMADOS
DESESPERADOS
TODAS AS HELENAS
TODAS AS CATARINAS
AS ANÃS, OS JOSÉS
E DO DES MARGARIDAS
TODAS AS SOFIAS
E DO DESESTESPERO
AS AGNES ÁGATAS

Tudo isso feito e dito 
Os acontecimentos começam a

Se desenvolver inexoravelmente

Não me resta nada além de

Dar rapidamente

Os títulos enigmáticos.

Eis aqui:

1.

Choques insistentes

e golpes violentos contra a porta.

2.

Entram os convidados conhecidos,

Hesitantes " este está bem aqui (?)"

\title{
Entrada dos Atores
}

\author{
A galinha d'Água \\ Oh la la, oh la la, \\ Isso não está ai...
}


Os dois Hassindim

Aiê aiê! Ele não está ai,

ele não está ai.

A Beata

Ele vira

Ele virá seguramente

Ele esta atrasado.

\section{O Vagabundo}

Não, não!

Isso não está ai!

Partamos!

A Galinha d'Água

Vamos nós!

Em pânico, todos deixam o bar.

3.

SEGUNDA ENTRADA DOS ATORES 


\section{A Galinha d'Água}

Eu, eu não vou mais longe.

Eu, eu permaneço aqui.

$\mathrm{Eu}$, eu permaneço aqui.

Eu devo dizer qualquer coisa

com "m"

m... m... morte

a morte não é nada para mim

tudo o que é sem retorno é grande.

Eis aí no que reside a grandeza da morte,

Do primeiro amor.

Os dois Hassidim

Aïe aïe aïe Her Typowicz

Aïe aïe aïe Herr Ewader

bis jetzt haben wir nur geniale induvidua.

Wir werden zeigen was wir als die Rasse können

\section{A Galinha D’Água}

Do primeiro amor

da perda da virgindade... 


\section{A Princesa Kremlinska}

Não me fales como a uma filha das ruas.

Não me conquistas mais com isso.

Não me conquistas pela complexidade do

psiquismo

ligado a uma força máxima.

\section{A Lady Inglesa}

Isso chegou a Edgard?

Um tigre o comeu na selva

de Manjapara,

ele morreu dois dias após o acidente

e sofreu cruelmente...

E até o último instante ele dizia

as obras de

Russel e Whitehead:

Principia mathematica.

\section{O Vagabundo}

Canto:

...Eu tenho ainda sobre os lábios o rastro

de uma extenuante noite branca,

ao grande Jozek, 
na rua do Esterco
onde a fina flor se juntou
Sem comer e sem dormir
contanto que ele tivesse alguma coisa para beber
Quando Felus...

O Beato

Eu também preciso agitar meus nervos

após todas essas perversões

e todos esses segredos...

O Jogador de Cartas

Damas não damas...

As damas sempre debaixo de si mesmas...

Quando não se tem aquilo que se anunciou, se entende bem com quem jogou...

Piques jogados isso é ganho...

O Vagabundo

Canto:

$\mathrm{O}$ acordeom marca um, três, quatro temos

em surdina,

a banda dança - eu não danço... 
ele se interrompe porque a porta

se abre e entram

EU com A JOVEM NOIVA

4.

Essa é minha volta.

Descuidada.

Quase estranha.

Eu entro com ELA.

A JOVEM NOIVA

A minha.

Morte.

Em seu véu nupcial.

Ela anda quase que sonâmbula,

se senta em minha mesa.

Ela desperta o interesse geral.

Eu também alhures.

Os dois Hassidim

É ele, vejamos.

É ele!

Eu te disse -

Sente as histórias aqui... 


\section{O Beato}

Sim é ele!

$\mathrm{Eu}$ o reconheço:

os mesmos olhos

e a mesma echarpe...

\section{O Vagabundo}

E tão semelhante

\section{O Jogador de Cartas}

Esse não é ele.

A Galinha d'Água

Se tem a echarpe, é ele!

Mas porque não diz nada...

\section{A Princesa Kremlinska}

Porque ele está petrificado

5.

Os insultos

6.

Meu testamento - Monólogo 
Os espectros do passado

como todos os espectros,

cruéis e impiedosos.

Eu me ergo diante deles

insultado,

ridicularizado

e acusado.

Eu

Senhoras!

E senhores!

De onde eu venho?

\section{O Padre}

Não do céu,

não do céu.

Eu sempre estava diante da porta

e... eu esperava

\section{Os Dois Hassidim}

Nós esperamos todos,

É necessário aceitar isso.

Que esperamos nós?

Mais vale não falar.

Todos sabem.

É necessário esperar. 


\section{O Vagabundo}

O quê esperar?

Desprezo sobre tudo.

Somente o idiota espera.

O Louco.

Não existe nada a esperar.

E agora eu estou sentado!

No centro!

Personagem importante

E todos esperam...

Que eu me vá

\section{A Galinha D’Água}

Ele queria sempre estar no centro

E agora ele aparenta

ser humilde.

Olhe-o!

VOCÊ...

Não me olhe assim!

Pouah!

\section{A Beata}


Uma galinha banal e idiota

Eu

Eu estava próximo da porta...

A porta...

A Beata

e essa espera

Ele estava sempre perto da porta

"molto importante"!

Sempre!

O que ele esperava?

Nós jamais saberemos.

\section{A Galinha D’Água \\ O que ele espera.}

Ele espera o dia do julgamento

Mas nós não esperamos.

Nós não vamos chorar.

\section{O Vagabundo}

Mas eles vão zombar de você.

E após te recobrir,

te enterrar,

te sepultar,

e não restará nenhum traço

Nada! 
Eu

É preciso ir...

É preciso que eu siga o caminho

Até à extremidade.

\section{Os Dois Hassidim}

O Fim...

Finalmente a cada um o seu próprio fim.

É esta sombra

que nos anda sobre os calcanhares.

Eu

Senhoras

e senhores

Vocês vão olhar

Isso!B

E em seguida você pode

Me esquecer!

Me esquecer!

\section{A Beata \\ Como tudo isso é triste!}

\section{A Galinha D’Água}

Agora ele quer

que nós olhemos,

que nós choremos.

Mas nós não vamos olhar.

Nós não vamos chorar. 


\section{Eu}

Nós dormiremos esta noite...?

Nós nos revelaremos ao meio...?

e nós olharemos o teto

com os olhos cegos?

Senhores e senhoras

Senhoras

e senhores

uma torrada senhores!

Dança geral

O casamento

\section{Eu}

Queridos colegas

Atores

Vocês os atores

vocês devem ter forças

Todos

e conservar uma higiene de vida

No meio dos

afim de ir na direção das alturas

aplausos!!!

razoavelmente e terapeuticamente

no meio dos aplausos. 
Eu

Sim, no meio dos aplausos.

E eu afim de criar alguma coisa,

De criar esse mundo no qual

Você se içará solidamente

em direção das alturas

e no meio dos aplausos

eu devo cair até o fundo

e... eu caio,

eu caio terrivelmente.

\section{O Padre}

Que falta de fé!

\section{A Galinha D'Água}

Que ele caia,

Que ele caia.

E nós, nós içaremos

em direção das alturas.

Eu

Eu sujeira, lixo

esterco, porcalhão 
repugnante, podre

porco, barbilhão

eu - eu desço

para o diabo

Os Dois Hassidim

Mas no caminho eu

Zum Teufel!

Gritarei em alta voz

Zum Teufel!

Eu vou gritar

Feito um possesso.

\section{A Galinha D'Água}

Não trabalhou?

Nós sabemos a que nos segurar

Nós não moveremos um dedo

\section{A Princesa Kremlinska}

Um pouco mais de

grandeza de alma!

Eu

Tal são nossos

O Padre

Caminhos

Oh não!

OPOSTOS!

Existem dois caminhos.

Um caminho aqui,

e outro lá adiante; 


\section{A Beata}

Isto que dizer que

nós devemos nos separar.

Que pena!

Eu

Quando se está

muito infeliz

A Princesa Kremlinska

de repente nasce

Bem, bem!

no homem -

Alguém que torça como

você,

neste dejeto

e que ousa dizer tais coisas,

uma força prodigiosa.

e mesmo em francês.

É preciso

cuidar

De início

o infortúnio e em seguida

esta força

E em verdade

eu não tenho nada mais

A Princesa Kremlinska

a dizer

Se poderia duvidar. 


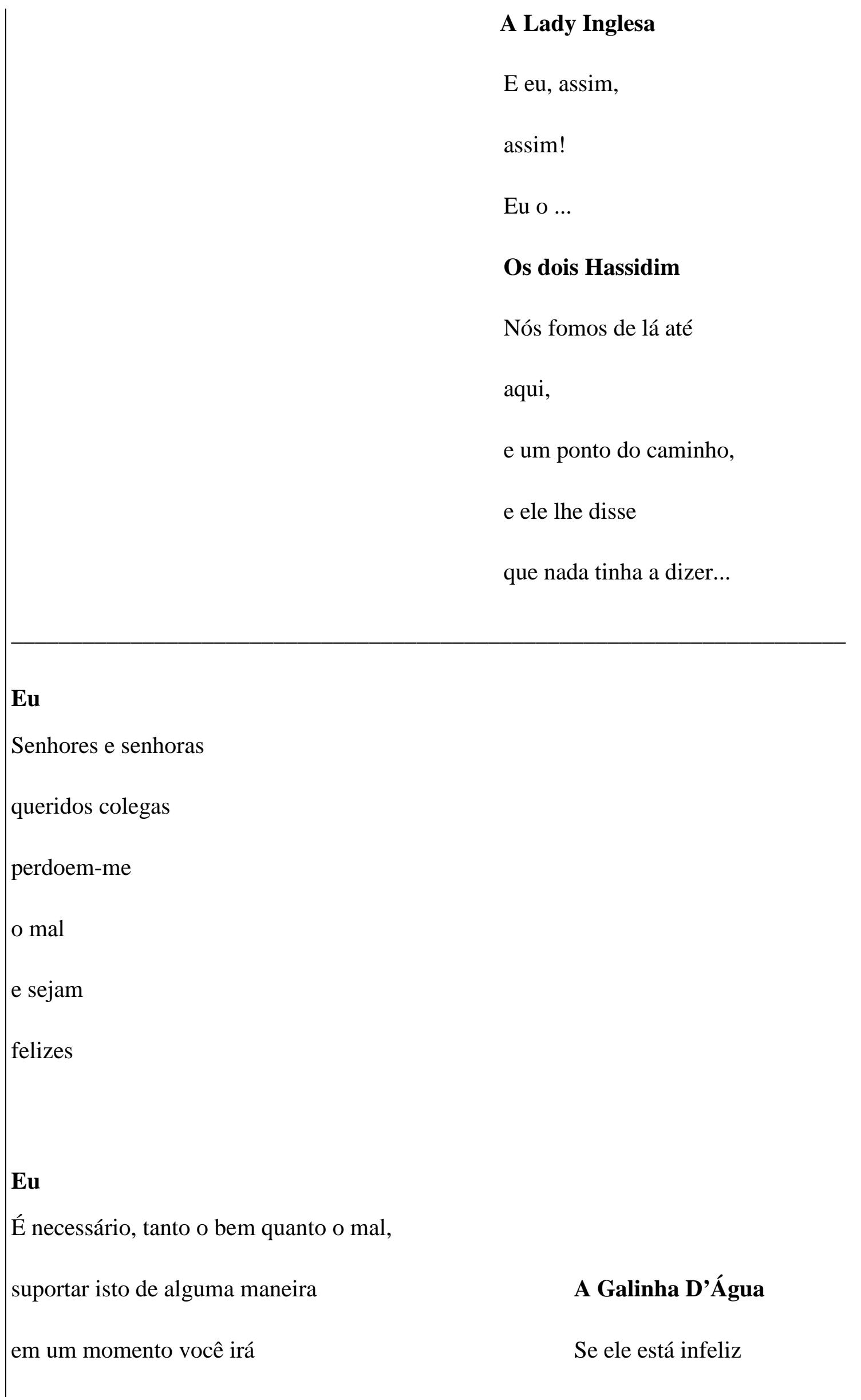


comigo até as profundezas -

é preciso ajudá-lo.

as profundezas -

$\mathrm{O}$ artista deve estar

Todos

sempre nas profundezas

Ajudar!

porque para ser entendido

Ajudar!

não se pode gritar

Que ele não sofra.

das profundezas.

Lá, nestas profundezas

\section{A Beata}

talvez

Mas o mais importante,

nós compreenderemos.

isto tudo

terminará bem?

Em seguida

Não desças mais

Se não sabia...

ao inferno

a menos que

\section{O Vagabundo}

Pouco tempo te resta,

o homem,

é preciso te apressar.

Apressa-te homem, 
apressa-te.

7.

A execução.

8.

A metralhadora nascida em "Wielopole"

tiro em série,

sem sucesso.

É sempre assim

na ilusão e no sonho.

Sem prejuízo, eu parto.

9.

Os espectros fogem

porque este é o destino dos espectros.

10.

Somente ELA permanece. 
Minha jovem esposa.

Como se ela soubesse que seu papel

ainda não estava terminado...

11.

Mas o Proprietário do Bar

E os convidados,

que vieram,

não se sabe porque.

Com respeito, elegância

Ele estende a mão,

Levanta seu chapéu,

E passo a passo

solenemente

a conduz,

como nas danças antigas,

ou como em um enterro...

\section{Digressão}

Esse é o momento

de se recordar dos participantes

das antigas batalhas do Cricot 
que foram arrastados até aqui

para o último encontro.

Eis aqui:

\section{A Galinha d'Água}

com sua

banheira

na qual impiedosamente

ela mergulhou em 67.

\section{Os dois Hassidim}

com

o último palco de teatro (tábua de salvação)

testemunho dessa infame

morte de circo.

\section{A Lady Inglesa}

Se exibe com as

santas memórias, do marido,

o Lord, comido por um tigre

em Manjapara - Selva.

ela o transportava sempre em uma valise 
ao redor do mundo com o Teatro Cricot.

\section{O Vagabundo}

com seu amante

o rival do Lorde de santa memória,

em 67, até a

galinha d'Água...

Adiante

\section{O Grande Ginasta}

"preso" um saco nas costas,

pesadelo

que faz

de uma certa maneira, a nova espécie humana.

Meio-homem, meio-saco.

Como as metamorfoses antigas.

No final

O ano de 85 , e

Que Morram os Artistas:

O velho Vagabundo é transformado

No enforcado

Ele se realiza agora

com suas canções chulas sobre um 
bordão.

O pequeno Adam de Wielopole

torna-se um

Jogador de Cartas

inveterado.

A Corte do Santo

François Villon.

SEQUÊNCIA DOS ACONTECOMENTOS

12.

Eu volto só.

Tudo está confuso

na expectativa de alguma coisa importante.

Como em um sonho.

13.

Entrada do Padre

que deve realizar uma cerimônia

de caráter indefinido. 
14.

O Padre negligencia

seus deveres.

15.

A porta principal se abre.

para a frente

se escorrega,

porque é difícil de dizer

"ande"

UM JOVEM CASAL.

Nós sabemos finalmente

qual é o motivo

desse bizarro e múltiplo

REENCONTRO.

O JOVEM CASAL

é: minha JOVEM ESPOSA

morta

e EU -manequim.

Sim - Eu estou duplicado.

Essa não é a primeira vez, 
alhures.

16.

Um casamento não habitual.

Ou seja: uma Barraca de Feira.

\section{O Padre,}

que, se possa acreditar, está presente

afim de cumprir dignamente e solenemente

a cerimônia do casamento,

está tomado de uma maneira absolutamente afastada de toda espiritualidade

de um furor de dançar ao ritmo de uma melodia de tango argentino

que ressona repentinamente.

No final das contas o casamento é celebrado

pelo Proprietário do Bar.

E na verdade tudo está

em seu lugar,

e tudo está de acordo: com o Bar e as leis do Bar,

com as leis do circo e do teatro

Cricot. 


\section{O Proprietário de Bar}

declama a fórmula do casamento

sem convicção pessoal.

É difícil chamar isso de uma cerimônia solene.

\section{O PROPRIETÁRIO DO BAR}

É POR VONTADE PLENA E SEM CONSTRANGIMENTO

PARA RECEBER ESTE QUE ESTE QUE VOCÊ VÊ AQUI

POR ESPOSA?

E VOCÊ... É POR VONTADE PLENA E SEM CONSTRANGIMENTO

PARA RECEBER ESTE QUE ESTE QUE VOCÊ VÊ AQUI

POR ESPOSO?

EU... EU TE RECEBO POR ESPOSA

E TE PROMETO FÉ, AMOR E OBEDIÊNCIA

E TAMBÉM QUE EU NÃO TE ABANDONAREI

ATÉ A MORTE.

COM A AJUDA DE DEUS TODO PODEROSO

ÚNICO EM TRÊS PESSOAS E DE TODOS OS SANTOS

AMÉM.

17.

O proprietário do Bar preparou algumas surpresas. 
De antigas aparições "usadas"

datando do grande esplendor do teatro do passado:

Dois bispos,

Os Hassindim com seu "Mazel Tov" nupcial

e o rabino de Wielopole.

18.

Não previsto pelo proprietário do Bar

Surge um desfile alucinado de espectros

"da orquestra de Violinos dos Blindados".

Uniformes conhecidos,

os pés em botas lustradas

projetadas para o alto,

vários violinos de ferro,

com seus arcos - para o alto, e para baixo.

E para completar esse

pesadelo,

diante deles o Rabino

Szmul, saído de

sua Sinagoga em Wielopole,

louco de terror

ele dirige seus 
Carrascos.

E com a Orquestra dos Blindados

breve, igualmente aterrorizado

a Louca Lavadora de Louça.

Em um instante nós a veremos

em seu papel verdadeiro:

a trágica Cantora

da Terra Prometida.

Os espectros desaparecem.

A cerimônia do CASAMENTO-SONHO

de toda evidência está concluída.

A JOVEM NOIVA do sonho

de casamento

desaparece, como acontece

normalmente nos sonhos.

Em seguida o Jovem Casal desaparece

o Proprietário do Bar

fecha a porta

com solenidade.

Como uma pedra funerária.

19. 
O Proprietário do Bar

teve emoções suficientes.

ele se lançará sobre a Lavadora de Louça com os Pés-Nus.

Ele a cobre com as piores injurias

e a coloca na porta.

Ele limpa tudo como se pudesse

apagar todo traço

dos convidados do "outro lado".

Um último olhar para ver

se tudo está em ordem.

20.

É quem se esperava,

a Louca Lavadora de Louça.

Ela surge.

Em uma loucura de destruição

ela revira as mesas e

e bate os bancos

como castanholas.

- Após um casamento deve se

desenrolar as núpcias. 
E o Baile.

21.

Os convidados do casamento saltam.

Em uma espécie de frenesi

uma barulhenta dança para o casal

rodopios em círculo.

22.

De repente se bate á porta.

Cada batida é mal um agouro.

Silêncio.

A música se para

a Louca Lavadora de Louça, abre a porta.

Sobre o umbral

o "espectro" de Ulisses.

Um convidado retardatário do Casamento.

Ele chega das profundezas do tempo,

do tempo da guerra dos anos 44 .

Nada além dos RESTOS,

como saídos da tumba.

Um uniforme de Guerra, 
estendido sobre a cruz.

E uma voz, vinda do alto:

...’Eu sou Ulisses

Senhor de Ítaca..."

Repete com em eco.

A Lavadora de Louças grita:

"Na noite de 24 de janeiro

do ano de 44

Ulisses retornou

à Cracóvia

junto de sua Ítaca"

Ulisses que, neste tempo,

sobre a cena do Teatro Clandestino

indicou a direção

de minha VIAGEM,

após os numerosos anos

voltam ao meu Sonho

de Casamento, para a Festa.

ele estava aparentemente ansioso 
por estar PRESENTE.

23.

Lentamente nós chegamos ao ponto.

Os convidados da festa de casamento, dançando

retiram-se.

como diante de uma aparição da guerra.

24.

Batendo novamente.

A Lavadora de Louças canta pequenos versos

A porta. Abre.

sobre o umbral um novo

convidado:

O Espectro de meu PAI.

Se coloca brutalmente

no interior.

Após ele, na porta,

se comprime totalmente

a orquestra dos Blindados.

Voz de meu Pai:

"Eu morri em 24 de janeiro, 
do ano de 44".

A mesma data.

E imediatamente

o comunicado "administrativo"

do Campo da Morte.

Wir machen Ihen bekannt da

Marian Kantor

Den vier-und-zwanzigsten Januar

Den vier-und-zwanzigsten Jahres

Am Herzschlag

Gestorben. Gezeichnet

Obersturmführer Rudolf Stamm.

25.

Agora nós sabemos:

este é o tempo da guerra.

pela porta surge uma loucura de

fugitivos

do ano de 39.

Os fugitivos carregam penosamente as 


\section{CARTEIRAS ESCOLARES,}

em pânico e desespero.

Esses são os mesmos,

os espectros de meus atores ambulantes.

O ano de 75.

A Classe Morta.

Permanece somente o eco das palavras,

dos papéis e dos cantos.

Eis ai

as "Chamadas" de A Classe Morta

tal como se entende

no curso do "Dia dos Mortos" polonês

nas igreja e nos cemitérios:

PELAGJA SITO

BASIA WYPOREK

JOZEK WRONA

MARCIN POKORNY

SZCZEPAN PALUCH

JASIU MICHNIK

WOJTEK MARTYKA

LEOS PIERONEK

EMILKA MIGON

TEOS PIETRYKA 


\author{
BLAZEJ PIETRAS \\ HELKA WYLEGALA \\ PELAGJA SZUREK \\ GRZEGORZ MICHTA \\ HALINA MIGON \\ BRONKA MIKRUT \\ JEDREK MATELA \\ HELA MAGIERA \\ PAWEL LOBODA \\ JOZEF LICHWALA \\ WITKA LEGUTKO \\ STASZEK KURTIKA \\ FRANCISZEK KUSIAK \\ JOZEF KOPEC \\ WIKTOR KONDELKA \\ LUDWIG KAPALA \\ WIKTOS PLICHTA \\ WINCENTY PISCZEK
}

em seguida,

em A Classe Morta igualmente, os jogos de palavras,

sem significação,

cheia de brincadeiras de crianças: 
FUMCE KAKA

FUNCE KAKA

FUM CE KA KA

FUMCE KAKA

FUMCE KAKA

FUM CE KA KA

PERE PERE PERE

PERE PERE PERE

PERE PERE PERE

E no final

as lamentações.

\footnotetext{
“aj na nyna

aj na nyna

aj na nyna nyna nyna

aj na nyna

aj na nyna"

e assim ao infinito...
}

No extremo do esgotamento 
Eles adormecem sobre as "ruínas"

Dos bancos.

26.

O Proprietário do Bar

outra vez perde a paciência.

ele expulsa a Trupe Ambulantes

dos atores.

Eles partirão na direção de outras viagens.

Assim é seu destino.

27.

Pobre Albergista.

Ele não pressente

Que ainda representará um papel,

E qual papel!

Ainda uma vez A Orquestra dos Blindados.

Eles aparecem de todos os lados.

Marcham ao passo.

Seus calçados ressonam. 
esta mesma melodia:

O canto daqueles que se dirigem às câmaras de gás.

Eles se lançam sobre o Proprietário do bar.

Colocam nele

O UNIFORME DE ULISSES.

"fantasia de guerra"

O Proprietário do Bar-Ulisses.

Ainda

uma brincadeira -

como sobre o Gólgota

e a orquestra dos blindados

dispara.

Começa o espetáculo

O Retorno de Ulisses do ano de 44.

- aparece o deportado da Sibéria,

o violinista das ruas de Wielopole,

aqui Fémios, o poeta.

Ulisses mata o Pastor

O pastor é

"O Valete da Princesa Kremlinska" 


\section{O Pastor}

Você o mendigo, - vem e

mostra o

"Deportado da Sibéria".

Fémios representa...

Eu reconheço isso que ele representa: como Ulisses venceu os muros

Troianos e como assassinou Tróia.

\section{Ulisses}

Eu retorno de Tróia!

Eu sou Ulisses, o senhor de Ítaca.

Olhe!

\section{O Pastor}

Pelas sombras do Hades, - Ulisses vivo.

Se dizia que você havia perecido,

se dizia que você havia perecido.

\section{Ulisses}

Eu posso entrar em minha moradia eu pensei, em observar de longe, 


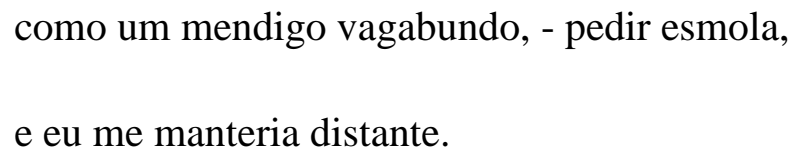

\section{O Pastor}

Os pretendentes estão em sua casa.

\section{Ulisses}

Não diga nada.

\section{O Pastor}

Vá dormir.

\section{Ulisses}

E você sabe velho,

talvez seja eu um fantasma que amedronta as pessoas.

\section{O Pastor}

Você um fantasma!

Mas eu segura a mão.

\section{Ulisses}

Largue minha mão! 


\section{O Pastor}

Ajuda! ajuda! Socorro!

\section{Ulisses}

Olhe! Você vê um espectro!

Deite aí! Cachorro!

Ulisses mata o pastor e sai.

Telêmaco é

“A Beata" (de Que morram os artistas)

O Segundo Beato é

"A Galinha d'Água"

Telêmaco se revela um filho idêntico ao seu Pai.

\section{Telêmaco}

Quem está ai?! - Responda, quem está ai!

\section{O Pastor II}

Eu vi uma sombra! O espectro de meu mestre.

\section{Telêmaco}

O espectro de meu Pai! 
Para!

\section{O Pastor II}

Seu Pai retornou em segredo.

\section{Telêmaco}

Meu Pai retornou!

Retornou - meu Pai.

\section{O Pastor II}

Você o reconheceu por seu movimento, como ele batia, - a mão segura.

Os pretendentes ocupam os quartos de sua casa.

\section{Telemaco}

E se eu -

\section{O Pastor II}

É você? Você pode?

Não importa qual dentre eles você derruba com um soco.

\section{Telêmaco}

Cala-te, cão, patife! 


\section{O Pastor II}

Você não pode nada. O casamento de sua mãe acabou, você

veio a mim, meu querido. É sem dúvida isso que você espera.

\section{Telêmaco}

O quê?!

\section{O Pastor II}

É sim, caçado.

\section{Telêmaco}

Cachorro!

Os teus! - Os teus!

Ele caiu, - Ele agoniza -

Eu matei.

Pai! Pai!

O sangue de meu Pai!

Telêmaco mata

o segundo Pastor

com o bastão

que Ulisses utilizou para abater 
o primeiro pastor.

Apertados

sobre os bancos

"Os Fugitivos da Guerra",

"Os alunos de A Classe Morta",

e agora

“Os Pretendentes" de Penélope

aguardam sua cena

e... Penélope

é conduzida por um desses

artistas-vagabundos...

morta.

Ele a carrega em seus braços

inacreditavelmente rígida.

Seu véu nupcial cai por terra.

Nesse mesmo tempo Eu entro -

$\mathrm{Eu}$,

porque aquela que se carrega

morta,

que deve ser Penélope -

vem de meu

SONHO de CASAMENTO.

Minha JOVEM ESPOSA. 
- Praticas desavergonhadas dos Pretendentes.

- Um Miserável Vagabundo

transmite aos Pretendentes distraídos,

a “mensagem" de Penélope.

“Cubram suas cabeças em sinal de adeus.

Eu chamei os deuses hoje

eu disse que os presságios ordenam

que os ruídos cessem em nome dos deuses

reinará aquele que ultrapassar os outros sob meus olhos.

até amanhã à aurora eu lhes dou o tempo,

quem vergar o arco pela força, este será meu esposo

que venha a mim aquele que quer esticar o arco".

Os Pretendentes ao redor

pegam o célebre arco

de Ulisses.

Eles tentam curvá-lo e esticá-lo.

Mas isso não pode ser realizado

a não ser pela força de Ulisses.

Entre os Pretendentes de Penélope 
começa uma luta.

Cada um deles

pega o arco, o dirige na direção

de seus companheiros

anunciando.

Eis aqui exatamente

"o diálogo de guerra"

de Wyspianski:

\section{Antínoos \\ Me dê o arco. \\ Eurymachos \\ Com qual direito? \\ Antinoos \\ Eu sou o primeiro entre vocês}

\section{Eurymachos}

Empáfia.

Antínoos

Me dê o arco! 
Agleaos
É a para nós que ele quer apontar!

\section{Eurymachos}

Pegue você o arco e aponte para mim!

Frouxo!

Agleaos

Curve o arco!

Arnajos

Curve o arco!

Os Pretendentes

Curve o arco!

\section{Melantios}

Ah! Socorro!

\section{Antinoos}

Bandido! Traidor impiedoso. 
Ulisses

Entra sorrateiramente.

Ele aproveita o barulho da luta,

ele apanha do chão

o arco

deixado pelos Pretendentes.

Em um instante se realizará

a cena do

MASSACRE

e da

VINGANÇA.

O padre que está em evidência

Habitante de

A Classe Morta

coloca todos

nas carteiras

Ao seu sinal

toda a classe começa

a falar:

Trumf

trumf 
Misia bela
misia kasia
Komfacela
Misia a
misia b
misia kasia
Komface...

Eles repetem mais e mais rápido.

A esse alegre

jogo de palavras

se juntam pela terceira vez

os sons violentos da

metralhadora -

$\mathrm{O}$ arco de Ulisses.

Massacre

e vingança.

Os Bancos e os Corpos dos

mortos

formam

um grande

amontoado 
de a Classe Morta

e do

Retorno de Ulisses.

Eu aguardo a saída

da Galinha D’água

que em um instante

deve transformar

sua banheira

dos anos 67

no barco de Caronte.

28.

Eu estou sentado com Ulisses em uma mesa de bar.

É necessário terminar a história do herói de Tróia.

Mas Ulisses, sentado, rígido,

em seu uniforme de guerra

faz o efeito de um

MANEQUIM.

"Em baixo"

está o Proprietário do Bar...

Em meu exemplar de encenação do ano 44 
eu leio com dificuldade

o epílogo.

Em minha própria Pátria

eu encontrei o inferno.

Eu penetrei em um cemitério

eu tudo matei.

Eu tudo rejeitei.

Aquilo que era felicidade falsa

Fugiu.

Nada, nada

depois de mim

nada antes de mim.

As praias de Ítaca de meus Pais.

Criança, eu percorri

esses caminhos.

As gaivotas planam

sobre os mares,

pássaros de minha infância.

Por lá! Por lá!

Por lá é Ítaca.

Por lá está

minha Pátria. 
Por lá o canto de minha vida
terminou!
Ninguém volta vivo
ao país de sua juventude.
Eu tinha minha Pátria em meu coração
- hoje eu a inalo
e só adoeço dela.
Sombra, eu adoeço após uma sombra.

Ouve-se um tumultuo.

O barco está cheio

de pessoas! Eles se movem,

eles chamam.

Eu não os posso reconhecer.

O que é isso?

Quem são eles?

Eles gritam alguma coisa. Eles reclamam,

Se divertem?

As ondas me separam das suas vozes,

as ondas separam

o Barco dos mortos.

29. 
O Barco e Caronte.

A Galinha D’água

está transformada em Caronte.

Sua banheira

num Barco transportando

os mortos para

a outra margem do Aqueronte ${ }^{18}$.

O Barco conduz

as vítimas tombadas sob

o Arco de Ulisses.

Os personagens do Teatro Cricot.

30.

Ulisses (o Proprietário do Bar transformado)

muda definitivamente.

31

Eu permaneço só.

Eu, Ulisses.

\footnotetext{
${ }^{18}$ Em Francês - Léthé - Rio dos infernos, cujo nome significa esquecimento.
} 
32.

Minha "antiga

identidade"

é confirmada energicamente pela entrada

de alguém que não é outro

senão

o Proprietário do Bar.

Ele retorna para, ainda uma vez,

repor a ordem

e mostrar

que apesar

dos

convidados e acontecimentos

"sobrenaturais",

Tudo isso trata-se de um bar convencional

e verdadeiro.

33.

Por trás retorna

minha JOVEM MARIA.

Ela se senta em minha 
mesa.

Imóvel.

34.

Inexoravelmente os Espectros dos Atores do Teatro Ambulante

retornam.

Como para uma revanche

eles dão uma magnífica demonstração da arte dos atores.

Confusão total.

Cada um deles quer se apoderar da palavra.

Eis aí!

\section{Os Hassindim}

Todos vão ao diabo. Os semitas se afastarão sempre. Existem muitos cadáveres na rua. Tomaram nosso carro. Aqueles que nós transportávamos foram espancados, e eles partiram com loucura sobre as barricadas na direção da rua dos Rapazes Sem Escrúpulos. Mas isso é o que eu digo, tudo é como um sonho. Nossa companhia não existe. O novo governo suprimiu todos os empreendimentos privados. Nós não temos aquilo que está nos bancos estrangeiros.

\section{A Beata}

Quem quer viver a felicidade maior do esgotamento consciente. 


\begin{abstract}
A Lady Inglesa
O que aconteceu com Edgard?

Um tigre o comeu na Selva de Manjapara. Ele morreu dois dias após o acidente.Ele tinha o ventre dilacerado e sofria horrivelmente. E até o último instante ele lia as obras de Russel e Whitehead: Principia mathematica.
\end{abstract}

\title{
A Princesa Kremlinska
}

Não me fales como uma filha das ruas. Não me conquistas assim. Me conquistas pela complexidade do psiquismo ligado à uma força máxima.

\section{O Jogador de Cartas}

As pego uma vez.

Espadas são jogadas, pequeno naipe de espada sobre pequeno az - e pequenas espadas para o herdeiro.

E ele, com um naipe de paus.

Os paus, cor pequena, mas tomadora.

Az em guarda, nada nas cartas.

Nenhuma figura, e figura sobre figura como dizia Santo Igure.

Não saia ruminando naquilo que não é exposto.

Ele está exposto e decomposto.

Escurece em Szczecin minhas crianças

Quando não existe aquilo que foi anunciado se expõe com aquilo que se representa.

Damas não damas - As Damas sempre debaixo de si mesmas.

A carta não é um porco, à meia noite ela muda novamente... 


\section{A Galinha D’Água}

Há, há, há!

Eu minto sempre.

Eu não estou nem aí.

Eu vivo na mentira.

Existe superioridade na mentira.

\section{A Beata}

Eu daria tudo para morrer como ele!

\section{A Galinha D’Água}

Tudo o que é irreversível é grande.

Somente nisso consiste a grandeza da morte, do

primeiro amor,

da perda da virgindade e assim sucessivamente...

Vem, beije-me o rosto uma última vez..

35.

Entrada de "Esses Senhores Sérios"

E o último deles, aquele que

na lista dos personagens

é brevemente notado:

MADAME. 
Não se sabe se ela está

entre eles, se

ela os dirige...

E talvez dirija

todo o espetáculo...

36.

A Grande Embalagem

do fim do século XX.

Sem comentários!!!

37.

A Criada com os Pés Nus

A Criada do Grande Caronte,

A "Cantora da "Terra Prometida"

desenterra o esplendor do nosso século.

Sua "Pompéia".

38.

Todos, como de hábito, 
ao final

abandonam a cena.

Eu permaneço só. Com a minha JOVEM NOIVA.

É ELA quem termina o espetáculo.

Eu não LHE sirvo de ajuda.

“depois de vocês!"

e: aqui, Eu não voltareis jamais.

Fim 
TADEUSZ KANTOR

\section{HOJE É MEU ANIVERSÁRIO}

Tradução feita a partir da versão francesa publicada em: Kantor T. Les voies de la création théâtrale. Paris: C.N.R.S. Vol. 18, 1993. 


\section{APRESENTACÃO}

De uma maneira geral, é possível dizer que as personagens do teatro de Kantor são projeções do próprio artista; e que as imagens, as palavras, emergem de largos planos de obscuridades, onde todas as tentativas para se encontrar uma coerência, ainda que figurativa, para que se possa organizar, em uma sucessão narrativa as imagens formadas na memória, tornam-se inexoravelmente arruinadas. Dessa mesma forma se dá a montagem em 1990, do seu derradeiro espetáculo: Hoje é meu Aniversário (DZIS AS MOJE VRODZINY).

O pobre "quarto da imaginação" de Kantor, colocado em cena, sofre constantes transformações: um asilo noturno, um cemitério e o próprio ateliê do pintor. Neste quarto ele encontra a sua "sombra", a sua própria embalagem, seguindo o mesmo exemplo da Infanta de Velázquez: seu Auto-retrato o imita, copia seus gestos. Em determinado momento, Kantor fala ao público acerca do fato dele estar em cena, e que isso se trata de um resumo da sua vida, da sua obra e do seu método. Durante o tempo da fala de Kantor, o Auto-retrato tem uma crescente loucura de imitação. Ele se debate no estreito interior da moldura onde se encontra. O Auto-retrato tenta repetir as frases ditas por Kantor ao público, mas tudo acaba em um grito ou em um balbuciar desconexo. Mais uma vez se percebe uma linha que caminha no sentido da ilusão para o mundo real. Esta operação sempre ocorre no sentido da ilusão para a realidade. Segundo Kantor, esse é um acontecimento único e deve se constituir em uma revelação cênica repleta de uma potência de ação transtornadora, situada entre as dimensões do riso e do choro.

Saindo da tela o Auto-retrato fixa seu olhar sobre Kantor tentando imitá-lo fielmente: seus movimentos e seus gestos. Mas suas imitações são sempre medíocres. O Auto-retrato volta ao seu lugar no interior da tela. Hoje é meu Aniversário tornou-se um espetáculo onde Kantor expõe suas convicções acerca da estética teatral. Uma dessas convicções trata a questão do ator e da imitação. Para ele, a imitação sempre deforma o 
objeto real. Segundo suas convicções, os atores não devem imitar o que não são. Devem sobretudo ser aquilo que realmente são no cotidiano:

“... nós não representávamos. Nós éramos no palco o que éramos no nosso dia a dia...”."

Nesse espetáculo-síntese, a exemplo de Não Voltarei Jamais, aparecem personagens de outras peças como o Bedel e a Mulher do Berço Mecânico de A Classe Morta e o Carregador de Água de Wielopole Wielopole. No contexto da redescoberta das personagens e dos objetos que povoam a sua memória, a Infanta de Velázquez se materializa no palco. E por mais uma vez, a ilusão caminha de encontro com a realidade. As duas telas pintadas pelo pintor e que convivem mutuamente no seu quartoreal, encontram-se na ficção. No palco o seu Auto-retrato e a Infanta têm vida própria, e suas peripécias não concordam com as intenções do autor da tela. É possível perceber aqui a idéia de que uma vez constituída, a obra de arte é, e existe, independentemente das intenções do criador. Ela torna-se autônoma transcendendo qualquer vontade que limite sua natureza que é a de causar estranheza e fascínio.

Esse último espetáculo é todo construído antes de ser colocada, no papel, qualquer espécie de reflexão. Isso tornou-se necessário para que as ações fossem totalmente espontâneas e tivessem plena liberdade. Existe aqui uma necessidade de libertação de certas idéias e obsessões que o impedem de criar livremente. Estas obsessões possuem sua origem na brutal necessidade que Kantor possui em detalhar toda a carga emocional que ele investe em cada elemento de cena. Este "quarto da imaginação" que se instala sobre o palco acaba por se tornar uma grande digressão teórica do seu espírito criador. Nele estão reflexões de toda a sua vida de artista. Toda a sua riqueza, não somente de seu conteúdo visual, mas principalmente de toda a sua dimensão histórica e afetiva, da sua percepção do irreal, dos seus encontros com a morte, às vezes companheira, às vezes adversária. Às vezes rival e ao mesmo tempo cúmplice e amiga. Estas reflexões são analisadas e entregues ao público que pode seguir as várias fases dessa longa e fascinante jornada artística. Contudo, Kantor não necessita

\footnotetext{
19 Zófia Kalinska, atriz polonesa que por vinte anos trabalhou com Tadeusz Kantor e o Cricot 2. Entrevista realizada no Brasil no ano de 2002.
} 
justificar as variações ou as contradições contidas nas suas idéias ou nos seus diferentes itinerários, muito menos as suas ligações com outros criadores e seus julgamentos e aproximações com as diversas correntes artísticas do século XX. Kantor é um artista que se dá o direito de conceber a arte e o mundo a sua maneira e sem restrições. A sua própria história trata-se de um "objeto pronto" no qual ele se utiliza do passado e dos elementos deste contidos na sua memória para os fins da arte. $\mathrm{Na}$ verdade, desde Wielopole Wielopole, o mais importante para Kantor não era contar a sua história pessoal, mas antes, de se criar uma conjunção, uma unidade que fosse baseada sobre a manipulação do passado, e isso é muito fascinante. Ele não acredita no artista que quer ser futurólogo. O futuro não existe. No entanto, o passado é muito concreto, e o passado são os fatos que existem em nossa memória. Dessa forma, ao manipularmos os acontecimentos do nosso passado, nós também manipulamos uma porção do nosso tempo presente. Este é o método de Kantor: criar algo de novo com os restos do passado.

Em toda a obra de Tadeusz Kantor existe uma abundância de metáforas visuais, uma constante variedade de manipulações sonoras e uma multiplicidade de textos que reforçam a complexidade de funcionamento do espetáculo em relação aos elementos gestuais, espaciais e pictóricos. A complexidade dessa multiplicidade de elementos torna impossível uma leitura única, homogênea e reconfortante. A obra de Kantor se constitui em um universo peculiar e que atende aos interesses do seu entendimento pessoal da existência da arte. Esse universo é composto sobre uma constante e permanente necessidade de liberação das sensações e das emoções presente em cada um dos elementos individualizados. Este é o puro teatro de emoções onde o espectador é convidado a viajar por um mundo insólito e desafiador, um mundo que, na sua constante referência à morte nos lembra constantemente sobre a vida e suas condições. A morte como paradigma para o ator acaba por se tornar o verbete essencial para a fascinante aventura de viver. 


\section{TRADUCÃO}

\section{Hoje é meu aniversário.}

Tadeusz Kantor

Guia

ATO I

O público no local.

EU

eu ando pela cena

na direção do meu pobre quarto

da imaginação,

com minha

sombra,

entre minhas telas,

por terra jazem minhas

EMBALAGENS. Humanas.

Meu

Pobre Quarto da imaginação 
está transformado

em um albergue noturno

ou em

cemitério.

Sob as coberturas

sob os colchões

feitos sacos

repletos de palha -

jazem mendigos

ou cadáveres.

Em uma das telas

meu auto-retrato,

EU "pinto"

eu ando, pensativo,

eu arrumo alguma coisa,

a Sombra

brevemente, atrás de mim, diante de mim,

adivinha meus pensamentos...

Meu ato-retrato

me imita,

copia meus gestos,

inquieta,

porque existe um pouco do lugar na tela, 
ela me espia

com atenção, fervorosamente,

e repete como pode os meus

movimentos, e espia sempre,

imita.

EU

eu começo a falar ao

público:

"Eu estou novamente em cena ${ }^{20}$.

Jamais sem dúvida...

até ao:

magnífico resumo de minha

Teoria e de meu método".Durante este tempo:

Meu Auto-retrato

em uma loucura crescente

de imitação,

se debate na esquerda

interior do palco, grita. Finalmente

não podendo ai se

limitar

${ }^{20} \mathrm{O}$ traço vertical indica a parte verbal do espetáculo, monólogos e diálogos. 
ele salta

fora da tela.

Ele consegue que

o personagem de um retrato renasça

e que ele comece a falar,

isto seria um monólogo em

fragmentos,

recortado,

desesperado.

Ele é assim:

Meu auto-retrato

tenta repetir as frases

de meu discurso ao público

mas tudo se rompe,

de vez em quando

um grito,

ou uma gagueira...

isto é o rompimento da fronteira

do mundo da ILUSÃO

na direção do nosso mundo REAL -

este rompimento

se opera sempre

em outro sentido - 
isto porque

este acontecimento único

deve ser uma revelação cênica.

Esta passagem

se produzirá entretanto

sem pathos, sem "milagre"

e sem procedimentos

cênicos

pretensiosos e formais,

todo simplesmente,

conforme o hábito do Cricot,

pelos procedimentos do circo

no limite do riso

da palhaçada

e dos choros.

Triste tela

da imitação,

falsa caricatura

que termina praticamente por um

defeito, um fracasso.

Saído do quadro

Meu Auto-retrato

fixa seu olhar sobre mim - 
tenta imitar fielmente

meus movimentos,

somente meu gesto

de arrumar minhas fichas de texto

em meu bolso é repetido

às avessas:

ele tira do seu bolso

fichas parecidas com um texto

(evidentemente o meu).

Ele começa a ler,

provavelmente

ele não compreende grande coisa,

má entonação,

ele eleva a voz

em momentos inoportunos

muito de: hum... hum... ho... ho...

sorri ao público

signos de conivência,

movimentos,

movimentos,

enfáticos, 
mas imitação

medíocre...

Meu Auto-retrato

retorna

ao seu lugar

no interior o quadro,

tentando ainda as últimas

tentativas ridículas. Vans

Ele retorna provavelmente com a consciência

que

"não se pode sair

impunemente

do quadro".

Mas essa não será

a última tentativa

tal qual nos conhecemos o teatro cricot

e suas tendências

para as ações

ilegais.

EU

em um momento crítico 
em que meu auto-retrato

surge na tela,

com muito tato

eu me retiro

para o lado e olho

com atenção e um pouco de

sarcasmo salutar,

as peripécias e as possibilidades

da minha "obra"

- quando tudo fica

em ordem -

eu continuo o meu

discurso ao público.

“era um sábado,...

No momento em que eu digo

"sobre o umbral da porta
Está sentada uma Menina,

Pobre,

Cinza de pobreza..." 


\section{A PORTA}

se entreabre no fundo,

a porta da tela na penumbra,

somente ela na cena, aquela

pela qual entram os

MORTOS ...

essa porta se abre

e no enquadramento aparece

A POBRE MENINA,

ela chora,

diz alguma coisa,

como

uma lembrança

do acontecimento

que eu contei ao público,

como a continuação

desse acontecimento,

que possui provavelmente

para mim uma

significação extraordinária,

interrompido

impiedosamente

e inexoravelmente, 
por uma sentença

da qual

somente

a MORTE

pode ser a responsável

na vida...

O constante retorno só é possível

de se realizar na arte.

É aí que talvez resida

a importância,

aparentemente incompreendida,

desse acontecimento.

EU, eu continuo

Minha fala.

"Em seguida ela parte,

desaparece,

eu a procuro diante da casa

mas ela não está em nenhum lugar

e ela não voltará mais

nunca mais..." 
A Pobre Menina desaparece

atrás da PORTA

(dos mortos).

Aos poucos

ela volta

das profundezas.

Na direção da PORTA

meu PAI

minha MÃE

o Tio-músico

e

o Padre Smietana,

estão em pé, juntos, em um canto (do quadro)

abatidos, eles não sabem onde estão e

porque estão aqui.

A Pobre menina desamparada

chora,

sustenta esses pobres

personagens

do outro mundo

ela não sabe o que fazer

com eles,

(provavelmente ela sabe porque os trouxe) 
E EU

eu termino lentamente meu

discurso

cada vez mais triste

enfim a última frase:

“não convém perguntar

porque se chora"...

A Pobre Menina sustenta

os personagens e ao mesmo tempo

procura alguma coisa com os olhos:

"sempre os mesmos objetos,

esta mesma pobreza... mas...

ele não está à mesa!'

(se produz alguma coisa

de excepcional.

Raramente, ou mesmo jamais,

encontrei

na convenção da arte teatral.

Desde o início tudo 
parecia indicar que

a peça terminaria logo,

ou ela se revela

estar apenas começando).

Neste momento

surge

não no quadro

(ali adiante tudo é irreal,

morto),

mas em algum lugar ao lado, à frente

da cena -

a CRIADA

carregando uma longa tábua de madeira

(a parte superior da mesa)

A criada:

Mais qu'est-ce qu'elle raconte ${ }^{21}$

cette Pauvre Fille?

Mais il y a la table!!

Monsieur, c'est pour vous,

vous m'entendez?

C'est votre aniversaire aujourd'hui,

\footnotetext{
${ }^{21}$ Os textos em negrito são falados em francês pela atriz no curso do espetáculo.
} 
vous avez soixante-quinze ans!

Répétez!

Soixante-quinze!!

A Criada

conseguiu finalmente

instalar a mesa no quadro.

Com tenacidade ela repete que

eu tenho 75 anos.

$\mathrm{Eu}$

eu estou sentado à mesa, imóvel

absorvido na contemplação

de uma velha foto

de minha família.

A Pobre Menina

senta à mesa dos personagens

MORTOS.

Meu AUTO-RETRATO

saído do seu quadro,

se aproxima da minha mesa

olha a foto de família 
a compara com o que

aparece no interior do quadro

como se ele quisesse

reproduzir

fielmente

a disposição da foto,

visivelmente

algum intento "insalubre"

acredito nele,

ele vai bruscamente para o fundo do quadro

e se senta atrás da mesa

abaixando seu chapéu sobre os olhos -

A Pobre Menina

não tem mais nada a fazer

ela se detém no enquadramento da PORTA

lança as últimas palavras:

"como tudo isso é triste"

e se vai.

$\mathbf{E U}$, eu retorno

eu vejo a silhueta desaparecer

eu digo

... pois ela partiu..

desapareceu 
e não voltará jamais...

Um momento de silêncio.

E começa

A vida no quadro.

O quadro se cria por si mesmo.

Vindo do alto-falante, como de um outro mundo,

se entende a voz

do padre Smietana.

(O discurso que ele fazia

na igreja, em Wielopole

no tempo do espetáculo

Wielopole-Wielopole

em 19..)

e ai uma "mistura de materiais"

excepcional:

A REALIDADE da vós,

a voz do verdadeiro padre

Smietana, o padre de Wielopole

(ele vive ainda).

A ILUSÃO do personagem.

O verdadeiro padre Smietana é

"representado" pelo padre Smietana 
ilusório, artificial

e do acréscimo no interior

do quadro (e não sobre o espaço do palco)

que aprofunda a ILUSÃO.

Mas o jogo do padre artificial

Smietana possui um alto

grau de REALIDADE:

O padre artificial escuta a vós

do verdadeiro padre

e como ele transmite

aos convidados ao redor da mesa,

ele não tenta repetir

fielmente, ele o faz

assaz negligentemente, com suas próprias

palavras, sem bem entender,

nos temos um jogo suplementar

e a auto-satisfação.

O PADRE SMIETANA (pelo auto-falante)

Nós lemos no evangelho onde se fala da origem de Jesus de Nazaré

Nós lemos no evangelho: 


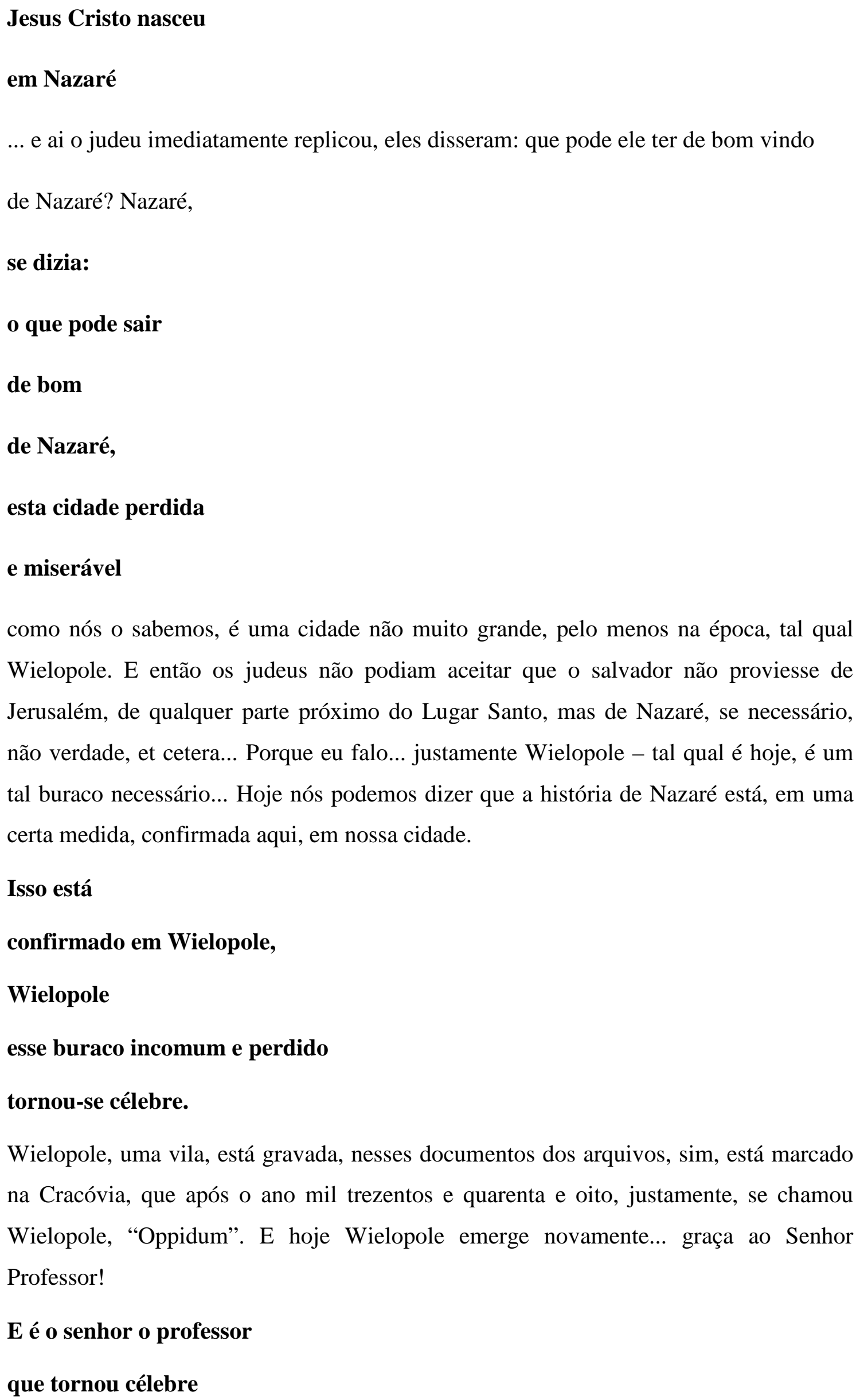




\section{o nome desse buraco}

\section{no mundo inteiro}

Por seu trabalho, Senhor Professor tornou célebre através do mundo inteiro, não somente o seu nome mas... onde ele é conhecido, se ouviu falar de Wielopole! Assim, do mais profundo do meu coração, reconhecendo... eu quero em nome de toda Wielopole e, em meu próprio nome, fazer um brinde em honra do Senhor Professor, que o Senhor Professor viva o maior tempo possível! Cem anos, cem anos...

O PADRE SMIETANA (em cena, em polonês)

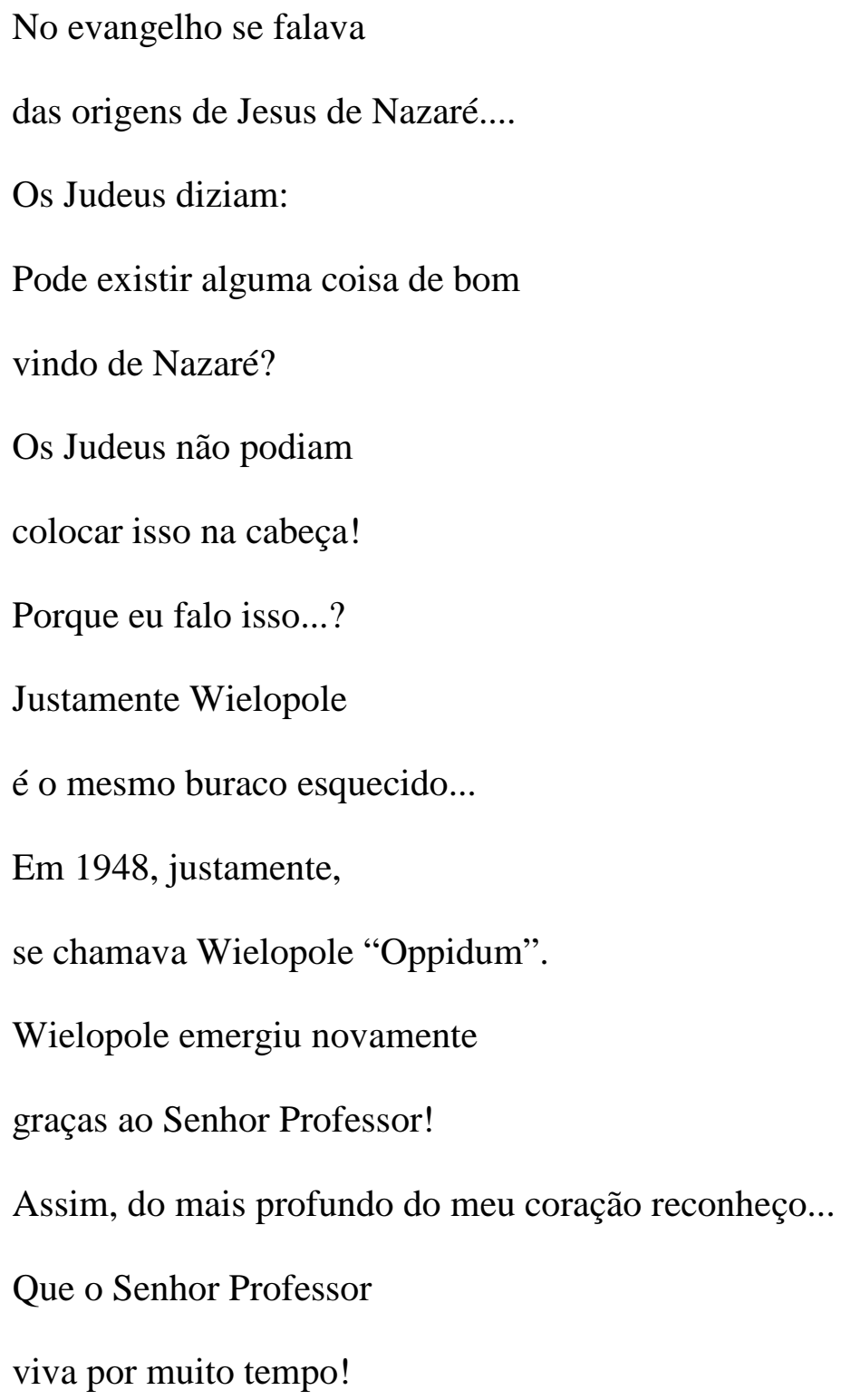


Cem anos, cem anos!

\section{O TIO STASIO}

tem seus momentos onde ele pode

mostrar seus dons de músico.

\section{O PAI}

A Mãe

repetem entediados

os gestos da foto familiar:

ele tem um copo

e serve o vinho

da garrafa.

\section{Meu AUTO-RETRATO}

de tempos em tempos desperta

de sua pose de retrato ( $\operatorname{sim} !)$

e discursa conforme seu

hábito

\section{O PAI}

de tempos em tempos tem

crise psíquicas.

E justamente esse momento chega. 


\section{O PAI}

O Pai, com um copo na mão.

A Mãe serve o vinho da garrafa

no copo do Pai.

O Pai eleva o copo

bem alto. Bebe.

Ele coloca o copo sobre a mesa

A Mãe serve, o Pai levanta

o copo, bebe, o coloca sobre

a mesa.

A Mãe serve, o Pai - como tal, mais alto -

e assim, sem interrupção

ao infinito.

A velha foto começa a viver.

\begin{tabular}{|ll} 
À ele mesmo & eu não posso mais \\
& Eu não posso mais \\
Para a Mãe & ele me segue por todos os lugares \\
ele conta tudo & ele me segue \\
desesperado & por todos os lugares cessar \\
& sem cessar \\
Para o auto-retrato & eu o vi.
\end{tabular}




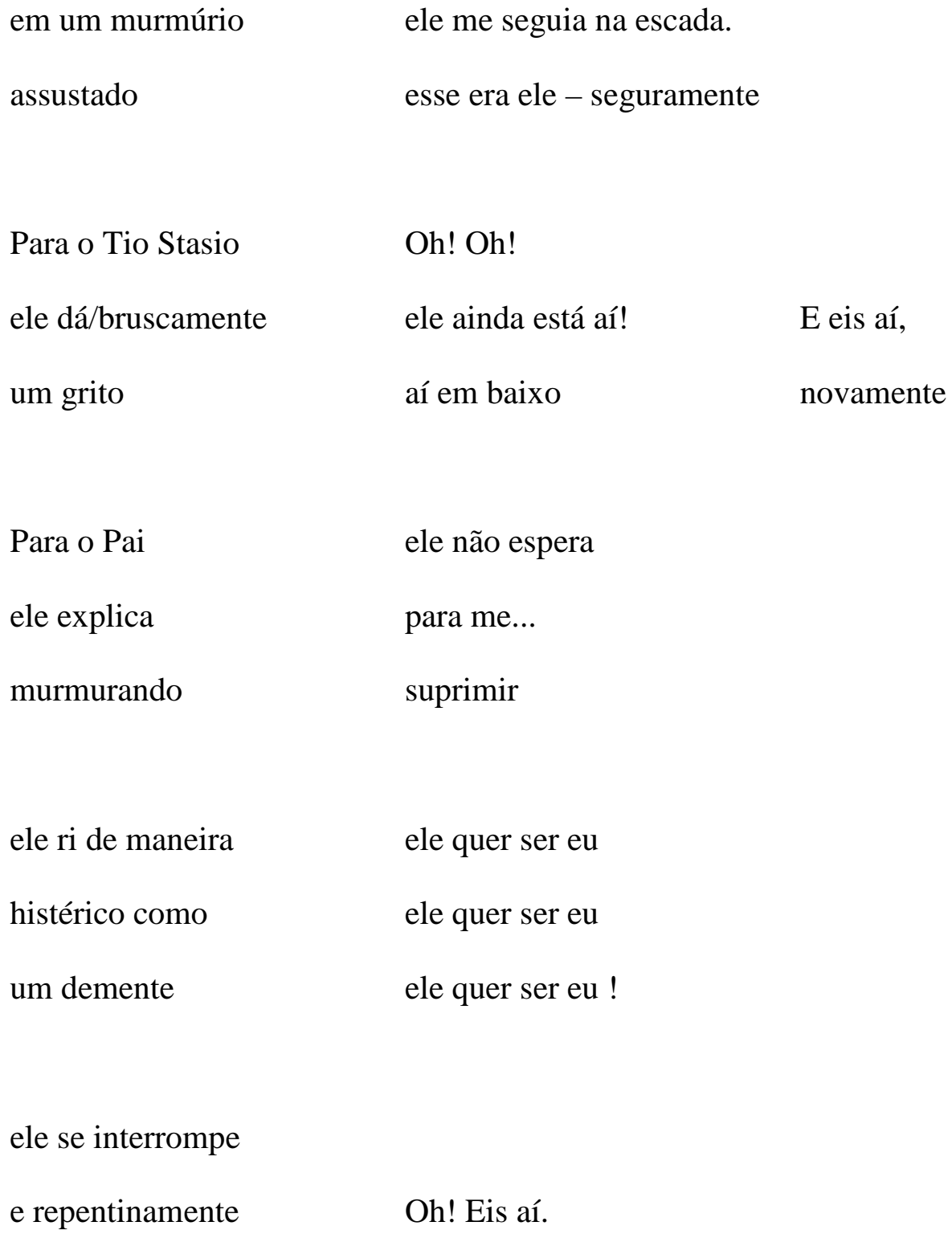

para o Outro

ele mesmo

Ele o

procura não se esconda

eu o pegarei

Você tem o meu rosto

você pegou o meu rosto

Devolva o meu rosto

O resto me é igual! 


\begin{tabular}{|l|l} 
& Mas o rosto! \\
& Meu rosto. \\
& Você tem o meu rosto \\
& Você aprisionou o meu rosto \\
& Devolva meu rosto \\
Para o auto-retrato & Ele sou eu! \\
(eles têm os mesmos & E eu então? \\
problemas) & Eu não existo mais? \\
Eue vergonha, \\
canalha \\
Rosto
\end{tabular}


servo

\section{pano de chão}

ele o persegue,

ao redor da mesa

ele dá duas voltas

Deus sabe o que ele faz com esse rosto.

E se ele perdesse esse rosto

Hoje tantas pessoas perdem seu rosto

Eles lhe cuspirão então sobre o meu rosto

Eu devo procurar e pegar o meu rosto

Mais um pouco e eu a pego

Mais e mais perto

Eu quase a tive

e novamente nada.

ele corre

mas em sentido

contrário

Talvez seja disso que eu fuja

e o que eu procuro

eu procuro a mim mesmo

Toda vez, eu fujo e procuro

E talvez seja eu que

me fujo e que me procuro? 


\begin{tabular}{|ll} 
Ele foge e se & Eu não vou devolver esse rosto \\
põe em direção & eu peguei o seu rosto \\
a alguém que & e farei com \\
o procura & que isso me agrade \\
ele procura e olha & Eu te alcançarei \\
diante de si & Eu levarei meu rosto \\
alguém que foge & Devolva meu rosto \\
A história do Pai e de seu duplo & \\
acaba
\end{tabular}

acaba

Surge

O VENDEDOR DE JORNAL

ele cria o título dos jornais.

E nós sabemos assim de qual ano se trata,

e de qual guerra.

O VENDEDOR DE JORNAL

Leszek Stangret

Últimas notícias

Direto da capital da Bósnia

Horrível morte, abominável crime! Em Sarajevo

O Arquiduque Ferdinando é assassinado. 
Sua esposa igualmente fuzilada!

O Sérvio Príncipe Gavrilo acusado...

As últimas informações por trinta gronschens ${ }^{22}$ !

Tudo o que se passa no mundo,

unicamente nesse jornal.

O mundo na véspera da guerra,

ninguém informa o que querem os Habsbourg...

Última notícia direto de Berlim, a capital!

No império alemão o Kaiser ordenou

a mobilização geral

cada informação é uma sensação.

Grande sensação, mobilização.

Um assassino solto, um crime terrível

em Sarajevo

as últimas informações

as últimas informações

direto da capital da Bósnia

as últimas notícias!

Das minhas embalagens

surgem mãos

tensas.

As mãos apanham os jornais.

As embalagens criam os títulos

dos jornais.

${ }^{22}$ Centavos em polonês. 
Não se vê as cabeças.

Guerra.

Mobilização.

$\mathrm{Na}$ "foto de família"

os homens desaparecem.

Em um instante nós os veremos

em uniformes.

$\mathrm{Na}$ mesa permanecem

a Mãe e o Padre.

A PORTA DA MORTE se abre

O Bedel de A Classe Morta

coloca diante dela uma metralhadora.

A MÃE, o PADRE e o AUTO-RETRATO

fogem precipitadamente da mesa,

carregando com eles a mesa de aniversário.

Eles a colocam no quarto.

Sentam-se.

Na tela, o BEDEL, a METRALHADORA

e o hino solene Austríaco.

Pela PORTA surgem

três soldados (o Pai,

seu Duplo e Tio Stasio)

eles vão ao ataque 
A MENINA POBRE os

conduz.

Meu POBRE QUARTO DA IMAGINAÇÃO

torna-se um campo de batalha.

A guerra destrói as telas...

e as leis da ILUSÃO

ela surge no QUARTO

e semeia a destruição.

EU, MINHA SOMBRA E A MULHER DA LIMPEZA

nós nos entrincheiramos nos cantos

do quarto,

o AUTO-RETRATO entra

em sua tela

e se instala como se nada tivesse acontecido

os SOLDADOS

forçam o ataque

na direção da mesa,

a MÃE e o PADRE perecem.

Minhas EMBALAGENS

esmagadas.

Os soldados saem,

seu desaparecimento se opera

de acordo com a idéia

de todo o espetáculo. 
eles entram na tela

de onde eles saíram

e dessa "GUERRA"

termina com uma

FOTO LEMBRANÇA

Com o Bedel e a metralhadora

No centro

Magnífico e solene,

HINO AUSTRIACO

EU

NARRATIVA

SOBRE A MENINA POBRE

Primeira parte

Eu estou novamente "em cena"

provavelmente eu nunca explicarei

claramente e a fundo esse "habito"

nem a vocês, e nem a mim mesmo.

Mas para dizer a verdade, essa não é a cena,

mas a fronteira.

Diante de mim: a sala,

vocês Senhores e Senhoras, ou, 
(conforme meu vocabulário)

a realidade,

atrás de mim, isso que se chama a cena,

que em meu vocabulário foi substituído

pelas palavras: Ilusão, ficção,

... eu não me inclino

nem de um lado

nem de outro,

com inquietude eu olho

e lanço um olhar

de fé para um

de fé para outro

de fé para vocês,

e após tudo isso...

Magnífico resumo

da minha teoria e do meu método -

Nessa situação

não habitual

e não explicada ou

inexplicável -

eu penso

que isso não estará

deslocado

se eu vou contar

a aventura que 
eu vivi recentemente.

Eu

A POBRE MENINA

\section{Segunda parte}

Era um sábado qualquer

eu descia pelas escadas

para o porão

onde existe meu museu,

No porão

sombrio,

frio

uma última lâmpada,

eu tropecei

em meu carrinho, aquele de

"quando eu tinha 6 anos"

e lá em baixo se elevava o cavalo do marechal,

nada dos ossos,

e mais longe, “a máquina de nascer”,

o berço...

E na soleira estava sentada uma 
Menina,

Pobre, cinza de miséria,

que encarquilhada

chorava,

ela dizia alguma coisa

à si mesma ou a mim,

eu ouvi:

"porque tudo isso

é tão triste?”...

Porque ela chorava?

De onde ela vinha...

Ela era a própria tristeza...

Ela repetia:

"porque tudo isso

é tão triste?"...

Então ela partiu...

Desapareceu...

Eu me precipitei diante da casa,

mas ela não estava em nenhum lugar,

e ela não voltou mais, jamais, jamais!....

Eu não preciso mais

de seus lamentos,

nem ela mesma.

Eu a chamarei:

A Pobre Menina. 
Isso não é um sonho...

Esse é um lugar verdadeiro

Eu a vejo distintamente...

Ela estava sentada sobre a soleira...

ela olhava através de seus olhos cheios

de lágrimas,

como se ela esperasse uma

resposta...

Ela chorava por alguma coisa

De muito importante.

Eu estou ali, diante de vocês,

Eu não tenho nada para

Mostrar a vocês,

Somente essa menina,

...Que não está lá

e que não dirá a vocês

mais nada sobre suas lágrimas,

Eu mesmo não sei nada

sobre elas...

Não convém perguntar

porque se chora... 
A cena do Cricot tornou-se

"campo de batalha",

lembrança da Primeira Guerra

mundial,

na metade dos meus cinco anos

de idade

e na medida dos hábitos

do Teatro Cricot. Nós os conhecemos.

A "Grandeza" dessa guerra

a qual foi demonstrada somente

pelo Hino Austríaco, mas sobre a música de Haydin.

Sobre o "campo de batalha" estão

minhas

Embalagens,

inertes,

na Mesa da Família

o Corpo da minha mãe

e do Padre.

Meu Auto-retrato está protegido

cuidadosamente na tela.

Minha SOMBRA

e a SERVENTE - MULHER DA LIMPEZA

marcha em direção a esse "campo de batalha",

como se fosse um hábito

em semelhantes ocasiões.

Quando tudo acaba 
eles se transformam em

\section{ENFERMEIROS}

e afim de que não exista dúvida,

vestem os jalecos

tiram os corpos-embalagens

e os colocam no interior da tela.

Meu Auto-retrato até o presente

intacto (e em segurança)

se move novamente

de forma bruta fora da tela,

caminha entre as embalagens

como se ele as examinasse ou

superasse formalmente

sua forma visual,

ele exprime pomposas

formulações

do manifesto "Embalagens".

Ele seria imprudente

o conhecimentos dos lugares

em generalizar o que quer que seja

se chocava

ou de tentar criar

com as tradições sagradas

fórmulas.

Embalagens, Embalagens

Qual sorte!

Polissêmicas

Embalagens 
e o que é pior

ambíguas

símbolos de potencia,

possuem a força de

conjuração.

possibilidades metafísicas

perpetuar.

farrapos miseráveis

escapar em frente ao tempo

de esplendores

Embalagens.

o acontecimento descrito

alguma coisa quer se

oscila

esconder profundamente

entre as

Embalagens, Embalagens

para a integração

e a eternidade

a ignorância

e a vulgaridade

a lata de lixo

nós nos tornamos as testemunhas

de uma palhaçada específica

se equilibrando

entre o pathos e uma miserável

queda

Embalagens, Embalagens, Embalagens.

Meu Auto-retrato 
como todo personagem

pinta,

- digamos poético -

vivem no interior da tela -

não é como um envelope

Ilusão

de uma atividade intelectual e sentimental.

Lamentável,

sobre o principio cricotiano

de um milagre,

ele sai da tela, isso não

significa que

seu estado e sua condição

melhore.

Ele não será sempre

o reflexo

de um personagem vivo, que age mecanicamente,

(essa precisão exclui

toda paródia,

caricatura, etc.)

que age mecanicamente

e "compreende" mecanicamente

todas as formulações

teóricas ou filosóficas,

após a passagem por essa

trágica "armadilha" 
caem na esfera

de um cômico pouco sério.

Isso é no entanto melhor -

O espectador efetua a correção

e chega de maneira autônoma

às suas próprias conclusões.

Sérias.

Assim Meu Auto-retrato

se exprime "teoricamente"

e isso num momento

o menos oportuno:

após a batalha, se ouve ainda ao longe os tiros das

metralhadoras

os enfermeiros transportam os "Cadáveres"

sobre as macas. E o incansável

auto-retrato explica

aos enfermeiros a essência

das embalagens, ele os interrompe

e explica a eles -

Situação absurda

boa cenicamente para um e para o outro

lado.

Essa é uma cena importante apesar de

seu aspecto fortuito

e ilógico. 
OS ENFERMEIROS

transportam as embalagens e as colocam

no interior da tela.

Se forma uma grande pilha de corpos

cobertos de panos.

Não se pode dizer então

grande coisa ao sujeito dessa cena assaz

desesperadora.

A situação aos poucos

torna-se clara.

Por um instante se sabe que

essas são as embalagens

minhas embalagens

que ultimamente sofreram alguns

danos,

que existem pessoas no seu interior,

ainda com vida,

que em breve veremos a sua aparência

e que nós seremos as testemunhas de acontecimentos

que decidirão o seu destino.

Justamente a PORTA bem conhecida

se abre

e entra um personagem vestido

com um jaleco branco de hospital

Na mão ele tem uma grande orelha (de estetoscópio)

ligadas por tubo 
preso em seu pescoço.

$\mathrm{Na}$ lista dos papéis ele figura

Como

DOUTOR KLEIN.

Se supõe que ele venha

trazer ajuda

a essas criaturas humanas -

às "embalagens".

Ele se coloca ao lado da pilha de corpos,

se dirige na direção do centro da cena.

No lado oposto

entre o Carregador de Água

de Wielopole, pés nus, em trapos

com os baldes,

o profeta inspirado

dança ao ritmo saltitante e melancólica

de uma melodia típica judia.

Apesar da sua

seriedade, DOUTOR KLEIN é subjugado pelo charme

do Carregador de Água de Wielopole,

ele dança

esquecendo completamente

seu papel.

Ele não é mais o médico

de uma clínica.

Ele poderia ser, talvez 
Jeová.

A loucura da dança aumenta.

Se juntam

barulhos surdos e inquietantes -

um batimento de coração

ou ainda, batimentos de corações

esse não é mais um hospital

com os doentes,

com os enfermeiros,

com um diretor, talvez

um médico.

Mas uma espécie de

ritual bíblico,

talvez

O DIA DA CRIAÇÃO

DO GÊNERO HUMANO

renovado,

após a catástrofe,

e a festa bíblica, uma dança radiosa,

o triunfo da vida sobre a

MORTE,

talvez o ato solene

a consagração

das embalagens

demais "laicas",

alguma grande MISSA, 
(eu não posso me deter

em juntar meu qualificativo

de circo!)

o teste

da elevação

do meu Pobre Buraco,

de meu Pobre Quarto

de minha miséria,

de minha pequena

lembrança familiar

"Hoje é meu aniversário".

Essa lembrança familiar

"Hoje é meu aniversário"

não se deixa abater

não o vencerá

nem a guerra,

nem essa onda

de loucura bíblica.

Em algum lugar, em um canto

na estreiteza da tela

se repete

ainda

incansavelmente

a cena à mesa,

sempre a mesma! 
Mas com uma espécie de pressa-

e finalmente

em um vôo...

Mas tudo isso, essa cena familiar

será um pouco mais tarde.

Para o instante as embalagens

Tornam-se mais "humanas".

Nos rostos, as aparências se mostram.

Alongadas, eles deixam suas cabeças

sobre a parte inferior da tela

e olham pasmados

aquilo que acontece

no centro da cena.

Para "animar"

provavelmente

o miserável aspecto das "embalagens"

os enfermeiros

colocam

longas e largas camisas de hospital.

Essas também são embalagens,

mas como que para uma festa

da pureza e da inocência.

Eles podem ir corajosamente ao céu.

Em seguida as novas

“embalagens" se colocam 
enfileiradas em uma dança de circo

se movimentando ao redor de Jeová

e do Carregador de Água de Wielopole.

Jeová/Doutor Klein

em um élan

religioso, ritual

e um reflexo profissional

usa seu aparelho estetoscópio

sobre os corpos das embalagens

cantando religiosamente -

"todos iguais"

todos iguais...

Mas de forma que não exista em tudo a mesma

alegria,

afim de encontrar tanto o bem quanto o mal em um lugar,

em nosso horrível

século XX.

Todos os convidados de minha mesa

de aniversário,

e meus próximos

não podem se privar de sair

as "máquinas" prontas para

o epílogo,

os “organismos" do poder - 
e de os utilizar contra

o "CÉU" solto

como seu próprio chefe,

como um usurpador

exterminou

meu aniversário.

As pessoas desaparecem

lentamente.

Somente as máquinas

permanecem.

\section{ATO III}

Meu Pobre Quarto da Imaginação.

Na cama, embaixo do cobertor, minha SOMBRA.

A SERVENTE perto do fogão de ferro esquenta água para o chá.

EU, eu estou também à mesa e escrevo uma carta.

Sobre a mesa, uma lamparina.

Tudo está como cada dia, e sem dúvida não se produzirá nada de extraordinário.

Mas não pré-julguemos a situação.

Anteriormente eu queria contar a história da INFANTA.

A INFANTA foi pintada (por mim),

como aliás meu AUTO-RETRATO. 
As duas telas estão em meu Quarto. Após o início.

Admitamos, entretanto, que

As PERSONAGENS pintadas podem ter na tela

SUA VIDA PRÓPRIA E SUAS PERIPÉCIAS QUE NÃO CONCORDAM COM

COM AS INTENSÕES DO AUTOR DA TELA.

E isso é O ESTRANHO desse espetáculo.

Assim:

No ato I, no momento em que a Primeira Guerra Mundial eclode,

A INFANTA se enfia aterrorizada no fundo da tela.

No ato II, ela não aparece.

No ato III, ela entreabre a sua porta (em sua tela)

E escuta como

EU leio aquilo que escrevi (carta à Maria Jarema):

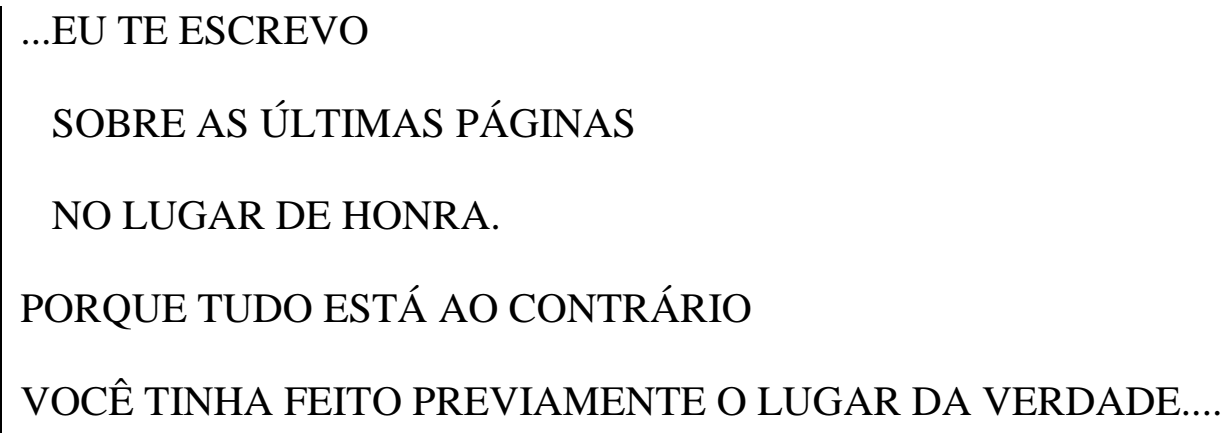

Meu AUTO-RETRATO se anima

Com toda evidência à vista da INFANTA:

"Uma certa tarde ela entrou em meu Pobre Quarto

a INFANTA de Velázquez.

Título de minha tela..." 
A INFANTA leva as poses para a tela e apresenta

todo o seu charme,

como que guiada pelo ciúme...

Mais tarde aparece JONASZ STERN - morto - e nu,

Ela pensa que sua presença no tempo se é

distante, é preferível se afastar.

Ela se esquiva discretamente.

Nós temos então a INFANTA na tela.

Uma surpresa espera.

Não muito gentil.

Pode ser que ela esteja com medo do personagem do século XX

que em um instante dará uma lição de uma abstração

totalmente incompreensível, mas ela será salva por

sua MAGESTADE e sua BELEZA.

EU continuo a leitura da carta.

Batidas na porta.

A SOMBRA corre, abre a porta...

Alguém....

A SOMBRA

NON C' E NESSUNO...

Ela se move para a porta

Novas batidas...

Dessa vez a porta se abre e entra 
MARIA JAREMA,

carregando a sua misteriosa bagagem:

uma grande caixa negra fechada, como um caixão.

Ela deixa o interior da tela, como em um hotel,

tratando a personagem da SOMBRA como um vulgar garoto de hotel.

A SOMBRA docilmente e com um ligeiro medo executa as

ordens, colocando a caixa negra na tela e, em uma

cadeira...

Apostrofando o personagem de minha SOMBRA que ela toma sempre

como um servente, ela utiliza expressões da estética

ABSTRATA, se volta constantemente,

não se atendo ao fato de que EU continuo lendo a carta

(que a ela (outra) é destinada).

Ela se aproxima da minha mesa, com um revolver, o coloca sobre a mesa.

A FAXINEIRA que preparou o chá

o serve e o coloca sobre a mesa.

\section{MARIA JAREMA}

folheia um livro, bebe o chá

"Quando ele voltará?"

\section{A SERVENTE}

"Ele vem raramente aqui...

E quando ele vem, ele dorme..." 
MARIA JAREMA

"Isso não é nada, nos o esperávamos..."

O AUTO-RETRATO

não está mais

“então nós o esperávamos...”

MARIA JAREMA

volta bruscamente

vê meu AUTO-RETRATO

se aproxima dele

e começa

sua exposição....

I

“O espaço!

somente o espaço existe,

o espaço puro!

Rejeitar finalmente

Todos esses

corpos

pernas,

barrigas,

coxas,

quadris, 
seios,

e suas aparências,

seus narizes,

seus olhos...!"

Jaremianka (Maria Jarema) sobe sobre um pequeno palco (atrás de uma das molduras)

senta-se sobre a cadeira

e nesse local anuncia suas últimas instruções,

sublinhando os fragmentos mais importantes

com tiros de revolver.

II

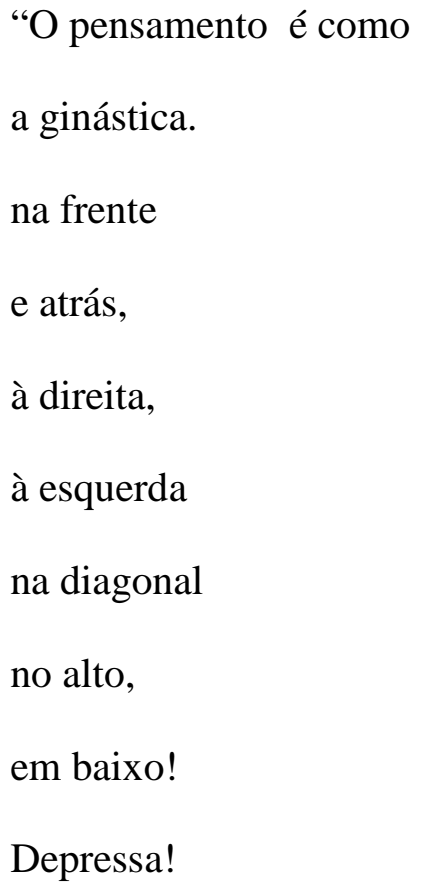


stop!

lentamente para frente!

E agora para baixo".

III

“A abstração!
a abstração é somente
o laxativo
para essa matéria impura
da natureza.

- A aparência

o espaço não suporta as aparências, as pequenas aparências como sobre uma foto...

Retire então a sua aparência.

Sua aparência me desagrada.

Retorne na direção do muro.

Isso, assim!

Está melhor!

- O pensamento 
Nada como o pensamento!

Pensar!

Eu penso

Tu pensas

Nós pensamos

Pensar tudo e nada"

Em um momento dado, uma parte da tampa

Do baú se abre,

Uma mão aparece, e progressivamente um corpo quase nu,

JONASZ STERN sai.

Ele começa a falar:

JONASZ STERN

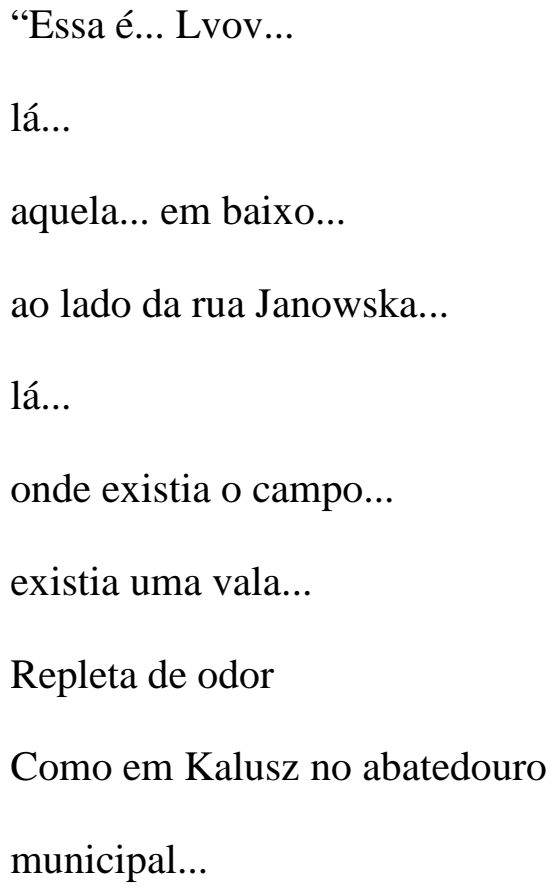


o mesmo odor.

Lá, já havia fuzilamentos.

Antes das dez.

Cada um devia entrar

então eles atiravam do alto.

Eu estava em pé um pouco estupefato.

Eu me disse...

então, eu oporei uma resistência

E o que deve ser será.

E existem algumas pessoas em pé

que batem com um bastão...

então eu... eu fugi!

E ele, ele apontou, lá de cima

para a fuzilaria.

Sim.

Havia alguém sentado lá em cima.

$\mathrm{Eu}$ o vi, seu rosto

Ele estava com essa metralhadora.

Então eu chorei.

Eu me deitei.

Eu não queria estar em pé.

Eu queria que eles me... aqui...

para que eu não caminhasse enquanto

eles atirassem.

Eu estava deitado assim, sobre os

cadáveres. 
E...

O pior foi uma mosca que

me exasperava.

Oh! Aquela mosca!

Ela começou a passear sobre minhas costas...

E eu não podia me mover.

E eu fiquei deitado assim até à noite.

A noite...

Eu estava deitado assim...

Eu não mexia nem os olhos.

- para que aparecesse o signo de que

eu vivia ainda...

Sim.

E aí eu fiquei deitado

E ele estava sentado....

com a metralhadora...

Ou eu o tinha hipnotizado,

ou o que...

eu não sei...

e somente em um momento, tarde da noite..

eu me disse...

e $\operatorname{sim} .$.

eu não posso ficar aqui...

eles virão de manhã...

enterrarão...

Então eu comecei em pensar uma maneira 


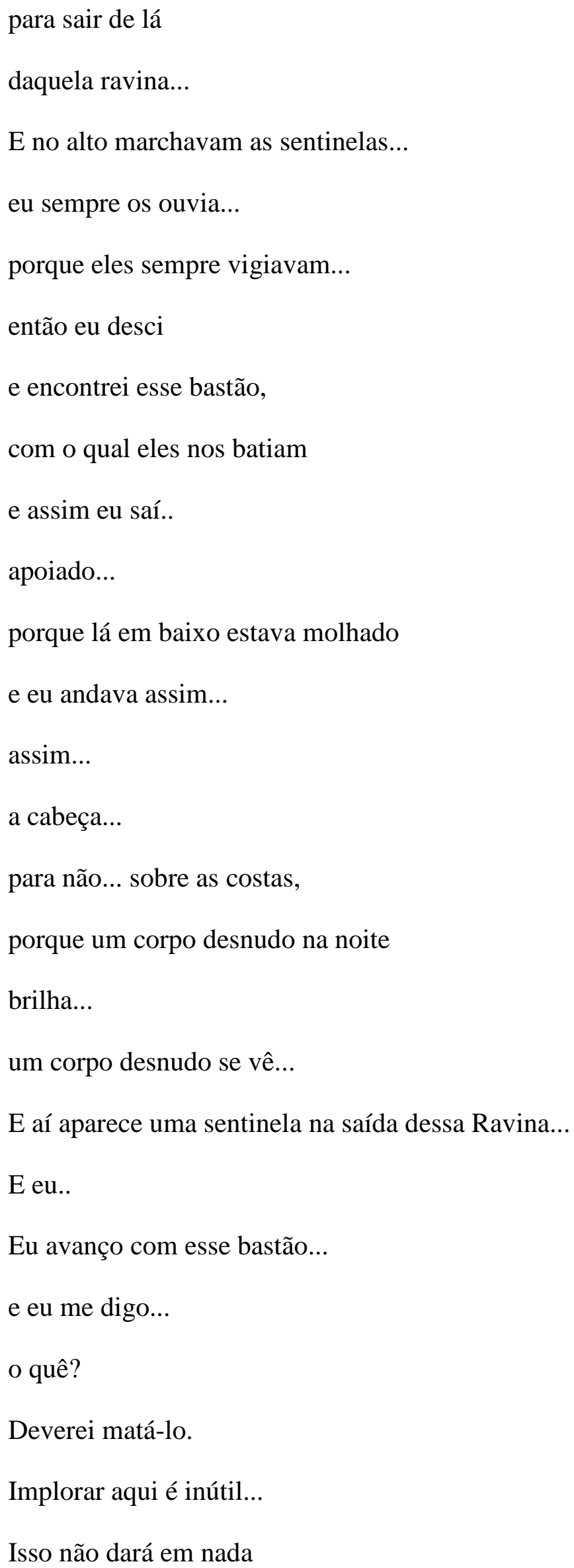


e agora

que chance eu terei aqui?

Do alto ele chama os outros e diz

que ele tem vodka e salsichão

e ele vai na direção dos outros...

deixando ou meu caminho livre.

E agora - qual a chance?

Eu ou ele?

E então...

eu corri..."

Jonasz vai em direção do

baú

abre a tampa

e com infinita lentidão

após ter feito

esse relato

"póstumo"

entra no interior,

desaparece,

a mão ainda fica visível...

Maria Jarema

que durante todo esse tempo

escutou as palavras

de Jonasz 
parte sobre seus traços,

com uma espécie de determinação

ela desaparece lentamente

no interior desse baú.

AÇÃO

Sobre a cama, minha SOMBRA dorme sobre o cobertor.

Ela fala durante o sono,

cria,

se agita,

se acalma...

Eu estou próximo da mesa

sobre a qual, uma pequena lamparina.

\section{A SERVENTE}

próxima do fogão de ferro, lava a louça em uma bacia

ela usa ruidosamente a vasilha...

EU

nessa noite também, como de hábito

A INFANTA DE Velázquez

provavelmente virá

em meu Pobre Quarto da Imaginação.

Meu AUTO-RETRATO interfere como de hábito 
em meu quarto...

minha Infanta de Velázquez...

a minha!

A SOMBRA

Então nós esperamos

Ela se acalma

A SERVENTE

Então ele espera

Algumas batidas na porta

A SOMBRA

se estica

entontecida pelo sono

se move rapidamente, se precipita para o interior da tela

abre a porta - alguém!

não é ninguém!

A SOMBRA

voltando,

outras batidas:

entra A INFANTA

\section{A SOMBRA}

na direção da bacia 
se lava

faz sua cama

aqui e ali...

A INFANTA

sai do interior da tela

se dirige para a mesa

senta-se em minha frente

(como na minha tela)

Meu AUTO-RETRATO

Inquieto

EU

Em meu Obre Quarto da Imaginação está

a INFANTA de Velázquez

\section{A INFANTA}

Está sentada imóvel

como morta.

Batidas na porta.

A porta se abre.

Sobre o umbral aparece

A POBRE MENINA

Na tela ela ocupa o lugar vazio deixado pela INFANTA. 
Isso acontece pela segunda vez.

A Pobre Menina

se movimenta na direção da infanta

com aversão

com ódio...

Ela ocupa seu lugar,

ela seduz e joga seu charme à sua maneira...

lamentosa e trágica...

Atrás da POBRE MENINA chega

toda a FAMÍLIA

com a mesa.

\section{OS MORTOS}

estão repletos de um fervor insano,

eles se apressam,

gritam,

se empurram,

saltam, agitam os braços,

como em um filme em ritmo acelerado.

a tela com a família (ainda a moldura da tela)

se aproxima perigosamente da

tela na qual se produziu

a infeliz MENINA POBRE.... 
A confusão é cada vez maior

A FAMÍLIA salta,

Gritam sobre a POBRE MENINA

A POBRE MENINA tem enfim seus espectadores

O padre se aproxima dela

Que se joga em seus braços...

ATRÁS DA PORTA SE PERCEBE O BARULHO DA LOUCURA...

\section{ATO IV}

Meu pobre Quarto da Imaginação.

Minha casa.

Minha casa na cena.

Como uma fortaleza

que se defende contra

a loucura,

contra o poder,

contra a política,

contra a ingerência,

contra a ignorância,

contra a vulgaridade

e a tolice.

Minhas armas são

minha imaginação, 
a memória da infância,

minha pobreza,

a solidão...

e a morte que espera,

grande atriz

e seu rival: $o$ amor.

Nos momentos de desordem e desespero

eu criava sempre.

ela empurra essa gentalha

em meu pobre quarto

da imaginação.

Esse grito pode ser

o título

da cena que começa

a se desenrolar.

O barulho da loucura

ali

no exterior -

Em meu quarto

os defensores!

um fogão de ferro

um lavabo com uma toalha

uma mesa com uma lamparina

eu estou à mesa - 
uma cama com um colchão.

Um travesseiro e uma cobertura

para as telas.

Meu AUTO-RETRATO

a infanta (após Velázquez)

minha sombra,

A FAXINEIRA

que se faz passar por um

CRÍTICO

$\mathrm{E}$

OS QUERIDOS AUSENTES

que

vieram ao meu aniversário

e estão ao redor da mesa

familiar.

Eles repetem os restos dos

seus papéis,

lamentosos fragmentos de memória.

No exterior

novamente

o barulho da loucura.

Expectativa.

Tudo está mortalmente

congelado.

O barulho da loucura 
está cada vez mais próximo,

o MURO desaba

e

surge a

GENTALHA

"os organismos do poder"

as metralhadoras,

o canhão,

o carro,

os capacetes,

os secretários do partido,

os policiais com suas matracas,

categoria particular de indivíduos.

“Os soldados",

os assassinos

e os assassinados.

meus queridos ausentes

fugiram em pânico

levando

a tábua da mesa

da qual eles não se separam

como a última tábua da salvação,

com uma espécie de desespero

eles falam os restos dos seus papéis.

Os "organismos do poder" 
se descontrolam,

os tipos humanóides

igualmente.

Atos de violência

sobre os personagens

de meu Quarto.

Sucessivamente:

o Auto-retrato -

representando, o que quer

que ele seja, a arte

a Infanta,

criação da imaginação

interditada

Minha Sombra, personagem suspeita

e

a faxineira-crítica

sobre a qual se precipita

um soldado, como em Goya -

e

o Padre com a cruz, inimigo

ideológico -

Esses senhores

inspecionam tudo o que está

no quarto -

sobretudo a papelada 
Após a devastação

metódica

e

a pilhagem,

todo o bando deixa

meu quarto.

A Pobre Menina

resume:

“que barbárie"!

ATO V

Após a tormenta

do pesadelo noturno

que atravessou o meu

Pobre Quarto da Imaginação,

minha Sombra

e a FAXINEIRA

coloca a casa

em ordem,

erguendo

um muro de tijolos

na confusão

demolido pelo tanque,

instalam em seu lugar, 
sobre o cavalete, a tela

e seu "interior".

\section{OS QUERIDOS AUSENTES}

arrastam a pesada tábua

da mesa familiar,

se dirigem para o fundo do quarto

com a intenção de abandonar

a cena.

Mas sem dúvida

esse sonho deixou

atrás de si algum eco,

porque em um canto escuro

do quarto se erguem,

tais monstros,

três N. K. V. Distes.

Os Queridos Ausentes se salvaram,

em pânico, do lado

oposto.

Os três N. K. V. Distes

se dirigem muito lentamente

em um passo medido,

para a tela na qual

meu AUTO-RETRATO

está sentado em uma cadeira. 
Eles se jogam sobre ele.

O tiram da tela.

O carregam para a tela

central onde

a tábua

se ergue repentinamente como

se ela quisesse acolher o corpo

destinado à morte.

E já se ouve

a melodia russa característica

tchastcuchka

também selvagem qual

os três esbirros.

Eles arrancam as suas roupas,

o jogam nu

sobre essa tábua que

e é deixado só.

Nos lados

dessa terrível tela

aparecem, vindo do fundo

Maria Jarema

e

Jonasz Stern

como se eles quisessem estar presentes 
na morte da vítima.

Eles deixam a moldura da tela

avançam sobre ele,

como se eles quisessem que

o público lembrasse

exatamente

e para sempre.

A tela se aproxima

ao mesmo tempo que seu

interior,

permanece fixo diante do público.

Maria Jarema

senta-se em uma cadeira,

Jonasz Stern

cai por terra.

Os três N. K. V. Distes

completam o ato do assassinato

ao som do ritmo da

tchastouchka russa

essas bestas rejeitadas

estão

com os pés em sapatos soldadescos

com as patas armadas de metralhadoras

as monstruosas cabeças

voltadas triunfantes

para o alto 
para Stalin

e novamente para baixo

com furor

para sua vítima.

A tchastouchka descontrola-se

Maria Jarema

pega uma carta

na mão do mártir.

Ela diz:

Vsevolod Meyerhold

ao

Presidente do Conselho dos Comissários

do Povo da URSS,

Viatcheslav Molotov.

Agora nós sabemos

quem repousa sobre essa tábua

dessa cela da morte.

A carta é lida por uma voz

marcada pela emoção.

Tchastouchka

Convulsões dos 
N.K.V. Distes.

Em seguida a assinatura

Vsevolod Meyerhold.

Os esbirros carregam o corpo

Do Grande Mártir.

Eles completam o seu trabalho.

Eles se vão.

Então

das profundezas

desliza uma fina silueta

Todos os atores

da Pobre Barraca de Feira

Cricot

dançam

em homenagem.

Tchastouchka

triunfalmente.

No centro

O corpo desnudo

De Meyerhold

o Vencedor!

Meu Auto-retrato 
Descendo as tábuas

Da cela da morte,

desaparece.

A dança permanece

lentamente a fila das siluetas

em algum lugar das profundezas.

A faxineira

repousa

a moldura vazia

com a tábua da cela da morte

através da cena

até ao fundo

do interior da tela.

A tela vazia

é acompanhada

como em um cortejo

mortuário

por Maria Jarema

e

Jonasz Stern. 
Da cena anterior permanece

a tela, caída, esmagada,

a SOMBRA se coloca em um canto,

a FAXINEIRA deve arrumar somente

a tela, que não é mais

que uma velharia - finalmente

ela o coloca em um canto.

Entram "as pessoas"

(talvez sejam os coveiros) com as pás

e as cruzes funerárias.

Eles colocam essas cruzes

por todo o quarto.

Eles constroem as tumbas

com as terras transportadas em pequenos baldes:

Marcha Fúnebre.

Do fundo entra o PADRE com uma grande cruz.

Muito lentamente, passo a passo.

Após ele

os COVEIROS puxam

alguns "monumentos" funerários,

das "múmias" e dos semi-mortos

que se movem ainda,

não se sabe se são objetos de cemitério

ou jaulas de circo para animais ferozes, 
veículos de circo,

os monstros dos novos dirigentes,

dos comissários, dos secretários, dos informantes,

dos policiais violentos,

dos deuses sanguinários...

O horror da guerra e o terror

Assimilado pelo circo,

monumento em forma de tribuna com o orador bem conhecido,

monumento-carro com um corpo humano,

monumento móvel com um dignitário com um tamborete atrás,

monumento "cesto como capacete"

e atrás a janela com barras,

uma aparência humana

e as CRUZES,

muitas cruzes.

Essa terrível loucura

misturada tragicamente

girando

em um ritmo lento

ralentando gradualmente

onde

o mal se mistura ao bem,

o riso escarnecedor ao choro desesperado,

a emoção ao cinismo,

a crueldade ao lirismo. 
Agora

essa a loucura

do cemitério

avança para o meio da cena

como a verdadeira escolta

da família,

dos Queridos Ausentes,

dos Habitantes da casa,

entretanto, como um caixão

a TÁBUA da mesa

que nós já conhecemos,

eles a instalam no meio:

talvez para a refeição funerária,

o dia dos mortos.

Todos estão vestidos

como que para um enterro de alguém

muito querido.

No centro, meu Auto-retrato

se ergue pronunciando um discurso

soluçando -

e os seguintes:

o Padre Smietana

o Pai,

o Tio Stasio.

Meu auto-retrato pronuncia um discurso

discurso sobre a tumba - 
restos antigos,

palavras de ordem,

"embalagens",

"mais longe nada"...

Os "monumentos" distribuídos

de tempos em tempos

os gritos dos velhos - como

lamentos dos agonizantes.

A "Cerimônia"

termina.

Todos, progressivamente

abandonam a cena.

Permanecem apenas os monumentos

a Pobre Menina

que

não encontra outras palavras

a não ser:

"Tudo isso é triste".

Mas

ela também se vai. 


\section{TADEUSZ KANTOR}

\section{MANIFESTO DO TEATRO DA MORTE}

Tradução feita a partir da versão francesa que foi publicada em: KANTOR, T. - Le Theatre de La Mort - Textes Réunis et Rassemblés par Denis Bablet. Lausanne - L'Age D’Home - 1977. 


\section{O Teatro Da Morte}

\section{MANIFESTO}

1. Craig afirma: a marionete deve reaparecer; o ator vivo deve desaparecer. $O$ homem, criado pela natureza, é uma ingerência estranha na estrutura abstrata de uma obra de arte.

Segundo Gordon Craig, em algum lugar às margens do rio Ganges, duas mulheres entraram no templo da divina marionete, que guardava vigilantemente o segredo do verdadeiro teatro. Essas mulheres tinham ciúmes desse ser perfeito do qual invejavam o papel, que era o de iluminar o espírito dos homens pelo sentimento sagrado da existência de Deus: elas desejavam a sua glória. Elas imitaram os seus movimentos e os seus gestos, suas roupas maravilhosas, e, pelo viés de uma medíocre paródia, se colocaram a satisfazer os gostos vulgares da plebe. Quando, enfim, elas construíram um templo, feito à imagem daquele outro, o teatro moderno- aquele que nós conhecemos muito bem, e que assim permanece até hoje, nasceu - a brilhante instituição de utilidade pública. No mesmo tempo em que essa instituição, apareceu o ator. Para dar apoio à sua tese, Craig invoca a opinião de Eléonra Duse:

"Para salvar o teatro, é preciso destruí-lo. É preciso que todos os atores e atrizes morram da peste... São eles que atrapalham a arte...".

2. Teoria de Craig: O homem ator suplanta a marionete e assegura o seu lugar, causando assim, o declínio do teatro.

Existe qualquer coisa de imponente na atitude desse grande utópico quando ele afirma: "Eu exijo muito seriamente o retorno do conceito de surmarionete ao teatro. 
E desde que ela reapareça, as pessoas poderão novamente venerar a felicidade da existência e render uma divina e feliz homenagem à morte".

De acordo com a estética simbolista, Craig considerava o homem submisso a paixões diversas, e a partir dessas emoções incontroláveis, e por consequiência, ou destino (acaso), como um elemento absolutamente estranho à sua natureza homogênea e à estrutura de uma obra de arte, como um elemento destruidor do caráter fundamental dessa: a coesão. Craig - ainda bem que os simbolistas, cujo programa, em seu tempo, trouxeram um desenvolvimento notável - atrás deles haviam os fenômenos isolados, mas extraordinários., que no século XIX, anunciavam uma nova época e uma arte nova: Henrich Von Kleist, Ernest Theodor Hoffmann, Edgar Allan Poe...

Cem anos antes, e por razões idênticas àquelas de Craig, Kleist exigia que o ator fosse substituído por uma marionete, achando que o organismo humano, submisso às leis da natureza, constitui uma ingerência estranha na ficção artística nascida de uma construção do intelecto. Os outros protestos de Kleist recaem sobre os limites das possibilidades físicas do homem, e ele denunciava, além do mais, o papel nefasto do controle permanente da consciência, incompatível com os conceitos de encanto e beleza.

3. Da mística romântica dos manequins, e das criações artificiais do homem do século XIX ao racionalismo abstrato do século XX.

Sobre o caminho que se acreditava certo, e que emprestava ao homem do século das luzes e do racionalismo, eis que avançavam, saindo subitamente das trevas, sempre mais numerosa, os sósias, os manequins, os autômatos, os homúnculos criaturas artificiais que são tanto mais que ofensas às próprias criações da natureza e que carregam nelas todo o aviltamento, todos os sonhos da humanidade, a morte, o horror e o terror. Assiste-se à aparição da fé nas forças misteriosas do movimento 
mecânico, ao nascimento de uma paixão maníaca de inventar um mecanismo que superaria, em perfeição, em implacabilidade, o vulnerável organismo humano. E tudo isso em um clima de satanismo, ao limite do charlatanismo, das práticas ilegais, da magia, do crime, do pesadelo. Essa é a ciência-ficção da época, na qual um cervo humano demoníaco criava o homem artificial. Isso significava simultaneamente uma crise de confiança súbita em relação à natureza e de seu domínio das atividades dos homens que lhe estão intimamente ligados.

Paradoxalmente, é dessas tentativas românticas e diabólicas ao extremo de negar à natureza seu direito à criação, que nasce e se desenvolve o movimento racionalista ou mesmo materialista - sempre mais independente e sempre mais distanciado da natureza - correndo na direção de um "mundo sem objeto", do construtivismo, o funcionalismo, o maquinismo, a abstração ,e , finalmente, o visualismo purista, reconhecendo simplesmente a "presença física" de uma obra de arte. Essa hipótese arriscada tendendo a estabelecer a gênese pouco gloriosa do século do cientificismo e da técnica não engajada qual minha própria consciência e que serve apenas à minha satisfação pessoal.

4. O dadaísmo introduz a "realidade toda pronta" (os elementos da vida) destrói os conceitos de homogeneidade e de coerência de uma obra de arte postulada pelo simbolismo, pela Art Nouveau, e por Craig.

Mas retornemos à marionete de Craig. Sua idéia de substituir um ator vivo por um manequim, por uma criação artificial e mecânica, em nome da homogeneidade e da coerência da obra de arte, não é mais da nossa época. Das experiências posteriores onde foi destruída a homogeneidade da estrutura de uma obra de arte e nela introduzidos elementos estranhos, através da colagem e acoplamentos ${ }^{23}$ (reunião) ; a aceitação da realidade "toda pronta" ; o pleno reconhecimento do papel do acaso; a localização de uma obra de arte sobre a estreita fronteira entre a realidade da vida e ficção artística - tudo isso omitidos os escrúpulos do início do nosso século, do 
período do simbolismo e da "art noveau". A alternativa "arte autônoma de estrutura cerebral ou o perigo do naturalismo", deixou de ser a solitária possibilidade.

Se o teatro, em seus momentos de fraqueza, sucumbia ao organismo humano vivo e às suas leis, é que ele aceitava, automaticamente e logicamente, essa forma de imitação da vida que constituem sua representação e sua re-criação.

Ao contrário, aos momentos onde $\mathrm{o}$ teatro era suficientemente forte $\mathrm{e}$ independente para se permitir se liberar dos constrangimentos da vida e do homem, ele produzia equivalentes artificiais da vida que, ao se dobrar à abstração do espaço e do tempo, somente os mais vivos e os mais aptos seriam capazes de alcançar a absoluta coesão.

Nos nossos dias, essa alternativa na escolha perdeu também sua significação como seu caráter exclusivo. Porque ele criou uma nova situação no domínio da arte, surgiram novas formas de expressão.

A aparição do conceito de "realidade toda pronta", extraída do contexto da existência, tornou possível sua anexação, sua integração na obra de arte pela decisão, pelo gesto ou pelo ritual. E isso é no presente, muito mais fascinante e muito mais poderoso ao coração do real, que toda entidade abstrata ou artificialmente elaborada, ou que esse mundo surrealista do "maravilhoso" de André Bréton. Happenings, “acontecimentos", “ambientes”, são impetuosamente reabilitados das regiões inteiras da realidade até aqui desprezadas, libertando do peso de suas destinações terra-aterra. Esse deslocamento da realidade pragmática - esse "desencadeamento" fora da rotina da prática cotidiana - são colocados em balanço na imaginação dos homens muito mais profundamente que a realidade surrealista do irreal onírico. Eis que finalmente se perde toda importância dada aos temores de ver o homem e sua vida interferirem no plano da arte. 
5. Da "realidade imediata" do happening a desmaterialização dos elementos da obra de arte.

No entanto, como toda fascinação, tornou-se, ao final de um certo tempo, convenção pura - universalmente, estupidamente, vulgarmente implementadas. Essas manipulações quase rituais da realidade, ligadas à contestação do estado da arte e do lugar reservado à arte, foram, pouco a pouco, dando sentido a matéria física do objeto e o tempo presente no qual podem, somente, figurar a atividade e a ação que aparentemente alcançaram os seus limites e tornaram-se um entrave. Ultrapassá-los significava privar essas relações de sua importância material e funcional, ou seja, de sua possível apreensão. (Sendo dado, tratar-se esse de um período totalmente recente, ainda não acabado, fluída, as considerações que irão continuar se relacionando, e que estão relacionadas às minhas próprias atividades criativas).

O objeto ( A Cadeira, Oslo, 1970) tornou-se vazio, desprovido de expressão, de encantamentos, de pontos de referência, das marcas de uma intercomunicação desejada, de sua mensagem; ele não estava orientado em nenhuma direção e tornouse um engano. Situações e ações permanecem trancadas em seu próprio circuito, enigmáticos ( O Teatro Impossível, 1973). Em meu manifesto intitulado "Assalto" (Cambriolage) teve lugar uma invasão ilegítima sobre o terreno onde a realidade tangível encontrava seus prolongamentos invisíveis, de mais em mais, distintamente se determina o papel do pensamento, da memória e do tempo.

6. A recusa da ortodoxia do conceitualismo e da "vanguarda oficial das massas".

Em mim, tornou-se cada vez mais forte a convicção de que o conceito de vida não pode ser reentroduzido na arte a não ser pela ausência de vida no sentido convencional (ainda Craig e os simbolistas) . Esse processo de desmaterialização se instalou em minhas atividades criativas, evitando contudo toda a panóplia ortodoxa da lingüística e do conceitualismo. É certo que, em parte, essa escolha foi 
influenciada pelo gigantesco congestionamento que se acumulou nesse caminho, doravante oficial e que constitui, infelizmente, o último período da grande rota dadaísta, afixado de seus slogans - arte total, tudo é arte, todo mundo é artista, a arte está em sua cabeça, etc.

Eu não gosto dos congestionamentos. Em 1973, eu escrevi um esboço de um novo manifesto, que levava em consideração essa situação falsa. Aqui está o início. “Após o Verdun, o Cabaré Voltaire e o Water-Closed, de Marcel Duchamp, quando o "fato artístico" foi encoberto pelos resmungos da Grosse Bertha, a decisão ficou isolada, possibilidade que resta ao homem de ousar qualquer coisa ainda hoje inconcebível. Ela foi, por muito tempo, o primeiro estimulante da criação, uma condição e uma definição da arte. Esses últimos tempos dos milhares de indivíduos medíocres, tomam decisões, sem escrúpulos, nem reticências de nenhuma espécie. A decisão tornou-se um negócio banal e convencional. Esse que foi um caminho perigoso é agora um caminho cômodo segurança e sinalização hipermelhorados. Guias, agendas, painéis indicadores, placas, centros, congressos de arte - eis aí, aquilo que garante a perfeita criação artística. Nós somos testemunhas de um levante em massa de comandos de artistas, de combatentes de rua, artistas de impacto, de fazedores de arte, de escrevinhadores (rabiscadores), de caixeiros viajantes, de charlatões, chefes de escritórios, e de agentes. Sobre esse caminho, desde já oficial, o tráfico ameaçador do nosso afogar sob uma onda de rabiscos insignificantes e de pretendidos golpes de teatro, cresce todos os dias. É preciso deixá-lo o mais depressa possível. Mas isso não é nada fácil! Especialmente porque está no seu apogeu - cego e garantido pelo grande prestígio do intelecto, incluindo paralelamente, prudência e estupidez - a onipresente vanguarda.

7. Sobre os caminhos secundários da vanguarda oficial. Os manequins fazem sua aparição.

Minha recusa imutável de não aceitar as soluções do conceptualismo, se bem que elas me parecem como a única saída para o caminho escolhido, me tem conduzido ao lugar, marcado e circunscrito, os acontecimentos relatados, os maiores, 
que marcaram a última fase de minha atividade criativa por os caminhos secundários suscetíveis de me oferecer maiores chances de me debruçar sobre o desconhecido (incomum).

Tal situação, mais que qualquer outra, me enche de confiança. Todo período novo sempre começa por tentativas sem grande significação, dificilmente considerável, quietamente, não tendo grande coisa em comum com o caminho traçado; tentativas privadas, íntimas, eu diria mesmo, pouco inocentes, não claras em todo caso. Difíceis! Esses são os momentos mais fascinantes e mais carregados de sentido da criação artística.

De súbito, eu me interessei pela natureza dos manequins. $\mathrm{O}$ manequim em minha encenação de A Galinha D’água, de Witkacy (1967) e os manequins em Os Sapateiros, do mesmo Witkacy (1970) tinham um papel muito específico: eles constituíam uma espécie de prolongamento imaterial, qualquer coisa como um órgão complementar do ator que era o "proprietário". Quanto àqueles que utilizei em grande número na encenação de Balladyna, de Slowacki, constituíam em dubles de personagens vivas, como se fossem dotados de uma consciência superior, atingida “após a consumação de sua própria vida". Esses manequins já eram visivelmente marcados pelo selo da morte.

8. O manequim como manifestação da realidade mais trivial. Como um processo de transcendência, um objeto vazio, um artifício, uma mensagem de morte, um modelo para o ator.

O manequim que utilizei em 1967 no teatro Cricot 2 (A Galinha D'água), foi, após O Peregrino eterno, e as Embalagens humanas, o posterior dos meus personagens a entrar naturalmente em minha coleção como outro fenômeno a apoiar essa convicção ancorada em mim após um longo tempo, de que somente a realidade 
mais trivial, os objetos mais modestos e os mais desprezados, são capazes de revelar em uma obra de arte o seu caráter específico de objeto.

Manequins e figuras de cera sempre existiram, mas mantidos à distância, nas molduras da cultura admitida, nas barracas dos mercados, nas barracas duvidosas dos prestidigitadores, longe dos esplêndidos templos da arte, olhados como curiosidades menosprezados, boas apenas para o poder do gosto popular. Exatamente por essa razão, são elas - bem mais que as acadêmicas peças de museu - que podem ao tempo de um breve olhar, elevar, em um canto o véu.

Os manequins são também uma marca do pecado - de transgressão e delito. A existência dessas criaturas confeccionadas à imagem do homem, de uma maneira quase sacrílega e quase clandestina, fruto de procedimentos heréticos, carrega a marca desse lado obscuro, noturno, sedicioso do comportamento humano, a impressão do crime e dos estigmas da morte como fonte de conhecimento. A impressão confusa, inexplicável, que é para o intérprete de uma criatura nos fraudulentos aspectos da vida, mas privada de consciência e de destino, que a morte e o nada liberam sua inquietante mensagem - é isso que causa em nós esse sentimento de transgressão, ao mesmo tempo rejeitando e atraindo, isolando e fascinando.

$\mathrm{O}$ ato da acusação esgotou todos os argumentos. $\mathrm{O}$ primeiro a deixar-se atacar foi o próprio mecanismo dessa ação, considerada levianamente como um fim em si mesmo, e desde então relegado entre as formas medíocres da criação artística, colocadas no mesmo saco que a imitação, a ilusão enganosa destinada a abusar do espectador como as peças do manipulador de feira, e a utilização de ingênuos artifícios que escapam aos conceitos da estética, como o uso fraudulento das aparências e as práticas do charlatão. E para fazer boa aparência, juntaram-se ao processo as acusações de uma filosofia que, após Platão e freqüentemente, ainda hoje, designa como fim da arte o de revelar o ser e sua espiritualidade antes de afundar na concretude material do mundo, nessa trapaça das aparências que representam o mais baixo nível da existência. 
Eu não penso que um manequim ( ou uma figura de cera) possa substituir o ator vivo, como queriam Kleist e Craig. Isso seria fácil e por demais ingênuo. Eu me esforço em determinar os motivos e a destinação dessa entidade insólita surgida inesperadamente em meus pensamentos e nas minha idéias. Essa aparição concorda com a convicção cada vez mais forte em mim, que a vida só pode ser expressa na arte pela falta de vida e pelo recurso à morte, através das aparências, da vacuidade, da ausência de toda mensagem. No meu teatro, um manequim deve tornar-se um modelo que encarna e transmite um profundo sentimento da morte e da condição dos mortos - um modelo para o ator vivo.

9. A minha interpretação da situação descrita por Craig. A aparição do ator vivo, momento revolucionário. A descoberta da imagem do homem.

Eu Tiro minhas considerações da origem do teatro; mas elas se aplicam geralmente à arte atual. Existe um motivo para se pensar que a descrição imaginada por Craig, nas circunstâncias nas quais apareceu o ator, e que faz ele uma análise terrivelmente acusativa, devia servir ao seu autor como ponto de partida para as suas idéias concernente à "super-marionete". Ainda que seja eu admirador do menosprezo soberbo professado por Craig e de suas críticas passionais - sobretudo a de que nós estamos no total declínio do teatro contemporâneo - eu devo entretanto, fazendo minha, a primeira parte do seu credo, no qual ele denega ao teatro institucional toda razão de existir no plano da arte, levar meu distanciamento em relação às soluções bem conhecidas e que ele encontrou sobre o destino do ator. Porque o momento onde um ator apareceu pela primeira vez diante de um auditório (empregando o vocabulário atual) parece-me ser, bem ao contrário, um tempo revolucionário e de vanguarda. Eu vou experimentar compor e fazer "entrar na história" uma imagem oposta, cujos acontecimentos terão uma significação inversa:

Eis que do círculo comum dos costumes e dos ritos religiosos, das cerimônias e das atividades lúdicas, alguém saiu e tomou a decisão temerária de se desligar da comunidade cultural. Seu motor não era nem o orgulho (como em Craig), nem o 
desejo de atrair sobre ele a atenção de todos. Solução simplista ao excesso. Eu o vejo mais como um rebelde, um oponente (objecteur), um herético, livre e trágico por ter ousado permanecer só com sua sorte e seu destino. E se nos somarmos "ao seu papel", teremos diante de nós o ator. A revolta teve lugar sobre o terreno da arte. Esse acontecimento, ou ainda, essa manifestação, provavelmente provocou uma grande perturbação nos espíritos e suscitou opiniões contraditórias. Muito certamente se julgará esse ato como uma traição em relação às tradições antigas e às práticas do culto, se verá uma manifestação de orgulho profano; de ateísmo, de perigosas tendências subversivas; será criado no escândalo, na imoralidade, na indecência, se medirá o homem tal como um palhaço de feira, um cabotino, um exibicionista, um depravado. O próprio ator, afastado, será feito, não somente dos inimigos cruéis, mas de fanáticos admiradores. Infâmia e glória conjugadas.

Isso seria de um formalismo ridículo e superficial como querer explicar esse ato de ruptura pelo egocentrismo, pelo desejo de glória, ou uma tendência inata para a exibição. Ele devia se lançar em uma aposta mais considerável, de uma comunicação de importância capital. Tentaremos representar essa situação fascinante: Em frente àqueles que desse lado, um homem se ergue exatamente semelhante a cada um dos demais, entretanto, (pela virtude de qualquer "operação" misteriosa e admirável) infinitamente distante, terrivelmente estranho, como habitado pela morte, separado deles por uma barreira, que por ser invisível, não parecia menos assustadora e inconcebível, tal que o sentido verdadeiro e a honra, que só podem nos ser revelado pelo sonho.

Assim que na luz ofuscante de um raio, eles percebem repentinamente a imagem do homem, barulhento , tragicamente clownesca, como se eles o vissem pela primeira vez, como se eles vissem a si mesmos. Esse foi com toda a certeza, uma percepção que se poderia qualificar de metafísica.

Essa imagem viva do homem saindo das trevas, colocando sua marcha adiante, constitui um manifesto, irradiante, de sua nova condição humana, somente humana, 
com sua responsabilidade, e sua consciência trágica, determinando seu destino em uma escalada implacável e definitiva, a escalada da morte.

Foi aos espaços da morte que esse manifesto foi endereçado, revelador que provocou no público (utilizando um termo atual) esse acesso ao metafísico. Os meios e a arte desse homem, o ator (empregando nosso próprio vocabulário), ligando-se assim à morte, a sua trágica e horripilante beleza.

Nós devemos devolver à relação espectador/ator a sua significação essencial. Nós devemos fazer renascer esse impacto original do instante onde um homem(ator) apareceu pela primeira vez diante de outros homens (espectadores), exatamente semelhante a cada um de nós, e no entanto, infinitamente estranho, além dessa barreira que não pode ser transposta.

\section{Recapitulação}

Embora suspeitem, e nos acusem de nos alimentar dos escrúpulos sem propósito, nós expulsaremos nossos preconceitos e nossos temores inatos, e, para uma melhor imagem no interesse de conclusões eventuais, nós fincaremos as estacas dessa fronteira que tem nome: a condição da morte, porque ela constitui a marca mais avançada que não é mais ameaçada por nenhum conformismo da condição do artista e da arte... Essa relação particular, desconcertante e atraente por sua vez, entre os vivos e os mortos, que há pouco tempo atrás, quando eles estavam ainda em vida, não davam espaço a espetáculos inesperados, em inúteis divisões, à desordem, eles não eram diferentes e não tomavam grandes ares e em razão desse risco aparentemente banal, mas, como se verá, forte e importante, eles eram simplesmente, normalmente, respeitosamente não perceptível. 
E eis que agora, de súbito, do outro lado, frente a nós eles despertam a surpresa, como se nós o víssemos pela primeira vez exposto na vitrine numa cerimônia ambígua: honradas e rejeitadas, e ao mesmo tempo irremediavelmente outra e infinitamente estranha, e ainda: privado de qualquer espécie de significação, sem acordo, sem a mais magra esperança de ocupar um lugar à parte nas texturas de nossa vida que não são acessíveis, familiares, inteligíveis para nós, mas para eles desprovidos de sentido.

Se nós estamos de acordo que o traço dominante dos homens vivos é sua aptidão e sua facilidade em amarrar entre si múltiplas relações vitais, é somente frente aos mortos que surge em nós a captura da consciência repentina e surpreendente qual essa característica essencial dos vivos que se torna possível por sua ausência total de diferenças, por sua banalidade, por sua identificação universal que destrói impiedosamente toda ilusão diferente ou contrária por sua qualidade comum, aprovada sempre no vigor de um persistir indiscernível. São somente os mortos que tornam-se perceptíveis (para os vivos) obtendo assim, por esse preço o que é mais elevado: o seu próprio status, a sua singularidade, a sua silhueta brilhante (espetacular, quase como no circo). 
TADEUSZ KANTOR

\section{CRONOLOGIA}


1915 - Tadeusz Kantor nasce em Wielopole. 1934-1939 estuda pintura e cenografia na Academia de Belas Artes da Cracóvia onde foi aluno de Karol Frycz, amigo e admirador de Edward gordon Craig.

1942 - Criou na Cracóvia um Teatro experimental clandestino durante a ocupação da Polônia pelo exército alemão. Ele monta Balladyna de J.Slowacki (1942) e O Retorno de Ulisses de St. Wyspianski (1944). Duante a guerra ele pinta, redige escritos teóricos, etc.

1945 - Co-fundador do Grupo "Jovem Plástica". Ele começa uma atividade regular de cenografia que durará aproximadamente quinze anos. Durante esse período ele cria cenários e figurinos para mais ou menos cem espetáculos para teatros da Cracovia, Varsóvia, Lordz, etc. Em 1945 faz cenografia e figurinos para $O$ CID de P. Corneille, na Cracóvia, Teatro Stary.

1946 - Cenografia e figurinos para Escamas Caíram De Nossos Olhos de W. Karczewska.

1947 - Primeira viagem à França.

1948 - Kantor organiza na Cracóvia a primeira exposição de arte polonesa após a segunda guerra mundial. Ele é nomeado professor na Academia de Belas Artes da Cracóvia.

1949 - Ele é demitido desse cargo. 
1954 - Faz cenografia e figurinos para Santa Joana de G. B. Shaw, com direção de W. Krzeminski, no Teatro Stary, Cracóvia.

1955 - Viagens à Paris e Viena. Participa da exposição "9 pintores”, Cracóvia. Faz a cenografia e figurinos para Medida Por Medida de Shakespeare, direção de Skuszanka, Teatro Ludowy, Cracóvia. Funda o Teatro Cricot 2 com o qual encena $O$ Polvo de Witkiewicz, com figurinos de Maria Jarena, representado na Galeria Krzysztofory que transforma-se no principal lugar de criação e atividade do Cricot 2.

1956 - realização completa (encenação, cenografia, figurinos) de A Sapateira Prodigiosa de F. Garcia Lorca, Teatro Stary, Cracóvia.

1957 - Com o Teatro Cricot 2, Kantor cria a sua primeira “embalagem” por ocasião de sua realização do Circo de K. Mikulski. Faz a cenografia e os figurinos para Antigone de J. Anouilh, direção de Kalizewski, Teatro Stary, Cracóvia. Participa da fundação do "Grupo da Cracóvia" (pintores de vanguarda). Exposição individual na Galeria Krzysztofory da Cracóvia e no museu municipal de Lublin. Participa da exposição de arte moderna em Varsóvia.

1958 - Ilustrações para Yvonne Princesa de Burgogne de W. Gombrowicz, P.I.W., Varsóvia. Exposição individual na Galeria Samlaren en Estocolmo (Suíça). Participa da exposição "simbolismo e Surrealismo" na cracóvia e da exposição "arte do vigésimo primeiro século" em Charleroi (França).

1959 - Exposição individual em Paris (Galeria Legendre), Dusseldorf (Museu de Belas Artes). Participação na exposição de pintura polonesa ( Bruxelas, Estocolmo, Amsterdã, Copenhague), e "Documentos II"(Kassel). 
1960 - Tadeusz Kantor publica o seu manifesto do Teatro Informal. Exposição individual em New York (Galeria Sandberg), Göteborg (Galeria 54). Participa da XXX Bienal de Veneza.

1961 - Kantor viaja para a Alemanha, Suíça, Itália, França. Professor convidado pela Academia das Belas Artes de Hamburgo. Realiza com o Teatro Cricot 2 o espetáculo $A$ Pequena Mansão de Witkiewicz. Faz a cenografia e os figurinos para $O$ Rinoceronte de Ionesco, Teatro Stary, Cracóvia.

1962 - Tadeusz Kantor realiza suas primeiras "embalagens”. Na Suíça ele escreve o Manifesto das "Embalagens", uma das bases teóricas do seu trabalho. Cenografia e figurinos para Don Quichotte. Participa da exposição de pintura polonesa, folkwangMuseum, Essen, Stuttgart.

1963 - Realização do espetáculo O Louco e a Freira, de Witkiewicz com o Teatro Cricot 2. Na Cracóvia publica o "Manifesto do Teatro Zero". Realização de Chandelier de Alfred Musset. Teatro Stary, Cracóvia. "Exposição Popular" (ante-exposição), Galeria Krzysztofory, Cracóvia.

1964 - Viagem para a Suíça e Alemanha. Exposição individual na Galeria Pauli, Lausanne. Participa das Exposições "Perfil IV" (Städtische Kunst-galerie, Bochum, Kassel) e "Beeldent experiment op de planken"(Eindhoven). Realiza seu primeiro guarda-chuva sobre tela.

1965 - Viagem aos Estados Unidos da América. Primeiro "Happening-Cricotage" em Varsóvia com o grupo dos artistas da Galeria Foksal. 
1966 - Tadeusz Kantor realiza O Armário após A pequena Mansão de Witkiewicz em Baden-Baden. Tournées a Munique, Heidelberg, Bochum, Essen. Happening Linha de Partida na Cracóvia. Happening Grande Embalagem, em Bâle. Exposições pessoais em Baden-Baden ( Kunsthalle). Paris ( "Embalagens", Galeria da Universidade). Bâle (Galeria Handschin).

1967 - A Carta, "Happening-Cricotage" em varsóvia. Happening panorâmico do mar Báltico, em quatro partes: "O concerto marinho", "A jangada de medusa", "A Agricultura sobre a areia"), "Rabiscos eróticos". Exposição individual em Varsóvia (Galeria Foksal), Estocolmo (Galeria Pierre). Participa da Bienal de São Paulo.

1968 - Viaja para a Itália, França, Alemanha Federal. Com ligação com o filme Kantor ist da (Institut für moderne Kunst de Nuremberg), o happening A Lição de anatomia após Rembrandt. Happening Conferencia com o Rinoceronte, Nuremberg. Happening Homenagem a Maria Jarema, Galeria Krzysztofory, Cracóvia. Realização do espetáculo A Galinha D'água de Witkiewicz, com o Teatro Cricot 2. "Manifesto do Teatro dos acontecimentos". "A Cadeira embalada" (mosaico), Vela Luka, Iugoslávia. Participação na exposição "Von der Collage zur Assemblage", Nuremberg. Nomeado professor da Academia de Belas Artes da Cracóvia.

1969 - É destituído do cargo de professor da Academia de Belas Artes da Cracóvia. $O$ Teatro impossível realiza em Bled na Iugoslávia, Happenings-Actions), para a televisão Sarroise. Happening Lição de Anatomia II, Galeria Foksal, Varsóvia. O Teatro Cricot 2 apresenta A Galinha D’água em Roma (Festival Premio Roma, Galeria Nacional de Arte Moderna), em Módena e em bologna. Participa da ação coletiva "Assemblage d'hiver", Galeria Foksal, Varsóvia.

1970 - Publicação do "Manifesto 1970”, Varsóvia. Exposição "Multipart”, Galeria Foksal, Varsóvia, "Manifesto Multipart". Projeto de uma cadeira em concreto de 14 
metros de altura. Participação na "Exposição internacional das galerias-pilotos", em Lausanne Paris. Participação na exposição "happening und Fluxus”, Cologne.

1971 - O Teatro Cricot 2 apresenta A Galinha D’água no Festival mundial de teatro de Nancy. Realização de “A Grande Cadeira”, Sonja Henie Onstad Museum, Oslo. Participação no Primeiro Ateliê Internacional Experimental em Dourdan (França). Nesse quadro realização do Happening "Lição de Anatomia II". Exposição "Multipart II”. Exposição “Embalagens conceituais”, Galeria Foksal, Varsóvia.

1972 - O Teatro Cricot 2 apresenta A Galinha D’água no Teatro de Malakoff e em Edinbourg (Festival de Arte - Richard Demarco Gallery). Tadeusz Kantor concebe a encenação, a cenografia e os figurinos de Sapateiros de Witkiewicz, representado em francês no Teatro 71 em Malakoff.

1973 - Tadeusz Kantor realiza com o Teatro Cricot 2 As Graças e os Espantalhos de Witkiewicz na Cracóvia. O espetáculo também é apresentado em Edimburgo (Festival d'Art - Richard Demarco Gallery - Forrest Hill) e Glasgow.

1974 - O Teatro Cricot 2 apresenta As Graças e os Espantalhos em Roma (Festival Premio Roma, Galeria Nazionale d'Arte Moderna). Paris (Teatro Nacional de Chaillot). Nancy (Festival Mundial de teatro), Shiraz (Festival de Artes), Essen (FolkwangMuseum).

1975 - Exposição "Rezerwat Ludzki”(A Reserva humana) na Cracóvia, Galeria Desa. Grande retrospectiva no Museu de arte de Lodz, "Embalagens 1960-1975". Exposição "Embalagens", Kulturhuset, Estocolmo. Em 15 de novembro Tadeusz Kantor cria com o Teatro Cricot 2 A Classe Morta na Galeria Krzysztofory, Cracóvia. Kantor escreve e publica o Manifesto “O Teatro da Morte”, (Galeria Foksal, Varsóvia). 
1976 - O Teatro Cricot 2 apresenta A Classe Morta em Edimburgo (Festival d'Art Richard Demarco Gallery), Cardiff (Teatro Nacional), Londres (Estúdio Riverside). Exposição “Embalagens 1960 - 1976”em Londres (White Chapel Gallery) e Nuremberg (Galeria Richard/Institut für moderne Kunst).

1977 - O Teatro Cricot 2 apresenta A Classe Morta em Amsterdã (Mickery Theatre), Nuremberg (Galeria Richard Stadttheater), Nancy (Festival Mundial de Teatro), Shiraz (Festival de Artes), Belgrado (Festival Bitef onde ele obtém O Grande Prêmio), Paris (Festival de Outono, Teatro Nacional de Chaillot), Bruxelas (Teatro 140), Gand (Academia de Belas Artes), Lyon (Teatro Nacional Popular), Lille (Encontro internacional de teatro, Teatro popular de Flandres). A primeira antologia de escritos de Tadeusz Kantor é publicada: Tadeusz Kantor, O Teatro da Morte, textos reunidos e apresentados por Denis Bablet, Lausanne, L'Age d'homme. Tadeusz Kantor participa da exposição “Documenta VI”em Kassel.

1978 - O Teatro Cricot 2 apresenta A Classe Morta em Florença (Palazzo Pitti Teatro rondo di Bacco), Milão (Centro di ricerca per il teatro), Adelaide (Adelaide Festival of Arts. Recording Hall), Sydney (Opera House), Zurich (Teatro 11), Genève (Teatro Plainpalais), Caracas (Teatro das Nações, Primeiro prêmio, prêmio de crítica. Prêmio Teatral "Juana Sujo"), Roma (Teatro Tenda. Rassegna internacionale de teatro popolare), Berlin-ouest (Berliner Festspiele), Stuttgart, Graz. Tadeusz Kantor recebe o prêmio-Rembrandt 1978 atribuído pela Fundação Johann Wolfgang von Goethe de Bâle.

1979 - O Teatro Cricot 2 apresenta A Classe Morta em Nova Iorque (La Mama), México (Teatro "El Galeon”), Milão (Palazzo Reale), Estocolmo (Kulturhuset), Cracóvia ("Sokol"). É firmado um acordo entre Tadeusz Kantor e o Teatro Regional da Toscânia (Florença): ele assume a responsabilidade de organizar um ateliê Teatral do Cricot 2 em Florença. É colocado a sua disposição a igreja Santa Maria nas proximidades da Arena Goldoni onde Edward Gordon Craig se estabilizou antes da Primeira Guerra Mundial. Ele chegou a Florença com grande parte de seus 
colaboradores poloneses do Teatro Cricot 2. Jovens atores italianos são chamados para participar do empreendimento. Em novembro começam os trabalhos de montagem de Wielopole Wielopole. Edição Italiana de Tadeusz Kantor, Il Teatro della morte. Materiali raccolti e presentati da Denis Bablet, Milano, Ubulibri/Edizioni il Formichiere.

1980 - Criação de Wielopole Wielopole em Florença. O Teatro Cricot 2 apresenta Wielopole Wielopole em Edimburgo (festival of Art, Theatre Moray House), Londres (Riverside Studio), Paris (Festival d'automne, Thèâtre des Bouffes du Nord), Cracóvia ("Sokol”), Varsóvia (Club "Stodola”), Gdansk. O Teatro Cricot 2 apresenta A Classe Morta em Prato (Fabricone). Fundação das duas "cricotecas" (Arquivos e centro de documentação sobre o passado e o presente da atividade do Teatro Cricot 2) na Cracóvia e em Florença.

1981 - O Teatro Cricot 2 apresenta Wielopole Wielopole em Milão (Centro di ricerca per il teatro), Roma (Teatro Limonaia), Florença (Igreja de Santa Maria), Gênes (Teatro de la Ville), Parma (Teatro Regio), Genova, (Teatro Plainpalais) Zurich (Die rote Fabrick), Caracas (Festival Internacional de Teatro). Tadeusz Kantor publica Wielopole Wielopole.

1982 - O Teatro Cricot 2 apresenta A Classe Morta em Londres (Riverside Studio), Tokyo (Parco 3); Onde estão as Neves de antanho? Em Paris (Festival d'automne, Centre Georges Pompidou), Londres (Riverside Studio); Wielopole Wielopole em Guanajuato (Festival Internacional Cervantino, Teatro Principal), México (Teatro Juan Ruiz alarcon), Nova Iorque (La Mama Theater. Prêmio de critica OBIE), LyonVilleurbanne (Tèâtre National Populaire). Kantor expõe na Galeria de France "Metamorfoses". Com o mesmo título, Chêne/Hachette e a Galerie de France publicam uma antologia de escritos de Kantor consagrados a sua obra pictural. 
1983 - O Teatro Cricot 2 apresenta A Classe Morta em Cagliari (Pierluigi da Palestrina), Madrid (Teatro Maria Guerrero), Varsóvia (Club "Stodola"), Paris (Centro Georges Pompidou); Onde estão as Neves de Antanho? em Gênova (Teatro Plainpalais); Wielopole Wielopole em Valence (Teatro Principal, Palma de Mallorca (Auditorium). No Centro George Pompidou (Paris), exposição "O teatro Cricot 2 e sua vanguarda". Kantor participa da exposição "Presenças polonesas" Centro George Pompidou, 23 de junho a 23 de setembro) onde são expostas sessenta e uma obras. No fim do ano, Kantor começa na Cracóvia as "repetições" de seu novo espetáculo que virá a se chamar Que Morram os Artista!.

1984 - O Teatro Cricot 2 apresenta A Classe Morta em Murcie (Teatro Romea), Las Palmas (Teatro Perez Galdas), Sevilha (Sala Municipal de Cultura), Los angeles (Olynpic Arts Festival); Onde Estão as Neves de Antanho? em Varsóvia (Club "Stodola") ; Wielopole Wielopole em Estocolmo (Kulturhuset), Iy vas Kyla (Esitykset Iyväskylän Talveass), Helsinki (Universidade, Paris (Thèâtre de Paris), Los Angeles (Olynpic arts Festival).

1985 - Criação de Que Morram os Artistas! em Nuremberg (Alte Giesserei, Kabelmetall), em junho. O Teatro Cricot 2 apresenta A Classe Morta em Tel-Aviv (Jaffa Harbour Theatre); Wielopole Wielopole em Salonique (Demeter); Que Morram os Artista! Em Milão (Teatro dell'Arte), Avignon (Gymnase Aubanel), Paris (Centre georges Pompidou), Nova Iorque (La Mama Theater. Prêmio de Critica OBIE). Exposição de pintura no quadro do Festival de Avignon. Apresentação do Filme de A. Sapija Teatr Cricot 2 (WFO Lodz). Apresentação do filme de Denis Bablet Le Thèâtre de Tadeusz Kantor (C.N.R.S. Audiovisuel/Arcanal, Ministère de la culture).

1986 - "L'attesa molto importante": Festival do Teatro Cricot 2 em Bari (Teatro Petruzzelli). O Teatro Cricot 2 apresenta A Classe Morta, Wielopole Wielopole e Que Morram os Artistas! De 3 a 6 de maio é feito um simpósio internacional consagrado a Tadeusz Kantor. Durante o simpósio são apresentadas comunicações por: D. Bablet, G. Bartolucci, W. Borowski, B. Eruli, Sisto Dalla Palma, N. Kiraly, T. Krzemien, K. 
Miklaszewski, R. Palazzi, E. Pani, J. Pomianovski, G. Raboni, U. Volli. A Galeria Bonomo de Bari apresenta em maio uma exposição de obras de Kantor como pintor e homem de teatro. O Teatro Cricot 2 apresenta Wielopole Wielopole em Berlim-Oeste (Theatermanufaktur); Que Morram os Artistas! em Varsóvia (Club "Stodola"), Cracóvia (Teatr im J. Slowackiego), Madrid (Sala Olimpia), Milão (Teatro dell'Arte), Turim (Teatro Colosseo), Lyon-Villeurbanne (Thèâtre National Populaire), Grenoble (Maison de la Culture), Berlin-Oeste (Theatermanufaktur); Anvers (De ingel), Ferrare (Teatro Comunale). De 25 de junho a 25 de julho, na Ecuola d'arte drammatica Paolo Grassi (Milão) Kantor dá um curso que resulta na apresentação da "cricotage" Um Casamento à Maneira Construtivista e Surrealista. Os textos das Aulas, serão editados com o título de: Lezioni milanesi 1 (1988). O Berliner Festwochen apresenta uma "Homenagem a tadeusz Kantor"com Wielopole Wielopole, Que Morram os Artistas! no Theatermanufaktur (setembro). Nessa ocasião, a Galeria Eva Poll apresenta uma exposição retrospectiva da obra de Kantor. Um colóquio internacional consagrado a Kantor em Anvers em 25 de outubro apresenta comunicações de: D. Bablet, K. Mikalaszewski, R. Palazzi, B. Eruli, Ph. Du Vignal, A. Mallems.

1987 - O Teatro Cricot 2 apresenta Wielopole Wielopole em Barcelona (Mercat de les Flors); Que Morram os Artistas! em Wroclaw (Teatr Polski), barcelona (mercat de les Flors), Lille (La Salamandre), Viena (Metropole), Florença (Teatro della Compagnia), Buenos Aires (Teatro Municipal San Martin). Realização por N. Lilenstein um documentário de televisão consagrado a Que Morram os Artistas! (La Sept). Kantor cria em Kassel (Documenta 8) a cricotage A Máquina do Amor e da Morte. Esse espetáculo também é apresentado em Milão, Reggio Emilia, Palermo.

1988 - Criação de Eu Não Voltarei Jamais em Milão (Teatro Studio), abril. O Teatro Cricot 2 apresenta Que Morram os Artistas! e Wielopole Wielopole em San Marino (Teatro Nuova Dogana), Salermo (Teatro A); Eu Não Voltarei Jamais em Berlin-Oeste (Akademie der Künste), Nova Iorque (New York International Festival of the arts. La Mama Theater), Paris (Centro George Pompidou), Palma de Mallorca (Auditorium), Toulouse (Thèâtre Garonne), Lyon-Villeurbanne (Thèâtre National Populaire). Kantor apresenta A Máquina do amor e da Morte em Helsinki e em Vaasa. De 16 de agosto a 
10 de setembro, Kantor dá uma oficina no Instituto Internacional da Marionete em charleville-Mézières que termina com a criação do espetáculo: Uma Lição muito curta.

1989 - O Teatro Cricot 2 apresenta Eu Não Voltarei Jamais em Montpellier (Thèâtre des Treize Vents), Marseille (Thèâtre Toursky), Lille (Thèâtre Roger Salengro), barcelona (Mercat de les Flors), Madrid (Teatro albeniz), Roma (Teatro Vascello), Lisboa (Grande Auditório da Fundação gulbenkian), Nuremberg (Tafelhalle). Festival do Teatro Cricot 2 "O retorno" (Paris, maio/junho). Thèatre National de Chaillot, salle Gémier): "O Teatro do amor e da morte-Cricot 2" (A Classe Morta, Wielopole Wielopole, que Morram os Artistas!, Eu não Voltarei Jamais). Reencontros: reencontros públicos com Tadeusz Kantor e Denis Bablet ("A morte, a blasfêmia e a ironia”, "a arte, a instituição e os poderes"). Simpósio internacional com Tadeusz Kantor (29/30 de junho, centro Georges Pompidou): "Tadeusz Kantor pintor, homem de teatro, suas ressonâncias no final do século XX". Exposições: "Tadeusz Kantor. Mais Longe, nada" (Galerie de France) ; "Tadeusz Kantor. A Viagem" (Centro George Pompidou). Tadeusz Kantor é feito commandeur da Ordem das artes e Letras. Apresentação do filme $O$ Retorno de Ulisses de A. Sapija (WFO Lodz). Realização Televisual por N. Lilenstein de A Classe Morta.

1990 - O Teatro Cricot 2 apresenta Eu Não Voltarei Jamais na Cracóvia (Teatr Stary), Varsóvia (Club "Stodola”), Tóquio (Parco Theater com Que Morram os Artistas!), Salerno (Teatro Capitol), Bari (Teatro Petruzzelli), Reykjavik (Reykjavik) Theatre). “A arte e a liberdade", colóquio consagrado a Kantor, Cracóvia, Aula da Universidade Jagellon, de 9 a 11 de abril. Comunicações por J. Blonski, M. Porebski, G. Banu, W. Borowski, P. Krakowski, M. rostworowski, G. Scarpetta, N. Kiraly, J. Klossowicz, D. Bablet, B. Dort, a Matynia, T. Krzemien, K. Plesniarowicz. Curso ministrado em Avignon (Instituto Superior das técnicas do espetáculo - Academia experimental dos Teatros, de 12 de junho a 13 de julho), como resultado a criação do espetáculo $O$ doce noite. Tadeusz Kantor recebe o prêmio Pirandello. Na Cracóvia e em Toulouse, Kantor repete com o Teatro Cricot 2 o seu último espetáculo: Hoje é Meu aniversário. Tadeusz Kantor morre na madrugado de 7 para 8 de dezembro. 
1991 - 10 de janeiro, “A última repetição do espetáculo de Tadeusz Kantor" Hoje é Meu Aniversário é apresentado pelo teatro Cricot 2 no Teatro Garonne em Toulouse. A morte empede Kantor de estar presente na cena no "pobre quarto de sua imaginação". Sua cadeira está vazia. Se entende a sua voz. O Teatro Cricot 2 apresenta em tournée Hoje é Meu Aniversário em Paris (Centro Georges Pompidou), Maubeuge (International Theatre), Nîmes (Thèâtre de Nîmes), Berlim (Hebbel-Theater), Milão (Teatro franco Parenti), Cracóvia (Sala Sokola), Nova Iorque (La Mama Theater), veneza (Tatro Goldoni), Munich (Volkstheater), Edinburgo (Empire Theatre), Madrid (Teatro albeniz), Brest (Carré de Brest), Anvers (De Singel), Gênes (Teatro della Corte), Cagliari (Auditorium del Conservatório); A Classe Morta em Pampelone (Teatro Gayarre), Saragosse (Teatro Principal), Montreal (Thêâtre denise Pelletier), Nova Iorque (La Mama Theater), Veneza (Teatro Goldoni). Exposição "Taeusz Kantor. Malarstwo i rzerzba”, Cracóvia, Museu Nacional, outubro 1991 a março de 1992. Exposição "Hoje é Meu Aniversário", desenhos de Tadeusz Kantor, Centro George Pompidou, 2 a 13 de outubro.

1992 - O Teatro Cricot 2 apresenta em tournée Hoje é Meu Aniversário em Wroclaw (Teatr Polski), Varsóvie (Teatr Dramatyczny), Strasbourg (Thèâtre du Maillon), Zurich (Theaterhaus Gessnerallee). 